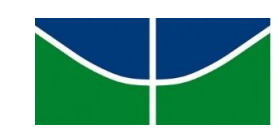

UNIVERSIDADE DE BRASÍLIA

FACULDADE DE EDUCAÇÃO

PROGRAMA DE PÓS-GRADUAÇÃO EM EDUCAÇÃ̃O

OS INÉDITOS-VIÁVEIS NA E DA FORMAÇÃO CONTINUADA DE PROFESSORES QUE ENSINAM MATEMÁTICA NOS ANOS INICIAIS DA EDUCAÇÃO DE JOVENS E ADULTOS

Rejane de Oliveira Alves

Brasília/DF

Maio de 2016 
REJANE DE OLIVEIRA ALVES

\title{
OS INÉDITOS-VIÁVEIS NA E DA FORMAÇÃO CONTINUADA DE PROFESSORES QUE ENSINAM MATEMÁTICA NOS ANOS INICIAIS DA EDUCAÇÃO DE JOVENS E ADULTOS
}

\author{
Tese desenvolvida na Linha de Pesquisa \\ Educação em Ciências e Matemática (ECMA), da \\ Pós-Graduação em Educação do Doutorado \\ Acadêmico da Universidade de Brasília (UnB) e \\ apresentada como requisito para obtenção do \\ título de Doutora em Educação. \\ Orientador: Prof. Dr. Cristiano Alberto Muniz
}

Brasília/DF

Maio de 2016 
Ficha catalográfica elaborada automaticamente, com os dados fornecidos pelo(a) autor(a)

A474i

Alves, Rejane de Oliveira

Os inéditos-viáveis na e da formação continuada de professores que ensinam matemática nos anos iniciais da Educação de Jovens e Adultos / Rejane de Oliveira Alves; orientador Cristiano Alberto Muniz. -Brasilia, 2016.

$305 \mathrm{p}$.

Tese (Doutorado - Doutorado em Educação) -Universidade de Brasília, 2016.

1. Inéditos-viáveis. Formação continuada. Professor que ensina Matemática. Educação de Jovens e Adultos (EJA). . I. Muniz, Cristiano Alberto, orient. II. Título. 
REJANE DE OLIVEIRA ALVES

\section{OS INÉDITOS-VIÁVEIS NA E DA FORMAÇÃO CONTINUADA DE PROFESSORES QUE ENSINAM MATEMÁTICA NOS ANOS INICIAIS DA EDUCAÇÃO DE JOVENS E ADULTOS}

\section{BANCA EXAMINADORA}

Prof. Dr. Cristiano Alberto Muniz (UnB/FE)

Prof $^{\mathrm{a}}$. Dr ${ }^{\mathrm{a}}$. Ana Lúcia Souza de Freitas (UNISINOS/FE)

Prof $f^{a}$. Dr ${ }^{a}$. Regina da Silva Pina Neves (UnB/MAT)

Prof. Dr. Renato Hilário dos Reis (UnB/FE)

Prof $^{a}$. Dr ${ }^{\mathrm{a}}$. Kátia Augusta Curado Pinheiro Cordeiro da Silva (UnB/FE)

Prof. Dr. Cleyton Hércules Gontijo (UnB/FE - Suplente) 
Às pessoas que acreditam que a Educação de qualidade é possivel: querido paizinho e serena mãezinha, adoráveis irmãos, amado esposo, doce vovó, professores e professoras, pesquisadores e pesquisadoras, alunos e alunas, pessoas de fé, esperança e sonhos. 


\section{AGRADECIMENTOS}

A Deus que zela pela minha vida e a dos meus familiares e que cuidou de cada detalhe para que eu tivesse saúde, sabedoria, tranquilidade e paz para produzir este trabalho.

Aos meus pais que desde minha infância fizeram todos os sacrifícios para que meus irmãos e eu estudássemos. Meu pai sem ter estudado já sabia a importância e a necessidade da Educação para os filhos. Minha mãe me ensinou a ler, quando eu tinha 6 anos de idade. Meus irmãos Rogério, Reginaldo, Renato e Raimundinha ajudam a alimentar o sonho de uma vida com mais amor. Minha família, responsável pelos ensinamentos e formação de valores a partir do princípio da alteridade, humildade e solidariedade.

Ao meu doce esposo José que comigo sonha e luta por uma Educação mais ética e democrática, e que, por isso mesmo, se fez presente em todos os momentos de minha vida, inclusive, participando de grupos de estudo e de reuniões do Edem e da SBEMDF, acompanhando-me em congressos e na caminhada acadêmica na UnB. Por tudo o que representa, pelo amor incondicional e pelo inédito-viável (sonho-possível) constituído cotidianamente ao meu lado.

A família que ganhei em Brasília (mãe, irmãos e sobrinhos de José), especialmente minha avó Maria Alves que sempre cultivou o amor materno e cuidou de minha alimentação para que eu tivesse força e saúde para continuar a produção acadêmica. Ainda pelo respeito aos momentos em que estive isolada em um quartinho, com os registros e as análises do material desta tese.

Ao orientador-companheiro, professor Cristiano, responsável pela minha formação enquanto educadora matemática e, mais que isso, pela formação humana, sempre contribuindo para o engrandecimento do ser matemático que há em cada um de nós. Pessoa humilde e generosa que tem seus orientandos como parceiros, acredita e se empenha para que possamos ser construtores de nossas aprendizagens.

Às professoras Meire Valina (Rita), Silvana Marques (Rute), Maronídia Dias (Rosa), Adriana Ferreira (Leitinho), Fabiana Santana (Fabí) e Jocelma Silva (Raquel) que sonharam comigo e enveredaram por caminhos novos de possibilidades, inaugurando um movimento formativo coletivo na escola e produzindo inéditos-viáveis tão necessários quanto importantes para a vida social e profissional de cada uma. Na mesma direção, o calor humano dos(as) alunos(as) que nos instigaram na busca pelo ser-mais. O apoio sem reservas do Centro de Ensino Médio 03 de Ceilândia, em especial dos gestores Divaldo e Rogério que garantiram a efetiva autonomia dos sujeitos da pesquisa e Fernando, pela ajuda de sempre.

À professora Ana Freitas que me conduziu no entendimento e aprofundamento da categoria do inédito-viável, especialmente pelas contribuições desde a qualificação e por me acompanhar na viagem a São Paulo para entrevistar a professora Nita Freire.

À professora Regina Pina pelas aprendizagens constantes, pelo olhar atento, cuidadoso que contribuiu para além da qualificação deste trabalho, mas principalmente pela parceria nas ações da SBEMDF que me inseriu definitivamente no universo da Educação Matemática. 
Ao professor Renato Hilário, pelas sábias provocações de um sujeito amoroso e comprometido com causas nobres da Educação, enquanto dimensão ética e política, pensamento com o qual comungo e pelo qual me empenho na luta esperançosa.

À professora Kátia Curado por me desestabilizar nas discussões acerca da formação de professores(as) e, por isso mesmo, provocar inquietações que me impulsionaram na busca pela formação crítico-emancipadora.

Ao professor Cleyton por aceitar contribuir neste trabalho, a partir da lente da Educação Matemática. Aos demais professores(as) da Faculdade de Educação da UnB com os quais cursei disciplinas e troquei experiências que serviram de aprendizagens e de ancoragem para a construção da aprendizagem significativa. À professora Albertina Martínez ensinou a importância dos processos subjetivos para a aprendizagem; professor Gilberto Lacerda desconstruiu ideias sobre a epistemologia do conhecimento; professora Wivian Weller abriu espaço para a discussão sobre análise de conteúdo.

Aos professores Balduíno Andreola, Conceição Fonseca e Nita Freire pelos ricos diálogos que aprofundaram conceitos importantes que discutimos neste trabalho, como: formação, letramento e inéditos-viáveis.

As amigas Patrícia Torres, Roberta Freitas, Wanna Santos, Ana Porto e Raquel Dörr. Patrícia pela acolhida em Brasília, por me ceder livros, pela doce companhia. Roberta que foi minha guia quando precisei me deslocar nessa nova cidade, uma amiga de todas as horas. Wanna pela ajuda mútua e incondicional em todas as instâncias da vida. Ana porque fez muitas perguntas para que eu mobilizasse as várias possibilidades de respostas, por estudar comigo, por me ensinar a ser uma professora que aprende e ensina Matemática. Raquel que se manteve presente com afeto e cuidou de trazer toda a sua tranquilidade para preencher os meus momentos de ansiedade na pesquisa.

Ao grupo Edem por fortalecer nosso diálogo em prol da Educação Matemática e pelo empenho e dedicação nas ações da SBEMDF, especialmente Rai Oliveira, Carine Noleto, Marilene Xavier e Fabiana Barros que em matéria de ajuda, apresentam boa vontade e companheirismo sem medida. Nesse contexto também a professora Nilza Bertoni pelos ensinamentos tão valiosos que me permitiram a construção de conceitos importantes nesse campo do conhecimento.

À Universidade de Brasília pela estrutura física, administrativa e pedagógica que me possibilitou crescer enquanto pessoa e como profissional docente, ampliando minha visão de mundo e contribuindo para meu desenvolvimento profissional. Estendo aqui o reconhecimento e agradecimento ao pessoal da secretaria do PPGEd pela agilidade na emissão de documentações.

A Capes que tanto no mestrado quanto no doutorado me concedeu bolsa de estudos, possibilitando que eu estivesse de dedicação exclusiva para estudar, pesquisar e publicar trabalhos, garantindo que eu tivesse melhor desempenho e aproveitamento na pós-graduação. 


\section{RESUMO}

A tese apresentada é produto de uma investigação que teve como pedra angular o estudo dos inéditos-viáveis constituídos por professores que ensinam Matemática na Educação de Jovens e Adultos (EJA). Os inéditos-viáveis e as situações-limite são categorias freireanas utilizadas no trabalho como elementos articuladores e provocativos da formação. Situação-limite diz respeito aos obstáculos e barreiras que interpõem na vida e no trabalho do sujeito; inédito-viável refere-se aos sonhos possíveis, à materialização desses sonhos. $\mathrm{O}$ pressuposto que rege as análises é que a constituição dos inéditos-viáveis propicia ao professor a construção de conhecimentos, a superação de situações-limite e a reorganização do trabalho pedagógico com a Matemática, o que pode ocorrer por meio da e na formação continuada. $\mathrm{O}$ cenário concebido para a formação continuada denominou-se círculos de investigação formativos - desenvolvidos em uma escola pública do Distrito Federal, com a participação ativa de seis professoras que ensinam Matemática nos anos iniciais da modalidade EJA. Nos processos formativos, a ação dialógica permitiu estudos, discussões e tomada de decisões por um coletivo de professoras, inscritas no movimento histórico de denúncia das situações-limite e anúncio de inéditos-viáveis. Nesse contexto, a epistemologia do conhecimento que dialoga com a relação e o ponto de tensão de tais elementos é a dialética. A estratégia investigativa tem características que se aproximam da pesquisa participante, e as participantes constituem um grupo coeso, articulado e comprometido político e pedagogicamente com a aprendizagem significativa que passa a ocupar um espaço privilegiado na pesquisa. $\mathrm{O}$ cerne da aprendizagem cuja contribuição teórica se filia este estudo foi de Ausubel (1968) e Vergnaud (2009). Os alinhavos conclusivos dessa investigação apontaram que a formação dentro da escola permitiu que as professoras desenvolvessem um trabalho coletivo, constituindo inéditos-viáveis que coincidiam substantiva e adjetivamente com a aprendizagem. Para dar conta de sua riqueza conceitual, realizamos uma análise qualitativa, organizando e reunindo elementos e conteúdos significativos em unidades de análises, que, de modo amplo, ficou assinalado como categoria do aprender. A aprendizagem significativa foi paulatinamente se configurando como um processo contínuo, construído por uma coletividade que se fortaleceu nas ações dialógicas em que se fez a opção por um trabalho na perspectiva da práxis. O resultado foi que as professoras construíram conhecimentos significativos a partir da utilização de situações-problema que permitiram a mobilização dos campos conceituais; estudaram e planejaram coletivamente as situações de aprendizagem envolvendo a conexão de saberes e as práticas de letramento, ampliando a concepção de Educação Matemática. Segundo as professoras, a superação do trabalho individual e solitário consistiu na potencialidade da formação, que, por esse motivo, denominaram de coordenações coletivas, porque oportunizou o diálogo e o trabalho articulado. Devido a essa característica, concluímos que a formação dentro da escola tornou-se um espaço fértil para a constituição dos inéditos-viáveis e de aprendizagens significativas e contínuas. O encorajamento do sujeito pelos pares favoreceu a autonomia, a criatividade e a criticidade para gerir os processos de aprender e ensinar Matemática, nas dimensões freireanas da ética, estética e política, inaugurando um movimento emancipatório na vida pessoal e profissional das professoras.

Palavras-chave: Inéditos-viáveis. Formação continuada. Professor que ensina Matemática. Educação de Jovens e Adultos (EJA). 


\begin{abstract}
The thesis here presented is the product of an investigation that had as its central element the study of the viableunknown composed by teachers who teach mathematics in Youth and Adult Education (EJA). The viableunknown and the limit situations are some of Freire's categories used in the present study as articulators and provocative elements of training. Limit situations encompasses the obstacles and barriers that intervene in the life and work of the subject; the viable unknown refers topossible dreams and the realization of said dreams. The main assumption of the analysis is that the establishment of viable unknown enables the teacher to build knowledge, overcomelimit situations and reorganize pedagogical work with mathematics, which may occur through and in continuing education. The scenario designed for continuing education was named formative research circles - developed in a public school in the Federal District, with the active participation of six teachers who teach mathematics in the early years of EJA. In the formative processes, the dialogic action allowed studies, discussions and decisionmaking through a group of teachers, insertedin the historical movement of calling outlimit situations and viable unknown. In this context, the epistemology of knowledge that speaks to the relationship and the pressure points of such elements is dialectics. The investigation strategy has characteristics that approach the participant research, and the participants compose a group that is cohesive, articulated and committed politically and pedagogically with significant learning, that comes to occupy a privileged place in the research. The core theoretical contribution to which this study is affiliated to was Ausubel (1968) and Vergnaud (2009). The conclusive outline of this research indicated that training within the school allowed teachers to develop collective work, building viable unknownthat coincidedsubstantively and adjectivally with learning. To cope with its conceptual richness, we conducted a qualitative analysis, organizing and bringing together elements and meaningful content in units of analysis, which, broadly, was marked as a category of learning. Meaningful learning was gradually shaping up as a continuous process, built by a community that strengthened itself through dialogic actions, which made the choice of a work from the perspective of praxis. The result was that the teachers have built significant expertise from the use of problem situations that allowed the mobilization of conceptual fields; studied and collectively planned learning situations involving knowledge connection and literacy practices, broadening the conception of mathematics education. According to teachers, overcoming the individual and solitary work brought potential to training, which, therefore, they named collective coordination, since it provided an opportunity for dialogue and joint work. Because of this characteristic, we conclude that the training within the school has become a fertile ground for building viable unknown and significant and continuous learning. The encouragement of the subject through peers favored autonomy, creativity and criticality to manage the processes of learning and teaching mathematics, in Freire's ethical, aesthetic and political dimensions, inaugurating an emancipatory movement in the personal and professional lives of teachers.
\end{abstract}

Key-words: variable-unknown. Continuing education. Teacher that teaches math. Youth and Adult Educations (EJA). 


\section{RESUMEN}

La tesis presentada es un producto de una investigación que tuvo como piedra angular el estudio de los inéditos viables constituidos por profesores que enseñan Matemática en la Educación de personas Jóvenes y Adultas (EJA). Los inéditos viables y las situaciones límite son categorías desarrolladas por Paulo Freire y utilizadas en este trabajo como elementos de articulación y promoción de la formación. Situación límite se refiere a los obstáculos y barreras que interponen en el trabajo y en la vida del individuo; el inédito viable se refiere a los sueños posibles y la materialización de eses sueños. El presupuesto que conduce los análisis es que la constitución de los inéditos viables propicia al profesor la construcción de conocimientos, la superación de situaciones límite y la reorganización del trabajo pedagógico en el ámbito de la Matemática, lo que puede ocurrir mediante la formación continuada y en la formación continuada. El escenario creado para la formación continuada se tituló círculos de investigación formativos: desarrollados en una escuela pública del Distrito Federal - Brasil, envolviendo la participación activa de seis profesoras que enseñan Matemática en los primeros años de la modalidad EJA. En los procesos formativos, la acción dialógica permitió estudios, discusiones y toma de decisiones por un grupo de profesoras, inscriptas en el movimiento histórico de denuncia de las situaciones límite y anuncio de los inéditos viables. En ese contexto, la epistemología del conocimiento que dialoga con la relación y el punto de tensión de dichos elementos de llama dialéctica. La estrategia investigativa tiene características que se acercan de la investigación participante y las participantes constituyen un grupo cohesionado, articulado y comprometido políticamente y pedagógicamente con el aprendizaje que viene a ocupar un espacio privilegiado en la investigación. El núcleo del aprendizaje cuya contribución teórica se une a ese estudio fue de Ausubel (1968) y Vergnaud (2009). Los rasgos conclusivos de esta investigación señalaron que la formación en las escuelas permitió que las profesoras desarrollaran un trabajo colectivo, constituyendo inéditos viables que coincidan de manera substantiva y adjetiva con el aprendizaje. Para alcanzar su riqueza conceptual, hemos realizado un análisis cualitativo, organizando y reuniendo elementos y contenidos significativos en unidades de análisis, que, de manera amplia, quedaron señalados como una categoría del aprender. El aprendizaje significativo se fue paulatinamente configurando como un proceso continuado, construido por una colectividad que se fortaleció en sus acciones dialógicas en las cuales se hizo la opción por un trabajo en la perspectiva de la praxis. Como resultado, las profesoras construyeron conocimientos significativos a partir de la utilización de situaciones problema que permitieron la movilización de los campos conceptuales; estudiaron y planificaron colectivamente las situaciones de aprendizaje que envuelven la conexión de los saberes y de las prácticas de la alfabetización, ampliando el concepto de Educación Matemática. Segundo las profesoras, la superación del trabajo individual y solitario consistió en la potencialidad de la formación, que, por ese motivo, la denominaron coordinaciones colectivas, porque dio oportunidad al diálogo y al trabajo articulado. Debido a esa característica, concluimos que la formación en la escuela se convirtió en un espacio fértil para constitución de los inéditos viables y de aprendizajes significativos y continuados. La incentivación del individuo por parejas favoreció la autonomía, la creatividad y la criticidad para gestionar procesos de aprender y enseñar Matemática, en las dimensiones ética, estética y política sostenidas por Freire, inaugurando un movimiento de emancipación en la vida personal y profesional de las profesoras.

Palabras clave: Inéditos-viables. Formación continuada. Profesor que enseña Matemática. Educación de personas Jóvenes y Adultas (EJA). 


\section{LISTA DE FIGURAS}

Figura 1: Integração-relação dos momentos pedagógicos de sonhar, estudar e criar ................. 35

Figura 2: Esquema conceitual para a teoria dos campos conceituais relacionando-a com a

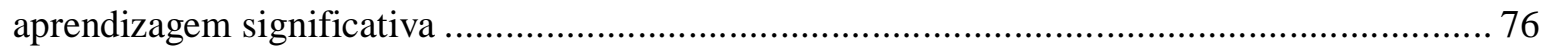

Figura 3: Mapa das Regiões Administrativas do DF, com destaque para Ceilândia/DF ........... 118

Figura 4: Mapa das escolas da Secretaria de Educação do DF - Regional Ceilândia ............... 120

Figura 5: Identificação simbólica das cédulas de real ...................................................... 152

Figura 6: Correspondência das cédulas de real ............................................................. 153

Figura 7: Cédulas de real com reverso e anverso ............................................................ 154

Figura 8: Bolsa da revista e bolsas vermelhas confeccionadas pelas professoras ................... 188

Figura 9: Bolsa da revista e bolsa verde confeccionada pelas professoras............................ 189

Figura 10: Bolsas confeccionadas pelos alunos da EJA em grupos....................................... 201

Figura 11: Bolsas confeccionadas e apresentadas pelos alunos da EJA............................... 202

Figura 12: Mapa do Brasil com a sigla dos estados e Distrito Federal .................................. 222

Figura 13: Gráfico desenhado pela professora Rute ...................................................... 228

Figura 14: Instrumentos de medidas de massa, alimentos e alunos (ao redor) ......................... 240

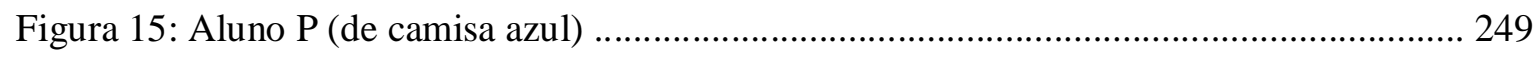

Figura 16: Contexto da constituição de inéditos-viáveis ..................................................... 262

Figura 17: Livros mais solicitados no ensino superior dos EUA, na área da Educação segundo o Projeto Open Syllabus 274 


\section{LISTA DE QUADROS}

Quadro 1: Organização dos segmentos da EJA no Distrito Federal ....................................... 69

Quadro 2: Organização dos componentes curriculares por segmento na EJA .......................... 71

Quadro 3: Correspondência entre etapas e conteúdos de Matemática para EJA..........................72

Quadro 4: Fases da pesquisa participante ..................................................................... 106

Quadro 5: Campos Conceituais na perspectiva de Vergnaud (2009) ..................................... 167

Quadro 6: Aprendizagem como processo contínuo e inconcluso .......................................... 179

Quadro 7: Aprendizagem como processo de construção coletiva e formativa.......................... 203

Quadro 8: Aprendizagem enquanto formação política ........................................................ 231

Quadro 9: Aprendizagem enquanto processo formativo emancipatório ................................. 253 


\section{LISTA DE TABELAS}

Tabela 1: Estado da Arte - publicações no Encontro Nacional de Educação Matemática (ENEM) 63

Tabela 2: Estado da Arte - publicações no Simpósio Internacional de Pesquisa em Educação Matemática (SIPEM) 65

Tabela 3: Estrutura física do Centro Educacional 03 de Ceilândia/DF 121

Tabela 4: Perfil pessoal dos alunos da $1^{\mathrm{a}}$ etapa da EJA.................................................129

Tabela 5: Perfil pessoal dos alunos da $2^{\mathrm{a}}$ etapa da EJA............................................... 130

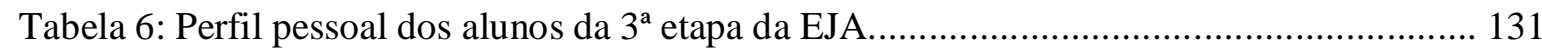

Tabela 7: Perfil pessoal dos alunos da $4^{\mathrm{a}}$ etapa da EJA ...................................................... 132

Tabela 8: Síntese realizada pelos grupos de alunos com as informações acerca do número de manifestantes divulgado pela organização do evento (conforme Apêndice F) ....................... 226 


\section{SUMÁRIO}

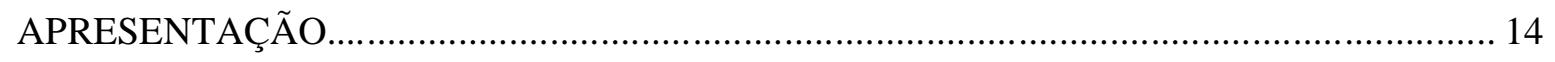

1 O INÉDITO-VIÁ VEL COMO CATEGORIA FUNDAMENTAL DA PESQUISA ............... 17

1.1 Constituição dos inéditos-viáveis na relação com a pesquisadora .................................. 19

1.2 Contexto dialético do universo da pesquisa .................................................................. 24

2 OS INÉDITOS-VIÁVEIS NA/DA FORMAÇÃO CONTINUADA DE PROFESSORES ...... 30

2.1 Inéditos-viáveis: contextualização e influência na formação de professores...................... 31

2.1.1 Situações-limite, atos-limite e inédito-viável: contribuições teóricas ......................... 37

2.2 Formação continuada de professores: concepções e perspectivas................................... 43

2.2.1 Formação continuada de professores que ensinam matemática: sentidos e

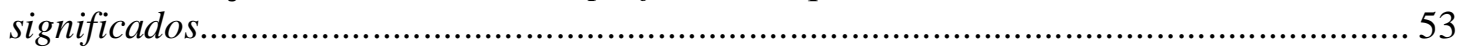

2.2.2 Formação continuada de professores que ensinam Matemática na Educação de Jovens e Adultos (EJA): uma experiência na perspectiva do letramento............................ 58

2.3 Organização do trabalho pedagógico e currículo da Matemática na EJA: olhar formativo

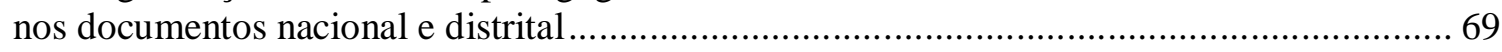

2.3.1 Do olhar formativo à ação formativa: aprendizagem matemática em foco ............... 73

2.4 O diálogo tecido com autores de nosso tempo sobre letramento, formação de professores e





$3.1 \mathrm{O}$ método dialético para tecer a pesquisa .............................................................. 97

3.2 A pesquisa participante na perspectiva do diálogo, da formação e da emancipação ....... 100

3.2.1 Do ocular aos vestígios que a pesquisa precisou captar ....................................... 108

3.3 A construção do diálogo na escola com os participantes da pesquisa ........................... 115

3.3.1 Demarcação física e histórica do contexto pesquisado ........................................ 117

3.3.2 Na relação dialógica fomo-nos constituindo participantes da pesquisa .................. 122

4 INÉDITOS-VIÁVEIS E A APRENDIZAGEM SIGNIFICATIVA ................................... 143

4.1 Mobilizar e gerar conhecimentos: privilégios da Teoria dos Campos Conceituais?........ 148

4.2 Diversas situações, variados conceitos: construindo aprendizagens significativas.......... 150

4.3 Construir conceitos envolve diálogo e ação que gera aprendizagens coletivas ............... 186

4.4 Condução e ampliação da aprendizagem pelo sujeito ativo........................................... 210

4.5 Aprender como condição ontológica e provocadora de inéditos-viáveis ........................ 238

4.6 O diálogo com as participantes e os sonhos como possibilidade .................................. 265

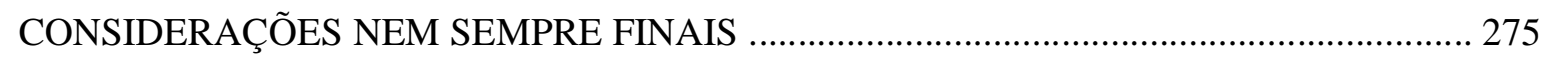

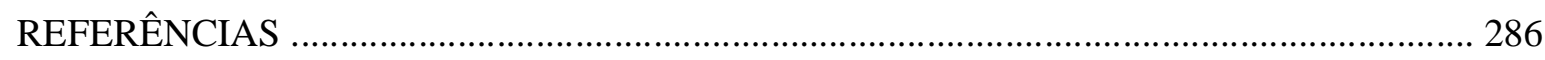

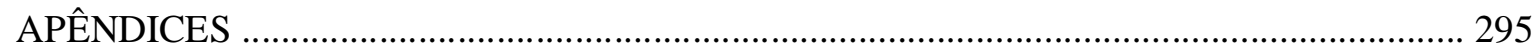




\section{APRESENTAÇÃO}

Durante a realização dessa pesquisa, marcadamente no ano de 2015, assistimos a situações de denúncia e anúncio no contexto nacional brasileiro, ao qual não estivemos imunes às condições sociohistóricas. Contudo, movidos pelo compromisso político com a Educação, não recuamos. Procuramos estabelecer relação entre o contexto social, econômico e político da realidade atual com a inauguração dos processos formativos coletivos que realizamos dentro de uma escola pública do Distrito Federal. Acreditamos no pressuposto que na e a partir da formação as professoras pudessem constituir inéditos-viáveis, construir conhecimentos, superar as situações-limite e reorganizar o trabalho pedagógico com a Matemática.

Essa foi uma das importantes contribuições deste trabalho, pois a ação dialógica permeou o processo formativo de seis professoras que ensinam Matemática nos anos iniciais da Educação de Jovens e Adultos (EJA). E o resultado do empenho, das trocas de experiências e dos consensos foi a aprendizagem significativa, ocorrida também em meio a negações, mas que foi possível, porque se deu no diálogo entre os diferentes e não antagônicos. Corroborando com Freitas (2014, p. 13) "é no diálogo entre os diferentes que vamos reunir forças para lutar contra os antagônicos!", nesse sentido, não poupamos esforços e mergulhamos nesse projeto de formação humana, epistemológica, social, filosófica e política, cenário fértil da constituição de inéditos-viáveis.

O diálogo, assumido como elemento estruturador da atuação pesquisante foi realizado com o mundo que uma vez pronunciado (STRECK, 2013), assume um papel fundamental de formação histórica, ética, política e socialmente comprometido do sujeito que se educa e educa aos outros, na ação solidária e não solitária. Nessa perspectiva foi que o diálogo se fez importante nas interlocuções entre esta pesquisadora e seu orientador, com as professoras e os(as) alunos(as) da modalidade EJA, alimentado continuamente pela escuta atenta, respeito, compromisso, afeto, esperança e sonhos.

Nosso compromisso aqui é trazer aspectos relevantes dessa trajetória de pesquisa, da afinidade teórica, da opção metodológica, das produções de informações e de seus resultados, do modo como organizamos a escrita desse trabalho, intencionalmente sistematizado em cinco grandes partes. Tal organização foi para permitir a fluidez no entendimento daqueles(as) que tiverem a curiosidade e interesse em estudar, contribuir e ampliar as questões que aqui discutimos: a constituição dos inéditos-viáveis por professoras em processos de formação no campo da Educação Matemática na EJA. 
A primeira parte da escrita é intitulada "O inédito-viável como categoria fundamental da pesquisa", em que se atém na definição e explicitação dos inéditos-viáveis, que é assumido como uma importante categoria freireana ${ }^{1}$, assim como as situações-limite. Destacamos a relação dos inéditos-viáveis como implicação formativa e avançamos no sentido de trazer as questões provocativas da pesquisa, os objetivos, a tese que defendemos.

Nessa linha, "Os inéditos-viáveis na/da formação continuada de professores" trata da segunda parte, em que se tem a abordagem teórica acerca da contribuição de Freire (2011), Freitas (2001) e Nita Freire (2014) sobre os inéditos-viáveis. E a partir disso, empreendemos um diálogo afinco com a formação de professores(as), especialmente discutindo a perspectiva, os sentidos e significados da formação continuada para as docentes que ensinam Matemática nos anos iniciais da EJA. Nesse cenário, também foi importante a utilização das práticas de letramento, fortalecida com a teoria vergnaudiana dos campos conceituais e a teoria ausubeliana da aprendizagem significativa.

As implicações teórico-metodológicas vêm descritas na terceira parte, em que se faz a “Tecitura dos caminhos da pesquisa”, na qual destacamos a contribuição do método dialético como interlocutor dos diálogos diferentes e não antagônicos e explicitamos nossa opção pela pesquisa participante, tendo em vista o compromisso de realizar a pesquisa com as professoras e não sobre estas. Também descrevemos os passos da pesquisa, desde a produção das informações nos círculos de investigação formativos até a organização e análise destas informações em categorias e unidades de análise, com a utilização da análise de conteúdo.

Em coerência com o estudo proposto, a quarta parte da tese, intitulada "Inéditos-viáveis e a aprendizagem significativa", aglutina as reflexões mais profícuas a respeito da ação dialógica formativa envolvendo pesquisadora, professoras e alunos e o resultado dessa relação de encorajamento para a constituição dos inéditos-viáveis. Desse movimento formativo, foi possível delinearmos unidades de análise concentradas em categorias mais amplas que se confirmaram na aprendizagem significativa. A aprendizagem esteve intimamente ligada à potencialidade dos processos formativos que são contínuos e se dão na perspectiva da coletividade, contribuindo demasiadamente para a formação política do sujeito, na dinâmica da práxis emancipadora.

Quando nos encaminhamos para a escrita da quinta parte do trabalho, intencionalmente denominada "considerações nem sempre finais", foi necessário condensar as ideias chave da pesquisa. De um lado tivemos o compromisso de alinhavar os aspectos mais importantes e os

\footnotetext{
${ }^{1}$ Optamos pela grafia com "e" (freireana) e não com "i”" (freiriana) para mantermos o sobrenome de Freire, embora saibamos que só os adjetivos terminados em "e" tônico exibem a forma sufixal - eano, recomendando-se assim a grafia freiriano, com sufixo - iano, porque o "e" de Freire é átono.
} 
resultados que essa experiência de investigação nos oportunizou. De outro lado sentimos que em mil páginas não seria possível dizer tudo o que nos ocorreu, a situação de afeto, de respeito, de crença, de trocas de saberes, as singularidades que se permitiram plurais na rica produção de aprendizagens, provocadas na e a partir da formação.

Enfim, no cenário histórico e político-social que vivemos, especialmente quando acompanhamos o posicionamento político dos sujeitos sociais, que ocupam as ruas em grandes manifestações, consideramos que este trabalho poderá contribuir para a ampliação das situações de aprendizagem. Aprendizagem não apenas no âmbito da formação escolar, mas também de formação humana, social e política, a partir de provocações e inquietações que associadas a estas, poderão inaugurar um tempo de esperança e possibilidades, na constituição de inéditosviáveis. Por isso, apresentamos aos estudantes, leitores e leitoras, professores e professoras ${ }^{2}$, pesquisadores e pesquisadoras, um material formativo que, engendrado pelo movimento histórico, precisa ser recriado e reinventado continuamente.

\footnotetext{
2 O emprego do substantivo masculino "professor" e/ou "professores" diz respeito a toda pessoa que tem por profissão ensinar, mesmo quando não grafarmos o substantivo feminino "professora" e/ou "professoras". A partir do quarto capítulo, faremos o uso do termo "professoras" para nos referir às participantes da pesquisa.
} 


\title{
1 O INÉDITO-VIÁVEL COMO CATEGORIA FUNDAMENTAL DA PESQUISA
}

\author{
A consciência do mundo e a consciência de si \\ como ser inacabado necessariamente inscrevem o \\ ser consciente de sua inconclusão num permanente \\ movimento de busca [...] \\ (FREIRE, Pedagogia da Autonomia, 1996, p. 57)
}

Nesse momento no qual se inicia um diálogo profundo com as questões que nos inquieta, trazemos, no primeiro instante, essa reflexão de Freire quanto à certeza de sermos inconclusos e incompletos. Fato esse que nos impulsiona na busca de ser mais curioso e criativo, para que o movimento de construção do conhecimento possa nos inquietar permanentemente, passando de um desejo para um sonho que é viável. Esse é o pressuposto básico deste trabalho de investigação.

Delinear o objeto de pesquisa é rememorar toda uma trajetória de inquietação de uma pesquisadora que tem se envolvido na luta ética, política e epistemológica a favor da modalidade de Educação de Jovens e Adultos (EJA). Modalidade essa com origem na luta pelos movimentos populares, e que é pertinente destacar que não se trata de uma luta solitária, pois há pessoas que se importam e que também lutam pelo seu desenvolvimento, como é o caso das professoras participantes da presente pesquisa. Essa união de esforços nos faz mais esperançosos de lutar para garantirmos um futuro com uma educação melhor, mais digna, mais democrática e ética na EJA.

Ao sermos conscientes da inconclusão e da incompletude é que nos inscrevemos como seres históricos e, assim, também é a pesquisa que, sendo histórica, não tem um fim. Somos inconclusos e nos dispomos a aprender continuamente. Certos da incompletude, buscamos uma aprendizagem com o outro. É nessa relação dialógica e dialética, por meio da pesquisa, que nos formamos e somos formados, mas não é uma formação por inteiro, podemos dizer que se trata de fragmentos formativos, porque é um processo infinito que envolve "sonhar, estudar, criar" (FREITAS, 2001). E, inevitavelmente, não é um processo livre de obstáculos e de armadilhas, mas é um caminho cheio de possibilidades quando percorrido por um coletivo que tem sonhos que não é apenas um desejo que esbarra na teoria, mas ações concretas que se materializam na e da constituição de inéditos-viáveis.

O inédito-viável constitui a categoria fundamental desta pesquisa porque representa o modo mais coerente de mostrar as possibilidades e a potencialidade de uma modalidade educacional, às vezes, tão esquecida pelas políticas públicas. Mas, então, o que é e como definimos essa categoria? Em que teórico(s) nos apoiamos e qual sua validade? 
Os inéditos-viáveis correspondem à concretização dos sonhos, à materialização das conquistas, dos resultados da superação de obstáculos que interferem na vida pessoal, social e profissional. É um passo decisivo pela transformação de dada realidade, ocorre no movimento dialético e crítico entre o ser e o não ser, defendido por Freire, a favor da emancipação.

Estamos denominando categoria, primeiramente, por reconhecermos que imprime os principais conceitos que contribuem para o entendimento dos conhecimentos construídos pelos participantes da pesquisa. Em segundo lugar, porque nos permite perceber o desenvolvimento do profissional que atua na EJA. E, por fim, porque amplia um conceito tão pouco estudado e pesquisado no meio acadêmico. Além disso, outras duas ideias importantes de Freire aparecem neste trabalho que são as situações-limite (barreiras, obstáculos) e os atos-limite (ações concretas), os quais detalharemos adiante.

O inédito-viável foi empregado pela primeira vez por Freire, em sua obra Pedagogia do Oprimido. Esse conceito aparece sete vezes em todo o livro, está grafado sempre no singular e sem hífen (inédito viável). Contudo, optamos por grafar no plural e com hífen (inéditos-viáveis) porque na junção desses dois elementos obtemos a palavra composta que exprime a necessidade de uma para validar a outra: inédito = sonho; viável = possível. Nesse contexto, não pensamos em um sonho que não possa se concretizar tampouco em possibilidade que não seja mediada pelo sonho. Além disso, Freire sinalizava que não queria seguidores, mas recriadores, comprometidos em dar a materialidade ao sonho.

\begin{abstract}
Talvez para alguns o nome Paulo Freire tenha virado marca, uma espécie de grife para garantir credibilidade ou legitimidade, desde nome de escolas a citações de trabalhos acadêmicos. Mas, para a grande maioria que se ocupa com seu pensamento e sua obra, Freire simboliza a possibilidade de se pensar o que ele chamava inéditos-viáveis. Essa busca de inéditos-viáveis ou do sonho possível pode acontecer no cotidiano da sala de aula, na gestão de escolas ou de sistema de ensino, no trabalho com saúde pública, em movimentos sociais e em qualquer lugar onde se aceita a premissa de que o futuro não precisa ser a repetição do presente e que a educação tem um papel em projetar e construir este outro futuro. A educação, está certo, não tem o poder da economia, o voto dos políticos ou as armas do exército. Mas, paradoxalmente, para Freire, é nesta sua fraqueza que reside sua força. A palavra, quando unida à ação, tem um poder mágico (STRECK, 2007, p. 7).
\end{abstract}

A escrita de Streck traduz a importância da fundamentação freireana que gostaríamos de expressar e também mostra a coerência do pensamento de Paulo Freire em relação à educação enquanto sonho possível, o inédito-viável. Nessa mesma perspectiva, acreditamos na validade e atualidade de tal pensamento para o contexto educacional. Assim, tomamos os inéditos-viáveis como categoria fundamental para que os(as) professores(as) construam conhecimentos em e $a$ partir da formação continuada. 
Essa foi apenas uma prévia do diálogo que propomos ao longo deste trabalho, que não dispensa um olhar curioso e crítico a fim de contribuir para o enriquecimento e ampliação deste. É nesse e por esse inédito-viável que nos constituímos e somos constituídos diariamente.

\subsection{Constituição dos inéditos-viáveis na relação com a pesquisadora}

A contento, queremos justificar que o relatório completo deste trabalho de pesquisa foi escrito na primeira pessoa do plural, tendo em vista que, desde o princípio, quando ainda estava no plano das ideias, o objeto já havia se manifestado a partir de inquietações que emergiram de experiências coletivas. A exceção se dará apenas quando for de extrema necessidade, como é o caso do texto a seguir que conta a trajetória pessoal e profissional de uma pesquisadora comprometida com o contexto da EJA.

De modo singular, a relação com os inéditos-viáveis aconteceu de forma não linear e no conjunto das relações sociais, culturais e históricas, na vida pessoal e no mundo acadêmico. Ao me reconhecer no contexto social de dificuldades, mas de possibilidades, fui me inscrevendo esperançosa no mundo dos sonhos possíveis, o que na perspectiva freireana denominamos de ser e estar no mundo.

No espaço desta escrita, biografar-me é também historicizar-me, é assumir minha identidade enquanto gente que sonha, enquanto profissional que acredita e que adota uma postura ética e política de luta em favor da educação. Esse registro escrito apresenta característica ímpar de como me constituí ao longo da vida.

Nasci em 1984, em Pedreiras/MA, cidade localizada a 236 km da capital São Luís. Mas fui criada em Campo Maior/PI (localizada a $80 \mathrm{~km}$ da capital Teresina), só em 2001 retornei à minha cidade natal e fiquei até janeiro de 2011. Sou filha de Antônio Sousa Alves e Laura Rosa de Oliveira Alves. Ele não teve a oportunidade de estudar porque seu pai dizia que apenas o trabalho dignificava o homem e que traria comida à mesa. Antônio, aos 18 anos de idade, casouse com Laura de 17 anos de idade e, desse casamento, nasceram duas meninas e quatro meninos (um não vingou) e criaram os cinco.

Laura conseguiu estudar até a $4^{\mathrm{a}}$ série (atual $5^{\circ}$ ano), assim lê e escreve muito bem, já Antônio só trabalhou. No entanto, o sonho de Antônio era que seus filhos estudassem e se formassem para que tivessem um futuro melhor que o dele. Tinha orgulho de levar os cinco filhos em uma bicicleta da marca Monark para a escola. Os vizinhos ficavam admirados com a força daquele homem, com a coragem e determinação com que levava seus filhos para o lugar que acreditava ser o que lhes proporcionariam um futuro melhor: a escola. 
Os cinco filhos que estudaram em escola pública tomaram o sonho de seu pai e de sua mãe como seus sonhos também. Tornou-se um sonho coletivo que precisava vencer as barreiras financeiras, haja vista que o pai era um marceneiro (sem carteira assinada) e a mãe cuidava do lar, do marido e dos filhos. O caderno, a borracha e o lápis eram os mais baratos e o sacrifício maior era para comprar a farda (apenas a camisa) para os cinco, mas, depois de negociar com a diretora que compraria duas fardas por mês, as coisas iam se ajeitando, tudo porque o sonho era viável. Contudo houve um tempo em que a situação ficou mais difícil e outras ações tiveram de aparecer, então, para que comprasse lápis, borracha e uma camisa de farda a menos, a metade dos filhos estudava de manhã e outra à tarde, para que os mesmos materiais pudessem ser usados. O resultado desse esforço foi a continuação dos estudos de uma das filhas que, em 2016, finaliza os seus estudos doutorais, na área da Educação, em uma Universidade pública brasileira.

Essa história é exemplificativa e real e foi relatada para expressar que os inéditos-viáveis constituem essa tomada de decisão e de ações que devem ultrapassar as situações-limite (as barreiras), em prol da concretude dos sonhos que são viáveis. Os sonhos, o investimento neles por meio do estudo, da pesquisa, da não acomodação fizeram emergir a criatividade, a autonomia, a transformação de uma realidade, pois, assim como os filhos de Antônio, também os seus netos não terão um futuro marcado pela falta da leitura e da escrita. Isso constitui os inéditos-viáveis na vida pessoal da pesquisadora e também no seu percurso acadêmico que é a continuidade dessa história.

No primeiro semestre de 2005, iniciei minha graduação em Pedagogia, na Faculdade de Educação São Francisco (FAESF), em Pedreiras/MA, e não sabia ao certo o que significava a minha opção por esse curso. O significado só foi construído a partir das leituras de Paulo Freire e a partir do estágio, em que tive a primeira experiência de trabalho na modalidade EJA. Foi decisivo porque direcionou meus primeiros passos para a docência e para a pesquisa, porque defini a EJA como meu campo de investigação. Foi uma construção marcante e irreversível: fui me constituindo professora.

Em outubro de 2008, antes de receber o grau de licenciada, fui convidada pela própria FAESF para lecionar no curso de Pedagogia, cujas turmas iniciariam no primeiro semestre letivo de 2009. Esse convite causou-me receio devido à responsabilidade de exercer a primeira experiência docente oficialmente no Ensino Superior, sem antes lecionar nos anos iniciais. Pedi um tempo para pensar, pois estava comprometida com a defesa da minha monografia, marcada para o mês de dezembro. Aconselhada pelas professoras, em novembro de 2008, matriculei-me na Pós-Graduação Latu Sensu e fui cursar a Especialização em Docência do Ensino Superior na FAESF e, ao final do curso, escrevi meu trabalho final sobre a atuação docente na EJA. 
Na semana seguinte à colação de grau, o convite de trabalho foi reforçado pela FAESF para lecionar no curso de Pedagogia. Recebi o incentivo da coordenadora do curso, a professora e amiga Dalva Queiroz, e realizei o processo seletivo de prova didática e prova oral. Fui aprovada. Assim, nos anos de 2009 e 2010, lecionei na instituição onde fiz minha graduação. Isso me deixava orgulhosa, pois os esforços empreendidos durante o curso foram reconhecidos e eu fui a primeira egressa a trabalhar na própria instituição: passei de graduada a professora da graduação. Confesso que ter sido convidada para trabalhar no Ensino Superior foi um desafio, pois, a priori, estava sendo formada para trabalhar com crianças. No entanto minha primeira experiência de trabalho foi no curso de Pedagogia.

Em 2010, fui aprovada no concurso para professor pedagogo das séries iniciais - 20 horas, com vínculo celetista pela Secretaria Estadual de Educação do Maranhão. A experiência de ensinar alunos do $3^{\circ}$ ano do Ensino Fundamental foi incrível e rendeu-me muita aprendizagem. Assim, com o apoio da gestão e da supervisão da Unidade Escolar Ciro Rêgo, trabalhei jogos e competições que envolviam a Língua Portuguesa e a Matemática, a fim de auxiliar os alunos no processo de leitura, escrita e cálculos.

Em Língua Portuguesa, desenvolvi dois projetos de leitura durante o ano, um deles resultou em uma revista denominada Cadê, o outro projeto foi Leitor mirim. Na Matemática, construí, com meus alunos, materiais didáticos (roletas, boliche, dominó, ábaco, figuras geométricas e outros recursos) para trabalhar operações e medidas, e promovemos as Olimpíadas Mirins de Matemática. Todo o material produzido com os alunos foi doado para a escola estadual.

No final de 2010, fui aprovada no processo seletivo do mestrado em Educação na Universidade Federal do Piauí (UFPI), na Linha de Pesquisa: Ensino, Formação de Professores e Práticas Pedagógicas. Por esse motivo, mudei para Teresina em fevereiro de 2011, pedindo demissão da faculdade e da Secretaria Estadual de Educação do Maranhão. Tomei essa decisão porque entendia que meu aproveitamento no curso de mestrado acadêmico seria melhor se eu tivesse dedicação exclusiva, pois disporia de mais tempo para me dedicar às produções acadêmicas, à participação em eventos científicos e publicações. Além disso, tinha convicção de que precisava continuar a pesquisa na EJA.

$\mathrm{O}$ interesse em investigar a EJA partiu das inquietações que as leituras de Freire me proporcionavam (Pedagogia do Oprimido, Pedagogia da Esperança, Pedagogia da Autonomia, Educação como Prática da Liberdade e outras obras). Sentia-me instigada a compreender, a partir do mundo empírico, a realidade dessa modalidade de ensino. 
Então, a proposta de estudo que apresentei na seleção do mestrado foi trabalhar a formação de professores, sob o tema de pesquisa Formação do professor da EJA: implicações políticas e pedagógicas. A definição do meu campo de pesquisa foi Pedreiras/MA porque sentia a precariedade dos processos de formação continuada do município. Então, propus-me a realizar um trabalho assegurado não somente na construção de informações sobre a formação, mas principalmente desenvolver o primeiro projeto de formação continuada com professores e professoras da modalidade EJA daquele município. Foi uma experiência marcante e inquietante.

Em março de 2011, iniciamos as aulas da Pós-Graduação da $19^{a}$ turma de Mestrado da UFPI. Durante o segundo mês de aula, concorri à bolsa da Coordenação de Aperfeiçoamento de Pessoal de Nível Superior (Capes). Fui a primeira bolsista dessa turma, porque os critérios eram a boa classificação no processo seletivo e não ter vínculo empregatício.

Ainda no primeiro semestre de 2011, fui filiada ao grupo de pesquisa, coordenado pela professora Dra Maria da Glória Carvalho Moura (minha orientadora no mestrado), denominado Núcleo Interdisciplinar de Pesquisa em Práticas Curriculares e Formação de Profissionais da Educação (NIPPC). Neste núcleo, fizemos estudos e promovíamos discussões de temáticas relacionadas às práticas pedagógicas, ao currículo e à formação dos(as) professores(as) que atuavam na modalidade de EJA.

No segundo semestre de 2011, ministrei a disciplina Metodologia da Língua Portuguesa, no $6^{\circ}$ bloco do curso de Pedagogia da UFPI, como requisito de estágio docente para os mestrandos bolsistas. Na oportunidade, assumi a sala de aula com a proposta de desenvolver um projeto denominado "Brincando também se aprende". Para este projeto, consegui o consentimento do Departamento de Métodos e Técnicas (DMTE), ao qual a disciplina e a minha orientadora estavam vinculadas. Então, conquistei a confiança e a adesão dos acadêmicos do curso para desenvolvermos o projeto com crianças de faixa etária entre 7 e 10 anos de idade. $\mathrm{O}$ objetivo do projeto foi desenvolver os processos de leitura, escrita e cálculo, a partir de jogos e competições educativas. Esse projeto foi avaliado com conceito excelente pela coordenação do curso de Pedagogia, pela professora orientadora, pelos acadêmicos e pela Secretaria da PósGraduação. E o mais importante foi que nos rendeu muito aprendizado.

Em novembro de 2011, surgiu uma oportunidade ímpar na minha vida profissional: fui convidada para ministrar a disciplina Educação de Jovens e Adultos, Educação do Campo e Educação do Sistema Prisional: aspectos legais e políticas públicas, no curso de Especialização em Docência dos Anos Iniciais do Ensino Fundamental, das Populações do Campo e Carcerária, na modalidade EJA, vinculado à Pró-Reitoria de Extensão da UFPI. O objetivo da disciplina era contribuir para formação do profissional da Educação Básica na modalidade EJA, refletindo os 
aspectos legais e políticas públicas na trajetória histórica da educação brasileira, considerando o contexto urbano, do campo e do sistema prisional.

Depois, fui convidada novamente para ministrar outra disciplina: Metodologia do Ensino da Matemática, cujo objetivo geral consistiu em discutir o processo de aquisição do conceito de número na EJA, desde as mais simples operações concretas até sua abstração, visando ao desenvolvimento de atividades voltadas ao seu ensino na primeira fase do Ensino Fundamental.

Essa última experiência foi singular porque representou a oportunidade de trabalhar a formação do educador matemático, haja vista que nessa especialização, havia as disciplinas: Metodologia do Ensino de Geografia, de História, de Língua Portuguesa e de Matemática. Destarte, para a disciplina voltada ao ensino da Matemática, os(as) professores(as) apresentaram rejeição, justificando que, além de ser muito difícil, era a que os alunos menos gostavam. Contudo, durante o curso, fui percebendo que os(as) próprios(as) professores(as) é que tinham dificuldade em estudar, conhecer e dominar os conceitos matemáticos.

Essa experiência foi imprescindível para construção de indagações que mereciam aprofundamento por meio da pesquisa. Não porque o conteúdo é tudo, mas não se pode deixar de reconhecer que é necessário o conhecimento de conteúdo. Além disso, a preocupação me conduzia a reflexões sobre a função do professor: a de ensinar. Como bem salienta Roldão (2007), a função do professor é de ensinar algo a alguém. Entretanto outro aspecto interferia nessa questão, que era o fato de esses(as) professores(as) não poderem ensinar aquilo que não aprenderam com significado.

Vale destacar que não estamos culpabilizando a formação inicial que não deu conta de preparar o(a) professor(a) com conteúdos matemáticos, pensamos que as situações-limite dessa aprendizagem podem ter decorrido da própria condição de ser e estar no mundo, que injustiça e desoportuniza esses profissionais. Então, diante dessas situações-limite (barreiras), é preciso pensar em elementos que possam superar e transformar essa realidade, o que é possível, a partir da constituição de inéditos-viáveis (que aprofundaremos adiante).

Nessa perspectiva, desejando ampliar os conhecimentos e contribuir com a elevação do quadro de pesquisas e publicações nessa área, resolvi, quando ainda cursava o último semestre do mestrado, tentar a seleção do doutorado na Universidade de Brasília (UnB). Como não foi oferecida vaga na linha de pesquisa voltada à EJA, tentei para a Educação Matemática e foi a decisão mais feliz da minha vida acadêmica. Assim, como fui aprovada na seleção do doutorado e precisava mudar para Brasília, agilizei e defendi minha dissertação em dezembro de 2012. Casei e mudei para Brasília em janeiro de 2013. Foram muitos os acontecimentos e as emoções vividas nos quatro últimos meses do ano de 2012. 
A escolha pela UnB aconteceu porque foi onde encontrei projetos educacionais bem articulados, voltados à Educação Matemática, especialmente dois me despertaram interesse e atenção. Um deles foi "A mediação do conhecimento matemático: uma proposta de (re)educação Matemática" para educandos em situações de dificuldade Matemática na Escola Classe 304 Norte, sob a coordenação do professor doutor Cristiano Muniz. Outro projeto denominava-se "Alfabetização e Formação de Alfabetizadoras(es) de jovens e adultos de camadas populares" desenvolvido no Paranoá/DF, coordenado pelo professor doutor Renato Hilário.

Durante o curso de doutorado em Educação, na Linha de Pesquisa Educação em Ciências e Matemática, busquei aprofundar os estudos sobre o ensino de Matemática com o foco na constituição de inéditos-viáveis, a partir da e na formação continuada de professores(as). Esses estudos foram fundamentais para que se estruturassem as questões de pesquisa, tal como trazemos a seguir.

\subsection{Contexto dialético do universo da pesquisa}

A partir da compreensão de como Freire (2011) descreveu as investigações realizadas com comunidades colaboradoras ${ }^{3}$, determinamos essa linha investigativa como promotora do diálogo que encaminhará para análises mais detalhadas sobre que relação e quais as contribuições da formação continuada para se constituir os inéditos-viáveis.

Note-se que investigação "é investigar, o pensar dos homens referido à realidade, é investigar seu atuar sobre a realidade, que é sua práxis” (FREIRE, 2011, p. 136). Mas não é uma investigação que se faz verticalmente, pois envolve diretamente o olhar atento e o pensamento crítico dos participantes sobre o tema que remete à "totalidade" de um dado contexto. Desse modo, essa totalidade não está na reunião dos fatos, mas na sua relação dialética (FREIRE, 2011).

O que estamos entendendo por relação dialética é a contraposição, a contrastação, a contradição de ideias que geram outras ideias. É, portanto, um diálogo que não é linear, mas um movimento de ir e vir sobre a realidade, sem negar os conflitos e os opostos, mas, ao contrário, buscando a comunicação entre esses, refletindo seus elementos e extraindo as principais ideias que as mantêm.

A partir desse contexto e mediados pelo diálogo com os(as) professores(as), buscamos identificar as situações-limite e reunir elementos que deem conta da constituição dos inéditos-

\footnotetext{
${ }^{3}$ Conferir as fases da investigação que Freire descreveu no livro Pedagogia do Oprimido (2011, 50. ed., p. 133 a 166).
} 
viáveis na práxis dos(as) professores(as) da EJA. Essas situações-limite também constituem categoria freireana e diz respeito aos obstáculos que interpõe a prática do professor. Voltaremos a descrevê-la com mais detalhes.

As inquietações mais amplas da pesquisa que auxiliam na compreensão e condução desse processo investigativo são as seguintes:

1) Quais as condições materiais e de tempo dos professores que ensinam Matemática na EJA para constituir círculos de investigação formativos que favoreçam a construção da práxis?

2) Quais situações-limite instigam a mobilização de inéditos-viáveis no contexto de professores que ensinam Matemática na EJA?

3) Como os inéditos-viáveis são constituídos na e a partir da formação continuada de professores que ensinam Matemática na EJA?

4) Que relação pode se constituir entre inéditos-viáveis e situações-limite na organização do trabalho pedagógico e na construção do conhecimento, na e a partir da formação continuada?

Cientes de que a busca por essas respostas tem implicado diálogo que envolve a afirmação e a negação de dada realidade, tendo em vista sua relação dialética, buscamos nos inéditos-viáveis elementos que contribuem para o avanço teórico e metodológico necessários ao desenvolvimento da investigação. Para essa mediação teórica utilizamos os processos de sonhar, estudar e criar (FREITAS, 2001), que aprofundaremos adiante. Quanto às contribuições metodológicas, buscamos relacioná-las com os próprios caminhos da investigação.

Essas questões não são mera formalidade acadêmica, representam a inquietação de quem realmente busca respostas, caminhos e diálogos dentro de uma importante modalidade de ensino, a Educação de Jovens e Adultos. Representa a oportunidade de fazer emergir elementos epistemológicos importantes, como a formação continuada, as ações dos(as) professores(as) que atuam no $1^{\circ}$ segmento da EJA e sua relação com o ensino da Matemática. Como sinalizamos anteriormente, a experiência com a formação inicial e continuada fez despertar o interesse em pesquisar os inéditos-viáveis de professores(as) que ensinam matemática na modalidade EJA.

Com isso, a finalidade era (e ainda é) de contribuir na construção de conhecimentos que pudessem (e que possam) ampliar o entendimento dessa modalidade. Entretanto, enquanto pesquisa de mestrado, não tivemos como aprofundar os estudos sobre uma área específica do conhecimento (como a Matemática, por exemplo). Naquela oportunidade, os colaboradores da pesquisa ministravam várias disciplinas (alguns polivalentes e outros de formação específica), 
pois o interesse de estudo era identificar como a formação continuada trazia implicações para a prática pedagógica do professor.

Então, em continuação aos estudos, mas, particularmente, no exercício da docência no curso de especialização, é que foi percebido que os professores e as professoras (a maioria com formação em Pedagogia) que atuavam nos anos iniciais da EJA apresentavam dificuldade para ministrar o conteúdo matemático, o que, algumas vezes, resultava na abstenção desse conteúdo em sala de aula em detrimento do ensino da escrita e da leitura.

Como nosso eixo de interesse e compromisso sempre foi a modalidade EJA, continuamos estudando sobre as contribuições da formação continuada para professores(as) dessa modalidade. Especialmente por acreditarmos que, em processos formativos, os(as) professores(as) constroem condições para investigação, contrastação e ruptura de dada realidade, que se dá pela constituição de inéditos-viáveis que também culmina na ação de (re)construir conhecimentos e conceitos que auxiliam para significação dos acontecimentos em sentido macro e para reorganização do ensino de suas matérias, no sentido micro.

Quando explicitamos o sentido macro e micro, estamos chamando a atenção para uma perspectiva do sujeito como ser que desenvolve a ação, quando da produção de significados e sentidos - nesse caso dos objetos matemáticos. Nesse sentido, a visão micro é aquela que busca a compreensão dos processos de produção de aprendizagem por aquele que se engaja em processos educativos. Os(as) professores(as) não buscam apenas os padrões gerais-universais e regulares (sentido macro), mas importam-se com as estratégias utilizadas no processo de produção e apropriação do saber pelo aluno da EJA. Ou seja, os(as) professores(as) podem assumir seu aluno e sua aluna como sujeito(a) único(a), com histórias próprias que definem sua relação com esse mundo. Esse esforço e envolvimento do professor é um exemplo de empenho para construção dos inéditos-viáveis.

Daí a justificativa para tomar como conceito orientador da pesquisa os inéditos-viáveis constituídos pelo professor que ensina Matemática nos anos iniciais da EJA, porque, nesse processo, o professor reúne elementos que o auxiliam a enfrentar as situações-limite que interferem na sua função de ensinar, mas também na sua vida social.

É preciso esclarecer o que são essas situações-limite que perpassam a vida do professor. As situações-limite são concebidas inicialmente por Álvaro Vieira Pinto (1960) como situação de luta e também de culpa e de fracasso frente às barreiras que o homem vê como intransponíveis. Contudo Freire, em Pedagogia do Oprimido (2011), amplia esse entendimento, assinalando que são freios e obstáculos que se interpõem na vida do homem e da mulher, mas que são passíveis de superação. Quando se empreendem ações refletidas e 
planejadas, constroem-se elementos para seu enfrentamento e, nesse caso, constroem-se os inéditos-viáveis. Impende que as situações-limite vão se mostrando aos seres humanos

\footnotetext{
como se fossem determinantes históricas, esmagadoras, em face das quais não lhes cabe outra alternativa, senão adaptar-se. Dessa forma o homem não chega a transcender as "situações-limite" e a descobrir ou divisar, mais além delas e em relação com elas, o inédito-viável (FREIRE, 2011, p. 130).
}

A análise do autor remetia à negação de uma atitude de acomodação frente ao mundo e à exploração em detrimento de uma postura de rupturas. Trata-se de uma chamada para o despertar, para a luta política pelos direitos de ser-mais e de realizar mais e, para isso, é necessário e urgente transpor as situações que limitam a vida social e profissional. Diz respeito à negação do que está posto e a afirmação pela mudança, a partir da luta ética e política, esperançosa e confiante, solidária e coletiva.

Assumimos essa postura de luta e, por isso, este estudo é um tanto complexo, desafiador e estimulante, à medida que nos lançamos com a responsabilidade de construir, em conjunto com as professoras - em uma relação dialógica - caminhos de investigação e transformação das situações-limite. Vamos assim reunindo elementos que ajudam a tornar os sonhos possíveis, pois como alertava Freire, somos seres de esperança que acreditam na realidade histórica.

Consideramos relevante esta pesquisa pois não se trata de um processo investigativo sobre os(as) professores(as), mas com os(as) professores(as). Assim, mobilizamos elementos que contribuíssem para uma práxis emancipadora. O estudo também possibilitou a ampliação dos horizontes de pesquisa no campo da Educação Matemática para a EJA, e esperamos que possa influenciar no empreendimento de políticas de formação continuada para a modalidade.

Este estudo foi orientado por objetivos que traduzem a clareza conceitual de nossa proposta de ação no contexto da EJA, conforme descrevemos a seguir.

\section{Objetivo geral}

- Analisar como a constituição dos inéditos-viáveis auxiliam na construção de conhecimentos e na superação das situações-limite as quais interferem na organização do trabalho pedagógico do professor que ensina Matemática nos anos iniciais da EJA.

\section{Objetivos específicos:}

- Identificar as condições materiais e de tempo para constituir círculos de investigação formativos, que favoreçam a construção de processos de ação e reflexão da práxis no campo da Educação Matemática no contexto da EJA. 
- Identificar que situações-limite instigam a mobilização de inéditos-viáveis no contexto de professores que ensinam Matemática na EJA.

- Analisar como os inéditos-viáveis são constituídos na e da formação continuada de professores que ensinam Matemática na EJA.

- Analisar a relação entre inéditos-viáveis e situações-limite na organização do trabalho pedagógico e na construção do conhecimento, na e a partir da formação continuada.

Os objetivos correspondem às ações empreendidas a fim de dialogar com as questões propostas neste estudo, mas também o seu conjunto concorre para uma função mais ampla, qual seja, a de despertar cada vez mais a curiosidade epistemológica (FREIRE, 2011). A partir desta, provocar descobertas e construções conceituais importantes, inclusive para organização do trabalho pedagógico do professor. Nesse sentido, as questões do estudo e os objetivos formulados encaminharam-se para validar a tese deste trabalho.

Os estudos realizados e a leitura atenta acerca dos inéditos-viáveis em Freire (2011) e em Freitas (2001) nos fizeram pensar sobre sua dinamicidade e extensão, pois o concebemos como a própria ação que desencadeia outras ainda mais importantes para o desenvolvimento profissional do professor. Então, não é só conceber inéditos para ensinar e para aprender, trata-se de construir teorias - conhecimentos e conceitos; superar os desafios do processo de ensinar-aprender (e viceversa); criar estratégias pedagógicas e metodológicas para promover uma Educação de qualidade e, por conseguinte, auxiliar para uma possível contribuição ao desenvolvimento profissional docente, fortalecendo sua função de ensinar. É nesse contexto que fazemos os alinhavos que resultam na defesa da seguinte tese:

\section{A concepção dos inéditos-viáveis propicia ao professor a construção de} conhecimentos, a superação de situações-limite e a reorganização do trabalho pedagógico com a Matemática, o que pode ocorrer por meio da e na formação continuada.

Os fios que teceram esta tese surgiram da inquietude e, principalmente, da esperança freireana de que a mudança não só é necessária como também é possível. Não se promove mudança na espera inerte, mas na esperança nutrida de ações que provocam e desestabilizam. A formação continuada em serviço pode e deve ser sutilmente provocativa, quando mergulhada no desenvolvimento da práxis. Então, bem mais que sugerir ou hipotetizar essa possibilidade, nos comprometemos em desenvolver um trabalho coletivo de formação com característica investigativa e formativa dentro da escola. Nosso interesse não se resume na comprovação da tese, trata-se do compromisso com os(as) professores(as) que ensinam Matemática, para que 
tenham oportunidade de perceberem o potencial que têm para superar os obstáculos da prática, construir conhecimentos e reorganizar o trabalho pedagógico.

Nossa caminhada com a EJA e com a comunidade acadêmica nos fez recorrer à teoria e à prática para compreender, explicar e contribuir com o processo de formação continuada em serviço, haja vista que ocorre dentro da escola. Com essa perspectiva, buscamos valorizar as concepções, considerar as fragilidades, as potencialidades de transformação dessa formação em um movimento crítico-emacipatório, em que se denunciam as situações-limite resultando na constituição coletiva de inéditos-viáveis.

O movimento crítico-emancipatório implica as idas e vindas, é próprio o movimento dialético dos participantes da pesquisa em que eles apreendem o conjunto de contradições implicado em suas relações profissionais e pessoais, no âmago e cotidiano da escola, mergulhados em contextos complexos. Assim, dizemos que o movimento é crítico porque advém da capacidade de questionar, de analisar de forma racional, e é emancipatório porque confere a liberdade por decidir sozinho(a) o caminho mais viável, o percurso não alienante, mas democratizante e democratizado.

Eminentemente, a importância da formação consiste na possibilidade de transformar uma realidade em que os próprios sujeitos compreendem que a ação e o pensamento não são etapas inseparáveis, mas sua dialogicidade sem hierarquias permite fugir do fatalismo e aderir ao movimento do ser-mais (FREIRE, 2011). Isso implica realizar mais porque é viável, portanto, é possível. E nesse cenário investigativo, o diálogo consiste em um elemento importante e indispensável para trazer os consensos e dissensos nas trocas, nas falas e escutas.

Para Zitkoski (2008, p. 131), “o desafio freireano é construirmos novos saberes a partir da situação dialógica que provoca a interação e a partilha de mundos diferentes, mas que comungam do sonho e da esperança de juntos construirmos o nosso ser-mais". O entendimento que temos a partir da leitura da perspectiva freireana é que o diálogo aqui não é uma técnica tampouco uma metodologia, por onde chegaremos aos conhecimentos, mas trata-se de um elemento de proximidade e interação com professoras e alunos(as) para problematizarmos os conhecimentos. E também, como incansavelmente defendeu Freire, esse diálogo deve estar a serviço do homem e da mulher para que tenha o direito de dizer sua palavra. 


\title{
2 OS INÉDITOS-VIÁVEIS NA/DA FORMAÇÃO CONTINUADA DE PROFESSORES
}

\author{
Um desses sonhos para que lutar, sonho \\ possivel mas cuja concretização demanda \\ coerência, valor, tenacidade, senso de justiça, \\ força para brigar, de todas e de todos os que a \\ ele se entreguem, é o sonho por um mundo menos \\ feio, em que as desigualdades diminuam, em que \\ as discriminações de raça, de sexo, de classe \\ sejam sinais de vergonha e não de afirmação \\ orgulhosa ou de lamentação puramente cavilosa. \\ No fundo, é um sonho sem cuja realização a \\ democracia de que tanto falamos, sobretudo \\ hoje, é uma farsa. \\ (FREIRE, Política e Educação, 2001, p. 25)
}

Neste capítulo, somos instigados e movidos pela possibilidade de realizar os sonhos porque eles movem a humanidade na busca do ser-mais e na conquista de um mundo mais humano, livre da opressão, mais solidário, democrático e criativo. Esse sonho é possível e é viável de se tornar real quando nos constituímos pela força coletiva, no processo transformador que gera os inéditos-viáveis.

Para que se torne entendível, discutiremos o conceito de inédito-viável com base em Freire $(1992,2011)$, Freitas $(2001,2005,2014)$ e Nita Freire (2014), a fim de explicitar no que consiste, como surgiu, de que modo tem sido empregado e em que contexto, quem usou esse conceito e com qual finalidade. Esse movimento faz-se necessário para compreendermos a influência e a relação entre esse conceito e a formação continuada de professores(as).

Utilizamos as contribuições de estudiosos como Gatti (2009, 2010, 2012), Nóvoa (1997, 1999, 2009) e Silva (2008, 2011), que discutiram concepções e perspectivas de formação de professores, ampliamos o diálogo ao tratar da formação continuada com os estudos de Santos (2010), Carr e Kemmis $(1988,2004)$ e outros autores que discutiram os resultados de pesquisas sobre algumas perspectivas teórico-metodológicas dos estudos ligados à formação continuada de professores(as).

No que concerne ao tema Matemática, dialogaram conosco os autores que discutiram formação continuada do professor que ensina Matemática - são eles: Muniz (2001, 2003, 2007, 2009, 2014), Fiorentini (2003, 2005), Nacarato (2009, 2013), Curi $(2005,2008)$, entre outros.

Em relação à formação continuada do professor que ensina Matemática na EJA, nosso diálogo foi com a professora Fonseca $(2004,2005,2014)$ e com outros autores que abordam 
questões ligadas às especificidades da modalidade EJA, como Soares (2011, 2013), Moura (2009, 2011) e Reis (2000, 2012).

Um último aspecto teórico, e não menos importante, é a abordagem do ensino de Matemática no Currículo em Movimento da Educação Básica (DISTRITO FEDERAL, 2014) em consonância com o documento do Currículo Nacional (PROPOSTA CURRICULAR, 2001) para pensar a organização do trabalho pedagógico do professor na EJA.

\subsection{Inéditos-viáveis: contextualização e influência na formação de professores}

Nosso interesse em estudar e aprofundar os conhecimentos em torno da categoria inéditoviável partiu de inquietações provocadas pelo educador que recebeu o título de Patrono da Educação Brasileira - conforme Lei no 12.612, de 2012 (BRASIL, 2012), o qual é nosso convidado de honra para esse diálogo, Paulo Freire (1992, 2011). O conceito de inédito-viável foi explicitado de modo mais detalhado por Nita Freire nas notas explicativas da primeira edição de Pedagogia da Esperança (1992) o que nos instigou por saber mais e por isso mesmo a trazemos para este diálogo. Nessa mesma direção a professora Freitas $(2001,2005)$ que aceitou o desafio de esclarecer e aprofundar tal conceito a partir de sua Tese de Doutorado Intitulada "Pedagogia do inédito-viável” (2004), por isso não podemos deixar de convidá-la também para contribuir neste trabalho.

Freire foi o recifense Paulo Reglus Neves Freire, bacharel em Direito, que não quis exercer a carreira, e então se tornou um educador e filósofo brasileiro, tendo sido considerado um dos mais notáveis pensadores na história da Pedagogia mundial. Este estudioso das questões do oprimido faleceu em maio de 1997, em São Paulo, aos 75 anos de idade. Se estivesse vivo, estaria completando seus 95 anos em setembro de 2016.

Nita Freire é a recifense Ana Maria Araújo Freire, nascida em 1933, pedagoga, mestra em Educação, História, Política e Sociedade; doutora em Educação; historiadora, que foi casada com Paulo Freire e, atualmente, dedica-se a organizar, publicar e divulgar suas obras, como sua sucessora legal.

Freitas é a gaúcha Ana Lúcia Souza de Freitas, pedagoga, mestra e doutora em Educação. Realizou estudos pós-doutorais em Educação, acerca da Pedagogia Crítica, pela Liverpool Hope University/Inglaterra. Foi professora adjunta na Faculdade de Educação da Pontifícia Universidade Católica do Rio Grande do Sul (PUCRS). Atualmente é professora colaboradora no Curso de Mestrado Profissional em Gestão Educacional da Universidade do Vale do Rio dos Sinos (UNISINOS/RS). 
Alguns trabalhos de pesquisa, como o que explicitaremos adiante, estão em defesa da ideia de que é possível denunciar a opressão e anunciar a liberdade por meio de processos de luta em favor da emancipação. Nossa proposta foi e ainda é alimentar esse diálogo para que as categorias situações-limite, atos-limite e inédito-viável utilizadas por Freire (2011) apareçam como possibilidade de conduzir o movimento dialético da práxis em favor da construção de um movimento maior que é a busca pelo ser-mais em um contexto histórico e emancipatório.

Essa contribuição teórica foi empregada pela primeira vez na obra Pedagogia do Oprimido, escrita por Paulo Freire na época de seu exílio - na década de 1960, mas não teve repercussões nem outras escritas acerca do tema. A primeira explicação das três categorias ficou sob a responsabilidade de sua segunda esposa, Nita Freire, nas "Notas Finais" da obra Pedagogia da esperança, com primeira edição publicada no ano de 1992. Então, as categorias situações-limite, atos-limite e inédito-viável são assim explicitadas:

Para Freire, as mulheres e os homens como corpos conscientes sabem bem ou mal de seus condicionamentos e de sua liberdade. Assim encontram, em suas vidas pessoal e social, obstáculos, barreiras que precisam ser vencidas. A essas barreiras ele chama de situações-limite. (NITA FREIRE, 2014, p. 277)

As situações-limite são entendidas como obstáculos que se interpõem na vida pessoal e profissional e que, às vezes, parecem intransponíveis, são os incômodos, os inconvenientes que atrapalham o trabalho do(a) professor(a). Na concepção da autora, enquanto algumas pessoas se adaptam, outras buscam formas de superar os entraves e o fazem com ações concretas, denominados atos-limite.

Os atos-limite são entendidos como estratégias de superação dos obstáculos, vêm à tona quando da execução de ações em prol da resolução dos problemas enfrentados pelo professor, ou seja, são ações de combate. Esses atos-limite "se dirigem, então, à superação e à negação do dado, da aceitação dócil e passiva do que está aí, implicando dessa forma uma postura decidida frente ao mundo" (NITA FREIRE, 2014, p. 278).

A categoria inédito-viável apareceu, primeiramente, relacionado à ideia que André Nicolai defendeu como "soluções praticáveis despercebidas" (apud FREIRE, 2011, p. 149). O que implica que não se tratava de obter soluções prontas, mas de sonhar com a possibilidade de agir no mundo, transformando-o. Assim, o sentido estabelecido por Freire foi de sonho possível. Possível a partir de ações potenciais que enfrentam e superaram um cotidiano complexo e árduo, necessitado de mudanças.

Para Nita Freire (2014, p. 278-279):

Esse "inédito-viável" é, pois, em última instância, algo que o sonho utópico sabe que existe mas que só será conseguido pela práxis libertadora que pode passar pela teoria da 
ação dialógica de Freire ou, evidentemente, porque não pela dele, por outra que pretenda os mesmos fins.

Nesse contexto, para Nita Freire, o inédito-viável não é apenas a junção de letras ou uma simples expressão, mas sim "palavração", práxis, como possibilidade de não se adaptar, mas de transformar o mundo. Trata-se da palavra na qual está intrínseco o dever de mudarmos a nós mesmos dialeticamente mudando o mundo e sendo por este mudado, em um devir utópico por uma educação emancipadora.

Não estamos nos reportando à utopia no sentido de não realizável, mas naquela que impulsiona para se distanciar do inalcançável e se aproximar do possível. Maximizar a esperança e mobilizar ações que suprimam o individualismo, o conformismo, a alienação, dando lugar ao coletivo, à emancipação e à democratização.

Tal utopia tem um significado forte e instigador, segundo Freire (1983, p. 100):

A questão dos sonhos possíveis, repito, tem que ver com a educação libertadora enquanto prática utópica. Mas não utópica no sentido do irrealizável; não utópica no sentido de quem discursa sobre o impossível, sobre os sonhos impossíveis. Utópica no sentido de que é esta uma prática que vive a unidade dialética, dinâmica, entre a denúncia e o anúncio, entre a denúncia de uma sociedade injusta e expoliadora e o anúncio de uma sociedade que pelo menos seja menos expoliadora [...].

A utopia é a circunscrição da criação, da ação transformadora que se manifesta entre a denúncia das situações-limite e o anúncio dos inéditos-viáveis. Em nosso estudo, utilizamos os inéditos-viáveis como significado dos conhecimentos que os(as) professores(as) e os seus pares constroem em processo de formação continuada, e esse processo implica na transformação de uma práxis emancipadora.

Dessa maneira, ao tratarmos a formação continuada na perspectiva crítico-emancipatória, defendemos que é a oportunidade para professores(as) tornarem-se profissionais engajados na transformação do mundo, a partir da superação das "situações-limite" (FREIRE, 2011, p. 125), que constituem freios, barreiras, obstáculos da relação teoria e prática e também na vida pessoal, social e profissional do professor. Assim, professores e professoras provocados(as) pelas discussões na e da formação continuada mobilizam-se na transformação da realidade, constituindo os inéditos-viáveis.

Sob essa perspectiva, Freitas (2001, p. 99) já afirmava que o inédito-viável era:

a materialização historicamente possível do sonho almejado. É uma proposta prática de superação, pelo menos em parte, dos aspectos opressores percebidos no processo de conhecimento que toma como ponto de partida a análise crítica da realidade. [...]

O risco de assumir a luta pelo inédito-viável é, pois, uma decorrência da natureza utópica, própria da consciência crítica, e encerra em si uma perspectiva metodológica, visto que faz do ato de sonhar coletivamente um movimento transformador. 
A expressão sonhar coletivamente tem relação com a perspectiva emancipadora, haja vista que se constitui no movimento transformador da realidade, portanto, são as possibilidades, os inéditos-viáveis (FREIRE, 2011) que surgem como conhecimentos, como forma de superação das situações-limite. Assim, conforme a colocação da autora, esse inédito representa a concretização de sonhos que só é possível a partir de duas posturas: da análise crítica da realidade (denúncia) e de ações coletivas (anúncio).

Sumariamente, o professor que ensina Matemática precisa superar as situações que limitam a sua vida e a sua prática e, ao elaborar estratégias de superação de obstáculos, cria, portanto, os atos-limite (FREIRE, 2011). Isto é, realiza tarefas que visam à resolução e à superação de problemas, institui os inéditos que se refletem na práxis. É, portanto, a realização de sonhos (inéditos) possíveis (viáveis) na práxis.

Para Álvaro Vieira Pinto (1960, p. 286), a situação-limite só poderá ser superada se os sujeitos estiverem "participando do projeto coletivo de transformar a realidade". Assim, entendemos que isso só se dará por meio da denúncia, da não alienação, do não comodismo, do enfrentamento, do pôr em questão. Desse modo, estar disposto a aderir ao processo formativo é uma forma de sair da zona de conforto e incomodar-se com as situações-limite e suplantá-las por meio da construção dos inéditos-viáveis.

A título de exemplificação, Pinto (1960) utiliza o subdesenvolvimento para dizer que se trata de um conjunto de situação-limite e sua superação depende da criação de estratégias, as quais denominou atos-limite, que foram concebidos como ações de negação de uma dada realidade opressora. Em consequência, surgem os inéditos-viáveis que são a concretização de um sonho (FREIRE, 2011) de supressão do subdesenvolvimento em favor do desenvolvimento.

Em linhas gerais, quanto ao subdesenvolvimento, Pinto (1960, p. 285) expressou:

O país, compreendendo conscientemente como "situação-limite" o estado de seu subdesenvolvimento, dispõe-se a formular o seu projeto de superação e se decide a executar os "atos-limite", que devem arrancar das limitações que o restringem e o subjulgam ao estado de pobreza e atraso. Põe em ação insuspeitadas reservas de liberdade, desencadeadas nessa fase para produzir o rompimento dos limites. Promove o futuro projetando-o e se projetando nele, na negação objetiva da "situação-limite". Esta não aparece mais como "muro" no qual esbarramos, porque não é mais vista como termo final de uma possibilidade estática e definitiva de ser, mas como momento de um processo histórico. Aqui se descobre a razão da necessária superação de todo limite coletivo.

A partir da colocação do autor sobre o exemplo do subdesenvolvimento, podemos inferir que as situações-limite constituem problemáticas que não fazem parte da realidade de apenas um indivíduo, mas de uma coletividade. Portanto, essas situações-limite deverão ser percebidas por sujeitos que se sentem implicados, prejudicados e injustiçados. Daí a importância de entender 
que tanto as situações-limite, quanto os atos-limite e os inéditos-viáveis são importantes para pensar em novas perspectivas que embasam a construção de conhecimentos, na relação dialética entre os sujeitos e o mundo.

Em outras palavras, "as condições objetivas, em permanente mudança, nos desafiam ao inédito-viável, ou seja, à criação de condições para a realização do historicamente possível, a fim de que se viabilize no futuro o que no presente se faz impossível" (FREITAS; MACHADO, 2010, p. 140). Nesse sentido, o inédito-viável surge em resposta a uma situação-limite, em um contexto que pede por mudança, diante das condições objetivas, em que são criadas condições para realização do historicamente possível. Isso pode levar a pensar em contextos macros, mas também podemos exemplificá-lo em contextos micro, o que optamos por fazer por meio de uma dimensão pedagógica, tomando de empréstimo a síntese elaborada por Freitas (2001, p. 231) que denomina três momentos pedagógicos: sonhar, estudar e criar. Esses três momentos complementam-se, conforme estabelecemos a seguir.

\section{Figura 1: Integração-relação dos momentos pedagógicos de sonhar, estudar e criar}

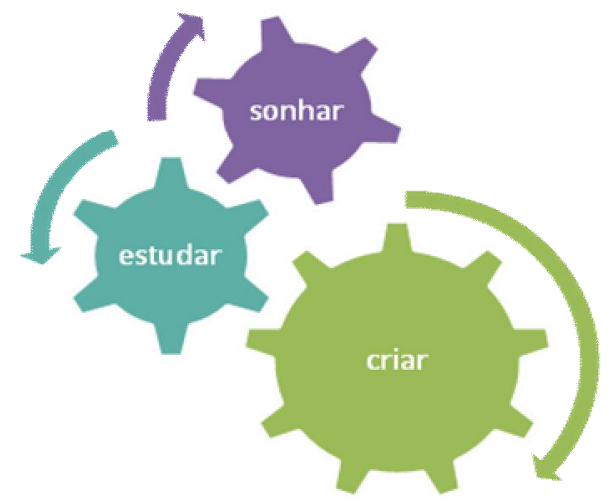

Fonte: elaboração da pesquisadora com base em Freitas (2001).

O primeiro momento é o do sonhar no sentido da possibilidade de um trabalho coletivo, que nos remete ao princípio metodológico de problematização, construído a partir de uma dada realidade (às vezes codificada), em que se precisa descodificar (organizar as informações), codificar (transformá-las em categorias) e criticizá-la (olhar conscientemente e analisar), mas esse movimento só pode ser feito quando se ultrapassa a desesperança de que nada se pode fazer, a não ser acomodar-se. Assim, o sonhar coletivamente ganha força e assume a luta pela transformação, pela construção dos inéditos-viáveis. 
O segundo momento pedagógico diz respeito ao estudar e, nesse sentido, refere-se ao processo de teorização sobre a prática, é a práxis que se dá na própria transformação, mas esse estudo também pressupõe uma coletividade para auxiliar na compreensão de dada realidade. Esse momento pedagógico é marcado pela construção de uma curiosidade epistemológica (FREIRE, 2011) que se dá pela pesquisa e que remete à possibilidade de criar o inédito-viável, pois a teoria carregada de intencionalidade política é indispensável para construção de ações críticas, que visam à emancipação.

O terceiro momento pedagógico refere-se ao criar e está ligado à própria capacidade de criatividade e de autonomia, em que se pode superar os limites, propor os novos caminhos, criar as estratégias, a partir de uma postura crítica de criação e de reinvenção. Esse momento pedagógico reacende a esperança de criação, pois contribui, com os dois momentos anteriores, para constituição do inédito-viável. Contudo vale dizer que essa criação não pode ser sustentada por um conhecimento comum, mas é preciso passar pela rigorosidade metódica (FREIRE, 2011) no que concerne a ter objetivos para tal criação, uma justificativa, um método e uma aplicabilidade, que, em sentido amplo, possa servir à coletividade, à comunidade, ao "mundo que estar sendo" (FREIRE, 2011, p. 67).

Vamos pensar em um modo de exemplificar como esses momentos pedagógicos acontecem dentro de dada realidade. Entretanto antecipamos que, apesar do exemplo que daremos, não se trata de uma realidade fora da complexidade, em que, em um passe de mágica, teremos a resposta para todas as perguntas e a resolução para todos os problemas. Trata-se tão somente da necessidade de se fazer entender que os momentos pedagógicos são inseparáveis, estão inter-relacionados e são viáveis.

A título de exemplo, imaginemos um adulto que opera mentalmente e resolve uma subtração, mas na escola ele é desafiado a utilizar o código escrito e registrar no papel essa operação. O registro da operação é um desafio para fazer avançar sua aprendizagem e, ao mesmo tempo, um desafio para o professor ensiná-lo, assim, é preciso criar estratégias de ensino. Essa é uma situação-limite (exige o sonhar) que exigirá um ato-limite (sonhar/estudar) e esse movimento constituirá o inédito-viável (sonhar/estudar/criar). Então, quando os dois parceiros (professor e jovem/adulto/idoso) conseguirem superar essa situação e vencer esse desafio, poderão construir conceitos e ressignificar os conhecimentos, ou seja, constituir os inéditosviáveis que não servem apenas para justificar ou resolver a situação estrita, mas abre possibilidades para um novo inédito-viável bem como outra situação-limite.

Salienta-se que a subtração é uma operação que historicamente trouxe dificuldades de compreensão, pois acrescentar é sempre fácil, remete à ideia de adicionar, enquanto retirar uma 
quantidade de outra, ou comparar o que tenho com o que outra pessoa tem, ou admitir que a quantidade que tenho está incompleta gera certo desconforto e dificuldade na compreensão dessa operação. Subtrair não é algo simples, especialmente porque envolve um sentido psicanalítico de perda e de desapropriação, e o algoritmo operatório correspondente também é complexo, então esse pode se tornar um desafio que precisará ser superado, por isso, é importante sonhar que é possível, estudar as estratégias de superação, e criar ações transformadoras para essa dada realidade.

Os inéditos-viáveis constituem a materialização de um sonho que é histórico e que é possível quando as pessoas enfrentam as situações-limite, criam ações e estratégias de superação e de transformação. Os inéditos-viáveis fazem-se de e nas ações criativas e emancipadoras de pessoas que projetam em suas mentes e lutam por um mundo melhor, mais justo e mais democrático. Nesse sentido, Freitas pontuou que por isso

\footnotetext{
faz-se necessária uma formação permanente, crítica e coletiva, que reflita sobre o caráter opressivo das situações-limite e construa, na prática e em sua reflexão, as condições teóricas e sociais que viabilizem a proposição de inéditos-viáveis democratizados e democratizantes (2001, p. 102).
}

De acordo com a autora, a democratização é o resultado de uma luta política e ideológica conquistada pelo trabalho coletivo e sério. Ser inédito não implica ser exclusivo, mas refere-se a um sonho, um desejo, uma conquista almejada por um coletivo e, por não ser um ato isolado (pela união de forças), é viável, é realizável, é possível. O que era apenas vontade e que parecia distante torna-se realidade, mas não em um passe de mágica. É fruto da luta política e coletiva e faz-se mais forte quando emerge de um movimento formativo.

A partir do contexto explicitado, podemos ainda indagar: Como essas categorias freireanas têm sido estudadas na atualidade? Que contribuições apresentam para a formação de professores, a aprendizagem e, também, para a ampliação de pesquisas no campo educacional?

\subsubsection{Situações-limite, atos-limite e inédito-viável: contribuições teóricas}

Por considerarmos que essas três categorias têm sido pouco aprofundadas no âmbito de pesquisas em Educação, realizamos um levantamento de dissertações e teses nas bases de dados das universidades federais brasileiras, por meio do portal das instituições de ensino, e também artigos em periódicos e anais de congressos. Encontramos poucos trabalhos e nestes, os(as) pesquisadores(as) focaram os estudos das situações-limite, dos atos-limite e do inédito-viável nas diversas teias de conhecimentos (Educação do Campo, Educação Social e Educação Ambiental são alguns desses exemplos). A seguir, organizamos os trabalhos por ordem cronológica de 
publicação - de 2006 a 2013. Tal recorte temporal se deu porque tomamos como referência o ano de 2004, quando a professora Ana Freitas defendeu a Tese sob o título "Pedagogia do inédito-viável: contribuições da participação pesquisante em defesa de uma política pública e inclusiva de formação com educadores e educadoras", haja vista sua discussão e ampliação acerca da categoria que nos interessa.

- Artigo publicado na revista eletrônica Fórum Paulo Freire, em 2006, por Telmo Adams, intitulado “As 'situações-limite' como mediações pedagógicas para chegar a 'inéditosviáveis’: o trabalho associado na Associação dos Recicladores de Dois Irmãos".

- Artigo publicado na Revista do Instituto Humanistas Unisinos de São Leopoldo, no Rio Grande do Sul, em 2007, por Danilo Romeu Streck sob o título “Algumas lições do mestre".

- Dissertação de mestrado defendida na Universidade Federal de Mato Grosso, em 2008, por Janaína Santana da Costa sob o título: A emancipação como inédito-viável no projeto da educação do campo: uma viagem etnográfica a Escola Paulo Freire.

- Artigo publicado no caderno de resumos do $17^{\circ}$ Congresso de Leitura do Brasil, em Campinas - Unicamp/FE, em 2009, por Juliana Bello Lopes, intitulado "Mulheres adultas e idosas em busca do inédito-viável: as táticas empregadas no cotidiano de uma turma de EJA".

- Tese de doutorado defendida na Universidade de Madeira/Portugal, em 2010, por Maria Isabel Nascimento Ledes Monteiro, intitulada Inovação Pedagógica no Curso de Pedagogia da Universidade de Brasília (UnB): um estudo de abordagem etnográfica.

- Artigo publicado na Revista Caminhando da Universidade Metodista de São Paulo, em 2011, por Renilda Martins Garcia intitulado "Ser mais: um princípio educativo".

- Artigo publicado na Revista Linhas Críticas da Universidade de Brasília/DF, em 2012, por Carlos Alberto Lopes de Sousa, intitulado “Professor, quero ser oprimida!": situaçãolimite e atos-limites no habitus professoral".

- Artigo publicado no VII EPEA - Encontro Pesquisa em Educação Ambiental em Rio Claro/SP, em 2013, por Danieli Veleda Moura; Carlos Frederico Bernardo Loureiro; Lúcia de Fátima Socoowski de Anello; Maria Odete da Rosa Pereira, intitulado "Situação-limite, ato-limite e inédito-viável: as categorias freireanas presentes nas representações e práticas de educação ambiental no fórum da Lagoa dos Patos”. 
Cada um dos trabalhos aqui descritos foi analisado em termos de profundidade de discussão teórica e metodológica no que concerne às três categorias defendidas por Freire: situações-limite, ações-limite e inédito-viável. Daí, dialogaremos acerca de suas peculiaridades, contribuições e importância no contexto em que se deu a pesquisa e, de modo mais amplo, para a formação de professores(as).

Vale ressaltar que cada autor dos trabalhos analisados aqui empreendeu sentidos e significados às categorias, de acordo principalmente com o contexto e o lugar em que ocupavam na sociedade naquela ocasião. São pesquisadores críticos, os quais demonstraram sensibilidade às questões sociais, políticas e econômicas que se interpuseram com certa frequência. Embora cada autor(a) tenha desenvolvido o seu trabalho em uma comunidade com contexto diferente, analisamo-los levando em conta as categorias freireanas apresentadas em comum.

Adams (2006) desenvolveu uma pesquisa participante com recicladores(as) da cidade de Dois Irmãos, localizada há $60 \mathrm{~km}$ de Porto Alegre/Rio Grande do Sul. Esses trabalhadores receberam a denominação de mutirão-empreitada. De acordo com o autor, mutirão relaciona-se com comunidade e empreitada com o trabalho realizado. Assim, esses trabalhadores superaram as situações-limite, comprometendo-se em transformar a cultura do trabalho assalariado em cultura do trabalho associado.

Nesse processo que foi formativo estava em jogo não apenas as trocas previstas pelo capitalismo, mas também a educação ambiental, a responsabilidade pela natureza e pelo meio social mediada pela relação dialógica entre os recicladores. Entre os atos-limite, esteve essa troca dialógica de estudo da realidade.

Os inéditos-viáveis apareceram como atitudes de "evitar a poluição do ar, da água, as queimadas, derrubadas de árvores, o cuidado com os recipientes de veneno e outros objetos altamente poluentes enviados pelo lixo" (ADAMS, 2006, p. 9), além da tomada de postura para se reconhecerem enquanto associação. Para esses trabalhadores, não se tratava apenas de recolher e destinar aqueles materiais, mas de cuidar para a preservação do meio ambiente e o desenvolvimento do espírito educativo para a reciclagem. Ou seja, não se tratava apenas de receber dinheiro por um trabalho prestado, mas de aderir a uma cultura de trabalho que primava pelo esforço coletivo e pela preservação do meio.

Streck (2007) fez uma discussão crítica em torno das contribuições de Paulo Freire para construção do conhecimento e da pesquisa. Com esse enfoque, tratou sempre de reafirmar a coerência do posicionamento crítico e político de Freire, concebidos por sua própria práxis. Assim, fez críticas àqueles que utilizam as ideias freireanas apenas para dar credibilidade ao 
trabalho, mas afirmou que aqueles que acreditam e o seguem o fazem porque buscam a concretização dos sonhos (inéditos) possíveis (viáveis).

Os inéditos-viáveis na vida social, política, religiosa, profissional, econômica, cultural, são resultados de um complexo processo de luta (atos-limite) pela superação das situações-limite e da possibilidade de um mundo transformado. Nesse sentido, fica clara a perspectiva do vir a ser, em que somos movidos pela esperança de que, em todos os lugares e por todos os cantos, poderá existir uma força conjunta de quereres em função da possibilidade de tornar real aquilo que estivera no plano das ideias.

Costa (2008) desenvolveu uma pesquisa etnográfica de cunho fenomenológico com professores e alunos de uma escola de assentamento em Mato Grosso que lutavam pela terra e, também, lutavam por uma educação conscientizadora que lhes permitissem lutar pelos direitos que dignificassem suas vidas e que os fizessem superar a percepção ingênua da realidade e criar mecanismos de mudança para um mundo mais humano, mais democrático e mais digno.

As situações-limite aparecem como impeditivos das condições humanas de vida marcadas, principalmente, pela falta de moradia e de escola. Os atos-limite davam-se no trabalho coletivo da posse de terra e na luta por condições mínimas de vivência, em assentamento de reforma agrária em favor da construção de uma perspectiva emancipatória, que foi entendida como inédito-viável. Afinal, a autora percebe "a emancipação como inédito-viável na práxis da educação do campo" (COSTA, 2008, p. 126). Isso significou a tomada de atitudes de reflexão com os debates nas plenárias, em que os sujeitos participavam ativamente com suas opiniões e votações acerca de encaminhamentos políticos, econômicos e sociais que diziam respeito à vida da comunidade.

A importância deste trabalho foi trazer elementos para pensarmos as estratégias de luta pela não alienação, pela força da coletividade em favor de um bem comum, que é o respeito à dignidade humana, aos direitos garantidos aos cidadãos por uma Constituição. Também ficou clara a intenção da autora em não deixar morrer a esperança de que é possível vencer barreiras e construir um mundo que, embora não estivesse livre das contradições, permitisse a convivência sem exclusões.

Lopes (2009) trabalhou com a perspectiva de que é possível superar as situações-limite impostas na produção de texto escrito, por meio de atos-limite possibilitados pela participação no Projeto de Educação para Jovens e Adultos, o Eduvitra (Educação, Vida e Trabalho) - no Rio de Janeiro -, a fim de produzir inéditos-viáveis. Estes foram representados pela leitura e escrita e pela humanização das mulheres empenhadas nesse projeto que lhe possibilitara a emancipação crítica e criativa dos modos de produção intelectual. 
A contribuição deste trabalho residiu no fato de que as mulheres participantes do projeto tiveram consciência de que existia um problema que era a dificuldade para produzir texto (a situação-limite), assim, não se conformaram com a realidade e empreenderam ações de superação desse obstáculo (os atos-limite). Entre essas ações, estava a atitude de constituir um grupo de estudos que auxiliava no contexto de escrita, mas sem desprezar o contexto da vida cotidiana das mulheres com suas lutas contra o sistema excludente.

Monteiro (2010) realizou uma pesquisa etnográfica no curso de Pedagogia da Universidade de Brasília sobre inovação pedagógica como "utópico realizável" capaz de assumir o repensar da prática pedagógica a partir da mudança ontológica da educação. Essa mudança pressupõe um trabalho de ensino e aprendizagem do coletivo professor e aluno, rompendo com os métodos tradicionais de ensino.

A pretensão da pesquisadora era de compreender como professores e alunos do curso de Pedagogia definiam inovação pedagógica e, em sua análise, constatou que esses atores sociais entendiam que a "inovação pedagógica acontece de fato quando há uma alteração na natureza das relações sociais dos sujeitos no mundo e com o mundo" (MONTEIRO, 2010, p. 320). Nesse contexto, professores e alunos partiam de situações-limite que consistiam no engessamento do aprender e do ensinar rumo a sua superação e constituição de novas possibilidades de ensino e aprendizagem.

A contribuição do trabalho de Monteiro foi significativa porque apresentou recomendações para: a) a prática pedagógica; b) a pesquisa educacional; e c) as políticas públicas. No primeiro aspecto, reafirmou que inovação pedagógica não reside na adoção de métodos, tecnologias e novos currículos, mas na postura dialética e transformadora da práxis. Em segundo, trouxe indicações de quais problemáticas podem ser investigadas por ocasião de outras pesquisas acadêmicas - conforme páginas 322 e 323 da tese de Monteiro; em terceiro, fez provocações às propostas de governo que até faziam investimento financeiro na escola e na universidade a fim de promover a inovação, mas a falta de princípio pedagógico reduziu essa ação ao tecnicismo.

Garcia (2011) trouxe contribuições acerca do que Paulo Freire definiu como ser-mais. Assim, a autora nos quer chamar a atenção para o fato de que só é possível o ser humano sermais se empreender lutas contra as situações-limite que se dão de toda ordem (políticas, econômicas, sociais, históricas, culturais, educacionais) e daí constituir inéditos-viáveis que impulsionam para um mundo possível de igualdades.

Sua maior contribuição foi de visar um mundo diferente em que as pessoas, na busca pelo ser-mais, enchiam-se de coragem e de estímulo para: superar os obstáculos que atravessaram 
suas vidas; adotar posturas mais democráticas e solidárias para também contribuir com a completude do outro, haja vista sua consciência do inacabamento; e inserir-se no mundo das possibilidades em que se realizavam sonhos porque eram possíveis e viáveis.

Sousa (2012) escreveu sobre a experiência registrada em um diário de campo das aulas de Sociologia da Educação e descreveu que, em suas aulas, eram estudadas obras de autores renomados, e que, ao final da disciplina, cada acadêmico deveria escolher temas discutidos em sala de aula que tivessem ligação com um dos autores estudados. Um desses nomes foi o de Paulo Freire com a obra Pedagogia do Oprimido. Todavia uma situação-limite constituiu-se quando uma de suas alunas dirigiu-se a ele (ao professor da disciplina) e disse: "Professor, eu quero ser oprimida! Diga-me o tema ou questão que devo desenvolver. Não quero escolher o meu tema livremente!" (SOUSA, 2012, p. 561).

A análise feita pelo professor foi que os alunos não deram tanta importância para a atitude crítica de analisar temas e assuntos, contudo apresentaram uma preocupação com a nota, a menção final. Os atos-limites se constituíram na devolutiva, pelo professor, para toda a classe do que fora dito pela aluna. Apesar de no início ter tido um silenciamento, depois se constituiu na oportunidade para reflexões e debates, e isso culminou com a elaboração de estratégias de mudança quanto ao desenvolvimento da aula, ao se considerar maior participação dialógica, o que remeteu à constituição dos inéditos-viáveis.

A contribuição desse texto foi trazer aspectos importantes e simples do cotidiano da sala de aula, como momento de pensar a prática e a teoria como par irremediavelmente dialético que, na trama da aula, é a pedra angular, no sentido de importante. Provocativo de reflexões e mudanças, transformação e qualificação para o ensino e a aprendizagem na medida em que permitiu uma relação dialógica dos atores educativos.

Moura, Loureiro, Anello e Pereira (2013) propuseram-se em compreender como as categorias freireanas: situação-limite, ato-limite e inédito-viável tinham relação nas representações (e práticas) de Educação Ambiental. Assim, partiram do princípio de que a situação-limite residia no fato de que os pescadores que trabalhavam com a pesca artesanal sofriam o grande impacto do modo de produção capitalista na cidade do Rio Grande, no Rio Grande do Sul.

Entretanto esses autores defenderam que há atos-limite capazes de transformar essa realidade e isso se dava principalmente pela adesão ao Fórum da Lagoa dos Patos que representa um órgão colegiado que cooperava com o setor pesqueiro. Esse órgão permitiu a Educação Ambiental Crítica em que os pescadores (re)criaram conhecimentos importantes para se reconhecerem enquanto classe trabalhadora e reivindicarem seus direitos. Os inéditos-viáveis 
decorriam, então, da realização de sonhos, da democratização de ações que envolviam a atividade pesqueira, como, por exemplo, a conquista do licenciamento ambiental na pesca e seguro-defeso para as mulheres pescadoras.

O que este trabalho teve de relevante foi exatamente a luta por uma causa humana e social que envolveu trabalhadores que não lutavam pela pesca apenas enquanto meio de subsistência, mas como um retrato da vida e do trabalho que desenvolviam como profissionais pescadores. Sua potencialidade residiu no fato de que o trabalho coletivo e as discussões no fórum proporcionaram a (re)construção de conhecimentos que permitiram uma luta democrática e crítica em favor da emancipação.

Em suma, a análise desses oito trabalhos permitiu o entendimento de que as categorias situação-limite, atos-limite e inédito-viável apresentaram uma relação dialética e se comunicaram não como causa-consequência, estímulo-resposta. Estes fizeram parte de um processo contínuo, complexo e inacabado em que novos desafios surgiam e estimularam a produção de forças que deviam fazer frente para transformar e melhorar as condições de vida no / do / com o mundo.

Não foram encontrados outros estudos sobre tais categorias freireanas que fizesse relação com o ensino da Matemática, a não ser os artigos publicados por esta pesquisadora em anais de eventos científicos de amplitude nacional e internacional nos anos de 2013 a 2015. Daí a importância de realizarmos um trabalho com esse comprometimento, a fim de ampliar esse campo epistemológico e fortalecer as discussões em torno dos profissionais da EJA que atuam no ensino da Matemática, especialmente no primeiro segmento.

\subsection{Formação continuada de professores: concepções e perspectivas}

Para iniciar nosso diálogo, acerca da formação, convidamos Gatti (2009, 2010, 2012), Nóvoa (1997, 1999, 2009), Silva (2008, 2011), Carr e Kemmis (1988, 2004), pois estes têm em comum a docência e a discussão sobre ensino e formação de professores(as). Então, optamos por falarmos sobre quem são eles, onde atuam e que concepção de formação cada um defende.

Gatti é a paulista Bernardete Angelina Gatti, pedagoga e doutora em Psicologia, docente aposentada da Universidade de São Paulo (USP). Atualmente, é pesquisadora colaboradora no Departamento de Pesquisas Educacionais da Fundação Carlos Chagas.

Nóvoa é o português António de Sampaio da Nóvoa, psicólogo, doutor em Ciências da Educação e em História. Atualmente é professor do Instituto de Educação da Universidade de Lisboa, em Portugal. 
Silva é a goiana Kátia Augusta Curado Pinheiro Cordeiro da Silva, pedagoga, mestra e doutora em Educação. Atualmente é professora adjunta da Faculdade de Educação Universidade de Brasília (UnB). É coordenadora do Grupo de Pesquisa sobre Formação e Atuação de Professores/Pedagogos (GEPFAPe) da UnB.

Carr e Kemmis são, respectivamente, Wilfred Carr, filósofo, professor catedrático de Filosofia da Educação na Universidade de Sheffield, no Reino Unido. Stephen Kemmis é mestre e doutor em Educação e atualmente é professor adjunto do Instituto de Pesquisa de Prática Profissional, Aprendizagem e Educação na Universidade Charles Sturt, em Wagga, na Austrália.

Tomamos o entendimento de que a formação continuada de professores(as) é um processo contínuo de ações que perpassa a teoria e a prática (na práxis). Assim, pretende-se que esteja relacionada aos processos de transformação da práxis, uma vez que proporciona a reflexão e a ação crítica acerca da realidade que pode ser melhor teorizada, tanto para ser compreendida quanto para sofrer a ação transformadora, sob a perspectiva crítico-emancipadora.

Nóvoa (1997) chamou a atenção para o entendimento de como acontece a formação, explicando que essa não deveria ser construída por acumulação (de recursos, de conhecimentos ou de técnicas), mas por meio do trabalho de reflexividade crítica sobre as práticas e de (re)construção permanente da identidade pessoal. Acrescentamos a esse entendimento que a formação continuada deve ser espaço para confrontação, elaboração de conhecimentos e compreensão do papel profissional do docente. Essas características somam o cenário propício para a constituição dos inéditos-viáveis.

Na perspectiva crítico-emancipadora, os(as) professores(as) envolvidos(as) em processos de formação continuada constroem elementos capazes de transformar uma dada realidade, esses elementos são a teoria e a prática que, indissociavelmente, provocam mudança no mundo natural e social. Essa concepção "entende a formação como atividade humana que transforma o mundo natural e social para fazer dele um mundo humano" (SILVA, 2011, p. 22). Sob esse prisma, abandona-se o conceito de formação como aquisição de informações didáticas para apoiar-se em uma conceituação mais dinâmica, reflexiva, científica, crítica e amparada na práxis emancipadora.

Emancipação é entendida aqui como a "capacidade do sujeito de dizer não ou sim, de ter autonomia, poder escolher, não pela aderência, mas pelo conhecimento da realidade" (SILVA, 2008, p. 19). Nesse sentido, defendemos a necessidade de se oferecer condições formativas adequadas a fim de mobilizar a ação e a reflexão do professor (a práxis), com a finalidade última de transformar não apenas a sala de aula, mas também a escola e a sociedade. Para isso, é 
importante que o professor tenha as condições para pensar, investigar, propor estratégias/ações que possam superar as situações-limite em prol de uma profissão que seja respeitada, valorizada e assistida por políticas educacionais.

As condições formativas às quais defendemos também estão associadas aos espaços físicos, à dedicação de tempo, ao investimento financeiro, à valorização e ao fomento à pesquisa, à divulgação dos conhecimentos construídos, somado a isso, ascensão na carreira, melhoria salarial, caráter de continuidade nos processos formativos que poderiam ir além de grupos de estudos, de pesquisas e de transformação da práxis.

Vale pôr em relevo que o processo formativo que realizamos na escola, os círculos de investigação formativos, tem características peculiares do que Gatti (2012) e Santos (2010) denominam de formação continuada em serviço. Entre essas características, podemos citar que se trata de formação realizada dentro da escola com parceria da universidade, em que o professor não precisa se ausentar do local de trabalho e não faz investimento financeiro para custear a própria formação. Contudo não adotaremos essa terminologia para que não fique parecendo mais um modismo, e especialmente porque a concebemos como formação continuada, tendo, em seu cerne, um objetivo muito maior que é constituir inéditos-viáveis na perspectiva transformadora e considerando as condições de trabalho docente as quais já citamos.

Ao adotarmos uma postura que defende a formação continuada visando à transformação da práxis, tomamos como pressuposto para pensar a práxis a seguinte contribuição de Freire (2011, p. 172-173):

É preciso que fique claro que, por isto mesmo que estamos defendendo a práxis, a teoria do fazer, não estamos propondo nenhuma dicotomia de que resultasse que este fazer se dividisse em uma etapa de reflexão e outra, distante, de ação. Ação e reflexão se dão simultaneamente.

Nesse contexto, a práxis é uma atividade, mas isso não implica que toda atividade é práxis, pois, segundo Freire, a práxis é, simultaneamente, uma atividade de ação e de teorização - reflexão. Portanto, não é uma atividade mecanizada, decorrente apenas de ação física. Assim, pensar a formação na e pela práxis é projetar a relação inseparável entre conhecer e transformar. Conhecer a realidade e agir sobre essa realidade, questionando-a, contrastando-a, modificando-a e gerando outros conhecimentos e conceitos que aqui estamos denominando de inéditos-viáveis.

Faz parte da vida humana a curiosidade como característica ontológica, mas não se reduz a uma curiosidade ingênua, mas àquela movida por perguntas e respostas, que cria fundamentação rigorosamente metódica, denominada curiosidade epistemológica, segundo 
Freire (2011). Por causa dessa curiosidade, somos movidos pela busca do ser-mais, em um profundo movimento pela práxis, é um trabalho de quem sonha transpor o impossível.

É imperativo destacar que não se trata de trabalho na individualidade, mas na coletividade e defendemos que os espaços de formação favorecem esse movimento. Nesse contexto, concordamos com Nóvoa (2009) quando alertou quanto à busca isolada pela formação e aconselhou que o professor se vinculasse a uma instituição, defendendo o local de trabalho como espaço ideal para que aconteça a formação continuada.

Concordamos com o autor quando defendeu que o professor deveria vincular-se a uma instituição, como a de ensino superior, especialmente porque é o espaço de formação que possui a estrutura fundamental ao direcionamento e à realização de pesquisas. Essa parceria com a instituição escolar é imprescindível e necessária, visto que a escola é o espaço cultural e histórico que contém as marcas de uma docência que, ao longo da carreira, foi sendo construída com teorias, lutas, dificuldades, trocas de saberes, estranhamentos, dúvidas, angústias, alegrias, conquistas, decepções, diálogos e construção de conhecimentos. Por esse motivo, propomos realizar os círculos de investigação formativos dentro da escola, porque acreditamos que constitui importante espaço para construção de conhecimentos. Esse cenário será melhor explicitado no capítulo metodológico deste trabalho.

No contexto da escola, está o(a) professor(a), que é (espera-se que seja) o profissional do ensino que detém os conhecimentos de sua área, que faz abstrações (compreende uma "realidade" para produzir sobre esta - que hipotetiza e teoriza a sua realidade, o plano de sua ação pedagógica e educativa), que (re)constrói conhecimentos, que é um ser inconcluso, incompleto, histórico, criativo, crítico e intelectual. É o profissional que ministra 60 horas de aula (ou mais) semanalmente; que constrói planejamentos; que elabora, aplica e corrige provas; que preenche diários; que faz parte da gestão pedagógica e elabora o projeto pedagógico da escola; que faz parte dos conselhos; que é (ou que deve ser) pesquisador; que precisa publicar e que, muitas vezes, não dispõe de tempo, de espaço e de investimento para continuar sua formação.

Nessa perspectiva, defendemos uma formação articulada e coletiva de professores(as), dentro do seu ambiente de trabalho e que se atenha aos aspectos teóricos e práticos desse contexto educacional. No entanto alguns estudos se têm feito sobre os processos formativos, muitas críticas existem acerca do tipo de formação, do seu tempo de duração, das concepções ligadas ao aligeiramento dessas formações e das perspectivas a que se filiam algumas instituições, mas não se têm visto muitas pesquisas que apresentem propostas para mudar essa 
realidade. Então, consideramos que o desenvolvimento desta pesquisa pode sinalizar esse processo de transformação da realidade a partir da mobilização da práxis.

Para Vaillant (2011), educadora uruguaia, presidenta do Observatório Internacional da Profissão Docente, é pequena a possibilidade de formar um bom docente em nível superior se ele teve um ensino básico deficiente. Em outra pesquisa, em um estudo da arte sobre formação de professores, afirmava que esses profissionais precisavam de uma boa gestão, boa remuneração e boa formação (VAILLANT, 2003).

Há de se considerar que já existem projetos de formação em que universidades, institutos e faculdades de Educação, por meio de projetos de extensão, fazem parcerias com a comunidade. Por esse meio, alguns pesquisadores aproximam-se dos(as) professores(as) e criam grupos de estudos e discussão no espaço acadêmico ou na própria escola.

Todavia essa realidade nem sempre foi assim, como asseguravam Nóvoa (2009) e Saviane (2011), pois, em se tratando de situar os acontecimentos históricos que marcaram as décadas de 1970, 1980 e 1990, os autores descreveram a realidade do trabalho do professor e como a formação era concebida. Para Nóvoa (1999, 2009), a década de 1970 foi marcada pela racionalização do ensino, em que predominava uma pedagogia por objetivos, o ensino tecnicista. Nos anos 1980, ocorreram as reformas educativas em que o currículo ocupava o centro das atenções. Os anos 1990 foram marcados por organização, administração e gestão dos estabelecimentos de ensino, até que vieram as reformas neoconservadoras.

O filósofo e pedagogo paulista Saviane (2011), em sua obra História das Ideias Pedagógicas no Brasil, descreveu cinco atos ${ }^{4}$ que marcaram o drama do(a) professor(a) entre as décadas de 1970 a 1990. Vamos explicitar resumidamente esses atos, porque, a partir daí, podemos notar um movimento histórico contraditório na vida do profissional docente. $\mathrm{O} 1^{\circ}$ ato é que o professor adotou uma cabeça escolanovista, mas tinha que atuar em escolas tradicionais; o $2^{\circ}$ ato foi marcado pela moda da eficiência e da produtividade docente, o lema era maximizar os resultados e minimizar os dispêndios; o $3^{\circ}$ ato foi tomado pela onda crítico-reprodutivista; o $4^{\circ}$ ato foi a instalação da pedagogia pelas competências, cujo lema era aprender a aprender; e o $5^{\circ}$ ato foi marcado pelo neoprodutivismo.

Como situado pelos autores, a perspectiva de formação docente era pensada no saber fazer, com a finalidade de melhorar a qualidade do ensino, por isso, nesse período, reforçaram os cursos de capacitação e aperfeiçoamento do professor, para que se aprendesse principalmente

\footnotetext{
${ }^{4}$ Para ler na íntegra os cinco atos que representam o drama do professor, conferir Saviane (2011, p. 446-450).
} 
sobre metodologias de ensino. Não se discutiram as condições da carreira do(a) professor(a), pois este era visto apenas como executor de tarefas.

Especialmente, após a década de 1990, o Brasil começou a investir na Educação, segundo o levantamento feito por Gatti (2012, p. 424), e algumas das providências foram:

\begin{abstract}
reorganizar aspectos do financiamento da educação; aumentar os anos de escolaridade da população; investir em infraestrutura; orientar os currículos da educação básica; ampliar as oportunidades no ensino superior; formar docentes por diversos meios; deslocar a formação dos professores da educação básica do nível médio para o nível superior; desenvolver programas de formação continuada de professores; melhorar os livros didáticos e sua distribuição; orientar a elaboração de planos de carreira docente; instituir o piso salarial nacional para professores, entre tantas outras ações políticas.
\end{abstract}

No entanto, apesar de todos esses investimentos, as provas nacionais e internacionais que avaliam a qualidade da Educação dos países não têm apresentado uma variação positiva considerável em relação ao Brasil. Uma mudança relevante no cenário educacional, por exemplo, foi o crescente número de creches, escolas de Educação Básica, instituto federais, campi universitários, no entanto esses números quantitativos não fazem relação com a qualidade do serviço prestado, conforme tem aparecido na mídia e nas pesquisas em Educação.

A título de exemplificação, devido a essas mudanças, o número de horas aula tem diminuído, mesmo com a adoção do ensino integral que acaba prevendo mais atividades recreativas/esportivas (na realidade) que atividades pedagógicas de sala de aula ${ }^{5}$; o número de atestado médico apresentado pelos(as) professores(as) tem aumentado e, por consequência, têm crescido os contratos temporários de professores(as).

Todas essas problemáticas talvez não possam ser sanadas a partir da formação, mas podem ser discutidas no contexto da formação continuada. A saber, estamos denominando formação o processo de construção e alimentação da docência e defendemos que essa construção é um processo permanente e complexo que se dá na e pela práxis e que envolve a dimensão pessoal, social e profissional do professor.

A formação tem sido um tema que ganhou espaço nas publicações em periódicos, desde a década de 1990, como apontou o estudo realizado por Gatti (2012), intitulado "Formação de professores e profissionalização: contribuições dos estudos publicados na Rbep entre 1998 e 2011”. Nesse período, a Revista Brasileira de Estudos Pedagógicos (RBEP), com sede em Brasília, publicou 22 edições. Entre as publicações, Gatti fez o levantamento de 38 artigos que foram categorizados em subtemas os quais convergiram para a formação de professores(as),

\footnotetext{
${ }^{5}$ A esse respeito, conferir o trabalho de mestrado de Côrtes (2015), defendido no Programa de Pós-Graduação da Universidade de Brasília (UnB).
} 
inclusive, mostrou-se um aumento gradativo ao longo dos anos. Isso já sinaliza uma inquietação com a realidade educacional do professor.

Essa formação, vamos reforçar, tem dimensão humana e social, não acontece na individualidade, não é caracterizada por acúmulo de cursos. É uma formação que não deve ter fim, porque, assim como o conhecimento e a história, o processo formativo não pode ter um prazo para ser concluído. Trata-se de uma formação do profissional docente que precisa ser de qualidade, que deve ser atrativa, que ofereça condições para o professor ser pesquisador, fazendo-o superar os tipos de investigações que se pautam apenas na investigação de sua prática. A saber, não estamos criticando esse tipo de pesquisa, mas defendemos que ela pode ter uma rigorosidade metódica ${ }^{6}$ que parta, essencialmente, de uma curiosidade epistemológica (FREIRE, 1996) para além da sala de aula.

Constituir-se pesquisador(a) é uma possibilidade que acreditamos estar associada à formação continuada, por ser um contexto de aproximação com a ciência e com os métodos de pesquisa. Além disso, é possível olhar, com criticidade, uma realidade que não é, mas que está sendo (FREIRE, 2011) e que, desse modo, poderá ser transformada. Ao usarmos a expressão "está sendo", corroboramos com Freire quando se reportava ao processo histórico da realidade que não está pronta, mas está em constante construção, como a formação que é um processo e não um produto.

A formação continuada é tomada aqui como a possibilidade de o professor formar-se e transformar-se no e para o contexto educacional e social. A formação constitui também a oportunidade para (re)pensar a organização do trabalho pedagógico e as suas crenças. Trata-se de um direito exclusivo que deve servir para superar os paradigmas, o tradicionalismo, o individualismo e construir uma visão crítica e emancipadora a partir do trabalho coletivo, da imersão na pesquisa, da troca com seus pares, proporcionando a transformação da práxis.

A expressão formação continuada remete à formação permanente, em oposição aos termos reciclagem, capacitação, treinamento que, por sua vez, representam ideias estanques de ações controladas. A saber, não concordamos com a terminologia reciclagem porque é como se reificasse o professor. Reiteramos também que não estamos falando de formação como um programa com regras e receituários que acontecem como cursos de $\mathrm{X}$ horas em $\mathrm{Y}$ semanas ou que, às vezes, acontece somente uma vez por ano.

Esses tipos de cursos também são válidos, mas não se constituem como projetos formativos permanentes, pois, como a evolução/atualização/transformação do mundo ocorre

\footnotetext{
${ }^{6}$ Curiosidade metódica e curiosidade epistemológica é uma preocupação de Freire em Pedagogia da Autonomia (1996, 39.ed., p.26-29).
} 
ininterruptamente, assim também deve ser a formação continuada, a fim de acompanhar esses avanços e provocar mudanças positivas na Educação.

Há possibilidades de formar professores(as) para a trans-formação. O prefixo trans significa além de. Portanto, almeja-se uma formação que garanta a possibilidade de trans-formar para além da sala de aula, que assegure o direito ao conhecimento e à (re)elaboração destes, à contrastação de ideias, à tomada de decisões, à adoção de postura mais crítica, à construção de conceitos, à emancipação, haja vista que o exercício profissional está carregado de intencionalidade política. O professor é um agente político que possui um corpo de saberes, de técnicas, de normas, de valores e de postura específicos de sua profissão docente.

Alguns autores e autoras, como aqueles supracitados, têm criticado a organização de ações pontuais de formação, mas, como assevera Gatti (2012), já houve evolução no sentido de incluir essa formação em um contexto maior de desenvolvimento profissional e organizacional, como é o caso dos programas de governo que preveem uma diversificação dos processos formativos. Contudo, a partir do levantamento realizado, temos que reconhecer que esses programas não têm dado conta de mudar as condições materiais de trabalho, de carreira, de salário do professor e de sua condição de pesquisador, aliado a todos esses fatores, o resultado da avaliação da educação brasileira ainda continua com baixos índices.

No cenário da pesquisa educacional, a investigação sobre os(as) professores(as) tem cedido lugar à investigação com os(as) professores(as) e em favor desses, isso implica na construção de um corpus teórico sobre a profissão e a profissionalidade docente e isso pode contribuir para o desenvolvimento profissional docente ${ }^{7}$. Essa evolução tem sido mostrada nos resultados de pesquisas em que se adotaram metodologias como a pesquisa-ação, a pesquisa colaborativa ou a participante, segundo Gamboa (1998). Isso é salutar porque pode incidir sobre o(a) profissional professor(a) a constituição de uma profissão mais crítica, fortalecida na e pela pesquisa.

É conciliável explicitarmos o que entendemos por desenvolvimento profissional docente, seguindo o raciocínio de Ponte (1995) e García (2009), que entenderam como uma atitude de construção permanente de conhecimentos movida pela curiosidade epistêmica. Portanto, faz parte de um contínuo de formação que acompanha o professor ao longo de sua carreira docente, o que lhe permite um crescimento pessoal, profissional e intelectual.

Compreendemos que o desenvolvimento profissional, em sentido positivo, envolve a formação continuada, a participação em projetos, as trocas de experiências, os estudos e as

\footnotetext{
7 A tese de CRUZ (2012), defendida na Universidade Federal do Pernambuco, trata acerca dos temas desenvolvimento profissional, profissão e profissionalidade.
} 
leituras, as reflexões e as tomada de decisões, desenvolve também as potencialidades, tem relação com os aspectos cognitivos, afetivos e relacionais do ensino e privilegia a práxis.

Tomado de um sentido social e político, o desenvolvimento profissional do professor envolve um processo dinâmico e dialético entre os conhecimentos acadêmicos, as crenças e as experiências em que se relacionam teoria e prática, desenvolvimento pessoal e profissional. Com base nessa afirmativa, Alonso descreveu as seguintes características do desenvolvimento profissional docente:

Perspectiva de evolução e continuidade ao longo da carreira, que se contrapõe à tradicional justaposição entre formação inicial e formação contínua.

Caráter contextual, organizacional e orientado para a mudança, em que a formação formal e a informal se entrecruzam e enriquecem mutuamente, colocando o foco na investigação e reflexão conjunta sobre os processos de desenvolvimento curricular tendentes a melhorar as aprendizagens dos alunos.

Superação da dicotomia entre as dimensões pessoais (o professor como pessoa) e profissionais (o professor como pertencente a um grupo ocupacional).

Caráter processual, sistemático e permanente, por contraposição ao caráter pontual de ações ou realizações encaradas como atualização de conhecimento ou "reciclagem".

Caráter ativo, reflexivo e autodirigido da formação, por contraposição à passividade, rotina, irreflexão.

Natureza global e integradora, que afeta a pessoa como um todo, incidindo em todas as dimensões do desenvolvimento: cognitivas, afetivas, sociais e instrumentais, ultrapassando o aspecto redutor de muitas perspectivas.

As abordagens construtivistas e ecológicas, que sustentam esta concepção de desenvolvimento profissional, relevam a escola como contexto (social e político) para a emergência da mudança, realçam a importância da colegialidade e da colaboração, trabalham com uma perspectiva praxeológica e construtivista das relações teoria-prática, ligando intrinsecamente os processos de inovação educacional com os processos de desenvolvimento pessoal e profissional dos professores (ALONSO, 2007, p. 109).

Entre essas características, os círculos formativos que propomos aos participantes desta pesquisa buscaram salientar essa continuidade de formação, a transformação da realidade, o crescimento pessoal e profissional, o realce da colaboração entre os pares, a construção do conhecimento e a conexão da teoria com a prática. Nesse sentido foi que não apenas refletimos acerca das situações-limite, mas desenvolvemos os atos-limite, a fim de constituir os inéditos.

Reforçamos mais uma vez que estamos nos referindo a uma formação que tem desenvolvimento na práxis, que visa à trans-formação não apenas da escola, como ação imediata, mas também do contexto na qual está inserida. A finalidade da formação continuada é, antes de qualquer outra coisa, a (re)construção de conhecimentos, é a própria ação teorizada - é a teoria em ação, é a oportunidade de intervir em uma realidade que não é, mas que está sendo (a 
realidade é histórica, portanto, não é completa nem finita), é a problematização (movida na dialética), é a ação de pesquisar.

A formação continuada que estamos defendendo possui elementos importantes para sua sistematização, conforme pontuamos a seguir:

- Diálogo inicial e imersão investigativa de todos os envolvidos no processo formativo.

- Problematização em que se passa a investigar e denunciar as situações-limite que obstacularizam a organização do trabalho do professor e dificultam seu desenvolvimento pessoal e profissional.

- Teorização da prática (e seu contrário) - a práxis que é o elemento-chave para construção dos conhecimentos.

- Formação de grupos, dentro da escola, com propósitos de investigação coletiva, em favor da ciência, da construção de um acervo cultural de conhecimentos (os inéditos-viáveis) que auxiliem em sua profissão e que contribuam para o desenvolvimento profissional.

No que concerne a esse desenvolvimento profissional Fullan e Hargreaves (1992) mencionaram que envolve:

- os objetivos, as intenções e o papel que o professor se coloca;

- o professor como pessoa, os seus valores e as características individuais;

- o contexto real em que o professor trabalha; e

- a cultura escolar presente no cotidiano do professor e os seus colegas.

O desenvolvimento profissional ocorre durante toda a carreira, e a formação continuada faz parte dessa trajetória, portanto, contribui para o desenvolvimento da profissão, especialmente porque envolve a práxis. Além disso, não perde a essência da função docente, está amparada na pesquisa e busca a emancipação pessoal, profissional, social e política do professor e, portanto, é muito mais que um processo de reflexão no próprio espaço de sua experiência profissional.

Carr e Kemmis $(1988,2004)$ desacreditaram que apenas a reflexão pode provocar mudanças emancipatórias. E nós concordamos com essa posição, pois acreditamos que o simples processo reflexivo não dá conta de trazer os elementos demonstrativos de uma realidade. O movimento dialético só se dá na e pela práxis.

Esses autores apoiaram-se na Escola de Frankfurt, mais especificamente na teoria crítica de Habermas para questionar as perspectivas do professor pesquisador e do professor reflexivo por não considerarem as limitações/barreiras impostas pela estrutura social e política às práticas 
docentes. Freire $(1982,2011)$ deu um nome específico para isso: alienação. O profissional alienado é aquele que não se dá conta ou faz que não percebe as situações opressivas sobre seu trabalho.

É preciso propor projetos de formação que visem às mudanças na organização do trabalho pedagógico, que, além de prever inteligibilidade e importância para os participantes, precisam estar articulados a processos de mudança na cultura escolar e de alcance extraescolar, implicando relações sociais mais participativas e muito mais democráticas. É pensando nessa proposta que ampliamos essa discussão com as questões formativas relacionadas ao professor que ensina Matemática.

\subsubsection{Formação continuada de professores que ensinam matemática: sentidos e significados}

Em nosso diálogo sobre formação, vamos acrescentar mais um elemento para discussão, trata-se do ensino da Matemática, então, convidamos para a conversa Muniz (2001, 2003, 2007, 2009), Fiorentini (2003, 2005), Nacarato (2009, 2013), Curi $(2005,2008)$ e outros especialistas no assunto.

Muniz é o paulista Cristiano Alberto Muniz, bacharel e licenciado em Matemática, mestre pela UnB e doutor em Educação pela Sciences de Education - Université Paris Nord/França. Realizou estudos pós-doutorais na linha de pesquisa: Escola, Aprendizagem, Ação Pedagógica e Subjetividade na Educação pela UnB. Atualmente é professor adjunto da Faculdade de Educação da UnB. Foi coordenador e um dos autores do Programa Gestar de Matemática e do PNAIC de Matemática - Pacto Nacional pela Alfabetização na Idade Certa, ambos vinculados ao Ministério da Educação (MEC).

Fiorentini é o gaúcho Dario Fiorentini, licenciado em Matemática, mestre em Matemática aplicada e doutor em Educação. Atualmente é professor da Universidade Estadual de Campinas, no Departamento de Ensino e Práticas Culturais da Faculdade de Educação e no Programa de Pós-graduação em Educação.

Nacarato é a mineira Adair Mendes Nacarato, licenciada em Matemática, mestra e doutora em Educação. É docente da Universidade São Francisco (USF), Itatiba/SP no Programa de Pós-Graduação em Educação. Realizou estágio de pós-doutoramento junto ao PPGE da Universidade Federal do Rio Grande do Norte no campo dos estudos biográficos. É membro da Comissão Permanente de Avaliação (CPA) da USF e coordenadora de Iniciação Científica (PIC/CNPq). 
Curi é a paulistana Edda Curi, bacharel e licenciada em Matemática, mestra e doutora em Educação. Atualmente é professora titular e coordenadora do Programa de Pós-Graduação em Ensino de Ciências e Matemática da Universidade Cruzeiro do Sul (Unicsul). Pesquisadora coordenadora de Projeto de Pesquisa no âmbito do Projeto Observatório da Educação financiado pela Comissão de Aperfeiçoamento de Pessoal do Nível Superior (Capes). Pesquisadora coordenadora de Projeto de Pesquisa na linha Ensino Público financiado pela Fundação de Amparo à Pesquisa do Estado de São Paulo (Fapesp) em conjunto com a Pontifícia Universidade Católica de São Paulo (PUCSP).

A expressão professores que ensinam Matemática faz referência, conforme explicam Nacarato e Paiva (2013, p. 19-20), “aos professores polivalentes - aqueles que atuam na educação infantil ou nas séries iniciais do Ensino Fundamental - e que ensinam Matemática, apesar de não serem denominados 'professores de Matemática', visto não serem especialistas". Por esse motivo, justificamos a necessidade de aprofundarmos o estudo acerca desse campo de conhecimento, especialmente, quando entendemos a importância e a contribuição da formação continuada para esses profissionais.

No que se refere à formação continuada para o professor que ensina Matemática, compreende-se, à luz de Muniz (2001, p. 8) que esta "deve garantir a aquisição de algumas competências consideradas essenciais para a atuação junto a crianças, jovens e adultos, que favorecem a aprendizagem da Matemática." O sentido sugerido não se reporta apenas à competência de ensinar conteúdos, mas essa atuação pode ser relacionada à elaboração de finalidades e de conhecimentos que validam a atividade teórica e dão sentido à prática ressignificam a práxis.

Ao afirmar que a formação deve garantir aquisição de competências ${ }^{8}$, na verdade, se está chamando a atenção para uma dimensão pedagógica que alertamos anteriormente, a de criar. Além de criar estratégias para favorecer a aprendizagem Matemática, não podemos deixar de considerar a criação de laços afetivos que permitam a aproximação com a disciplina, e uma das formas de fazer isso é valorizar o conhecimento do educando e encontrar maneiras de ampliá-lo. Essa é a base da aprendizagem significativa (AUSUBEL, 1968; MOREIRA \& MASINI, 2001; MOREIRA, 2015) que abordaremos posteriormente.

Para Muniz (2001, p. 9):

Ser professor de matemática não significa, de forma alguma, ser matemático, tampouco significa não ter dúvidas acerca de seus conceitos, teoremas e formas de representação. Saber matemática implica possuir as noções fundamentais da constituição do número

\footnotetext{
${ }^{8}$ Competência é o tema que pode ser aprofundado na leitura da obra de Terezinha Rios (20.ed.,2011).
} 
[...]. Mas, antes de dominar esses conteúdos, o bom professor de matemática deve estar disponível a APRENDER SEMPRE, a partir das situações impostas pelos desafios da vida do magistério e da vida cotidiana dentro da nossa cultura.

A formação continuada envolve processos de construção permanente, por esse motivo, não se deve pensar que o professor precisa ter domínio total de todas as teorias, até porque a formação, assim como a história, não tem finitude, está se construindo, conforme já assinalamos. Nesse contexto, todos nós precisamos estar abertos para novas aprendizagens que nos ofereçam condições de teorizar a prática e de atuar sobre a realidade, com vista à transformação. É o que compreendemos por práxis na perspectiva da emancipação.

Como afirmou Muniz (2001, p. 24), não se deve limitar a ação do professor de Matemática à transmissão de conhecimentos matemáticos, contudo é preciso formar em cada professor que ensina matemática "um profissional comprometido com as transformações necessárias e desejáveis, buscando a valorização do ser matemático que é cada uma de nossas crianças, jovens e adultos que passam pelas nossas salas de aula". Nesse sentido, valoriza aquilo que o aluno sabe e investe no desenvolvimento do potencial de aprendizagem, porque todos temos condições para aprender. $\mathrm{O}$ autor também alertou sobre o investimento na formação como possibilidades de construção de competências no professor que ensina Matemática. Assim, descreveu que:

[...] é necessário uma multiplicidade de competências que só o investimento na nossa formação pode garantir. Pensar diferentemente o que é fazer matemática implica assumirmos uma vontade política que busca resgatar em cada aluno, e em nós mesmos, o ser matemático que foi historicamente calado, amordaço, ferido e, por vezes, assassinado. (MUNIZ, 2001, p. 28).

O autor utilizou a formação como meio de transformar o pensar e o fazer matemático, contribuindo para enxergarmos professor e aluno como seres matemáticos que outrora eram sufocados pelas raízes históricas dessa disciplina. Ademais, a formação continuada em Educação Matemática precisa ser um mecanismo de construção de autoestima e autoconfiança para resolver os problemas que afligem professores, professoras, alunos e alunas nos mais variados contextos, a superação de situações-limite.

Nesse sentido não podemos pensar em formações marcadas por intervalos de tempo, que acontece com alguma periodicidade, tal como afirmaram Fiorentini e Castro (2003, p. 124):

Acreditar que a formação do professor acontece apenas em intervalos independentes ou num espaço bem determinado é negar o movimento social, histórico e cultural de constituição de cada sujeito. O movimento de formação do professor não é isolado do restante da vida. Ao contrário, está imerso nas práticas sociais e culturais. 
Estamos falando do envolvimento em processos formativos que ofereçam condições não apenas de construir as competências necessárias para o ensino do conteúdo, mas também que desenvolva a sensibilidade do professor para valorizar a cultura (FIORENTINI; NACARATO, 2005), o conhecimento e a dialogicidade como práticas de aprendizagem.

Vale dizer que, quando nos referimos às competências específicas para ensinar Matemática, estamos chamando atenção para algo que é próprio do exercício docente que é considerar "os objetivos da formação para o ensino de Matemática, a seleção e escolha de conteúdos, a organização de modalidades pedagógicas, dos tempos e espaços da formação, a abordagem metodológica, a avaliação" (CURI; PIRES, 2008, p. 3). Esses elementos são importantes para pensar a organização do trabalho pedagógico e, muitas das vezes, esses mesmos se constituem situações-limite da prática que precisam ser superados.

A formação continuada é uma característica importante do desenvolvimento profissional docente e pode auxiliar os professores a superar os entraves teóricos e práticos do seu exercício profissional. Esses entraves não são poucos se levarmos em conta que os professores, que atuam nos anos iniciais do Ensino Fundamental, não são especialistas em Matemática, mas pedagogos que, segundo Curi (2005), têm entre 36 a 72 horas da disciplina Conteúdo e Metodologia do Ensino de Matemática em um universo de 2.880 horas de todo o currículo do curso.

Nesse contexto de discussão, Roldão (2007) trouxe aspectos importantes quanto à função de ensinar e, mais especificamente, fez alusão aos conhecimentos próprios do professor como aqueles corpos de saberes necessários à formação de alguém que ensina. Todavia a autora explicitou que a formalização do conhecimento necessário para ensinar envolve uma série de saberes científicos, didáticos, pedagógicos que se referem a que conteúdo ensinar, como ensinar, a quem e com que finalidades, condições e recursos.

Consoante a isso no contexto do ensino, ocultam-se as situações-limite que não são superadas só com a formação inicial ou com a formação continuada, pois permanece existindo, ainda que de modo diferente, porque as questões ligadas ao ensinar não são estáticas, haja vista que o conhecimento evolui e, portanto, as estratégias também evoluem. Com isso, estamos chamando a atenção para algo muito importante: que a constituição dos inéditos-viáveis não significa a resolução eterna de todos os problemas de ensino e de aprendizagem, mas são mecanismos de desocultação da exploração, da superação e da transformação da realidade.

Outro pesquisador que tem sido muito citado quando o assunto é o conhecimento docente é Shulman (1986), ele identificou três importantes vertentes: a) o conhecimento do conteúdo da disciplina; b) o conhecimento didático do conteúdo da disciplina; e c) o conhecimento do currículo. O primeiro está ligado à compreensão e à sua organização, ou seja, para ensinar é 
preciso utilizar diferentes perspectivas e estabelecer relações entre os tópicos do conteúdo e outras áreas do conhecimento. O segundo é denominado conhecimento pedagógico disciplinar e inclui o planejamento e a instrução na sala de aula. Quanto ao terceiro, diz respeito ao conhecimento do programa que contém todas as disciplinas, a fim de que se faça articulações e se entenda o movimento histórico que o constitui.

Ao fazer uma análise sobre os saberes do professor que ensina Matemática, Albuquerque e Gontijo (2013) defendem que estes não são constituídos como saberes profissionais na ausência de processos formativos e afirmam que "o saber docente é necessário para que, além de dominar o conhecimento matemático, por meio da construção desse conhecimento específico, o professor consiga transformá-lo em conhecimento matemático escolar". Contudo, além de dominar esse conteúdo matemático, é preciso promover um diálogo com o conhecimento didático em um movimento dialógico capaz de organizar o trabalho pedagógico, trazendo sentido para o estudo da Matemática.

Segundo a concepção de D’Ambrósio (1993), o verdadeiro motivo de estudarmos Matemática tem a ver com cinco valores: o valor utilitário, o valor cultural, o valor social, o valor formativo e o valor estético. Assim, somos todos desejosos de que a escola utilize cada vez mais esses valores em favor da aprendizagem.

A Matemática representada a partir do valor utilitário pode ser relacionada com o consumismo - por exemplo, a compra de alimentos, roupas, remédios. O valor cultural que se dá pela oportunidade de planejar caminhos e estratégias cotidianas, favorecendo o pensamento abstrato. O valor social está na nossa própria constituição enquanto pessoa que nasceu em um universo de conhecimentos e construções matemáticas. $\mathrm{O}$ valor formativo, às vezes, é o mais explorado na escola porque diz respeito ao conhecimento mais elaborado, como o que exprime leis e fórmulas científicas. E o valor estético tem a ver tanto com o poder de organização da Matemática quanto da admiração que esta causa.

O que desejamos em relação ao ensino da Matemática é que todos esses valores possam estar conectados em favor da aprendizagem significativa. Isso é que alimenta nossa esperança de que é possível ensinar conhecimentos matemáticos, utilizando-nos do movimento dialógico, a partir da perspectiva do letramento. A respeito dessa perspectiva, trazemos considerações na sequência.

Para criar esse movimento dialógico, é interessante ver a proposta de Nacarato, Mengali e Passos (2009), ao sugerir uma aula diferente de Matemática, que foi denominada de cenário de investigação. Para as autoras, nesse cenário, devem surgir perguntas que possam estimular o pensamento do aluno e do professor, a fim de que se construam uma rede de conceitos, de 
teorização. Essa ideia tem aproximações com aquilo que propomos neste presente trabalho, qual seja, de inquietar os envolvidos no processo formativo e fazer emergir conhecimentos que gerassem outros conhecimentos, o que pode resultar em amplo corpus teórico capaz de provocar novas pesquisas.

A formação específica para se ensinar Matemática nos anos iniciais do Ensino Fundamental tem sido alvo de grandes debates em periódicos de todo o mundo e em eventos importantes na área da Matemática, conforme viemos discutindo até esse parágrafo. Mas já não se pode dizer o mesmo quando a temática é formação do profissional docente para atuar na EJA, que ainda possui escassa produção, especialmente se for em relação ao professor(a) que vai trabalhar com Matemática em sala de aula. É esse o nosso próximo tópico de discussão que nos inquieta e por isso mesmo já estamos em curso com uma investigação mais aprofundada e atual acerca da importância que se tem dado a essa temática, nas pesquisas em Educação.

2.2.2 Formação continuada de professores que ensinam Matemática na Educação de Jovens e Adultos (EJA): uma experiência na perspectiva do letramento

Nossa discussão tem pontuado elementos importantes para explicitar a concepção de formação continuada, mas ainda está faltando chamar para essa conversa os professores Fonseca (2004, 2005, 2013, 2014), Soares $(2011,2013)$, Moura $(2009,2011)$ e Reis $(2000,2012)$ para contribuir com suas experiências de pesquisas e com questões ligadas às especificidades da modalidade EJA.

Fonseca é a mineira Maria da Conceição Ferreira Reis Fonseca, licenciada em Matemática, mestra em Educação Matemática e doutora em Educação. Atualmente é professora titular da Universidade Federal de Minas Gerais (UFMG), da Faculdade de Educação, e coordenadora do Programa de Pós-Graduação em Educação e do Programa de Educação Básica de Jovens e Adultos da UFMG.

Soares é o mineiro Leôncio José Gomes Soares, graduado em Letras, mestre e doutor em Educação. Realizou pós-doutoramento na Universidade Federal Fluminense e pósdoutoramento na Northern Illinois University, em Illinois, Estados Unidos da América. É professor associado da UFMG, na Faculdade de Educação.

Moura é a alagoana Tânia Maria de Melo Moura, pedagoga, mestra e doutora em Educação. Realizou estágio pós-doutoral pela Universidade do Porto, Portugal. Professora Emérita da Universidade Federal de Alagoas (aposentada). Atualmente pesquisadora visitante na 
Universidade Estadual de Alagoas (UEA), bolsista da Fundação de Pesquisa do Estado de Alagoas e professora da Sociedade de Ensino Universitário do Nordeste em Maceió/Alagoas.

Reis é o mineiro Renato Hilário dos Reis, licenciado em Filosofia, mestre e doutor em Educação. Atualmente é professor Associado II da UnB. É coordenador do Grupo de Ensino, Pesquisa e Extensão em Educação Popular e Estudos Filosóficos e Histórico-Culturais (Genpex) e coordena a pesquisa "A significações do Texto Coletivo no processo alfabetizador de jovens e adultos do Paranoá/Itapoã" - vinculada à UnB e ao Centro de Cultura e Desenvolvimento Popular do Paranoá (UnB/Cedep).

A formação continuada para o(a) professor(a) da EJA precisa garantir seus princípios básicos para fortalecer a profissão dos(as) professores(as). Esses princípios, em nosso entendimento, incluem a construção de conhecimentos e envolve: a participação no processo de investigação e de construção dos saberes; a emancipação política que diz respeito à tomada de decisões sem a influência de outrem ou cooptação, refere-se à possibilidade de denunciar injustiças, de dar opiniões críticas e não permite conformismos; incluem também professores como intelectuais transformadores e críticos (GIROUX, 1997), portanto deve-se oferecer condições para que o professor seja um intelectual.

Na EJA, as situações-limite vão surgindo, seja referente à limitação das práticas pedagógicas, seja referente ao domínio de conteúdo pedagógico ou matemático, ou à aplicação de metodologias de ensino e até mesmo referente à própria formação continuada. Nesse aspecto, o(a) professor(a) que ensina matemática pode ter as possibilidades sufocadas "pelas "situaçõeslimite', que se apresentam aos homens e às mulheres como se fossem determinantes históricas, esmagadoras, em face das quais não lhe cabe outra alternativa senão adaptar-se" (FREIRE, 2011, p. 130, grifo nosso). Então, é preciso reagir para transcender a coisificação e compreender que se pode fazer muito, a partir de ações críticas, criativas, democráticas e emancipadoras.

Cumpre ressaltar que, no contexto dos anos iniciais da EJA, o professor que ensina matemática precisa ter sensibilidade para reconhecer a Matemática que seus alunos sabem e utilizam, mesmo que seja informalmente. Isso porque a aprendizagem matemática extrapola a escola e o currículo escolar, assim como se aprende matemática para além da relação pedagógica aluno-professor. É neste sentido que devemos ampliar a noção do valor cultural da Matemática que está impregnada nos mais diferentes contextos, seja nos processos produtivos, nas expressões culturais, como música, artes plásticas e cênicas, seja nos esportes, na forma de ler e interpretar a natureza e na nossa relação de exploração e sua conservação etc.

Assim, é necessário para o docente "a presença de espírito que lhes provê de estratégias para considerá-la, integrando-a na negociação de significados e intenções forjada na situação de 
ensino-aprendizagem para (re)significá-la [...]" (FONSECA, 2005, p. 57). O sentido empregado pela autora remeteu à sensibilização do professor a qual é possível a partir do momento em que esse profissional se permite teorizar a prática e agir pensando na teoria, indagando-a e flexibilizando, na perspectiva de provocar mudanças.

Uma reflexão importante diz respeito à relação que esse professor mantém com o conhecimento matemático. Essa relação passa primeiro pelos saberes cotidianos, conforme pontua Barcelos (2009, p. 30):

A nossa formação como educadores e educadoras passa, necessariamente, pelo nosso cotidiano. Ela - a formação docente - está intimamente ligada aos nossos costumes, hábitos, conceitos, preconceitos. Tem muito que ver com nossas representações e nosso imaginário social vigente. Enfim, formação e experiência são irmãos inseparáveis.

A formação a qual se fez referência é aquela que acontece independentemente de sistemas formais de ensino. Ela parte da vivência do professor e, por isso, às vezes, aprisiona-se em conceitos mais concretos, em oposição às questões mais abstratas, tal como se dá a concepção de Educação Matemática. Outrossim, a formação deve ser uma necessidade coletiva de aprimoramento de ações e aperfeiçoamento do ser matemático.

Assim, especialmente, se considerarmos que o perfil dos professores que historicamente trabalharam na EJA era de "estudantes em processo de habilitação para o magistério, agentes comunitários e voluntários com distintos níveis de escolaridade” (DI PIERRO, 2011, p. 167), faz-se mais urgente pensar nas condições de formação do professor. Nesse sentido, é importante trazermos para essa discussão elementos para dialogar sobre como os cursos de Pedagogia tem preparado os professores para atuarem na EJA e se a disciplina Metodologia do Ensino da Matemática tem sido trabalhada, considerando a estrutura organizacional e pedagógica dessa modalidade de ensino.

Para Moura (2009) e Soares (2011), a falta de qualificação é uma das muitas barreiras encontradas pelo professor da EJA e suas consequências apresentam-se nas ações pedagógicas desenvolvidas que são alheias às especificidades e às peculiaridades dessa modalidade de ensino. Ressalta-se que as disciplinas oferecidas pelos cursos de Pedagogia (nem todos os cursos) não dão conta de trazer aspectos importantes que permitam conhecer melhor a EJA, favorecendo um trabalho pedagógico comprometido.

A realidade da EJA é preocupante, como já sinalizava a professora Tânia Moura que coordenou uma investigação realizada pelo Programa Institucional de Bolsas de Iniciação Científica (Pibic) pela Universidade Estadual de Alagoas (Uneal), no período compreendido entre agosto de 2008 a agosto de 2009; essa autora deparou-se com uma ação pedagógica 
desarticulada que sinalizava a carência formativa. Assim, descreveu: "em uma de nossas investigações realizada numa turma da $3^{\mathrm{a}}$ fase do $1^{\mathrm{o}}$ segmento de EJA, a professora fotocopiava os textos do livro de sua filha de 5 anos, que estudava numa escola da rede particular, para utilizar com seus alunos" (MOURA; RIBEIRO, 2011, p. 61).

A análise feita pela pesquisadora permitiu concluir que a professora não percebia diferença entre a forma de aprender de um adulto e a de uma criança, ou não valorizava o que Freire (1996, p.64) denominou de conhecimentos de experiência feitos. Isso reflete a necessidade de formação, de conhecimento de outras áreas do conhecimento, como a psicologia e a sociologia, para que se tenha o entendimento de que as estruturas mentais, os procedimentos, as relações, a elaboração de conceitos e o tempo de aprendizagem acontecem de modo diferente entre crianças e adultos. Do contrário, teremos sérios problemas sociológicos e pedagógicos.

É evidente que os problemas pedagógicos (a matéria a ensinar, os currículos, os métodos) correspondentes a cada faixa etária são distintos. Por isso a alfabetização do adulto é um processo pedagógico qualitativamente distinto do infantil (a não ser assim, cairíamos no erro da infantilização do adulto) [...] (PINTO, 2010, p.74).

Essa afirmação é compatível com o que estamos defendendo enquanto formação que vise à aprendizagem significativa, ocorrendo dentro de contexto próprio do cotidiano do adulto, em que, além de se reconhecer enquanto agente ativo, também crie estratégias de resolução e de tomada de decisões no contexto real. Esse modo de olhar para o mundo do adulto (inclui-se em nossa pesquisa todos aqueles que passaram da fase da infância) foi cuidadosamente registrado na obra Sete lições sobre educação de adultos ${ }^{9}$, da autoria do fluminense Álvaro Vieira Pinto, intelectual e filósofo brasileiro. Essa obra, além de ter sido a última que o autor publicou em vida, traz contribuições acerca da experiência e das reflexões de aulas ministradas para adultos.

Essa ênfase foi dada para chamar atenção para algumas práticas de professores que estudam fundamentos de todas as disciplinas, mas com uma demarcação acentuada de que vão ensinar crianças, ou seja, não é feito uma especificidade de estudo e pesquisa acerca da modalidade EJA como possibilidade de lotação de trabalho nessa área. Por exemplo: fulano é aprovado em concurso público e recebe a lotação em uma escola que funciona com a modalidade EJA. Então, o que ensinar, como, de que modo, com qual finalidade? O que temos que saber sobre as características desse público e quais suas necessidades?

Em se tratando de aprender e ensinar Matemática, a situação é ainda mais preocupante, porque só o estudo da disciplina Metodologia do Ensino da Matemática ou Fundamentos da Matemática, na formação inicial, não dá conta de uma formação Matemática, conforme

\footnotetext{
${ }^{9}$ A obra é organizada em sete temas compreendidos desde o conceito de Educação até a formação do educador para atuar na EJA (PINTO, 2010).
} 
investigou Nacarato e Paiva (2013). Estamos nos referindo a uma formação que ofereça aos professores e professoras, além de bases conceituais, outras informações importantes para trabalhar os conhecimentos matemáticos na EJA.

Essa formação matemática representa a oportunidade de estudar a Matemática como uma ciência dinâmica e flexível que acompanha a evolução social, superando um caráter mecânico de ensino. Dessa forma, pensamos em uma formação que contribua para a pesquisa, para a elaboração de conhecimentos, para a transformação de realidades, para pensar nas condições de trabalho e de pesquisa sem dissociá-las das condições de ensino e de aprendizagem, que garanta a emancipação.

Tome-se nota que emancipação diz respeito ao campo cognitivo, social e político. Esses não são estágios separados, mas uma conjuntura em que é preciso ter autonomia acerca da construção e da reelaboração do conhecimento. Esse conhecimento e essa autonomia devem pertencer a uma comunidade que sonha e, portanto, o poder de decisão e de crítica devem estar acima de qualquer situação de opressão. Esse sonho não pode se limitar a pensar e planejar algo, mas precisa de impulso e de ação para que se torne concreto.

Apesar de defendermos a concretude dos sonhos a partir do engajamento em processos de formação continuada, temos de reconhecer que os próprios estudos e publicações acerca da formação dos professores que ensinam Matemática na EJA são praticamente inexistentes. Isso implica, de certa forma, uma falta de compromisso com a comunidade de professores dessa modalidade, porque provoca uma escassez teórica de materiais que poderiam contribuir com a formação continuada e com a própria práxis.

Quanto a esse aspecto, destacamos a pesquisa de Soares e Pedroso (2013, p. 255-256) com a afirmação de que "nas últimas dez Reuniões Anuais da ANPEd (25 a 2002 a 34 , 2011), dos 233 trabalhos apresentados no GT8 sobre Formação de Professores, não foi encontrado nenhum no campo da EJA”. Se na Associação Nacional de Pós-Graduação e Pesquisa em Educação (Anped), os grupos de trabalhos (GTs) não têm apresentado trabalhos que contemplem a formação do professor que atua na EJA, isso já é preocupante, pois trata-se de um evento com representatividade de pesquisadores de todas as linhas de pesquisas educacionais.

Vale destacar que na Anped o GT 18 é de Educação de Jovens e Adultos e o GT 19 é de Educação Matemática, já estamos realizando estudo paralelo a este trabalho para fazer tal levantamento sobre a incidência ou ausência do tema em ambos os Grupos de Trabalhos (GTs). Isso está sendo desenvolvido como extensão das provocações na escrita da Tese, a fim de dialogarmos com outros pesquisadores interessados na discussão. 
Colocamos em relevo que precisamos de mais adeptos para lutar por essa causa, pois tanto nos eventos de Educação quanto nos de Educação Matemática, há escassez de trabalhos que investigam a formação dos profissionais que ensinam Matemática na EJA. A esse respeito, vamos conferir o levantamento que realizamos do estado da arte dos trabalhos apresentados no GT 07 - de formação de professores que ensinam Matemática - nos encontros específicos do campo da Educação Matemática, como o Encontro Nacional de Educação Matemática (ENEM) e o Simpósio Internacional de Pesquisa em Educação Matemática (SIPEM). O resultado foi preocupante, pois encontramos um irrisório número de abordagem na formação dos professores que ensinam Matemática na EJA, conforme trazemos adiante.

As pesquisas não têm priorizado essa temática, como se a formação não fosse relevante, contudo isso não significa a ausência de problemas, mas a ocultação deles. Essa é uma situação que nos provoca e nos faz criar mais coragem para colaborar com essa modalidade educativa, contribuindo para que se fortaleça enquanto campo de conhecimento.

Apesar desse cenário, somos movidos pela esperança de que o trabalho de pesquisa que realizamos possa contribuir para mudar esse lamentável quadro e que mais pesquisadores e professores intelectuais possam se unir para criar espaços de discussão acerca da formação do profissional que atua com a Matemática na EJA. Nesse contexto, acompanhemos o estado da arte referente às publicações no ENEM, conforme tabela a seguir.

Tabela 1: Estado da Arte - publicações no Encontro Nacional de Educação Matemática (ENEM)

\begin{tabular}{|c|c|c|c|}
\hline $\begin{array}{l}\text { Ordem dos } \\
\text { eventos }\end{array}$ & Local e ano de realização & $\begin{array}{c}\text { Quantidade de trabalhos } \\
\text { do tipo comunicação } \\
\text { científica apresentados } \\
\text { no GT 07 } \\
\end{array}$ & $\begin{array}{l}\text { Quantidade de trabalhos do } \\
\text { tipo comunicação científica } \\
\text { sobre formação para o } \\
\text { professor da EJA (GT07) }\end{array}$ \\
\hline I Enem & PUC/São Paulo - 1987 & 2 & 0 \\
\hline II Enem & Maringá/Paraná - 1988 & 5 & 0 \\
\hline III Enem & Natal/RN - 1990 & 23 & 0 \\
\hline IV Enem & Blumenal/SC - 1992 & 18 & 0 \\
\hline V Enem & Aracaju/SE - 1995 & 3 & 0 \\
\hline VI Enem & São Leopoldo/RS - 1998 & 18 & 0 \\
\hline VII Enem & Rio de Janeiro/RJ - 2001 & 5 & 0 \\
\hline VIII Enem & Recife/PE - 2004 & 30 & 0 \\
\hline IX Enem & Belo Horizonte/MG - 2007 & 13 & 0 \\
\hline X Enem & Salvador/BA - 2010 & 54 & 1 \\
\hline XI Enem & Curitiba/PR - 2013 & 133 & 2 \\
\hline
\end{tabular}

Fonte: elaboração da pesquisadora (2015).

Ao analisar as informações da tabela, notamos que o ENEM tornou-se um evento trianual a partir de sua $5^{\mathrm{a}}$ edição e, em 2013 , realizou sua $11^{\mathrm{a}}$ edição. Apesar de mostrar uma oscilação na quantidade de artigos aprovados e apresentados na qualidade de comunicação científica no GT 
07, cumpre destacar que, em alguns eventos, o eixo temático ficou desfocado. Por exemplo, alguns artigos de formação estavam no GT 01 da Educação Matemática nas séries iniciais do Ensino Fundamental. No entanto optamos por registrar a partir dos títulos (e considerando a leitura do resumo e de palavras-chave) que constavam nos anais de cada edição do evento.

Outra análise a ser feita é que, de 1987 a 2013, foram apresentados e publicados 304 trabalhos no GT 07, mas apenas três ${ }^{10}$ foram dedicados aos professores da EJA. Salienta-se que, em outros grupos de trabalho, a modalidade EJA foi contemplada, mas trazendo aspectos como: currículo, ensino e aprendizagem, avaliação e práticas de ensino de dado conteúdo. Esses temas são importantes, mas não constituem o foco do nosso trabalho.

Também percebemos, na organização dos Anais do XI ENEM, uma mistura de temáticas que, além dos temas descritos anteriormente, também abordaram aspectos sobre livro didático, identidade, educação profissional, inclusão, TICs e conteúdos específicos como geometria (record em produção), álgebra e estatística. Todavia as providências para resolver esse impasse já estão a caminho, prevista para a $12^{a}$ edição do ENEM, que será realizada em julho de 2016, na cidade de São Paulo. Trata-se da implantação do Eixo 6 - Educação de Jovens e Adultos e Educação Matemática sob a coordenação dos professores Maria da Conceição Ferreira Reis Fonseca da Universidade Federal de Minas Gerais (UFMG) e Emerson da Silva Ribeiro da Universidade Federal de Rondônia (Unir).

Segundo a divulgação no site do evento, a finalidade do Eixo 6 do ENEM é promover a divulgação de

Estudos e experiências pedagógicas em Educação Matemática no âmbito da Educação de Jovens e Adultos (EJA) em contextos formais e não-formais; práticas matemáticas de pessoas jovens e adultas excluídas do sistema educacional e daquelas que retornam à escola ou a acessam pela primeira vez.

Nesse contexto, estamos comemorando esse avanço e já ficamos na expectativa de inaugurar esse eixo com a publicação de parte desse trabalho de doutorado.

Ademais, o mesmo ainda não aconteceu com o Simpósio Internacional de Pesquisa em Educação Matemática (SIPEM) que já concluiu sua sexta edição e não tem publicado trabalhos que se ocupem da formação do professor que ensina Matemática na Educação de Jovens e Adultos, conforme podemos conferir na tabela a seguir.

\footnotetext{
${ }^{10}$ Os três artigos publicados no Enem foram: "Formação de professores de matemática 'para' e 'na' EJA: saberes docentes necessários e saberes construídos na prática” de Lailson dos Reis Pereira Lopes e Marilene Ribeiro Resende da Uniube - publicado em 2010; "O processo de ensino-aprendizagem em matemática na perspectiva freiriana" de Adriano Cavalcante da Silva da Universidade Estadual do Rio Grande do Norte (UERGS); e "Algumas reflexões sobre a formação continuada desenvolvida pelos Cefapros para os educadores de matemática que atuam na EJA", de Osinéia Albina Brunelli e Marta Maria Pontin Darsie do Matro Grosso. Esses dois últimos foram publicados no evento de 2013.
} 
Tabela 2: Estado da Arte - Publicações no Simpósio Internacional de Pesquisa em Educação Matemática (SIPEM)

\begin{tabular}{c|c|c|c}
\hline $\begin{array}{c}\text { Ordem } \\
\text { dos } \\
\text { eventos }\end{array}$ & Local e ano de realização & $\begin{array}{c}\text { Quantidade de trabalhos } \\
\text { do tipo comunicação } \\
\text { científica apresentados no } \\
\text { GT 07 }\end{array}$ & $\begin{array}{c}\text { Quantidade de trabalhos do } \\
\text { tipo comunicação científica } \\
\text { sobre formação para o } \\
\text { professor da EJA (GT 07) }\end{array}$ \\
\hline I Sipem & Serra Negra/SP - 2000 & 25 & 0 \\
\hline II Sipem & Santos/SP - 2003 & 23 & 0 \\
\hline III Sipem & Águas de Lindóia/ SP -2006 & 37 & 1 \\
\hline IV Sipem & Taguatinga/DF - 2009 & 26 & 0 \\
\hline V Sipem & Petrópolis/ RJ - 2012 & 24 & 0 \\
\hline VI Sipem & Pirenópolis/GO - 2015 & 29 & 0 \\
\hline
\end{tabular}

Fonte: elaboração da pesquisadora (2015).

O SIPEM é um evento de alcance internacional que vem sendo realizado desde o ano 2000, com edições também trianuais e já realizou sua $6^{\mathrm{a}}$ edição. Trata-se de um evento que reúne importantes pesquisadores da área da Educação Matemática e, assim, como o ENEM, é organizado pela Sociedade Brasileira de Educação Matemática (SBEM) Nacional.

Conforme análise da tabela, percebemos um número de publicações no GT 07 sem grande oscilação, sendo que, do ano 2000 a 2015, totalizaram-se 164 trabalhos aprovados e publicados nesse grupo de trabalho. No entanto, desse universo, apenas um $^{11}$ artigo tratou do aspecto formativo do professor que ensina Matemática na EJA.

Essa escassez de publicação pode ser encarada pela comunidade acadêmica e científica como uma situação-limite, ou seja, um obstáculo que precisa ser vencido. Alguns dos atos-limite a se empreender para transformar essa realidade poderiam ser a estimulação de pesquisas nessa modalidade de ensino, a promoção de parcerias entre educadores matemáticos das universidades e professores da EJA, bem como a abertura de cursos de especialização para professores da rede de ensino estadual e municipal. Nesse último caso, temos que registrar a contribuição da UnB que tem ofertado a especialização Lato Sensu: Educação na Diversidade e Cidadania com ênfase na Educação de Jovens e Adultos. Todas essas ações formativas culminariam na elevação de produções nessa área de conhecimento, o que vamos denominar de constituição de inéditosviáveis.

Há de se considerar que existem muitos desafios a serem superados até que se construam os inéditos-viáveis e essa superação depende dos momentos pedagógicos aos quais fizemos referência anteriormente: sonhar, estudar, criar (FREITAS, 2001). Em todos esses momentos, é importante destacar que o conhecimento do senso comum (da experiência) faz-se necessário para

\footnotetext{
${ }^{11}$ Essa publicação foi de 2006 e se intitulou "Dilemas práticos para a formação de professores em Educação Matemática de Jovens e Adultos”, de Sônia Maria Scheider da Universidade Federal Fluminense (UFF).
} 
construção do conhecimento mais elaborado, consequente da rigorosidade metódica (FREIRE, 1996) de aprendizagem, criticidade, curiosidade e investigação.

A relação entre esses três momentos faz maximizar a ideia principal de que estamos defendendo, desde as palavras iniciais desse texto, que é a possibilidade de construir coletivamente os inéditos-viáveis, a partir de atitudes formativas, críticas e emancipatórias em desfavor das situações-limite.

As situações-limite assemelham-se ao que o professor Reis (2000) denominou de "situações-problemas-desafio", que são os obstáculos, as dificuldades que interferem na vida pessoal e na existência do homem e que podem ser superadas com as ações coletivas, visando à transformação da realidade social. O movimento formativo reforça essa ideia de coletividade, de junção de forças em prol de um bem maior: a superação dos problemas e da opressão que afligem uma sociedade.

A título de exemplo de situações-limite, vamos pensar na vastidão de conteúdos matemáticos apresentados no currículo da EJA, tendo em vista o pouco tempo dedicado a cada série/ano (um semestre) e que o professor precisa dar conta. Então, é preciso fazer relações entre os conhecimentos de cada bloco de conteúdo.

A primeira ponderação a se fazer é que os professores da EJA, assim como aqueles do ensino regular, priorizam, nos anos iniciais, o ensino da língua materna em detrimento da Matemática. Contudo os programas nacionais de formação, como o Pró-Letramento e o Pacto Nacional pela Alfabetização na Idade Certa (PNAIC), tentam desmistificar essa prática quando mostra a possibilidade de alfabetizar e letrar matematicamente.

No caso do Distrito Federal, há também dois projetos de extensão cadastrados na plataforma da Capes que auxiliam a ação do professor, quais sejam: o Grupo de EnsinoPesquisa-Extensão em Educação Popular e Estudos Filosóficos e Histórico-Culturais (Genpex) e o Grupo de Pesquisa, Aprendizagem, Tecnologia e Educação a Distância (Gatead). Ambos os projetos são da Faculdade de Educação da UnB e, segundo Reis, Rêses e Vieira (2012), contribuem para a formação de professores que vão atuar na EJA, pois trabalham não apenas a dimensão conteudista, mas também a dimensão humana e social do processo de ensino e aprendizagem.

Com essas propostas formativas, tanto em âmbito nacional quanto no caso do DF, é proposto aos professores que trabalhem a partir da conexão de saberes, isto é, estabeleçam relações entre os conhecimentos a fim de elaborar uma rede de conceitos válidos para a Educação Matemática. A isto se pode denominar de inéditos-viáveis, porque são estratégias encontradas para superar o problema do curto tempo para ministrar todo o currículo. 
Para dar conta de trilhar esse caminho, fomos em busca de uma perspectiva que possibilitasse a articulação dos conhecimentos, de modo a conferir significado às ações realizadas no campo da Educação Matemática. Essa contribuição veio de Fonseca (2004, 2005, 2013, 2014) e Soares (2004, 2014), que tem defendido o letramento como elemento de ampliação da possibilidade de leitura do mundo. Entretanto vale destacar que não estamos confundindo com alfabetização matemática, muito embora não sejam excludentes.

Soares é a mineira Magda Becker Soares, graduada em Letras Neolatinas, doutora em Didática. Atualmente é professora titular emérita da Faculdade de Educação da UFMG e livredocente em Educação. Pesquisadora Fundadora do Centro de Alfabetização, Leitura e Escrita (CEALE) da Faculdade de Educação da UFMG. Em maio de 2015, recebeu a mais importante honraria $^{12}$ nacional do setor de Ciência e Tecnologia, concedido pelo Conselho Nacional de Desenvolvimento Científico e Tecnológico (CNPq/MCTI).

Definições sobre alfabetizar e letrar como perspectivas complementares e não exclusivistas (SOARES, 2014) são contribuições necessárias para o ensino, haja vista que alfabetização e letramento não são estanques nem precisam estar separadas como momentos específicos. Desse modo, defendeu alfabetização como processo de aquisição da língua (oral e escrita) e letramento como o processo de desenvolvimento do uso da língua (oral e escrita) nas práticas sociais que a envolvem. Isso significa que são processos que convergem para a aprendizagem, nesse sentido, o ser matemático constrói o próprio valor e significado ao conceber todos os valores matemáticos presentes em seu cotidiano.

Letramento é um termo em ebulição ao qual Soares (2004, p. 96) remetia "necessidade de configurar e nomear comportamentos e práticas sociais na área da leitura e da escrita que ultrapassem o domínio do sistema alfabético e ortográfico". Desse modo, estamos utilizando essa perspectiva porque entendemos que, na modalidade EJA, os interesses de educadores e educandos não estão simplesmente voltados para grafar letras, símbolos e números, mas na possibilidade de ir além desses objetivos.

Especialmente os alunos desejam compreender os acontecimentos que estão à sua volta, pois envolve um processo que depende da etapa anterior: a de alfabetização. Assim, letramento é o desenvolvimento de ações que vão dar significado às práticas sociais-educacionais-culturaispolíticas-éticas da vida do sujeito continuamente. A esse respeito, Soares (2014, p. 24) pontuou com certo detalhamento:

\footnotetext{
${ }^{12}$ O Prêmio Almirante Álvaro Alberto para a Ciência e Tecnologia é concedido anualmente a um pesquisador que tenha se destacado pela realização de obra científica ou tecnológica de grande valor para o progresso da sua área do conhecimento. Conferir matéria completa no portal <http://www.plataformadoletramento.org.br/emrevista/857/magda-soares-e-a-primeira-educadora-a-receber-importante-premio-do-cnpq.html >.
} 
Um indivíduo pode não saber ler e escrever, isto é, ser analfabeto, mas ser de certa forma, letrado (atribuindo a este adjetivo sentido vinculado a letramento). Assim, um adulto pode ser analfabeto porque marginalizado social e economicamente, mas, se vive em um meio em que a leitura e a escrita tem presença forte, se se interessa em ouvir a leitura de jornais feita por um alfabetizado, se recebe cartas que outros lêem para ele, se dita cartas para que um alfabetizado as escreva (e é significativo que, em geral, dita vocabulário e estruturas próprios da língua escrita), se pede a alguém que lhe leia avisos ou indicações afixados em algum lugar, esse analfabeto é, de certa forma, letrado, porque faz uso da escrita, envolve-se em práticas sociais de leitura e de escrita.

Esse contexto tem sido valorizado pelas professoras da escola onde realizamos a pesquisa, pois trabalhamos a Matemática nesse universo social em que há jovens, adultos e idosos que precisam não apenas decodificar o número da linha de ônibus, por exemplo, mas sentem a necessidade de saber qual seu trajeto. Além de muitas outras necessidades da vida que demandam habilidades de leitura e escrita de números e representações matemáticas como: mapas, escalas, gráficos, folhetos, telefones, calendários, relógios, fita métrica, situaçõesproblema (que exigem interpretação e solução). O letramento é imprescindível para a realidade da EJA.

Corroboraram com esse entendimento Fonseca e Souza (2013, p. 924), embora utilizassem outra terminologia - a de numeramento - concordaram que era referente a um conjunto de práticas sociais que, além dos processos de leitura e escrita, também envolviam "relações de quantificação, mensuração, classificação geradas por processos sociais mais amplos" surgidos no cotidiano. Todas essas ações fazem parte de um dia a dia cheio de enfrentamentos que precisam ser superados.

Esse contexto é permeado pelo que denominamos de situação-limite e que, em se tratando de EJA, é preciso bem mais que supor questões matemáticas artificiais, mas explorar a própria realidade para trabalhar com os conteúdos que compõe o currículo escolar. A busca pela superação dessas situações-limite favorece a instituição dos inéditos-viáveis, daí sua estreita relação com a Educação Matemática, cujo papel social é contribuir com a construção de conceitos significativos para a vida.

Trata-se de uma relação de descobertas, de superação de problemas, de construção de novo modo de educar matematicamente. Esse é um processo que demanda estudo, cooperação, rigor metodológico, criatividade, criticidade e resulta em uma postura político-pedagógica mais centrada, em favor de uma práxis emancipadora. Isto é, uma prática vivida na teoria e, indissociavelmente, uma teoria conectada na prática, a partir de experiências autônomas e críticas do professor em processo dialógico de aprendizagem, e isso contribui para a organização do seu trabalho pedagógico. 


\subsection{Organização do trabalho pedagógico e currículo da Matemática na EJA: olhar formativo nos documentos nacional e distrital}

Concebemos que o conhecimento é um processo humano e histórico, que transforma o mundo vivido, que é sempre provisório, com origem na prática teorizada do homem e nos processos de transformação da natureza. Esse conhecimento faz parte da necessidade do sujeito pelo saber. Entretanto, por seu caráter histórico, tanto o conhecimento, quanto o sujeito, fazem parte de um todo incompleto e inconcluso e, portanto, precisa de pessoas e elementos que possam complementá-los continuamente.

Em se tratando do profissional professor e ao considerar que sua função é ensinar, os elementos que complementam essa função dizem respeito à organização do trabalho pedagógico, o que implica diferentes formas de planejamento: que compreende desde a organização da sala até o fechamento da aula. No que concerne à pessoa do professor, o que lhe complementa é a qualidade de vida que inclui dedicação de tempo para a família e para alguma forma de lazer.

A organização do trabalho pedagógico do professor da EJA deve iniciar-se a partir do conhecimento da estrutura organizacional dos segmentos da modalidade de ensino. No entanto o documento oficial que trata dessa questão no DF, o Currículo em Movimento da Educação Básica (DISTRITO FEDERAL, 2014), traz uma organização que, na teoria, funciona com o Ensino Fundamental de nove anos. Contudo essa distribuição não apresenta correspondência de conteúdo, tampouco é reconhecida por professores, gestores, coordenadores e alunos. Na escola, o primeiro segmento é identificado e registrado nos diários como etapa (da $1^{\mathrm{a}}$ a $4^{\mathrm{a}}$ ), na fala das professoras a nomenclatura é semestre.

Por esse motivo, procuramos a equipe da Secretaria de Educação do DF - no Departamento de Educação de Jovens e Adultos - e conversamos com a coordenadora-geral do documento, a professora Leila Maria de Jesus Oliveira. A justificativa foi que essa alteração (ensino de nove anos) passou pela votação dos professores e que já deveria estar em prática. Depois disso, não nos alongamos na discussão, tendo em vista que o tema não é foco desse trabalho, mas esperamos que outras pesquisas possam contribuir no sentido de aprofundá-lo e esclarecê-lo. Aqui optamos por trazer a configuração estabelecida no documento oficial.

Quadro 1: Organização dos segmentos da EJA no Distrito Federal

\begin{tabular}{|c|c|c|}
\hline Segmento & Educação básica & Carga horária \\
\hline Primeiro segmento & Anos iniciais $\left(1^{\circ}\right.$ ao $5^{\circ}$ ano $)$ & 1.600 horas \\
\hline Segundo segmento & Anos finais $\left(6^{\circ}\right.$ ao $9^{\circ}$ ano $)$ & 1.600 horas \\
\hline Terceiro segmento & Ensino Médio $\left(1^{\circ}, 2^{\circ}\right.$ e $3^{\circ}$ ano $)$ & 1.200 horas \\
\hline
\end{tabular}

Fonte: Currículo em Movimento da Educação Básica - da EJA (DISTRITO FEDERAL, 2014). 
Nesse caso, os estudantes da EJA precisam de seis anos para concluir todas as etapas de ensino (total de 12 semestres) - do primeiro ao terceiro segmento. Isso implica que, em 12 semestres, o conteúdo da Educação Básica precisa ser trabalhado e, para que isso se torne viável, o professor faz opções e seleciona o que é mais importante ensinar. Ao estudarmos o currículo nacional para o $1^{\circ}$ segmento (PROPOSTA CURRICULAR, 2001) e o currículo em movimento (DISTRITO FEDERAL, 2014), percebemos um vasto conteúdo que só é possível ser contemplado se trabalharmos na perspectiva da conexão de saberes. Nesta pesquisa, conseguimos vivenciar tal experiência a qual descrevemos adiante.

Importante ressaltar também que um único professor deve dar conta de ministrar os conteúdos de toda a disciplina no prazo de um semestre que, em linhas gerais, corresponde ao intervalo de meses de março a julho. Além de ministrá-los, espera-se que professores e alunos construam, na relação dialógica, mecanismos de estudo e investigação, como é o caso sugerido por Freire (2011) acerca do universo temático do aluno. Por exemplo, se o conteúdo a ser estudado é medida de tempo, é importante que se valorize a rotina do aluno(a) e que ele perceba que, a partir dos conhecimentos que já possui, é possível avançar e fazer relações com os conhecimentos escolarizados. Se isso não acontece, pode-se tornar uma situação-limite que impede a aprendizagem com mais significado.

Entretanto não podemos deixar de lado o conhecimento cultural mais formal e mais articulado, proveniente do mundo letrado, das mídias e das redes sociais, para não incorremos na redução do acervo teórico-epistemológico que todos têm direito. Nesses termos, defendemos que possamos partir dos contextos cotidianos e específicos em direção a conhecimentos mais amplos - como estratégia para instigar a participação - ao questionamento e à construção de outros conhecimentos. Afinal de contas, todos os conhecimentos - informais ou formais - são necessários para a vida, mas só passa a ser significativo se estabelecermos relação com eles (FREIRE, 2011).

Didaticamente, tais conhecimentos estão ligados a um campo do saber que na escola recebe o nome de disciplinas. A esse respeito, observemos, no quadro a seguir, a correspondência dos componentes curriculares conforme os segmentos de ensino, considerando que todas as disciplinas devem ser ministradas no período de um semestre letivo, que corresponde a um ano/série cursado. Nesse contexto, ao professor e à professora fica a complexa tarefa de identificar o que é mais importante ser priorizado para ensinar. 
Quadro 2: Organização dos componentes curriculares por segmento na EJA

\begin{tabular}{|c|c|}
\hline Educação básica & Componentes curriculares \\
\hline $\begin{array}{l}1^{\circ} \text { Segmento: anos iniciais } \\
\left(1^{\circ} \text { ao } 5^{\circ} \text { ano }\right) \\
\mathbf{1 . 6 0 0 ~ h o r a s ~}\end{array}$ & $\begin{array}{l}\text { Língua Portuguesa, Arte, Educação Física, Matemática, Ciências, } \\
\text { Geografia, História e, opcionalmente, Ensino Religioso. }\end{array}$ \\
\hline $\begin{array}{l}2^{\circ} \text { Segmento: anos finais } \\
\left(6^{\circ} \text { ao } 9^{\circ} \text { ano }\right) \\
\mathbf{1 . 6 0 0} \text { horas }\end{array}$ & $\begin{array}{l}\text { Língua Portuguesa, Arte, Educação Física, Língua Estrangeira } \\
\text { Moderna (Inglês), Matemática, Ciências, Geografia, História e, } \\
\text { opcionalmente, Ensino Religioso. }\end{array}$ \\
\hline $\begin{array}{l}3^{\circ} \text { Segmento: Ensino Médio } \\
\left(1^{\circ}, 2^{\circ} \text { e } 3^{\circ} \text { ano }\right) \\
\mathbf{1 . 2 0 0} \text { horas }\end{array}$ & $\begin{array}{l}\text { Língua Portuguesa, Arte, Educação Física, Língua Estrangeira } \\
\text { Moderna (Inglês e Espanhol), Matemática, Física, Química, } \\
\text { Biologia, Geografia, História, Filosofia, Sociologia e, } \\
\text { opcionalmente, Ensino Religioso. }\end{array}$ \\
\hline
\end{tabular}

Fonte: elaboração da pesquisadora com base no Currículo Nacional (PROPOSTA CURRICULAR, 2001) e no Currículo em Movimento (DISTRITO FEDERAL, 2014) com foco na EJA.

Note-se que, em termos de distribuição de horas versus conteúdos, não há uma equidade e isso se percebe também na quantidade de páginas dedicadas a cada componente curricular no documento do Currículo em Movimento do $\mathrm{DF}^{13}$. Além disso, não há uma correspondência de conteúdo para a $5^{\mathrm{a}}$ etapa, o que seria o $5^{\circ}$ ano.

Quanto ao currículo nacional para o $1^{\circ}$ segmento da EJA, este toma a Matemática como ciência e explicita que a "Matemática engloba um amplo campo de relações, regularidades e coerências, despertando a curiosidade e instigando a capacidade de generalizar, projetar, prever e abstrair" (PROPOSTA CURRICULAR, 2001, p. 99). Nesse trecho, podemos perceber a dimensão humana, social e científica da Matemática, pois ela relaciona-se com os aspectos da vida pessoal, cultural e sistematizada do sujeito.

No que concerne à tarefa de selecionar e ensinar conteúdos, isso também consiste em situações-limite, ou seja, são obstáculos que se interpõem na prática de ensino. Em sentido mais amplo, poderíamos dizer que teríamos os "obstáculos epistemológicos" (BACHELARD, 1996) que se diz da estagnação dos conhecimentos não questionados, são os conflitos, as barreiras que impedem o avanço do conhecimento.

Em sentido mais restrito, que se reporta à realidade de sala de aula, poderíamos denominar de obstáculos didáticos (PAIS, 2001) que se referem às barreiras na ação de ensinar. Essas barreiras são criadas pelos professores e, consequentemente, pelos alunos, mas sem que estes se deem conta disso. São estratégias criadas a partir de um contexto de ensino e isso pode ser decorrente de uma postura de acomodação epistemológica e inclui a falta de conhecimentos conceituais.

\footnotetext{
${ }^{13} \mathrm{O}$ detalhamento dos conteúdos do $1^{\circ}$ segmento se encontra da página 32 a 73 do documento oficial (Currículo em Movimento do DF, 2014), que inclui todos os componentes curriculares.
} 
Tangenciamos questões importantes que fazem parte da organização do trabalho pedagógico do professor, como é caso do ensino que pressupõe um planejamento, com elaboração de objetivos, construção de metodologias, seleção de recursos didáticos e conhecimento profissional (ROLDÃO, 2007). Qualquer um desses pode representar obstáculos para a prática e interferir nos objetivos do ensino da Matemática que se referem a estimar, contar, comparar, medir, somar, subtrair, multiplicar, dividir, interpretar informações e realizar atividades cotidianas pelos alunos.

Para as professoras da pesquisa, um obstáculo na EJA é ensinar uma grande quantidade de conteúdos em um espaço de tempo reduzido (cada etapa é semestral), como é proposto no currículo. Esses conteúdos estão no quadro a seguir e foi elaborado de acordo com o Currículo em Movimento da Educação Básica (DISTRITO FEDERAL, 2014).

\section{Quadro 3: Correspondência entre etapas e conteúdos de Matemática para EJA}

\begin{tabular}{|c|c|}
\hline $\begin{array}{c}1^{\circ} \text { segmento da EJA - } \\
\text { etapas }\end{array}$ & Conteúdos da área de Matemática \\
\hline $1^{\mathrm{a}}$ etapa & $\begin{array}{l}\text { Números naturais e sistema decimal de numeração; números racionais: sistema de } \\
\text { numeração decimal; adição e subtração com números naturais; medida: sistema } \\
\text { monetário brasileiro; medida: tempo; medida: temperatura; medida: comprimento; } \\
\text { medida: capacidade; medida: massa; geometria: espaço, dimensão, posição, direção e } \\
\text { sentido; geometria: formas bi e tridimensionais, figuras planas e sólidos geométricos. }\end{array}$ \\
\hline $2^{\mathrm{a}}$ etapa & $\begin{array}{l}\text { Números naturais e sistema decimal de numeração; números racionais: sistema de } \\
\text { numeração decimal; representação fracionária; adição e subtração com números } \\
\text { naturais; medida: sistema monetário brasileiro; medida: tempo; medida: temperatura; } \\
\text { medida: comprimento; medida: capacidade; medida: massa; geometria: espaço, } \\
\text { dimensão, posição, direção e sentido; geometria: formas bi e tridimensionais, figuras } \\
\text { planas e sólidos geométricos. }\end{array}$ \\
\hline $3^{\mathrm{a}}$ etapa & $\begin{array}{l}\text { Números naturais e sistema decimal de numeração; números racionais: sistema de } \\
\text { numeração decimal; representação fracionária; adição e subtração com números } \\
\text { naturais; adição e subtração com números naturais na forma decimal; multiplicação e } \\
\text { divisão com números naturais; medida: sistema monetário brasileiro; medida: tempo; } \\
\text { medida: temperatura; medida: comprimento; introdução à estatística: coleta, } \\
\text { sistematização e análise de dados; tabelas e gráficos; média aritmética. }\end{array}$ \\
\hline $4^{\mathrm{a}}$ etapa & $\begin{array}{l}\text { Números naturais e sistema decimal de numeração; números racionais: sistema de } \\
\text { numeração decimal; representação fracionária; adição e subtração com números } \\
\text { naturais; adição e subtração com números naturais na forma decimal; multiplicação e } \\
\text { divisão com números naturais; medida: sistema monetário brasileiro; medida: tempo; } \\
\text { medida: temperatura; medida: comprimento; medida: capacidade; medida: massa; } \\
\text { medida: superfície; geometria: espaço, dimensão, posição, direção e sentido; geometria: } \\
\text { formas bi e tridimensionais, figuras planas e sólidos geométricos; introdução à } \\
\text { estatística: coleta, sistematização e análise de dados; introdução à estatística: tabelas e } \\
\text { gráficos; média aritmética. }\end{array}$ \\
\hline
\end{tabular}

Fonte: elaboração da pesquisadora com base no Currículo em Movimento da Educação Básica (DISTRITO FEDERAL, 2014, p. 48-59). 
É importante destacar que o Currículo em Movimento da Educação Básica, da EJA, estabelece que "os Primeiros e Segundos Segmentos da EJA estão regidos pelas Diretrizes Curriculares Nacionais para o Ensino Fundamental de Nove Anos, estabelecidas pela Resolução CNE/CEB n ${ }^{\circ}$ 7, de 14 de dezembro de 2010" (DISTRITO FEDERAL, 2014, p. 27). E mais adiante esclarece que $o$

primeiro segmento equivale aos anos iniciais do ensino fundamental e é dividido em 4 etapas semestrais, podendo, portanto, ser concluído em, no mínimo, dois anos de estudo contínuo. Nesse caso, cada etapa do primeiro segmento corresponde a um ano do ensino fundamental (p. 31).

O fato é que não encontramos essa correspondência de etapas de ensino com os conteúdos a serem ministrados, pois, se a $1^{\mathrm{a}}$ etapa corresponde ao primeiro ano do Ensino Fundamental e seu conteúdo está exposto no quadro anterior e o ensino é de nove anos, então, o primeiro segmento deveria ser organizado até a $5^{\mathrm{a}}$ etapa que corresponde ao $5^{\circ}$ ano, mas como se pode perceber, este segmento termina com a $4^{\mathrm{a}}$ etapa $\left(4^{\circ}\right.$ ano).

Esse fato traz implicações importantes para a EJA, porque se trata de uma modalidade de ensino em que o período letivo é semestral, ou seja, a cada ano letivo o aluno cursa duas etapas do ensino, que desde sua estruturação foi organizada em séries: de $1^{\mathrm{a}}$ a $4^{\mathrm{a}}$ que se refere ao primeiro segmento, e de $5^{\mathrm{a}}$ a $8^{\mathrm{a}}$ compondo o segundo segmento.

Assim, por exemplo, quando perguntamos aos professores do primeiro segmento, em qual ano ou etapa eles ensinavam e que referencial utilizavam para ministrar os conteúdos, nos foi relatado que atuavam no $1^{\circ}, 2^{\circ}, 3^{\circ}$ ou $4^{\circ}$ semestre (usam essa terminologia para referir à etapa de ensino). No que diz respeito aos conteúdos, justificaram que pesquisavam na internet e utilizavam minimamente o livro didático porque esse "tem pouco ou nada a ver com a realidade de seus alunos", segundo eles. Os professores fizeram provocações para desenvolvermos não apenas ações, mas que as registrássemos a fim de que todos os materiais pudessem compor um material didático específico para a modalidade EJA.

\subsubsection{Do olhar formativo à ação formativa: aprendizagem matemática em foco}

Nas tramas dialógicas, os pronunciamentos e as expectativas das participantes da pesquisa nos instigaram na ampliação de nosso projeto de investigação, por se tratar de um compromisso ético, político e pedagógico com a modalidade e, nesse caso, com a Educação Matemática. Então, nos lançamos (todos os participantes da pesquisa) nesse desafio e iniciamos a elaboração de um material didático que, entre outras características: valoriza o contexto local 
da EJA, aborda situações-problemas contextualizadas que partem do cotidiano, utiliza a conexão de saberes matemáticos com outras áreas do conhecimento, trabalha a perspectiva do letramento (as práticas de numeramento já mencionadas) e se fortalece com a teoria dos campos conceituais (VERGNAUD, 2009) visando à aprendizagem significativa (AUSUBEL, 1968; MOREIRA \& MASINI, 2001; MOREIRA, 2015).

Pensar um trabalho articulado e sensível às especificidades dessa modalidade é não desprezar a possibilidade de oferecer condições de aprendizagem que tenha significado, principalmente quando se relaciona à Educação Matemática. Daí, tomamos a decisão de adotar uma vertente teórica que atendesse às necessidades desse contexto e que pudesse se estabelecer em meio a uma rede de conceitos.

Para atender a essa necessidade relacionada à aprendizagem e ao ensino da Matemática, recorremos à Teoria da Aprendizagem Significativa e à Teoria dos Campos Conceituais, de Ausubel e Vergnaud, respectivamente. Para nossa realização, conseguimos chegar a estudos de um pesquisador que é um dos maiores expoentes da teoria da aprendizagem na atualidade: Marco Antonio Moreira que trabalha com a ideia de Ausubel de que a aprendizagem significa e busca a relação com a teoria dos campos conceituais de Vergnaud. Essa perspectiva de aprendizagem foi se consolidando em nosso trabalho de pesquisa, por isso esses autores são convidados para dialogarem conosco. Então, como já nos propomos neste trabalho, vamos também apresentá-los.

Moreira é o gaúcho Marco Antonio Moreira, licenciado e mestre em Física; doutor em Ensino de Ciências pela Cornell University, nos Estados Unidos. Foi professor do Instituto de Física da Universidade Federal do Rio Grande do Sul (UFRGS) no qual se aposentou como professor titular. É professor colaborador da Universidade de Burgos/Espanha e coordenador da Comissão de Pós-Graduação do Mestrado Nacional Profissional em Ensino de Física (MNPEF/Profis).

Ausubel foi o nova-iorquino David Ausubel, graduado em Psicologia e Medicina, doutor em Psicologia do Desenvolvimento na Universidade de Columbia, onde depois foi professor durante muitos anos no Teachers College. Foi também professor nas Universidades de Illinois, Toronto, Berna, Munique e Salesiana de Roma. Nos últimos anos de vida, dedicou-se a escrever sobre Psicologia da Educação: uma visão cognitiva. Faleceu em 2008.

Vergnaud é o francês Gerárd Vergnaud, matemático, filósofo e psicólogo. Formado em Genebra, compôs o segundo conjunto de pesquisadores doutorados por Jean Piaget. Professor emérito do Centro Nacional de Pesquisa Científica (CNRS), em Paris. É pesquisador em didática da matemática e elaborou a Teoria dos Campos Conceituais. 
A contribuição de tais teorias está totalmente voltada para a organização do trabalho pedagógico do professor, pois, em primeira e última instância, tem relação com o compromisso de aprendizagem de professores(as) e alunos(as). A matriz cognitiva dessas teorias é a aprendizagem e seus autores preocupam-se com o modo como o sujeito aprende, as condições de aprendizagem, a utilidade e a valorização dos campos de conhecimentos na vida cotidiana.

Para a Teoria da Aprendizagem ausubeliana, de todos os elementos que influenciam na aprendizagem, o mais importante é aquilo que o aluno já sabe (AUSUBEL, 1968). Essa é a premissa mais importante quando se diz da relação com a modalidade EJA, porque o que se pretende é que os conhecimentos prévios dos alunos sejam valorizados e ampliados. Esses conhecimentos iniciais são denominados subsunçores, na teoria ausubeliana. Nesse sentido, o teórico defendeu que a aprendizagem implicava a organização e integração das informações na estrutura cognitiva, ou seja, os primeiros significados serviam de pontos de ancoragem para outros significados mais amplos.

Moreira e Masini (2001, p. 13) explicitaram do seguinte modo:

Quando se fala em aprendizagem segundo o construto cognitivista, está se encarando a aprendizagem como um processo de armazenamento de informação, condensação em classes mais genéricas de conhecimentos, que são incorporados a uma estrutura na mente do indivíduo, de modo que esta possa ser manipulada e utilizada no futuro.

Esse modo de pensar vai ao encontro do entendimento de que o conhecimento inicial que o(a) jovem, o(a) adulto(a) e o(a) idoso(a) trazem para a escola estão incorporados em suas mentes e podem sofrer modificações, a fim de que se torne um conhecimento mais escolarizado e mais significativo para suas vidas. No entanto, é imprescindível que sejam oferecidas condições para que a aprendizagem tenha significado e uma das formas de fazer isso é construir um ambiente letrado com várias situações-problemas diferentes, abordando o mesmo conteúdo matemático. Acerca desses conhecimentos prévios, Freire denominou de conhecimentos de experiência feitos (1996, p.64) que correspondem aos saberes acumulados que os sujeitos apresentam e que pela curiosidade epistemológica vão sendo ampliados e (re)significados.

Em nossas ações, trabalhamos com conjuntos de situações, a fim de evitar uma Matemática memorística que culminasse na aprendizagem mecânica que, segundo Moreira e Masini (2001, p. 18), "envolve informações com pouca ou nenhuma interação com conceitos relevantes existentes na estrutura cognitiva”. Essas ações têm relação direta com os conteúdos matemáticos trabalhados na perspectiva do letramento e serão descritos e analisados no capítulo seguinte. 
No que compete à contribuição da Teoria dos Campos Conceituais, o trabalho só ficou mais rico por entendermos que a aprendizagem é progressiva e envolve certo nível de complexidade. É nessa perspectiva que essa teoria vai ao encontro de Ausubel, pois, segundo Vergnaud, os conhecimentos precisam ter sentido para que se tenha uma aprendizagem com significado. Os conceitos mais importantes dessa teoria são os conceitos de: esquema, situação, invariante operatório (teorema-em-ação e conceito-em-ação) e também a concepção do que é um conceito.

O próprio autor explica de vários modos o que é um campo conceitual. Assim, utilizamos, para ampararmos nossas ações, o entendimento de que se trata de um conjunto de problemas e situações que requer conceitos, procedimentos e representações de tipos diferentes e intimamente relacionados (VERGNAUD, 2009).

A esse respeito, Moreira (2015, p. 16) elaborou um mapa conceitual em que enfatizou as relações entre campos conceituais e aprendizagem significativa. Esse esquema traduz o contexto de formação e aprendizagem constituído na escola onde realizamos a pesquisa, daí a justificativa para trazermos neste trabalho.

Figura 2: Esquema conceitual para a teoria dos campos conceituais relacionando-a com a aprendizagem significativa

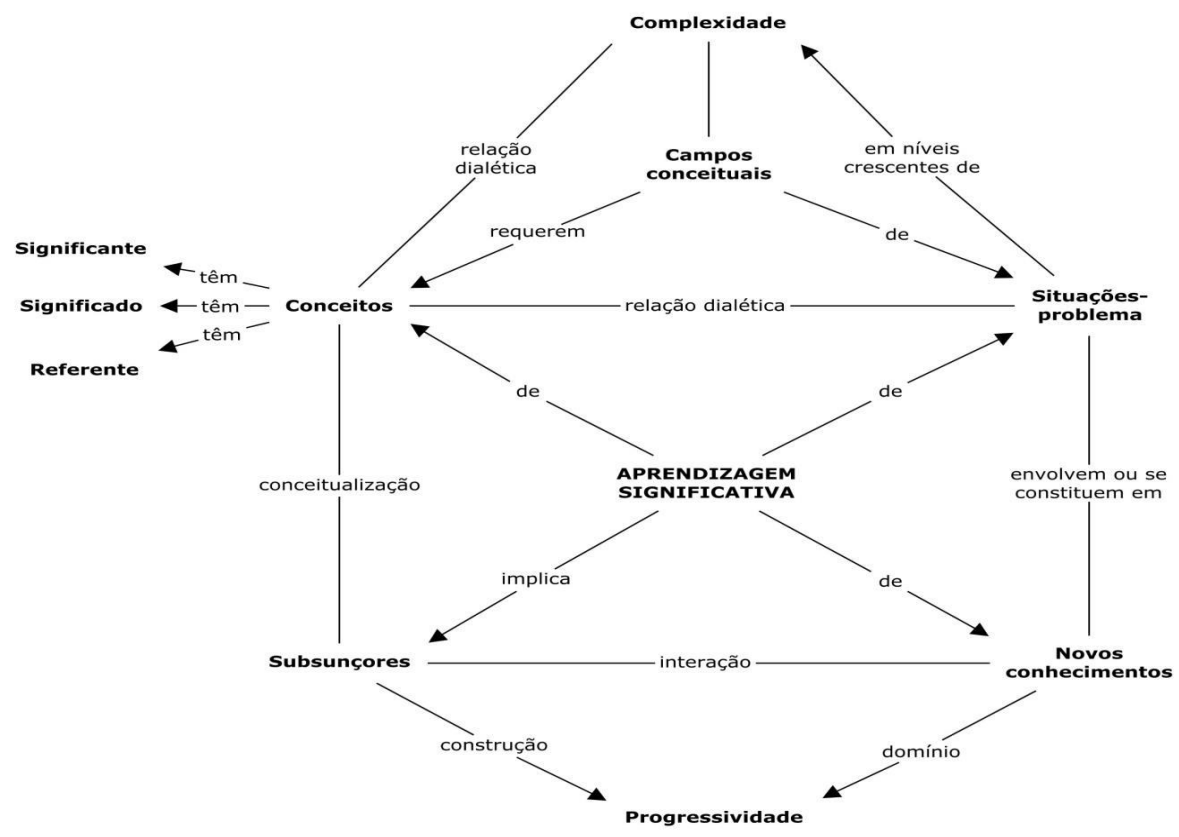

Fonte: elaborado por Moreira (2015, p. 16). 
O eixo orientador de ambas as teorias é a aprendizagem. Assim, consideramos que não apenas o aluno, mas principalmente o professor precisa centrar sua prática pedagógica na aprendizagem de conceitos e concomitantemente na aprendizagem significativa. Elas estão intimamente relacionadas, conforme antecipou Moreira (2015, p. 15) sobre o esquema anterior:

\begin{abstract}
À luz da teoria dos campos conceituais se percebe que a aprendizagem significativa é progressiva. Há uma relação dialética entre a conceitualização e o domínio de um campo conceitual. Enquanto vai dominando mais situações, em crescentes níveis de complexidade, mais o sujeito conceitualiza e vice-versa, quer dizer, quanto mais conceitualiza mais situações domina. E nessa dialética a aprendizagem vai ficando mais e mais significativa, os subsunçores vão ficando mais elaborados, mais ricos, mais diferenciados e mais capazes de dar significados a novos conhecimentos.
\end{abstract}

Esse modo de conceber a relação entre as teorias nos ajuda a compreender melhor o que ocorre na aprendizagem da Educação Matemática, pois, olhando o lado esquerdo do mapa conceitual, observamos que, para construção do conceito, há elementos essenciais: o significante (representações simbólicas); o significado (invariantes operatórios); o referente (conjunto das situações). Todos esses elementos foram considerados na construção das situações-problemas matemáticas contextualizadas as quais trabalhamos com as professoras e os(as) alunos(as) da EJA. Como já pontuamos, o material e as estratégias serão descritos no capítulo seguinte.

Vale ressaltar que o material começou a ser elaborado com base no contexto da EJA sinalizado pelas professoras durante as formações, solicitado pelos(as) alunos(as) em roda de conversa na sala de aula, observado na imersão da pesquisadora. Somado a isso, utilizamos o Currículo em Movimento da EJA com o direcionamento de conteúdos matemáticos, a Proposta Curricular Nacional, os cadernos do Projeto em Início de Escolarização - Módulo IV: Matemática e Cultura (MUNIZ; BATISTA; SILVA, 2008) e estabelecemos relação com o acervo teórico utilizado na pesquisa, conforme citado ao longo deste trabalho.

Nossa intenção com essa produção teórica é disponibilizá-la para professores(as) e alunos(as) das escolas de EJA que manifestarem interesse pelo material. Decidimos priorizar o trabalho sem abordar os conteúdos como se estivessem em caixinhas separadas. Por exemplo: trabalhamos as operações dentro da perspectiva da Teoria dos Campos Conceituais que Vergnaud (2009, p. 29) definiu como "o conjunto de situações cujo domínio progressivo pede uma variedade de conceitos, de esquemas e de representações simbólicas em estreita conexão; o conjunto de conceitos que contribuem com o domínio dessas situações”.

A diversidade de ações criadas e utilizadas nos processos formativos, além de atenderem à demanda da EJA, também foi validada entre professores(as) e alunos(as), a fim de que tivéssemos resultados concretos: o rompimento das situações-limite e a constituição dos inéditosviáveis. Antes de ser disponibilizado, o material ainda precisará da análise crítica de especialistas 
com habilitação na área da Matemática, para não incorrermos em erros conceituais importantes. Dito isso, ressaltamos que os conteúdos matemáticos foram trabalhados em conexão com outros saberes e os principais serão detalhados ainda nessa escrita, no capítulo seguinte que traz a análise das informações, das ações, das significações.

Por todos esses motivos, já sinalizados, mais uma vez chamamos a atenção para a necessidade dos processos formativos para os professores que ensinam Matemática nos anos iniciais da EJA, porque estes têm se tornado importantes espaços de constituição de acervo teórico e metodológico para esses profissionais. Todas as ações empreendidas têm resultado na constituição de inéditos-viáveis, além de contribuir para o desenvolvimento profissional docente, se considerarmos o envolvimento de esforços do coletivo para sua assunção teórica e prática, no bojo de uma práxis transformadora e emancipadora.

Esses processos contínuos de formação são viáveis quando da aproximação universidade e escola, de pesquisadores(as) e professores(as) da Educação Básica com propósitos definidos: sonhar, estudar, criar (FREITAS, 2001) um corpus de conhecimentos úteis, válidos e necessários para todos(as) os(as) que fazem a modalidade EJA. Ao refletirmos sobre essa relação entre instituições e seus profissionais, sentimentos a necessidade de buscar aprofundamentos teóricos acerca dos elementos conceituais importantes no nosso trabalho investigativo e que endossam as discussões que temos feito ao longo do texto. Por isso, buscamos dialogar com autores de nosso tempo acerca de conceitos importantes para o desenvolvimento deste trabalho de tese, conforme se pode conferir a seguir.

\subsection{O diálogo tecido com autores de nosso tempo sobre letramento, formação de professores e inédito-viável}

O diálogo possui um encantamento para envolver pessoas, aproxima opiniões, encurta distâncias, pode se consentir em um tratado de paz, de confidências. Além disso, o diálogo também apresenta uma função investigativa, a exemplo da relação de um médico com seu paciente quando quer encontrar as causas de certa enfermidade; ou quando alguém é vítima de um acidente em que os primeiros socorros iniciam-se com um diálogo para saber o grau de consciência, a fim de manter a vítima acordada até a chegada da emergência médica.

É por acreditarmos na dimensão humana e epistemológica do diálogo que abrimos um espaço neste trabalho para dialogarmos com três autores importantes para o cenário educacional atual: Conceição Fonseca, Balduíno Andreola e Nita Freire. Essas pessoas foram entrevistadas 
acerca de temas que denominamos âncoras do trabalho que realizamos, qual seja: letramento, formação de professores na perspectiva de Freire e inéditos-viáveis.

Quando o diálogo vem em formato de livro, precisamos interpretar aquilo que o autor está tratando. Contudo não existe diálogo mais latente do que aquele que fazemos presencialmente com pessoas que apresentam um brilho no olhar, que refletem a esperança por uma Educação mais humana, ética, política e possível. Por isso, fizemos todo o esforço para ir ao encontro dessas pessoas, a fim de dialogarmos sobre os temas que mais abordamos dentro desta pesquisa de doutorado. Assim, aqui já não fizemos uso da interpretação sobre ideias, mas deixamos que os autores - que são também professores - falassem abertamente dos temas.

Esses temas são pedra angular de nossa pesquisa porque dão sentido ao trabalho que desenvolvemos, explicam e justificam a intencionalidade e o nosso comprometimento com a EJA e são os que alinhavam todo o projeto de investigação. O diálogo com professores, autores de nosso tempo traduz o posicionamento e a postura que adotamos frente a esses temas e que abordamos ao longo da escrita da tese. A saber, quando apresentamos o projeto de qualificação, esses diálogos ainda não estavam previstos, mas sentimos a necessidade de aprofundar o estudo, ampliando a compreensão acerca de cada um dos temas anteriormente especificados.

O diálogo é uma importante contribuição que Freire deixou como elemento da possibilidade. Na visão de Streck, Redin e Zitkoski (2008, p.19) Paulo Freire foi "um pensador dialógico em busca de novas sínteses”. E essas sínteses eram possíveis quando das oportunidades do diálogo que sinalizava "a certeza de que posso saber melhor o que já sei e conhecer o que ainda não sei” (FREIRE, 1996, p.135). Foi essa motivação que me encaminhou para os diálogos com os autores de nosso tempo.

Para falar sobre letramento, fui participar da "37" Reunião da Anped" (Associação Nacional de Pós-Graduação e Pesquisa em Educação), que aconteceu de 4 a 8 de outubro de 2015, na Universidade Federal de Santa Catarina (UFSC), em Florianópolis/SC, para encontrar a professora Maria da Conceição Ferreira Reis Fonseca (conhecida como Ção). Fui movida pelo interesse de saber a relação entre numeramento e letramento, haja vista que é referência importante no desenvolvimento de nosso trabalho.

No segundo dia de evento, nos encontramos na sala em que se reunia o grupo de trabalho de EJA e agendamos nossa conversa sobre letramento para o dia seguinte, no intervalo da manhã. Assim, dia 6 de outubro, no saguão do Centro de Convenções da UFSC, em meio a muita gente, com bastante barulho ao redor e sentadas em duas cadeiras (em determinado canto do salão), iniciamos o diálogo em que me interessei por saber: 
Rejane: Em que contexto surgiu o estudo do conceito de numeramento (ou práticas de numeramento) e a que se referia? $O$ termo poderia ser correspondente a letramento matemático?

Fonseca: Você explica para o leitor como é que você está usando esse conceito em função das suas intenções e dos seus interesses. Agora, nosso grupo de estudos sobre numeramento tem trabalhado com o conceito de práticas de numeramento - sempre acompanhado - numa perspectiva em que o numeramento está associado ao letramento, mas não como uma analogia do tipo: "assim como tem o letramento em Português, tem o numeramento em Matemática". NÃO É ISSO. A gente está focalizando essas práticas de quantificação, ordenação, organização do espaço, apreciação de formas, enfim, essas práticas que a gente de alguma forma associa a conceitos matemáticos que poderíamos chamar de práticas matemáticas. Agora, a razão de não chamarmos essas práticas simplesmente de práticas matemáticas é uma estratégica retórica. Tem a intenção de não levar a uma associação exclusivamente às práticas matemáticas da escola para poder ampliar um pouco o conceito para um conjunto mais amplo de práticas associadas a esses modos de lidar com o mundo. Agora não podemos esquecer que vivemos em uma sociedade grafocêntrica. Mesmo quando estou falando de práticas que não usam a mídia escrita, como vivemos em uma sociedade muito marcada pela escrita, elas têm algum tipo de relação com a cultura escrita, mesmo que seja para desdenhar do recurso escrito. Por outro lado, vivemos também numa sociedade que podemos chamar de quanticrata, em que as relações de poder e as relações sociais são marcadas pela quantificação. $O$ nosso modo de produzir conhecimento é muito marcado pela quantificação. Com isso, mesmo as práticas de leitura, elas não podem prescindir dessas práticas matemáticas - pensando em práticas matemáticas - nesse sentido que estamos falando, por isso usamos a expressão práticas de numeramento, para ampliar o repertório de práticas matemáticas. E não é só porque tem muito número nos textos. É isso também, mas tem, além de informações quantitativas explícitas nos textos, uma lógica na cultura escrita que é a mesma lógica que define um certo modo de quantificar, um certo modo de organizar as formas... Então, no trabalho com as professoras e também com os alunos, o termo que vamos "vender" é letramento. É LETRAMENTO E PONTO. NÃO É LETRAMENTO MATEMÁTICO. É letramento. Porque os alunos estão afoitos para se inserirem, de alguma maneira mais autônoma, na cultura escrita e os professores aflitos para possibilitar essa inserção. Então, o que temos que mostrar nesse nível é que esta Matemática que estamos aprendendo aqui é fundamental para o cara aprender a ler. Por isso, NÃO FALAMOS EM LETRAMENTO MATEMÁTICO. É letramento mesmo. Só que não é só por aprender a parte técnica da alfabetização que uma pessoa dará conta de ler os textos que circulam na vida social e ler este mundo que é marcado por essa cultura escrita. A pessoa precisa de diversificar suas práticas de leitura. E essas práticas de leitura desse nosso mundo, que é todo quantificado, não podem evitar as práticas de numeramento, porque elas são incorporadas, de maneira inevitável, nas práticas de leitura. Mas o nome que se dá a isso vai depender do arcabouço teórico que dá sustentação ao discurso. Por exemplo, esse discurso que fiz aqui para você é o que eu faço no texto de apresentação que escrevi para o PNAIC. Só que no PNAIC, eu chamo de Alfabetização Matemática porque foi esse o termo que o MEC adotou: Alfabetização Matemática na perspectiva do letramento. No texto do INAF, a gente adotou alfabetismo funcional, e aí tem a dimensão desse alfabetismo funcional que é a dimensão do numeramento, mas a gente até parou de fazer um teste de uma coisa e de outra porque no fundo muitas coisas do "teste de matemática" acabavam envolvendo práticas de leitura e habilidades de leitura que poderiam muito bem estar "na prova de português", e vice-versa [...]. Nesse momento da fala, o áudio ficou prejudicado pelo barulho ao redor, mas Fonseca deu continuação:

Então, eu evito esse termo letramento matemático porque, às vezes, se usa letramento na perspectiva mais metafórica, ou seja, fala-se em letramento matemático, como se fala em 
letramento musical, letramento digital, usando a palavra LETRAMENTO para destacar que se está preocupado com a técnica e também com as práticas sociais. Isso é legal, mas, nesse caso em que você está trabalhando em sua pesquisa que é com professores, o que nós temos que mostrar não é o letramento assim como um termo retórico usado para destacar que estamos com a dimensão sociocultural das práticas matemáticas. No seu trabalho de Tese, creio que é preciso destacar que contemplar práticas matemáticas é fundamental para o letramento. Por exemplo, a leitura de folhetos de supermercados, a tabela com as rodadas de um campeonato, a leitura de um cartaz que diz assim "vacinação contra a gripe do período de tanto a tanto" etc. Neste último caso, por exemplo, a compreensão de intervalo pode até parecer trivial, mas não é. Então, não é só a habilidade da leitura, no sentido de saber oralizar o que está escrito, mas é preciso entender o que está compreendido dentro do intervalo. Isso é fundamental para que a pessoa possa ler.

A professora Fonseca refere-se à utilização de letramento de acordo com as circunstâncias, como é o caso do PNAIC e do INAF. O PNAIC é o Pacto Nacional pela Alfabetização na Idade Certa, promovido pelo MEC com o objetivo de assegurar que todas as crianças estejam alfabetizadas até os 8 anos de idade, ao final do $3^{\circ}$ ano do Ensino Fundamental. O INAF é o Indicador Nacional de Alfabetismo Funcional que consiste no levantamento periódico de dados sobre as habilidades de leitura, escrita e matemática da população brasileira (FONSECA et. al., 2004). Assim, em cada um, há uma nomenclatura específica, no entanto a mesma intencionalidade se propõe quando se fala em letramento.

Mas não encerramos nosso diálogo. Depois de escutar, continuei com a intervenção.

Rejane: Professora, foi excelente ouvir seu posicionamento, porque o que nós queremos em nosso trabalho não é inventar moda nem trazer um termo novo como denominar letramento matemático. Nossa intenção é mesmo identificar que estamos trabalhando na perspectiva do letramento, mas não como algo exclusivista, pelo contrário, é para incluir os conhecimentos e fazer que sejam ainda mais fortes as práticas matemáticas dentro da sala de aula.

Fonseca: Se você está adotando a perspectiva do letramento, necessariamente tem que incluir essas coisas. Porque uma pessoa não lê qualquer coisa. A pessoa vai ler certos textos. Textos de uma sociedade em que as relações com as instituições e com as pessoas estão marcadas por essa dinâmica quantitativa. E não tem como escapar disso e você pode até colocar essa tendência à quantificação sob crítica, mas, até para colocar sob crítica, você tem que se dar conta de que ela acontece e de como ela acontece. Então, a pessoa poderá optar por isso ou não, mas para isso é preciso entender como e para quê isso acontece em nossa sociedade. Então, essa quantificação, reflexo da racionalidade que permeia a Matemática, a Ciência, a Geografia, a História é o que impregna os textos que temos à disposição. E aí nós vamos ter que ensinar os alunos a ler. Mas é ensinar a ler certos gêneros textuais, porque nós não vamos dar conta de ensinar a ler tudo. E os gêneros textuais que estão à nossa disposição e que nos são impostos são marcados por essa racionalidade, e nós temos que criar condições e propor eventos de letramento para que nossos alunos se apropriem dessas práticas. 
Rejane: E por falar nisso, você tem percebido, na comunidade acadêmica, o avanço de pesquisas em relação às práticas de numeramento, ou letramento, levando a ênfase para a Matemática?

Fonseca: Eu acho que sim. A própria pegada da matemática no PNAIC é um exemplo disso, ainda que depois, quando a gente traduz em atividade pedagógica a gente seja capturado pelo nosso anseio de "professor de matemática". Mas eu acho que o documento tem esse espírito de mostrar a contribuição da Matemática na alfabetização na perspectiva do letramento. Depois, traduzir isso em práticas pedagógicas é uma coisa mais difícil porque você tem uma memória resistente de um certo modo de ensinar matemática e que não se submete muito a essa perspectiva de ser um coadjuvante. Mas o importante é que isso já está no discurso porque estar no discurso é fundamental para que isso emplaque, porque o discurso nos faz exercer uma certa crítica, vai nos confrontando. É assim: "olha o que você está falando e olha o que está fazendo". Eu citei o PNAIC porque é uma política pública universalista de grande alcance. Do ponto de vista da pesquisa, vemos que essa perspectiva vai aparecendo com muitos nomes, ainda não há um que seja universal e nem está em todas as linhas de pesquisas, mas já tem o espírito disso, disseminado em pesquisas em Educação Matemática e em Letramento. Olha, em muitos trabalhos, há pesquisadores que estão atentos para essa dimensão de impregnação da cultura matemática nas práticas sociais. E aí se estamos no esforço de fazer com que os sujeitos crianças, adolescentes, jovens, adultos e idosos se apropriem dessas práticas socialmente valorizadas, então, não podemos nos furtar a oferecer condições para que eles se apropriem dessas práticas matemáticas.

Rejane: E nesse sentido, você acha que essa amplitude de trabalhar as práticas matemáticas na perspectiva do letramento contribui, de alguma forma, para a práxis?

Fonseca: Na perspectiva do letramento contribui. Mas tem que ser aos poucos porque a escola é resistente, ela se apega muito às suas práticas. A perspectiva da disciplinaridade, ela nos amarra muito e a gente tem um apego a ela porque a gente se sente ainda muito ameaçado sem ela, porque ... "ah, eu sou formada em Matemática e jamais me vi em nenhuma discussão sobre práticas de leitura e como eu vou fazer isso agora?”. Então, tem essa angústia do professor de Matemática, de Geografia, de História, de Português que é a mesma coisa em relação a seu papel no ensino, porque o papel do professor (qualquer professor) é promover condições para que o sujeito se aproprie de práticas de leitura, de certos gêneros textuais. Mas nenhum profissional, além do professor, eventualmente, o professor de Português jamais teve sua atenção voltada para isso. Então, o célebre discurso dos professores de Matemática é que os alunos não sabem ler os problemas. Mas aí nós, professores de Matemática, temos que entender que ensinar Matemática é ensinar a ler problemas, porque a leitura de problemas não é uma leitura igual a de um romance. Eventualmente, o problema tem uma estrutura narrativa e isso facilita o problema, mas isso não quer dizer que nós só vamos dar problemas nesse formato. Vamos dar outros problemas que transgridem a cronologia do caso. Exemplo: "Quanto será que fulano gastou se ele tinha tanto e recebeu tanto de troco?" Então, eu rompi a cronologia porque já estou perguntando uma coisa do meio. Isso não é trivial. Isso requer um modo de enfrentamento desse texto que é papel do professor de Matemática ensinar. No caso do ciclo da alfabetização, tem uma certa facilidade porque é o mesmo docente que alfabetiza, que vai dar acesso a esses primeiros textos e aí poderá usufruir da competência que adquiriu a partir de sua formação de trabalhar com outros gêneros textuais. Tem que se preparar para trabalhar com esses gêneros, mas se tem toda uma reflexão em cima da leitura e da escrita que pode deixá-la em vantagem. Então, ao contrário do que você falava que "ah, eu sou pedagoga e tenho 
dificuldade para ensinar Matemática”. Não, não... Você tem a vantagem de saber ensinar a ler. É disso que se trata na perspectiva do letramento.

Rejane: Já conversamos, antes da gravação, sobre o objetivo do meu trabalho de pesquisa. Nosso interesse é trabalhar com as práticas de letramento para que os professores constituam inéditos-viáveis. Então, eu gostaria de saber se você acha pertinente esse trabalho de utilizar como pano de fundo a perspectiva do letramento para a constituição dos inéditos-viáveis?

Fonseca: A perspectiva do letramento no seu trabalho ela é a utopia. Ela não é a perspectiva pela qual você vai olhar os inéditos-viáveis. Ela é a INTENÇÃO dos inéditos-viáveis. Você está apostando na perspectiva do letramento, voltando-se para a Matemática, mas o que você vai trabalhar é a leitura de mundo (termo freireano), pois é o que nós queremos desenvolver com os nossos sujeitos da Educação de Jovens e Adultos. Agora, você tem uma situação-limite que é essa resistência à Matemática, tanto dos alunos quanto dos professores, que de certa forma inviabiliza, ou pelo menos limita o desenvolvimento de práticas pedagógicas que promovam esse letramento. Então, é nessa perspectiva que você está querendo ver parte dessa formação na condição do professor e da professora de instaurar ou de criar esses inéditos-viáveis. Eu gosto muito quando alguém se dispõe a mobilizar um conceito freireano, porque em geral os trabalhos que lançam mão das teorizações freireanas, lançam mão de um espírito. É bom. Mas acho que a gente deixa de usufruir da riqueza conceitual. Então, esse conceito aqui é PODEROSO. Ele é capaz não só de articular minha análise, mas, no seu caso, tem a intenção de apontar possibilidades para a prática. Para a prática de formação docente e para a prática docente, consequentemente. Então, eu acho um conceito FORTE porque ele tem uma dimensão assim de ENCORAJAMENTO. Os nossos alfabetizadores estão precisando disso, e então quando eles se veem diante de uma limitação e aí você apresenta uma possibilidade carregada de um discurso encorajador. Isso pode ser decisivo, porque o cara diz "eu sou o agente desse negócio"que tem um nome bonito e essa FORÇA. É um empoderamento nesse lugar de alfabetizadora de jovens e adultos. E tem que mostrar que esse lugar é um lugar "revolucionário" do ponto de vista do sujeito que constrói os inéditos-viáveis, ele é importante. Do ponto de vista acadêmico também é importante porque você vai dar substância para um conceito que está subaproveitado. Está mesmo sem aproveitamento porque eu sou da Matemática e não me lembro de ninguém que trabalha com esse conceito. E eu vejo que é um conceito muito operacional e eu acho que "dá caldo".

Rejane: Agradeço suas colocações e corroboro com elas. O conceito que estou utilizando é exatamente para fazer com que as pessoas possam romper com aquele discurso de que "não dá certo" e que "não dá conta" e que os professores possam ver além, o quanto podem ensinar.

Fonseca: No caso da Matemática para os alfabetizadores, tem uma certa aceitação social de que "eu não dou conta de Matemática", "eu não sei nada de Matemática” e também que "os meus alunos não vão saber nada de Matemática", que é o que todo mundo diz, mesmo porque "ninguém sabe mesmo nada de Matemática... Entendeu?" Tem uma certa aceitação em relação a isso, e com isso ninguém fica escandalizado, mas era pra escandalizar, porque lá no Ensino Médio, antes da reprovação em Matemática, tem a reprovação em Física e Química. E aí, Física e Química eu até aceitaria que se mostrasse tão difíceis para os alunos, porque os meninos ainda estão começando a ver Física e Química, que ainda é uma novidade. Mas Matemática é inaceitável porque esses meninos estão aprendendo Matemática há nove anos, pelo menos. Então não podemos nos conformar com esse insucesso, com essa conclusão de que realmente ninguém aprende Matemática porque "é difícil" ou que "não é pra todo mundo". Então não podemos nos conformar com isso. A gente precisa de algo que tenha mesmo essa coisa de poder 
mesmo, de empoderamento. Eu falo isso com meus alunos: "olha como vocês repetem esse negócio de que não sabem Matemática, como vocês estão fazendo o jogo do poder, porque vocês dizem que não entra na cabeça a Matemática. Mas, na verdade, colocaram na sua boca isso e você fica repetindo, tirando o poder do seu saber e conferindo aos que estão dominando". Então, eu acho bom que você usa esse termo freireano que já tem essa "marca revolucionária" e, depois, ele tem uma coisa bacana que é o ineditismo, a novidade, mas também tem uma coisa mais pragmática que é a viabilidade.

Rejane: Eu agradeço muito a sua disponibilidade para essa conversa aqui em meio à Anped. Sua fala me emocionou muito porque eu estou desenvolvendo um trabalho que eu acredito muito e me faz acreditar cada vez mais que eu não estou no lugar errado, por eu ser Pedagoga. Eu estou no lugar certo, contribuindo para que eu e outros professores possamos dar conta de aprender e ensinar Matemática. E usar a perspectiva do letramento na Educação Matemática é ampliar as possibilidades, porque estamos utilizando no contexto do aluno e do professor.

Conceição: Então, talvez ao invés de você usar letramento na Matemática, talvez seja melhor usar Matemática no letramento. E talvez seja mais fácil de eles entenderem o que você está querendo dizer, porque o aluno precisa aprender a ler. Concordo totalmente. Só que nessa sociedade em que vivemos, sem a Matemática não dá para aprender a ler

Rejane: Acho que o trocadilho pode fazer diferença e vou pensar um pouco sobre isso. E mais uma vez agradeço as palavras gentis e humildes para dialogarmos em um lugar tão tumultuado e cheio de gente. Foi importante e esclarecedor.

A conversa com a professora Conceição Fonseca nos proporcionou a ampliação do conceito de letramento que está muito mais na dimensão formativa e humana do que propriamente técnica. Assim, ficamos a pensar nas palavras da professora e que intencionalmente as grafamos em caixa alta porque traduzem nosso sentimento e nossa esperança de que os inéditos-viáveis possam representar, com as características forte, poderoso, encorajador das possibilidades, um mundo melhor.

Outro diálogo enriquecedor foi o que realizamos sobre formação continuada na perspectiva freireana com o professor Balduíno Antonio Andreola, gaúcho nascido em 1932 em Caxias do Sul/RS. Bacharel em Filosofia pelo Seminário Central de São Leopoldo/RS; bacharel em Teologia pelo Instituto San Pietro na Itália; licenciado em Filosofia pela Faculdade Nossa Senhora Medianeira/SP; mestre em Educação pela Universidade Federal do Rio Grande do Sul (UFRGS); mestre em Psicopedagogia e doutor em Ciências da Educação pela Université Catholique de Louvain na Belgica; pós-doutorando em Educação pela UFRGS e professor aposentado da mesma. Atualmente é professor do Programa de Pós-Graduação em Educação do Centro Universitário La Salle de Canoas (Unilasalle/RS).

Em setembro de 2015, participei do "V Congresso Brasileiro dos Profissionais de Educação", na cidade de Porto Alegre/RS, e o professor Balduíno que era um dos 
intermediadores da mesa de discussão tratou das "Interfaces entre ética, ecologia e educação na formação de professores", tendo por base Paulo Freire. Então, aproveitei a oportunidade para pedir que me concedesse um momento de diálogo porque havia me interessado em saber mais sobre a formação continuada na perspectiva freireana. Falei um pouco sobre o projeto de doutorado que eu estava desenvolvendo e tinha interesse nesse diálogo porque o professor Balduíno é um intelectual que se doutorou na Bélgica desenvolvendo estudos sobre Freire.

Então, ele falou que poderia ser uma excelente oportunidade se nos encontrássemos no Seminário Nacional Diálogos com Paulo Freire que aconteceria em Igrejinha/RS, no mês de novembro (dois meses depois), e ficamos de acertar detalhes desse encontro por $e$-mail. Depois de todas as tratativas, inscrevi-me com apresentação de trabalho no "IX Diálogos em Paulo Freire: Utopia, Esperança e Humanização”. Esse evento tinha um formato diferente, funcionava com rodas de conversa e círculos de cultura que dispensava uso de data show e tinha como ponto alto o diálogo, a troca de experiências, exatamente no formato freireano. Assim, no dia 6 de novembro, ao final das apresentações, sentamo-nos (professor Balduíno e eu) em uma sala de coordenação da escola municipal (onde ocorria o evento) para dialogarmos sobre as questões freireanas. E nossa interlocução foi iniciada assim:

Rejane: Professor Balduíno, fale sobre a grande contribuição de Paulo Freire para a formação de professores na atualidade.

Balduíno: Paulo Freire é universal. Eu senti na Bélgica, na França, na Itália e na Espanha que ele é valorizado e aqui há educadoras e educadores brasileiros que parece que a dor de cotovelo diz "Paulo Freire já era”. E eu não preciso citar alguns nomes aí. Mas ele é importante em todos os campos e na formação de professores. E a obra de Paulo Freire, Pedagogia da Autonomia é uma obra importante para a formação de professores: os saberes necessários para a prática pedagógica. Mas os saberes necessários não são apenas os saberes da academia.

Rejane: Nós partimos desse princípio, do saber contextualizado que valoriza o saber do educando e também o saber do professor...

Balduíno: E aí tem todo um questionamento da pedagogia bancária, porque formação de professores não é como a pedagogia bancária [...] Eu falo em um capítulo de livro e, em algumas vezes, que temos grandes eventos pra formação de professores qeu também participei. Fui vítima desse esquema e me prestei de certo modo. A gente quer criticar, mas, em dado momento [...], então, se convida estrelas de primeira grandeza que venham de fora e algumas estrelas menores daqui. Então fazem grandes mesas-redondas e palestras e eles falam e falam [...]. Mas eu considero esses eventos em que só se fala e depois se diz que abrem os debates ou ainda às vezes se distribui uns bilhetinhos em que se pede: "escrevam as perguntas". Nem deixam que leiam as próprias perguntas e de novo os palestrantes falam e falam. Isso é pedagogia bancária. Com três mil professores e professoras. Isso é uma falta total de respeito 
com eles. E cadê o diálogo? Eu mesmo já fiz experiência de eventos com oitenta, duzentas e até trezentas pessoas e a gente pode tabular o diálogo. E sempre o pessoal reage bem.

Rejane: $O$ senhor está trazendo uma categoria muito importante que eu valorizo no meu trabalho, que é uma perspectiva muito bonita para a formação de professores - é o diálogo. $O$ diálogo não é uma fala solitária, não é uma fala isolada. É justamente essa troca entre professores e formadores que engrandece o professor. E, na minha pesquisa, buscamos não ficar apenas atentos para a prática das professoras, mas auxiliamos para a vivência de uma práxis emancipadora, ou seja, oportunizamos a reflexão e ação quanto às práticas matemáticas. E é nesse sentido que eu gostaria de perguntar o que é uma práxis emancipadora na perspectiva de Paulo Freire?

Balduíno: É uma pesquisa na prática, ou da prática e, a partir da prática para a transformação da prática, é o que chama de práxis. E Benincá faz uma crítica ao que são Seminários que são cursos das universidades que jogam teoria, o saber de cima que não muda nada. Então, a práxis é partir da prática e a reflexão crítica sobre a prática, então é ação-reflexão-ação, a construção da nova ação. [...] Eu costumo dizer que, no campo das Ciências Humanas e Sociais e, sobretudo, na Educação, toda pesquisa é participante ou então não é pesquisa. É chantagem. É exploração. Eu vou lá pra saber tudo que eles têm pra me dizer como meros informantes. Eu não tenho esse direito. Ou eles são sujeitos da pesquisa e participam na construção dessa caminhada, desse novo conhecimento, se sentem sujeitos e coautores, ou então, eu os transformei em meros informantes e estou me apoderando do conhecimento deles, explorando e oprimindo como se eles fossem objetos. E tem mais uma coisa, tratados assim será que eles irão dizer tudo o que pensam? Eles criam distância. E, se eu não estabelecer um diálogo respeitoso que eles se sintam valorizados e sujeitos, eles podem criar uma barreira. Então, é necessariamente no diálogo que a práxis emancipatória se dá, na ação sobre a qual eu reflito e faço o salto qualitativo [...] que não se dá de uma hora para outra.

Rejane: Eu considero, em minha pesquisa, que os inéditos-viáveis constituem a própria práxis emancipadora pelos professores. O que o Senhor pensa sobre essa afirmação?

Balduíno: $O$ inédito é o que não aconteceu. Não é isso? Viável é que não é impossível e aí vem toda uma pedagogia da esperança. Se o inédito não fosse viável, pra que serviria esses cursos e o que vocês gastaram e investiram (nos projetos) se fosse inviável? Só nos restaria o desespero. É, só nos resta o desespero ou a luta ou o suicídio. Mas não precisa ser um suicídio corporal. Pode ser um suicídio político, quando se pensa "nós não podemos sair dessa situação, não podemos mudar, não podemos sonhar com algo de melhor porque é impossível". Pensar que é impossível porque Deus decretou que eles merecem e eu não mereço. Isso é inviabilidade total e o suicídio não é uma coisa tão infrequente. Eu tenho um artigo que fala disso. [...] Mas antes, as situações-limite, segundo Jaspers era numa esfera mais individual, é quando uma pessoa não consegue ir além, não consegue recuperar. Ou é morte, aniquilamento, fim, não avança, não se liberta. Mas aí o Álvaro Vieira Pinto levou para um lado mais social e político, deu um sentido mais amplo e coletivo, e Paulo Freire também levou para esse lado. Então, o inédito que seria inviável e que permanece inédito, não acontece, mas a um dado momento dá um salto qualitativo e percebe que é viável e aí podemos partir pra luta e, de novo, é na práxis, na reflexão sobre a prática, na reflexão crítica é que eu vou além da minha consciência ingênua, ou da consciência semitransitiva para uma consciência transitiva crítica. [...] nós falamos da consciência crítica no campo da ação, da práxis histórica, da transformação. 
Rejane: O Senhor e o professor Gomercindo Ghiggi publicaram um texto, em 2013 - na Revista Educação Online - denominado Atualidade de Paulo Freire, e na página 101 destacam que Paulo Freire "crê na possibilidade do inédito-viável, que desafia humanos a romper redes de opressão”. Como essa frase tão impactante poderia se aplicar a professores(as) em suas condições atuais de trabalho?

Balduíno: Aí vem o problema das condições de trabalho, porque não podemos ser idealistas $e$ fazer belos discursos sobre o trabalho dos professores, quando sabemos que eles são mal remunerados. Isso é uma crueldade. E os políticos dizendo que Educação é prioridade! Se é prioridade, a primeiríssima coisa é dar condições aos educadores e educadoras de realizarem a própria ação educativa, pedagógica com dignidade e com tranquilidade. Não é apenas aquela tranquilidade de consciência, mas de ter condições de vida adequada e digna para si e para a própria família. E agora mesmo no Rio Grande do Sul, os professores recebendo seu pagamento parcelado. Isso é um desespero pra muitos. Há professores aí dizendo que estão dependendo da ajuda da mãe que é aposentada, ou dependendo do marido. Isso é cruel! Mas olha, eu tenho dito que há uma reserva fabulosa de esperança do magistério público, magistério das escolas particulares, das confessionais, das comunitárias. Falo isso porque sou aposentado de universidade pública, sou octogenário e estou ainda trabalhando porque gosto, mas também porque precisei continuar trabalhando por causa de doença na família [...]. Nós, formadores de professores e de professoras, somos comprometidos e temos que ajudar. Dar todas as condições de formação na ação, porque os professores não conseguem ser liberados (do trabalho). Nós temos que ajudar na formação e apoiar as lutas. [...] Paulo Freire diz em sua obra que as famílias e os alunos sabem que os professores têm direito de lutar por melhores condições, inclusive com greve, mas Paulo Freire acrescenta: "Eu pergunto aos professores se não há outras formas de luta?". E eu, quando eu tenho oportunidade, questiono: "estou com vocês na luta”. [...] Eu fui diretor da Faculdade de Educação da UFRGS e a minha gestão de quatro anos foi marcada por três grandes greves que duraram meses, mas eu nunca reprimi ninguém. Mas eu pergunto: "Não há outras formas de lutas? Por que não fazer uma luta conjunta das famílias e dos alunos?" para que haja diálogo, não pra fazer discurso sobre as situações financeiras. Há professores que dizem: "não me cobrem porque eu sou mal pago". Não, tu não tens esse direito. Tu tens direito de lutar contra quem te paga mal, mas não tens o direito de descarregar em sala de aula, dando aulas ruins ou descarregando sobre os alunos a tua mágoa. Mas deve-se levar os professores a lutar. Não sei exatamente como. Veja só, quando eu estava me preparando para ir para o doutorado, estourou uma grande greve na universidade. Eu que sempre fui representante do comitê de greve, dessa vez me pus contra e quis me posicionar. Enquanto isso, algumas pessoas já começaram a ensaiar vaias, mas eu pedi ao senhor presidente da comissão de greve que me garantisse democraticamente a palavra, haja vista que muito respeitosamente eu já havia escutado os que me antecederam. Então eu falei sob três argumentos. Um de ordem política: Fernando Henrique Cardoso está preocupado com outras coisas e não vai dar a mínima para nossa greve e aí nos vamos ficar dois ou três meses de greve e aí vamos voltar a trabalhar de cabeça baixa, humilhados. Não é o momento estrategicamente. $O$ outro argumento de natureza ética: Nós dissemos que vamos marchar com os outros trabalhadores lá para a praça central, no nosso protesto. Sim, junto com os outros trabalhadores se nós tivermos coragem de mostrar pra eles o nosso contracheque. A diferença salarial. O terceiro argumento é de natureza estratégica: há quatro integrantes do Movimento dos Sem Terra (MST) fazendo greve de fome. Eu não tô querendo pra nós, pequenos burgueses, uma greve de fome. Eu ironizei. Estou apenas questionando: "a greve é a única forma de luta?". Os quatro do MST estão sacudindo a consciência brasileira, diante daquilo que deveria ser a reforma agrária. "E nós não temos uma outra forma de luta?", questionei. Mas depois de minha fala, houve votação a favor da greve. Mas eu acho que nós temos que questionar e deve haver 
criatividade por uma luta maior. [...] Por que não se pode fazer uma luta com as crianças e as famílias para que se mude a Educação, se mude as condições de trabalho? Estou falando e sonhando com um inédito que se torna viável através de uma luta maior que, de fato, tire os políticos de seus interesses, porque sem condições não podemos exigir dos professores e das professoras.

Rejane: Professor Balduíno, quero agradecer ao Senhor por ter dedicado esse precioso tempo para essa conversa sobre Paulo Freire e a formação de professores. Quero reafirmar o quanto eu acredito na formação como sonho possível, e então deixo esse espaço para que faça as considerações que achar pertinente.

Balduíno: Vou dizer uma coisa que considero importante. Em uma das últimas vezes que Paulo Freire esteve em Porto Alegre, ele esteve em minha casa, almoçou um galeto conosco e à tarde ele tinha uma fala na universidade. Em uma sala com mais de três mil pessoas, Paulo Freire fez uma breve introdução e depois disse: "Quem sabe hoje ao invés de fazer uma palestra, eu possa responder algumas perguntas de vocês”. E foi uma riqueza extraordinária de perguntas. E aí ele disse: "se eu não souber responder eu vou dizer que não sei e nós vamos buscar juntos". Eu gosto de contar isso porque têm muitos professores que tem vergonha de não saber. E tem mais um detalhe: em uma das últimas entrevistas concedidas por Paulo Freire, ele disse: "Os problemas são tantos e tamanhos que eu não tenho ideias e soluções para todos eles. Cabe a vocês inventarem novas pedagogias". Então, nós acreditamos que Paulo Freire abriu pistas para nós o recriarmos e nós estamos recriando continuamente, nada de repeti-lo, em diálogo, inclusive com outros autores. E Paulo Freire foi um homem de grandes diálogos. E eu disse para Paulo Freire: "Paulo, eu nunca quis e nunca vou querer fundar o clubinho do Paulo Freire, porque os grandes pensadores e grandes educadores são pessoas de horizontes abertos e de diálogos com outros pensadores, inclusive de linhas diferentes". E Paulo Freire me respondeu: "Balduíno, eu gostei que tu não queres fundar o timinho do Paulo Freire”. E daí ele sorriu. O que fazemos é promover um diálogo. Veja, por exemplo, que a professora Ana Lúcia Freitas organizou um livro que é "Paulo Freire em diálogo com outros autores" e tem um capítulo que escandalizou algumas pessoas. Eu e a professora Ana Maria Colling fizemos uma aproximação entre Paulo Freire e Foucault. Assim como eu, quando vi pela primeira vez essa aproximação, levei um susto psicológico, pedagógico e filosófico. Mas depois, quando eu fui ler, o Foucault quando fez a pesquisa dele com os encarcerados, ele disse: "nós não temos que falar por eles. Eles mesmos têm que falar entre si e com a comunidade". Então, porque não pode pensadores de diferentes linhas filosóficas convergir na luta contra a opressão? Ora, o personalismo não tem nada a ver com o estruturalismo, mas eles estão numa luta para a libertação ou contra as injustiças. Então, porque não podem estar juntas? Daí porque Paulo Freire já dizia que o diálogo só não é possível com os antagônicos, mas com os diferentes o diálogo é sempre presente.

A decisão de dialogar com o professor Balduíno ocorreu devido à sua gentilidade e intelectualidade no trato com os conceitos freireanos, da proximidade pessoal com o autor e, principalmente, porque tem sido um estudioso interessado em divulgar e ampliar as questões apontadas por Freire. Além disso, sua sensibilidade na luta em favor e com os professores, a crença na formação continuada, a coerência e consistência de uma práxis em favor da emancipação foram fatores preponderantes para que o trouxéssemos para este trabalho. 
A formação de professores, como bem ressaltou, passa pela denúncia da alienação e do anúncio do ser crítico que adota uma postura política própria, que luta por condições de trabalho, que argumenta porque é sujeito do diálogo. Essa categoria ficou muito evidenciada tanto em sua fala quanto nos relatos acerca de Paulo Freire dialogando com outros autores.

Para dialogar sobre o inédito-viável, buscamos a pessoa mais próxima a Paulo Freire, que também é a que mais tem entendimento do que foi pensado por ele, além disso viveu, sonhou e compartilhou desse sonho, a sua segunda esposa Nita Freire. Fizemos o contato com ela pelo $e$ mail cadastrado no currículo lattes e expressamos o desejo de entrevistá-la sobre a categoria inédito-viável, tendo em vista a relevância para a pesquisa de doutorado que estamos realizando. No e-mail, nos colocamos inteiramente à disposição para irmos ao seu encontro no dia, local e horário que indicasse. Naquele mesmo dia, recebemos a resposta positiva em que a professora Nita Freire escrevera que nosso encontro seria em sua casa, na cidade de São Paulo, conforme endereço descrito por ela. Assim as passagens de Brasília a São Paulo foram providenciadas com ida no início da manhã e retorno no final da tarde do mesmo dia.

Então, na manhã do dia 25 de janeiro de 2016, peguei o voo para São Paulo e depois um táxi para o endereço que tinha o nome de um Estado Brasileiro (Rua Sergipe), bem como todas as outras ruas paralelas. Na portaria do edifício, estava o Senhor Pedro que já trabalhava como porteiro naquele mesmo lugar há mais de 26 anos. Enquanto ele me recebera sorridente, eu me apresentei já emocionada e ele falou de forma mansa que a Senhora Nita já havia anunciado que eu e a professora Ana Freitas chegaríamos para uma entrevista. Ele perguntou porque eu estava chorando, ao passo que lhe falei da emoção que estava sentindo porque seria recebida na casa da esposa Paulo Freire. Então, tentando acalentar-me, ele falou o quanto delicada e acessível era a Senhora Nita. Ali ficamos a conversar por alguns minutos, enquanto aguardava a chegada da professora Ana Freitas, que vinha de Porto Alegre/RS para me acompanhar no encontro. Ela chegou e nos dirigimos para o $8^{\circ}$ andar do prédio.

Quando tocamos a campainha, a professora Nita Freire abriu a porta sorridente e com um afetuoso abraço nos recebeu em seu apartamento e nos fez entrar. Falou o quão feliz estava por nos receber, nos deixou à vontade e logo nos convidou para um café que acabara de preparar. Ao redor de uma mesa, na copa, sentamo-nos as três para saborear o café e iniciarmos um diálogo sobre a viagem que fora tranquila porque era aniversário da cidade de São Paulo. Enquanto isso, eu estava com os olhos fitos nela porque observava a vivacidade, a capacidade intelectual de perceber e opinar sobre os acontecimentos.

Depois, fomos para a sala onde havia muitas fotos e lembranças de Paulo Freire. Nesse lugar de recordações, iniciamos o diálogo sobre o meu interesse em pesquisar o inédito-viável e 
as motivações que me levaram a encontrar Nita Freire para conversarmos sobre como essa categoria é percebida na atualidade. Quase não conseguia falar, movida pela emoção daquele momento tão importante, histórico e único porque o sentimento era de estar com o próprio Freire, no aconchego de sua casa. Mas encorajada pela professora Nita, fiz a colocação.

Rejane: Professora Nita fale sobre o que é o inédito-viável.

Nita: Paulo deu uma conotação absolutamente sui generis e especial: INÉDITO-VIÁVEL É AQUILO QUE PODE SE REALIZAR, mas que não está ainda na consciência dos homens e das mulheres. Então isso entra pra categoria do sonho. Do sonho que é possível ou do que é impossível. Então, é um sonho possível eu conseguir a democracia no Brasil, por exemplo. Só que existem os empecilhos e esses empecilhos, para que se crie uma consciência crítica, pra chegar a entender e a trabalhar a favor de uma democracia, existem aqueles que não percebem os empecilhos e dizem "ah, nós estamos num regime democrático, o certo é isso mesmo e acabou”. Esses não têm um mínimo de vontade e de capacidade de refletir. Tem a segunda camada de gente da população que constata, mas diz "eu nada posso fazer porque sempre foi assim”. E existe a terceira camada que diz "isso existe, é uma injustiça. Foi criado por nós e nós podemos transformar isso, levando a concretização do fato”. Por exemplo: o analfabetismo, a democracia, ou um evento ou qualquer fato que seja. Então, eu entendo exatamente isso e ela está baseada na conscientização e na esperança. Na esperança como uma categoria intrínseca ao ser humano. Paulo dizia que não há um cara que diga "eu não tenho esperança em nada". Isso não é possível. Isso faz parte da constituição, da inconclusão do ser humano, porque quanto mais você caminha na vida, mais coisas você vai descobrindo que não sabe. E você tem vontade de saber e de saber mais. Então, esse motor desse movimento é a esperança. É a esperança de dias melhores. Nunca a gente ouviu dizer “ah, eu tenho esperança de que vai piorar”. Ninguém diz isso. Eu nunca ouvi. Eu acho que não se diz "a minha esperança é que vai tudo piorar". [...] A história também se faz assim, pelo ódio e pelo desafeto. Mas Paulo dizia "eu prefiro denunciar os ódios e os desafetos e com essa denúncia, dialeticamente eu já estou anunciando que uma outra coisa é possível". Então, inédito-viável é exatamente isso: é ALGUMA COISA QUE É POSSÍVEL EU ALCANÇAR, desde o momento que eu esteja consciente e queira uma sociedade melhor. Porque pode se conscientizar sem querer uma sociedade melhor, uma sociedade mais justa e mais igualitária.

Ana Freitas: Relendo a nota explicativa, na Pedagogia da Esperança, eu relembro o que me moveu para estudar o inédito-viável e o fato de Nita dizer que é uma categoria tão importante quanto pouco estudada e isso foi há mais de 20 anos. E a minha tese se chamou Pedagogia do inédito-viável. E logo que terminei o doutorado, fizemos um Seminário que Nita foi falar sobre o inédito-viável na Educação Cidadã. Então, a minha pergunta é como é que a gente atualiza essa categoria? Porque, há 20 anos, era uma categoria pouco enxergada e pouco falada. E, hoje, a minha preocupação é que às vezes ela pode ser usada e esvaziada no seu sentido político, porque hoje estamos no contexto da inovação e principalmente fundado pelas novas tecnologias, com novas metodologias para tornar a sala de aula mais atraente. Assim, eu não fiz um estudo aprofundado sobre isso, mas, daqui a pouco, essa categoria do inédito-viável está sendo usada para referir-se a uma inovação sem estar conectado com esse sentido político que o inéditoviável tem na origem da sua concepção.

Nita: Quando Paulo me entregou os originais do livro Pedagogia da Esperança, ele vinha como um menino. Paulo tinha um gestual, atos que era belamente menino, aí ele vinha assim [...]. Ele 
já tinha sondado se eu escreveria as notas. Aí ele veio e disse "Nita, aqui estão os meus manuscritos para tu escreveres onde quiseres as notas explicativas". E eu disse: "Paulo, isso é verdade mesmo?". E ele confirmou que sim. Aí, a primeira coisa que me veio de ideia foi "eu vou escrever sobre inédito-viável porque eu acho uma coisa belíssima”. Não é só uma palavra belíssima, mas ela tem uma CARGA POLÍTICA, ANTROPOLÓGICA e SOCIAL muito profunda. E quando eu fui lá para o Congresso e disse que "eu já escrevi a nota, e eu acho que já exauri o que eu tinha que dizer". Depois eu mesma me disse "isso não é uma postura de uma intelectual, de alguém que está pesquisando, porque a gente sempre vai encontrando mais alguma coisa”. Então, hoje eu encontraria mais alguma coisa pra dizer.

Rejane: Por que Paulo Freire não explorou a categoria inédito-viável em seus escritos?

Nita: Paulo não teve uma intenção de abandonar o termo inédito-viável, como ele fez com o termo conscientização. Sobre conscientização ele disse: "eu não vou mais escrever sobre conscientização, porque estão dizendo coisas que não são para serem ditas. Eu jamais disse o que dizem que eu disse”. Durante muitos anos, ele, intencionalmente, não falava mais sobre conscientização. Ele escrevia outras palavras e ia por outros caminhos, que você diz "mas isso é conscientização". Mas ele não usava a palavra porque ele teve um desgaste muito grande. Agora inédito-viável, acho que foi uma coisa não pensada. Ele foi se afastando [...]

Ana Freitas: Mas na Pedagogia da Esperança, ele retoma e retoma as origens, falando do Álvaro Vieira Pinto e da relação com as situações-limite [...]

Nita: É sim, ele retoma. Até porque eu dizia que era uma categoria muito bonita e ele disse: "Nita, sempre pensei que um dia, quando fosse mais adequado, talvez eu voltaria a falar".

Ana Freitas: Mas talvez essa perspectiva esteja presente na escrita dele, mesmo quando ele não usa o termo.

Nita: É sim. A perspectiva sempre esteve presente e você diz assim "ah, ele está dizendo com outras palavras" [...]

Rejane: Eu, por exemplo, se eu falar em esperança como Paulo Freire, eu não penso a esperança dissociada de inédito-viável.

Nita: Não pode pensar a esperança segundo a Igreja Católica. Porque veja, tem uma influência de Paulo que traduziu a esperança num conceito mais político [...]

Rejane: Esperar e agir...

Nita: Não é como esperança de conhecer a vida eterna, como é na religião. A caridade, Paulo substituiu pela solidariedade. A caridade é o que a Igreja fala tanto, e a solidariedade é a cumplicidade. E a fé é a crença nos homens e nas mulheres. Então houve uma transmutação dos conceitos. Tanto que, às vezes, ele diz "fé nos homens", mas normalmente ele diz "crença nos homens e nas mulheres".

Rejane: Professora Nita, a senhora tem percebido a utilização do termo inédito-viável, exceto na pesquisa de Ana Freitas, enquanto categoria fundamental em pesquisas, dando a devida importância? 
Nita: Não. Não conheço ninguém que tenha escrito.

Rejane: A primeira vez que o termo inédito-viável apareceu nas escritas de Freire foi mesmo em Pedagogia do Oprimido?

Nita: Exatamente. Foi em Pedagogia do Oprimido sim.

Rejane: Então, quando Paulo Freire trouxe essa terminologia que eu chamo de categoria, a senhora acha que ele não se dava conta da sua dimensão? E essa dimensão pode ser trocada somente pelo termo sonho, por exemplo?

Nita: $O$ engraçado é que Paulo nunca pensava na repercussão que ia dá o que ele fazia. Nunca. E eu acho que isso seria "ser um pouco pavão". Paulo era muito humilde. Quando Paulo escreveu Pedagogia do Oprimido não podia ser publicado no Brasil, porque foi o auge da repressão, em 1970. Então, ele quis traduzir para o espanhol e publicar no Chile em alguma editora. Paulo não tinha consciência do que tinha escrito. Então, Paulo foi denunciado pelo presidente de que ele tinha escrito um livro contra o povo chileno, contra o presidente: o livro Pedagogia do Oprimido. Então, ele mandou que entregasse todo o manuscrito - porque Paulo escrevia tudo à mão - e assim foi feito, mas ele já havia garantido a sua tradução [...]. Os chilenos estavam zangados porque dois brasileiros mudaram consistentemente a Educação no Chile. Foi Paulo, com toda a teoria dele e o trabalho de alfabetização e o Ernani Maria Fiori, gaúcho, que fez a reforma na Universidade Católica. [...] Foi que escreveu o prefácio de Pedagogia do Oprimido. Ele leu os três primeiros capítulos do livro que Paulo escreveu em três semanas de férias. O livro já estava na cabeça de Paulo e ele só teve que escrever. Paulo tinha uma capacidade incrível [...]. Então, voltando ao Ernani Maria Fiori, ele disse: "Paulo, esse livro é lindo, mas está faltando uma coisa nele, uma justificativa sociológica maior. Você tratou mais a epistemologia. Agora você precisa tratar mais a questão sociológica”. Foi quando Paulo foi ler mais sobre Ciências Sociais e aí escreveu o quarto capítulo. Aí o quarto capítulo ele ficou seis meses para escrever porque ele trabalhava de mais e só tinha quatro ou cinco horas para dormir. Então, quando ele ia para o interior, ele ia escrevendo, anotando, fazendo as fichas

Rejane: Eu estava conversando com a professora Ana Freitas e falando sobre como me sinto realizada em fazer esta pesquisa. As professoras falavam em nossas formações que consideravam uma formação de verdade porque elas não estavam recebendo certificado, nem bolsa-auxílio, mas estavam ali porque queriam aprender. Isso não tem preço.

Nita: É a única profissão que faz tanto sacrifício, em nome do bem do outro, que repercute o bem dentro de você mesmo.

Ana Freitas: Poderíamos pensar juntas no que faz essa diferença. Talvez seja porque É UMA FORMAÇÃO ORGANIZADA NESSA PERSPECTIVA DO INÉDITO-VIÁVEL. Porque não é alguém que vai lá dizer o quê que eles têm que fazer e reciclar e atualizar. Mas vai ajudá-los a se perceber, a dar conta das situações-limite e se sentir capazes de construir alternativas.

Rejane: Elas mesmas (são só mulheres) disseram isso. Falaram do quanto tem sido uma aprendizagem. E eu falei desde o princípio que minha função na escola não era ditar regras, $e$ reafirmei: vocês têm tanto tempo de EJA, então, quem sou eu para determinar algo. E também eu não vim para apontar os defeitos da EJA, porque defeito todo mundo adora apontar. Mas não é essa a minha contribuição. O que eu pretendo é mostrar os inéditos-viáveis, é exatamente o que vocês conseguiram superar para dar conta de tanta aprendizagem. 
Nita: O inédito-viável é aquilo que eu digo, no momento que você desvela um inédito-viável, você já está apontando um novo inédito-viável. É o mesmo PROCESSO DE DENÚNCIA E ANÚNCIO. No momento que denuncio, já abro uma nova esperança.

Rejane: Eu defendo a seguinte tese: "A concepção dos inéditos-viáveis propicia ao professor a construção de conhecimentos, a superação de situações-limite e a reorganização do trabalho pedagógico com a Matemática, o que pode ocorrer por meio da e na formação continuada”. Queria saber sua opinião sobre isso.

Nita: Através das ações editantas. Mas eu queria recomendar que não usasse alguns termos que Paulo não usava. Por exemplo, não use a palavra reciclagem, porque o que se recicla é plástico e papel. E também não use empoderamento. Paulo nunca falou em empoderamento, porque ele não suportava esse termo. Porque empoderamento é o seguinte: se cria a verticalidade no humano; "ah, eu sou mais poder, eu tenho poder e de cima para baixo eu despejo o meu poder".

Ana Freitas: Nita, mas ele discute isso no Medo e ousadia [livro]. Exatamente esse mau uso do empoderamento, dizendo que o empoderamento é uma questão social.

Nita: Sim, quando é o empoderamento de um sindicato, de uma comunidade aí, sim, repercute para o bem de todos. Mas o empoderamento pessoal não.

Ana Freitas: O problema é o uso do termo ou a distorção do termo?

Nita: As duas coisas. Paulo não suportava nem o termo, nem a compreensão que se tem dele.

Rejane: Nossa! Pois eu usei empoderamento e eu utilizei numa vertente freireana, pois, quanto mais os professores se percebem construindo conhecimentos, mas empoderados eles se sentem em relação a conhecer e dar conta desse conhecimento.

Nita: Bom, nesse sentido que é coletivo, ainda se suporta. Mas se você puder evitar e até dizer "evitei de usar o termo empoderamento". Coloque uma nota de rodapé. Evitar porque Paulo não gostava desse termo.

Rejane: Vou rever a utilização do termo na escrita do trabalho. Tem outra coisa que gostaria de falar: no meu trabalho tenho utilizado a perspectiva dialética que denomino de dialética de Freire. Assumi desse modo porque algumas linhas acham que a dialética válida é a marxista, e Paulo Freire não se assumiu da linha do materialismo histórico dialético, mas ele dialogava com a dialética de Hegel, Marx e outros. Qual sua opinião sobre isso?

Nita: A dialética de Paulo é quase totalmente diferente das outras dialéticas. Não é? Porque a dialética socrática é aquela em que a coisa está coberta e aí eu vou lá e descubro e lá está o conhecimento. E para Paulo não, você não descobre nada. Não existe isso no conhecimento de Paulo.

Rejane: Como estava falando, eu usei o termo dialética freireana e encontrei consistência no prefácio que Danilo Romeu Streck escreveu no livro organizado pela professora Ana Freitas que se denomina Paulo Freire em diálogo com outros(as) autores(as) e também no trecho dessa entrevista que Freire concedeu à PUC de São Paulo, em 17 de abril de 1997. Mas eu não consigo ler... [emocionada]. 
Nita: Deixe-me ler:

\section{Entrevista com Freire: "Cristo, meu camarada"}

\section{(Parte II da Entrevista - na gravação está de 6min15 até $8 \mathrm{min45}$ )}

"Quando muito moço, muito jovem, eu fui aos mangues do Recife, aos córregos do Recife, aos morros do Recife, às zonas rurais de Pernambuco, trabalhar com os camponeses, com as camponesas, com os favelados, eu confesso sem nenhuma choramingas, eu confesso que fui até lá movido por uma certa lealdade ao Cristo de quem eu era mais ou menos camarada.

Mas acontece que, quando eu chego lá, a realidade dura do favelado, a realidade dura do camponês, a negação do seu ser como gente, a tendência aquela adaptação [...], aquele estado quase inerte diante da negação da liberdade. Aquilo tudo me remeteu a Marx.

Eu sempre digo, não foram os camponeses que disseram a mim: 'Paulo, tu já lestes Marx?'. Não, de jeito nenhum, eles não liam nem jornal. Foi a realidade deles que me remeteu a Marx. E eu fui a Marx. E aí é que os jornalistas europeus, em 70, não entenderam a minha afirmação. E que quanto mais eu li Marx, tanto mais eu encontrei uma certa fundamentação objetiva para continuar camarada de Cristo. Então, as leituras que eu fiz de Marx, e alongamentos de Marx, não me sugeriram jamais que eu deixasse de encontrar Cristo na esquina das próprias favelas.

Eu fiquei com Marx na mundanidade, à procura de Cristo na transcendentalidade."

\section{Nita termina de ler o trecho da entrevista de Freire e comenta:}

Bom, isso você pode citar. Porque era isso mesmo. Um jornalista que assistiu uma conferência de Paulo em Londres foi o primeiro a perguntar, porque ele dizia "o Senhor é isso e não pode ser alguma coisa contraditória a isso". Marx dizia que religião era alienação, era a fonte maior de alienação de homens e mulheres. Mas aí tem Cristo que é misericordioso. Ele aceita outras interpretação do mundo. Então, porque que eu, acreditando em Marx, tenho que negar Cristo? Paulo não negou nem um nem o outro. Aliás, Paulo negou muita coisa em Marx. Por exemplo, Paulo dizia: "a certeza que Marx tinha, eu não tenho e nem devo ter, porque a certeza me impede de andar, de caminhar. A relação não é somente entre sujeitos. É entre sujeitos e o mundo objetivo". E Marx também não aceitava isso. Então esse determinismo histórico de Marx que a gente teria que passar pela ditadura do proletariado pra chegar a uma sociedade socialista justa e igualitária, diz o seguinte: “eu cruzo os braços e fico esperando”. E é por isso que Paulo dizia: "não se pode esperar na espera vã e cruzar os braços. Se espera na esperança esperançada. Na esperança, diante da luta para obter os inéditos-viáveis que vou vivendo e gerando outros".

Rejane: Eu não tenho palavras para descrever o quanto eu estou feliz por esse momento.

Nita: Eu fico feliz por esse carinho que é muito recompensador.

Rejane: Eu sempre tenho defendido que Paulo Freire tem uma vertente muito forte, que é formativa. Enquanto algumas pessoas ficavam reduzindo Freire a um método de alfabetização, eu sempre teimei que é muito além, eu vejo uma dimensão bem maior, é uma dimensão formativa. Forma o ser humano como pessoa e como profissional. E o nosso projeto de formação visa ao desenvolvimento pessoal e profissional. E aí eu gostaria de saber o que a senhora acha desse projeto? É muito sonho? 
Nita: Não. Eu achei seu projeto muito bonito. Muito perspicaz. Você foi num ponto que ainda é obscuro e pouco utilizado, e você pode obter uma eficiência enorme na correção e no desvio que se usa o inédito-viável, fazendo um trabalho eficiente.

Não poderíamos deixar de dialogar "diretamente" (de alguma forma) com Paulo Freire, por isso fomos ouvir e falar com a professora Nita Freire, uma historiadora intelectual, porta-voz das questões freireanas. Sua fala referia-se a Paulo sempre com orgulho, afeto, amor, respeito e zelo. Foi um diálogo que trazia toda a "boniteza" do conhecimento que construíra com e a partir de Paulo Freire, na relação que mantiveram de professor e aluna; orientador e orientanda; marido e mulher que ainda rememora.

Os trechos de sua fala que grafamos em caixa alta, o fizemos intencionalmente porque trazem consigo um valor político e epistemológico validado em nosso trabalho de pesquisa acerca do que temos compreendido sobre o inédito-viável. Principalmente porque, segundo Nita, essa categoria traz consigo "uma carga política, antropológica e social" que serve como orientadora de nossas ações.

Organizar e orquestrar um processo formativo na perspectiva do inédito-viável foi pensar na possibilidade de fazer com que o sonho desse lugar à realização e, no caso específico, as professoras que ensinam Matemática na EJA puderam identificar as situações-limite, superá-las e (re)significar a aprendizagem. Elas foram agentes da sua formação porque optaram por uma práxis em favor da emancipação, do processo criativo e autônomo que contribuiu e vai continuar contribuindo para seu desenvolvimento pessoal e profissional.

Vale ressaltar que não pensamos nem no inédito sozinho nem no viável isoladamente. Inédito-viável é um par indissociável que se dá pela denúncia de uma situação que oprime e no anúncio de possibilidades que inaugura um novo tempo, o do conhecimento. Por isso, o que fica de mais significativo desses três ricos diálogos é a afirmação do sonho como possibilidade nos alinhavos do letramento, com a formação de professores e os inéditos-viáveis, a partir da proposta de formação que ocorreu dentro da escola pública. Acerca disto, detalharemos as ações de investigação, proporcionando uma visão ampla e clara das estratégias investigativas, que conduziram a relação dialógica dos participantes da pesquisa. Esse percurso metodológico está detalhado no próximo capítulo. 


\section{TECITURA DOS CAMINHOS DA PESQUISA}

\author{
É porque podemos transformar o mundo, que \\ estamos com ele e com outros. Não teríamos \\ ultrapassado o nível de pura adaptação ao mundo \\ se não tivéssemos alcançado a possibilidade de, \\ pensando a própria adaptação, \\ nos servir dela para programar \\ a transformação.
}

(FREIRE, Pedagogia da Indignação, 2000, p.17)

A pedra angular deste trabalho de investigação é o inédito-viável concebido a partir da e na formação continuada realizada na escola com um grupo inquieto e inquietante, pois uma vez superadas as situações-limite, circunscreve-se a possibilidade de elaboração de um conjunto de conhecimentos que tem contribuído para a práxis de docentes que atuam na EJA. Portanto, tratase de uma imersão no processo contínuo de formação, cheia de intencionalidade política e pedagógica, em que se pretendeu mobilizar os desejos e as crenças nos professores, em suas capacidades de transformação da realidade educativa da qual são agentes de construção. Entendemos a transformação como um processo antecedido pelo movimento problematizador em que o sujeito ativo percebe os desafios e busca meios para superá-los.

Defendemos um movimento formativo que combata o imobilismo e a adaptação, ao possibilitar a construção de ações que vislumbrem um trabalho articulado e criativo com os professores. É um caminho que vai sendo tecido por um coletivo de profissionais do ensino, dentro da escola, movidos pela esperança e pelo sonho freireano de ser-mais, entusiasmados com a possibilidade de um mundo melhor, impulsionados pela onda da criatividade, da autoconfiança, da autonomia, que contribui para o desenvolvimento profissional docente.

É conciliável esclarecer neste capítulo que procuramos seguir um caminho metodológico que desse conta do movimento investigativo de idas e vindas sobre a categoria mais importante deste estudo, os inéditos-viáveis. Por isso, trazemos a justificativa pela opção do método de pesquisa, que se centra na dialética de Freire $(1981,2011)$.

No decorrer deste capítulo, trazemos elementos que sinalizam a opção pela pesquisa participante como a que mais se aproxima dos objetivos dessa investigação. Nosso embasamento teórico reside em Fals Borda (1978), Brandão (1981, 1984, 1999, 2006), Freire (1981, 1982, 2011), Demo (1984, 1999) e Streck (2006, 2013). Propomos para organização, categorização e análise das informações, a análise de conteúdo com a afinidade teórica de Bardin (2011). 


\subsection{O método dialético para tecer a pesquisa}

Tecer os caminhos da pesquisa implica ligar fio a fio os tecidos desta, com vista a mostrar a rigorosidade metódica (FREIRE, 1996) da construção de uma investigação que, por sua perspectiva dinâmica e histórica, toma o método dialético como seu eixo estruturante. Sem ser contrastante e, por ter um aspecto dialógico, a pretensão neste trabalho não é de chegar às certezas ou verdades universais, mas reunir elementos que possam tornar a discussão compreensível. Por isso, ao mesmo tempo que tomamos a epistemologia como proposta de constituição dos elementos teóricos que sustentam a pesquisa, viabilizamos a possibilidade de construção do conhecimento e entendemos que o melhor modo de fazê-lo é pela dialética.

Na obra Pesquisa Participante: mito e realidade, o pesquisador Pedro Demo (1984) assinala que "a dialética, como qualquer outra metodologia, não é a unitária. É um erro primário supor que a única dialética possível ou aceitável seja o materialismo dialético" (1984, p. 66). Nestes termos, é importante explicitar o que compreendemos por dialética e que perspectiva adotamos para tecer os caminhos dessa investigação.

A dialética é um modo de filosofar que pretende construir o conhecimento a partir da contradição, da argumentação. Sua abordagem segue várias perspectivas e é identificada, como, por exemplo, dialética de Sócrates, de Platão, de Aristóteles, de Hegel, de Marx. Aqui não temos a pretensão de criticar ou discordar de nenhuma dessas abordagens, pois cada uma tem sua contribuição para a filosofia, a história e a ciência.

Ademais, nossa intenção é explicitar que, tendo Freire como matriz teórica, estruturamos nosso trabalho com base no que denominamos de dialética freireana. Os estudos sobre o autor revelam que as dialéticas de Hegel e de Marx influenciaram paulatinamente seu pensamento, principalmente no que concerne à sua práxis educativa. Observamos isso em sua vivência e nos seus escritos. A esse respeito, no prefácio do livro Paulo Freire em diálogo com outros autores organizado por Freitas, Ghiggi e Pereira (2014), o professor Streck reportou-se aos escritos de Freire da seguinte maneira:

As palavras de Paulo Freire traduzem bem a sua maneira de lidar com as ideias e opiniões alheias, fossem essas de autores renomados ou de camponeses, de operários ou a de professores. Em sua vasta obra não encontramos um apego fanático a alguma teoria ou a uma defesa intransigente de algum autor. Sabemos que ele bebia de fontes marxianas, existencialistas, fenomenológicas, pragmatistas (escolanovistas), entre outras. Ele lançava mão da filosofia, da sociologia, da linguística, da teologia e de outras ciências com as quais se encontrou ao longo de sua trajetória de educador, que no seu caso significava ser um pensador da educação. Também não encontramos em seus livros grandes debates teóricos sobre a validade ou não de determinada teoria, ou o menosprezo de autores que expunham pensamentos diferentes (STRECK, 2014, p. 5). 
É possível conferir a validade dessa afirmação de modo mais concreto quando se estuda as ações desenvolvidas por Freire quando esteve como Secretário de Educação do estado de São Paulo. Observamos, por exemplo, uma das entrevistas concedidas a Rosa María Torres, em 3 de setembro de 1994, impressa na revista Novedades Educativas, n. 79, de 1997, em Buenos Aires e, posteriormente, publicada como artigo com o título "Eu gostaria de morrer deixando uma mensagem de luta" no livro Pedagogia dos sonhos possíveis (2014) sob a organização de sua esposa Nita Freire.

Nessa entrevista, Torres solicitou que Freire comentasse porque os pais de família exigiam que os(as) professores(as) não se ausentassem da escola, não fizessem greves, e Freire relembrou um acontecido na Secretaria de Educação de São Paulo em que os professores foram acusados de que não estavam cumprindo sua função de ensinar. Por conta disso e em sentido de defesa, o presidente da associação de professores(as), à época, deu a seguinte resposta: "Não, isso não é verdade. Nós estamos ensinando o que significa uma luta democrática" (FREIRE, 2014, p. 278).

$\mathrm{Na}$ ocasião, Freire comentou que os pais ainda não tinham entendido o que era essa luta e pontuou: "Em lugar de colocar-se contra os professores, os pais de família deveriam reagir contra o estado e lutar a favor dos professores, irmanar-se com eles” (FREIRE, 2001, p. 221). Em continuação, arrematou que, por meio de sua postura ética e política, ele "convidaria o magistério e seus dirigentes a reexaminar as táticas de luta. Não para abandoná-las" (p. 278). Freire acreditava que o mundo era repleto de contradições e de armadilhas que levavam à alienação e que, somente a partir da luta consciente e política, as condições de trabalho e as condições sociais seriam transformadas.

A influência da dialética hegeliana e marxista ficam evidentes nessa entrevista de Freire, pois, assim como Hegel, concebeu que o mundo estava em contínuo movimento e que envolvia processos de contradição e de luta de contrários (tese, antítese e síntese); também, como Marx, buscou demonstrar as contradições da realidade social e superá-las ao longo de seu desenvolvimento histórico.

A dialética marxista defende que a matéria é a única forma de realidade e que mais importante que a essência é a existência, por isso, a denominação materialismo dialético. É histórico porque o homem constrói a história e é produto desta mesma construção, mesmo em meio a contradições sociais, as quais só podem ser superadas pela luta de classes.

Na concepção de Hegel, a dialética é responsável pelo movimento em que se tem uma ideia (denominada tese) e formula-se uma ideia contrária à primeira (é a antítese). Da relação de ambas, constrói-se uma ideia mais concreta que supera a fragilidade e a dicotomia das anteriores, 
sem contudo desprezá-las (é a síntese). Este é um movimento contínuo e é assim porque se compraz de uma realidade que não é, mas está sendo, que também é histórica e como tal, não tem um fim.

O fato é que, enquanto algumas dialéticas são mais objetivistas, outras são subjetivistas. O materialismo histórico admite a intervenção política humana, mas em última instância a infraestrutura econômica, ou seja, se acentuam os condicionamentos objetivos. Enquanto a dialética hegeliana vê a história construída pelo homem, o que lhe imprime um condicionamento subjetivo (DEMO, 1984).

Analisando essas duas perspectivas e compreendendo que Paulo Freire esteve em defesa insistente pela mudança da realidade, a partir da contrastação dos fatos pela práxis consciente, tomamos a iniciativa de denominar, neste trabalho, o método como dialética de Freire. A justificativa para essa decisão é que, quando estudamos as teorias do conhecimento, o fazemos não na intenção de adotar modelos fechados de pesquisa, ou modelos mais eficientes. Destarte, temos o intuito de ampliar as possibilidades e mostrar que, a partir de uma mesma matriz teórica (a dialética), podemos explorar os mais variados aspectos que possam dar sustentabilidade e validade ao trabalho de pesquisa (DEMO, 1999), tendo o cuidado e o rigor metodológico que se fazem necessários. Por esse motivo, denominamos o método de dialética de Freire.

Para Freire (1996, 2011), o mundo não é aquilo que está posto, o mundo está sendo, e, por isso mesmo, o homem pode interferir, conhecer esse mundo, para transformá-lo, mas, para que isso seja possível, defende que é preciso haver libertação. Ou seja, é preciso que se pulverize a intolerância e a alienação, para dar lugar aos conhecimentos. E defendemos que isso é possível por meio dos inéditos-viáveis.

Para efeito de exemplificação, podemos pensar que se o(a) professor(a) reconhece que não tem seu trabalho valorizado, ele(ela) luta para que se tenham melhores condições de trabalho (inclui-se também a estrutura física da escola), melhores salários e investimento na carreira docente. Como fazer isso? Aqui não se admite apenas uma resposta, como, por exemplo, pensar que ele(a) deve fazer greve. Além disso, o(a) professor(a) também pode se organizar como classe docente, aderir a um sindicato, participar de grupos de discussão e de pesquisa, manter-se ligado ao mundo da pesquisa e continuar as parcerias com as universidades, para que se fortaleça de conhecimentos, coragem, ousadia, curiosidade epistemológica e vá à luta pela garantia de seus direitos como profissional do ensino.

No contexto exemplificado, encontramos na dialética a fundamentação que mais pode contribuir para que o(a) professor(a) seja provocado no sentido de estranhamento dessas condições e de encorajamento para transformá-las, e isso vai se dar com uma práxis que fortaleça 
seu trabalho e que lhe permita emancipar-se profissional e socialmente. Contudo acreditamos que as ações da pesquisa podem muito mais que levar o(a) educador(a) a refletir sobre essas condições e vai muito além disso, elas contribuem para que se possa conhecer, contrastar e transformar uma dada realidade.

Quando nos apoiamos na epistemologia do conhecimento da dialética de Freire, consideramos que seu princípio fundamental é a busca pela contradição de uma dada realidade (tese, antítese e síntese). O movimento dialético na e da práxis acontece da seguinte maneira: observamos determinada realidade ou conhecimento, elaboramos uma série de reflexões aprofundadas, abstraímos sua aparência para compreender sua essência e agimos sobre essa pseudorealidade (aparente realidade).

Para viabilização dessa investigação, optamos pela pesquisa participante (que explicitaremos adiante) por acreditarmos que o movimento investigativo para produção do conhecimento se dá na convivência, na relação dialógica e na participação do investigador no contexto investigado. Esse movimento caracteriza a pesquisa como participante. Demo (1984, p. 80) trouxe importante contribuição nesse sentido, quando fez a seguinte afirmação:

Se aceitarmos o relacionamento dialético entre teoria e prática, não seria possível negar que a prática é componente essencial também do processo de conhecimento e de intervenção na realidade. Ao mesmo tempo, a metodologia que cabe à Pesquisa Participante é certamente a dialética, porque é a que assume o contexto histórico, privilegia a apreensão e o tratamento dos conflitos sociais, propugna a transição histórica e acredita no fator humano como capaz de interferir em condições objetivas dadas.

Por essas razões, a tomamos como opção metodológica, porque acreditamos que se trata de uma proposta de pesquisa alicerçada na dimensão ética e política que permite a construção do conhecimento por todos os participantes no processo investigativo. Essa construção é processual porque acontece em um contexto histórico e, como tal, não está livre dos conflitos, da contradição. Doravante, em torno desse processo de construção de conhecimentos, está a justificativa mais importante da escolha da pesquisa participante na perspectiva da dialética: contribuir para ampliar os conhecimentos daqueles que estão diretamente envolvidos no movimento.

\subsection{A pesquisa participante na perspectiva do diálogo, da formação e da emancipação}

Nosso diálogo acerca da pesquisa participante acontece com Fals Borda (1978), Brandão (1981, 1984, 1999, 2006), Freire (1981, 1982, 2011), Demo (1984, 1999) e Streck $(2006,2013)$. Assim, explicitaremos quem são esses autores, de que contextos falam, que contribuições seus 
estudos têm acrescentado para a comunidade acadêmica, em termos de compreensão e operacionalização do nosso estudo.

A saber, muitos estudos realizados no campo da Educação Matemática têm utilizado outros pressupostos teórico-metodológicos, como se pode conferir no "mapeamento das 80 pesquisas de abordagem qualitativa aprovadas pelo GT 19 da ANPED, no período de 1999 a 2004, focalizando as questões metodológicas" (NACARATO; FERREIRA; LOPES; FIORENTINI; GRANDO, 2005, p. 17). Estamos nos reportando ao levantamento feito sob as publicações do Grupo de Trabalho de Educação Matemática (GT 19), e as principais abordagens encontradas foram: estudos e ensaios teóricos; estudos históricos e/ou bibliográficos; estudos quase-experimentais; pesquisas de intervenção; pesquisa de observação participante; pesquisas com grupos coletivos/ colaborativos; pesquisas que combinam duas abordagens metodológicas; pesquisas exploratórias/diagnósticas.

Uma vez que optamos por desenvolver a pesquisa participante por suas características peculiares, buscamos apoio nas ideias de Freire (que já foi apresentado) devido à valiosa contribuição de seus escritos que trouxe a descrição de fases da investigação, os passos e a evolução da pesquisa. As experiências de alfabetização-letramento-formação que desenvolveu junto aos movimentos de classes populares foram decisivas para que, ao longo da história, a pesquisa participante alcançasse amplitude significativa nos estudos realizados em e por universidades e escolas de todo o nosso país.

Fals Borda foi o colombiano Orlando Fals Borda, graduado em Literatura Inglesa e ph.D. em Sociologia. Foi um dos fundadores da primeira Faculdade de Sociologia da América Latina. Tornou-se um dos fundadores e representantes de destaques da Pesquisa-Ação Participativa (PAR), o método de pesquisa qualitativa que não só visa atender às necessidades sociais de uma comunidade, mas também aos esforços do grupo para transformar a realidade com base nas necessidades sociais.

Brandão é o carioca Carlos Rodrigues Brandão, graduado em Psicologia, mestre em Antropologia e doutor em Ciências Sociais. Foi professor visitante na UnB. Atualmente é professor colaborador do Programa de Pós-Graduação em Antropologia da Universidade Estadual de Campinas (Unicamp) e professor visitante sênior da Universidade Federal de Uberlândia (UFU). Atua com os seguintes temas: Cultura, Educação popular, Campo Religioso, Religião e Educação.

Demo é o catarinense Pedro Demo, graduado em Filosofia, doutor em Sociologia pela Universität Des Saarlandes na Alemanha; com pós-doutorados na Universität ErlangenNürnberg, na Alemanha, e na University Of California At Los Angeles, nos Estados Unidos. 
Trabalha com metodologia científica, no contexto da Teoria Crítica e Pesquisa Qualitativa. É professor titular aposentado da UnB, no Departamento de Sociologia.

Streck é o gaúcho Danilo Romeu Streck, graduado em Letras, mestre em Educação Teológica, doutor em Fundamentos Filosóficos da Educação. Realizou estágio de pós-doutorado na Universidade da Califórnia, Los Angeles, e no Max-Planck Institute for Human Development, em Berlim. É professor titular da Universidade do Vale do Rio dos Sinos (Unisinos), onde atua principalmente nos seguintes temas: educação popular, educação e exclusão social, mediações pedagógicas e processos participativos. É editor executivo da Revista International Journal of Action Research.

Todos esses autores entrelaçam fio a fio o tecido da pesquisa participante. Seus modos de conceber e trabalhar nesse campo de construção do conhecimento são coerentes e complementam-se, mesmo quando as experiências acontecem Brasil afora, por esse motivo, são nossos principais interlocutores teóricos, além de outros pesquisadores.

Quando, nesta proposta de pesquisa, propomos investigar um contexto educacional, interagindo nele, o fazemos com duas intenções: de favorecer a construção de uma dimensão mais humana (perspectiva emancipadora) na formação continuada dos professores que atuam na EJA e de possibilitar a elaboração de conceitos, concepções e conhecimentos que deem significado à Educação Matemática.

Apostamos em uma proposta de pesquisa um tanto complexa, desafiadora e estimulante que só foi possível a partir da ação conjunta de todos os envolvidos no processo. Isso justifica a opção pela pesquisa participante que contou com a participação dos professores permitindo a elaboração de conceitos, de concepções e conhecimentos e a viabilização da práxis no processo formativo que também é investigativo.

A pesquisa participante foi trabalhada na América Latina - entre os anos de 1960 e 1970 - pelo brasileiro Paulo Freire e o colombiano Fals Borda e, posteriormente, ficou conhecida com o Movimento da Educação Popular. Tanto Freire (2011) quanto Fals Borda (1978) defenderam que esse tipo de pesquisa integrava investigação, educação popular e participação social, o que possibilitava aos sujeitos envolvidos compreender e interpretar como ocorria o funcionamento dos sistemas de dominação social, objetivando a construção de conhecimentos para mobilização social em prol de mudanças na realidade.

Essas características da pesquisa participante abriram muitas possibilidades em consonância com o processo formativo que estamos defendendo, pois não se tratou de promovermos um curso para os professores da EJA, mas desafiá-los a buscar estratégias de 
reconhecimento, enfrentamento e superação das situações-limites, visando à constituição de inéditos-viáveis e, por conseguinte, à transformação pessoal, social, profissional.

Um dos motivos mais significativos para utilizarmos a pesquisa participante neste trabalho consistiu na possibilidade de sua contribuição enquanto práticas social, política e pedagógica (STRECK; ADAMS, 2011). Para estes, considerar a pesquisa como uma prática social significava pensar no conjunto de ações como processo em permanente produção que colaboram com o tecido social. Enquanto prática política, referia-se para dar voz aos participantes do processo investigativo. No que concerne à prática pedagógica incluíam-se os processos de aprendizagem e de ensino que se inscrevem na produção de conhecimentos.

A pesquisa participante foi assim definida por Brandão (2006, p. 31):

Um instrumento científico, político e pedagógico de produção partilhada de conhecimento social e, também, um múltiplo e importante momento da própria ação popular. Esta alternativa de investigação social é 'participante' porque ela própria se inscreve no fluxo das ações sociais populares. Estamos em uma estrada de mão dupla: de um lado a participação popular no processo de investigação. De outro, a participação da pesquisa no correr das ações populares.

Quando o autor explicitou que a pesquisa participante era instrumento científico de mão dupla, ele queria chamar a atenção para o fato de que tanto os participantes contribuíam para a pesquisa quanto a própria pesquisa oferecia elementos importantes para sua ação. É importante perceber que o processo formativo serve de pilar para a pesquisa participante, proporcionando essa mudança de postura em todos os envolvidos.

Trazendo para o contexto real da pesquisa, tivemos a participação dos professores da escola pública, ao mesmo tempo em que nos inserimos na escola, a fim de provocarmos a ação investigativa e formativa, para a (re)construção de conhecimentos e também para o desenvolvimento profissional docente.

Nesses termos, a pesquisa participante consistiu em instrumento de trabalho carregado de intencionalidade política com vista à transformação de uma realidade e à emancipação. Assim, nosso ponto de partida foi a formação continuada, haja vista que estabelece caminhos na relação teoria e prática.

Com base em Freire (2011), nesse processo investigativo, o pesquisador adentra na realidade de uma comunidade e, a partir de uma relação dialógica, todos os envolvidos produzem conhecimentos, mas não estamos nos referindo ao conhecimento do senso comum e, sim, ao conhecimento elaborado que ocorre na e pela práxis.

A articulação da pesquisa ocorreu na relação horizontal de diálogo com os participantes para que pudessem problematizar, criticizar, refletir, discordar, reelaborar e (re)construir a 
realidade e os conhecimentos. Um elemento importante na pesquisa participante é o diálogo porque "não é no silêncio que os homens se fazem, mas na palavra, no trabalho, na açãoreflexão" (FREIRE, 2011, p. 108). Todas as formas de expressão foram valorizadas porque representou a afirmação de si enquanto ser individual e coletivo, também porque se constituiu em pronunciamentos que suscitaram a criatividade.

Dialogar acerca da Educação Matemática foi romper silenciamentos, oportunizar momentos de trocas de experiências e de falar de angústias acerca do compromisso de ensinar e aprender um campo do conhecimento tão necessário em nossas vidas. Nesse espaço os professores sentiram-se mais confiantes e autônomos, mais companheiros e sem receios de cometer erros e tentar de novo, de se assumirem enquanto seres incompletos e inconclusos. Aqui restou-nos a convicção de que "a confiança vai fazendo os sujeitos dialógicos cada vez mais companheiros na pronúncia do mundo" (FREIRE, 2011, p. 113). Isso porque contribui para o pensar crítico que rompe a ingenuidade, a alienação e instaura um novo momento histórico, o do sonho possível, dos inéditos-viáveis.

Esse diálogo, que é a comunicação entre os envolvidos, foi o que demarcou a formação continuada, porque não realizamos um curso em que havia um formador que ditava regras e os demais escutava e as cumpria. Se tivesse sido, haveria uma relação de verticalidade e teríamos uma pessoa que sabia muito ensinando aos que sabiam menos ou nada sabiam. Entretanto, ao contrário disso, o próprio diálogo configurou-se em elemento de formação porque escutávamos uns aos outros, refletíamos acerca das questões que estavam sendo pontuadas e em coletividade acordávamos as ações que seriam desenvolvidas.

Tivemos, em todos os encontros - nos círculos de investigação formativos -, um contexto de aprendizagens, porque atendemos aos princípios formativos (que descrevemos adiante) e respeitamos uns aos outros, porque construímos um cenário de formação pautado na ética, na estética e na política. Tratava-se de uma relação de maturidade e respeito às diferenças, na organização das ideias e no direito de todos à sua palavra (FREIRE, 1996).

Desse modo, trabalhar o processo de formação continuada, dentro da escola, na perspectiva da pesquisa participante, foi muito enriquecedor do ponto de vista epistemológico, devido à liberdade de adesão, reflexão e intervenção no contexto educacional em que "as propostas de mudanças implicam em incertezas e em acertos e erros, como em todo sistema complexo" (D’AMBRÓSIO, 2008, p. 13). Nesse contexto, os participantes são professores que, muitas vezes, ensinaram Matemática nos anos iniciais com base nas vivências de seus tempos de escolarização, o que representara 11 anos em que a Matemática fez parte do currículo por eles 
estudado (LOPES; SILVA et. al., 2012) e que precisava ser repensado. Tempo esse que incluía da $1^{a}$ série do Ensino Fundamental ao $3^{\circ}$ ano do Ensino Médio (o ensino não era de nove anos).

De acordo com Freire (1981, 1982, 2011), Brandão (1981, 1999, 2006) e Streck (2006, 2011, 2013), a pesquisa participante permitia a intervenção do pesquisador na comunidade participante e envolvia um processo de desconstrução, construção e reconstrução de conhecimentos para práxis emancipadora. Nesse sentido, contribuiu para viabilizar a instituição dos inéditos-viáveis na práxis dos professores que ensinam Matemática, fazendo-os superar as situações-limite.

Segundo Brandão (2006), além de construir conhecimentos, esse movimento formativo proporcionava a ampliação dos conhecimentos dos envolvidos. Isso implica a capacidade de o coletivo de professores realizar, por si mesmos, as mudanças necessárias para evoluir e se fortalecer. Tratava-se de um processo emancipatório em que já não havia privação de direitos nem restrição de valores nem negação das condições de um trabalho digno.

Para Fals Borda (1978, p. 18), esse processo investigativo e formativo, representava

la posibilidad de crear y poseer conocimiento científico en la propia acción de las masas trabajadoras: que la investigación social y la acción política con ellas, pueden sintetizarse e influirse mutuamente para aumentar tanto el nivel de eficacia de la acción como el entendimiento de la realidad.

O autor destacou que a importância da participação investigativa remeteu à capacidade que os sujeitos tinham de criar o próprio conhecimento científico para fundamentar a ação das massas trabalhadoras. Nesses termos, a investigação social e a ação política influenciam-se mutuamente contribuindo para eficácia da ação e da compreensão da realidade. Desse feito, fica clara a posição de que o processo investigativo, que também é formativo, reúne e constrói elementos que vão dar conta de legitimar outros conhecimentos.

A pesquisa participante tem suas fases e o cumprimento é compromisso de todos os participantes, porque pesquisar é pronunciar o mundo (STRECK, 2013). Essa pronúncia é um ato público, solidário, histórico, ético e político que deve fazer parte da vida de quem, ao pesquisar, se forma e também se educa porque pratica uma ação intencional, carregada de sentido epistemológico.

As próprias características da pesquisa participante denotam nossa opção de pesquisa, pois, em se tratando de investigar com uma população educacional, a EJA, cuidamos de garantir os elementos essenciais no diálogo entre pessoas que produzem conhecimentos a partir de uma realidade histórica. Sendo histórica, é inacabada e contraditória. Daí a importância de haver uma 
intervenção que seja dinâmica e dialética com a intenção de transformar a realidade e de construir conhecimentos.

Essa transformação não é pura palavra, é uma ação teorizada em que o sujeito, ao se dar conta das situações-limites, esforça-se para superá-las, para criar os inéditos-viáveis. A construção de conhecimentos diz respeito à elaboração teórica que serviu e ainda servirá de acervo para as modalidades educativas do presente e do futuro. Assim, com a concepção de que é o tipo de pesquisa que mantém a sintonia com nossos objetivos, elaboramos um quadro com o resumo das etapas de investigação propostas por Freire (2011, p. 149-166), correlacionando-o aos passos e às decisões que tomamos com a pesquisa participante que realizamos. Nas páginas que o autor escreveu acerca de como se processaram as fases da investigação, fez referência às situações-limite e aos inéditos-viáveis em vários trechos, com a finalidade de que pudéssemos atentar e levar em consideração sua carga educacional, epistemológica e política.

\section{Quadro 4: Fases da pesquisa participante}

\begin{tabular}{|c|c|}
\hline $\begin{array}{c}\text { Descrição em Freire } \\
\text { (Pedagogia do Oprimido, 2011) }\end{array}$ & $\begin{array}{l}\text { Descrição dos passos da pesquisa, considerando as situações- } \\
\text { limite e os inéditos-viáveis }\end{array}$ \\
\hline $\begin{array}{l}1^{\text {a }} \text { ) Inserir-se no campo de pesquisa, fazer as } \\
\text { parcerias e negociações. }\end{array}$ & $\begin{array}{l}1^{\circ} \text { ) Imersão no cenário da pesquisa para convidar os participantes } \\
\text { para o estudo, conforme critério de aceitação voluntária e } \\
\text { disponibilidade de tempo. Essa formalização se efetivou via } \\
\text { assinatura do Termo de Consentimento Livre e Esclarecido } \\
\text { (Apêndice A). Realizamos a negociação coletiva dos tempos e do } \\
\text { espaço para vivenciarmos os círculos de investigação formativos. }\end{array}$ \\
\hline $\begin{array}{l}2^{\text {a) }} \text { Observar o contexto e os seus } \\
\text { participantes e levantar, pelo diálogo, as } \\
\text { temáticas (conjunto de contradições) } \\
\text { presentes na realidade daquela comunidade: } \\
\text { investigação temática para codificar e } \\
\text { descodificá-las. }\end{array}$ & $\begin{array}{l}2^{\circ} \text { ) Observação da organização do trabalho pedagógico, da rotina } \\
\text { escolar e da relação formativa na escola. As informações foram } \\
\text { captadas pelo sentido da pesquisadora, anotadas em um caderno } \\
\text { de campo, registradas por gravação, foto e filmagem } \\
\text { (devidamente autorizados). Utilizamos questionário impresso } \\
\text { acerca do perfil dos professores participantes, entrevistamos e } \\
\text { gravamos em áudio professoras e alunos(as) para levantar } \\
\text { informações acerca da relação com a Matemática. }\end{array}$ \\
\hline $\begin{array}{l}3^{\text {a })} \text { Iniciar os círculos de investigação } \\
\text { temática que constituem momentos de } \\
\text { discussão e análise do conjunto de } \\
\text { contradições que permeiam a realidade e } \\
\text { gravar as discussões para posterior análise. }\end{array}$ & $\begin{array}{l}3^{\text {o) }} \text { Realizamos os círculos de investigação formativos que foram } \\
\text { os processos formativos para identificação e discussão de } \\
\text { situações-limite, para estudo e possibilidade de construção de } \\
\text { conhecimentos, que são os próprios inéditos- viáveis. Esse foi um } \\
\text { espaço de troca de informações, de planejamento das ações e de } \\
\text { elaboração de conceitos, concepções e conhecimentos. Utilizamos } \\
\text { um gravador de áudio nesta etapa. }\end{array}$ \\
\hline $\begin{array}{l}4^{\mathrm{a})} \text { Estudar sistematicamente os achados da } \\
\text { investigação e discussão que estão nos } \\
\text { registros gravados e escritos. }\end{array}$ & $\begin{array}{l}\left.4^{\circ}\right) \text { Analisamos as informações da pesquisa com base na análise } \\
\text { de conteúdo, em que se permitiu a interpretação do conteúdo que } \\
\text { contém as mensagens. As informações (gravadas e escritas) foram } \\
\text { organizadas em categorias para realizar a análise. }\end{array}$ \\
\hline $\begin{array}{l}5^{\text {a) }} \text { Constituir os conteúdos em unidades de } \\
\text { aprendizagem para que se constituam em } \\
\text { materiais teórico para formação do educador } \\
\text { e do educando. Essas unidades tendem a } \\
\text { fazer parte de um programa educativo. }\end{array}$ & $\begin{array}{l}5^{\circ} \text { ) Socialização do resultado do processo investigativo, } \\
\text { constituição do acervo teórico para os professores que ensinam } \\
\text { Matemática na EJA, ampla divulgação acadêmica para que essa } \\
\text { experiência se constitua em uma práxis contínua de pesquisa- } \\
\text { formação-educação. }\end{array}$ \\
\hline
\end{tabular}

Fonte: elaboração da pesquisadora (2015). 
A descrição dos caminhos que trilhamos resume nosso compromisso com a comunidade pesquisada, que são as professoras que ensinam Matemática nos anos iniciais da modalidade EJA, em que o propósito foi centrar na realidade social vivida pelas pessoas em uma relação dialética, com vista à conscientização popular e à participação (BRANDÃO; STRECK, 2006). O ponto de partida foi a realidade da comunidade pesquisada e o que esperávamos era que as professoras pudessem tomar consciência das condições materiais e de tempo e se encorajassem na participação efetiva do movimento pela transformação.

A experiência de Freire com a pesquisa participante aconteceu por ocasião da alfabetização de adultos em que seu objeto consistia na alfabetização. A investigação temática proposta por ele apareceu nas obras Pedagogia do oprimido (2011, p. 138-166); em Educação como prática da liberdade (1982, p. 112-115); em Educação e mudança (1979, p.73-78); além de constar em um livro de bolso da autoria de Brandão (1984) intitulado O que é o método Paulo Freire.

Nessas obras, Freire descreveu que fazia o levantamento do universo temático (vocabulário) dos sujeitos carregado de contradições, codificava-os (representava-os, escreviaos), descodificava-os (análise crítica, compreensão do vocabulário) com os sujeitos que estudavam as possibilidades de transformação desse universo temático em conteúdo de aprendizagem educativa. Este constituía o programa (currículo) que professores(as) e alunos(as) deveriam utilizar para a alfabetização.

No caso de nosso trabalho, vivemos a denúncia das situações-limite (que foram registradas por escrito e pelas gravações), posteriormente transcritas (codificadas), analisadas e discutidas pelos participantes (descodificadas) nos círculos de investigação formativos. Em continuação ao processo, vivemos o anúncio dos inéditos-viáveis que, pela consistência teórica e conceitual, servirá de referência para a modalidade e para outros estudos acadêmicos.

Em suma, esse tipo de pesquisa correspondeu a uma estratégia metodológica em que os envolvidos construíram conhecimentos, pois "ela não é privilégio nem de pesquisador nem de alfabetizados [...]. Antes do domínio de determinadas técnicas, pesquisar implica capacidade de escutar, um escutar denso, intenso e (im)paciente" (STRECK, 2006, p. 265). Então, nesse processo denso de diálogo e escuta, foi que construímos o contexto da pesquisa e fomos tocados na dimensão do aprender enquanto processo contínuo.

Durante todo o processo de pesquisa na escola, fomos decidindo que procedimentos e instrumentos de investigação atenderiam aos objetivos do presente estudo e da formação continuada. Na troca dialógica com as professoras, estas sugeriram a presença da pesquisadora 
em suas aulas a fim de colocar em ação as estratégias de trabalho com os conteúdos matemáticos, também autorizaram que as entrevistassem e aos alunos(as), bem como permitiram o registro com fotos e filmagem.

A saber, muitas fotos foram tiradas pelas professoras e compartilhadas no grupo de rede social (WhatsApp), que criamos para socializarmos informações imediatas. Além disso, utilizamos bastante o e-mail para trocarmos materiais de estudo. Todas as informações construídas e levantadas por meio desses procedimentos constituíram uma fonte rica de material que precisou ser minuciosamente analisada e, para isso, utilizamos a análise de conteúdo de Bardin (2011).

\subsubsection{Do ocular aos vestígios que a pesquisa precisou captar}

O mais importante passo foi o contato inicial com os professores que ensinam Matemática nos anos iniciais da EJA (1 $1^{\mathrm{a}}, 2^{\mathrm{a}}, 3^{\mathrm{a}}$ e $4^{\mathrm{a}}$ etapas). Estes formalmente aderiram à pesquisa quando assinaram o Termo de Consentimento Livre e Esclarecido (Apêndice A). Após essa fase e as tratativas para realização dos círculos de investigação formativos, iniciamos as observações nas salas de aula, haja vista a solicitação das professoras.

A observação foi uma forma de estar mais perto dos participantes, do contexto de trabalho e de inteirar-se dos obstáculos que interferem em sua práxis (as situações-limite). Além disso, estar inserido no campo investigado, por meio da observação, permite que o agente externo (o pesquisador) deixe, aos poucos, de ser visto como um estranho. Essa etapa foi fundamental para que pesquisador e participantes estreitassem os laços e a confiança, configurando-se como um grupo de trabalho articulado e coletivo, construindo ações que fossem ao encontro das necessidades da EJA. Entretanto, se a entrada no campo de pesquisa fosse brusca, poderia ter ocasionado mudança de postura, de pensamento, de ações dos sujeitos para mostrar uma falsa realidade.

Os registros dos fenômenos observados foram guardados em caderno de campo, em gravações de áudio, fotografias e filmagens. Em muitas das aulas, a pesquisadora realizou observação participante porque as professoras iam conduzindo as ações nesse sentido. Nos muitos momentos em que estivemos nas aulas, alunos(as) e professoras agiam com naturalidade e tinham boa receptividade, ou seja, não olhavam para a pesquisadora como um agente estranho. No caso dos(as) alunos(as), logo no primeiro mês, estabeleceram uma relação afetiva com a pesquisadora, chamavam-na de professora e, quando se encontravam na entrada da escola ou nos corredores, já perguntavam quando estaríamos juntos novamente. 
Mesmo com todo o lado positivo da observação, se esta tivesse sido usada apenas como instrumento na pesquisa, em que adentrássemos à sala de aula a fim de registrar comportamentos e a relação professor-aluno, teríamos deixado de participar dos ricos processos de aprendizagem. Aprendizagem que não ocorria apenas com alunos(as), mas também com professoras e pesquisadora continuamente, por isso as observações participantes tiveram um caráter formativo.

Nesse contexto, quanto mais nos percebíamos fazendo parte desse contexto e sentindo a atmosfera de respeito e afeto entre professoras e alunos(as), tanto mais tivemos a curiosidade de conhecer melhor os docentes. Então, utilizamos um questionário impresso (Apêndice B), estruturado com perguntas abertas acerca das informações pessoais e profissionais dos professores, de suas experiências com ensino e com a formação inicial e continuada.

A utilização do questionário foi importante e necessária, no entanto, se tivéssemos optado apenas por esse instrumento, não teríamos chegado a tantas informações e com tamanha profundidade. De qualquer modo, a intencionalidade da pesquisa andou longe de ser uma investigação que se importasse apenas em saber sobre a vida e as opiniões dos professores. Nosso compromisso não era de saber as versões acerca do ensino, nem de apontar defeitos e lançar críticas sobre o trabalho docente. Nosso compromisso com os professores era conhecer a identidade profissional e entender as relações estabelecidas no contexto de trabalho, no trato com a Educação Matemática e as outras áreas do ensino.

Haja vista a abertura e a confiança que construímos, foi possível perguntar e decidir em conjunto sobre todos os passos da pesquisa. Os professores já falam com intimidade sobre a relação com a Educação Matemática, a formação continuada e a contribuição da pesquisa. Nas formações, ocorridas todas as quartas-feiras letivas de 2015, esses temas eram recorrentes e as falas uns dos outros eram complementadas.

Ao final do primeiro semestre de 2015, levantamos a possibilidade de entrevistarmos os(as) alunos(as) para sabermos o que eles gostariam de aprender de Educação Matemática. Só foi no final do semestre porque as professoras tinham também interesse de saber qual a expectativa dos(as) alunos(as) em relação à continuação dos estudos e como tinham avaliado as ações desenvolvidas durante o projeto formativo. Então, pensamos nas questões e produzimos um roteiro de entrevista coletiva para os alunos (Apêndice C) e utilizamos em uma roda de conversa em cada sala de aula. Em uma das salas, tivemos a presença de uma professora substituta. Em todas as salas, pedimos permissão para gravar o diálogo.

Os(as) alunos(as) ficaram à vontade e fizeram o uso da palavra sem receios, o que nos fez considerar que essa estratégia foi significativa porque permitimos aos discentes falarem sobre o que tinham vontade de aprender, sobre a motivação para estarem estudando, a relação com a 
Educação Matemática. Eles também expressaram a admiração pelos professores e a afetividade nessa relação e queriam continuar a conversa, porque, segundo eles, parecia aquelas entrevistas que passam na televisão (comentaram isso porque a pesquisadora apontava o gravador de áudio na direção de quem estava fazendo o uso da palavra). Foi uma oportunidade ímpar em que os(as) alunos(as) se sentiram importantes, tinham desejo de falar das esperanças que os moviam na direção do aprender. Para nosso grupo formativo, serviu como ânimo e direcionador para continuarmos as ações com foco na aprendizagem matemática, conforme traremos no capítulo das análises.

Outra experiência de entrevista foi com as professoras, de forma individual, porque nas formações as falas se davam em um formato coletivo (de acréscimos e afirmações). Então, propusemos uma entrevista (Apêndice D) ao final do primeiro ano de projeto formativo. Como muitas questões sobre a formação já faziam parte da fala de algumas professoras, organizamos um roteiro para evitar digressões e orientar o diálogo em torno do que significou a parceria no projeto de Educação Matemática. Nessa relação dialógica, o papel fundamental de pesquisadores é estimular que os participantes falem sobre a temática anunciada a partir de seus conhecimentos, valores, cultura, postura ética e política.

Esse momento individual com cada professora foi determinante e decisivo para pensarmos na continuidade do projeto na escola, porque cada fala teve como ponto marcante a necessidade desses processos formativos. As professoras descreveram os obstáculos quanto às condições materiais, pedagógicas, políticas de sua vida profissional, falaram das situações-limite superadas e dos elementos que contribuíram para seu desenvolvimento profissional.

De modo geral, todas as informações foram gravadas e transcritas, com o cuidado de manter a originalidade do material para análise, de estudo e de formação. Sua transcrição incluiu todos os elementos possíveis de significação (risos, silêncios, hesitação, angústia, movimento e estímulo do entrevistador). Tivemos diálogos espontâneos sobre o que as participantes pensavam acerca dos itens já citados, isso envolveu valores, emoções, afetividade, que auxiliaram na descrição de práticas, episódios e acontecimentos.

Na concepção de Bardin (2011, p. 94)

qualquer pessoa que faça entrevistas conhece a riqueza desta fala, a sua singularidade individual, mas também a aparência por vezes tortuosa, contraditória, "com buracos", com digressões incompreensíveis, negações incômodas, atalhos, saídas fugazes ou clarezas enganadoras.

As digressões foram comuns, isso acontece quando o medo de transpor as barreiras são latentes e isso, às vezes, gera um recuo, uma tendência a esquivar-se da denúncia e do anúncio 
(FREIRE, 2011). Em decorrência disso, lançamos mão de diferentes recursos que instigassem a fala, de modo a permitir a compreensão até dos silêncios.

Outros instrumentos importantes que aparentemente não intimidaram nem alunos(as) nem professoras foi o uso do registro por fotografia e filmagem. Algumas vezes, as próprias professoras registraram e socializaram. O objetivo da filmagem foi captar informações que não foram percebidas na observação, no questionário e na entrevista ou até mesmo reforçá-los, se já tiverem sido anunciados anteriormente. Neste último caso, os denominados "percebidos destacados" (FREIRE, 2011) porque receberam um tratamento e um olhar mais atento e cuidadoso.

Em nossas formações, recorremos a esses registros para investigarmos os sentidos e os significados que os professores atribuíam à aprendizagem e o material passava pela análise crítica dos participantes. Servia como pretexto para identificação das situações-limite e dos inéditos-viáveis a partir da e na perspectiva da práxis. Assim, esse momento de identificação e análise crítica do conteúdo da fotografia e da filmagem aconteceu durante as sessões formativas - denominados círculos de investigação formativos.

Em meio aos demais procedimentos, destacamos os círculos de investigação formativos como aquele que acreditamos ter sido o determinante ao bom andamento do estudo. Com características similares ao que Freire (2011) denominou de círculos de investigação temática porque os envolvidos se reuniam em círculos para discutir os temas que haviam sido captados pelos investigadores, esses temas eram descodificados, ou seja, eram problematizados no decorrer do diálogo.

Para Freire, "os participantes dos círculos de investigação temática vão extrojetando, pela força catártica da metodologia, uma série de sentimentos, opiniões, de si, do mundo e dos outros, que possivelmente não extrojetariam em circunstâncias diferentes" (2011, p. 156). Não era à toa esse tipo de organização metodológica e dialógica, era intencional, para que os sujeitos pudessem, inclusive, validar e negar os seus ditos e criar, naquele meio coletivo, estratégias de superação daquilo que os oprimiam.

De modo análogo, os círculos de investigação formativos constituíram para nós sessões de discussões, aprofundamento teórico e fomentador de ações com as professoras em torno da Educação Matemática. Para isso, nosso primeiro material teórico orientador dos estudos foi o Currículo em Movimento para os anos iniciais da EJA (DISTRITO FEDERAL, 2014) que nos possibilitou pensarmos nos direcionamentos em termos de conteúdo, metodologia e objetivos e caminhos formativos. Além disso, como elementos provocativos, sempre trazíamos informações 
provindas de observações, questionário, entrevistas, filmagens e fotos. Estes suscitavam problematizações coletivas.

Nesse contexto formativo, tivemos oportunidade de desocultar as situações-limite e construir, coletiva e individualmente, os inéditos-viáveis. Foi importante espaço para teorização das práticas - ação reflexiva concebendo a práxis e a construção de conhecimentos, sem que necessariamente pudessem acontecer na ordem aqui descrita. Ressaltamos, mais uma vez, que estamos concebendo a formação como estratégia de pesquisa para criar os inéditos-viáveis no e a partir do processo formativo.

Para garantir a organização e a estruturação dos círculos de investigação formativos, elaboramos alguns princípios, de acordo com o que estamos propondo como processo formativo. Com base nesses princípios, a formação:

- ancora-se na perspectiva crítico-emancipadora e na práxis - desde a seleção de teóricos que falam em formação até as ações concretas;

- negocia as ações que devem orientar o processo formativo - sempre no coletivo;

- compromete-se com o desenvolvimento humano e profissional do professor - esforço pelo ser autêntico, autônomo e intelectual;

- incorpora o trabalho coletivo como possibilidade de transformação humana e profissional - reúne teoria e ação na práxis coletiva;

- contribui para ampliação do conhecimento - os inéditos-viáveis que se constituem em significativo acervo teórico para a modalidade educativa;

- possibilita a pesquisa-formação-educação que, segundo Freire (1982, 1996, 2011), são condições que não podem existir em separado - essa experiência deve ser uma atitude contínua para intervenção crítica e política na realidade; e

- $\quad$ socializa os resultados das análise feitas no grupo de formação - porque a divulgação dos conhecimentos, dos conceitos e das concepções será pública.

A finalidade dos círculos de investigação formativos foi proporcionar a interação dos participantes, planejar as ações de intervenção e organizar um grupo fixo que mantivesse a formação como parte do projeto político-pedagógico da escola, mesmo depois de cumpridos os prazos desta pesquisa - que o movimento formativo seja permanente e busque novos adeptos para essa onda dinâmica da formação. Esse objetivo foi cumprido, pois, mesmo tendo delimitado como recorte temporal da pesquisa as informações construídas durante o ano de 2015, nos 
comprometemos nesse novo ano de 2016 na continuidade do projeto com o ponto de partida no material didático-pedagógico para a EJA.

Apesar de outros projetos já terem se instalado na escola, o nosso projeto foi o primeiro no campo da Educação Matemática e também foi a primeira formação em Matemática que os participantes vivenciaram durante toda a carreira docente. Cada hora no projeto foi dedicada ao estudo, à pesquisa e à formação e representou o investimento no desenvolvimento profissional. Isso implica também em qualidade para a vida do professor que, quanto mais formação tem, tanto mais condição apresenta para oferecer uma formação de qualidade ao educando.

\subsubsection{O caminho do registro à análise das informações da pesquisa}

Nossa trajetória de pesquisa não foi encerrada na busca por informações e impressões das observações realizadas, do questionário, das entrevistas com alunos(as) e professoras, ou da análise do conteúdo das filmagens e fotos e ainda das reflexões e ações nos círculos de investigação formativos. De posse de todo esse material, começamos outra etapa de organização e análise das informações utilizando o procedimento de análise de conteúdo proposta por Bardin (2011). Para isso, transcrevemos os áudios, organizamos e separamos o material em categorias de análise. Entretanto, antes de tratarmos dessa técnica de análise, vamos conhecer um pouco sobre a autora que a propôs.

Bardin é a francesa Laurence Bardin, professora-assistente de Psicologia na Universidade de Paris V. Essa pesquisadora aplicou as técnicas da análise de conteúdo na investigação psicossociológica e no estudo das comunicações de massas. Depois disso, essa técnica passou a ser utilizada em linguística, na informática, nas ciências da comunicação e nas ciências sociais por se tratar de um tipo de técnica, ou conjunto de técnicas que, devido à sua dinamicidade, exige do pesquisador a sensibilidade crítica para perceber os conteúdos expressos nas mensagens faladas e escritas dos participantes.

Para Bardin (2011, p. 48), a análise de conteúdo consistia em:

Um conjunto de técnicas de análise de comunicações visando obter por procedimentos sistemáticos e objetivos de descrição do conteúdo das mensagens indicadores (quantitativos ou não) que permitam a inferência de conhecimentos relativos às condições de produção/recepção (variáveis inferidas) dessas mensagens.

Por isso, foi importante estarmos atento às expressões faladas e escritas, a fim de nos aproximarmos da compreensão real do contexto e das condições em que foram elaboradas as mensagens emitidas pelos professores que ensinam Matemática na EJA. Isso nos remeteu às significações, ao modo como ocorria a fala que, carregada de conteúdo, sinalizava uma 
mensagem. O papel do analista de conteúdos (pesquisadores) é compreender o sentido da comunicação e perceber a significação que está implícita na fala, por isso, diz-se que o objetivo desse tipo de técnica consiste na inferência - na dedução.

Esse conjunto de técnicas envolve etapas analíticas de investigação e incluem a descrição objetiva e sistemática do conteúdo expresso na comunicação, a fim de interpretá-lo. Por isso, o analista tem um trabalho semelhante a um detetive, porque procura vestígios (BARDIN, 2011) na comunicação, no conteúdo da mensagem. Contudo faz-se necessário codificar o texto para analisá-lo. Isso implica a organização do texto em categorias.

Segundo Bardin (2011, p. 43), a análise categorial "pretende tomar em consideração a totalidade de um 'texto', passando-o pelo crivo da classificação e do recenseamento, segundo a freqüência de presença (ou de ausência) de itens de sentido". Nesse aspecto, o conjunto de informações construído por meio da observação, do questionário, da entrevista, da fotografia e filmagem e do diálogo nos círculos de investigação formativos constituiu o texto que foi condensado e alocado em categorias de análise.

O objetivo da análise de conteúdo é manipular as mensagens (conteúdo e sua expressão), a fim de mostrar as evidências que permitam inferir sobre outra realidade exterior àquela, ou seja, é a busca de significações acerca de uma realidade que não se mostra de imediato, mas tem que ser encontrada no interior da mensagem dos participantes.

Neste trabalho, elegemos a análise temática como suporte para procedermos com a análise, que significa a contagem de temas de significação, conforme o grau de importância, de valor, de prestígio, de entonação e repetição que for aparecendo na comunicação dos envolvidos no processo investigativo. Para que fosse possível sua realização, foi necessário que o texto passasse pelo critério de classificação, ou seja, começamos a reunir temas idênticos ou aproximados, em termos de significação (nível semântico). Isso só foi possível após olharmos atentamente para os elementos constituintes deste texto.

Os passos para iniciarmos a análise são transcrição, leitura, condensação, classificação (que resulta na categorização), tratamento dos resultados e interpretação. Sabe-se que a transcrição é morosa e resulta em um acervo enorme de informação que precisou ser lido com cuidado e atenção. Enquanto lemos, foi possível nos perguntarmos "O que está dizendo esta pessoa? Como isso é dito? Que poderia ter dito de diferente? O que não diz? Que diz sem o dizer (o silêncio)? Como as palavras, as frases e as sequências se encadeiam entre si? Qual é a lógica discursiva do conjunto?” (BARDIN, 2011, p. 98, grifo nosso). Esses questionamentos facilitam o trabalho que temos de proceder com a condensação, ou seja, reduzir o texto bruto em trechos 
simplificados e claros, sem perder os principais elementos informativos da comunicação. Depois, a etapa seguinte foi a da classificação.

Nessa etapa de classificação, os temas são agrupados por aproximação de sentido, de significação e, ao final, atribuímos títulos às categorias e, quando necessário, às subcategorias. A saber, categoria consiste em um conjunto de coisas que se relacionam, são como gavetas que guardam objetos segundo critérios de inclusão e de exclusão de suas características. Sua maior contribuição consiste em transpor o texto de dados brutos a dados organizados, possibilitando tornar visíveis as informações que estão camufladas em forma de dados originais, os dados brutos.

A etapa subsequente foi o tratamento das informações que permitiu uma síntese dos resultados e sua interpretação, possibilitando responder aos questionamentos iniciais da pesquisa, atingindo os objetivos gerais pretendidos e confirmando a tese defendida. Cada uma dessas etapas teve sua contribuição para que este trabalho fosse claro e objetivo, coerente e articulado no sentido metodológico e epistemológico que se pretendia. Mas isso só foi possível porque as participantes da pesquisa foram também coerentes do discurso às ações.

\subsection{A construção do diálogo na escola com os participantes da pesquisa}

Descrever como se constituiu o contexto da pesquisa é, no mínimo, rememorar as dimensões da pesquisa participante que Streck (2006, p. 266-272) assim definiu:

\footnotetext{
investigação e formação estão inseridas no mesmo processo de produção de conhecimento; pesquisa e compromissos éticos e políticos; a pesquisa é a interação múltipla de sujeitos; pesquisa é uma ação pública para a constituição do público; o método é parte do movimento de pesquisa.
}

Quanto a essas dimensões, é importante saber que a produção de conhecimento aconteceu em todo o contexto. O compromisso da pesquisa proporcionou uma transformação social, política e cultural em todos os envolvidos, a partir da denúncia das situações-limite e do anúncio dos inéditos-viáveis. Os sujeitos que participaram desta pesquisa puderam modificar os conhecimentos e por eles foram modificados. A pesquisa como pronunciamento do mundo é de todos e para todos. Cabe ao método dialogar com todos os elementos da pesquisa, a fim de ter clareza e coerência com os objetivos, o objeto e os sujeitos envolvidos no processo investigativo.

Assim, para que fosse viável este estudo, construímos os seguintes procedimentos e etapas da pesquisa que, mesmo tendo sido previamente descrito no quadro anterior, nessa explicitação abaixo fazemos a correspondência com os momentos pedagógicos defendidos por Freitas (2001) que é o de sonhar, estudar e criar. 
i) Imersão no cenário da pesquisa para definição dos participantes do estudo, conforme critério de aceitação voluntária e disponibilidade de tempo. Essa etapa correspondeu ao momento pedagógico do sonhar com as possibilidades advindas do processo formativo, para aqueles que aderiram à proposta. Essa adesão aconteceu porque os professores tiveram esperança. Após a explicação dos objetivos do projeto formativo, deixamos os professores falarem sobre seus anseios e expectativas para que se constituísse em um compromisso pela escola. Depois disso, os professores assinaram o Termo de Consentimento Livre e Esclarecido e eles mesmos já negociaram coletivamente as datas, os horários e o lugar dos encontros formativos. Ficou combinado na sala de coordenação da escola, todas as quartas-feiras, a partir das 16h30, para nos envolvermos nos círculos de investigação formativos.

ii) Observação da organização do trabalho pedagógico, da rotina escolar e da relação formativa na escola. Nessa etapa, o momento pedagógico formativo é do estudar, com preponderância da observação, que corresponde ao estudo atento e curioso acerca das condições de trabalho do professor, da sua pseudorealidade e do seu projeto de formação. As informações levantadas e construídas tiveram o auxílio dos gestores da escola e foram anotadas em um caderno de campo, registradas por foto e filmagem (com devida autorização) a fim de permitir a análise do contexto.

iii)Identificação do perfil dos participantes e identificação das situações-limite via observação/questionário/entrevista com as professoras e os(as) alunos(as), com registro escrito, em foto e filmagem. Permanecemos no momento pedagógico formativo do estudar, mas, com enfoque investigativo, em que apresentamos o questionário impresso com perguntas abertas acerca do perfil profissional e das experiências formativas. Nessa etapa, utilizamos um gravador de áudio para registrar a entrevista com os professores sobre suas condições de trabalho e o reflexo disso para a vida pessoal e, desse diálogo, levantamos informações acerca da relação com a Matemática. Ainda nessa etapa, buscamos mais aproximação com os(as) alunos(as) da EJA, realizamos roda de conversa - diálogos em sala de aula (às vezes com e outras sem a presença do professor) para entender quais os principais obstáculos da vida pessoal e estudantil, quais as expectativas em relação à Educação Matemática. No que se refere às fotos e à filmagem, conseguimos autorização das professoras para registrar o envolvimento nas ações pedagógicas, que posteriormente foram discutidas nas formações. 
iv) Realização de círculos de investigação formativos (sessões de formação) que constituíram processos formativos para identificação e discussão das situaçõeslimite, para estudo e construção de conhecimentos - os inéditos-viáveis. Aqui alcançamos o ponto alto do momento pedagógico de criar que foi possibilitado por meio do diálogo, pela criticidade e o rigor, teias de discussão e de ação que envolveram a esperança e o empenho na transformação daquela realidade. Então, as situações-limite foram paulatinamente cedendo lugar aos inéditos-viáveis. A saber, esse processo não é uma relação linear e simplista de causa (situações-limite) e consequência (inéditos-viáveis), por termos a convicção de que é um processo complexo e dialético.

v) Análise das informações da pesquisa com base na análise de conteúdo, proposta por Bardin (2011). Os três momentos pedagógicos fundem-se quando da organização, da categorização e da análise das informações, a partir da análise de conteúdo que permitiu a interpretação do conteúdo contido nas mensagens. Desse modo, interpretamos as informações para comprovar a tese de que os inéditosviáveis constituídos no e a partir do processo de formação continuada colaboram para superação das situações-limite, a reorganização do trabalho pedagógico com a Matemática e para a construção de conhecimentos.

Explanar acerca de cada uma dessas etapas é tão necessário quanto reforçar que as bibliografias tiveram grande influência em nossas opções metodológicas, tanto no que concerne à possibilidade de elevação da qualidade investigativa-formativa-educativa deste trabalho, quanto para a contribuição nas ciências humanas e sociais, cuja finalidade maior se atenta este estudo.

\subsubsection{Demarcação física e histórica do contexto pesquisado}

Por compreendermos que o contexto da pesquisa envolvia pessoas e lugares com história, valores e culturas diversas, complexas, ricas e significativas, buscamos descrever informações importantes que justificaram a escolha pelo campo de investigação. O desenho do campo de pesquisa foi a Região Administrativa (RA) de Ceilândia/DF, e essa escolha ocorreu por dois grandes motivos: porque a pesquisadora reside nessa cidade e por levarmos em conta tanto as características quanto os seus acontecimentos históricos. Algumas informações históricas e de 
densidade populacional foram pesquisadas nos sites de consulta pública do $\mathrm{DF}^{14}$ e também em trabalhos publicados que citaremos adiante.

Figura 3: Mapa das Regiões Administrativas do DF, com destaque para Ceilândia/DF

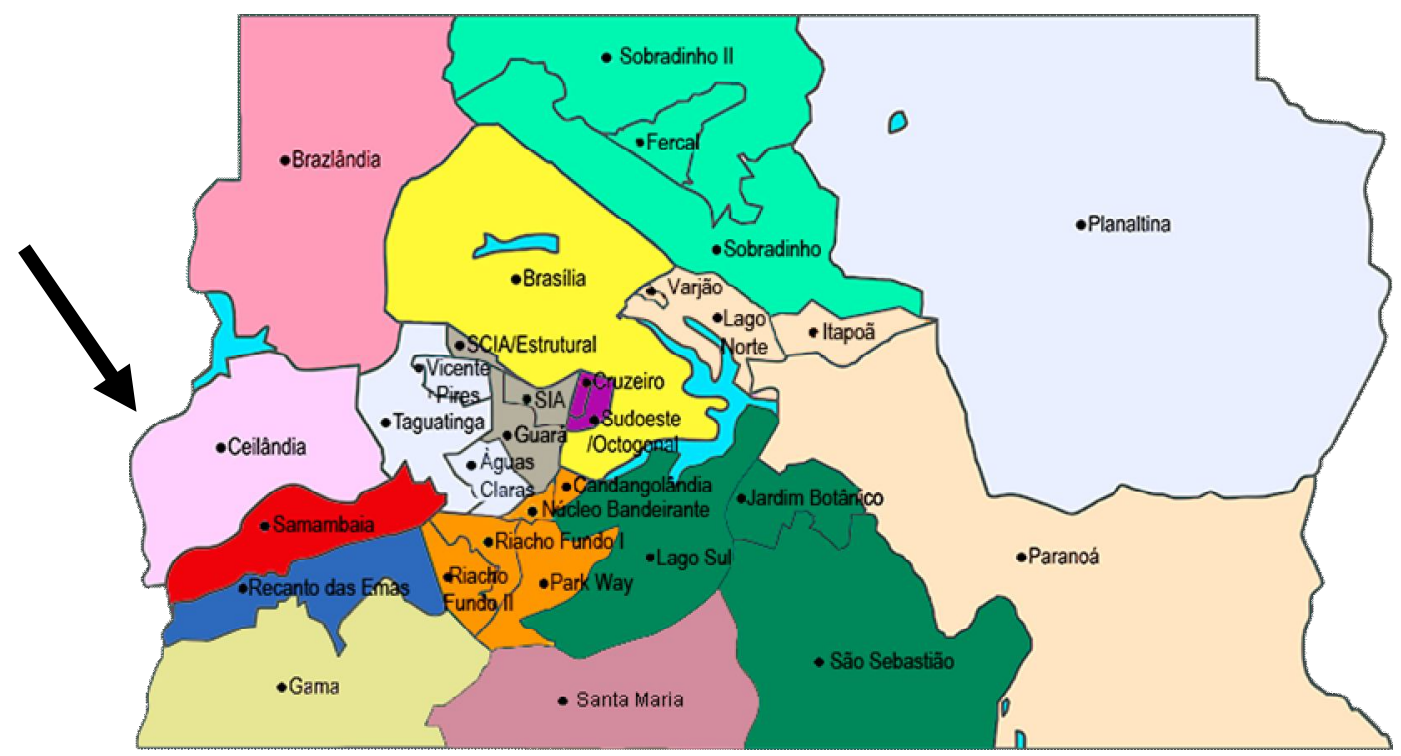

Fonte: 〈http://www.mapas-df.com/regioes.htm>

Quando à sua origem, Ceilândia é a nona RA do DF, fundada em 26 de março de 1971, com distância de 26 quilômetros de Brasília. O prefixo "cei" refere-se à sigla da Campanha de Erradicação das Invasões. O sufixo "lândia" significa terra, terreno, lugar (de land) em língua inglesa. A cidade foi dividida originalmente em três grandes áreas: Ceilândia Norte, Ceilândia Centro, Ceilândia Sul com a Guariroba. Na atualidade, é subdividida da seguinte forma: Ceilândia Sul, Guariroba, Ceilândia Norte, Ceilândia Centro, Setor O, Expansão do Setor O, Nova Ceilândia, P Sul, QNQ, QNR, Setor Industrial, Condomínio Privê, Condomínio Sol Nascente e Condomínio Pôr do Sol.

A respeito de Ceilândia/DF, ainda é importante saber:

- É a maior RA do DF, no que concerne ao contingente populacional - cerca de 600 mil habitantes, o que pode ser significativo em termos de representatividade regional. É onde está concentrado o maior número de pessoas nordestinas do DF (registre-se que a pesquisadora está incluída porque é nordestina).

\footnotetext{
${ }^{14}$ Disponível em: <http://www.ceilandia.df.gov.br/>

<http://www.anuariododf.com.br/regioes-administrativas/ra-ix-ceilandia/>. Acesso em: 7 set. 2015.
} 
- Foi e ainda é a cidade que mais recebeu e recebe colaboração e incentivo em termos de projetos para a EJA. Teve o privilégio de receber a visita de Paulo Freire em 1996.

- Recebeu o primeiro Decanato de Extensão da UnB. Inaugurou um campus também da UnB com o funcionamento dos cursos de Enfermagem, Farmácia, Fisioterapia, Gestão em Saúde, Terapia Ocupacional e Fonoaudiologia.

- Foi onde aconteceu o primeiro projeto de alfabetização de jovens e adultos do DF denominado "Alfanumerização que constitui-se como uma forma de compreender criticamente o mundo, na qual a aprendizagem se dá pelo princípio da descoberta e pela inserção na realidade" (REIS; RÊSES; VIEIRA, 2012, p. 540).

- Recebeu a sede do Centro de Educação Paulo Freire de Ceilândia (Cepafre), que reconhecido por suas políticas formativas, em 2005, foi condecorado com a medalha Paulo Freire (REIS; RÊSES; VIEIRA, 2012).

- Foi sede do Projeto Proeja-Transiarte, que é uma atividade com jovens e adultos, com o objetivo de despertar-lhes a identidade cultural por meio da produção artística virtual (REIS; CASTIONI; TELES, 2012).

A cidade possui uma rica trajetória histórica e cultural por sua singularidade, pelo aspecto acolhedor de pessoas nordestinas, por causa de tais qualidades, essa pesquisadora sente-se familiarizada e encontra representatividade em tantas situações de luta por uma vida mais digna e mais humana.

\subsubsection{A descoberta das riquezas da escola pela ação pesquisante}

Dentro de Ceilândia/DF, pretendíamos uma escola pública de grande porte para também termos uma representatividade considerável quanto à modalidade EJA. Então, um colega que cursou uma disciplina no doutorado comigo tinha o conhecimento de todas as escolas da Regional de Ceilândia e fez a indicação daquela que atendia aos critérios que eu desejava para a pesquisa. Assim, o colega Waldeck Batista dos Santos intermediou o contato com os gestores da escola e eu fui conhecê-la de perto.

Os gestores não apenas apresentaram a escola como também autorizaram a divulgação do nome da mesma neste trabalho, porque, segundo eles, a escola já foi sede de outros projetos, como o Transiarte, descrito anteriormente, em parceria com a UnB. Nesse cenário, os únicos nomes que foram substituídos para efeito de divulgação na pesquisa foram os das professoras, de 
modo a atender ao critério de confidencialidade dos nomes originais, conforme descrito no Termo de Consentimento Livre e Esclarecido (Apêndice A).

A escola está localizada próxima à Administração de Ceilândia e oferece a modalidade de EJA nos três segmentos - do Ensino Fundamental ao Médio. Contudo, delimitamos como recorte para a pesquisa o Ensino Fundamental menor que corresponde de $1^{\text {a }}$ a $4^{\mathrm{a}}$ etapas/série, que o currículo em movimento da Educação Básica - da EJA (DISTRITO FEDERAL, 2014) estabeleceu como de $1^{\circ}$ o $5^{\circ}$ ano.

Figura 4: Mapa das escolas da Secretaria de Educação do DF - Regional Ceilândia

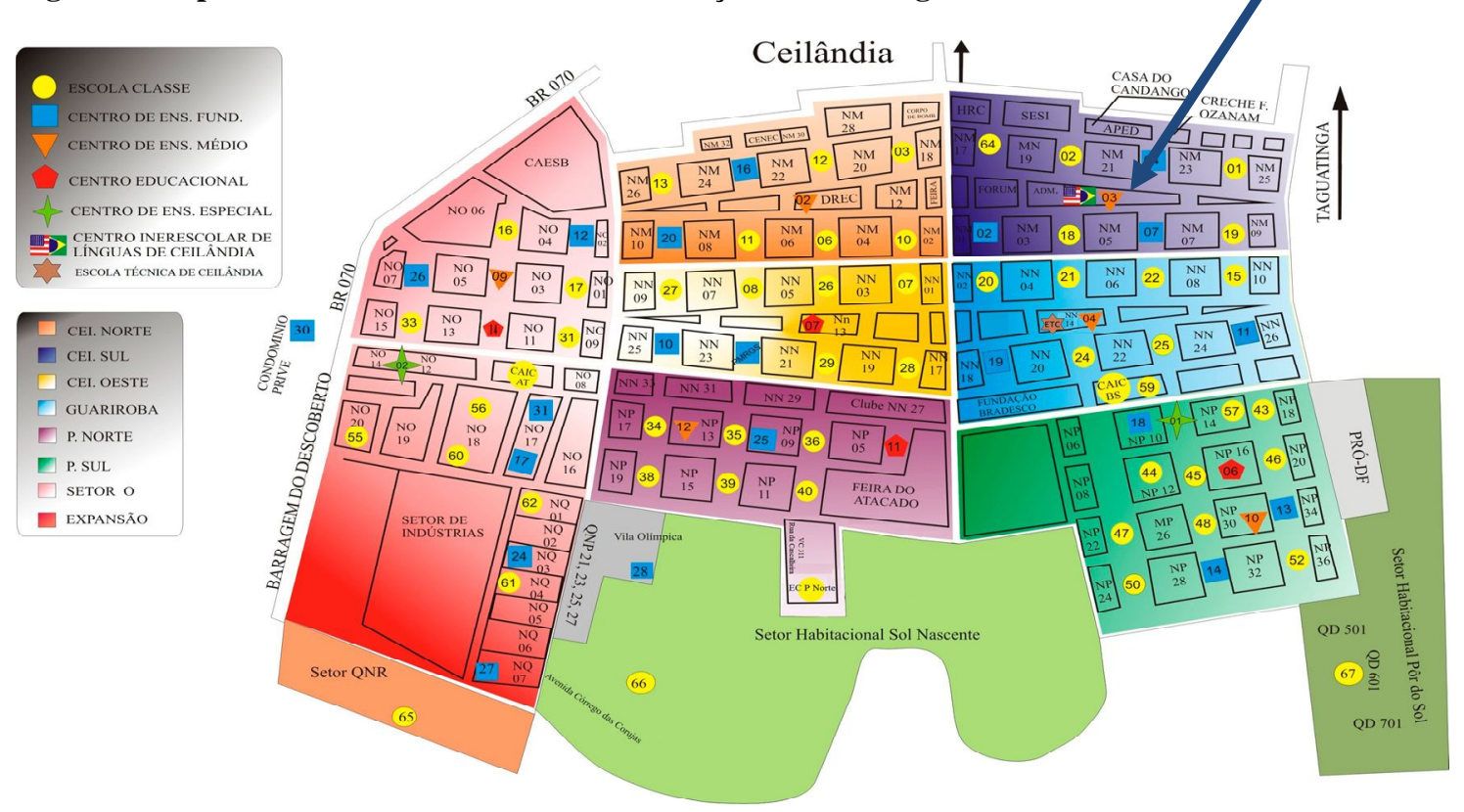

Fonte: Regional de Ensino de Ceilândia (2012).

O Centro de Ensino Médio 03 de Ceilândia foi criado em 12 de novembro de 1971, sob a Portaria nº 003, de 12 de janeiro de 2004, SEDF. Está localizado no seguinte endereço: QNM 13 Área Especial - Ceilândia Sul/DF. À época de sua criação, foi denominado Centro de Ensino de $1^{\circ} \mathrm{Grau}$; em 1977, foi Centro Interescolar $\mathrm{n}^{\circ} 01 \mathrm{e}$, no mesmo ano, meses depois, foi Centro Educacional 03 de Ceilândia, até que, no ano 2000, a instituição passou a ofertar Ensino Médio e EJA nos três segmentos e, por isso, passou a ter a denominação atual: Centro de Ensino Médio 03 (CEM 03).

O Projeto Político Pedagógico - PPP (DISTRITO FEDERAL, 2014) já foi atualizado e descreve o funcionamento da escola nos três turnos, atendendo aos moradores da RA de Ceilândia, do Setor O, Setor P, Expansão, Recanto das Emas, Samambaia e também Águas Lindas/GO. 
A estrutura física atual da escola está organizada conforme a tabela a seguir.

Tabela 3: Estrutura física do Centro Educacional 03 de Ceilândia/DF

\begin{tabular}{l|l|l|l}
\hline$N^{\circ}$ & ESPAÇO FíSICO & $N^{\circ}$ & ESPAÇO FísICO \\
\hline \hline 01 & Sala de professores & 01 & Sala de coordenação \\
\hline \hline 30 & Salas de aula & 01 & Mecanografia \\
\hline \hline 01 & Auditório & 01 & Biblioteca \\
\hline \hline 01 & Sala - laboratório de informática & 02 & Sala - laboratório de ciências \\
\hline \hline 01 & Sala de artes & 01 & $\begin{array}{l}\text { Sala de Serviço de Orientação } \\
\text { Educacional (SOE) }\end{array}$ \\
\hline \hline 02 & Banheiros para professores & 02 & Banheiros para alunos(as) \\
\hline \hline 01 & Sala do grêmio (em formação) & 01 & Sala de ginástica \\
\hline \hline 01 & Quadra poliesportiva coberta & 05 & Quadras de esporte \\
\hline \hline 01 & Secretaria & 01 & Mecanografia - particular \\
\hline \hline 01 & Sala de servidores & 01 & Cantina \\
\hline \hline 01 & Sala de recurso & 01 & Lanchonete particular \\
\hline \hline 02 & Banheiro no auditório & 01 & Depósito da cantina \\
\hline \hline 03 & Camarins & 01 & Depósito material de expediente \\
\hline \hline 01 & Sala de supervisão & 01 & Sala de expediente administrativo \\
\hline \hline 01 & Sala de Direção & 01 & Sala da Banda Toque Especial \\
\cline { 4 - 4 }
\end{tabular}

Fonte: Projeto Político-Pedagógico da escola CEM 03 (DISTRITO FEDERAL, 2014, p. 3-4).

De acordo com o PPP-2014, ocupam esse espaço 1.052 alunos(as) do Ensino Médio (distribuídos nas três séries) no turno matutino; 1.028 alunos(as) distribuídos(as) do seguinte modo: em quatro turmas de $1^{\circ}$ segmento, 12 turmas de $2^{\circ}$ segmento e sete turmas de $3^{\circ}$ segmento, no turno vespertino. Enquanto que no noturno só funciona o $3^{\circ}$ segmento com 14 turmas.

A escola possui características peculiares, porque oferta Ensino Médio e modalidade EJA, também porque é a única de Ceilândia onde a modalidade funciona no turno diurno. No que concerne ao espaço físico, a escola é ampla, arejada, com muitas árvores, tem espaço de recreação, há rampas de acesso, piso rebaixado nas entradas das salas de aula, banheiros com barras. Especificamente, as salas de aula estão equipadas com quadros brancos a pincel e a giz, as carteiras universitárias estão sendo substituídas por mesas e cadeiras, as salas possuem arcondicionado e tem largura medindo 5,70 metros por 8,10 metros de comprimento.

Outra importante e valiosa característica da escola é referente à gestão escolar que é articulada no que se refere à tomada decisões sempre em favor do bem-estar da comunidade. Isso foi percebido durante a inserção no campo de pesquisa em que pude perceber uma gestão democrática, com o respeito às opiniões de professoras e alunos(as), com abertura para votações 
e com a valorização de momentos culturais promovidos por todos os membros da escola. Além disso, a gestão sempre cuidou de repassar os avisos em caixa de som, no horário do intervalo das aulas, a fim de que toda a escola tivesse o acesso à informação e aos esclarecimentos acerca de matrícula, carteira estudantil, fardamento, eventos culturais, dias não letivos, eventos externos à escola, colação de grau e semana de desenvolvimento de projetos que, no caso da EJA, são os seguintes: Feira de Ciências, Semana Cultural, Semana da Consciência Negra, Leitura e produção de textos.

Mais que espaço físico, nossos laços foram estreitados com as pessoas que enchem de vida aquele lugar. O sentimento é de que não é apenas o lugar que fui fazer pesquisa, é um lugar de ampliação de saberes e de acolhimento. Esse acolhimento já começava com o porteiro Lincon que todos os dias me recebia sempre bem humorado e desejava boa tarde, com um sorriso na minha chegada e outro na saída, ao fim da tarde. Da mesma forma, foi a recepção sempre solícita dos gestores Rogério e Divaldo e do agente administrativo Fernando.

Nesse contexto, marcaram profundamente minha vida pessoal e profissional especialmente professoras e alunos(as) do primeiro segmento da EJA. Por isso, para apresentálos convido aos leitores para retornarmos ao dia 24 de março de 2015, quando fui à escola CEM 03 conversar com os gestores, para falar da minha proposta e objetivos de pesquisa e pedir a permissão para desenvolver o trabalho na escola, o que me foi prontamente concedido.

$\mathrm{Na}$ ocasião, também solicitei ao gestor a autorização e a concessão de um tempo para conversar com os professores do primeiro segmento da EJA. Nesse período, ainda não havia sido nomeado nenhum coordenador pedagógico para intermediar esse processo de convite e adesão à pesquisa, então, tudo foi tratado com os gestores - diretor-geral (Divaldo de Oliveira) e diretor adjunto (Rogério Taveira). Estes autorizaram a divulgação de seus nomes e também da escola.

\subsubsection{Na relação dialógica fomo-nos constituindo participantes da pesquisa}

Como em todo início de ano letivo, muitos(as) alunos(as) ainda não haviam realizado suas matrículas, por isso resolvi conversar individualmente com cada professor do primeiro segmento para compreender um pouco de sua realidade e já perceber se tinham interesse em participar da pesquisa. Essa estratégia foi fundamental porque cada dia estive com um ou dois deles (dias 30 e 31 de março; $1^{\circ}$ e 2 de abril), cada um representava uma etapa de ensino (de $1^{\mathrm{a}}$ a $4^{\mathrm{a}}$ ) e, portanto, tinham expectativas diferentes.

Depois de descrever sucintamente a proposta da pesquisa de doutorado, solicitei que eles agendassem uma data para que eu pudesse trazer em slides um panorama detalhado de como 
seria essa pesquisa e só depois disso eles dariam a resposta de adesão ou não. Eles não só concederam como também propuseram o dia 15 de abril de 2015, após o intervalo (às 16h30), justificando que, no dia de quarta-feira, todos os professores do $1^{\circ}$ segmento estariam na escola. Nos demais dias, sempre um deles estaria em momento de coordenação.

Assim, pedi novamente a permissão da gestão e o diretor adjunto concedeu esse tempo, reservou a sala de coordenação, disponibilizou o data show e convidou os demais professores (incluindo de Língua Portuguesa) para conhecerem a proposta de pesquisa. Adiantou que, caso aceitassem participar, poderíamos marcar nossas formações conforme qualquer decisão dos professores porque sabia da importância do projeto para o desenvolvimento profissional do corpo docente. Isso me encheu de alegria e esperança de que pudéssemos realizar um trabalho articulado, pois não é todo pesquisador que consegue esse apoio e essa abertura da gestão da escola que acredita no potencial formativo das atividades realizadas.

Conforme combinado, no encontro formal, dia 15 de abril de 2015, cheguei cedo na escola e o diretor adjunto me acompanhou até a sala de coordenação, já levando o data show. Então, arrumei a sala para recepcionar os professores. A sala dispunha de uma mesa grande rodeada de cadeiras, e para marcar cada assento coloquei uma rosa vermelha com uma mensagem de Paulo Freire para acolher cada pessoa que estaria naquele encontro. Os professores que denominamos de João, Rita, Rosa e Rute chegaram e comentaram o clima harmonioso daquela acolhida com rosas, expressaram estar se sentindo importante. Também levei impresso um recorte do meu trabalho de qualificação que trata da contextualização e influência dos inéditos-viáveis na formação de professores.

Aproveitei e perguntei se eles me autorizavam gravar aquele encontro - usando um gravador de áudio. Eles consentiram e assim iniciei o registro de nosso primeiro encontro formal na escola. Após acomodarem-se nas cadeiras, iniciei a conversa pedindo que acompanhassem a leitura da mensagem extraída da obra Educação e Mudança: "Quando o homem compreende a sua realidade, pode levantar hipóteses sobre o desafio dessa realidade e procurar soluções. Assim, pode transformá-la e o seu trabalho pode criar um mundo próprio, seu Eu e as suas circunstâncias" (FREIRE, 1979, p.30).

Começarmos com a discussão acerca do pensamento do autor foi intencional porque trazia implícito o objetivo da pesquisa, qual seja, superar as situações-limite e constituir os inéditos-viáveis, ou seja, tornar possível e material as ações, mobilizar a práxis. E, assim como o próprio nome sugere, não devemos pensar em Educação sem pensar nos processos de mudança. Falei sobre a importância do nosso projeto que se importaria apenas de mostrar o potencial que os professores do $1^{\circ}$ segmento têm para aprender e ensinar Matemática. 
Pedi licença para falar um pouco de minha história enquanto pessoa e enquanto profissional. Falei de minha relação pessoal com a EJA, haja vista a condição do meu pai enquanto pessoa desprovida de leitura e escrita e relatei o potencial dele enquanto trabalhador e conhecedor de assuntos que a escola não faz articulação. Nesse momento, todos nos emocionamos e os professores também entraram na história porque tinham necessidade de falar sobre o esforço de seus pais para que eles estudassem.

Na sequência, retomei a fala e comecei a descrição da minha trajetória com a EJA, desde meu estágio de docência na graduação e meu envolvimento com pesquisas nessa modalidade de ensino. Todas essas experiências foram de encorajamento para continuar minha luta ética e política porque acredito no potencial que professores e alunos(as) têm de fazer história e de se inscrevem na história. Desenvolver com os professores esse projeto é manter viva a esperança de que o trabalho coletivo e formativo nos faz ter esperança de que a transformação da realidade e de nós mesmos é possível.

Depois dessa fala inicial, perguntei se queriam perguntar algo sobre minha pessoa. Eles acenaram com a cabeça afirmando que não. Então, iniciei a apresentação de outra pessoa de fundamental importância para meu trabalho, o meu orientador professor Cristiano Muniz. Então, descrevi um pouco de sua trajetória acadêmica, falei sobre o compromisso dele com os professores do DF e da parceria e dos encaminhamentos que ele dava à presente pesquisa. Muito emocionada, relatei que, para ele me orientar nesta tese, não estava em jogo apenas o contrato didático assinado com a Pós-Graduação da Faculdade de Educação da UnB, foi um ato solidário de quem também acredita na EJA e um compromisso de amor e respeito pelos saberes daqueles que, cada vez mais, se descobrem como seres matemáticos.

Em seguida, pedi permissão para iniciar a apresentação em slides, onde priorizei os seguintes tópicos: explicação dos inéditos-viáveis; justificativa do trabalho; inquietações para a pesquisa; objetivos; bibliografia sucinta; proposta provisória, aberta e negociável da metodologia de trabalho; eixos importantes para o estudo; algumas dificuldades da EJA já percebidas em trabalhos anteriores; os princípios formativos da pesquisa; e as expectativas. Ao finalizar a projeção dos slides, perguntei se eles tinham dúvidas e depois falei que a parte mais importante do trabalho ainda não era a que apresentei. O lado mais significativo e importante era eles que deveriam dizer, pois tratava-se do que os professores queriam que o projeto contribuísse, quais suas expectativas acerca da proposta de trabalho.

Nesse primeiro encontro, o professor João também se fez presente, seria a única reunião, porque a aposentadoria dele (por tempo de serviço) já estava prevista para o próximo dia 18 de abril de 2015. Mesmo assim, ele quis participar para saber acerca do novo projeto e conversar 
sobre os tipos de pesquisas que já apareceram na escola, mas que os pesquisadores não davam o feedback para os professores. Segundo o professor, apareciam pessoas na escola, faziam observação, entrevistas e depois não davam retorno da pesquisa. Entendi a fala dele como "denúncia" de que alguns pesquisadores já apareceram na escola e fizeram promessas, mas não cumpriram com os compromissos acordados com os professores.

Então, com respeito a esse posicionamento, reafirmei que nossa proposta de pesquisa era com os professores e não sobre os professores, tal como propõe a pesquisa participante. Falei que nossas formações seriam na escola, conforme disponibilidade deles, porque não era um curso de capacitação com certificado ao final, mas momentos formativos em que discutiríamos conteúdos do currículo a fim de trabalharmos com atividades contextualizadas. Reafirmei que deixava em aberto todas as tratativas quanto a dias e horários das formações, também me dispus a estar na escola todos os dias, caso sentissem necessidade.

Apresentei o termo de compromisso e perguntei se gostariam de pensar sobre a adesão à pesquisa para depois entregarem o documento assinado. Para minha surpresa e alegria, as três professoras aceitaram, assinaram logo o termo e me entregaram e, na ocasião, fizeram os seguintes comentários: "Estou sentindo que esse trabalho não é como os outros. Começando com a recepção que foi diferente" (JOÃO); "Nós temos a necessidade da formação" (RUTE); "Podemos começar nossas formações já na próxima quarta-feira, que é dia 22 de abril, depois do feriado" (ROSA); "É mesmo, porque a quarta-feira é o dia em que todos nós estamos na escola" (RITA).

Todas essas falas comoveram-me porque não pensei que o retorno deles seria tão imediato. Outra surpresa foi que uma das professoras de Língua Portuguesa (Rosa) também aceitou fazer parte do projeto e disse que, além de contribuir para o aprendizado de outra área do conhecimento, também poderia articular os trabalhos desenvolvidos em sua turma pela professora que ensina Matemática. Essa colocação só reforçou nosso desejo de desenvolver um trabalho na perspectiva do letramento e da conexão de saberes, valorizando o contexto social da EJA a partir da resolução de problemas.

Como o professor João aposentou em abril, no mesmo mês abriram contrato temporário para uma professora assumir a turma. Seu nome fictício era Raquel e ela ficou conosco até julho de 2015. No segundo semestre letivo, vieram mais duas professoras compor nosso grupo, sendo uma de Língua Portuguesa (Leitinho) e a outra de Matemática (Fabí). A saber, os professores do $1^{\circ}$ segmento fazem acordos acerca de quem vai ministrar Língua Portuguesa ou Matemática em cada semestre letivo. De certo modo, essa prática faz com que a formação em Educação 
Matemática seja ainda mais necessária, tendo em vista que as professoras têm experiência com as duas disciplinas.

Pela descrição já pudemos notar que só ficamos com mulheres no grupo da pesquisa, por isso, a partir daqui vamos nos reportar sempre às professoras. Mas afinal, quem eram essas professoras participantes da pesquisa? Quais formações acadêmicas? Quanto tempo de magistério e na EJA? Para responder a essas perguntas, fizemos o levantamento do perfil a partir de um questionário individual (Apêndice B), que resumimos nos textos a seguir.

Rita nasceu em Taguatinga/DF, tem 46 anos, casada e tem dois filhos. Cursou Escola Normal no Ensino Médio; graduada em Pedagogia (curso presencial, 2000-2004); especialista em Ciências Sociais (curso presencial); tem 25 anos de magistério, sendo 14 anos só no primeiro segmento da EJA. É concursada da Secretaria de Educação do Distrito Federal e trabalha 20 horas na $1^{\text {a }}$ etapa da EJA - turno vespertino do Centro de Ensino Médio (CEM) 03 com a disciplina Matemática; e mais 20 horas na $1^{\mathrm{a}}$ etapa - turno noturno do Centro de Ensino Fundamental (CEF) 02, ambas escolas em Ceilândia/DF.

Fabí nasceu em Brasília/DF, tem 42 anos, casada e tem dois filhos. Cursou Escola Normal de Ceilândia; graduada em Educação Física (curso presencial, 1996-2001); especialista em Inclusão e Educação especial (curso semipresencial); tem 23 anos de magistério, sendo 20 anos só no primeiro segmento da EJA. É concursada da Secretaria de Educação do Distrito Federal. Trabalha 20 horas no primeiro segmento da EJA - turno vespertino da escola CEM 03 com a disciplina Matemática. No semestre anterior, ela ministrou aula de Língua Portuguesa na $4^{\mathrm{a}}$ etapa. Nesse segundo semestre letivo, fez acordo com as demais professoras que ministraria Matemática na $3^{\mathrm{a}}$ e na $4^{\mathrm{a}}$ etapa, fazendo o revezamento com a professora Rute. Outras 20 horas são ministradas na $3^{\mathrm{a}}$ etapa - turno noturno do CEF 02 .

Leitinho nasceu em Brasília/DF, tem 41 anos, casada e tem três filhos. Cursou Escola Normal; graduada em Educação Física (curso presencial, 1988-1991); especialista em Educação Especial e Inclusão (curso presencial); tem 24 anos de magistério, sendo três anos no primeiro segmento da EJA. É concursada da Secretaria de Educação do Distrito Federal e trabalha 20 horas na $3^{\text {a }}$ etapa da EJA - turno vespertino do CEM 03 com a disciplina Língua Portuguesa.

Rute nasceu em Brasília/DF, tem 38 anos, casada, sem filhos. Não cursou a Escola Normal; graduada em Pedagogia (curso presencial, 1995-1998) e licenciada em Educação Física (modalidade semipresencial, 2013-2015); especialista em Docência do Ensino Superior (semipresencial) e em Educação Especial; tem 17 anos de magistério, sendo 15 anos no primeiro segmento da EJA. É concursada da Secretaria de Educação do Distrito Federal e trabalha 20 horas na Associação de Pais e Amigos dos Excepcionais e Deficientes (Apaed) de Ceilândia, no 
turno matutino. Outras 20 horas, no turno vespertino, são dedicadas ao ensino de Matemática no $1^{\circ}$ segmento da EJA do CEM 03, na $2^{\text {a }}$ etapa e reveza com a professora Fabí na $3^{\text {a }}$ etapa.

Rosa nasceu em Brasília/DF, tem 38 anos, solteira, sem filhos. Cursou Escola Normal; graduada em Letras (presencial, 1994-1999); especialista em Direito Educacional (A distância); tem 20 anos de magistério, sendo 19 anos no primeiro segmento da EJA. É concursada da Secretaria de Educação do Distrito Federal e trabalha 20 horas na $3^{\text {a }}$ etapa da EJA - turno vespertino do CEM 03 com a disciplina Língua Portuguesa; Outras 20 horas na $1^{\mathrm{a}}$ etapa - turno noturno do CEF 02.

Raquel nasceu em Brasília/DF, tem 37 anos, solteira e não tem filhos. Não cursou Escola Normal; graduada em Letras (presencial, 2003-2007) e em Pedagogia (semipresencial, 20132014). Sempre atuou como professora de contrato temporário, trabalhou um ano na EJA, sendo que, no primeiro semestre letivo de 2015, assumiu a disciplina de Matemática na turma da $2^{\mathrm{a}}$ etapa que era do professor João.

Após a descrição das professoras, é importante destacar que tivemos um grupo dinâmico e coeso com quatro professoras que ensinavam Matemática e duas de Língua Portuguesa. Essa composição nos rendeu uma produção de grande valor, no que concerne à aprendizagem e ao ensino de Matemática, tendo em vista que compreendemos a ideia e agimos de acordo com a perspectiva do Letramento, conforme descrições adiante.

O fato de todas as professoras serem naturais do Distrito Federal contribui para que saibam um pouco mais da história de como se organizaram as RAs, especialmente Ceilândia que concentra muitos nordestinos. Como todas trabalham nessa cidade há mais de uma década, conhecem as histórias, as necessidades e os anseios de alunos(as) que frequentam suas escolas.

Também é importante destacar que as trocas de disciplinas (Matemática e Língua Portuguesa) são possíveis devido à maioria das professoras terem sido normalistas, a exceção se dá com Rute e Raquel, mas ambas cursaram Pedagogia que as habilitam para trabalhar com conteúdos dos anos iniciais. Note-se que não estamos justificando que a formação inicial prepara o professor para ministrar todas as disciplinas, mas de acordo com a legislação educacional, o Curso Normal e o de Pedagogia habilitam profissionais para atuar nos primeiros anos de escolaridade. As professoras de concurso efetivo que foram normalistas também cursaram uma graduação presencial e todas possuem pós-graduação. Elas não trabalham com jornada ampliada.

Somado a isso, ressaltamos também a sintonia de trabalho, pois as professoras Rita, Rosa e Fabí atuavam nas mesmas escolas e nos mesmos turnos: no CEM 03 no período vespertino e no CEF 02 no turno noturno. Isso facilitou o trabalho coletivo e ampliou a extensão do nosso projeto, pois elas afirmaram que estavam levando as ideias e atividades para a outra escola e que 
tinham resultados muito animadores no que concerne à aprendizagem. Outro destaque é que essas três professoras já possuem mais de uma década de experiência na EJA, que, segundo elas, é uma realização, porque as histórias de luta dos(as) alunos(as) fazem valer a pena o empenho pelo processo de ensino e aprendizagem.

Não podemos deixar de descrever as qualidades de todas as professoras do grupo: o espírito de equipe, a solidariedade, o respeito às opiniões contrárias e ao momento da fala de cada uma, a pontualidade, o compromisso com o nosso projeto, a prontidão para definir o cronograma de formação e os conteúdos que seriam trabalhados, a divisão de tarefas para providenciar os materiais nas aulas, o engajamento pela própria aprendizagem, a preocupação com o aprendizado do aluno da EJA e a amorosidade para com essa modalidade.

Esse termo amorosidade foi uma categoria importante na tese de doutorado do professor Renato Hilário dos Reis, e a esse respeito fez a seguinte afirmação: "É o que chamo amorosidade: o desenvolvimento dessa capacidade de escutar/ouvir/pensando o outro e falar/pensando, levando em conta o outro que ouve/escuta" (REIS, 2000, p. 136). Em outras palavras, ele se reportava àquela pessoa que era acolhida e que também acolhia. A esse respeito, Freire afirmou que "sendo fundamento do diálogo, o amor é, também, diálogo" (FREIRE, 2011, p.110) e adiante continuou frisando que "o amor é compromisso com os homens [...] o ato de amor está em comprometer-se com sua causa. A causa de sua libertação. Mas, este compromisso, porque é amoroso, é dialógico" (p.111).

Na perspectiva freireana, a escuta atenta e respeitosa é um ato de amor e de compromisso com a vida dos sujeitos que se faz presente na Educação dialógica, portanto, no diálogo. Nesse sentido, a ternura, o acolhimento, o respeito, o desejo por compartilhar histórias e aprendizagens fez com que nos reportássemos aos alunos(as) da EJA como seres amorosos.

Estamos falando do mesmo "ser amoroso - ser de sentimento/amor" (REIS, 2011, p. 149) que contribuiu para a construção de um contexto singular e plural de Educação na escola CEM 03. Esses seres amorosos eram os jovens, os adultos e os idosos aos quais nos afeiçoamos e que tiveram grande importância no projeto, muito mais do que esperávamos. Por isso sentimos necessidade de descrevê-los, inclusive porque serviram de orientação para nossas ações, porque estivemos comprometidos com a aprendizagem da Educação Matemática por todos os participantes (diretos e indiretos) da pesquisa. Então, organizamos uma tabela para preenchermos as informações dos(as) alunos(as) do primeiro segmento, conforme segue. 
Tabela 4: Perfil pessoal dos(as) alunos(as) da $1^{\text {a }}$ etapa da EJA

\begin{tabular}{c|c|c|c|c|c|c|c|c}
\hline \multicolumn{2}{c|}{ Perfil dos(as) alunos(as) da 1a etapa (2015.1) } \\
\hline Nome & Idade & Naturalidade & $\begin{array}{c}\text { Mora há } \\
\text { quanto } \\
\text { tempo no } \\
\text { DF (anos)? }\end{array}$ & $\begin{array}{c}\text { Estado } \\
\text { civil }\end{array}$ & $\begin{array}{c}\text { Quantos } \\
\text { filhos? }\end{array}$ & $\begin{array}{c}\text { Qual sua } \\
\text { ocupação } \\
\text { anterior e a } \\
\text { atual? }\end{array}$ & $\begin{array}{c}\text { Utiliza que } \\
\text { transporte } \\
\text { para ir à } \\
\text { escola? }\end{array}$ & $\begin{array}{c}\text { Ler e } \\
\text { escreve? }\end{array}$ \\
\hline AT & 68 & Ceará & 49 & Solteiro & 4 & $\begin{array}{c}\text { Novacap/ } \\
\text { Aposentado }\end{array}$ & Moto & Não \\
\hline FL & 69 & Bahia & 41 & Viúva & 8 & $\begin{array}{c}\text { Do lar/ } \\
\text { Aposentada }\end{array}$ & Ônibus & Não \\
\hline IV & 47 & Bahia & 5 & Casada & 5 & $\begin{array}{c}\text { Doméstica/ } \\
\text { do lar }\end{array}$ & Ônibus & Não \\
\hline JF & 67 & Bahia & 40 & Casada & 4 & $\begin{array}{c}\text { Serviços } \\
\text { gerais/ } \\
\text { aposentada }\end{array}$ & Ônibus & Sim \\
\hline MA & 61 & Maranhão & 5 & Solteira & 8 & $\begin{array}{c}\text { Trabalhador } \\
\text { a rural/ } \\
\text { aposentada }\end{array}$ & Ônibus & Não \\
\hline MD & 42 & Piauí & 22 & Casada & 1 & $\begin{array}{c}\text { Serviços } \\
\text { gerais/ } \\
\text { do lar }\end{array}$ & Ônibus & Sim \\
\hline RO & 41 & Bahia & 30 & Solteira & 1 & $\begin{array}{c}\text { Doméstica/ } \\
\text { do lar }\end{array}$ & Nenhum & Não \\
\hline VD & 55 & Bahia & 23 & Solteira & 1 & $\begin{array}{c}\text { Doméstica/ } \\
\text { do lar }\end{array}$ & Ônibus & Sim \\
\hline
\end{tabular}

Fonte: Levantamento realizado pela professora da $1^{\mathrm{a}}$ etapa.

Obs.: são oito alunos(as) frequentes na $1^{\mathrm{a}}$ etapa, sendo sete mulheres e nenhum jovem ou adolescente. A turma é composta por adultos e idosos. Todos são nordestinos, sendo que dois moram há cinco anos no DF e os demais já residem há mais de 20 anos. Os(as) alunos(as) que se declararam solteiros já foram casados. Todos têm filhos. A maioria desempenhou trabalhos domésticos e serviços gerais e já está na condição de aposentado. A maioria depende de transporte público para ir à escola. Cinco dos oito não sabem ler ainda e só escrevem copiando do quadro. 
Tabela 5: Perfil pessoal dos(as) alunos(as) da $2^{\text {a }}$ etapa da EJA

\begin{tabular}{|c|c|c|c|c|c|c|c|c|}
\hline \multicolumn{9}{|c|}{ Perfil dos(as) alunos(as) da $2^{a}$ etapa (2015.1) } \\
\hline Nome & Idade & Naturalidade & $\begin{array}{c}\text { Mora há } \\
\text { quanto } \\
\text { tempo no } \\
\text { DF (anos)? }\end{array}$ & $\begin{array}{c}\text { Estado } \\
\text { civil }\end{array}$ & $\begin{array}{l}\text { Quantos } \\
\text { filhos? }\end{array}$ & $\begin{array}{c}\text { Qual sua } \\
\text { ocupação } \\
\text { anterior e a } \\
\text { atual? }\end{array}$ & $\begin{array}{c}\text { Utiliza que } \\
\text { transporte } \\
\text { para ir à } \\
\text { escola? }\end{array}$ & $\begin{array}{c}\text { Ler e } \\
\text { escreve? }\end{array}$ \\
\hline $\mathrm{AL}$ & 54 & $\begin{array}{l}\text { Minas } \\
\text { Gerais }\end{array}$ & 35 & Casada & 3 & Do lar & Ônibus & Sim \\
\hline $\mathrm{A}$ & 52 & Ceará & 42 & Solteiro & 1 & $\begin{array}{l}\text { Construção } \\
\text { civil/ } \\
\text { desempre- } \\
\text { gado }\end{array}$ & Ônibus & Sim \\
\hline $\mathrm{C}$ & 60 & Bahia & 40 & Viúva & 1 & $\begin{array}{c}\text { Vendedora } \\
\text { pensionista }\end{array}$ & Nenhum & Sim \\
\hline CL & 43 & Piauí & 27 & Casada & 3 & $\begin{array}{c}\text { Doméstica/ } \\
\text { do lar }\end{array}$ & Ônibus & Sim \\
\hline $\mathrm{E}$ & 47 & Maranhão & 38 & Solteira & 1 & $\begin{array}{l}\text { Vendedora } \\
\text { / esteticista }\end{array}$ & Ônibus & Sim \\
\hline EV & 61 & $\begin{array}{l}\text { Minas } \\
\text { Gerais }\end{array}$ & 20 & Casada & 5 & $\begin{array}{l}\text { Vendedora } \\
\text { / do lar }\end{array}$ & Nenhum & Sim \\
\hline $\mathrm{J}$ & 15 & Brasília & 15 & Solteira & 0 & $\begin{array}{l}\text { Auxiliar de } \\
\text { salão/ } \\
\text { estudante }\end{array}$ & Ônibus & Sim \\
\hline $\mathrm{M}$ & 69 & Bahia & 42 & Viúvo & 0 & $\begin{array}{c}\text { Servente/ } \\
\text { aposentado }\end{array}$ & Nenhum & Sim \\
\hline $\mathrm{RD}$ & 19 & Piauí & 16 & Solteiro & 0 & Estudante & Ônibus & Sim \\
\hline $\mathrm{RO}$ & 57 & Goiás & 30 & Viúva & 3 & $\begin{array}{l}\text { Doméstica/ } \\
\text { pensionista }\end{array}$ & Nenhum & Não \\
\hline
\end{tabular}

Fonte: Levantamento realizado pela professora da $2^{\mathrm{a}}$ etapa.

Obs.: são dez alunos(as) frequentes na $2^{\mathrm{a}}$ etapa, sendo sete mulheres. Na turma, há uma jovem e um adolescente. Seis são nordestinos. Todos residem há mais de 15 anos no DF. Três adultos são casados e há três viúvos (aposentados e pensionistas). A maioria desempenhou serviços de vendedor e de servente. A maioria usa ônibus para ir à escola. Apenas um não sabe ler ainda e só escreve copiando do quadro. 
Tabela 6: Perfil pessoal dos(as) alunos(as) da $3^{\text {a }}$ etapa da EJA

\begin{tabular}{|c|c|c|c|c|c|c|c|c|}
\hline \multicolumn{9}{|c|}{ Perfil dos(as) alunos(as) da $3^{a}$ etapa (2015.1) } \\
\hline Nome & Idade & Naturalidade & $\begin{array}{c}\text { Mora há } \\
\text { quanto } \\
\text { tempo no } \\
\text { DF (anos)? }\end{array}$ & $\begin{array}{c}\text { Estado } \\
\text { civil }\end{array}$ & $\begin{array}{l}\text { Quantos } \\
\text { filhos? }\end{array}$ & $\begin{array}{l}\text { Qual sua } \\
\text { ocupação } \\
\text { anterior e a } \\
\text { atual? }\end{array}$ & $\begin{array}{c}\text { Utiliza que } \\
\text { transporte } \\
\text { para ir à } \\
\text { escola? }\end{array}$ & $\begin{array}{c}\text { Ler e } \\
\text { escreve? }\end{array}$ \\
\hline $\mathrm{AM}$ & 65 & Bahia & 45 & Viúva & 4 & $\begin{array}{c}\text { Babá/ do } \\
\text { lar }\end{array}$ & Ônibus & Sim \\
\hline $\mathrm{L}$ & 16 & Brasília & 7 & Solteiro & 0 & Estudante & Nenhum & Sim \\
\hline MS & 58 & Bahia & 35 & Casada & 4 & Do lar & Ônibus & Sim \\
\hline $\mathrm{P}$ & 72 & Paraíba & 50 & Casado & 7 & $\begin{array}{c}\text { Motorista } \\
\text { de ônibus/ } \\
\text { aposentado }\end{array}$ & Carro & $\begin{array}{c}\text { Escreve, } \\
\text { mas não } \\
\text { lê }\end{array}$ \\
\hline $\mathrm{R}$ & 75 & Ceará & 49 & Casado & 9 & $\begin{array}{c}\text { Pedreiro/ } \\
\text { aposentado }\end{array}$ & Bicicle-ta & $\begin{array}{c}\text { Escreve, } \\
\text { mas não } \\
\text { lê }\end{array}$ \\
\hline $\mathrm{V}$ & 57 & Paraíba & 36 & Solteiro & 0 & $\begin{array}{c}\text { Cozinheiro } \\
/ \\
\text { aposentado }\end{array}$ & Nenhum & $\begin{array}{c}\text { Escreve, } \\
\text { mas não } \\
\text { lê }\end{array}$ \\
\hline
\end{tabular}

Fonte: Levantamento realizado pela professora da $3^{\mathrm{a}}$ etapa.

Obs.: são seis alunos(as) frequentes na $3^{\mathrm{a}}$ etapa, sendo quatro homens e apenas um jovem. A turma é composta por adultos e idosos. Apenas um aluno não é nordestino, mas mora há sete anos no DF, enquanto os demais já residem há mais de 30 anos. Dois são solteiros e nunca casaram. Os casados têm quatro ou mais filhos. Os que desenvolveram trabalhos de pedreiro, cozinheiro, motorista já estão na condição de aposentados. Apenas dois dependem de transporte público para ir à escola. Interessante dado é que os homens mais idosos da turma não sabem ler textos, mas leem palavras soltas e só escrevem copiando do quadro. 
Tabela 7: Perfil pessoal dos(as) alunos(as) da $4^{\text {a }}$ etapa da EJA

\begin{tabular}{|c|c|c|c|c|c|c|c|c|}
\hline \multicolumn{9}{|c|}{ Perfil dos(as) alunos(as) da $4^{\mathrm{a}}$ etapa (2015.1) } \\
\hline Nome & Idade & Naturalidade & $\begin{array}{c}\text { Mora há } \\
\text { quanto } \\
\text { tempo no } \\
\text { DF } \\
\text { (anos)? }\end{array}$ & $\begin{array}{c}\text { Estado } \\
\text { civil }\end{array}$ & $\begin{array}{l}\text { Quantos } \\
\text { filhos? }\end{array}$ & $\begin{array}{l}\text { Qual sua } \\
\text { ocupação } \\
\text { anterior e a } \\
\text { atual? }\end{array}$ & $\begin{array}{c}\text { Utiliza que } \\
\text { transporte } \\
\text { para ir à } \\
\text { escola? }\end{array}$ & $\begin{array}{c}\text { Ler e } \\
\text { escreve? }\end{array}$ \\
\hline $\mathrm{AO}$ & 16 & Piauí & 1 & Solteiro & 0 & $\begin{array}{c}\text { Empacotad } \\
\text { or }\end{array}$ & Nenhum & Sim \\
\hline $\mathrm{AD}$ & 50 & Minas Gerais & 36 & Casada & 5 & Do lar & Carro & Sim \\
\hline $\mathrm{EN}$ & 39 & $\begin{array}{c}\text { Rio Grande } \\
\text { do Norte }\end{array}$ & 32 & Casada & 4 & $\begin{array}{c}\text { Comercian } \\
\text { te }\end{array}$ & Ônibus & Sim \\
\hline $\mathrm{JE}$ & 23 & Macapá & 1 & Casada & 2 & Vendedora & Ônibus & Sim \\
\hline JO & 46 & Piauí & 28 & Casado & 3 & $\begin{array}{c}\text { Porteiro/ } \\
\text { aposentado }\end{array}$ & Ônibus & Sim \\
\hline MI & 15 & Piauí & 9 & Solteira & 0 & Estudante & Ônibus & Sim \\
\hline MJ & 81 & Minas Gerais & 55 & Casada & 2 & $\begin{array}{c}\text { Do lar/ } \\
\text { aposentada }\end{array}$ & Ônibus & Sim \\
\hline ML & 15 & Piauí & 1 & Solteira & 0 & Estudante & Nenhum & Sim \\
\hline MO & 44 & Minas Gerais & 30 & Solteira & 5 & Do lar & Ônibus & Sim \\
\hline $\mathrm{S}$ & 36 & Bahia & 8 & Casada & 3 & Do lar & Ônibus & Sim \\
\hline VA & 74 & Minas Gerais & 54 & Solteira & 0 & $\begin{array}{c}\text { Do lar/ } \\
\text { aposentada }\end{array}$ & Ônibus & Sim \\
\hline $\mathrm{W}$ & 18 & Brasília & 18 & Solteiro & 0 & Estudante & Nenhum & Sim \\
\hline
\end{tabular}

Fonte: Levantamento realizado pela professora da $4^{\mathrm{a}}$ etapa.

Obs.: são 12 alunos(as) e a metade é de nordestinos e casados. São nove mulheres e a maioria é do lar. O número de filhos varia entre dois a cinco. A maioria usa ônibus para ir à escola.

Todos sabem ler e escrever. 
As informações acerca do perfil dos(as) alunos(as) da EJA reforçam as características que falamos anteriormente quanto à população de Ceilândia que tem sua composição basicamente de nordestinos. São pessoas que vieram para o Distrito Federal em busca de emprego, mas que desenvolveram ou ainda desenvolvem trabalhos com baixos salários e que não depende de escolaridade (pedreiro, cozinheiro, servente, serviços gerais etc.).

O fato de dependerem de transporte público para ir à escola é porque moram em lugares que não são perto da escola. Há pessoas que moram em Águas Lindas/Goiás e que vem estudar nessa escola por causa da oferta de EJA no período vespertino, pois não é uma prática em outras cidades do Brasil. A pesquisadora pode atestar, por exemplo, que as cidades do Maranhão e do Piauí só têm experiência de oferta dessa modalidade no turno noturno.

Da $1^{\mathrm{a}}$ à $3^{\mathrm{a}}$ etapas da modalidade EJA, a organização dos(as) alunos(as) é basicamente de adultos, e esse perfil já havia sido antecipado pelas professoras, justificando que os adultos e os idosos têm histórias do tipo: já aposentaram e agora tem tempo para estudar; os filhos já estão casados e os netos auxiliam nas tarefas da escola; estudam durante o dia porque sair de casa à noite é perigoso; tem desejo de aprender a ler e a escrever para ser independente. Essas e outras motivações dos(as) alunos(as) foram confirmadas por eles(elas) na ocasião da roda de conversa.

A $4^{a}$ etapa tem um perfil diferenciado porque tem uma diversidade de faixa etária, assim é composta por adolescentes, jovens, adultos e idosos. Todavia também, ao final do ano letivo, os mais jovens evadem da escola por causa do aumento da empregabilidade - das contratações de final de ano. Então, no início do ano seguinte, esses alunos retornam à escola.

O levantamento desse perfil foi realizado no mês de maio de 2015 porque, em março, ainda há bastante aluno se matriculando, em abril já se tem uma configuração das turmas, mas em maio tivemos como acompanhar quais eram os(as) alunos(as) frequentes. No segundo semestre de 2015, essas listas voltaram para as mãos das professoras a fim de que analisassem quantos alunos(as) ficaram retidos, os que evadiram e quais foram aprovados e seguiram para outras etapas, continuando na escola.

Um dado interessante é que as professoras sabem o motivo do abandono à escola, porque os(as) próprios(as) alunos(as) falam a respeito, o que demonstra a relação de amizade e respeito entre docente e discente. O principal motivo da evasão se dá quando o aluno precisa mudar de RA ou porque conseguiu um emprego durante o dia. Todavia, nesse caso, não permanecem na escola porque no turno matutino só é ofertado Ensino Médio e, no noturno, só Ensino Médio específico da EJA. No geral, os(as) alunos(as) matriculados na $1^{\text {a }}$ etapa continuam seus estudos na escola e as professoras conseguem ver a evolução deles(as). 
Consideramos importante destacar que essas informações foram utilizadas também para que pudéssemos pensar em ações que atendessem à necessidade desse público, por isso, as atividades matemáticas foram contextualizadas e focadas na resolução de situaçõesproblemas, para que contribuísse com a aprendizagem significativa. Então, para avaliarmos se nossas ações estavam atendendo às expectativas do aluno da EJA, foi que, ao final do semestre letivo, realizamos as rodas de conversa com adolescentes, jovens, adultos e idosos.

A cada dia, estivemos em uma das turmas para dialogarmos acerca das questões envolvendo a Educação Matemática. Nosso modo de proceder foi o mesmo em todas as turmas: entramos na sala com a presença da professora às 14h40, explicamos aos alunos(as) o objetivo da entrevista, organizamos as cadeiras em círculo, pedimos autorização para gravação e, ao ter em mãos o roteiro de entrevista (Apêndice $\mathrm{C}$ ), iniciávamos o diálogo abordando os seguintes pontos:

1) Motivo de estudarem na Educação de Jovens e Adultos (EJA).

2) Relação com os(as) professores(as) e os(as) outros(as) alunos(as).

3) Convívio diário com a Matemática

4) Opinião sobre a disciplina de Matemática e sugestão de mudança para a aula de Matemática.

5) Assunto/conteúdo que gostariam de aprender em Matemática.

\section{Rodas de conversa:}

Dia 22 de junho de 2015 (segunda-feira) - alunos(as) da $4^{\text {a }}$ etapa (25min30seg de gravação)

Dia 23 de junho de 2015 (terça-feira) - alunos(as) da $2^{a}$ etapa (38min44seg de gravação)

Dia 24 de junho de 2015 (quarta-feira) - alunos(as) da $1^{\text {a }}$ etapa (19min20seg de gravação)

Dia 25 de junho de 2015 (quinta-feira) - alunos(as) da $3^{\text {a }}$ etapa (29min34seg de gravação)

Apesar de o diálogo coletivo ter acontecido em etapas diferentes de ensino, os discursos dos(as) alunos(as) têm muito em comum, por isso, agrupamos as falas nas temáticas. Contudo, para facilitar a identificação das turmas do primeiro segmento, usamos na transcrição os seguintes marcadores:

\footnotetext{
Alunos(as) da $1^{\mathrm{a}}$ etapa

- Alunos(as) da $2^{a}$ etapa

- Alunos(as) da $3^{\text {a }}$ etapa

$\checkmark$ Alunos(as) da $4^{\text {a }}$ etapa
} 


\section{1 a temática: motivo de estudar na EJA}

RO (41 anos, baiana, solteira, 1 filho): A gente estuda porque a gente quer aprender.

$>$ MA (61 anos, maranhense, solteira, 8 filhos): Eu tive filhos e um marido enjoado e aí não dava pra vir pra escola. Mas eu sempre quis estudar.

$>\mathrm{JF}$ (67 anos, baiana, casada, 4 filhos): Eu vim estudar pra ficar mais sabida. Eu já tinha estudado antes e parava. Mas agora eu comecei e não vou parar mais porque quero aprender mais.

$>$ MD (42 anos, piauiense, casada, 1 filho): Aprender é muito bom. Antes eu nem sabia ler. Agora eu não olho só para o número do ônibus não. Eu sei ler para onde o ônibus vai. Por isso que é bom aprender.

$>$ IV (47 anos, baiana, casada, 5 filhos): Eu já tinha estudado em outra escola, mas foi mesmo que nada. Eu só aprendi aqui. Comecei assinar o nome e comecei a aprender.

$>\mathrm{VD}$ (55 anos, baiana, solteira, 1 filho): Eu vim estudar porque quero aprender. A vida inteira eu fiquei trabalhando na casa dos outros e não tive oportunidade. Então eu tô correndo atrás agora. E vou continuar.

$>$ FL (69 anos, baiana, viúva, 8 filhos): Eu tenho tanta vontade de aprender, tanta vontade. Mas eu tô lutando pra aprender e eu tenho fé que vou aprender. Eu tive muitos filhos e ninguém tem paciência de me ensinar, mas minha netinha sempre diz assim: vovó eu vou te ensinar a tarefa.

> AT (68 anos, cearense, solteiro, 4 filhos): Antes eu trabalhava de vigia à noite, então eu não tinha como estudar. Eu vim estudar porque agora eu tô aposentado e tenho tempo e a minha filha me deu a maior força e procurou uma escola de dia para eu estudar. Ela me matriculou e providenciou tudo. E agora eu tô aqui pra aprender.

* M (69 anos, baiano, viúvo, sem filhos): Eu estudei no Mobral. Depois estudei em outras escolas e depois vim pra essa escola.

* RO (57 anos, goiana, viúva, 3 filhos): Eu não tive oportunidade de estudar quando era nova porque trabalhava na roça. Depois que eu casei, aí veio família e eu não estudei nada na vida inteira. Aí resolvi que eu queria aprender, porque até pra pegar um ônibus eu pedia ajuda, eu não sabia assinar o nome. Agora eu aprendi. Eu sei anotar as coisas sozinha e leio também. Eu aprendi né.

* EV (61 anos, mineira, casada, 5 filhos): Meu Deus a minha vontade de aprender é tão grande, tão grande que você nem imagina. É tão difícil pra vir pra escola, mas eu enfrento e venho porque quero aprender.

* C (60 anos, baiana, viúva, 1 filho): Eu tinha estudado antes e depois não vim mais pra escola. Aí a professora ficava mandando recado pela minha amiga, sempre dizendo que era pra eu vim pra escola, aí eu resolvi voltar pra aprender. Mas eu esqueço de mais as coisas.

* AL (54 anos, mineira, casada, 3 filhos): Eu queria estudar porque uma pessoa sem estudo é uma pessoa cega. Eu vim pra Brasília e comecei a trabalhar na casa de uma 
professora olhando o filho dela e achava bonito ela saber das coisas, aí eu me interessei pra estudar. Comecei estudando naquele método de Paulo Freire, sabe. Aí eu comecei a ler, mas demorei pra escrever direito. Mas se Deus quiser eu vou terminar o segundo grau e vou morar lá no Nordeste pra ensinar aquele povo que não sabe ler nem escrever. Tem tanta gente lá com vontade de aprender e não teve oportunidade.

* CL (43 anos, piauiense, casada, 3 filhos): Eu tenho vontade de aprender e o meu filho me dá a maior força e diz pra eu não desistir. Mas é difícil pra mim porque meu marido fica dizendo que gente velho não aprende. Mas meu filho disse que não é pra eu ligar pra esses comentários do pai dele e que é pra eu continuar. Meu filho já é casado, mas me liga e pergunta se fiz prova e fica dizendo pra eu não tirar nota baixa.

* E (47 anos, maranhense, solteira, 1 filho): Meu sonho é aprender. Eu me esforço pra aprender. Eu estou estudando desde o ano passado e parece que ainda não aprendi nada. Eu quero ler tudo, porque quero deixar de ser cega. Mas eu não tenho tempo de ficar treinando em casa porque os serviços de casa são muito.

* J (15 anos, brasiliense, solteira e sem filhos): Eu sempre estudei, mas como eu já morei em tanto lugar, aí eu ficava mudando e não terminava os estudos. Eu tenho um irmão que dá trabalho e faz umas coisas que aí, por causa dele, agente vive mudando de casa e de lugar, sabe. E isso me prejudica porque eu não consigo ficar na escola. Mas eu já disse lá em casa que eu quero e vou terminar meus estudos.

- R (75 anos, cearense, casado, 9 filhos): Eu quero continuar estudando pra aprender e pra fazer minhas coisas sozinho, resolver, anotar e aprender.

- V (57 anos, paraibano, solteiro, sem filhos): Estamos com interesse de aprender. Eu não tive oportunidade de estudar na juventude. No meu tempo, o meu pai dizia que tinha era de ir pra roça trabalhar porque o patrão só queria funcionário que desse lucro pra ele. Mas quando fiquei rapaz eu ia pro Mobral e foi lá que aprendi a assinar o nome. Mas só vim estudar de verdade pra aprender foi aqui nessa escola quando aposentei.

- P (72 anos, paraibano, casado, 7 filhos): Eu fui pra escola, mas depois fiquei namorador e comecei a me afastar dos estudos. Pelos meus pais eu teria até me formado, mas eu mesmo foi que me desinteressei. Uns anos atrás eu tive AVC e o médico disse que pra melhorar a memória era bom eu estudar. Então eu vim pro colégio porque o remédio pra cabeça é estudar.

- MS (58 anos, baiana, casada, 4 filhos): Meu sonho é aprender. Se no tempo que comecei a estudar, se eu tivesse continuado, eu já teria me formado, mas eu parei. E na minha mocidade eu não estudei porque meu pai dizia que nós ia era aprender a fazer carta para mandar para o namorado. Mas não era assim, nós queria era aprender. Hoje, o meu sonho é ler a Bíblia e entender.

- AM (65 anos, baiana, viúva, 4 filhos): No meu tempo, eu era como os jovens de hoje que não tava nem aí pros estudos. Muitas vezes, eu saia de casa pra escola e desviava o caminho pra ir tomar banho nos rios e eu fazia isso porque os outros alunos ficavam jogando piada em mim por causa do meu problema de vista. Eu tenho estrabismo. Hoje não pode fazer isso, mas antigamente não tinha isso. Aí por isso eu não ia na escola. Mas mudei de estado aí fui estudar. Depois de muito tempo eu encontrei essa escola de dia e aí eu voltei a estudar porque à noite é muito perigoso pra sair de casa. 
$\checkmark$ EN (39 anos, norte-rio-grandense, casada, 4 filhos): Estudo para aprender. Eu casei muito cedo e parei de estudar. Agora meus filhos estão todos grandes e eu agora posso estudar e aprender. Quero terminar o segundo grau que é meu objetivo, e devagarinho ir terminando porque quero fazer faculdade que é meu sonho.

$\checkmark$ S (36 anos, baiana, casada, 3 filhos): O meu motivo é o mesmo da colega. Eu quero aprender o que eu não tive como aprender antes, porque tive filho cedo e parei de estudar. Então eu quero aproveitar essa oportunidade que eu estou tendo de aprender e poder passar pra mais alguém que eu puder. Porque inclusive lá na Igreja eu fico na salinha com as crianças e a gente tem que ensinar, não é? Então, eu tenho que procurar aprender, para passar pra elas também.

$\checkmark$ ML (15 anos, piauiense, solteira, sem filhos): Eu passei quatro anos sem estudar e me arrependi. Agora resolvi voltar para aprender e eu quero continuar estudando.

$\checkmark$ JE (23 anos, macapaense, casada, 2 filhos): Eu voltei a estudar porque quero conseguir um bom emprego. E eu quero aprender porque eu parei de estudar quando tinha 11 anos.

$\checkmark$ MO (44 anos, mineira, declarou-se solteira, 5 filhos): Eu tive muito incentivo para estudar, mas era desinteressada. Só que agora eu vi é preciso estudar, por isso estou aqui e vou continuar.

$\checkmark$ MJ (81 anos, mineira, casada, 2 filhos): Eu trabalhei nas casas dos outros até meus 30 anos, depois casei e tive filhos e eu não tive oportunidade. Agora há quatro anos atrás eu comecei estudar aqui, mas parei porque adoeci. Aí, nesse ano, eu voltei, mas esqueci de muita coisa porque eu não sou boa de aprendizagem não. Mas eu tento aprender e vou continuar assim tentando, enquanto eu vida tiver vou continuar estudando.

$\checkmark$ AO (16 anos, piauiense, solteiro, sem filhos): Eu vim estudar porque quero terminar meus estudos. Eu parei de estudar dois anos, mas agora eu não pretendo parar não.

$\checkmark$ MI (15 anos, piauiense, solteira, sem filhos): Ah, eu também foi falta de interesse. Eu sempre parava de estudar no meio do ano. Eu morava longe da escola e fiquei nessa por três anos. Mas agora eu me interessei. Agora eu vou até o fim para aprender.

$\checkmark$ VA (74 anos, mineira, solteira - nunca casou nem teve filhos): Eu como sempre morei em roça, não tinha como estudar. E meu pai morreu quando eu tinha 15 anos, aí minha mãe criou um monte de filhos sozinha e botou agente pra trabalhar. Depois fui trabalhar nas casas e os patrão não deixava eu sair. Tanto é que nem casei porque ninguém deixava eu sair e aí como é que eu podia namorar? Aí quando eu vim embora pra Brasília naquele tempo eu fiz o Mobral e parei. E depois de muito tempo eu vim pra essa escola. Comecei na $1^{a}$ série e agora tô aqui na $4^{a}$ série. Mas eu sou ruim pra aprender. Eu pelejo lá em casa. Sento na mesa e fico tentando aprender. Mas parece que não entra nada na minha cabeça. Eu gosto dessa escola aqui porque não é só estudo. Eu aprendi muito aqui e é por isso que gosto daqui.

$\checkmark$ AD (50 anos, mineira, casada, 5 filhos): Eu voltei a estudar porque quero aprender mesmo. Hoje ninguém consegue nada sem estudar. 
$\checkmark$ W (18 anos, brasiliense, solteiro, sem filhos): Lá em casa ninguém nem se preocupa se eu tô estudando, mas eu quero ser gente e estou estudando.

\section{$2^{\text {a }}$ temática: relação com os(as) professores(as) e os(as) outros(as) alunos(as)}

As falas foram coletivas e não conseguimos definir os protagonistas. Mas foram só elogios.

As professoras são muito boas. Elas são preocupadas com a gente.

$>$ Os colegas dão força para a gente não desistir.

> A gente pergunta pro colega e aí a gente ajuda uns aos outros.

* A gente tem uma boa relação com as professoras e os colegas, mas o que faz com que eu aprenda mesmo é a dedicação que eu tenho pra estudar.

* As pessoas da sala de aula são uma família e a gente se distrai.

* A professora me desenvolveu muito e me ajudou muito. Ela dizia assim: Você tem que aprender, porque você é inteligente e você tem que passar pra outra série.

- As professoras dão força pra nós, pra aprendermos. Elas se esforçam.

- E os colegas nos ajudam a abrir a mente, principalmente estudando com esses meninos novos que tem a cabeça aberta.

$\checkmark$ As professoras são ótimas. E, se depender delas, nós vamos estudar até na faculdade porque elas têm paciência de ensinar.

$\checkmark$ Se fosse pra colocar no topo, nós íamos subir elas, porque elas são muito boas.

$\checkmark$ As professoras ajudam a gente. Elas querem que a gente aprenda de verdade.

$\checkmark$ E nossas colegas são muito companheiras. Tem gente que falta muito, mas a gente se preocupa e diz para não desistir e que é pra continuar os estudos.

$\checkmark \quad$ E a gente faz planos também para que a gente faça faculdade juntas.

$\checkmark$ E também a dona VA e dona MJ são um exemplo e incentivo pra nós que somos jovens. Pra nós não desistirmos de estudar.

\section{$3^{\text {a }}$ temática: convívio diário com a Matemática}

Nas compras, no troco, nos pagamentos de dívidas.

No dinheiro, no calendário.

Marcar o horário de tomar o remédio.

Tem que olhar o número do ônibus.

Eu sei a data de nascimento dos meus filhos, dos netos, dos meus irmãos. Isso tudo é matemática porque tem número. 
> Quando começou aquele negócio nos mercados de pedir CPF na nota. Aí eu não sabia o CPF e toda hora tinha que tirar o documento pra conferir. Mas de tanto falar o número eu aprendi. Agora eu sei de cabeça.

* Nas contas que precisamos pagar.

No supermercado - no preço dos alimentos.

- No número do ônibus porque é uma forma de ler mais rápido. Exemplo: Se eu for pegar um ônibus, de longe eu não enxergo bem e daqui que eu leia o ônibus já passou.

* No número do sapato e da calça que usamos.

* Tudo tem número, na nossa casa, o CEP do endereço.

- Os números do celular, o controle remoto da televisão.

- A gente ler os números do extrato do banco.

- Tudo que a gente vai resolver hoje é com senha que tem número.

- Nos exames tem número que são as taxas. Por exemplo, a taxa de colesterol.

- Quando você faz um cadastro, pede número de identidade e de CPF.

- Quando pega um ônibus ou avião, você tem que ver qual o número da poltrona.

- Pra usar micro-ondas e o forno pra marcar os minutos.

$\checkmark$ A matemática está nas contas. Nas despesas de casa.

$\checkmark$ Nos trocos. Nas dívidas.

$\checkmark$ Nos nossos salários.

$\checkmark$ Nos horários de tomar os nossos remédios. Na dosagem.

$\checkmark \quad$ Nas receitas.

\section{$4^{\text {a }}$ temática: opinião sobre a disciplina de Matemática e sugestão de mudança para a} aula de Matemática

Eu acho bom, mas é difícil.

$>$ É difícil, mas é a que a gente mais precisa pra tudo na vida.

> A gente precisa tanto da Matemática que não dá pra mudar nada nos estudos.

* A disciplina de Matemática é necessária de mais que não tem que mudar nada.

- As aulas aqui ensinam a gente a fazer muitas contas. Mas conta de vezes é complicado.

- Tem que ensinar direito o que é esse negócio de "tomar emprestado". 
$\checkmark$ A verdade é que a gente gosta mais de Matemática porque a professora fica na sala e ajuda a gente. Ela ensina mesmo.

$\checkmark$ A gente gosta mais de Matemática porque na vida a gente tem que calcular tudo.

$\checkmark \quad$ Não tem nada pra mudar nas aulas de Matemática porque as atividades estão melhores.

\section{$5^{\text {a }}$ temática: assunto/conteúdo que gostariam de aprender em Matemática}

Tem uma coisa que eu queria muito aprender que é aquele negócio de "pegar emprestado" nas contas de menos. Porque eu me enrolo toda nas contas de menos quando tem que pedir emprestado.

$>$ Às vezes, a gente fica com a cabeça lá em casa, com um filho, um neto com problema, aí fica difícil de concentrar aqui na aula. Mas se a gente perguntar de novo e o professor repetir, aí a gente consegue. E assim vamos fazendo cálculos e contas e vamos aprendendo.

$>$ A gente quer aprender muito essas atividades que você está fazendo com as professoras.

* O que a gente mais precisa é fazer contas porque é o que a gente precisa o tempo todo.

* A gente tem que aprender mais aquele negócio de "vai um".

- O que a gente quer de verdade é aprender todas as contas. O que é mais necessário é as contas de menos porque precisa "tomar emprestado". É complicado esse negócio de zero que vira dez, e o número do lado que era nove e vira oito. É difícil entender isso.

- É mesmo a de menos porque como é que eu tenho um e preciso tirar três e aí vira 11 pra tirar os três. Eita negócio embaraçado! Então tem que estudar muito, né.

$\checkmark$ A gente precisa muito saber as operações. Mais mesmo é a multiplicação.

$\checkmark$ As contas que são importantes. Mas o que precisamos mesmo é saber aquelas coisas assim: "se você tinha tanto no bolso, pagou tanto e tanto, com quanto ficou?". Porque é muita informação de uma vez, né.

$\checkmark$ Seria bom se a gente pudesse usar a calculadora, porque tabuada é difícil aprender.

Como já havíamos sinalizado, optamos por agrupar as falas dos(as) alunos(as), por alguns motivos: as falas tiveram muito em comum; as professoras fazem um revezamento nas turmas - ensinam de $1^{\text {a }}$ a $4^{\text {a }}$ etapa; os(as) alunos(as) também mudam de turma a cada semestre; realizamos um trabalho em que os conteúdos matemáticos eram os mesmos para cada etapa, mudando apenas o grau de complexidade das ações desenvolvidas. Assim, quando analisamos o diálogo dos(as) alunos(as), nos demos conta de que o planejamento de nossas ações estava no caminho certo. 
Algumas falas dos(as) alunos(as) nos marcaram muito no que concerne ao desejo de aprender mais de números e operações, principalmente por considerarem que no cotidiano fazer contas faz parte da rotina. Na roda de conversa, no início, os(as) alunos(as) ficaram um pouco tímidos, mas estavam atentos à fala uns dos outros. Como estivemos juntos em muitas aulas, já os conhecia pelos nomes, então, ao iniciar uma fala, já anotava a ordem de quem estava falando, para, em momento posterior, transcrever a fala com a identificação.

A opção por escrever idade, naturalidade, estado civil e quantidade de filhos teve a intencionalidade de situar o leitor quanto à origem daquele discurso, porque cada pessoa tem uma história e uma motivação. Para Freire (1996, p. 136), “o sujeito que se abre ao mundo e aos outros inaugura com seu gesto a relação dialógica em que se confirma como inquietação e curiosidade, como inconclusão em permanente movimento na História”.

Essa afirmação do autor podia ser confirmada naquela roda de conversa, em que cada um que falava tinha uma singularidade e fazia transparecer emoções, receios, encorajamento, a tal ponto que, no decorrer da entrevista, houve momento em que todos falaram ao mesmo tempo e não houve como transcrever esses trechos porque o áudio ficou prejudicado. Contudo eles tinham desejo e necessidade de falar e levantavam-se da cadeira e esticavam o pescoço como se quisessem alcançar o microfone (neste caso, o gravador de áudio). Nas primeiras colocações, observamos que a motivação deles(as) é aprender, mas fica clara a necessidade de um aprendizado no presente, como explicitam: "quero aprender"; "aprender mais"; "comecei a aprender"; "aprender é muito bom".

Se tomarmos a mensagem das falas quando se reportam à relação com as professoras e os(as) demais colegas de turma conseguimos reunir em duas grandes categorias: relação de afeto e relação de solidariedade. $\mathrm{O}$ afeto se percebe nas falas: "as pessoas da sala são uma família mesmo"; "as professoras têm paciência"; "os(as) idosos(as) são um incentivo"; "a gente se preocupa". Configura-se uma relação de afeto em que está em jogo o cuidado, a proteção como se tivesse parentesco familiar, o fato de se espelharem nos mais idosos(as) como fazemos nas relações familiares. E neste mesmo sentido, a relação solidária quando surgem os discursos: "as professoras são preocupadas"; "os colegas dão força"; "a gente ajuda uns aos outros"; "as colegas são muito companheiras". Essas falas ratificam nossa compreensão de que a escola contribui para a formação humana e essas relações pessoais ajudam na formação da pessoa, do seu caráter ético, social-afetivo e político.

Além disso, ao ter o momento da fala, os(as) alunos(as) apresentaram elementos importantes no que concerne à relação com a matemática no cotidiano e às necessidades de se estudar para compreender como esse campo do conhecimento funciona operacionalmente, 
social e culturalmente. Isso pode ser constatado se analisamos os discursos que se alternam entre a dificuldade e a possibilidade, no movimento dialético do processo de aprendizagem e do ensino, como explicitam quanto à Matemática: "é bom, mas é difícil”; "é necessária”; "a gente precisa tanto"; "a gente precisa pra tudo na vida"; "conta é complicado"; "pegar emprestado"; "a gente gosta de matemática".

Observamos que ao falar suas opiniões sobre a disciplina de Matemática já anunciavam os assuntos/conteúdos, o que nos permite pontuar alguns elementos como a necessidade de trabalhar com conceitos para compreender que "pegar emprestado" significa pensar no valor relativo e não no valor absoluto daquele algarismo. Além disso, tem a questão do contexto, para viabilizar o entendimento para resolução da situação. Exemplo: Ter na carteira 21 reais e precisar gastar 3,00 com a passagem de microônibus (21 - 3), mas ter que operar apenas com os algarismos em que se tem um na unidade do minuendo e precisaremos recorrer às dezenas - usando uma dezena que somada com uma unidade, passa a se constituir em 11 - para retirar as três unidades do subtraendo. Além disso, o modo como aparece a expressão "pegar emprestado" já sinaliza que o conceito pensado é só o de retirar (subtração), e não se considera o de completar (adição), embora esse seja mais utilizado no cotidiano.

A partir dessas discussões, entendemos que fomos tomados por aquele sentimento de que escolhemos o caminho certo para esse diálogo, uma entrevista com questões abertas, porque os(as) alunos(as) tiveram a liberdade que talvez com outra metodologia não teria sido possível. Adolescentes, jovens, adultos(as) e idosos(as) queriam contar suas histórias, suas vitórias, seus sofrimentos, seus sonhos. Eles sentiam-se importantes no diálogo de escuta, de igualdade e respeito aos seus saberes.

Vale pôr em relevo que muitos outros diálogos foram feitos com os(as) alunos(as) ao longo do ano letivo, tanto na sala de aula como nos corredores, mas não trouxemos para este trabalho porque, em nossa pesquisa, os protagonistas são as professoras da EJA. Desse modo, quando fizermos o recorte da fala dos(as) alunos(as), faremos com base no diálogo estabelecido com suas professoras, porque essa relação dialógica é importante e necessária. $\mathrm{O}$ diálogo é um exercício de escuta e de fala em que se trocam ideias acerca de temas polêmicos e complexos, além de possibilitar esclarecimentos em torno de conhecimentos que, às vezes, julgamos comuns que possuem certa dialeticidade. 


\section{INÉDITOS-VIÁVEIS E A APRENDIZAGEM SIGNIFICATIVA}

Todo amanhã, porém, sobre o que se pensa e para cuja realização se luta, implica necessariamente o sonho e a utopia.

Não há amanhã sem projeto, sem sonho, sem utopia, sem esperança, sem o trabalho de criação e desenvolvimento de possibilidades que viabilizem a sua concretização.

(FREIRE, Pedagogia dos sonhos possíveis, 2014, p. 77)

A prática de investigação nos remete à possibilidade de realização dos sonhos e do devir utópico, movidos pela esperança de que o amanhã e impreterivelmente o hoje será (e é) oportuno para "sonhar, estudar e criar" (momentos dos quais já falamos). É o que nos projeta enquanto ser que pensa e age na condição esperançosa de que mudar é possível, mas não sem sonho, sem encorajamento, sem enfrentamento, sem criatividade, sem trabalho coletivo para concretizar e materializar aquilo que desejamos profusamente. A outra grande contribuição dessa prática investigativa é a potencialidade formativa dos envolvidos, porque permite uma imersão muito grande em leituras, estudos, discussões e ampliação das práticas, por uma construção da práxis.

Os momentos de sonhar, estudar e criar (FREITAS, 2001) foram marcadamente importantes na relação com as professoras da pesquisa porque não foram segregados, ao contrário, estiveram harmonizados na dinamicidade da ação teorizada, em que buscamos a ampliação do que temos entendido por Educação Matemática. Todos os nossos círculos de investigação formativos foram de idas e vindas sobre a relação desse campo do saber com outros campos (Língua Portuguesa, História, Geografia, Ciências da Natureza e Artes) que denominamos conexão de saberes, na perspectiva do letramento.

A obra Pedagogia dos Sonhos Possíveis, organizada por Nita Freire, traz textos inéditos em que Paulo Freire "convida-nos a sonhar, a ousar e a lutar. A sonharmos sonhos possíveis. A ousarmos para fazer possíveis os sonhos impossíveis de hoje. A lutarmos sempre para a concretização dos sonhos de transformação para um mundo melhor, mais justo" (NITA FREIRE, 2014, p. 15-16). É com essa motivação que nos lançamos incansavelmente em defesa de uma Educação com todos, para todos e por todos, com direito ao conhecimento macro (geral, sem delimitações e sem separações).

Nesse sentido é que incluímos a Educação Matemática como um campo de conhecimento que não ocorre em separado de outros conhecimentos e isolada naquela visão da Matemática como ato de dar respostas exatas. Pensamos e defendemos a ideia de que o ato 
de dar respostas corretas simplifica um processo que é, por natureza, complexo e dinâmico, pois acreditamos que essa resposta precisa considerar/aproveitar/valorizar diferentes perspectivas que, por conseguinte, depende das experiências cotidianas, do contexto histórico em que estamos inseridos e das relações sociais, se não tenderemos ao fracasso escolar.

\begin{abstract}
O processo de explicação do fracasso escolar tem sido uma busca de culpados - o aluno, que não tem capacidade; o professor que é mal remunerado; as secretarias de educação, que não remuneram seus professores; as universidades, que não formam bem o professor; o estudante universitário, que não aprendeu no secundário o que deveria ter aprendido e agora não consegue aprender o que seus professores universitários lhe ensinam. Mas a criança que aprende matemática na rua, o cambista analfabeto que recolhe apostas, o mestre de obras treinado por seu pai, todos eles são exemplos vivos de que nossas análises estão incompletas, precisam ser desafiadas, precisam ser desmanchadas e refeitas, se quisermos criar a verdadeira escola aberta a todos, pública e gratuita, pela qual lutamos nas praças públicas. Os educadores, todos nós, precisamos não encontrar os culpados mas encontrar as formas eficientes de ensino e aprendizagem em nossa sociedade. (NUNES, CARRAHER; SCHLIEMANN, 2011, p. 37).
\end{abstract}

Em nosso trabalho, não buscamos os culpados pelo não saber, ao contrário, todas as ações de nossa pesquisa foram planejadas, especialmente para começarmos uma relação de confiança mútua, de respeito ao trabalho que realizamos e ao conhecimento que os alunos já apresentavam. Uma marca fundamental nessa relação de pesquisa foi principalmente a cumplicidade, porque nos envolvemos em um processo dialógico de busca por um objetivo comum: a ampliação da ênfase na Educação Matemática. No entanto, para isso, buscamos dialogar com as professoras acerca de quem eram os alunos do primeiro segmento, qual a relação com o ensino e a aprendizagem, as expectativas, os sonhos que envolvem a modalidade. Nossa conversa desenvolve-se a partir das questões retrodescritas.

\title{
Rejane: Os alunos da EJA têm um perfil, fale sobre quem são os alunos de vocês.
}

Rute: São alunos que têm faixa etária que começa dos 15 anos até mais de 80 anos.

Rita: A minha turma é a que tem mais mulheres e idosas.

Rosa: São classes bem heterogêneas. E atividades laborais dos alunos são bastante diversificadas. Na minha turma, há ambulante, empregada doméstica, cozinheiro, aposentados.

\section{Rejane: Falem sobre a quantidade de alunos nas turmas e como se dá a relação com eles.}

Rosa: São poucos alunos na minha turma, são 11 frequentes na $3^{a}$ etapa. E isso é bom porque como as classes são bem heterogêneas fica bem mais complicado se tiver mais alunos.

Rita: Se bem que nós queremos um pouquinho a mais de alunos para não acabarem com o segmento.

Rute: E é bom um número pequeno de alunos porque a gente consegue DAR MAIS ATENÇÃO a cada um. 


\section{Rejane: Essa mistura de faixa etária serve de estímulo ou atrapalha a aprendizagem?}

Rosa: Essa experiência tem sido muito INTERESSANTE na atualidade. Mas, em outros tempos, já foi complicado pelo fato dos alunos mais jovens serem mais elétricos enquanto que muitos senhores e senhoras mais idosos não toleravam o comportamento dos mais jovens e aí surgiam algumas situações chatas que nós professoras tínhamos que tentar resolver. Mas isso foi superado. Atualmente, os mais idosos INTERAGEM bem com os mais jovens e até APRENDEM um linguajar diferente. Tem sido gostoso.

Rute: Essa diversidade ajuda nas trocas e na aprendizagem sim.

Rejane: $O$ primeiro segmento, ao longo do tempo, tem esvaziado de alunos?

Rute: Geralmente a gente tem um esvaziamento maior é no segundo semestre do ano. Mas principalmente na $4^{a}$ etapa e, na verdade, a partir de outubro em diante porque as lojas vão contratando para o final de ano.

Rosa: Os motivos da evasão na EJA são os mais diversos possíveis: é volta à terra natal, é problema de saúde familiar, é também essa questão do trabalho. Então a pessoa não pode olhar cruamente e só simplificar: onde nós falhamos, onde a escola falhou, onde aquela professora falhou. Opa, espere lá, é preciso estudar com cuidado cada caso, pois nós que estamos em sala de aula sabemos quantos saíram porque encontraram trabalho, quantos que tiveram que dar assistência familiar, quantos que sofreram um assalto no caminho e não retornaram mais com medo da violência, muitos moram em locais que a parada de ônibus fica tão longe, tudo isso. [...]. Aí vem alguém aqui e pega os nomes e números da evasão e aí depois vão ler aqueles dados de uma forma totalmente fora da realidade, e aí vai passar uma informação errada.

Rejane: Quais são os motivos de os alunos estudarem aqui nessa escola e no turno vespertino?

Rute: Tem muitos que estudam aqui no vespertino porque não podem se ausentar de casa à noite, por medo da violência, ou no caso de algumas senhoras, os maridos não deixam que elas saiam de casa à noite.

Rosa: Alguns alunos também trabalham à noite. Nós temos alunos que são vigilantes e porteiros.

Rute: E eles vêm pra escola porque querem continuar os estudos, para fazer uma faculdade, mas também têm aqueles que só QUEREM REALIZAÇÃO PESSOAL, porque não puderam estudar quando jovens.

Rosa: Tem gente que acha que é só aprender a ler e a escrever e a resolver as quatro operações. Se bem que o tempo é muito escasso para ensinarmos além disso. Mas muitos SONHAM em cursar uma faculdade, tem gente que fala em passar um concurso público, tem alguns que vêm pra escola pra REALIZAR UMA TERAPIA ocupacional. Muitos melhoram de saúde, controlam a pressão arterial. A ESCOLA CUMPRE TAMBÉM ESSE PAPEL DE SOCIALIZAÇÃO.

Rita: Muitas senhoras falam que vêm pra escola pra não ficar em casa sozinha.

Rute: Nós temos muitas alunas que são viúvas, mas também têm umas que dizem que vêm estudar PORQUE PRECISAM ENSINAR AS TAREFAS DE ESCOLA PARA OS FILHOS $e$ dizem: "se eu não aprender, daqui uns dias eu não vou mais conseguir ensinar meu filho, porque ele já vai estar numa série mais avançada do que a minha”. É o que muitas falam. 


\section{Rejane: $E$ em relação aos alunos, falem se eles têm alguma preferência por disciplina ou matéria.}

Rute: Geralmente eles têm mais AFINIDADE, ou SIMPATIZAM mais com a Matemática, até porque eles ainda estão sendo alfabetizados, no caso da minha turma que é como se eles ainda estivessem em nível de alfabetização mesmo. Então, a Matemática, os números é mais fácil deles identificarem e conhecerem. Às vezes, eles não sabem interpretar um problema, mas se nós fizermos a leitura explicando [...] essa questão numérica, eles têm mais FACILIDADE, na verdade, AFINIDADE.

Rosa: Alguns alunos têm dificuldade na leitura e na escrita, então, essa é uma dificuldade para trabalharmos. Mas a Matemática eles têm mais AFINIDADE porque faz parte do cotidiano deles. E eles QUEREM APRENDER até para ninguém "passar a perna" neles como um troco na rua. Na verdade, as próprias brincadeiras desde a infância incentivam muito as questões matemáticas. Mas também têm alunos que conseguem vencer os obstáculos, enquanto que outros criam uma ojeriza à disciplina e aí acabam criando um bloqueio muito forte.

Rute: Eu pensei que a gente podia fazer algo diferente para trabalhar com os alunos. Não pensei de você trazer pronto. Pensei de nós construirmos juntos, porque os alunos gostam mais da Matemática, porque eles têm mais AFINIDADE com o número. [...] De um jeito ou de outro, eles lidam com os números no dia a dia, falam o número do documento, vão ao supermercado e tem que pagar contas e receber troco. Mas também eles acham importante a leitura. Alguns até falam que querem aprender a ler, para ler a Bíblia, principalmente as alunas mais idosas. Outros querem tirar a carteira de habilitação, também têm os que dizem: "eu quero saber pegar um ônibus direito".

Rita: Nós queremos que nosso grupo de pesquisa se amplie para que o primeiro segmento não feche.

Rosa: A gente sempre faz faixas falando das matrículas abertas. E fazemos isso independente da Secretaria de Educação, porque nós queremos que o primeiro segmento continue.

Destacamos os enunciados dar mais atenção, interessante, interagem que surgiram nas falas das professoras quando se reportaram aos alunos, à composição das turmas e à relação que mantém com eles. Podemos perceber como há afeto, cuidado e compromisso envolvido, portanto, preocupação com o processo de aprender e ensinar. A concepção de que os alunos também podem aprender uns com os outros, inclusive, afirmam que a diversidade auxilia nas trocas de experiências e aprendizagens.

As professoras também saíram em defesa da modalidade, pois, quando provocamos para que falassem do esvaziamento na EJA, um discurso crítico e político foi adotado pela professora Rosa, afirmando que cada professora sabe de perto os motivos de os alunos deixarem de frequentar as aulas. Desse modo, ela posicionou-se contrária às leituras enviesadas que algumas pessoas fazem sobre o número de não frequentes e começam a busca implacável dos culpados pela evasão, o que, em sua concepção, não passa de um grande equívoco. A professora imprime uma fala que, além de crítica, foi também um desabafo 
carregado de intencionalidade política, em que se viu oportunizada de denunciar uma falsa realidade, corrompida pela leitura superficial de um contexto.

Quanto à escolha dos alunos pela escola, as professoras falaram dos sonhos que moviam os alunos, da realização pessoal e da terapia, porque a escola cumpre o papel de socialização. Além da função educacional que é formar para a vida pessoal, social e profissional, a escola é vista, por alunos e professores, como lugar de aprendizagem e isso é percebido quando as alunas falam que estudam porque precisam ensinar os filhos. Então, mais uma vez percebemos a "boniteza" e a força que a educação-formação tem dentro dos processos de aprendizagem dos alunos, o quanto esses agentes do saber (professores e alunos) têm confiança e esperança no papel social-político-educacional da escola.

No que se refere ao processo de aprendizagem, as professoras destacaram que os alunos simpatizam e têm uma relação de afinidade e facilidade com a Matemática. Essas palavras estão carregadas de uma força emocional, porque se referem à familiaridade dos alunos com os números que complementam a rotina pessoal e, por isso, são mais fácies de conhecer e dominar. Além disso, remetem aos valores defendidos por D’Ambrósio (1993) os quais já descrevemos anteriormente, acerca do valor utilitário, cultural, social, formativo e o valor estético da Matemática.

Mas afinal de contas, porque precisamos estudar Matemática? Essa foi a primeira de várias provocações que lançamos em nossas formações e todas elas foram intencionais porque visava desestabilizar as participantes, de modo a pensar e a agir em prol de uma "Matemática viva" e articulada com nosso cotidiano. Dessa provocação, regada a muita discussão e contribuição, chegamos a um consenso que não chamamos de resposta, mas de direcionamento para nossas ações: estudamos Matemática para resolver as situações-problema que, em primeiro plano, aparecem em nosso cotidiano e, em segundo, ocorrem no conhecimento escolarizado. Mas o que então entendemos por situações-problema?

Essa foi outra discussão que não poderíamos deixar de fazer e chegamos a mais um entendimento coletivo em que não se pode confundir com problema matemático que se resume a passar um exercício de fixação para treinos de respostas corretas. Entendemos que trabalhar situação-problema se refere a "estar mobilizando diferentes conteúdos matemáticos num mesmo espaço e de forma articulada, o que deve gerar na escola e no currículo uma nova visão da matemática" (MUNIZ, 2009, p. 112). Foi com esse compromisso que pedagogicamente organizamos, em coletividade, todas as ações desse projeto investigativo, aproveitando também para valorizar aquelas situações presentes nos contextos socioculturais exteriores à escola. 
Com relação a resolver situações-problema, precisamos despertar a autonomia, a autoestima e a autoconfiança em nós professores e consequentemente nos nossos alunos. Foi com essa motivação que trabalhamos com a Educação Matemática dentro dos anos iniciais da EJA, porque apostamos na construção desse espaço em que professores e alunos podem se expor, refletir-agir e compartilhar diversos modos de fazer matemática, sem receios, sem ponderações, mas arriscando-se na construção de caminhos que valorizam o conhecimento matemático, mais expressamente que promova a aprendizagem significativa.

A resolução da situação-problema não está definida como conteúdo obrigatório do currículo escolar, contudo é a estratégia mais contributiva em termos de promover uma aprendizagem que tenha significado para o aluno adolescente, jovem, adulto e idoso. A diversidade delas também pode promover a diversidade de resoluções, se pensarmos que cada pessoa tem um procedimento diferente para perceber, refletir, interpretar e resolver as situações que interpõe suas vidas. É nessa perspectiva que analisamos as ações ocorridas em nosso processo de investigação.

\subsection{Mobilizar e gerar conhecimentos: privilégios da Teoria dos Campos Conceituais?}

Nossa linha de pensamento vai convergindo com a teoria de autores já apresentados neste trabalho, quais sejam Teoria dos Campos Conceituais de Vergnaud (2009) e Aprendizagem significativa de Ausubel (1968), Moreira e Masini (2001) e Moreira (2015), especialmente por dois motivos: que a resolução de situações-problema não ocorre apenas com registro do algoritmo formal; que a leitura interpretativa, a resolução e a sua validação dependem de como cada pessoa vivenciou certas situações no seu cotidiano.

A potencialidade apresentada por professores e alunos no trato com a Matemática é em decorrência da visualização da Matemática no cotidiano, nos meios de comunicação, nos empregos, na administração de doses de medicamentos, na lista de compras alimentícia, nas despesas mensais, no recorte temporal. Por esses motivos, para estudarmos Educação Matemática, precisamos considerar sua existência nos mais variados espaços e contextos como: comércio, jogos (loteria, por exemplo), prestação de serviços, pagamento de impostos, economia e nas demais áreas do saber. Sua importância é devido às experiências de fazer cálculo mental, estimar o tempo, ter noção de espaço, conhecer medidas arbitrárias que permite a tomada de decisões e até de prever acontecimentos. Todos esses conhecimentos os alunos de EJA já trazem para a escola e ao professor cabe a ampliação desses. Foi por termos ciência disso que fizemos levantamento do perfil dos alunos, a fim de trabalharmos questões 
que partissem da análise do cotidiano para a escola, por esse motivo, nossa primeira provocação foi para trabalharmos com o sistema monetário brasileiro.

No contexto social as pessoas manipulam cédulas e moedas, cheques e cartão de crédito, faturas, extratos bancários, promissórias e recibos, nas relações de compra e venda, dívida e troco, recebimento de salário e pagamento de impostos, composição e decomposição de valores, e essa é a razão principal para nossa opção de trabalharmos esse bloco de conteúdo. Contudo nossa primeira intenção era fazer com que as professoras pudessem se dar conta das possibilidades, haja vista que sinalizaram a falta de tempo como obstáculo para trabalhar todos os conteúdos e que a prioridade era o ensino das operações.

Buscamos desenvolver atividades e ações que promovessem o desenvolvimento matemático de jovens, adultos e idosos no que concerne à interpretação e ao levantamento de hipóteses que pudessem ser validadas ou refutadas. Para isso, não se podíamos negar o momento da experiência, da ousadia para se tentar acertar ou cometer equívocos. Sem correr riscos não se pode construir conhecimentos e constituir inéditos-viáveis.

Vale ressaltar que, de acordo com o Currículo em Movimento para a EJA (DISTRITO FEDERAL, 2014) - documento elaborado para contribuir com o desenvolvimento da modalidade - até a $4^{\mathrm{a}}$ etapa do primeiro segmento, os alunos precisam estudar os seguintes conteúdos matemáticos: números naturais; sistema de numeração decimal; números racionais: sistema de numeração decimal; representação fracionária; adição e subtração com: números naturais e números decimais; multiplicação e divisão; sistema monetário brasileiro; tempo; temperatura; comprimento; capacidade; massa; superfície; geometria: das formas e representações; da orientação e deslocamento; medidas e proporções; estatística: dados; gráficos e média aritmética.

O problema não reside nessa lista de conteúdos, mas na interpretação que se faz de que cada um deles representa um universo isolado do conhecimento, e foi nesse sentido que as professoras apontaram como situação-limite a priorização de alguns conteúdos em detrimento da quantidade de dias letivos para cada etapa de ensino. Para elas, seria impossível trabalhar todos os conteúdos, tal como dispunha no currículo, haja vista que o funcionamento da EJA ocorre com base na semestralidade, ou seja, cada semestre é correspondente a uma etapa/série. Isso implica que, enquanto outros alunos usam o ano letivo para cursar uma série (um ano completo de estudo), o da modalidade EJA cursa duas séries durante um ano letivo.

Tomados por essa provocação, frente à situação-limite referente ao tempo cronológico da aula versus conteúdos foi que propusemos realizar um trabalho amparado na conexão de saberes. Isto é, construir estratégias de ensino que utilizasse de conhecimentos envolvendo, 
por exemplo, geometria, sistema de medidas, tratamento da informação e operações. Essa experiência tem apresentado resultados satisfatórios em termos de aprendizagem matemática e, por esses resultados poderia indicar uma possibilidade de trabalhar os conteúdos na EJA.

Vale ressaltar que todas as atividades pensadas para a EJA, antes de serem levadas para a sala de aula, foram estudadas, vivenciadas pelas professoras, discutidas e redesenhadas para a realidade de cada turma. Respeitamos os tempos de aprendizagem dos educandos, seus contextos de interesse e necessidades socioculturais e humanas de aprendizagem, para potenciar suas leituras de mundo e ações transformadoras.

\subsection{Diversas situações, variados conceitos: construindo aprendizagens significativas}

Para nossa primeira experiência de formação, tomamos como referência a fala dos alunos (na roda de conversa) e também a das professoras quando apontaram que o principal conteúdo a ser estudado em Matemática é o de operações. Por outro lado, sinalizam as primeiras situações-limite que concerne na "impossibilidade de trabalhar outros conteúdos matemáticos por causa do tempo curto". Então, pensamos que um bloco de conteúdo inicial para estabelecer uma rede de relações e conexões matemáticas poderia ser o sistema monetário brasileiro, tal como passamos à descrição.

Nossa fonte de pesquisa foi o site do Banco Central do Brasil (BCB) do qual tiramos todas as informações necessárias para iniciarmos as provocações nos círculos de investigação formativos que tiveram, em seu cerne, a valorização do diálogo para comunicar, aprender, ensinar em um movimento que é dialógico e dialético. Ou seja, aproximamos conteúdos aparentemente diferentes, que, na perspectiva do letramento, se tornaram um conjunto de conhecimentos valiosos e necessários na vida cotidiana.

A título de provocação, perguntamos às professoras se sabiam lidar bem com dinheiro, pagamentos, trocos, descontos. Conheciam bem as notas? Confundiram alguma vez as cédulas? Cada uma tivera uma história para contar sobre o uso do dinheiro, pois conheciam as notas, mas já confundiram duas cédulas, não por conta dos valores, mas das cores: a de dois reais com a de cem reais. Mas isso era apenas o início de nossa discussão que pretendia começar pelo conhecimento que vem da vivência e ampliá-lo até chegar nas operações.

Depois dessa conversa inicial, pegamos envelopes fechados contendo cédulas de dinheiro, espalhamos sobre a mesa que estávamos (pesquisadora e professoras) ao redor. Disponibilizamos papel em branco com pincel. Prosseguimos com as provocações: quantas e quais são as cédulas? E quantas são as moedas de metal? Quanto às cédulas, já perceberam o 
que tem impresso em seu reverso e no anverso? Já associaram as cores aos respectivos valores monetários brasileiros? O interessante dessas questões é que exigia um exercício mental de buscar na memória esses elementos, porque, nesse primeiro momento, as cédulas não estavam à mostra.

Algumas respostas foram surgindo como: "tem nota de dez e de cinco"; "tenho uma onça no bolso", se referindo à cédula de cinquenta reais. E com a ajuda mútua foram resgatando na mente as informações acerca das notas, mas não lembravam o bicho estampado na cédula de cem reais. E o mais interessante foi quando essa atividade foi desenvolvida na sala de aula com os alunos, pois, quando um dos alunos falou "tenho uma azulzinha" se referindo à nota de cem reais, a professora fez a seguinte intervenção: "tem outra cédula de cor azul?". Então os alunos se olharam como quem procura a resposta. Essa ação de se entreolharem constituíram pistas de que estes estavam procurando encontrar coletivamente a resposta, construir o conhecimento. E como as respostas foram dúbias (só tem uma nota na opinião de alguns), a professora seguiu com a atividade para depois retomar essa curiosidade.

Foi solicitado que eles escrevessem, nas folhas em branco, os valores das cédulas que conheciam e as colocassem em ordem crescente sobre a mesa. Escreveram os valores 2, 5, 10, 20, 50 e 100. Então perguntamos se a grafia simbolizando dinheiro era apenas com o algarismo sozinho. Elas pegaram os papéis e inseriram as vírgulas, sem o símbolo do real. Voltamos a perguntar se já haviam se confundido com alguma cédula. E foram muitos casos contados de troca da nota de $\mathrm{R} \$ 2,00$ com a de $\mathrm{R} \$ 100,00$ e o motivo também foi o mesmo: a cor da cédula que é azul, pois, apesar dos tamanhos diferentes, se as notas já forem velhas, e se estiverem dobradas, fica difícil identificá-las, a não ser que esteja visível o algarismo. Aqui coube nossa intervenção novamente para informar que as duas notas possuem cores aparentemente iguais, mas, com pequena diferença, e deveriam ser observadas no momento oportuno, ou seja, quando tirássemos dos envelopes.

Prosseguimos com indagações para que relembrassem os bichos (animais) estampados nas cédulas. Todavia essa parte foi difícil de lembrar, então, pegamos as ilustrações dos bichos e deixamos em um lado da mesa para que elas colocassem embaixo do algarismo que representava o valor das respectivas notas. Vale destacar que todas essas etapas foram repetidas com os alunos em cada sala de aula, mas nossa descrição neste trabalho será feita basicamente da reflexão, das atitudes, da postura investigativa das professoras quando sentindo a Matemática se viram rompendo os obstáculos e criando inéditos-viáveis.

Essa etapa foi demorada e negociada entre elas, enquanto observávamos o diálogo, o olhar inquieto, a mão que coçava a cabeça como quem está curioso pela resposta e o 
engajamento de todas na atividade. A provocação era para que realizassem a correspondência do valor simbólico. Exemplo: uma tartaruga corresponde a valor de dois reais; uma arara equivale a dez reais. Pois esses conhecimentos são comuns em nosso cotidiano quando, às vezes, dizemos: "tenho uma onça no bolso" - ao se referir à nota de cinquenta reais. Aqui recorremos à importância da aprendizagem significativa que defende que possamos usar os saberes já disponíveis com a intenção de ampliá-los.

Na sequência, solicitamos que fizessem a correspondência entre cor da cédula e seu valor, mas essa etapa também exigiu certo esforço porque, nesse caso, não temos o hábito de relacionar cores e valores. Entretanto, exatamente por isso, foi que algumas pessoas já confundiram as notas de dois com a de cem reais, porque tem cor uma aparentemente igual. E sentindo a dificuldade de estabelecer essa relação entre cor e valor, fizemos a mediação com a leitura das características das cédulas: a cor e o bicho estampado no reverso de cada cédula.

Figura 5: Identificação simbólica das cédulas de real

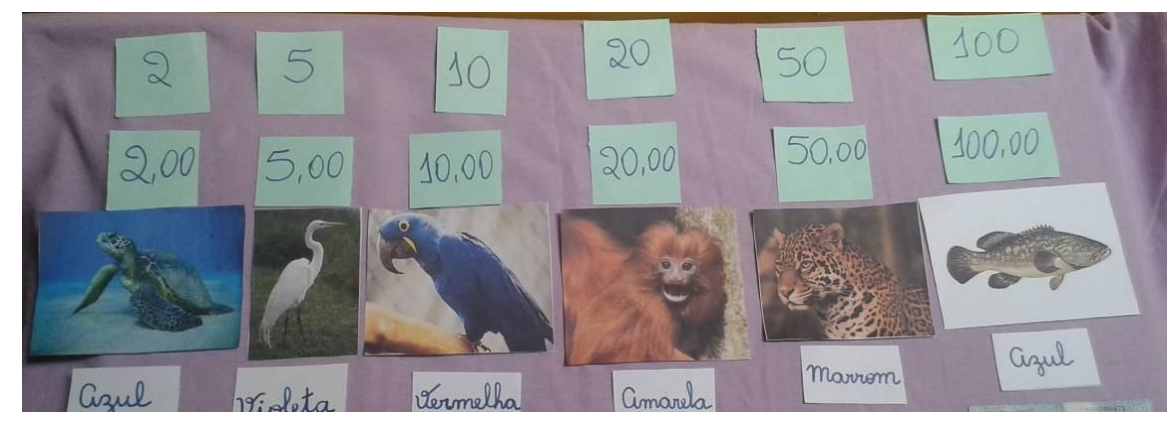

Fonte: arquivo da pesquisadora.

Além dessa abordagem, falamos também da personagem ilustrada no anverso das cédulas e perguntamos se lembravam de que se tratava a figura? As professoras ficaram divididas, algumas apostaram que era a imagem de um homem romano, e outras falaram que parecia a ilustração de uma mulher. Então, revelamos que se tratava de uma figura do sexo feminino que recebeu o nome de Marianne e remetia à história da efígie da República que simboliza a Liberdade da República Francesa. Trata-se de uma figura interpretada em forma de escultura e inspirada na obra Liberdade guiando o povo, do pintor Ferdinand Victor Eugéne Delacroix, em 1830, segundo informações disponíveis no site do $\mathrm{BCB}^{15}$.

\footnotetext{
${ }^{15}$ Site do Banco Central do Brasil: 〈http://www.bcb.gov.br/pt-br/>
} 
Em continuação à manipulação de cédulas, solicitamos que usassem a gravura dos bichos para compor o valor total daquele montante, fazendo a respectiva correspondência. Assim, utilizaram-se da estratégia de contagem a partir da ordem decrescente:

$$
\begin{aligned}
& \text { peixe }=100+ \\
& \text { onça }=50+ \\
& \underline{\text { mico-leão }=20}+ \\
& \text { arara }=10+ \\
& \text { garça }=5+ \\
& \text { tartaruga }=2
\end{aligned}
$$

TOTAL 187 reais.

Esse total representou a validação do procedimento mental construído para chegar ao resultado e, mais que isso, independentemente do valor simbólico (um valor para cada figura de bicho), revelou a habilidade com os conhecimentos mobilizados: adição, ordem crescente e decrescente, posicionamento, decimal. Trata-se de uma estratégia interessante porque, em se tratando de contabilizar valor monetário, na vida cotidiana, começamos a contagem das notas de maior valor às de menor valor, até chegarmos ao total.

Feitas todas essas etapas, a curiosidade já era tamanha que começamos a verificação/validação dos conhecimentos mobilizados, para isso fomos lendo as características de cada cédula. Então, de posse dos envelopes, retirávamos as notas e os colocávamos embaixo das figuras e das cores já representadas, pois nosso objetivo era chegar à formalização de atividades, envolvendo contextos que buscassem aproximação da realidade do aluno com a escola.

Figura 6: Correspondência das cédulas de real

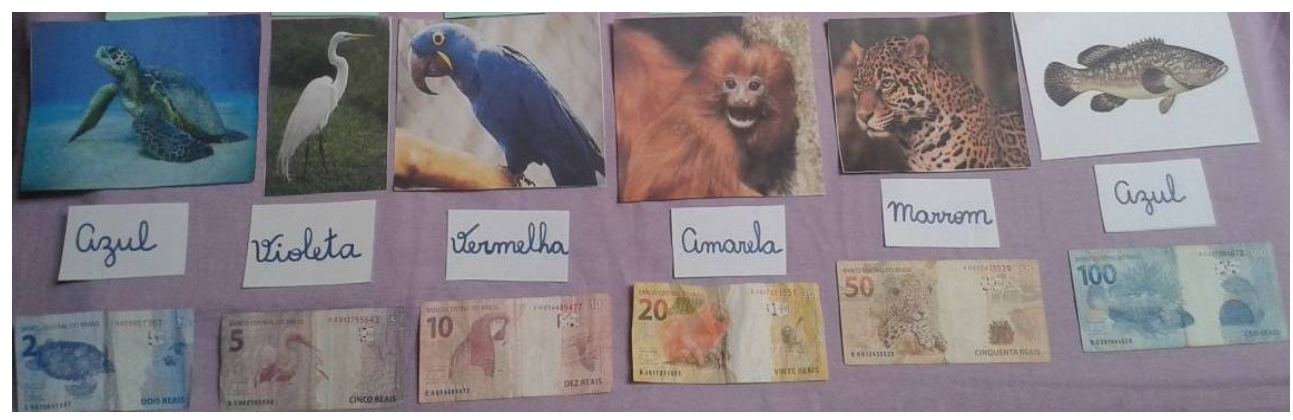

Fonte: arquivo da pesquisadora. 
Enquanto fazíamos a leitura das características de cada cédula, as professoras faziam a correspondência utilizando notas verdadeiras.

- Cores predominantes: azul e cinza - cédula no valor de $\mathrm{R} \$ 2,00$ (dois reais)

Reverso: gravura de uma tartaruga marinha (Eretmochelis imbricata ou tartaruga-de-pente). Homenagem a uma espécie que estava em extinção e que, graças ao trabalho desenvolvido pelo Projeto Tamar, agora é preservada no litoral brasileiro.

- Cor predominante: violeta - cédula no valor de $\mathrm{R} \$ 5,00$ (cinco reais)

Reverso: figura de uma garça (Casmerodius albus), ave pernalta (família dos ardeídeos), espécie muito representativa da fauna encontrada no território brasileiro.

- Cor predominante: carmim (corante ou vermelho) - cédula no valor de R $\$ 10,00$ (dez reais)

Reverso: gravura de uma arara (Ara chloreptera), ave de grande porte da família dos psitacídeos, típica da fauna do Brasil e de outros países latino-americanos.

- Cores predominantes: amarelo e laranja - cédula no valor de R \$20,00 (vinte reais)

Reverso: figura de um mico-leão-dourado (Leonthopitecus rosalia), primata de pelo alaranjado e cauda longa nativo da Mata Atlântica, que é o símbolo da luta pela preservação das espécies brasileiras ameaçadas de extinção.

- Cor predominante: marrom - cédula no valor de $\mathrm{R} \$ 50,00$ (cinquenta reais)

Reverso: figura de uma onça-pintada (Panthera onca), conhecido e belo felídeo de grande porte, ameaçado de extinção, mas ainda encontrado principalmente na Amazônia e no Pantanal Mato-Grossense.

- Cor predominante: azul - cédula no valor de $\mathrm{R} \$ 100,00$ (cem reais)

Reverso: Gravura de uma Garoupa (Epinephelus marginatus), peixe marinho da família dos serranídeos, e um dos mais conhecidos dentre os encontrados nas costas brasileiras.

Figura 7: Cédulas de real com reverso e anverso

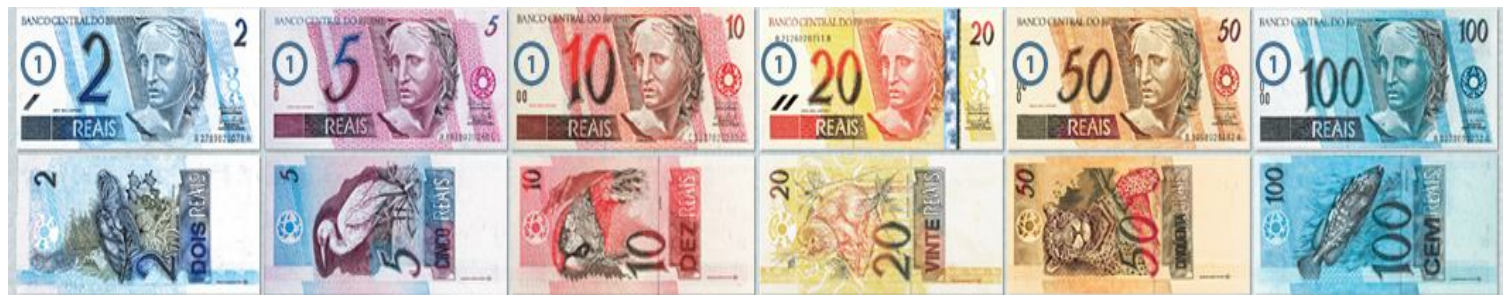

Fonte: disponível no site do Banco Central do Brasil (BCB). 
A justificativa para iniciarmos os trabalhos explorando as características das cédulas surgiu a partir dos acontecimentos sobre a crise financeira que, naquele momento econômicopolítico, era alvo de comentários e críticas, além disso, tivemos a pretensão de entrar em outras temáticas e conteúdos na perspectiva da conexão de saberes. As professoras validaram os conhecimentos e falaram da importância de sua abordagem em suas salas de aula, inclusive, dessa experiência trouxeram comentários dos alunos, como, por exemplo: "eu nunca mais vou esquecer"; "vou perguntar para o povo lá de casa, para saber se eles sabem de tudo isso"; "eu vou ensinar meu neto"; "eu vou ficar atento é nos números para não me enganar com as cores".

Vale tomar nota que até aqui já podemos listar uma série de conteúdos e disciplinas envolvidos no contexto criado para explorar o conhecimento acerca das cédulas de reais $(R \$)$, o que reforça a justificativa de utilizarmos a perspectiva da conexão de saberes, a fim de ampliarmos o campo do conhecimento: sistema monetário (matemática); bichos (ciências naturais); efígie da República (história), cores como valor simbólico (artes); além da contagem; das operações; da verbalização; da leitura de informações. Todo esse contexto nos remete também às condições sociais de letramento como possibilidade de enriquecer o campo do conhecimento relativo à Educação Matemática.

Essa atividade de reconhecimento e caracterização das cédulas foi imprescindível para exercitar a memória, pensando no contexto da sala de aula onde os alunos têm entre 35 a 78 anos de idade, mas também tratamos de composição e decomposição, envolvemos as operações e o tratamento de informações do cotidiano. Em se tratando de Matemática e da relação com outros saberes, a perspectiva do letramento foi adotada para promovermos as condições de leitura e interpretação dessa realidade que, neste caso, envolvia o dinheiro. Começamos de modo provocativo e fomos disponibilizando o material para manipulação. Agora, já era hora de avançarmos para outras ações. Nesse caso, começamos a planejar atividades que envolvessem bem mais que reconhecer e contar as cédulas, tais como descrevemos a seguir.

As descrições a seguir são das ações realizadas nas diferentes etapas. Distribuímos envelopes contendo várias cédulas (dinheirinho comprado em papelarias) para que realizassem cálculo mental e oral, antes mesmo de utilizarem registro escrito, etapa que foi posterior e depois fizemos as seguintes provocações:

- De quais maneiras podemos ter $\mathrm{R} \$ 20,00$ utilizando apenas cédulas e tendo que ser todas iguais? Eles manipularam as cédulas e encontraram as respostas 2 de $\mathrm{R} \$ 10,00 ; 4$ 
de $\mathrm{R} \$ 5,00 ; 10$ de $\mathrm{R} \$ 2,00$. A professora fez a intervenção dizendo que a ação realizada por eles corresponde à divisão de 20 por 10 ou por 5 ou por 2 e sistematizou a operação no quadro. Eles balançavam a cabeça concordando, mas também admirados dessa possibilidade. Então, com isso, a ideia das professoras era trazer o conceito de medida em divisão. Um aluno reiterou: "professora, é como se eu tivesse 20,00 e aí tivesse que pagar para dois amigos a mesma quantidade, e aí seria dez para João e dez para Pedro". Esse modo de pensar nos trouxe o conceito de partilha dentro da divisão. Nesse exemplo, observamos e pontuamos como os conhecimentos estão presentes em forma de rede, de campo conceitual, presentes de forma articulada e não fragmentada como propõe o currículo escolar tradicional.

- Outra questão foi para que utilizassem o menor número de notas possíveis para compor o valor do salário-mínimo. Eles começaram a perguntar uns aos outros, quanto estava valendo o salário-mínimo atual. Até que um aluno respondeu que o salário era de $R \$$ 788,00 (setecentos e oitenta e oito reais ${ }^{16}$ ). Daí, eles começaram a separar as notas que resultou na seguinte composição: 7 notas de 100,00; 1 de 50,00; 1 de 20,00; 1 de 10,00; 4 notas de 2,00. A professora questionou: "por que vocês não usaram a nota de 5,00?" Eles responderam quase que como um coro: "porque não temos moedas", se não seria 1 nota de 5,00; 1 de 2,00 e mais 1 moeda de 1,00". A título de provocação, mas também para perceber se haviam incorporado os conhecimentos anteriores, a pesquisadora interviu e pediu que colocassem as cédulas para trás e dissessem que bichos representavam aquele valor que estava nas mãos. Eles tiveram que buscar na memória para atribuir o valor simbólico, mas dessa vez não apresentaram dificuldade: 7 peixes; 1 onça pintada; 1 mico-leão-dourado; 1 arara; 4 tartarugas marinhas. Essa experiência também é de alfabetização, leitura de imagem e, em especial, diz respeito à mobilização da noção de valores, que remete tal situação ao contexto de letramento, uma vez que mobiliza significados do contexto sociocultural.

- Outra questão: se em um caixa eletrônico tem o aviso de que só há cédulas de $\mathrm{R} \$ 20,00$ e você precisa sacar R $\$ 400,00$. Quantas notas sairão? Eles começaram a separar as notas em montantes de 100,00 (composto por 5 notas de 20,00) cada monte; então, contaram 4 montes de R $\$ 100,00$ que teria os R \$ 400,00, chegando ao total de 20 notas de 20 reais. A professora fez intervenção perguntando se tinha outra forma de contar? Um aluno contou de 20 em 20 até chegar em 400,00. Aqui podemos ver a divisão e a

\footnotetext{
${ }^{16}$ Valor do salário-mínimo referente ao ano de 2015.
} 
multiplicação na mesma atividade porque os resultados denotavam o entendimento de vários conceitos, era a mobilização do campo conceitual multiplicativo.

Segundo Vergnaud (2009, p. 29), "além da definição dos conceitos, o pesquisador que quer compreender o desenvolvimento e a aprendizagem é, portanto levado a tomar por objeto de estudo um conjunto de situações e um conjunto de conceitos, ou seja, um campo conceitual". Essa configuração nos deu uma clara ideia de que nossas atividades estavam atingindo a proposta pretendida que era trabalhar na perspectiva da conexão de saberes e do letramento. Nesse contexto, utilizamos situações cotidianas que permitiram a estruturação do pensamento, a argumentação e a validação das ações envolvendo a manipulação do dinheiro.

Vale ressaltar que "as estruturas são trazidas em três níveis: em termos de ação mental; em ação material, e no último nível, materializada” (MUNIZ, 2003, p. 292). Essas atitudes foram desenvolvidas e percebidas exatamente nessa ordem, os alunos pensaram, entreolharam-se, sentiram o desafio e começaram a manipular o material, até chegarem na resposta que julgaram mais adequada. A culminância de todo o processo é o registro escrito dessa ação pensada, o que realizamos na sequência.

Depois dessas atividades, a professora registrou no quadro algumas questões escritas de divisão para que resolvessem, uma das questões foi “312 $\llcorner 2$ ". Como essas foram operações sem envolver contexto, os alunos apresentaram certa dificuldade. Então, a professora logo percebeu e foi inserindo contextos para auxiliar na compreensão e na resolução da situação-problema. Assim, a professora inseriu o seguinte contexto: "Você tem $R \$ 312,00$ e precisa dividir entre seus dois irmãos, filhos ou netos. Quanto cada um vai receber?"

Para essa atividade, eles dispunham de 3 notas de 100,00; 1 de 10,00 e 1 de 2,00. Então, a primeira atitude foi trocar o dinheiro, no contexto da partilha, de forma que as trocas permitissem prosseguir com a divisão dos valores, mas sempre a partir das cédulas de real. Assim, um dos alunos foi resolver na frente, simulando: deu 100, para cada irmão, filho ou neto; trocou uma de 100,00 por 2 de 50,00 (e deu para cada um); trocou uma de 10,00 por duas de 5,00 (e deu uma para cada um) e pediu para a professora trocar a nota de 2,00 por 2 moedas de 1,00. A professora o fez, então, ele deu mais 1,00 para cada e depois contou quanto cada recebeu: $100,00+50,00+5,00+1,00=156,00$ para cada. A atividade foi registrada no quadro, seguindo os mesmos passos, e entenderem que, ao dividir o primeiro 3 por 2, na verdade, tem 300 por dois e fica 100 (que precisa ser desmembrado, isto é, trocado) 
para continuar dividindo. Então, conseguimos perceber a admiração e o orgulho que sentem de si mesmos quando compreendem e resolvem uma situação-problema.

Destacamos aqui algumas considerações acerca da importância do registro, pois representa o caminho percorrido, as estratégias utilizadas, um modo de tornar a verbalização ou o pensamento com aspectos visíveis e compreensíveis e, principalmente, representa a validação. O aluno, ao registrar/escrever no quadro, sentia-se capaz e inteligente, porque o contexto fazia com que ele se reconhecesse, ou seja, as respostas eram construídas porque havia compreensão, significado, aprendizagem.

- Outra atividade contextualizada e simulada foi a seguinte: "Você é o encarregado para fazer o pagamento dos operários de uma obra. O supervisor lhe entregou um envelope em que tinham 22 notas de $R \$ 100,00$ e 20 notas de $R \$$ 50,00. Você precisa conferir quanto tem de dinheiro no envelope e pagar um valor igual para os quatro funcionários da empresa. Quanto cada operário receberá?" Ficamos a observar, alguns começaram a contar até chegar em 2.200,00 e anotavam 22 de 100,00 é 2.200,00. Depois juntavam as notas de 50,00 de duas em duas e já contava 100,00... 200,00 até $1.000,00$. Então, calculava $2.200,00+1.000,00=3.200,00$, mas, ao invés de fazer a operação $3.200\llcorner 4$, eles começaram a distribuir as notas em quatro montes até se esgotarem todas as notas, mas para não restar duas notas de 100,00 estas foram trocadas por quatro notas de 50,00. Depois, faziam a conferência de quanto havia em cada monte. Então, em cada monte, havia 5 notas de 100,00 (raciocínio multiplicativo) mais 6 notas de 50,00 (multiplicação), ou seja, multiplicava as quantidades de cada monte e, em seguida, somava essas quantidades 500,00 $+300,00=800,00$ para cada funcionário da obra.

Essas experiências fizeram com que as professoras se dessem conta de que é necessário construir atividades que representam situações do contexto cotidiano, isto é, as situações-problema precisam envolver contextos da vida diária. É necessária uma variedade de situações para que sejam mobilizados conhecimentos do campo conceitual, da estrutura de pensamento já construída pelo aluno. A experiência da manipulação do dinheiro retrata a vivência cotidiana e ajuda a dar significado ao que está sendo estudado que, nesse caso, é o sistema monetário, as operações e o tratamento de informações.

A apropriação de modelos matemáticos por jovens e adultos que aprendem Matemática na vida diária mostra, conscientemente, que o problema de escolher a 
operação correta, tão comum entre estudantes, não aparece entre jovens e adultos quando eles usam seus conhecimentos diários. Em contraste, quando os estudantes constroem sua compreensão dos modelos matemáticos na sala de aula, essa construção depende das experiências práticas que a escola lhe proporciona. Quando ensinamos a multiplicação como adição repetida, essa experiência talvez torne mais difícil para os alunos diferenciar o raciocínio aditivo do raciocínio multiplicativo. (NUNES, CARRAHER, CSHLIEMANN, 2011, p. 19)

Quando voltamos para nossos círculos de investigação formativos para fazer a discussão dessas experiências, as professoras identificaram que as situações-limite residiam no fato de realizarem atividades descontextualizadas. Essa evidência foi observada porque os alunos não tinham dificuldade em fazer cálculos mentais e orais, mas, quando se registravam "contas armadas" no quadro, a dificuldade aparecia. Como, por exemplo, a professora registrou no quadro: “1 1 2”. E perguntou: “Quanto é 1 divido para 2?”. E eles responderam "convictamente": "não dá para dividir, porque 1 é menor que 2 e não tem como pegar emprestado". Então, a professora tirou da bolsa uma laranja e colocou sobre a mesa da turma da $4^{\text {a }}$ etapa. Sem dizer uma palavra, os alunos já foram logo se antecipando e dizendo: “ $a h$, agora divide no meio".

Essa foi uma das atividades que mais analisamos e discutimos em nosso círculo de investigação formativo, porque, apesar de termos vivenciado todas essas atividades e as professoras já terem antecipado que poderia acontecer nas salas, ninguém tinha se dado conta de que isso era resultado da falta de domínio do campo conceitual. O algoritmo formal de $1\llcorner 2$ e o objeto material que é uma laranja dividida para duas pessoas, por exemplo, deveria envolver a mesma estratégia de resolução, mas os alunos só conseguiam chegar ao resultado se fosse a partir de um contexto, pois este gera significado conceitual. Assim, as professoras concordaram que a situação contextualizada contribui para a aprendizagem significativa e, nesse caso, depende do campo conceitual que gera uma sequência de ações cognitivas, produção de registros escritos e argumentação oral que, por conseguinte, permite socialização e validação de processos e resultados.

Se partirmos da análise da fala do aluno "ah, agora divide no meio", percebemos que seu raciocínio passa a ser diferente, ficando claro que se o dividendo é menor que o divisor, então, o resultado será um número menor que 1 . Se é menor, então é decimal, ou seja, o resultado não é um número inteiro e, nesse exemplo, começa com zero seguido de vírgula $(0,5)$. Do mesmo modo, se tivermos 1 real para dividir para duas pessoas: cada uma receberá cinquenta centavos que se registra da seguinte forma $\mathrm{R} \$ 0,50$. Outra aluna disse: "Mas a moeda de 1 real pode ser trocada por outras moedas. Pode ser 2 de 50 centavos, 4 moedas de 25 centavos, 10 moedas de 10 centavos, 20 moedas de 5 centavos". A professora perguntou: 
“Como é que você calculou essas 20 moedas de 5 centavos?”. A aluna respondeu: "Quando eu pago conta na loteria que tem troco em moedas, às vezes a moça lá me dá um monte de moedinhas coladas uma na outra com durex, aí ela diz assim que no monte tem 1 real".

Outro registro a se fazer é da fala do aluno quando se referiu a "pegar emprestado". Essa é uma constante na linguagem de professores e alunos e representa a reprodução do discurso e do ensino de professores que tradicionalmente tem utilizado essa terminologia no lugar de recursividade, presente na subtração. Nesse caso, nem seria "pegar emprestado", mas compor o algarismo, atentando para seu valor relativo. No exemplo dado, se, ao invés de 1 do dividendo, tivéssemos mais outro algarismo junto que formasse 11 ou 12 ou 13, implicaria ter uma dezena mais um, uma dezena mais dois, uma dezena mais três. Então, assim como o aluno fez a leitura "1 dividido para 2", também faria "11 dividido para 2", porque buscaria a composição no algarismo que estivesse imediatamente à direita.

Ainda em relação à operação $\mathbf{1} L \mathbf{2}$, a professora relembrou que a divisão também pode ser representada com outro símbolo que é $1 \div 2$, ou em forma de fração $1 / 2$ (que se lê: um meio ou um sobre dois). Nesse caso, trazemos para a atividade uma noção básica e primária de fração. Sobre este último, o que veio na cabeça dos alunos foi a lembrança de receitas em que se pede meio $(1 / 2)$ copo de óleo ou meia (1/2) xícara de açúcar. Dessa relação, nos voltamos tanto para o conteúdo de fração quanto de medida.

Outra decisão que tomamos foi de realizarmos ações que envolvessem alunos de todas as etapas de ensino, mesmo que o currículo trouxesse como direcionamento que a divisão é conteúdo para a $3^{\mathrm{a}}$ e $4^{\mathrm{a}}$ etapa. Então decidimos que, se o aluno já tem conhecimentos anteriores - são os subsunçores denominados por Ausubel (1968) -, não há impedimento para trazermos mais informações de modo a garantir a ampliação da aprendizagem. Nesse sentido, entendemos que "a aprendizagem significativa ocorre quando a nova informação ancora-se em subsunçores relevantes preexistentes na estrutura cognitiva de quem aprende" (MOREIRA; MASINI, 2001, p. 17). Nesse caso, se estamos trabalhando com o sistema monetário e nossa intenção foi lançar mão da conexão de saberes, então ampliamos o campo de ação.

Nessa mesma perspectiva, trabalhamos a divisão quando do manuseio de sistema monetário com as turmas de $3^{\mathrm{a}}$ e $2^{\mathrm{a}}$ etapas. Distribuímos entre os grupos: cédulas e moedas. As questões estiveram sempre voltadas para a realidade dos educandos da EJA. Exemplo disso foi entregar uma cédula de $\mathrm{R}$ \$ 2,00 para uma aluna e fazer a seguinte suposição: "Você 
tem dois reais e quer dar para seus oito netos comprarem balinhas. Quanto você vai dar para cada neto, a fim de que cada um receba o mesmo valor?". Entendemos que a utilização de situação-problema como esta pode provocar aprendizagens significativas.

Porém, Ausubel chama atenção para o fato de que se o aprendiz não é capaz de resolver um problema, isso não significa, necessariamente, que ele tenha somente memorizado os princípios e conceitos relevantes à solução do problema, pois esta implica, também, certas habilidades além da compreensão (MOREIRA; MASINI, 2001, p. 24).

Concordamos com o entendimento ausubeliano e acreditamos que as possibilidades de resolução das situações-problema aumentam quando se valoriza episódios ou vivências do cotidiano dos alunos. Em contraposição, as chances de resolução diminuem quando, por exemplo, se escreve no quadro um problema com a seguinte configuração: $2\llcorner\mathbf{8}$, porque os educandos podem verbalizar o seguinte: “o 2 é menor que o 8, então não dá para ser dividido". Essa resposta sinaliza que o conceito de divisão é entendido apenas em uma perspectiva, que se divide sempre pensando em um resultado com números naturais e descarta-se a possibilidade de números decimais e fracionários.

Voltando à situação em que a nota de 2 reais precisava ser dividida para 8 netos, a aluna resolveu assim: trocou por duas moedas de 1 real; trocou cada real por moedas de cinquenta centavos; depois trocou pelas de vinte e cinco centavos. Ficando com 8 moedas de 25 centavos e verbalizando do seguinte modo: "tenho oito vezes vinte e cinco". Quando perguntada quanto tinha ao todo, respondeu adicionando: "25 mais 25 é cinquenta, e mais 25 são 75 centavos [...]" até chegar à composição de 2 reais. Todavia outro aluno interviu dizendo: "eu sei fazer de outro jeito. É só multiplicar 8 x 0,25 (escreveu no quadro). Eu sempre faço isso quando quero comprar alguma verdura no Verdurão".

$\mathrm{Na}$ resolução da aluna, houve o processo de decomposição ou troca, seguido da adição. Enquanto que, no procedimento do aluno, o conceito mobilizado foi o de multiplicação. Nesses termos, foi possível perceber que, para uma mesma situação-problema, podem ser mobilizados vários conceitos para chegar ao mesmo resultado. Essa possibilidade se deu pela utilização de situações problematizadas que superam aqueles enunciados operacionais como: "resolva; faça, multiplique, calcule, some, seguidas de dezenas de exercícios do mesmo tipo, em que a única forma de representação são os números e os símbolos da aritmética” (PAIS, 2013, p. 35).

Inicialmente, quando utilizamos situações contextualizadas, provocamos certo receio nos alunos porque estes foram acostumados a resolver "contas armadas". Entretanto, se a conta já vem armada e acompanhada do respectivo sinal que a caracteriza como adição, 
subtração, multiplicação ou divisão, não há necessidade de esforço para pensar e criar estratégias de resolução. O que o aluno faz é operar tecnicamente com os números para encontrar a solução. Em contraposição, quando utilizamos situações do contexto sociocultural escritas no quadro ou em papel impresso, o aluno incorria naquela tão conhecida frase "que conta é?". Mas, aos poucos, essas ações eram incorporadas e passaram a fazer parte de uma rotina escolar matematizada.

Para o especialista em Educação Matemática, essa dificuldade acontece por alguns motivos, quais sejam:

Dificuldade de interpretação do texto que constitui o enunciado;

Operações ensinadas de forma estanque, uma a uma, sem uma articulação interna entre elas;

Falta de significado da situação para o aluno, levando-o a não identificar os conceitos que a mesma implica;

Ausência de autonomia intelectual e moral do aluno que foi levado a buscar, no adulto, o suporte para validação de suas ações cognitivas;

Baixa autoestima e insuficiente autoconfiança, uma vez que o aluno é submetido a um ambiente educativo em que o erro é fonte geradora de punições. [...]

Enunciado não evidencia apenas dois números a serem diretamente operados. [...]

Hábito de encontrar, no texto, palavras que conduzem de forma absoluta determinada operação aritmética, tais como: "juntos" é para somar, "retirar" é para subtrair, "repartir" é para dividir, e assim por diante. (MUNIZ, 2009, p. 102-103).

A partir da mediação das professoras para fazermos a aproximação com os alunos nos foi possível verificar que as dificuldades apresentadas por eles ficavam mais no âmbito dos dois primeiros e dos dois últimos pontos supradescritos. Era desse modo também porque não tiveram o hábito de conviver com esses contextos escritos, pois o que aprenderam, até mesmo nas reproduções de casa, foi operar com as "continhas". Esta era mais uma situação-limite para as professoras, pois era necessário conceber outras formas de conhecimento matemático para além das formatações ortodoxas via algoritmos clássicos, fazendo aproximar os registros das formas de pensamento mental e oral dos alfabetizandos.

Isso fez com que a reconhecêssemos como situação-limite a ser superada, por isso realizamos mais atividades com a manipulação do dinheiro e também com situações-problema envolvendo contextos cotidianos. A utilização do dinheiro funcionou como instrumento mediador para a construção de inéditos-viáveis, tendo em vista o forte significado cultural para os alunos da modalidade EJA. 
Nossos planejamentos estiveram ancorados na coletânea de Pedagogia, Educação e Linguagem Matemática - PEDEaD (BERTONI, 2007; MUNIZ, 2007); em Muniz (2009) e nas aulas de Educação Matemática da Universidade de Brasília (enquanto desenvolvimento da prática de estágio docente); nas discussões do grupo Edem - Grupo de Estudos de Educação Matemática da UnB; nas relações de troca de experiências com os sócios da SBEMDF; nos materiais do PNAIC/Matemática (BRASIL, 2014); e nas formações em Educação Matemática com a professora Nilza Bertoni.

Bertoni é a paulista, Nilza Eigenheer Bertoni, licenciada em Matemática; mestra em Matemática; doutora honoris causa pela UnB, de onde é professora aposentada. Possui larga experiência no campo da Educação Matemática e é um dos nomes mais importantes nessa área no DF e no Brasil. Atua principalmente nos temas: currículo e Educação Matemática no Ensino Fundamental; currículo de formação de professores; ensino-aprendizagem de números fracionários. Atualmente compõe a Diretoria Nacional Executiva da Sociedade Brasileira de Educação Matemática (SBEM), ocupando a função de vice-presidente (na gestão de 20132016), mas também já ocupou o cargo de presidente da SBEM Nacional.

Com a professora Nilza Bertoni aprendi o que é um pensamento aritmético e algébrico, o que são números naturais e inteiros, racionais e irracionais. Essa aprendizagem foi importante e significativa porque também foi possível ampliá-la dentro do contexto da EJA, com professoras e alunos, mesmo sem precisar usar a terminologia. Contudo foi importante porque nosso trabalho aconteceu na perspectiva da conexão de saberes e o que fizemos foi estabelecer a interligação de conteúdos diferentes dentro da mesma área e em áreas diferentes.

Também foi importante para alicerçar nossos conhecimentos matemáticos o estudo dos materiais que compõem o projeto "Um novo Currículo de Matemática "17", escrito por especialistas da área e coordenado pela professora Nilza Bertoni no ano de 1985. Este projeto representou e ainda representa importante contribuição para formação de professores, por isso, em 2015, a Sociedade Brasileira de Educação Matemática do Distrito Federal (SBEMDF) organizou, publicou em volume único e disponibilizou na versão on-line. A discussão do projeto foi tema central do III Seminário de História e Educação Matemática Nilza Eigenheer Bertoni. Este volume único está composto por um conjunto de apostilas com conteúdos de numerização, fração, decimais, volume e capacidade, razões e proporções, gráficos e outros conteúdos matemáticos que, embora tenha sido pensado na configuração da

\footnotetext{
${ }^{17} \mathrm{O}$ volume completo do projeto "Um novo Currículo de Matemática" com todos os conteúdos do ensino fundamental pode ser acessado em: 〈http://www.sbemdf.com/>, na aba III SEMINÁRIO NILZA.
} 
aprendizagem da criança, apoiei-me no material porque foi elaborado dentro da perspectiva dos campos conceituais e, portanto, contribui para pensarmos a aprendizagem do adulto dos anos iniciais.

Com base em todas essas experiências, lancei-me no desafio de contribuir com a modalidade EJA, e, uma vez conseguindo conquistar as parcerias na escola, construímos, coletivamente, estratégias para aprender e ensinar uma Matemática útil e interessante que pudesse atender às necessidades de etapas de ensino diferentes. Ao ter a fala dos alunos como referência para estudar as operações, fomos trabalhando vários exemplos de situaçãoproblema que envolvesse contextos diferentes, mas próximos da realidade daquele público. Assim, nosso objetivo não era reduzir a Educação Matemática ao manejo de fórmulas ou uso de técnicas de cálculo escrito, mas provocar reações de interpretação e tomada de decisão frente às situações-problema, conforme trouxemos na sequência.

- Situação-problema 1: Você vai sair para caminhar, o dia está frio e você precisa decidir que roupa vai usar. Se você tem uma camisa amarela, uma camisa azul e uma camisa branca e tem uma calça azul e uma preta, quais as combinações possíveis para usar a calça e a camisa?

- Situação-problema 2: Você vai se apresentar em uma entrevista de emprego e precisa decidir que roupa vai usar. Se você tem uma camisa preta, uma camisa azul e uma camisa branca e tem uma calça azul e uma preta, quais as combinações possíveis para usar a calça e a camisa?

Observamos que a situação-problema envolve o mesmo raciocínio multiplicativo, mas o contexto inicial vai ao encontro daquilo que os alunos vivenciam e conseguem se enxergar como sujeito. A saber, estamos denominando raciocínio multiplicativo o que se dá nos esquemas de ação de correspondência. No caso da situação-problema 1, pensamos em um contexto voltado para a realidade dos alunos mais idosos e aposentados que usavam agasalho para ir à escola naqueles dias em que fazia bastante frio. Já a situação-problema 2 estava voltada para os alunos mais jovens que estão na fase de empregabilidade.

Vale ressaltar que não estamos rotulando a origem ou destinação do tipo de questões, tão somente queremos destacar a importância de se pensar em um contexto em que o próprio aluno possa ter certa familiaridade. Isso pode representar uma contribuição para que os alunos 
da EJA construam diversas estratégias de pensamento e de resolução de situação-problema porque é como se estivéssemos descrevendo sua própria história. Nesse caso, estamos nos referindo às condições de letramento, porque, na vida social, passamos por situações que são as reais situações-problema e temos que mobilizar tanto os saberes cotidianos quanto os conhecimentos mais elaborados para resolvê-los.

Além disso, a importância de usarmos diferentes situações foi pela oportunidade de o aluno utilizar uma multiplicidade de conceitos, afinal de contas, a solução da situaçãoproblema é própria do sujeito, portanto, passa por sua interpretação, leitura de mundo, conhecimentos acumulados e depende do contexto social a que a pessoa está inserida. Nesse sentido, vamos ilustrar com o exemplo trazido por Nunes, Carraher e Schliemann (2011, p. 29), quando hipotizam: "se tivermos diante de nós a tarefa de distribuir iguais quantidades do feijão obtido após a colheita para 30 famílias, podemos contar grão por grão, dividir o número de grãos por 30, e depois contar, para cada família, o número de grãos que lhe cabe". Para eles, essa solução é matematicamente correta, mas exige um esforço que pode ser substituído por outros modos de resolver, como: utilizar uma lata como referência para medir o feijão para fazer a distribuição equitativa entre as famílias; ou utilizarmos uma balança. Em todas essas estratégias, utilizaremos o mesmo conceito matemático que é o de medida.

Outros exemplos de situações-problema contextualizadas e significativas foram trazidas por Nunes, Carraher e Schliemann (2011, p. 70-71), em que algumas situações configuravam contextos de compra, venda e troco. Neste estudo, os autores queriam saber os motivos de pessoas serem tão bem-sucedidas em cálculos fora da sala de aula (na vida dez) e na escola não conseguirem tanto êxito (na escola zero). Contudo observaram que o diferencial se dava porque o contexto dos sujeitos era de pessoas que trabalhavam em feiras no Nordeste e nesses locais usavam cálculo mental e oral, o que não era priorizado na escola, em detrimento da cobrança de um registro escrito que resultasse no algoritmo. Era exigida a utilização de regras fixas e uniformes para chegar ao resultado em forma de algoritmo formal.

Feita essa ressalva, voltemos para o cerne da situação-problema, que é a presença da estrutura multiplicativa nas duas situações-problema anteriormente citadas. Nos dois casos, os alunos tinham que mobilizar conhecimentos envolvendo o campo multiplicativo, utilizando um conceito que, muitas vezes, não é estudado na escola, o raciocínio combinatório. Contudo trata-se de situação que nos vemos diariamente fazendo: combinações de roupas, seja para qualquer finalidade (ir à festa, supermercado, trabalho, igreja, escola etc.), ou combinações de bebidas com comidas, ou de sabores de sorvetes com tipos de coberturas, em que temos que pensar e criar estratégias e procedimentos de resolução. 
Ao nos reportarmos às estratégias (no plural), estamos dando margem para novas possibilidades de utilização de vários procedimentos e conceitos para resolver as operações aritméticas e não restringir um conceito para cada operação, como costuma aparecer nos livros didáticos. Nesse sentido, Muniz (2009, p. 102) critica tais conceitos restritos como: “adição - juntar; subtração - retirar; multiplicação - adição de parcelas repetidas; divisão repartir". O cuidado que se deve ter com essa relação entre operação aritmética ligada a esse determinado conceito é para não esbarrar em obstáculos didáticos que impedem a resolução ou bloqueiam a estrutura cognitiva. Em outras palavras, devemos evitar fazer essa associação para não incorrermos no "reducionismo conceitual", que alerta Muniz (2009, p. 102-103):

O reducionismo conceitual das operações ocorre quando a escola elege para cada operação um único conceito, uma única classe de situação para a qual a operação de aplica. Quando isso ocorre, ao aluno, ao se defrontar com uma situação que apela para um conceito matemático não explorado pela escola, fica sem identificar qual o procedimento operatório que se aplica à situação.

De fato, o risco de utilizar as operações ligadas a conceitos únicos, como se fossem sinônimos, reduz a enorme capacidade e criatividade matemática daquele ou daqueles que se aventuram no rico universo da Educação Matemática. Sumariamente, é importante que os professores façam uso desses conhecimentos a fim de que também os pratique nas salas de aula, ampliando as possibilidades de uso de um conjunto de conceitos para um conjunto de ações e situações, o que culminará em uma aprendizagem significativa.

Eminentemente, se estamos defendendo uma aprendizagem matemática que considere a apropriação de conceitos, não podemos fazê-lo sem a Teoria dos Campos Conceituais (TCC) de Vergnaud (2009) para quem o conceito é concebido da relação indissociável entre situação, invariantes operacionais (teorema-em-ação e conceito-em-ação) e representação, que pode ser resumido pela "fórmula" $\mathrm{C}(\mathrm{S}, \mathrm{I}, \mathrm{R})$. A maior contribuição dessa teoria para a Educação Matemática é a produção de conhecimento pelo sujeito.

Segundo Vergnaud (2009, p. 29):

$\mathbf{S}$ conjunto de situações que dão sentido ao conceito

I conjunto de invariantes operatórios que estruturam as formas de organização da atividade (esquemas) suscetíveis de serem evocados por essas situações.

R conjunto das representações linguísticas e simbólicas (algébrica, gráficas...) que permitem apresentar os conceitos e suas relações e, consequentemente, as situações e os esquemas que elas evocam.

De acordo com o autor, não é apenas com uma situação que já se define o campo conceitual, mas um conjunto delas e é necessário tempo, porque os conceitos matemáticos envolvem estruturas complexas, como é o caso dos campos aditivo e multiplicativo. Daí que 
as situações precisam ser variadas e, paulatinamente, precisam incorporar certo grau de complexidade. Os invariantes que são conhecimentos não explícitos se mostram por meio do teorema-em-ação, que podemos denominar hipóteses levantadas acerca de determinada situação e do conceito-em-ação, que se refere ao que é pertinente para resolver uma situação. Enquanto a representação é a própria atividade que não necessariamente se dá em forma de registro escrito, porque há também a representação mental.

Vergnaud também explicitou conceito como "um conjunto informal e heterogêneo de problemas, situações, conceitos, relações, estruturas, conteúdos e operações de pensamento, conectados uns aos outros e, provavelmente, entrelaçados durante o processo de aquisição" (apud MOREIRA, 2002, p. 8). Esta forma de conceber o conceito vai ao encontro das ações que realizamos durante nosso trabalho investigativo, oportunizando professoras e alunos de lançar mão de conhecimentos aos quais já estão familiarizados, mas que, algumas vezes, a escola não favorece a ampliação. Assim, não criamos contextos atípicos que se distanciassem dos problemas que o aluno da EJA está acostumado a enfrentar e a resolver diariamente.

Em se tratando de campo conceitual como um conjunto variado de conceitos, trazemos a representação à qual nos apoiamos que tomou por base a síntese proposta por Muniz (2009, p. 104), pelo caderno 4 - de Operações na resolução de problemas - do PNAIC/Matemática (BRASIL, 2014) e ainda utilizamos o material (textos e slides) preparado para as formações no PNAIC. Acompanhemos a correspondência que elaboramos.

Quadro 5: Campos Conceituais na perspectiva de Vergnaud (2009)

\begin{tabular}{|c|c|c|c|c|}
\hline \multirow{2}{*}{$\stackrel{\frac{\pi}{\pi}}{\frac{\pi}{2}}$} & \multicolumn{2}{|c|}{ Campo conceitual aditivo } & \multicolumn{2}{|c|}{ Campo conceitual multiplicativo } \\
\hline & Adição & Subtração & Multiplicação & Divisão \\
\hline$\sum_{\Sigma}^{N}$ & $\begin{array}{c}\text { Juntar } \\
\text { Acrescentar }\end{array}$ & $\begin{array}{c}\text { Retirar } \\
\text { Completar } \\
\text { Comparar }\end{array}$ & $\begin{array}{l}\text { Proporção ou adição de } \\
\text { parcelas iguais } \\
\text { Raciocínio combinatório } \\
\text { Configuração retangular }\end{array}$ & $\begin{array}{l}\text { Repartir } \\
\text { Medir }\end{array}$ \\
\hline 畜 & \multicolumn{2}{|c|}{$\begin{array}{l}\text { Composição simples } \\
\text { Transformação simples } \\
\text { Composição com uma das partes desconhecida } \\
\text { Compação } \\
\text { Transformação com transformação desconhecida } \\
\text { Transformação com início desconhecido }\end{array}$} & \multicolumn{2}{|c|}{$\begin{array}{l}\text { Comparação entre razões } \\
\text { Raciocínio combinatório } \\
\text { Configuração retangular } \\
\text { Divisão por distribuição } \\
\text { Divisão por formação de grupos }\end{array}$} \\
\hline
\end{tabular}

Fonte: elaborado pela pesquisadora com base em Muniz (2009) e em PNAIC (BRASIL, 2014). 
Essa correspondência foi realizada para evitarmos o reducionismo conceitual, mas principalmente porque precisamos conhecer e utilizar uma variedade de procedimentos que dizem respeito a técnicas e estratégias de cálculo, mental ou escrito, e envolve conceitos que estão relacionados aos contextos, às ideias. Os conceitos estão ligados às classes de situações que utilizamos tanto com as professoras quanto com os alunos da modalidade EJA.

\section{Campo aditivo: operações de adição e subtração}

\section{- JUNTAR - reunião de duas ou mais quantidades}

Situação-problema 1: Se eu e meu irmão pegarmos as nossas economias, vamos poder comprar o presente de aniversário de nossa mãe. Eu contei e tenho 92,50 e ele tem 67,50. Então quanto é o valor total de nossas economias?

Situação-problema 2: Para pagar a conta de água, você pegou uma nota de $\mathrm{R} \$ 50,00$; duas notas de $\mathrm{R} \$ 20,00$ e uma nota de $\mathrm{R} \$ 5,00$. Quanto ao todo você pegou?

Nesses exemplos, mobilizamos a ação de juntar quantidades (dinheiro em reais), que, no caderno 4 do PNAIC/Matemática (2014), recebe a denominação de composição simples porque não provoca transformação em nenhuma das partes (parcelas) que compõem o todo (soma ou total). Na primeira situação simples, utilizamos duas parcelas que precisaram ser juntadas/somadas, chegando ao valor total de $\mathrm{R} \$ 160,00$.

No caso do segundo exemplo, aumentamos o nível de complexidade da questão porque professor e aluno precisaram estar atentos às quatro parcelas envolvidas na situação $(50,00+20,00+20,00+5,00=\mathrm{R} \$ 95,00)$, isso porque o anúncio das notas de $\mathrm{R} \$ 20,00$ está grafado por extenso (duas notas de $\mathrm{R} \$ 20,00$ ao invés de grafar com algarismo: 2 notas). Para esse caso, levantamos algumas hipóteses: adicionaria $50+2+20+5$ (em que o dois seria interpretado como parcela e o valor total seria $\mathrm{R} \$ 77,00$ ); ou $50+20+5$ (em que o dois não seria considerado, por visualizar apenas os algarismos numéricos, resultando em $\mathrm{R} \$ 75,00$ ); ou $50+40+5$ (em que já somaria direto as duas notas de $\mathrm{R} \$ 20,00$ ou se multiplicaria duas notas de vinte reais).

Nossas experiências seguiram o seguinte caminho: verbalizamos o contexto, entregamos os valores (cédulas e moedas) para as professoras que em dupla resolveram com a manipulação do dinheiro e em seguida realizaram o registro escrito. Enquanto que, no caso dos alunos, organizamos duplas e trios, verbalizamos oralmente cada situação-problema e disponibilizamos várias cédulas e moedas para que compusessem o valor pedido em cada 
questão e realizassem a soma. Eles foram oportunizados para mostrar à turma e em seguida distribuímos a mesma atividade digitada para que realizassem o cálculo escrito.

\section{- ACRESCENTAR - colocar uma quantidade em outra já presente na situação}

Situação-problema 1: Você costuma guardar seu dinheiro em envelopes. No mês passado, você guardou um envelope com a quantia de $\mathrm{R} \$ 120,00$ e no final do mês você colocou mais $\mathrm{R} \$ 80,00$. Quanto em dinheiro ficou no seu envelope?

\section{- RETIRAR - pegar uma quantidade de outra já presente na situação}

Situação-problema 2: No início deste mês, você conseguiu guardar R \$ 150,00 no envelope, mas precisou de $\mathrm{R} \$ 42,00$ para comprar um remédio. Quanto em dinheiro ficou no seu envelope?

A ação envolvida agora é a de transformação simples, em que se tem um estado inicial - ou seja, tem-se uma das parcelas - e ocorre uma transformação por ganho/acréscimo (no primeiro exemplo) ou decréscimo/perda (segundo exemplo) de outra parcela. Nesse último caso, temos a subtração com a ideia de retirar.

\section{- COMPLETAR - ideia de “quanto falta para” complementar uma quantidade}

Situação-problema 1: Você levou 130 reais a fim de comprar um tênis para trabalhar. Chegando à loja viu que o tênis mais barato custava 220 reais. Quanto ainda falta para você comprar esse tênis?

Situação-problema 2: Neste ano, você acumulou no Programa Nota Legal R \$ 152,00 e resolveu abater no valor do seu IPTU que custa $R \$ 286,00$. Com quanto você terá que completar para quitar o IPTU?

Os exemplos utilizam situações de composição em que se tem uma das partes desconhecida e, para resolvê-la, é necessário subtrair uma parcela do total para encontrar a outra parcela que está faltando. No primeiro exemplo, utilizou-se a contagem de dez em dez a partir de 130, até chegar em 220 (a estratégia foi de adicionar). No segundo caso, de acordo com os próprios alunos, eles já têm hábito de resolver pela subtração, em que se tem uma dívida maior do que o valor que tem disponível para pagá-la.

O interessante é que, no primeiro caso, os alunos não perceberam como uma dívida, podendo comprar o tênis ou desistir da compra, como eles brincaram dizendo: "eu volto para casa com os 130 e vou comprar outra coisa". No caso do segundo exemplo, como o Imposto 
Predial e Territorial Urbano (IPTU) é um imposto anual obrigatório, então, não tem como optar por não o pagar, porque faz parte da despesa familiar, e o modo que eles apresentaram de resolver foi pegar o maior valor (da dívida) e retirar o menor valor (a quantia disponível no Programa Nota Legal), para encontrar a diferença (o que faltava para completar).

- COMPARAR - verificar, em elementos de mesma natureza, a maior e a menor quantidade

Situação-problema 1: João e Mateus trabalham como flanelinhas e ganham por semana, respectivamente, $\mathrm{R} \$ 230,00$ e $\mathrm{R} \$ 300,00$. Quanto um ganha a mais que o outro?

Situação-problema 2: Antônio tem 68 anos de idade e Vanda tem 55. Quantos anos Vanda é mais jovem que Antônio?

Há nessas questões dois pontos interessantes a se observar. No primeiro exemplo, a palavra respectivamente dá uma ideia de ordem, ou seja, João que teve o nome citado primeiro ganhava $\mathrm{R} \$ 230,00$ e Mateus $\mathrm{R} \$ 300,00$. No questionamento, poderíamos ter explorado: "Quem ganha mais? Quanto ganha a mais?" Os alunos não apresentaram nenhuma dificuldade para resolver a questão, e, em um caso específico, uma das senhoras contou nos dedos de dez em dez (como se cada dedo fosse uma dezena), até contar 7 dedos e chegar a 70.

No segundo exemplo, deixamos um pouco o sistema monetário e nos aventuramos por outras informações, como a idade dos alunos da turma. Contudo a "novidade" nessa questão foi que fugimos do modo tradicional de solicitar a resposta de quem é mais velho e concebemos uma questão que poderia até ser uma "armadilha didática", porque queríamos saber quem era mais jovem e ficamos a observar a atenção e a interpretação dos alunos para chegar à solução. O modo de resolver foi quase uma unanimidade: conservaram o 55 e contaram nos dedos (adicionando sempre um) até chegar em 68, obtendo 13 como resultado.

Essas questões também foram bastante discutidas em nossos círculos de investigação formativos porque os adultos e os idosos lançaram mão de um método de contagem que até as crianças já estavam sendo proibidas de usar: os dedos. Não podemos negar essa possibilidade, haja vista que, no cotidiano, ninguém anda com papel e caneta no bolso para ficar realizando cálculos diversos. Essas operações são realizadas de forma oral, cálculo mental ou com a ajuda dos dedos que dão uma precisão porque se utiliza um processo mental denominado correspondência biunívoca.

Todas as atividades trabalhadas até aqui pertencem ao campo aditivo porque permitem ao aluno utilizar-se tanto do raciocínio aditivo quanto do subtrativo para chegar ao resultado. No caderno 4 do PNAIC/Matemática (BRASIL, 2014), ainda são propostas que o professor 
trabalhe situações de transformação com transformação desconhecida e transformação com a primeira parcela desconhecida. Mas vale lembrar que esse modo de conceber as situações não é para que os professores cobrem do aluno, mas para que possam se utilizar de um conjunto de situações diferentes a fim de favorecer a aprendizagem.

\section{- Transformação com transformação desconhecida:}

Situação-problema 1: João trabalha por comissão e, no mês de maio, não recebeu seu salário todo de uma vez. Na primeira parte do pagamento, recebeu $\mathrm{R} \$ 650,00$. Depois recebeu o restante, sendo que em maio seu salário foi equivalente a $\mathrm{R} \$ 1.250,00$. Quanto João recebeu na segunda parte do pagamento?

Situação-problema 2: No mês de junho, João tinha para receber de salário R $\$ 800,00$, mas pegou um vale durante o mês e só recebeu $\mathrm{R} \$ 580,00$. Quanto de vale João pegou?

Exemplo de transformação com a primeira parcela desconhecida:

Situação-problema 1: Imagine que você trabalha no caixa de uma lanchonete. Abre o caixa, mas não confere quanto tem em dinheiro. O primeiro cliente pagou 13,00 de lanche e em seguida você resolve contar o dinheiro e chega ao total de R\$63,00. Então, quanto de dinheiro tinha em caixa inicialmente?

Situação-problema 2: Você sai de casa com um dinheiro no bolso para pagar a conta de água que custa $\mathrm{R} \$ 98,30$. Depois de pagar, percebe que só ficou com $\mathrm{R} \$ 11,70$. Quanto tinha em seu bolso antes de pagar a conta de água?

Essas classes de situações geraram esquemas mentais diferentes e oportunizaram aos alunos, mas também às professoras de serem mais autoconfiantes e de conquistarem certa autonomia para trabalhar com situações-problema. Nas questões anteriores, mesmo que indiretamente ou de modo não intencional, há um tímido avanço do conhecimento aritmético para o algébrico. O conhecimento aritmético está relacionado aos números e suas operações. O conhecimento algébrico utiliza as operações com incógnitas (letras para representar valores desconhecidos). Exemplo disso são as operações em que acontecem as transformações. Veja um procedimento acerca da questão sobre o salário: $650+X=1.250$. Além disso, podemos notar também a grande contribuição da perspectiva do letramento adotada porque os contextos são familiares aos educandos da EJA, como: fazer economias, pagar impostos etc.

Em muitas dessas situações, foi feita a leitura dos exemplos e aos alunos foi permitido usarem a oralidade, pois "é importante que os professores reconheçam, entendam e valorizem 
a matemática oral, especialmente aqueles que lidam com alunos que têm oportunidade de trabalhar no setor informal da economia" (NUNES; CARRAHER; SCHLIEMANN, 2011, p. 86). É uma forma de deixar os educandos em posições mais confortáveis e até de estimulá-los à participação para expor os conhecimentos que já dominam e que muitas vezes a escola não oportuniza, em detrimento da valorização do registro escrito e do algoritmo formal.

Outras atividades com o sistema monetário foram propostas com uso de cédulas e moedas. O caminho pelo qual optamos foi partir do procedimento de cálculo oral e chegar ao registro escrito. Contudo selecionamos apenas alguns exemplos para não tornar a escrita deste trabalho muito extensa, haja vista que ainda descreveremos as ações desenvolvidas no campo multiplicativo.

\section{Campo multiplicativo: operações de multiplicação e divisão}

\section{- PROPORÇÃO ou ADIÇÃO DE PARCELAS IGUAIS - realizar adição sucessiva}

\section{de parcelas repetidas}

Situação-problema 1: A passagem de ônibus custa $\mathrm{R} \$ 3,40$. Se você pega ônibus todos os dias para ir à escola (de segunda a sexta), quanto você paga de passagem durante a semana só no transporte de ida?

Temos, nesse exemplo, uma situação que é comum para grande parte dos alunos (pegar ônibus para ir à escola), então, antes mesmo de terminarmos a leitura do enunciado da questão, alguns já anteciparam a resposta de quanto gastavam para ir e voltar durante a semana. Além disso, houve manifestação de indignação dos alunos acerca do preço da passagem que tem aumentado e que compromete o orçamento dos menos favorecidos economicamente. Esse ocorrido só reforçou a nossa crença de que a Matemática contribui para que as pessoas se tornem mais críticas, tenham pensamento e ações emancipadas e não alienadas, porque não se trata de disponibilizar informações, mas de permitir que as pessoas possam adotar postura crítica e política frente ao mundo e à opressão.

Retomar a discussão da questão tornou-se menos importante nesse contexto, por isso, deixamos que os alunos tomassem voz, dialogassem e assim fizeram e influenciaram uns aos outros de modo a convencer à não acomodação. Frases do tipo: "Trabalhamos só para pagar impostos"; "É mesmo. A gente trabalha tanto e estamos sempre endividados"; "Os políticos corruptos roubam milhões e na televisão passa toda hora, mas cadê o dinheiro que roubaram?". O momento de tomar a palavra envolve muita matemática no discurso dos alunos e muito entendimento do que é e do valor que tem o dinheiro, fruto de seus trabalhos. 
Quando planejamos a atividade sobre o preço da passagem, tínhamos considerado as informações acerca do perfil dos alunos da EJA, conforme já exposto neste trabalho. Entretanto, em nenhum momento, imaginamos a polêmica que seria gerada. Contudo também é função do professor trabalhar com a imprevisibilidade, mas sem ferir o direito do educando de expor seu ponto de vista e tornar-se mais autônomo.

Voltando ao exemplo, não se pode reduzir o raciocínio multiplicativo à adição de parcelas. O mais adequado é dizer que, quando o primeiro fator (o multiplicando) for um número natural maior que 1 , o resultado da multiplicação pode ser calculado por uma soma de parcelas repetidas. Isso porque o primeiro fator sendo um número natural tem o papel de indicar tantas vezes o segundo (o multiplicador), que indica uma quantidade de elementos. Nesse caso, o segundo fator pode ser repetido o número de vezes indicado pelo primeiro e daí podem ser somados.

Então, o exemplo em que o primeiro fator é um número natural se encaixa na questão: 5 X 3,40 (cinco dias da semana vezes o preço da passagem de ônibus), ou também 3,40 +3,40 $+3,40+3,40+3,40=\mathrm{R} \$ 17,00$ da passagem de ida para a escola. Isso é perfeitamente aceitável porque também se pode resolver pela soma de parcelas repetidas quando o segundo fator (o multiplicador) for um número racional ou um irracional. Exemplo: $n X 1 / 2=1 / 2+1 / 2+$ $1 / 2+\ldots+1 / 2(n$ vezes); ou n X $0,3=0,3+0,3+0,3+\ldots+0,3$.

É conciliável explicitar que a ação de resolver uma multiplicação pela adição de parcelas repetidas deve ser evitada quando o primeiro fator (o multiplicando) não for um número natural, para não provocar a redução, a ampliação ou a mudança do sinal do segundo fator (multiplicador). Vejamos, por exemplo, os conceitos que trabalhamos nas formações do PNAIC/Matemática (2014): 1/2 x 6 laranjas = metade de 6 laranjas = 3 laranjas (reduzindo o 6 a 3); ou 1,5 x 6 laranjas = uma vez e meia as 6 laranjas = 6 laranjas +3 laranjas = 9 laranjas (ampliando o 6 para 9). No caso de nossa pesquisa, perguntamos para as professoras: "Que número que multiplicado por 8 tem como resultado 2?" Elas se entreolharam porque esse enunciado não apresentava um contexto comum. Então, coloquei moedas sobre a mesa e aí elas compreenderam que estávamos falando da multiplicação enquanto redução e selecionaram 8 moedas de 25 centavos que resultava em 2 reais.

Esses conhecimentos foram tratados com as professoras de nossa pesquisa, mas não chegamos a trabalhá-los com os alunos tendo em vista que utilizar mais conceitos requer mais tempo para que cada vez mais se incorpore outras informações, e o conceito possa passar por aprimoramento. A saber, não estamos confundindo conceito com o termo definição. Por 
definição entendemos que se trata das informações contidas nos dicionários e materiais didáticos, ou seja, já está pronta, é fixa e imutável. Enquanto o conceito diz respeito à construção pelo sujeito que aprende e vai sofrendo mudanças de acordo com a maturidade de suas experiências, com a variedade de situações vivenciadas pelo sujeito da aprendizagem.

Ainda nesse contexto de variedade de situações, o material do PNAIC/Matemática trouxe o conceito de comparação entre razões que envolve o esquema "um para muitos", ou seja, há uma relação entre os elementos que constituem a situação-problema. Outro conceito para isso é o de proporção que se diz "temos quantidades associadas a valores, em que a unidade de contagem representa um grupo, como quando tratamos de quantias" (MUNIZ, 2009, p. 104). Nesse caso, buscamos exemplos para além do sistema monetário e aproveitamos o momento em que a escola vivenciava as festas juninas para transformar em oportunidade para trabalhar esse conceito e desmistificar algumas interpretações acerca da multiplicação quando associada a contextos, conforme os exemplos a seguir.

Situação-problema1: Em uma caixa de leite, há 12 unidades de leite. Para preparar a canjica da festa junina, precisaremos de 4 caixas completas. Quantas unidades de leite teremos ao todo?

Situação-problema 2: O engradado de refrigerante vem com 6 unidades grandes. Se vamos precisar de 5 engradados para servir todos da festa, quantos refrigerantes teremos?

Nessas questões, as professoras tinham o entendimento de que "a ordem dos fatores não altera o resultado", entretanto exemplificamos que, em se tratando de utilizar apenas os números na relação de multiplicação, talvez essa frase tivesse efeito, mas o mesmo não ocorre quando temos um enunciado, um contexto. Assim, falar de 4 grupos de 12 é conceitualmente diferente de conceber 12 grupos de 4, bem como 5 grupos de 6 é diferente de 6 grupos de 5 . Para ampliar a discussão, utilizamos o seguinte exemplo: "Supomos que a hora-aula do professor do Ensino Fundamental é R\$ 7,00. Se você trabalha 4 horas por dia, quanto ganha ao final desse período?" Então provocamos: “se disserem que 4 de 7 é o mesmo que 7 de 4 , podemos concluir que você concorda que tanto faz trabalhar quatro horas para ganhar sete reais/por hora, como também poderá trabalhar sete horas para ganhar quatro reais/hora".

Nossa formação nos permitiu ampliar o entendimento e o conceito de multiplicação, pois, se nossas decisões haviam sido para inserir contexto em todas as atividades, para promover condições de letramento, então era preciso não confundir ações e procedimentos como se fossem leis universais. Doravante, aproveitamos essa discussão para tratar sobre o fato de a multiplicação estar diretamente associada às tabuadas e como estas são impressas, 
comercializadas, adquiridas e cobradas nas salas de aula de todo o Brasil, pois há que se tomar certos cuidados e ponderações.

Uma primeira consideração a se fazer acerca da tabuada é que ela não deve ser evitada, mas também não precisa ser a única estratégia didática utilizada pelo professor, para inclusive, "ameaçar" o aluno. Essas cartilhas cheias de conhecimentos aritméticos propõem um método memorístico, que não estamos negando a validade, porém é interessante ser substituído por estratégias cognitivistas. Basta observar que nas tabuadas o primeiro fator é um termo fixo, enquanto que o segundo é que sofre variação $(3 \mathrm{X} 1 ; 3 \mathrm{X} 2 ; 3 \mathrm{X} 3 ; 3 \mathrm{X} 4 \ldots 3 \mathrm{X} 10)$ essa configuração incorre para a memorização que é diferente do aprendizado.

Como já falamos anteriormente, na multiplicação, o primeiro fator determina a quantidade de vezes do segundo. Assim, o segundo fator é que deve ser qualificado e, portanto, é o fator fixo da operação. O que se propõe com a estratégia cognitivista é que possamos proporcionar essa experiência $(1 \mathrm{X} 3 ; 2 \mathrm{X} 3 ; 3 \mathrm{X} 3 ; 4 \mathrm{X} 3 \ldots 10 \mathrm{X} 3)$. É como se qualificássemos o segundo fator como as pernas de uma mesa redonda. Então, se uma mesa tem três pernas; duas mesas de três pernas têm seis pernas, ou seja, se considerarmos que a ordem dos fatores não altera, estaremos confirmando que 2 de 3 é igual a 3 de 2 (mesas com duas pernas! E como fica o equilíbrio dessa mesa no chão?). Resumo: 2 de $3 \neq 3$ de 2 .

Sumariamente, chamamos a atenção para o fato de que não estamos negando a validade da tabuada, pois, didaticamente, ela tem sua justificativa de estar organizada dessa forma, mas não se pensarmos na contribuição para a aprendizagem significativa. Especialmente se entendemos que a multiplicação, em geral, é o resultado do primeiro fator operando sobre o segundo, de modo a aumentá-lo, mantê-lo ou reduzi-lo, conforme alertou a professora Bertoni, nas formações do PNAIC/Matemática (2014). Ainda avançamos para outro conceito importante e pouco explorado das estruturas multiplicativas que é o de combinação.

\section{- RACIOCÍNIO COMBINATÓRIO - ocorre da relação de combinação de dois conjuntos diferentes}

Além das duas situações já apresentadas, quando, por exemplo, falamos acerca de combinar calça e camisa para entrevista de emprego ou vestir-se em um dia frio, também propusemos outra questão com os algarismos recortados em papel para que pudessem manusear e depois foi registrado no quadro, conforme explicitamos.

Situação-problema: Se você tem os algarismos 6, 9, 3, quantos números diferentes você poderá formar com eles? 
Essa atividade foi interessante porque os alunos, após registrar no quadro, perceberam que não se tratava de mover mecanicamente os algarismos, trocando-os de posição, mas essa combinação gerava um valor numérico diferente: 369; 396; 639; 693; 936; 963. Esse olhar posicional foi também um interessante ponto de discussão na formação porque, segundo as professoras, alguns alunos tinham apresentado dificuldade na questão do posicionamento (alinhar parcelas a fim de operar com elas) e a abordagem dessa questão foi fundamental para trabalharmos essa dificuldade. Trouxemos o assunto sobre composição e o valor relativo dos algarismos em cada uma das possibilidades apresentadas. Exemplo: 369 significam $300+60$ + 9 que é menor que 396 que, por sinal, é igual a $300+90+6$.

Dito dessa forma, os alunos não compreenderam, por isso perguntamos: "Se alguém quisesse dar dinheiro para você, quanto você gostaria de ganhar: 369 reais ou 396 reais?” Eles responderam: "claro que é 396 reais, porque é mais". Ou seja, os alunos têm conhecimento sobre dinheiro que lhes permitem dar essa resposta, e mesmo que inconscientemente eles apresentam um conhecimento de composição e valor relativo, que a escola precisa ampliar e fazer com que se reconheçam enquanto seres que têm conhecimentos e também potencial para aprender continuamente.

\section{- CONFIGURAÇÃo RETANGULAR - diz-se de uma representação com linhas e colunas, em que o resultado ocorre pela multiplicação de ambos}

Situação-problema 1: Josué organizou seus sapatos em 7 fileiras com 5 caixas empilhadas. Quantas caixas de sapatos Josué organizou?

Essa experiência ocorreu com a utilização de papel quadriculado, assim, demarcavamse as linhas na horizontal e na vertical, encontrando o resultado, no caso das professoras. Contudo, com os alunos, aconteceu algo que já tínhamos discutido e as professoras anteciparam que poderia ocorrer: os alunos se deram conta de que se resolvia pela multiplicação, mas o formato da figura retangular foi diferente, ao considerarem na vertical as fileiras e na horizontal as caixas, sem a interpretação do empilhamento (um sobre o outro).

Então a professora fez a seguinte provocação: "Vocês sabem o que quer dizer, quando se fala em terreno 10 por 15 ?" Quase que como um coro os alunos responderam: "É 10 metros de frente por 15 de fundo". A professora pediu para que alguém fosse ao quadro mostrar como era que se registrava. Um aluno foi ao quadro e registrou: "10 X 15m" e fez um desenho de um retângulo com um dos lados maior - na vertical. Então, a professora desenhou ao lado um retângulo em que o lado maior era na horizontal e escreveu as medidas de 15 metros (de frente) e 10 metros (de fundo) e novamente perguntou à turma: "Não são os 
mesmos números?" Eles deram as seguintes respostas: "É diferente, porque o quintal não

pode ser menor..."; "É, geralmente a medida da frente é menor que a do fundo"; "E tem mais... se for do seu jeito, a planta da casa tem que ser toda diferente".

A discussão dessa situação-problema foi de uma riqueza tamanha, porque os alunos demonstraram dominar bastantes conhecimentos com essa atividade, falaram sobre medida, planta (construção) e noção de espaço e cálculo de medida de área. Então, chegamos à conclusão que não se tratava de resolver uma operação, mas de fazer a leitura e a interpretação do contexto. Talvez essa dificuldade tivesse acontecido porque utilizamos um exemplo que não fizesse muito sentido (organizar sapatos), a não ser para quem trabalha em loja de calçados, que não era o caso naquela turma. Cabe lembrar que as atividades foram vivenciadas em todas as etapas, mas, em algumas, com grau de complexidade diferente, fosse com valores mais baixos ou com enunciados reduzidos, mas sempre com a mesma finalidade.

\section{- DIVISÃO PELA PARTILHA - repartir uma quantidade entre grupos.}

Situação-problema 1: Uma empresa de panfletagem quer contratar você e vai lhe entregar 24 vales-transportes. Se você usar 2 por dia, em quantos dias você usará todos os vales?

Situação-problema2: Na Semana Santa, um comerciante entrega cesta básica para famílias carentes. Neste ano, ele entregou 300 cestas para 150 famílias. Quantas cestas básicas cada família recebeu?

Uma característica do conceito de repartir é que no divisor tem um tipo de elemento que é diferente do que existe no dividendo, e a resposta no quociente será com o mesmo elemento do primeiro fator, ou seja, ELEMENTOS $\div$ GRUPOS = ELEMENTO. Entretanto vale destacar que o sentido de partilha só é aconselhável quando o divisor é um número natural e, ao conceber desse modo, recebe a denominação de divisão por distribuição. No caso do primeiro exemplo, os alunos resolveram sem complicações, mas, no segundo, interpretaram que a quantidade que deveriam dividir era muito grande. Então foi lançado o seguinte desafio: "Imagine que você tivesse 300 reais e resolvesse colocar 150 reais em cada envelope. Quantos envelopes você teria que usar? Ou melhor, se fosse uma compra de 300 reais e você decidisse que queria pagar em parcelas de 150 reais?”. Nessa proposição apareceu um novo conceito, qual seja, o de medida.

- DIVISÃO COMO MEDIDA - formar grupos com quantidades já determinadas; ou ainda saber quantas vezes o divisor cabe dentro do dividendo.

Retomamos o exemplo anterior (do valor da compra) para trabalhar o conceito de medida, ou seja, já tínhamos um valor (300) que utilizaríamos para formar grupos (?) com a 
quantidade já determinada (150). Assim, temos a seguinte representação: ELEMENTO ELEMENTO = GRUPOS. Em nossa análise, não interpretamos essa ação da professora como algo negativo, pois observamos a capacidade e a criatividade na utilização de um novo contexto, inclusive mobilizando novo conceito, rompendo com a visão tradicional de que na escola só há privilégio para a divisão enquanto partilha, distribuição. Outra forma de reconhecer a ideia de divisão como medida é classificá-la como divisão por formação de grupos.

A divisão e a multiplicação estão dentro do mesmo campo conceitual porque permitem a construção de estratégias variadas para resolver diferentes problemas, e podemos percorrer caminhos inversos para chegar a um resultado comum. Em suma, todas as ações envolvendo adição, subtração, multiplicação ou divisão, foram iniciadas com situações-problema mais simples e depois avançamos para outras mais complexas a fim de favorecer a utilização de procedimentos em que os alunos pudessem superar as expressões como: "vai um", "pede emprestado", "abaixar o próximo número", porque eram verbalizações recorrentes quando estávamos em sala de aula e até mesmo durante as rodas de conversa. Esses modelos tradicionais errôneos foram paulatinamente sendo substituídos por conhecimentos acerca de agrupamento, composição e decomposição.

Outro ponto positivo foi a valorização do diálogo, do cálculo mental e oral, permitindo o registro dos processos de resolução, quebrando o silêncio que muitas vezes ocorre nas aulas de Matemática. Na concepção de Pais (2013, p. 44), "valorizar a argumentação oral não é uma estratégia comum no ensino da Matemática; pelo contrário, predomina uma prática voltada mais para o silêncio do que para o diálogo". Essa afirmação fez um reflexo da realidade educacional que acontece em toda modalidade de ensino no Brasil. Nesse sentido, tanto as formações quanto as aulas não priorizaram apenas o raciocínio formal, este não foi o princípio nem a finalidade última das ações desenvolvidas, mas foi um campo fértil para aprendizagens múltiplas de professoras, alunos e da pesquisadora. Também não queremos dizer que tudo o que realizamos resolveu os problemas vividos por professores e alunos na sua integralidade, porque isso seria negar os obstáculos didáticos e as fragilidades conceituais que se assemelharam ao que denominamos situações-limite.

O detalhamento dessas experiências com alunos e professoras foi para justificar como chegamos à primeira categoria de nosso trabalho, a partir da relação com as participantes da pesquisa que se lançaram no movimento de "sonhar, estudar e criar" (FREITAS, 2001), mergulhando nos campos conceituais para explicarem seus modos de construir o conhecimento continuamente. Algumas falas denunciaram as situações-limite e já sinalizaram 
o anúncio dos inéditos-viáveis e, com o movimento de idas e vindas, foi se constituindo o conteúdo principal das unidades de análise.

Quadro 6: Aprendizagem como processo contínuo e inconcluso

Trechos das falas das professoras participantes

Rosa: Os próprios alunos já estavam INTERPRETANDO os textos com as próprias palavras e isso foi fantástico, porque DESMISTIFICA um pouco essa coisa de interpretação textual, pois, como eles já estavam bem ENVOLVIDOS com a temática, o resultado foi positivo.

Rita: É essa coisa da significância né. Tudo é mais SIGNIFICATIVO. Tudo fica MAIS FÁCIL. Até pra gente que PRECISA ESTUDAR mais pra ensinar [...].

Rute: Os alunos APRENDEM MAIS QUANDO MANIPULAM MATERIAL concreto e quando trabalham em equipe. Mas isso até com a gente acontece porque duas cabeças pensam melhor juntas.

Raquel: Eles INTERAGEM tanto que até perguntaram sobre informações que eles não entendiam direito. Eles estavam se ESFORÇANDO mesmo PARA ENTENDER, então, eu acho que veio PRA ACRESCENTAR até na questão da linguagem.

Leitinho: Eu pensei que não dava para trabalhar todo o conteúdo do currículo, mas fomos PERCEBENDO que as atividades continham informações sobre sistema monetário, medidas, as quatro operações, composição e decomposição, e tudo sempre ESTIMULANDO a escrita.

Fabí: A construção e o desenvolvimento de todas essas atividades foram importantes, mas acho que ainda faltou mais tempo para CONSOLIDAÇÃO de alguns conceitos.

Fonte: arquivo da pesquisadora extraído dos diálogos gravados nas formações.

A saber, utilizamos duas estratégias para analisar a fala das professoras quando denunciam as situações-limite, anunciam os inéditos-viáveis e, nesse movimento, anunciam novas situações-limite. Os trechos em caixa-alta referem-se ao que denominamos unidades de análise. Todavia, antes disso, resgatamos um episódio ocorrido em sala de aula, envolvendo o diálogo entre professora e aluno, e de outro lado a ansiedade e emoção desta pesquisadora. Engendramos esse contexto para compreender como as ações estavam sendo percebidas e experienciadas pelas professoras enquanto agentes de aprendizagem. Então, vamos ao episódio?

Aluno V: Como faço pra calcular quanto tempo faz que cheguei em Brasília?

Professora Rosa: Em que ano você chegou em Brasília?

Aluno V: Em 1977.

Professora Rosa: Nós estamos em qual ano? 
Aluno V: 2015.

Professora Rosa: Então, vamos escrever o ano que estamos e o ano que você chegou em Brasília. (Registrando no quadro um ano ao lado do outro). Que operação devemos fazer?

Aluna J: Uma conta de mais.

Rejane: Uma conta de mais? (Perguntei admirada e pronta para interferir).

A professora rápida e sabiamente faz a mediação.

Professora Rosa: Vamos tentar para ver se é mesmo uma adição?

A professora registrou 2015 na primeira parcela e 1977 na segunda parcela e o sinal indicativo da adição (+), resultando em 3.992.

E o aluno ficou admirado com o total e fez um gesto reprovativo com a cabeça.

Professora Rosa: E aí pessoal, há quantos anos nosso colega mora em Brasília?

Aluno V: Nossa, mas isso aí não tá certo! Não é conta de mais!

Professora Rosa: Por que não é adição?

Aluno V: Porque eu não tenho mais de três mil anos que moro aqui. Isso nem é idade ...

(falou sorrindo). A conta é de menos.

A professora voltou para o quadro e falou:

Professora Rosa: Pessoal, o ano de 1977 está para frente ou para trás?

Alunos: Pra trás. (responderam em coro).

Professora Rosa: Isso mesmo. Está para trás porque já passou. Então, qual ano devemos registrar primeiro?

Aluno V: $O$ 2015, porque é o ano que estamos.

E a professora registrou 2015 na primeira parcela e 1977 na segunda parcela e o sinal indicativo da subtração (-), resultando em 38.

Aluno V: Agora essa conta tá certa. Falta mesmo dois anos pra completar quarenta anos que eu moro no DF. Eu só não sabia era fazer essa conta. (Falou sorrindo).

É salutar pontuarmos que a situação-problema poderia ter sido resolvida pela adição sim, bastaria ter utilizado o conceito de completar, o que teria surgido naturalmente se o contexto envolvesse manipulação de dinheiro. Apesar de não ter emergido nesse diálogo, já esteve presente em outros episódios que já citamos anteriormente. Voltando a esse exemplo, a adição seria possível se conservássemos o ano 1977 e a ele pudéssemos adicionar um ano, mais um ano e mais outro, até que chegássemos a 2015, ou de modo mais rápido, se contássemos mais dez anos e mais dez... até chegar no total, e o aluno encontrasse como resultado "38 anos". Entretanto isso não interferiu na riqueza de aprendizagens possível por causa da relação dialógica.

Naquele contexto dialógico, a professora então fez a seguinte mediação: 
Professora Rosa: Não é difícil, mas é preciso ter atenção para interpretar as informações.

Na maioria das vezes, a gente pergunta: "Quanto tempo faz que fulano mudou, ou morreu, ou aposentou ou quando nasceu [...]". Assim, se você disser que nasceu em ano tal, é só pegar o ano que estamos - que no caso é 2015 - e subtrairmos o ano em que você nasceu. Outro exemplo, se você começou a trabalhar em 1982 em uma empresa e saiu de lá em 2012 [...], então é só registrar sempre a data mais atual e retirar a data mais antiga que você encontra a resposta. Mas também você pode escrever a idade mais antiga e ir somando mais um ano e mais um, até chegar na data atual. Entenderam?

Esse episódio foi muito marcante porque eu estava na sala de aula, acompanhando as atividades e um aluno fez esse questionamento para a professora, e a trama do diálogo deles me oportunizou um grande aprendizado. Na ocasião, tive uma reação de rejeição da resposta do aluno quando ele disse que se resolvia com a conta de mais, e quase interrompi aquele momento rico de aprendizagem. Porém a professora brilhantemente fez a mediação e, sem criticar ou apontar erros, deixou que o próprio aluno percebesse o caminho percorrido para chegar ao resultado, que era consequência de seu pensamento, de seus procedimentos. Se a professora tivesse reagido como eu e já antecipado que o procedimento não era aquele, o aluno não teria sido oportunizado de perceber, sozinho, que usar a operação da adição era inviável para resolver aquela situação. O sorriso do aluno, ao final, não foi de vergonha ou decepção, mas de orgulho pela descoberta, pela aprendizagem, por sanar sua curiosidade.

Em muitos outros episódios, os alunos apresentam uma fala própria em que reconhecem as operações como contas "de mais", "de menos", "de vezes" e "de dividir". Mas a professora sem tentar corrigi-los nem obrigá-los a usar a terminologia matemática, se reportou a cada uma das operações aritméticas como adição, subtração, multiplicação e divisão. No episódio que descrevemos foi interessante também que a professora procedeu na operação utilizando o conceito de retirar. Mas depois que o aluno expressou seu raciocínio "falta mesmo dois anos pra [...]", a professora ampliou o conhecimento do campo aditivo.

O aluno mobilizou o conceito-em-ação de completar, que já era comum em sua prática cotidiana. Ainda, nesse raciocínio, o teorema-em-ação utilizado previu as adições sucessivas para chegar ao resultado, neste caso, foi para confirmar um total que já sabia. Percebemos esse fato com a utilização do adjetivo "mesmo" que denota a ideia de confirmação de algo.

Conciliável, atenta e sensível ao conceito mobilizado pelo aluno, a professora retomou com outros exemplos utilizando tanto o conceito de retirar quanto o de completar para mostrar outras possibilidades de se resolver uma subtração, como se pensássemos na seguinte situação: "Você vai comprar um quilo de carne vermelha que custa $\mathrm{R} \$ 18,00$. Paga com uma nota de $\mathrm{R} \$ 50,00$. Quanto receberá de troco?" 
Em nossa análise, nem professor nem aluno faz esse cálculo pegando 50 e retirando 18 (como é feito na escola), tampouco alguém tira papel e lápis do bolso para realizar um cálculo tradicional com uma parcela sobre a outra. O que se faz é buscar o meio mais eficiente que é utilizar-se do conceito de completar: conservo o 18 adiciono mais 2 que totaliza 20, daí calculo que para 50 faltam 30, assim, o resultado é $\mathrm{R} \$ 32,00$ de troco. Ou fazemos melhor: arredondamos, como se a nossa conta fosse 20, aí guardamos 2 na cabeça e sabendo que sobra 30, adicionamos aqueles dois (que ficaram aguardando). Também poderíamos resolver utilizando a calculadora que há em nossos aparelhos celulares para efetuar os cálculos que seriam mais rápidos e precisos.

Reforça essa ideia "o seguinte princípio fundamental de Ausubel: o fator isolado mais importante influenciando a aprendizagem é aquilo que o aprendiz já sabe. Determine-se isso e ensine-o de acordo" (MOREIRA; MASINI, 2001, p. 94). Desse modo, se valorizarmos aquilo que o aluno já domina, estamos por reconhecer que a disposição para a aprendizagem é muito maior, porque já existe um conhecimento disponível que precisará ser ampliado. Isso também acontece com professores que desafiados a pensar sobre os processos de aprendizagem também são oportunizados de olhar para seu modo próprio de aprender.

Se compararmos a afirmação das professoras, no início de nossos encontros, que a maior dificuldade em relação à Educação Matemática era trabalhar todo o conteúdo do currículo por causa da falta de tempo, podemos observar um avanço significativo quanto à superação desse ponto de vista. O conteúdo da fala das professoras denuncia algumas situações-limite que são tanto de alunos como delas e esse ato de denunciar é um pré-anúncio das possibilidades, pois vejamos o sentido que deram à experiência dessas atividades.

Postulamos que, para chegarmos à primeira categoria a qual denominamos Aprendizagem como processo contínuo e inconcluso, levamos em consideração a interpretação do sentido que as professoras deram à aprendizagem. Primeiramente pelo seu caráter contínuo, por isso, destacamos as palavras que foram ditas no gerúndio: interpretando, esforçando, estimulando, percebendo. Tais enunciados trazem um sentido de algo que está acontecendo no presente e que parece não ter interrupção.

Assim, quando anunciam que os alunos "já estavam interpretando", podemos analisar que a utilização do advérbio "já” sinaliza que agora os alunos conseguiam fazer interpretação, ou seja, antes das ações que desenvolvemos os alunos não conseguiam interpretar textos, mas essa situação-limite foi superada. Para essa superação, foi necessário que as professoras oportunizassem os alunos de realizarem atividades com enunciados, a fim de que mobilizassem leitura, interpretação e registro. De partida quando a professora diz que isso 
"desmistifica" o fato de pensarem que não seria possível o aluno passar de uma condição de "não capaz”, ela assume, mesmo que indiretamente, uma concepção própria que foi superada.

Quanto à utilização do termo "esforçando" que se refere ao aluno que estabelece uma relação com os enunciados para que estes passem a ser familiar ao contexto matemático na escola. Isso porque era uma prática comum nas aulas a utilização de operações apenas com algarismos e sem textos, especialmente porque as professoras assumiram que alguns alunos ainda não sabiam ler e escrever. No entanto Soares $(2004,2014)$ e Fonseca $(2004,2005$, 2013 , 2014) têm defendido que isso não é justificativa para professores se esquivarem de proporcionar condições de letramento para esses alunos, tendo em vista que o cotidiano é marcado por um mundo letrado e não se pode negar essa prática em sala de aula. Nesse contexto, a condição de não letramento foi superada pelo favorecimento de ambientes e situações que envolviam e valorizavam o letramento.

As palavras "percebendo" e "estimulando" fizeram parte de um mesmo enunciado em que a professora assumiu abertamente que foi possível trabalhar os conteúdos matemáticos na perspectiva da conexão de saberes, e que estes estabeleceram relação indissociável com a escrita. Nesse sentido, nossa análise permitiu conjecturar evidências de que também eram situações-limite a não crença na possibilidade de relacionar dois ou mais campos de saberes. Pois se levarmos em consideração o início de sua fala em que disse "eu pensei que não dava [...]" e a continuação do pensamento com a conjunção adversativa "mas fomos percebendo", percebemos uma mudança na postura epistemológica quando vislumbra a possibilidade do aluno enquanto ser-mais que aprende continuamente.

Ainda em diálogo com as professoras quanto à avaliação das ações e às impressões em relação à aprendizagem, destacamos, em suas falas, as palavras "estudar”, "entender", "acrescentar", “consolidar" porque todas apresentaram uma característica em comum: são verbos usados no infinitivo, ou seja, não dão indicação de temporalidade. Nesses casos, analisamos do ponto de vista da aprendizagem também como um processo inconcluso, que não faz o recorte temporal para acontecer. Esse é um dos princípios da Teoria dos Campos Conceituais que defende que a aprendizagem não é instantânea, pelo contrário, ocorre a partir de um longo período de tempo, e depende de uma vasta rede de situações e conceitos.

Essa possibilidade de estudar é assumida pela professora quando percebe que as situações-problema contextualizadas apresentam mais significado não só para o aluno, mas também para o próprio professor que "precisa estudar mais pra ensinar". Esse reconhecimento não é apenas para elaborar enunciados com contextos próprios da modalidade 
EJA, mas especialmente porque é necessário proporcionar diferentes situações a fim de que se possa mobilizar diferentes conceitos.

Então, se, por um lado, percebemos a superação de uma situação-limite, por outro vemos anunciar outra situação-limite que encontra a possibilidade no ato de estudar. Indissolúvel, "a posse de habilidades que tornam possível a aquisição, retenção e aparecimento de conceitos na estrutura cognitiva, é que capacitará o indivíduo a adquirir significados" (MOREIRA; MASINI, 2001, p. 15). Nesses termos, a produção de um inéditoviável aparece como potencializador para a criação de novas situações-limite, uma vez que a geração de inéditos gera maior capacidade de leitura crítica do sujeito e estimula a esperança de transformar seu mundo. Ele se descobre como autor, por isso constrói a aprendizagem significativa.

Seguindo esse mesmo raciocínio, as palavras "entender" e "acrescentar" aparecem como se quisessem reforçar que o aluno está apresentando um rendimento, um desenvolvimento favorável à aprendizagem, pois o seu esforço se dava porque ele começou a sentir autonomia nos processos de construção do conhecimento. Se os alunos estavam entendendo, isso representava um acréscimo, uma ampliação no processo cognitivo relacionado ao aprender. $\mathrm{O}$ sentido de nossa análise que as professoras sentiam a sensação de estarem no caminho certo, porque as ações desenvolvidas envolveram uma diversidade de conceitos que contribuiu para acrescentar não apenas os conhecimentos dos alunos, mas contribui para o repertório teórico-conceitual de sua própria profissão.

Por outro lado, o verbo "consolidar" apareceu com uma conotação diferente, porque seu enunciado foi de que "faltou tempo para consolidar alguns conceitos". Essa afirmação demonstra a capacidade intelectual da professora em reconhecer que a contribuição foi importante, mas que é necessário retomar conceituações importantes não apenas para que os alunos exercitem, mas para permanecerem no movimento próprio de estudar e criar estratégias e possibilidades de ser-mais, para realizar mais.

Temos presente que analisamos a formação como um processo permanente, histórico e inconcluso que precisa ser reinventado continuamente, porque "é na inconclusão do ser, que se sabe como tal, que se funda a educação como um processo permanente" (FREIRE, 1996, p. 58). Se, por um lado, a construção e o desenvolvimento de tais ações favoreceram a constituição de inéditos-viáveis, por outro, criou expectativas e encontrou obstáculos repercutidos na inconclusão de que ainda era necessário mais estudo e mais ação.

Em linhas gerais, para promover essa aprendizagem, o conhecimento matemático não pode e nem deve estar esvaziado da linguagem e do contexto porque também é isso que vai 
fazer com que a Matemática tenha sentido. Os conteúdos matemáticos foram trabalhados sempre em conexão com outros saberes com os quais os alunos não apresentaram dificuldade. A dificuldade existiu no momento de escrever os enunciados e inicialmente na interpretação destes porque não eram atividades com as quais tivessem familiaridade na escola. Contudo, à medida que se identificavam com o contexto das situações-problema, ficavam "bem envolvidos", tudo ficava "mais significativo" porque eles conseguiam resolver, utilizando estratégias próprias, portanto era "mais fácil". Segundo as professoras, desse modo eles "aprendem mais", "interagem", porque se reconhecem, o contexto é familiar, especialmente porque, nesses casos, utilizamos a manipulação das cédulas e moedas que trazem uma carga sociocultural, contribuindo para a aprendizagem significativa.

Em todo o planejamento de nossas ações, buscamos não impor nossa vontade e nosso jeito de operar, por mais que fosse uma "prática automatizada". Nosso desafio era romper com o "narcisismo pedagógico" (MUNIZ, 2014), em que o professor é o centro do processo de ensinar e, como detentor de conhecimento exige respostas como se fosse seu próprio espelho, com seu jeito de pensar, com os mesmos procedimentos, com esquemas e registros iguais aos seus. Assim, tivemos o cuidado de pensar em questões que trouxessem certa familiaridade no contexto dos alunos, por isso, eles mobilizaram procedimentos variados para chegar aos resultados, seja pela adição ou subtração, pela multiplicação ou divisão.

Para Ausubel (1968 apud MOREIRA; MASINI, 2001, p. 23), a aprendizagem significativa pressupõe que:

a) o material a ser aprendido seja potencialmente significativo para o aprendiz, ou seja, relacionável a sua estrutura de conhecimento de forma não-arbitrária e não-literal (substantiva);

b) o aprendiz manifeste uma disposição de relacionar o novo material de maneira substantiva e não-arbitrária a sua estrutura cognitiva.

Em nossos momentos nos círculos de investigação formativos, discutimos acerca do envolvimento e esforço que os alunos tinham para realização dos procedimentos que ocorreu por causa de seu caráter não arbitrário, tão necessário quanto importante para o desenvolvimento de outras aprendizagens. Por isso, o educando interagia com as situações propostas, relacionando os conhecimentos armazenados aos novos, ampliando-os.

O diferencial foi que os alunos foram encorajados a argumentarem e exporem seus modos singulares de produção de conhecimento, realizando as atividades em dupla ou trio (conferindo certa segurança na troca de saberes e na validação de pensamentos e ações), comunicando aos demais alunos a resposta a qual chegavam e registrando no quadro os procedimentos operatórios. Além disso, as atividades impressas tinham tamanho de letra 
grande, de modo a garantir a acessibilidade e a inclusão, principalmente porque lidamos com muitos idosos que apresentavam problema na visão.

O processo de construção de conhecimentos e de conceitualização não é linear nem segue regras. É complexo, moroso e dialético, apresenta avanços e recuos, continuidade e estagnação. Porém nem por isso é inválido ou inviável, pelo contrário, reside aí sua força e potencial para a aprendizagem significativa e, nesse sentido, para transformar sonhos em realidades, é a própria constituição dos inéditos-viáveis por todos os envolvidos.

\subsection{Construir conceitos envolve diálogo e ação que gera aprendizagens coletivas}

A Educação Matemática tem papel social importante, qual seja, favorecer o desenvolvimento muito além das habilidades de leitura e escrita, mas ampliar "possibilidades de leitura do mundo para as quais conceitos e relações, critérios e procedimentos, resultados e culturas matemáticas possam contribuir" (FONSECA, 2004, p. 13). Nesse sentido, foi que escolhemos como recorte para a segunda categoria de análise as ações que envolveram o sistema de medidas, tendo por ponto de partida medida de comprimento, mas estendendo-se na perspectiva da conexão de saberes.

É um privilégio trabalhar essa perspectiva no espaço da modalidade EJA, porque a utilização de questões contextualizadas e problematizadoras têm contribuído para a constituição/desocultação de inéditos-viáveis em um universo mais amplo, tanto em relação aos conteúdos matemáticos quanto em relação ao envolvimento de todos (professoras, alunos e pesquisadora). Adotar o letramento como elemento de construção é considerar um conjunto de possibilidades para romper com o ensino da Matemática enquanto método de transmissão de conhecimentos e inaugurá-lo como processo de análise de situações-problemas.

Segundo Soares (2004), o letramento constitui as práticas sociais na área da leitura e da escrita que estão muito além do domínio do sistema alfabético e ortográfico. Dito de outro modo, as práticas de letramento dão sentido às próprias práticas sociais dos sujeitos, isto implica que mais importante do que grafar letras/ palavras e números, o que é mais necessário e urgente é trabalhar o sentido que estes assumem no contexto social do adolescente, do jovem, do adulto e do idoso.

Compatível com nossa proposta formativa, em nossos círculos de investigação, buscamos sempre problematizar situações para que as professoras se sentissem provocadas a mobilizar conhecimentos matemáticos a fim de resolver e superar as situações-limite. Foram 
estratégias importantes de estudo, de formação e de investigação, que não se tornaram incólume à concepção freireana, porque estivemos comprometidos com

\footnotetext{
a formação com educadores/as, visto que contribuem para que os mesmos percebam que, a medida que assumem uma postura investigativa na relação com suas experiências, reúnem melhores condições para lidar com os limites que cotidianamente se apresentam (FREITAS, 2014, p. 61).
}

Corroboramos com a autora quando explicitou que a formação com os professores (em nosso caso as professoras) contribui para a adoção de postura investigativa, pois também defendemos que não deve ser encarado como um fardo ou trabalho a mais, ao contrário, pode ser tomado como exercício permanente de uma práxis na perspectiva emancipadora. Entretanto essa mesma postura torna-se inviável se a formação incidir sobre os professores, porque daí estaríamos nos reportando a um conjunto de normas já estabelecidas às quais caberia ao professor apenas se adaptar. Doravante, nossas formações caminharam na direção sinalizada pela autora, enriquecida pela ação dialógica, provocadora de inquietações, investigação e constituição de possibilidades que foram os inéditos-viáveis.

Como as professoras, no exercício de denúncia das situações-limite (FREIRE, 2011), trouxeram à tona as dificuldades curriculares em termos de delimitação ou priorização de conteúdos, então continuamos provocando-as a pensar sobre os rumos que tomariam para ensinar e os caminhos para aprender. Nesse sentido, problematizamos: Como abordar outros conteúdos além das operações? É possível trabalhar outros conhecimentos na perspectiva da conexão de saberes e do letramento?

Quando se tratava de operações, por exemplo, as professoras concordavam que a dificuldade dos educandos não residia em "fazer contas", mas em realizar a leitura e a interpretação de situações-problemas, pois eles costumam calcular de cabeça, fazem até operações bem complexas. Essa dificuldade costuma ocorrer, segundo Fonseca (2004, p. 22), porque "na vida e na escola, as pessoas parecem ter sido treinadas para execução de tarefas pré-definidas, mas não para análise de situações [...]”.

Por essa razão, nos permitimos ousar com atividades que contribuíssem para romper com essa situação-limite, então, desenvolvemos ações envolvendo conceitos de medidas de comprimento, dentro do eixo Grandezas e Medidas, na perspectiva da conexão de saberes e do letramento. Para isso, utilizamos como material de apoio a indicação dos eixos de conteúdo do PNAIC/Matemática (BRASIL, 2014), o Currículo em Movimento para a EJA (DISTRITO FEDERAL, 2014), o Módulo IV de Matemática e Cultura: Decimais, Medidas e 
Sistema Monetário (MUNIZ; BATISTA; SILVA, 2008) e as leituras sobre letramento (FONSECA, 2004; SOARES, 2014).

A título de provocação, perguntamos às professoras se tinham o hábito de fazer pedido em revistas de consultoria. Elas confirmarem que faziam pedido em revistas. Então interrogamos: O que costumam pedir? O que é importante observar quando se vai fazer pedido em revista? Algumas respostas foram: "pedimos objetos de uso pessoal e utensílios de casa. O que levamos em consideração é o preço, necessidade, utilidade, tamanho e qualidade". Então, lançamos o desafio para que as professoras simulassem que queriam fazer o pedido de uma bolsa na revista. Para isso, solicitamos que escolhessem a bolsa e a reproduzisse.

Os materiais para a confecção da bolsa foram disponibilizados: TNT (tecido não tecido) de cor vermelha e verde, linha e agulha, tesoura, fita métrica e revista de pedidos. Solicitamos que realizassem a atividade em duplas. Elas escolheram a bolsa, observaram a ilustração, realizaram a leitura das informações incluindo as medidas, cortaram o TNT e começaram a costurar, mas não tiravam o olho do trabalho das outras duplas e faziam comparações. Enquanto isso, gravamos o diálogo entre elas, desde as negociações de como realizar os procedimentos até sua validação conjunta. Ao final, solicitamos que cada dupla trocasse as bolsas para verificar se a medição estava de acordo com a indicação das medidas disponíveis na revista.

Figura 8: Bolsa da revista e bolsas vermelhas confeccionadas pelas professoras

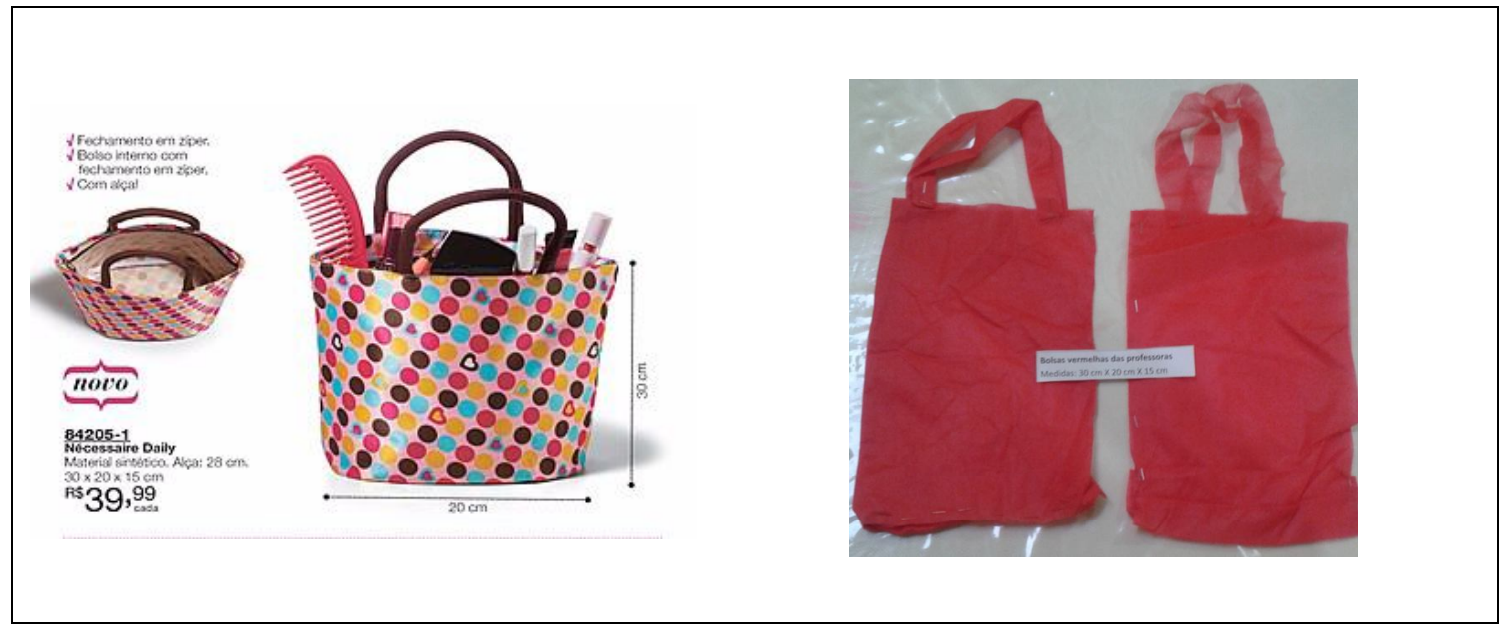

Fonte: arquivo da pesquisadora. 
Essas duas bolsas vermelhas foram confeccionadas por duas duplas de professoras, e, por terem o mesmo modelo (da ilustração à esquerda), resolvemos deixá-las juntas nesse arquivo. As medidas envolvidas foram: $30 \mathrm{~cm}$ X $20 \mathrm{~cm}$ X $15 \mathrm{~cm}$.

Figura 9: Bolsa da revista e bolsa verde confeccionada pelas professoras

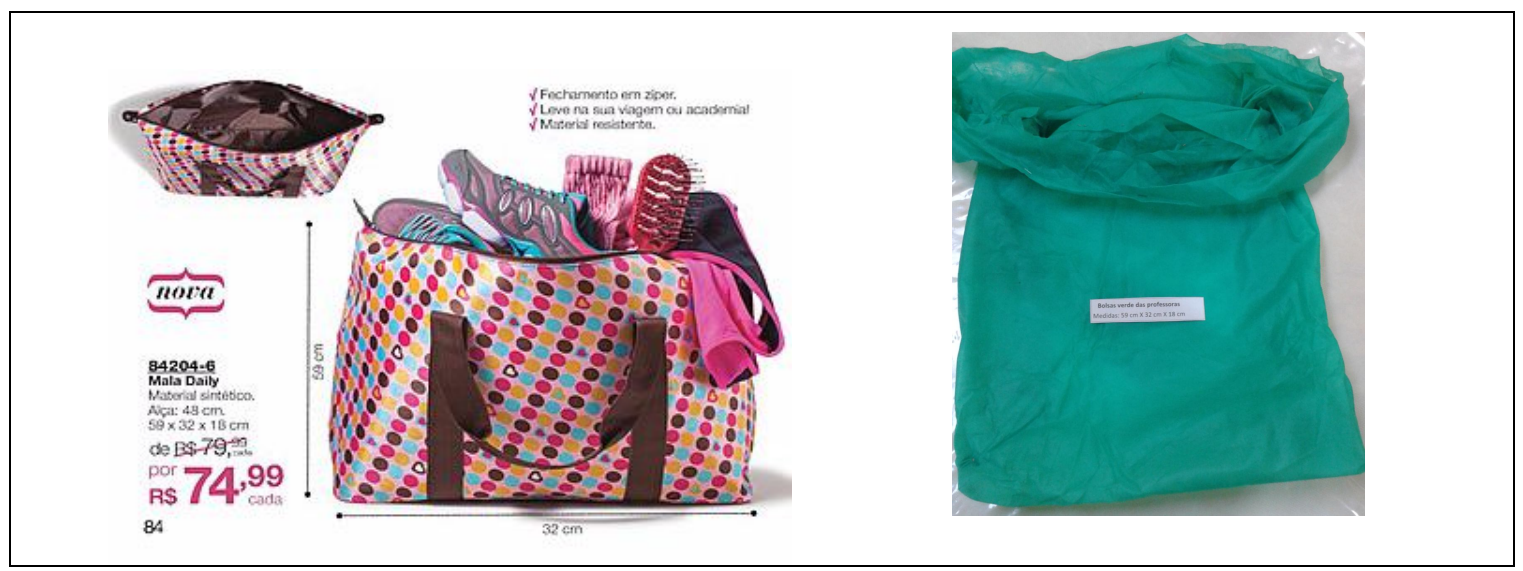

Fonte: arquivo da pesquisadora.

Uma terceira dupla de professoras confeccionou essa bolsa verde e utilizaram como modelo a ilustração à esquerda. As medidas envolvidas foram: $59 \mathrm{~cm} \mathrm{X} 32 \mathrm{~cm} \mathrm{X} 18 \mathrm{~cm}$.

Nossos alinhavos foram feitos com interlocuções acerca da confecção das bolsas, tais como: Que conhecimentos matemáticos estavam envolvidos? Que conceituações matemáticas tiveram que ser mobilizadas para a construção da bolsa? Quais as dificuldades para a realização dessa atividade? É uma atividade válida para trabalhar com os alunos da EJA? Mudariam algo na atividade? E o trabalho em dupla contribuiu para a realização da atividade?

Em nossa análise, essa foi mais uma atividade significativa porque tínhamos a intenção de provocar a mobilização de conceitos e conhecimentos matemáticos, a fim de que as professoras percebessem o conjunto de informações e possibilidades para serem exploradas além das operações aritméticas. Quanto às provocações, pontuamos as falas das professoras acerca da experiência.

\section{- Quanto ao conteúdo e aos conhecimentos matemáticos mobilizados, disseram}

Todas: MEDIDAS DE COMPRIMENTO.

Rute: DIMENSÃO.

Leitinho: Fizemos a LEITURA DA INFORMAÇÃO. O que tinha de informação na revista: as dimensões da bolsa e a UNIDADE DE MEDIDA, que era o centímetro, a medida da alça bem pequenininha. E têm também os NÚMEROS. 
Rita: A medida de comprimento em que usamos a fita métrica para demarcar a largura, a altura e o fundo da bolsa.

Rosa: Tinha GEOMETRIA também, no formato da bolsa. Envolve formas. A bolsa não está fotografada de frente. Só mostra o lado, foi fotografada de PERSPECTIVA. Aí a gente vê nitidamente uma PROFUNDIDADE.

Raquel: Olhando na ilustração o que CABIA DENTRO da bolsa, já dava uma ideia do TAMANHO da bolsa.

Fabí: E tem mais, eu sei que meu PALMO tem 20 centímetros, então, como a medida era 30 por 20 por 15 centímetros, então eu já tinha uma ideia de que um dos LADOS DA BOLSA seria um palmo e meio, a outra dimensão seria um palmo certinho e a outra - que seria o fundo - daria menos de um palmo. Mas depois era só conferir com a fita métrica. Tem também medida de CAPACIDADE.

Em uma análise prévia, observamos que as professoras conseguiam enxergar outros saberes que se conectavam no ensino da Matemática, isso implicava aprendizagens mais amplas. Assim, mobilizavam conhecimentos que, além de medidas arbitrárias (como o palmo), também instigava a utilização da unidade legal de medida - tendo por referência o metro, mas necessariamente usando o centímetro. Concordamos que para medir é necessário ter um rigor, conforme alerta Muniz, Batista e Silva (2008, p. 69) é preciso "juntar a extremidade do objeto a ser medido com a extremidade do instrumento de medida". Que nesse caso seria colocar a extremidade do TNT junto à extremidade da fita métrica.

A ideia de medida estava clara quando se falou em "cabia dentro da bolsa", pois o conceito de medida reside no entendimento de caber, de contar (quantas vezes, ou quantos objetos cabem na bolsa). Mas também se refere a comparar e, nesse caso, houve a comparação com o palmo da mão, além disso, na hora da confecção da bolsa, as professoras olhavam a bolsa do outro grupo, comparando, mas também tentado validar sua ação, a partir da interação com o outro.

Outro destaque que damos é para as falas das professoras que ensinam Língua Portuguesa porque interagem com a Matemática e não se esquecem de citar a importância da "leitura da informação" como ponto de partida para interpretar a situação a fim de resolvê-la. Essa é a demonstração de como são favoráveis as condições de letramento para compreender melhor o contexto e interagir nele.

\section{- Quanto às dificuldades}

Rosa: A bolsa saiu muito diferente da ilustração, porque na ilustração a bolsa PARECE MUITO MAIOR e até o FORMATO É DIFERENTE dessa aqui. 
Rute: ESSA ILUSTRAÇÃO SÓ SERVIU PARA ATRAPALHAR. E se os nossos alunos fossem fazer essa atividade, eles teriam dificuldade por causa da ilustração da bolsa.

Raquel: Os nossos alunos conseguiriam fazer uma bolsa, mas só se dessem a imagem correta ou só as medidas, porque muitos iriam DESCONSIDERAR AS MEDIDAS.

Rita: Por causa da ilustração, achamos que a bolsa vermelha seria MAIS LARGA.

Leitinho: A bolsa ficou muito diferente da imagem, mas geralmente na REVISTA VEM A INFORMAÇÃO "imagem meramente ilustrativa".

Fabí: Não tenho habilidade de corte e costura. Só consegui fazer a atividade porque tive ajuda da minha colega.

Leitinho: Só teríamos dificuldade se não tivesse o material para produzir.

A maioria das dificuldades relatadas pelas professoras tem relação com um conhecimento matemático acerca de escala, isto é percebido quando apareceram os enunciados sobre a bolsa: "parece muito maior", "formato diferente", "mais larga". Isso mostrou que as professoras mobilizaram saberes que se chocaram, porque envolvia a relação entre a área real (as medidas expressas em centímetros) e sua representação (a ilustração), que é o que entendemos por conceito de escala.

Quando pontuaram "essa ilustração só serviu para atrapalhar", ficou nítido que a utilização da gravura impressa na revista causou certo impacto, durante a realização dos procedimentos e ao final deles, porque foi tomado como elemento de referência. Então, dialogamos sobre esse possível impacto para as pessoas (adolescentes, jovens, adultos e idosos) ao se perceberem em situações de compra, como pedido de revista em que tomam como referência um objeto ilustrativo para fazer o pedido. Ao passarem por essa experiência, poderão viver um conflito no ato do recebimento do objeto que é "diferente do objeto real" aquele projetado em suas cabeças sob a influência da ilustração.

Nesse contexto sociocultural, será que os alunos da EJA têm o cuidado de verificar as dimensões dos objetos pedidos, ou se baseiam pela imagem, às vezes ampliada, haja vista que se trata de um texto de propaganda para conquistar clientes? A quais informações se apegam para comprar um objeto que não está materializado como em uma loja física, por exemplo?

As professoras afirmaram que os educandos levariam em conta a imagem e não teriam a preocupação ou até o conhecimento acerca das medidas de certos objetos. Por outro lado, uma das professoras destacou geralmente "na revista vem a informação" que se trata de uma foto ilustrativa, ou seja, mostra até o modelo, as cores, as dimensões, mas não o tamanho real. Contudo temos dois possíveis agravantes: um grupo de pessoas que tem conhecimento e 
habilidade da leitura, mas optam por não ler, e outro grupo não faz a leitura das palavras ou textos porque não domina.

No contexto descrito, vale destacar o que Soares (2014, p. 58) vem nos alertando quanto às condições de letramento "que nosso problema não é apenas ensinar a ler e a escrever, mas é, também, e sobretudo, levar os indivíduos - crianças e adultos - a fazer uso da leitura e da escrita, envolver-se em práticas sociais de leitura e de escrita". Por isso, é importante, promovermos essa condição, pois, assim como a autora, concordamos que não podemos negar essa prática social por considerar que está em determinado nível além da capacidade intelectual de qualquer pessoa. Além, disso, defendemos a ideia de que todas as pessoas têm potencial para a aprendizagem, embora necessitando de diferentes tempos para que aconteça tal aprendizagem.

\section{- Quanto à validade e a organização da atividade}

Raquel: Nós começamos a cortar e depois costuramos, mas só depois nos demos conta de que faltava o fundo da bolsa, porque NA REVISTA ESTÁ MOSTRANDO TRÊS MEDIDAS e nós só usamos duas, a largura e o comprimento da bolsa e aí tivemos que corrigir.

Rosa: A atividade nos ensina e ensinará ao jovem e ao adulto a NÃO SER MAIS ENGANADO, PORQUE A GENTE APRENDE A PRESTAR ATENÇÃO, a medir. Mas o aluno precisa ficar atento e medir de verdade e não ficar preso à ilustração da revista.

Rita: É por isso que tem gente que faz pedido em revista e DEPOIS RECLAMA QUE NÃO ERA DAQUELE TAMANHO, porque vê uma imagem diferente do objeto real. E eu fiquei mesmo com vontade de pedir essa bolsa da revista só pra ver e conferir esse tamanho.

Fabí: É tudo muito válido, mas acho que NÃO VAMOS TER TEMPO PARA CONCEITUAR TUDO, porque aí trabalho essa atividade, mas depois tenho que passar outras atividades para FIXAR O CONTEÚDO e para trabalhar o conceito. Mas o bacana de construir a bolsa é porque não envolveu só medidas nem só geometria, envolveu outros conteúdos matemáticos.

Leitinho: Achei importante porque NÓS MOBILIZAMOS VÁRIOS CONHECIMENTOS MATEMÁTICOS, em relação aos mesmos conteúdos.

Rute: Essa é uma ação com MUITOS CONHECIMENTOS ENVOLVIDOS e que aparecem de modo bem claro. Não precisamos trabalhar esses conteúdos separados. É muito legal isso. E também É LEGAL ESSE TEMPO QUE ESTAMOS TENDO PARA ESTUDAR E DISCUTIR ESSES ASSUNTOS PARA MELHORAR NOSSO TRABALHO, porque eu sinto falta de fazermos uma coordenação juntas.

Analisando as contribuições das professoras, percebemos, na primeira fala, a mobilização de conhecimento sobre figura bidimensional na construção da bolsa em que assumiram que só usaram duas medidas (largura e comprimento). Depois de costurada a bolsa, perceberam que faltava a medida referente ao fundo, ou seja, a figura era 
tridimensional. Então, reelaboraram o trabalho, dando ênfase ao processo de significação da atividade, porque mobilizaram conceituações diversas, quando elas mesmas perceberam que faltava um elemento importante, uma medida fundamental que envolvia o conceito de caber.

A atividade trouxe contribuições acerca do conhecimento matemático e também pode contribuir para as práticas sociais que, por um lado, auxilia no processo de medir e, por outro, nos alerta para que estejamos atentos ao que é veiculado nas propagandas, nas revistas, nos folhetos de supermercados; pois, no caso das bolsas, os números disponíveis acompanhados da unidade de medida são as informações que darão mais precisão da dimensão e do formato daquele objeto e não a imagem que o ilustra.

A ação de confeccionar a bolsa e perceber os conhecimentos matemáticos mobilizados foi fundamental para rompermos com a visão fragmentada de que os conteúdos devem ser trabalhados em caixinhas. Contudo não elimina todas as situações-limite presentes, como percebemos na fala da professora ao dizer "não vamos ter tempo para conceituar tudo" porque é necessário trabalhar outras atividades "para fixar o conteúdo". A preocupação sinalizada aponta para algo que alertamos anteriormente que é o entendimento da importância de usar a conceitualização no processo de aprendizagem, levando em consideração sua morosidade e complexidade, conforme alertou Pais (2013, p. 122):

A complexidade é muito mais ampla do que de uma definição, pois conceituar não é uma ação localizada como a expressão ou um registro linguístico. Conceituar exige muito mais do que definir. Em termos de tempo, a conceitualização é muito mais demorada que a aprendizagem ou a memorização de uma definição. O domínio de um nível conceitual passa pelo domínio de sua definição, mas vai além.

O autor trouxe uma questão importante para pensarmos: conceituar e definir são instâncias diferentes. Quanto a isso, ao nos lançarmos no desafio dessa formação, nossa proposta já pré-anunciava uma possibilidade, um sonho possível que podemos ver materializado na fala da professora, quando se inquieta com a possibilidade (trabalhar conceitos) e o limite (tempo disponível), dialeticamente. Por outro lado, foi notória a manifestação das demais professoras ao se perceberem mobilizando conhecimentos e conceitos e proporcionando essa experiência aos educandos, porque assumem seu compromisso com a educação-formação. Isso demonstrou que o sonho não foi apenas de uma pesquisadora, mas passou a ser um sonho coletivo que, por sua natureza de constituição, com planejamento, com decisões coletivas e ações coordenadas, tornou-se campo fértil para o anúncio de inéditos-viáveis.

Em linhas gerais, a atividade de confecção da bolsa contribuiu para mobilização de conceitos matemáticos e, por meio das trocas dialógicas, as professoras descobriram que 
havia possibilidade de trabalhar os conhecimentos matemáticos propostos no currículo. A atividade contextualizada ajuda tanto para situar o aluno da EJA como também para envolvêlo, haja vista que se trata do reflexo de sua realidade. Exemplo disso foi simular uma prática comum, como é o caso de fazer pedido em revista.

Desse modo, aquilo que se mostrava como situação-limite (trabalho só com operações) foi cedendo lugar aos inéditos-viáveis (a possibilidade de explorar outros conteúdos e de mobilizar vários conhecimentos), na perspectiva da conexão de saberes e do letramento. Vale ressaltar que os círculos investigação formativos tiveram importante contribuição para o processo formativo, porque foi um espaço conquistado dentro da escola para estudar e planejar as ações para a EJA. Compatível com isso é o reconhecimento da professora quando disse "é legal esse tempo que estamos tendo para estudar e discutir esses assuntos para melhorar nosso trabalho". Nesse trecho, a professora não só explicita a satisfação de estudar os conteúdos e os conceitos que os envolvem, mas a possibilidade de organizar o espaço de tempo que favorece o trabalho coletivo.

Nessa perspectiva, todas as ações depois de realizadas com as professoras eram adaptadas e realizadas em cada turma, no entanto nosso grupo optou por realizarmos um trabalho integrativo, reunindo todas as turmas (de $1^{\mathrm{a}}$ a $4^{\mathrm{a}}$ etapa) em um mesmo espaço a fim de iniciarmos o trabalho com o conteúdo medida de comprimento.

De partida, primeiro conversamos sobre como os alunos reagiriam com a proposta de juntarmos as turmas. Quanto a isso, as professoras disseram: "vai ser uma oportunidade de troca que a escola não tem o costume de promover" (RITA); "acho que vai gerar muito aprendizado" (RUTE); "e também o fato de estarem em outro ambiente diferente da sala de aula pode ser um diferencial até pra eles se soltarem e produzirem" (ROSA). A justificativa para essa decisão foi para oportunizar a comunicação e troca de saberes entre pessoas de diferentes idades e níveis de ensino, a fim de favorecer a promoção de uma aprendizagem significativa para grupos maiores.

O segundo ponto foi planejar como desenvolveríamos essa ação. As professoras concordaram que seria interessante começarmos resgatando os conhecimentos prévios que os alunos tinham sobre medida de comprimento, para ampliarmos o conceito de grandezas e medidas. Então, foi proposto que usássemos como estratégia inicial o estudo das medidas arbitrárias, ou seja, os sistemas de medidas não precisos utilizados historicamente, como passadas, palmos, braça. Tínhamos presente que precisávamos nos preparar, estudar, discutir 
e ampliar os conhecimentos em torno do sistema de medidas. Por isso, buscamos os livros adotados na modalidade EJA, organizados em três volumes ${ }^{18}$.

Entretanto as professoras já haviam adiantado que quase nunca os utilizavam porque o material era condensado com todas as disciplinas, além de não dispor de contextos que favoreciam e valorizavam a realidade dessa modalidade. Então, adotamos como referencial teórico para organizarmos os conteúdos o material do PNAIC/Matemática (BRASIL, 2014) e o Módulo IV de Matemática e Cultura: Decimais, Medidas e Sistema Monetário (MUNIZ; BATISTA; SILVA, 2008), que traz uma contextualização importante sobre grandezas e medidas baseado em 12 princípios fundamentais ao desenvolvimento do trabalho pedagógico. Para isso, providenciamos instrumentos de medidas, como régua, trena, fita métrica e até o metro (confeccionado em cartolina), que foi doado para cada aluno.

Decidimos juntar as turmas na sala onde funciona a segunda etapa. Reunimos um conjunto de quatro mesas com os grupos em volta e deixamos que os próprios alunos se engajassem na equipe de sua escolha. O diálogo estabelecido em sala de aula iniciou com o resgate da história das medidas arbitrárias que, concomitantemente, correspondia ao resgate das histórias e tempos de vida dos senhores e das senhoras que estudam na EJA. Eles tomaram a palavra porque tinham vivência e conhecimento sobre passadas, braças e falavam também em léguas, ao se referir à distância que percorriam quando moravam em seus municípios de origem. Logo apareceram também medidas de área e superfície, como hectare, alqueire que utilizavam, principalmente, para medir terrenos com as plantações, as roças.

Depois de longo diálogo e histórias de vidas, as professoras perguntaram como eles costumavam medir as coisas na atualidade e a unanimidade falou que usa o metro. Então a professora Rute perguntou se os alunos tinham uma percepção da medida de um metro e pediu para que os alunos mostrassem com os braços, e eles abriram bastante os braços. Então a professora relatou a prática usual dos tradicionais vendedores de tecidos que faziam uma medição aproximada de um metro, utilizando como referência a distância entre o ombro esquerdo e o polegar direito (tendo o braço direito estendido na horizontal). Os alunos quiseram conferir a medida, a professora distribuiu o metro que confeccionamos em cartolina e eles ficaram admirados com a descoberta.

Depois dessa prévia, outros instrumentos de medidas entraram em cena como régua, trena, fita métrica e o metro (confeccionado em cartolina) - todos em quantidades suficientes

\footnotetext{
${ }^{18} \mathrm{O}$ volume 1 traz, em duas páginas, a abordagem sobre o metro, seus múltiplos e submúltiplos; o volume 2 aborda em dez páginas o conteúdo de medida de comprimento, de perímetro, de área e de superfície, mas não dá ênfase para as medidas arbitrárias; o volume 3 dedica uma página para a medida de comprimento e inicia medindo a cabeça de uma formiga vermelha.
} 
para os grupos utilizarem. Cada grupo foi sorteado com algo para medir na sala de aula (mesa do professor, colega de classe, porta, janela, armário, quadro branco e uma folha de caderno); de acordo com o que precisavam medir, escolhiam o instrumento mais adequado para realizar a medição. Depois de medir, eles teriam que anotar e escrever no quadro o nome do objeto medido e o registro de sua medição, sendo que outro grupo precisava conferir se a medição estava correta desde o intervalo numérico à grandeza utilizada (centímetro ou metro).

A saber, todas as vivências matemáticas foram realizadas com as professoras na ocasião de nossos círculos de investigação formativos e, quando estudávamos e planejávamos medidas de comprimento, as participantes já anteciparam o que aconteceria com os alunos: ao solicitar que medissem, alguns iriam considerar apenas uma dimensão para medir e exemplificaram, por exemplo, que, ao medir a mesa do professor, levariam em conta o comprimento e a largura, mas não fariam a medição da altura do móvel. Na prática isso se confirmou e no quadro foi feito uma grande tabela com essas medidas, tanto para visualização de todos os grupos, como também para auxiliar no registro escrito.

Durante a atividade, as professoras fizeram a mediação explicando que podemos verificar as dimensões de comprimento, largura e altura de objeto, pessoas, lugares. Em alguns casos, também se pode medir a espessura e a gramatura (exemplo: no caso do papel, para se referir à grossura, à densidade), contudo nesse exemplo as unidades de medida já não seriam centímetro e metro, mas outras menores que seriam exploradas em outra ocasião.

Consultando o material do PNAIC/Matemática (BRASIL, 2014, p. 26), caderno 6 de Grandezas e Medidas, “o 'tamanho' de cada dimensão é mensurado pela mesma grandeza”, ou seja, todas as dimensões se medem pelo comprimento, mas, para cada tamanho, se dá um nome específico. Nesse sentido, ao medir, fazemos a comparação entre grandezas de mesma natureza, isto é, verificamos quantas vezes uma grandeza "cabe" dentro da outra. Assim, se tomamos como grandeza o comprimento e utilizamos, por exemplo, a fita métrica para medir a mesa, então temos que saber quantas vezes o comprimento da mesa corresponde ao comprimento da fita métrica.

Na sequência, a professora Rosa chamou a atenção para a grafia da palavra comprimento que era diferente de cumprimento e perguntou o que significava cada uma. Os alunos souberam responder, afirmando que um era de medida e o outro era "de dizer oi para alguém". Observamos aqui um jeito próprio de expressar aquilo que sabe, quando pretendia responder que cumprimento grafado com "u" referia-se à saudação. A professora Rosa, sem corrigi-los, ampliou esse conhecimento, escrevendo que comprimento com "o" referia-se a 
uma grandeza que expressa a distância entre dois pontos, enquanto que cumprimento grafado com "u" estava relacionado a cumprir (com compromisso) ou saudar alguém.

Quando voltamos para nossos círculos de investigação formativos, dialogamos sobre como foi importante e significativo a professora Rosa (de Língua Portuguesa) ter aproveitado a oportunidade para fazer essa contribuição. Isso mostrou mais uma vez o engajamento e a sintonia das participantes na pesquisa e o papel do letramento que ganhou visibilidade dentro do processo formativo, pois, como já temos afirmado, nosso compromisso não é apenas grafar letras e números, mas fazer emergir seus significados no processo de aprendizagem. É nesse contexto que temos nos dado conta do quanto os inéditos-viáveis são possíveis quando da adoção de nova postura pedagógica-formativa-investigativa, no movimento pela práxis emancipadora.

Engendramos esse entendimento para dar sequência às atividades do encontro posterior, em que tínhamos a proposta de confecção da bolsa pelos alunos. Todavia, antes, algumas precauções foram tomadas como: pensar em um local na escola que tivesse espaço o suficiente para reunirmos todas as turmas, que disponibilizasse mesas para sobrepor os materiais, organizar material em número suficiente para a confecção das bolsas, pensar sobre uma quantidade de participantes por grupo e planejar os objetivos específicos para a ação. Por apresentar essas características, as participantes falaram que as mesas da sala de aula e a própria sala de aula seria pequena para a realização da atividade.

Era momento oportuno para explorarmos outros espaços na escola, por isso as professoras propuseram o refeitório como o espaço ideal, porque só era usado para uma única finalidade, para que os alunos realizassem suas refeições. $\mathrm{O}$ espaço amplo e arejado dispunha de 14 metros de largura por 17 metros de comprimento e não era cercado de paredes, mas por grades, favorecendo a ventilação. Além disso, havia várias mesas com aproximadamente três metros de comprimento cada uma (eram mesões). As professoras providenciaram rolos de TNT, levamos linhas, agulhas e tesoura sem ponta. Entramos em consenso que a agulha não representaria risco para os alunos, tendo em vista que a maior parte é composta de adultos e mulheres (que provavelmente já teriam hábito de manusear agulha).

Então, fomos adiante com a ideia, comunicamos à direção da escola e aos funcionários responsáveis pela limpeza e pelo lanche que utilizaríamos o espaço do refeitório das 14h (horário do início da aula) às $16 \mathrm{~h} 10$, porque o horário do intervalo era às $16 \mathrm{~h} 30$. Então, chegamos cedo, deixamos uma pequena distância entre as mesas para que os alunos pudessem se organizar em grupos a fim de desenvolvermos as atividades. Enquanto isso, as professoras ficaram nas salas aguardando os alunos e avisaram que juntaríamos as turmas no refeitório, e 
quanto a isso houve aceitação plena. Durante a realização da atividade, as professoras e os alunos autorizaram o registro com filmagem e fotografias, os quais utilizamos na etapa posterior, quando voltamos para discutir e avaliar as ações.

No refeitório, as professoras orientaram para que os alunos sentassem em qualquer mesa e escolhessem qualquer grupo para realizar uma atividade. Na sequência, já iniciaram com questionamento para saber se eles tinham hábito de fazer pedido em revista, em qual tipo de revista e que mercadorias compravam. Tínhamos um grupo grande, formado em sua maioria por mulheres que afirmaram gostar de fazer pedidos, confirmaram ter uma revista de preferência e as mercadorias que mais pediam eram: perfumaria, maquiagens, utensílios de casa e materiais de uso pessoal como bolsa, sandália e roupa.

Os materiais para a confecção da bolsa foram distribuídos entre os grupos, e professora Rosa foi a responsável por fazer as orientações quanto ao desenvolvimento da atividade e propôs que folheando a revista escolhessem uma bolsa como se quisessem comprá-la. Depois de escolhida a bolsa, poderiam utilizar o material para reproduzi-la. Enquanto isso, as professoras faziam a mediação nos grupos e a pesquisadora filmava as ações e as negociações entre os integrantes e algumas situações mereceram ser destacadas. Então, para descrever os episódios, usamos as iniciais dos nomes dos alunos. No grupo 1, o Aluno L mostrou-se indiferente, de braços cruzados, dizendo que costurar era atividade de mulher. Entretanto, ao perceber que as mulheres do seu grupo, ao usarem a fita para medir, não estavam considerando a medida do fundo, resolveu intervir e participar.

Aluno L: Vocês não estão vendo: falta o fundo da bolsa! O fundo não é mole. O fundo da bolsa é mais durinho.

Aluna J: É assim mesmo menino!

Aluno L: Vão fazendo aí que vou dar um jeito. (O aluno saiu do refeitório e quando retornou trouxe um pedaço de caixa de papelão, fez a medição, cortou e colocou no fundo da bolsa).

Aluno L: Olha aí a diferença. Agora eu me zanguei (falou sorrindo), a nossa bolsa vai ser a mais bonita daqui.

Aluna J: Agora eu gostei. Trabalho em conjunto é assim, cada um dá uma opinião e todo mundo trabalha.

Aluno L: É, mas vamos medir esse negócio direito (pegando a fita e conferindo as medidas).

Os alunos de outros grupos começaram a olhar o trabalho do grupo 1, então, o grupo 2 e o grupo 5 pediram um pedaço do papelão para fazer também o fundo da bolsa, porque para eles essa medida precisava estar evidente. Surge aqui a ideia de figura bidimensional e 
tridimensional que para o aluno precisava estar visível, por isso usaram o papelão no fundo da bolsa, a fim de se aproximar da imagem de bolsa já armazenada na mente.

Em nossa análise, observamos não apenas o envolvimento para confeccionar a bolsa e mobilizar os conhecimentos acerca da medida de comprimento, mas também o empenho do grupo em customizar a bolsa, deixá-la bonita e, nesse caso, não se apegaram à ilustração (como supunham as professoras). Como muitas falas captadas durante a filmagem: "vamos caprichar na bolsa"; "acho que a nossa vai ser a mais bonita de todas"; "gente, não é pra caprichar só na beleza não, viu! Tem que ficar na medida certinha"; "olha professora, como a nossa bolsa tá ficando show!'. (Essa palavra show até aparece na bolsa do grupo 5).

Foram falas recorrentes nos seis grupos, em que homens e mulheres se engajaram, dividiram tarefas e trabalharam em equipe. Contudo trabalhar em equipe representa lidar com opiniões diferentes e exige que o grupo entre em consenso, o que inicialmente comprometeu o grupo 3 no qual ficou concentrado as mulheres mais idosas (tinha uma de cada etapa de ensino), que não conseguiram entrar em acordo quanto às medidas. Cortaram e mediram várias vezes e não chegavam a um consenso, porque uma aluna do grupo era costureira e tinha uma opinião de acordo com sua experiência, que era o caso da Aluna MS. Por isso, trouxemos também o diálogo do grupo 3, porque discutimos acerca dos conhecimentos mobilizados, gerados em meio a afirmações e negações das integrantes daquele grupo.

Aluna MS: Gente, não vamos nos importar com o desenho, tem que fazer o molde de acordo com as medidas.

Aluna RO: Tá vendo que cortando desse jeito é muito diferente da foto!

Aluna VA: Enquanto vocês brigam, o nosso trabalho vai ficando pra trás, porque todo mundo já tá fazendo.

Aluna C: Mas nós já cortamos e medimos de novo. Estamos só desperdiçando [...]

Aluna RO: Então faz aí do jeito que vocês sabem. Mas a nossa bolsa vai ser a mais feia! (olhando as demais bolsas dos grupos).

Aluna MS: Mas se a medida tá aí e nós já conferimos. (balançava a cabeça discordando da fala da Aluna RO).

Aluna C: Eu tô costurando aqui, quem vai fazer as alças? Olha que bonita a alça da bolsa marrom ali. (falando da bolsa do grupo 6).

Aluna RO: E tá colorida. Acho que vou fazer um laço de outra cor pra enfeitar a nossa bolsa. (se dirige ao grupo 1 para pedir um pedaço de TNT azul).

Como podemos perceber, a Aluna MS mobiliza um conceito que é familiar ao mundo das costureiras ou dos artesãos, quando fala em "fazer o molde" e vai afirmando que a bolsa precisava ser construída com base nas medidas, independentemente da ilustração que estava 
na revista. Enquanto que a Aluna RO se apegava à imagem da revista para comparar com o formato e, além disso, observava as bolsas dos grupos ao redor e também comparava com a de seu grupo, afirmando que seria a mais feia. As demais alunas se importavam em dar coesão ao grupo, chamando a atenção para o trabalho coordenado, conforme os demais grupos. O que nos sugeriu pensar que a aprendizagem coletiva também se dá em meio a negações, no diálogo entre os diferentes, mas não antagônicos.

Os dois episódios que descrevemos trazem não apenas sinais da mobilização de conhecimentos, mas também imprimem um cenário em que estão envolvidos cognição, afetividade e subjetividade. Nesse contexto, concordamos com Fávero (2007 apud FÁVERO; NEVES, 2013, p. 320):

[...] o desenvolvimento do adulto apresenta fases e essas fases são caracterizadas pela união entre o aspecto cognitivo e o afetivo, entre o self e o outro. O adulto é, portanto, um construtor ativo de verdades múltiplas e polissêmicas: ser adulto significa estar em desenvolvimento no universo do desenvolvimento do pensamento coletivo $[\ldots]$.

O tema candente nos traz aspectos importantes para pensarmos como a pessoa adulta constrói sua aprendizagem que não é no isolamento, mas na mediação do outro, mesmo que esse outro tenha pensamentos e procedimentos diferentes, porque é possível mediar pelo diálogo. Envolver os aspectos cognitivos diz respeito aos conhecimentos mobilizados no cenário coletivo, que muitas vezes pode estar conturbado, mas ainda têm pessoas dispostas a devolver a harmonia ao trabalho - envolve, portanto, aspectos subjetivos e afetivos.

Nas produções de cada grupo, percebemos como se empenharam não apenas em medir corretamente, mas também se esforçaram para deixar cada bolsa esteticamente mais bonita, utilizando o próprio TNT fizeram tranças, laços, flores e bolsos como ornamentação. Ao final da atividade, foi solicitado que eles escrevessem o nome dos integrantes da equipe e colocassem com a revista dentro da bolsa para que identificássemos os artistas (modo como os denominamos). Na sequência, solicitamos que eles trocassem as bolsas com outros grupos, a fim confirmarem as medidas e depois retomassem as bolsas para os grupos de origem. Foi uma maneira de validação em que descentralizamos a função do professor de avaliar e validar a construção dos alunos e deixamos que eles mesmos realizassem essa etapa.

Eles espalharam as bolsas sobre as mesas e, observando as medidas impressas na revista, foram medindo a largura, o comprimento e o fundo da bolsa, atentos aos detalhes, como se estivesse realizando o papel de avaliador da atividade. Para essa etapa, os alunos também negociavam, dialogavam e conferiam, até chegar à conclusão de que a bolsa atendia 
às medidas ou se aproximava (centímetros a mais ou a menos) daquelas medições descritas nas revistas.

Figura 10: Bolsas confeccionadas pelos alunos da EJA em grupos

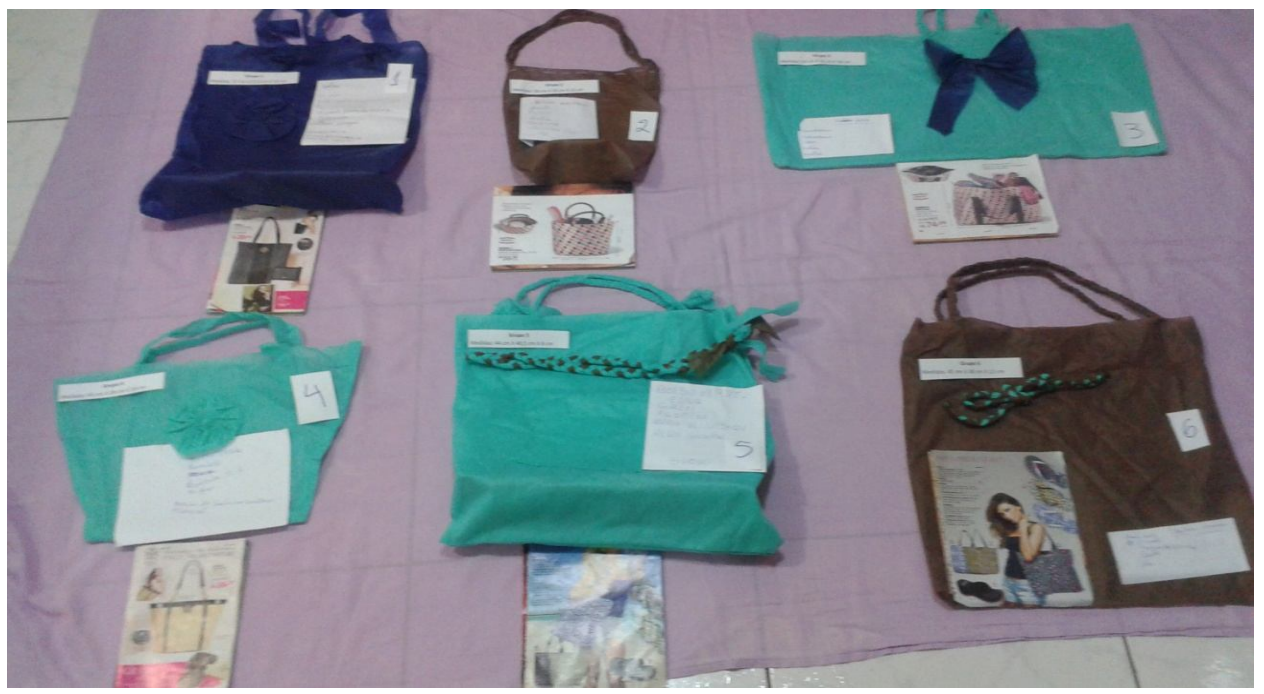

Fonte: arquivo da pesquisadora.

Como fechamento, solicitamos que todos os grupos sentassem virados de frente para os outros grupos e apresentassem a bolsa que haviam construído, simulando que queriam vender a bolsa que era referente àquela revista. Esse momento de socialização entre os grupos foi semelhante a "um desfile de modas", pois os alunos mostravam orgulhosos suas bolsas, com exceção do grupo 3 que expressou insatisfação porque a bolsa não ficou como as dos outros grupos. De acordo com a Aluna RO: "não ficou bonita". Contudo os demais colegas levantaram a autoestima do grupo 3 dizendo que o mais importante era fazer a bolsa na medida certa.

O objetivo da atividade era mobilizar os conhecimentos referentes à medida de comprimento, bem como favorecer um contexto de aprendizagem significativa, em que eles ficariam mais atentos para medir os produtos a fim de saber se atendiam às suas necessidades. Nesse sentido, os alunos avaliaram a atividade e como ponto positivo destacaram: "a partir de agora, temos que ter mais atenção na hora de comprar qualquer mercadoria, porque temos que medir"; "esse lugar aqui foi bacana porque as mesas são bem grandes e foi melhor para cortar o tecido"; "também foi bom trabalhar com os colegas das outras turmas, porque dividimos as tarefas". A saber, os alunos não manifestaram os pontos negativos da atividade. 
Nossa análise quanto ao feedback dos alunos foi devido à experiência de estarem em outro ambiente com uma proposta diferente de realmente construir alguma coisa que não fosse para ocupar o tempo, mas que, por trás da atividade em si, havia um objetivo maior: tratava-se de uma dimensão social e política que era conhecer para não ser enganado.

Figura 11: Bolsas confeccionadas e apresentadas pelos alunos da EJA

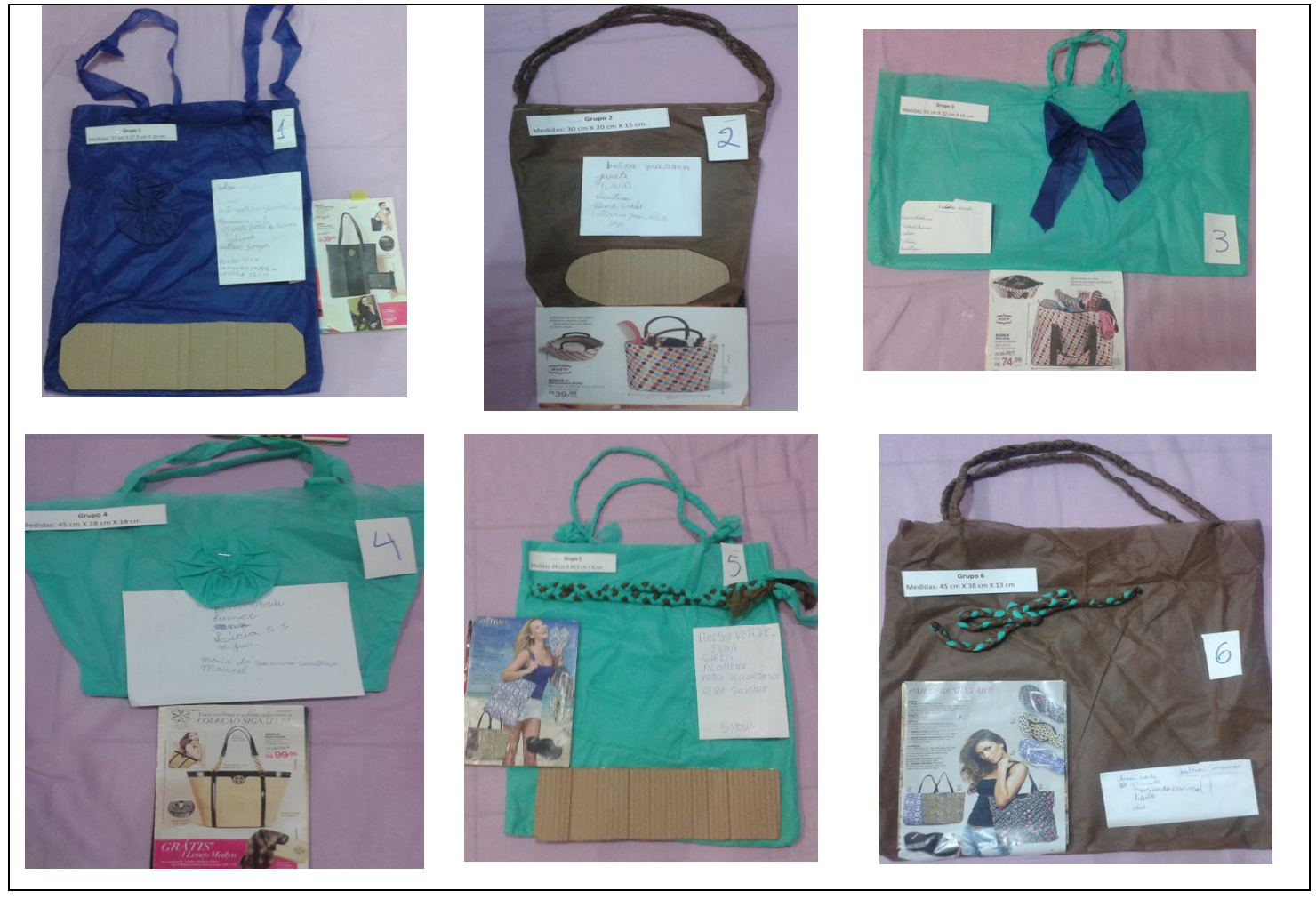

Fonte: arquivo da pesquisadora.

Quando voltamos para nosso círculo de investigação formativo, discutimos quanto de conhecimento os alunos mobilizaram, o engajamento na atividade, os consensos e dissensos, a importância do letramento para leitura das informações contidas na revista, esses percebidos foram reiterados pela análise das fotos e da filmagem. O sentido dado pelas professoras foi que o conhecimento matemático é muito mais abrangente, em comparação ao que se exige no currículo escolar, por ser um conhecimento que ajuda na vida cotidiana.

As professoras falaram da autonomia dos educandos para tomar decisões, da importância de explorar outros ambientes, da contribuição do trabalho em grupo, do quanto é importante promover diferentes situações de aprendizagem. Também destacaram que a aprendizagem diária tem sido de cada uma delas que se percebem construindo significados na 
prática, porque se envolvem no estudo e na discussão sobre os conhecimentos, em especial da Matemática em relação com outros saberes. Tais concepções foram instigadoras de um diálogo mais profícuo, conforme os trechos das falas registradas nas análises a seguir.

Quadro 7: Aprendizagem como processo de construção coletiva e formativa

\section{Trechos das falas das professoras participantes}

Rosa: $O$ fantástico é perceber que A MATEMÁTICA ESTÁ EM TUDO. Aí percebemos que ESSES CONHECIMENTOS SÃO MESMO PRA VIDA, e que não serve só para tirar nota na prova. Mais uma coisa, ESSA FORMAÇÃO AQUI É TÃO DIFERENTE DAS OUTRAS que já participei porque as coisas ficavam só no blá blá blá e ficava por isso mesmo. Mas essa aqui não, NÓS VIVENCIAMOS, NÓS ENTENDEMOS, TEM SIGNIFICADO E TEM FEITO A DIFERENÇA.

Rute: Eu ESTOU REPENSANDO MUITO A MINHA PRÁTICA, PORQUE EU TINHA FALADO QUE NUNCA DAVA PRA CHEGAR EM GEOMETRIA E NUNCA DAVA PRA CHEGAR EM FRAÇÃO. ENTÃO, AGORA VI QUE DÁ PRA TRABALHAR TUDO ISSO AÍ. Posso começar com as operações e aí vou avançando, fazendo uma interlocução. Não preciso terminar um conteúdo pra começar o outro. Posso ir fazendo a relação com medidas, com geometria, do jeito que diz a conexão de saberes. Por isso quero agradecer porque ESSAS FORMAÇÕES TEM SIDO UM APRENDIZADO em tanto.

Rita: Puxa, dá pra estudarmos muitos conteúdos em uma mesma atividade. Achei muito interessante porque TAMBÉM FOGE DAQUELE JEITO DE DAR AULA E FICAR ESCREVENDO O TEMPO INTEIRO. Os alunos se cansam e nós também nos cansamos, mas, às vezes, estamos tão acostumados com isso que PARECE DIFÍCIL DE ROMPER. MAS É POSSÍVEL. A gente viu na prática que é possível. E tem mais uma coisa, eu NÃO TENHO VERGONHA DE DIZER QUE EU ESTOU APRENDENDO MATEMÁTICA com essas experiências. Eu gosto e quero é aprender mesmo porque eu ainda tenho quatro anos pela frente, antes de aposentar, e eu preciso aprender porque eu tenho prazer em trabalhar tudo isso. A GENTE TEM TANTOS PERCALÇOS E DIFICULDADES, ENTÃO, A GENTE TEM QUE APROVEITAR ESSAS OPORTUNIDADES, a gente tem que ser feliz.

Leitinho: Essas formações e as atividades nos ajudam a DESPERTAR A CURIOSIDADE, é um conhecimento válido e necessário.

Fabí: Trabalhar em dupla ou em grupo é sempre bom porque CADA PESSOA TEM SEU DOM, SUA CAPACIDADE E SEU CONHECIMENTO e aí há a OPORTUNIDADE DE TROCA DESSAS EXPERIENNCIAS.

Raquel: Com certeza é uma prática que ENRIQUECE NOSSO TRABALHO e que faz sentido trabalhar com os alunos. A GENTE AMPLIA O MODO DE VER E IMAGINAR A MATEMÁTICA porque veja só, utilizamos uma revista de pedidos e simulamos uma situação que faz parte da vida do aluno e olha quanto conteúdo matemático está envolvido!

Fonte: arquivo da pesquisadora extraído dos diálogos gravados nas formações.

O hiato da pesquisa residiu na constituição dos inéditos-viáveis pelas professoras em processos de formação continuada na escola e sua mobilização foi possível a partir do reconhecimento e da denúncia das situações-limite que, por sua vez, foram instigadas pelas provocações dialógicas. Assumir a existência desses obstáculos para trabalhar com o ensino 
de Matemática representou a abertura para a possibilidade de aprendizagens significativas que contribuísse para o desenvolvimento de uma práxis emancipadora. Tal concepção foi apresentada pelas participantes da pesquisa em um contexto de discussão sobre os avanços e as fragilidades das nossas ações no primeiro segmento da modalidade EJA, que se traduzem em "Aprendizagem como processo de construção coletiva e formativa".

Olhar "tudo" e enxergar a Matemática ou pela lente da Matemática compreender o mundo pode não ser apenas um trocadilho, se analisarmos o sentido atribuído pelas professoras a partir do olhar sobre as ações teorizadas no campo da Educação Matemática. Se buscarmos a fala da professora Rosa, teremos indícios da superação de uma postura conservadora adotada na escola, ligada ao paradigma do exercício. Esse paradigma, na visão de Skovsmose e Alre (2010, p. 52), “diz respeito à organização das aulas, aos padrões de comunicação entre professor e alunos, bem como ao papel que a Matemática desempenha como um todo, por exemplo, com uma função fiscalizadora".

Tal visão se mostra superada pela professora Rosa quando reconhece a validade dos conhecimentos matemáticos que "não serve só para tirar nota na prova". Na mesma direção, a professora Rute expressou que o modo como concebia o ensino da matemática não oportunizava de estabelecer conexões com outros saberes como a geometria e as frações. Essa "certeza" já estava tão arraigada ao seu modo de pensar a Matemática, como podemos notar quando usou o termo "nunca", demonstrando um discurso carregado de negatividade e descrença, especialmente por ter provindo de uma cultura que valoriza os exercícios e a memorização no trato com as questões matemáticas.

As falas das professoras Rita e Raquel também sinalizaram essa Matemática enrijecida em que se prevalece a educação bancária na qual o "educador sendo sujeito, conduz o educando à memorização mecânica do conteúdo" (FREIRE, 2011, p. 80). Essa prática vai sendo paulatinamente substituída, e as professoras abrem espaço para o protagonismo dos alunos no processo de aprender, conforme explicitado por Rita: "também foge daquele jeito de dar aula e ficar escrevendo tempo inteiro". Mas o emprego do verbo fugir anuncia a decisão por uma postura pedagógica e epistemológica com caráter intencional em detrimento de uma educação narradora, dissertadora.

Essa ideia de educação dissertadora foi criticada por Freire (2011, p. 80), uma vez que "uma das características desta educação dissertadora é a sonoridade da palavra e não a sua força transformadora. Quatro vezes quatro, dezesseis; Pará, capital Belém, que o educando fixa, memoriza, repete, sem perceber o que realmente significa quatro vezes quatro". Em outras palavras, a crítica do autor foi, na verdade, um repúdio às práticas esvaziadas de 
sentido, tendo o aluno como mero expectador e o professor que alimenta uma relação de verticalidade no ensino, constituindo o que Freire (2011) denominou educação bancária.

Na escola, a matemática é uma ciência, ensinada em um momento definido por alguém de maior competência. Na vida, a matemática é parte da atividade de um sujeito que compra, que vende, que mede e encomenda peças de madeira, que constrói paredes, que faz o jogo na esquina. (NUNES; CARRAHER; SCHLIEMANN, 2011, p. 35)

Na contramão dessa educação dissertadora/bancária, estamos ampliando o modo de conceber a Matemática tanto como lente para conhecer o mundo quanto também reconhecemos que o mundo possui trilhas que conduzem ao conhecimento matemático. Por isso, as nossas ações foram teorizadas, vivenciadas e articuladas em contextos como se representasse uma extensão do cotidiano de adolescentes, jovens, adultos e idosos, pois reconhecemos o potencial destes para contornar e resolver os problemas do dia a dia.

Cumpre ressaltar que a ênfase no ensino repetitivo favorece o torrenciamento de uma situação em que se mantém "de um lado, estudantes com dificuldades conceituais, de outro, professores com dificuldades em significar as dúvidas conceituais e de planejar ações para superá-las" (NEVES; FÁVERO, 2012, p. 50). As pesquisadoras trouxeram essa preocupação em um trabalho desenvolvido com alunos da graduação, prevendo a necessidade de o professor administrar as competências conceituais para ensinar e aprender Matemática. Temos presente que esse é um ponto que coaduna com um de nossos esforços neste trabalho, qual seja, de promover experiências em que as professoras se sintam provocadas à criação de estratégias fomentadoras de aprendizagem significativa.

Consoante a esse pensamento, foi a impressão da professora Raquel ao confirmar que "a gente amplia o modo de ver e imaginar a Matemática", haja vista que as próprias professoras foram rompendo com a situação-limite em que se tinha o ensino dos conteúdos matemáticos em "caixinhas" isoladas. A saber, não foram só essas ações realizadas, não apenas a reflexão dessas ações, mas o movimento de contornar as demais dificuldades, conquistando tempo para "sonhar, estudar e criar". Foi necessário abrir mão do ensino acomodado e alienante, do cansaço e da rotina para dar espaço ao ser criativo, autônomo que envereda arriscadamente por caminhos e atalhos, visando, em primeira e última instância, à aprendizagem do coletivo. Essa afirmação é possível se percebermos que, cada vez mais, as professoras vão abandonando um discurso do eu e passam a aderir ao "nós" ou "a gente", porque falam representando uma coletividade que vive os anseios, os medos e os riscos.

Sem assumir um caráter de intervenção, mas com intencionalidade parcialmente semelhante, nossas formações na escola foram planejadas de tal modo que pudessem 
"instigar, propor, incitar o grupo a observar, a falar, a questionar, a debater e a propor" (NEVES; FÁVERO, 2012, p. 61). As professoras assumiram-se em diálogo permanente buscando consensos que se materializavam em inéditos-viáveis na e a partir da formação, mas também contornando os dissensos, as opiniões contrárias em favor do amadurecimento dos processos formativos embasados na coletividade. $\mathrm{O}$ fato do pertencimento ao grupo, como parte da ontologia humana, ocorre pela necessidade de comunicação em que os sujeitos são ativos e, por esta condição, alteram o curso de suas histórias no intenso movimento de práxis.

Maximize-se que o diálogo possui uma carga epistemológica e política que só deve ocorrer na relação horizontal entre as pessoas, porque "participar de um diálogo pressupõe certo tipo de humildade. Não se pode manter uma relação de diálogo numa atitude de autossuficiência” (SKOVSMOSE; ALRO, 2010, p. 14). O exercício da escuta foi importante em nossas formações porque nos permitiu enxergar uns nos outros que temos situações-limite em comum, para isso tivemos humildade para reconhecer as fragilidades, e também os saberes e a potencialidade para mudança. Daí porque não figuramos e não prezamos o espírito da autossuficiência, pelo contrário, primamos pelo respeito, pela reflexão crítica fundamentada, pela ação teorizada, para não cairmos nas armadilhas de um discurso vazio e sombrio que é consequente da "pseudoparticipação" (FREIRE, 2011, p.78), e não do engajamento efetivo.

Fazer uma análise dessa natureza só foi possível porque buscamos os desvelamentos nas falas das professoras em que explicitaram "essa formação aqui é diferente das outras" (ROSA); "essas formações tem sido um aprendizado" (RUTE); "não tenho vergonha de dizer que eu estou aprendendo Matemática" (RITA). Dois pontos a considerar é primeiro, pensar na dimensão que a formação tomou, e o segundo conceber como espaço de aprendizagem contínua em que as participantes se assumem enquanto seres em formação, sem receio de se assumirem como aprendizes. Em especial, o depoimento da professora Rita que fala do quanto sua aposentadoria está próxima, mas ao invés de se acomodar com essa condição, apresenta um comportamento humilde de pessoa consciente da inconclusão. Eclode assim sua imponente força de vontade contra os obstáculos, reconhecendo que "parece difícil romper". A utilização do termo "parece" é entendido por nós como algo que nem chegava a ser uma situação-limite e que o movimento formativo foi sinalizando possibilidades, fazendo que reconhecesse que mesmo diante dos "percalços e dificuldades", a ação e a reflexão, como par dialeticamente inseparável, contribuiu para a mudança, vista como "possível".

A aprendizagem mobilizada na e a partir da formação também se compraz na ação editanda (FREIRE, 2011) da qual compartilham teorização e ação não individual, mas, na perspectiva coletiva em que as professoras pontuaram, "nós vivenciamos, nós entendemos, 
tem significado" (ROSA) e "enriquece nosso trabalho" (RAQUEL). Trata-se eminentemente do ato consolidado e não do ato passivo em que um formador "ensina" métodos eficientes para serem fielmente aplicados ao qual a professora Rosa fez referência ao usar uma terminologia informal de que cursos desse tipo "ficavam só no blá blá blá". Diferente deste tipo, a formação desenvolvida na escola CEM 03 contribuiu para "despertar a curiosidade" (LEITINHO), o que implicou nova práxis, inaugurando uma perspectiva de trabalho, pautado no planejamento de ações que dialogavam com o contexto dos alunos da EJA.

Dizer "nós vivenciamos, nós entendemos" é muito mais que a comunicação dos atos, é o reconhecimento da aprendizagem significativa, que impressiona a professora pela possibilidade, pela própria realização. Na concepção de Moreira e Masini (2001, p. 35), “o que o impressiona é sentido, percebido e compreendido, passando constante e dinamicamente, por um processo psicológico de elaboração e organização denominado aquisição de conceitos". Essa compreensão é, ao mesmo tempo, situante e situada porque permite que os envolvidos no processo, apercebendo-se dos eventos e da situação, reúnam elementos o suficiente para intervir e transformar o contexto. No sentido macro, esses elementos são conceituais, no sentido micro são apenas procedimentais e técnicos.

O que queremos dizer é que o conjunto de conceitos adquirido e reelaborado favorece ao homem situar-se no mundo e agir sobre ele (MOREIRA; MASINI, 2001), porque sendo histórico tem o poder de intervir no mundo, modificando-o em benefício próprio e de uma coletividade. Não se trata apenas de uma intervenção teórica, envolve a dinâmica de um trabalho coletivo, planejamento, dedicação de tempo, esforço, negação da acomodação, risco ao novo, sonho, ousadia, estudo e criatividade. Afinal, para que serve o domínio de conceitos? O que significa dominar conceitos na perspectiva do ensino da Matemática? Adiantamos que não é para satisfação de um ego, nem para conferir títulos honoríficos, tampouco para descrever a essência de objetos e coisas. A importância da construção de conceitos é para explicarmos a origem e a finalidade das coisas, sua aplicação, sua validade, as relações que estabelece com as pessoas e com o mundo.

Conceituar é diferente de definir, conforme Pais (2013, p. 120-121):

Uma definição matemática é como uma expressão linguística formal, que resume por meio de palavras e expressões as características essenciais de determinado conceito [...], percebe-se que uma definição em si mesma, isolada de outras ideias, não tem significado preciso, pois sempre é preciso recorrer a outros conceitos e outras definições, conhecidos no contexto da aprendizagem em questão [...].

Os conceitos são ideias gerais e abstratas, associadas a certas classes de objetos, criados e transformados nos limites do território de uma área de conhecimento [...] 
As prescrições dos livros didáticos e até o formato de alguns cursos de formação trazem implícita e explicitamente a ideia de definição como finalidade de trabalho. Nesse caso, é desnecessário um processo de reflexão e criticização, a isto basta seguir as regras e aguardar o resultado, como se tivesse que seguir uma receita. Na contramão disso, a formação que postulamos na perspectiva da práxis maximiza o conceito, a conceitualização como eixo potencializador do trabalho coletivo em favor da aprendizagem. Para esclarecer nosso posicionamento, podemos dizer que todo conceito envolve definições, mas as definições não podem ser confundidas com conceitos.

Se tomarmos a confecção das bolsas como exemplo e dissermos que um dos conhecimentos geométricos envolvidos foi formas/formato, poderíamos pensar em propriedades (características) próprias da representação de uma figura geométrica plana, aquela que possui apenas duas dimensões (como comprimento e largura). Explicitaremos melhor: tomemos a bolsa do grupo 1 como referência. Se olharmos na perspectiva frontal, teremos a ideia de quadrado. Mas até aí é apenas uma forma linguística e precisamos conhecer seus invariantes, ou seja, precisamos conhecer suas características, como se estivéssemos descrevendo a característica física de alguém. Então, como definir o quadrado?

- é um polígono porque é uma figura com lados fechados;

- é um polígono regular porque todos os lados e ângulos são iguais;

- é um quadrilátero porque é formado por quatro lados;

- é um retângulo por ser formado por quatro ângulos retos;

- é um paralelogramo porque seus lados são paralelos dois a dois;

- é um losango porque tem quatro lados iguais;

Como podemos perceber, trabalhar na perspectiva da construção de conceitos não é fácil nem simples, depende do quanto estamos dispostos a dedicação de tempo e de esforço coletivo, além do mais, o conceito não é transferível, não é dado. O conceito precisa ser construído pelo sujeito ativo, mas para isso é necessário experienciarmos um conjunto de situações, mobilizando procedimentos próprios que nos permita a reconstrução permanente das ideias. Nesse sentido, a construção da aprendizagem exige muito mais que dizer o que é um quadrado ou saber o resultado da operação quatro vezes quatro, como já alertamos, por isso mesmo implica enfrentamento.

As participantes de nossa pesquisa estiveram cientes da dimensão de nosso trabalho, o que podemos perceber na fala da professora Rute: "estou repensando muito a minha prática". Contudo procuramos nos desviar do trabalho pautado na prática pela prática, mas fizemos 
opção pela práxis, em que as professoras faziam parte de um coletivo que rejeitava o engessamento, engajando-se na luta por uma educação formativa, em favor da emancipação.

A emancipação do professor que ensina Matemática pode ser impulsionada e motivada pela reflexão, na qual o conhecimento crítico tem que começar pela crítica do conhecimento, visto que este é uma construção da mente humana na busca de responder a perguntas que fazemos ao mundo e à realidade, e não somente um reflexo da realidade (CYRINO, 2013, p.82, grifo nosso).

A propósito do que autora discorreu, a reflexão é uma condição para a emancipação, mas trata-se de refletir crítica e politicamente acerca do nosso papel enquanto agente de conhecimento, em processo de formação continuada. Corroborando com essa concepção, para as professoras a formação continuada representou uma "oportunidade" (RITA; FABÍ) de troca de experiências, de ampliação de ideias e de projetos, de denúncias e anúncios. Principalmente representou a oportunidade para pensar-agir criticamente acerca dos conhecimentos matemáticos em conexão com outros saberes, e de como estes conciliam os desafios e conflitos dentro de uma dada realidade, objetivando a aprendizagem significativa.

Os alinhavos das unidades de análise dessa categoria foram constituindo um corpus teórico importante em nossa pesquisa porque trouxe similitudes quanto ao modo das professoras se perceberem em processos de construção coletiva de aprendizagem, posto que se encontram em formação continuada. Os inéditos-viáveis constituídos por esse grupo tão coeso vão sinalizando que é possível a mudança quando se permite aos sujeitos ativos a utilização de sua cultura, dos conhecimentos já armazenados e, principalmente, quando se cultiva o diálogo, favorecendo o dessilenciamento e anunciando as possibilidades.

O conhecimento resultante de um processo dialógico contribui para que possamos nos situar no mundo, refletir-agir, conhecer os limites e as possibilidades, significar os eventos e acontecimentos e, especialmente, contribui para que façamos história. Porque não se pode conceber alguém que já sabe de tudo e que não tenha necessidade de ter mais conhecimentos. Se, de um lado, estes representam as armas para lutarmos contra as situações-limite, de outro podem ser a condição para o caos se estabelecer.

Neste último caso, podemos reagir e enfrentar a situação com a adoção de ações afirmativas que combatam o imobilismo e a passividade, como fizemos ao propor a conexão de saberes como possibilidade de diálogo entre os conhecimentos diferentes e não antagônicos. Os inéditos-viáveis constituídos pelas professoras revelaram o potencial para a aprendizagem de conceitos matemáticos que são importantes no contexto escolar e não escolar, são conhecimentos intelegíveis responsáveis pela condução do sujeito que aprende. 


\subsection{Condução e ampliação da aprendizagem pelo sujeito ativo}

Como já temos defendido, pressupomos que a aprendizagem seja um processo próprio do sujeito social e histórico e não concerne estritamente ao acúmulo de conhecimentos e informações, mas depende de um conjunto desses e envolve as relações sociais e culturais, portanto, é uma ação intencional do sujeito que aprende. Nessa perspectiva, a aprendizagem do professor é um processo contínuo, cultural e psicológico, impregnado de sentidos emocionais, que assume uma dimensão maior: aprender para contribuir com o próprio desenvolvimento humano e profissional (tanto complexo quanto contínuo, que se pauta na permanente busca pela completude do sujeito) e também incentivar a aprendizagem do aluno que se dará pela apropriação e produção de bens culturais.

Corroboram com esse entendimento Prada e Longarezi (2008, p. 107) ao defenderem que "a aprendizagem docente é potencializadora do desenvolvimento desse profissional. Por isso precisa alicerçar-se nas condições objetivas desse sujeito, nas situações propriamente ditas da prática social desse profissional, fundamentada nos conhecimentos prévios dos professores". Nesse sentido, a aprendizagem faz com que o aprendiz saia de determinada condição para outra, elevando/ampliando sua aprendizagem e, ao mesmo tempo, implica o próprio desenvolvimento do sujeito que aprende.

Arriscamos apostar no processo de formação como maximizador desse potencial para a aprendizagem, mas o equilíbrio que buscamos residiu exatamente em resgatar os conhecimentos que as professoras já haviam construído ao longo da carreira docente, que corresponde ao cerne da aprendizagem significativa. A esse respeito Cyrino (2013, p. 83) explicitou que

pensar numa formação que busque a emancipação do professor como profissional pressupõe conhecer o que ele entende por matemática e como relaciona com outras áreas que, de certo modo, nos revelam aspectos presentes na sua cultura e estão enraizados na sua tradição histórica de formação.

A maneira como a autora concebeu a formação vai ao encontro das ideias e concepções que temos acerca dos processos formativos, pensando na dimensão epistemológica, cultural, humana e profissional que não tem finalidade em si mesma, mas supera a condição de curso de formação. Por isso mesmo, ao longo do desenvolvimento de seu trabalho, a autora denunciou que o conhecimento predominante nesses processos de formação tem sido, conforme asseveram Boaventura de Sousa Santos (2000) e Cyrino (2013), conhecimento-regulação em detrimento do conhecimento-emancipação. Em outras palavras, traduz-se uma denúncia do comodismo, da alienação e, ao mesmo tempo, uma alerta para 
incorporarmos processos formativos emancipatórios em que não seguimos receitas, mas criamos contextos de formação e de aprendizagem.

Andamos na contramão desse tipo de formação e lançamos mão de uma proposta formativa articulada com a realidade, a atualidade e a necessidade daqueles e daquelas que fazem a modalidade EJA. Nesse sentido, como nosso primeiro princípio formativo, esteve ancorado na perspectiva crítico-emancipadora, então em todo o tempo, estudamos a melhor maneira de abordarmos conhecimentos tanto do campo da Educação Matemática quanto de outras áreas do saber. Assim, criteriosamente estivemos atentas para as inquietações dos alunos e fomos fazendo links que pudessem contribuir para a aprendizagem significativa do coletivo (alunos, professores, pesquisadora).

Uma das preocupações das professoras, conforme já sinalizamos anteriormente, era aprofundarmos os elementos conceituais e, como nosso fio condutor era medida de comprimento e sua relação com outros conhecimentos, tínhamos não só que garantir certo amadurecimento conceitual, mas também era necessário ampliá-lo. De partida, ressaltamos mais uma vez que as provocações iniciavam-se com as professoras e estendiam-se para os alunos. Mas como deveríamos continuar as discussões, a partir de que ponto? Isso não foi difícil de decidir, pois, no ano em que estávamos mergulhados neste projeto formativo, acontecia manifestações populares em todas as regiões brasileiras com protestos em oposição ao governo federal e à corrupção no Brasil ${ }^{19}$. Esses acontecimentos serviram de base para continuarmos nosso trabalho na perspectiva do letramento e da conexão de saberes e, em nosso planejamento, pretendíamos trabalhar o conceito de metro quadrado.

Decidimos assim, no círculo de investigação formativo, que o fio condutor seria uma temática que fomentaria uma discussão mais política e participativa: "As manifestações no Brasil". Contudo tínhamos propósitos bem engajados com os objetivos de emancipação, o que nos inquietou para estabelecermos a relação entre as manifestações e o metro quadrado. Como todas as nossas ações tinham fundamentação teórica e intenção pedagógica, afetiva, social e política, aproveitamos as discussões do momento para ampliarmos o campo de saber, o que nos rendeu muita aprendizagem. A sugestão da temática e a articulação com o conteúdo matemático partiu das professoras e começamos a discutir até que ponto adolescentes, jovens, adultos e idosos da EJA se envolviam com essas questões e que postura política adotavam frente a essa realidade.

${ }^{19}$ Segundo a Revista Época (ago. 2015), os protestos antigovernamentais no Brasil foram manifestações populares que ocorreram em diversas regiões do Brasil tendo como principais objetivos protestar contra o governo federal e a corrupção. Esse protesto Reuniu milhões de pessoas nos dias 15 de março, 12 de abril, 16 de agosto de 2015. 
A importância desse tipo de articulação é também para oportunizar a construção de conceitos relacionados a acontecimentos que marcam dada realidade. Nesse sentido, concordamos com Moreira e Masini (2001, p. 45) que afirmaram: "a veracidade de um conceito determina, em larga medida, sua utilidade tanto na estrutura do conhecimento como para propósitos de aprendizagem, solução de problemas e comunicação". Ou seja, quanto mais nos apropriarmos dos eventos que implicam contextos reais, mais favorecemos a aprendizagem significativa, porque já incluiremos os conhecimentos prévios dos sujeitos envolvidos em dado contexto.

Partindo desse pensamento coletivo, as professoras pesquisaram um modo de suscitarmos essas discussões, assumindo o risco (tendo em vista a imprevisibilidade) de envolver assuntos partidários e posicionamentos políticos na sala de aula. Então, fizeram a opção de trabalhar com todas as turmas juntas, para que pudessem se organizar em equipes com uma diversidade na composição (conforme atividade da confecção da bolsa). A priori seria desenvolvida também no refeitório da escola, no entanto, naquela tarde, estava muito quente e o sol entrava quase que na metade do espaço, por isso resolvemos reunir todas as turmas em uma das salas de aula.

As professoras sugeriram como material de análise, estudo e ampliação as informações acerca do número de manifestantes veiculados pela mídia e o modo de calcular a quantidade de pessoas em um local, usando como referência o metro quadrado. Contudo teríamos que fazer uma discussão inicial sobre o metro quadrado, buscando saber como era compreendido pelos alunos e qual sua utilização no cotidiano. As manifestações ocorrem quando um grupo de pessoas se reúnem com o objetivo de reivindicar alguma questão social, econômica ou política. Entendido isso, nosso ponto de partida foi problematizar por que a polícia divulga um total de manifestantes que difere do número divulgado pelos organizadores de um evento como os protestos? Explicitamos que, para chegar àquele número de manifestantes, calcula-se a área do local e estima-se o número de pessoas que ocupam cada metro quadrado $\left(\mathrm{m}^{2}\right)$. Mas como tornar visível e compreensível essa informação?

$\mathrm{Na}$ EJA, a prioridade não foi ensinar fórmulas aos alunos, mas buscar meios para que compreendessem o significado das informações e as professoras entraram em acordo que a maneira mais apropriada seria simular a construção de um metro quadrado utilizando jornais. Então, construímos o metro quadrado para depois chegarmos ao contexto das manifestações. Por isso providenciamos jornais, réguas, fitas métricas, pincéis e tesouras e distribuímos entre os grupos para que construíssem um metro quadrado. De partida, perguntamos o que era um metro quadrado e onde eles mais escutavam falar de metro quadrado. Os alunos não tiveram 
nenhuma dificuldade em dizer que se tratava de uma medida em que tínhamos um metro em cada um dos lados e falaram que o metro quadrado estava relacionado a terrenos, às cerâmicas que se compra em madeireiras, aos cômodos de uma casa.

A professora pediu para que uma aluna fosse ao quadro desenhar a representação de um metro quadrado. A aluna disse: "eu preciso de uma régua pra ficar certinho". Depois de representado, a professora perguntou: "ficou a medida de um metro de cada lado?". Os alunos disseram que tinha que ser quase do tamanho do quadro para dar um metro. Duas alunas tiraram da bolsa aquele metro confeccionado em cartolina (aquele que receberam quando fizemos a primeira atividade de medidas com eles). Esse fato foi registrado no caderno de campo porque, se não tivesse sido significativo, eles nem teriam mais utilizado o material, mas se estava de prontidão, na bolsa, foi devido à utilidade e importância.

A aluna foi ao quadro novamente e pediu que outra colega a auxiliasse segurando a fita métrica enquanto ela demarcasse a medida de um metro de cada lado e daí ela escreveu 1 m (um metro) em cada um dos lados. Um colega falou: "desse jeito aí, tem é quatro metros". A professora Fabí interviu: "como assim?". O aluno respondeu "um mais um, mais um, mais um e mais um, dá quatro". Desse modo, estava tratando da medida de superfície. Mas a aluna retrucou: "não é pra somar não. É de multiplicar: um metro vezes um metro de cada lado, que dá um metro quadrado. Entendeu?”. Eu quis saber como ela sabia calcular o metro quadrado, e ela respondeu: "meu marido é pedreiro". E assim ficou clara a utilização de seu conhecimento sociocultural. Nesse diálogo, reportamo-nos para o que Moreira $(2015$, p. 4) alertou quanto à aprendizagem significativa na concepção ausubeliana:

\section{Condições para aprendizagem significativa:}

1. Materiais potencialmente significativos (devem ter significado lógico e conceitos e proposições pertinentes e significativos devem estar disponíveis na estrutura cognitiva do aprendiz).

2. Disposição para aprender (o aprendiz deve apresentar uma intencionalidade, uma disposição para relacionar de maneira substantiva e não-arbitrária o novo material, potencialmente significativo, com sua estrutura cognitiva).

No processo de aprendizagem significativa, o significado lógico dos materiais passa a ter significado psicológico para quem aprende.

O material potencialmente significativo a que o autor se referiu estava materializado na fala da aluna quando explicando ao colega o faz com propriedade, dizendo que não se realiza o cálculo pela adição das medidas dos lados, mas pela multiplicação. Foi o modo que encontrou para validar o conhecimento que aprendera na convivência com o esposo pedreiro. Em relação à turma, foi significativa essa discussão inicial porque envolveu a todos e, então, 
propusemos que os grupos realizassem a confecção de um metro quadrado utilizando os jornais e os demais recursos para recorte e colagem.

Propositalmente, entregamos jornais de diferentes tamanhos para que eles fossem justapondo de tal modo que fechassem as medidas pretendidas. A segunda etapa foi estimar quantas pessoas caberiam dentro de um metro quadrado (confeccionado), para isso um dos metros quadrados foi disponibilizado no meio da sala e um grupo ficou em pé "dentro" (em cima). Os outros colegas foram dizendo que cabia mais pessoas e outros alunos se juntaram naquele espaço demarcado, até que eles mesmos disseram "agora não cabe mais", apresentando entendimento que se ampliaria quando retomássemos a discussão do números de manifestantes.

A professora Rosa, como sempre provocativa de situações interessantes, se juntou àqueles alunos, levantou os braços e pediu para que os alunos fizessem o mesmo, e perguntou se cabia mais gente. Eles disseram que daquele jeito cabia mais pessoas. Ao todo, ficaram dez pessoas em pé e os próprios alunos comentaram: "a quantidade de pessoas que cabe em um metro quadrado depende do jeito que estiverem, em pé ou sentada. Se for em pé, cabe mais, se for com mãos levantadas assim, aí cabe mais ainda”; "é, mas se for sentada ou abaixada, aí cabe menos"; "se tiver cadeirante cabe menos"; "se for só criança cabe mais"; "se for adulto com criança no colo cabe mais gente".

Dois alunos paralelamente fizeram uma associação daquele episódio à realidade deles que andavam de ônibus ou de metrô em horário de maior fluxo de gente e de veículos no trânsito: "vocês tão parecendo a gente no ônibus em horário de pico"; "é igualzinho a quando estamos no metrô no horário que as pessoas vão pro trabalho"; pois, se aí cabe dez pessoas, imagina num vagão do metrô, quanta gente não cabe?"; "é gente de mais!!! Porque o espaço de um vagão dá umas sete vezes ou mais desse metro quadrado ẩ'. Observamos a riqueza da discussão e o envolvimento dos alunos que estabeleciam relação entre o conteúdo matemático, profundamente imbricadas com questões sociais e políticas, as ações que estavam realizando com aquilo que lhe ocorriam no cotidiano. Esse diálogo ficou ainda mais interessante porque foi alimentado pela mediação das professoras.

Professora Fabí: Agora imaginem quanto de dinheiro o governo arrecada de cada usuário! Essa provocação fomentou a discussão e os alunos interagiram.

Aluno R: Vixe, é dinheiro demais! A passagem está de quatro reais, aí se multiplicar pelo tanto de gente que cabe em um vagão. 
Aluna MJ: Se nesse metro quadrado aí deu dez pessoas. Então, num vagão do metrô cabe muito mais de 100 pessoas.

Professora Rosa: Vamos juntar aqui esses metros quadrados para ver quanto dá. (falando dos jornais construídos com a medida de um metro quadrado)

Os alunos se mobilizam colocando os metros quadrados no chão, justapondo suas extremidades, totalizando seis jornais com medidas de um metro quadrado cada.

Professora Rosa: Se em um espaço de metro quadrado cabem aproximadamente dez pessoas, quanto cabe nesses seis?

Aluno V: Depende professora, porque o povo quando vê muito espaço vazio, aí fica à vontade e ocupa mais espaço ainda. Tem gente que senta. No metrô mesmo têm muitas pessoas que sentam. E no último carro (referindo-se ao vagão do metrô) que as pessoas podem levar bicicleta! (Os outros colegas balançam a cabeça confirmando).

Professora Rosa: Nós sabemos que isso acontece, mas vamos pensar na mesma lógica da atividade que fizemos que foi de ficar dez pessoas em pé no espaço do metro quadrado. Então, quantas pessoas caberiam se tivéssemos esses seis espaços aqui?

Aluno R: Aí é fácil. Ou pega dez, mais dez, mais dez (repetiu seis vezes) e caberia aí 60 pessoas em pé. Ou então só multiplica esses seis por dez que dá 60 do mesmo jeito.

Aluno V: A conta tá até certa, mas no vagão do metrô cabe muito mais pessoas.

Aluna MJ: Eu já calculei aqui na cabeça. Se for 60 pessoas pagando quatro reais de passagem, dá 240 reais.

A pesquisadora também se sente provocada pela riqueza da discussão e intervém, dizendo: Essa simulação que vocês estão fazendo é referente a uma viagem de metrô. E se consideramos que a cada 15 minutos o metrô passa novamente?

Aluna MJ: Aí é dinheiro de mais em jogo. Porque em 15 minutos são 240, mais 15 minutos são mais 240. Ou seja, em meia hora já tem 480 reais de um vagão só.

Aluno V: Pra você vê que o governo ainda tem coragem de ficar aumentando passagem. Olha o tanto de dinheiro que eles recebem por dia só de passagem!

Aluna J: Temos que trabalhar pra comprar ônibus e van, minha gente. Porque esse negócio dá é muito dinheiro.

As discussões foram mais amplas, mas destacamos esse primeiro trecho porque também passou pela nossa avaliação e análise durante os círculos de investigação formativos, em que conceitos e procedimentos matemáticos estiveram associados às questões sociopolíticas. O primeiro elemento que observamos foi o estabelecimento de relações do cotidiano com o conteúdo matemático que provocou uma ampliação do conceito, haja vista que os(as) alunos(as) mobilizaram a noção de medida que traz a "ideia de caber". Além disso, os(as) alunos(as) fazem suposições conforme as suas experiências e de acordo com o comportamento social das pessoas ao se reportar ao modo como essas pessoas procedem quando se veem com mais espaço. Ou seja, mobilizam a ideia de espaço total e espaço 
ocupado. E mais interessante ainda é a dimensão que vai tomando a conexão de saberes, pois as próprias professoras transitam do metro quadrado, para as operações e o sistema monetário. A título de provocação, a pesquisadora também interfere trazendo o elemento do tempo para o contexto em discussão, com o objetivo de mostrar as possibilidades de estudar e trabalhar os conhecimentos "fora das caixinhas".

Esse contexto se aproximou da realidade dos alunos da EJA, por isso eles entraram no diálogo com seus conhecimentos, opiniões, hipóteses, mobilizaram conceitos próprios com a contribuição do campo conceitual aditivo e multiplicativo, realizaram cálculo mental e fizeram o uso ininterrupto do diálogo para comunicar seus procedimentos e validá-los. As professoras já tinham antecipado que as discussões renderiam e foram ainda mais longe no que concerne ao objetivo pedagógico, social e político de formação humana.

Em nossos planejamentos, discutimos uma matéria jornalística que nenhum livro didático aborda e que, muitas vezes, os(as) professores(as) também não fazem referência a qualquer coisa que tenha relação a cemitério que lembra a morte. Nossa hipótese é que os materiais didáticos não abordam esse tema porque remete à morte e tristeza. Contudo as professoras assumiram que não poderíamos nos esquivar de trabalhar com qualquer temática que tivesse relação com a vida do ser humano, por isso, prosseguimos com a ideia e utilizamos um artigo publicado no Jornal Diário do Grande ABC, da cidade de São Paulo.

"Metro quadrado em cemitério é mais caro que o de casa"

É caro viver em São Paulo. Morrer também. A lógica da valorização imobiliária, em que o preço cobrado é o que o mercado está disposto a pagar, prova isso. O metro quadrado de nove cemitérios da Capital é tão ou mais caro do que o de casas e apartamentos em seus bairros. Quem pretende comprar jazigo em Parelheiros, na zona Sul, por exemplo, começa pagando $\mathrm{R} \$ 9.403$ pelo metro quadrado e pode chegar a $\mathrm{R} \$ 25$ mil, se quiser adicionais, como ossário ou maior número de gavetas.

O metro quadrado em imóvel da vizinhança custa quatro vezes menos. No Morumbi, o preço do metro quadrado varia de $\mathrm{R} \$ 2.000$ a $\mathrm{R} \$ 9.300[\ldots]$.

Fonte: Diário do Grande ABC Paulista. Disponível em:

<https://www.dgabc.com.br/(X(1)S(2lykbnstw1 fvir5s20aorxec))/Noticia/978545/metro-quadrado-emcemiterio-e-mais-caro-que-o-de-casa>. *Publicado em 26 de julho de 2010 às 07:00.

O texto não foi disponibilizado para os(as) alunos(as), foi lido pela professora Rute. Vale destacar que, embora a matéria tratasse da realidade de São Paulo, resolvemos abordar o assunto porque, além de trazer as informações numéricas que estabelecem a relação entre metro quadrado e sistema monetário, também aproveitamos o contexto do letramento, fizemos 
a abordagem acerca da cidade que tem o maior contingente populacional do país, e a cidade mais presente nos programas televisivos. A partir dessa discussão, pretendíamos que os próprios alunos buscassem relacionar essas informações à realidade do DF.

Apesar de nosso planejamento e das discussões que prevíamos que geraria, nos surpreendemos com a amplitude que a discussão tomou em sala de aula. Os alunos ficaram impressionados com a disparidade e diferença exorbitante dos preços, afinal, o impacto já começara com o primeiro enunciado do texto "É caro viver em São Paulo. Morrer também". Esse modo jornalístico de iniciar uma matéria já trouxe informações que puderam ser analisadas com os alunos, quando pedimos para supor a intenção dessa afirmação. Pois prevíamos que se perguntássemos "por que morrer é caro?", os alunos listariam desde as despesas com a funerária até o pagamento do terreno para proceder com o enterro.

Além de estarmos abordando o tema da valorização imobiliária que envolve custos, qualidade e utilidade, também discutimos a diferença entre o preço de um metro quadrado de imóvel e de terreno no cemitério. Esse tema afligiu os alunos que não tiveram uma reação negativa por conta da presença da temática "morte", mas pela indignação por conta dos preços absurdos dos terrenos, fosse para morar ou para enterrar pessoas. Logo de início, tivemos uma participação tumultuada, porque muitos queriam falar de uma vez só, mas as professoras tomaram conta da situação, solicitando que se organizassem para falar, levantando a mão, apenas para que os outros pudessem escutar uma fala por vez.

Tínhamos consciência da importância dessa discussão e por isso não nos preocupamos em equacionar o tempo a fim de cumprirmos com o planejamento daquela atividade que, inclusive, ganhou uma dimensão muito maior do que os objetivos pretendidos para uma aula. Pois inauguramos um típico "seminário de participação popular" a cerca de um tema polêmico que a escola, muitas vezes, exime de fazê-lo. Queremos pedir permissão aqui para chamar a atenção de um tema que até poderia vir a ser objeto de estudo de outras pesquisas, a fim de sabermos que motivos levam professores a não abordar tal temática.

Voltando à descrição em análise, um importante ponto a destacar é que, enquanto uma professora lia a matéria, a professora Fabí registrava aqueles valores (em reais) no quadro e os alunos escutavam atentos e faziam "cara de reprovação" quando escutavam que o preço do metro quadrado em cemitérios era mais caro que os de casas e apartamentos. Isso nos levou a considerar que, para os alunos, era um conhecimento novo. Um segundo ponto a ressaltar é que a interpretação que deram à informação foi imediatamente remetida à realidade do DF, sem que tivéssemos apontado para essa necessidade. Tanto é que, em suas falas, notamos a referência que fizeram entre os preços do metro quadrado nas regiões administrativas 
vizinhas, como por exemplo, Ceilândia, Taguatinga e Águas Lindas/GO (locais onde residem). Os alunos sabiam o cálculo (pelo menos aproximado) e de cabeça, acerca do enunciado "o metro quadrado em imóvel da vizinhança custa quatro vezes menos".

Observamos, escutamos e nos reportamos às falas dos alunos:

Aluno A: Professora é um absurdo! E no DF que todo terreno é caro, como faz pra ser enterrado aqui? É o fim do mundo mesmo!

Aluna VD: Como pode ser mais caro um terreno no cemitério do que de uma casa?

Aluna MJ: Mas dentro desse metro quadrado aí não cabe um caixão não! Tem que ser dois ou três metros quadrados.

Aluno A: Então o jeito agora é colocar o caixão em pé, porque deitado vai ocupar mais espaço ainda. Aí só cava pra baixo.

Aluna J: E não pode comprar só a conta do terreno não, porque a pessoa depois que morre aumenta mais o tamanho. Vocês sabiam? (Tumulto na sala, mas a professora retoma)

Professora Fabí: Aumenta em torno de cinco centímetros o tamanho da pessoa.

Aluna J: Nesse caso tem que considerar o tamanho da pessoa e o caixão ainda precisa ser maior que o morto.

Aluno R: Então o negócio agora é investir em terreno e transformar em cemitério para ganhar dinheiro. Porque se um metro quadrado custar até 25 mil reais ... já pensou!

Aluno P: É um roubo! E esse metro quadrado ainda é mais caro do que o de terreno de casa.

Aluno V: Só que o preço do lote muda, dependendo do lugar. Se você for olhar o preço de um lote em Ceilândia e comparar o mesmo tamanho em Taguatinga ou em Águas Lindas, aí você vê uma diferença bem grande de preço.

Aluna MA: Eu e meu marido compramos um lote no Sol Nascente (na cidade de Ceilândia) por sete mil e quinhentos.

Professora Fabí: E qual era o tamanho do seu terreno?

Aluna MA: É 200 metros quadrados, porque é dez de frente e vinte de fundo.

Aluna IV: Mas isso deve fazer muito tempo né, porque já aumentou foi muito. Ninguém encontra mais lote desse preço não. Isso era no início, quando eles começaram a vender os lotes lá.

Aluna MA: Eu comprei em 2006.

Professora Fabí: Então vamos ver aqui o terreno da dona MA. Vamos desenhar ele aqui no quadro. (Ela desenha duas figuras: um representado com 10 metros de frente e o outro com 10 metros de fundo). Em seguida pergunta: Qual desses terrenos é o seu, dona MA? Tem diferença, pessoal, entre esses dois terrenos?

Aluna MA: $O$ meu lote é esse primeiro exemplo aí (apontando para o desenho representado com 10 metros de frente e 20 de fundo).

Nesse momento, muitas conversas paralelas, mas, apesar do áudio prejudicado, podemos perceber o incômodo dos alunos em relação à variação de preços de terrenos nos diferentes locais do Distrito Federal. Inclusive, alunos que falavam do sonho da casa 
própria, do preço dos aluguéis e os diálogos tomavam amplitude, até que a professora Fabí retomou a discussão.

Professora Fabí: E aí pessoal, tem ou não diferença entre esses dois terrenos?

Todos: Tem sim! (respondem em coro)

Aluno V: Nós trabalhamos isso em outra aula. Dependendo do tipo de medição, aí tem que fazer uma planta da casa diferente.

Professora Fabí: Na minha opinião, tudo depende do seu projeto. Por exemplo, se meu terreno for mais comprido, aí eu posso optar para construir uma casa deixando uma área na frente, aproveitando também o quintal. E isso faz muita diferença na hora de vender porque aí eu tenho uma área total e o espaço da área construída.

Aluna MA: No meu lote foi construído duas casas. Mas ainda sobrou espaço.

Professora Fabí: Então a área construída não é igual à área total. É bom ter atenção na hora que vemos um anúncio que fala assim: tantos metros quadrados de área construída. $O$ que significa? É o tamanho da edificação construída dentro de um lote que inclui desde o piso, o telhado, as paredes e os pilares. (Um elemento interessante na fala da professora Fabí é a propriedade com que fala do assunto, pois seu esposo é engenheiro, o que mostra que não apenas o aluno mobiliza um conhecimento sociocultural).

Professora Rosa: Agora voltando para a questão do preço do metro quadrado. Se a gente pegar o exemplo da dona MA que comprou o lote por 7.500 reais. Quanto ela pagou por cada metro quadrado? Como a gente calcula?

Professora Fabí: Veja só que dona MA comprou o terreno em 2006. Já estamos em 2015. Então já passaram nove anos. O salário-mínimo aumentou, os preços das coisas aumentaram, assim como o preço do terreno. Mas vamos calcular qual o preço do metro quadrado que a dona MA pagou na época. Como fazemos essa conta?

Todos: Divide. (A maioria da turma responde)

Professora Fabí: Então como fazemos?

Aluno V: Pega os 7.500 e divide pelos 200.

Aluna J: Pode usar a calculadora?

Professora Rosa: Pode sim.

Aluna J: Então dá 37,50.

Professora Fabí: Faz aqui no quadro J.

A aluna vai ao quadro e reproduz “7500 $\llcorner 200=\mathbf{R} \$ 37,50$ ”.

Professora Rosa: Olha que interessante! Tá vendo esse metro quadrado aqui? (mostra o metro quadrado feito com jornal). Você pagou por ele 37,50 dona MA. Então, se você pegar 200 desses, é correspondente ao tamanho e ao preço do seu lote.

Aluno V: Foi até barato, mas, hoje em dia, eu duvido que você ache um lote desse preço. Um lote hoje em dia com esse tamanho, aqui em Ceilândia, não é menos 100 mil.

Professora Fabí: Pois vamos pegar esse valor de 100 mil por esse mesmo terreno de 200 metros quadrados. Quanto vocês teriam pagado por cada metro quadrado?

Todos: 500. (Alguns alunos respondem) 
Professora Rosa: Vocês estão bons de conta hein! É isso aí, cada metro quadrado desse (mostra o metro quadrado feito com jornal), vocês teriam pago 500 reais em cada um.

Aluna IV: Professora eu sei que é caro e tudo o mais. Mas só de pensar que o terreno no cemitério é mais caro do que isso. Eu fico indignada! Eu vou até procurar saber direito no Campo da Esperança quanto é. (Campo da Esperança é como se denomina o cemitério do Plano Piloto do Distrito Federal).

Professora Rosa: $O$ mais importante é que vocês saibam fazer a medição correta para não serem enganados. Vocês sabem aquela história em que o vizinho diz: Ah, fulano "comeu” um pedaço do meu lote. Construiu aí passando meio metro e tal. Pois é bom conferir e medir direitinho seus terrenos.

A discussão continuou, mas fizemos o recorte até essa parte do diálogo porque já tínhamos elementos o suficiente para analisarmos. As professoras ficaram impressionadas com a maturidade dos alunos para se posicionarem em relação à inflação imobiliária. Além disso, foi possível percebermos a conexão de saberes envolvendo conhecimentos de área, configuração do terreno, sua relação com sistema monetário, as operações, a relação entre trabalho e investimento (quando falaram em investir na compra de terrenos). Um campo fértil para a constituição de inéditos-viáveis, percebidos a partir da integração teoria e ação na área do ensino e da aprendizagem da Matemática. Com base nesse episódio descrito, convém ressaltar que

\footnotetext{
necessitamos de um novo olhar para a escola como espaço de produção de conhecimento matemático, concebendo cada aluno e cada professor como sujeito epistêmico dotado de esquemas de pensamento e significações que permitem a possibilidade de diversidade no desenvolvimento de conceitos e procedimentos matemáticos. (MUNIZ, 2009, p. 37, grifo nosso)
}

Também vale dizer que não é só na escola que os conhecimentos matemáticos são construídos, porque, a todo instante, percebemos como a experiência da vida cotidiana influencia professoras e alunos na tomada de decisões e como externam seus esquemas de pensamento. Desse modo, quanto mais se valoriza os aspectos sociais e culturais do sujeito epistêmico (aquele capaz de produzir conhecimentos), mais possibilidade este tem de (re)construir conceitos e mais conhecimentos. Para isso, nosso olhar precisa ser diferente e de longo alcance porque é necessário perceber o potencial criativo.

Os inéditos-viáveis constituídos coincidem com as ações mergulhadas no campo de conceituação em que as professoras se percebem "trazendo novos conceitos, revendo os antigos, desconstruindo-os, promovendo o desenvolvimento conceitual, procedimental, profissional" (MUNIZ, 2009, p. 37). Especialmente porque a aprendizagem é contínua e se dá na relação com o outro - os alunos. Assim, rompe com a tradicional ideia de que os papéis já estão definidos, em que ao professor só cabe ensinar e ao aluno aprender. O caminho inverso 
também é possível e passa a ser não só reconhecido como também valorizado, porque os alunos são oportunizados de expressar verbalmente o raciocínio, as estratégias de resolução, as hipóteses e validam o conhecimento. Esse é um movimento forte da aprendizagem que transita entre professoras e alunos, alunos e alunos, professores e professoras, em situações anteriormente não experimentadas.

Foi possível percebermos até aqui que o movimento formativo tanto de alunos quanto de professores não acontece em espaços isolados e em momentos específicos, mas se dá no conjunto das relações sociais, emocionais e culturais e, portanto, acontecem dentro e fora da sala de aula. Um planejamento não dá conta de todos esses aspectos, contudo não podemos nos esquivar de aproveitar os momentos de efervescência de discussão porque residem aí toda a potencialidade da formação humana, epistemológica, social e crítica do sujeito que aprende. Assim, nossa aprendizagem não acontece de maneira linear e fora da complexidade, e por isso mesmo precisamos lançar mão de elementos cada vez mais diversos para promover e ampliar as aprendizagens individuais e coletivas.

Como já havíamos anunciado, não conseguimos concluir o planejamento no mesmo dia, tendo em vista a amplitude das discussões, mas, de outro lado, foi importante porque já antecipou o comportamento das turmas quando se refere às questões sociais. Afinal, o desenvolvimento do planejamento não está nas mãos do professor, mas nas muitas mãos que constituem o coletivo rico e complexo, portanto, dinâmico, incerto, empolgante, como deve ser toda aula na EJA. No encontro da quarta-feira seguinte, retomamos a discussão do metro quadrado, a fim de aprofundar os conceitos e, para isso, abordamos a questão das manifestações no Brasil, pois para chegar àquele número de manifestantes divulgado pela polícia ou pelos organizadores, calcula-se a área do local e estima-se o número de pessoas que ocupam cada metro quadrado $\left(\mathrm{m}^{2}\right)$. Mas como tornar visível e palpável essa informação? Como fazer com que o conceito fosse construído e apreendido pelo sujeito? Por que a polícia divulgava uma quantidade de pessoas e os organizadores do evento divulgavam outra? Qual o mecanismo usado para contar um grande número de pessoas em determinado local? Essas foram inquietações iniciais.

As informações acerca do número de manifestantes foram reunidas em um quadro (Apêndice F), organizado de tal modo que constassem as regiões brasileiras com estados e capitais e os números de pessoas participantes de acordo com a polícia e segundo a organização do evento. Tratava-se de dados referentes às manifestações ocorridas em 16 de agosto de 2015 em todos os estados brasileiros. Cada aluno recebeu um quadro, mesmo tendo sido a discussão em cinco grupos. É conciliável ressaltar que as professoras providenciaram 
para essa discussão um mapa do Brasil. Ao invés de utilizar o material cartográfico que a escola dispunha, resolveram encomendar um desenho do mapa brasileiro apenas com a demarcação geográfica em cores, contendo as siglas dos estados e do DF.

Figura 12: Mapa do Brasil com a sigla dos estados e Distrito Federal

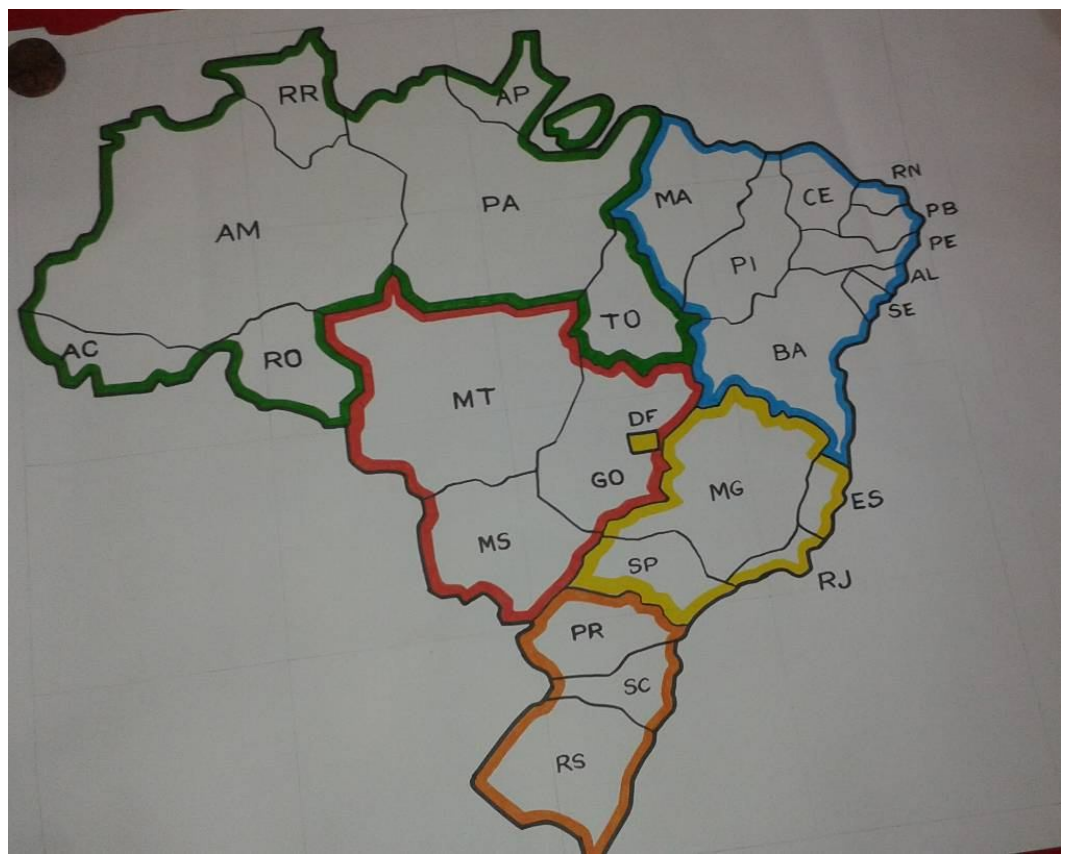

Fonte: arquivo da pesquisadora.

O objetivo era que os alunos, em grupos, pudessem realizar as seguintes ações: identificar os estados que faziam parte de cada uma das cinco regiões brasileiras, observando a sigla com o nome dos estados e sua respectiva capital, relacionar o número de manifestantes em cada um dos locais, comparar as regiões com maior e menor concentração de pessoas nos protestos. Além disso, outras ações foram possíveis como trabalhar a leitura das informações veiculadas pela mídia, por exemplo, ao se referir a "1,2 mil manifestantes em Roraima - Boa Vista”. O que significa dizer 1,2 mil manifestantes? Como escrever esse número?

Antes de chegarmos a esse nível de discussão, a tempo, destacamos que a primeira provocação foi perguntar aos alunos o que eles sabiam acerca da veiculação das informações sobre o número de manifestantes que era divergente, ou seja, a polícia militar divulgava um número de manifestantes e os organizadores dos protestos mostravam outros números. Eles sugeriram algumas respostas que sinalizaram uma ideologia: "para chamar mais pessoas para participar do protesto"; "porque é uma estratégia política"; "a polícia defende o governo e os manifestantes estão contra o governo [...]". 
A segunda provocação foi perguntar como a polícia ou a organização de um evento fazem a contagem de quantas pessoas estão em determinado local, seja em manifestação ou em festas. Para essa questão, eles disseram que tanto a polícia como a organização do evento faziam uma estimativa, conforme as falas: "não dá pra contar de um por um, aquele tanto de gente, é mais ou menos aproximado"; "eles comparam a quantidade com o de outro evento"; "num clube de festa é mais fácil calcular porque eles sabem pelo número de ingressos vendidos"; "já vi na televisão que usam um satélite e lá do alto dá pra demarcar o espaço".

Além de conhecimento acerca do assunto e da clareza política, os alunos mobilizaram conceitos matemáticos como de estimativa que é elemento válido e importante quando se trata de calcular número de pessoas por metro quadrado. Outras habilidades como contar e comparar são mobilizadas para dar respostas acerca das hipóteses que eles levantam e que tentam validar. Subjaz que, ao tentarmos assumir a ênfase no assunto, os alunos começaram a levantar questionamentos e usaram um tom de denúncia quanto às manifestações: "esse tanto de gente ainda não conseguiu mudar muita coisa nesse governo"; "mas não é só por causa do governo não. Aqui mesmo no DF já teve tanta passeata e protesto por causa de salário dos servidores"; "só que o número de manifestantes no DF foi uma vergonha. Olha aí os números no quadro".

As falas dos alunos andaram nessa direção e muitas outras reivindicações e comentários foram feitos, mas optamos por trazer apenas esses trechos para destacar a presença da crítica e da conscientização dos adolescentes, jovens, adultos e idosos. Essa discussão também daria um valioso objeto de pesquisa e fica a sugestão para que outros pesquisadores se lancem na inquietude de investigar quais as reações e posturas adotadas pelos alunos da EJA quando estão diante de temas polêmicos e atuais como esses. Em nosso caso, abordar tal temática foi também uma forma de enxergar e explorar o conteúdo matemática implícito e explicitamente.

Para mediar as discussões, as professoras intervieram e "deslocaram" a discussão para o campo da Educação Matemática. Os alunos foram organizados em cinco grupos para que cada um ficasse responsável por uma das regiões: Norte, Nordeste, Sul, Sudeste e CentroOeste. No início, os grupos tiveram que identificar no mapa os estados com suas capitais, relacionando as siglas aos nomes que dispunham no quadro (Apêndice F). Em seguida, precisaram calcular quantos manifestantes havia em cada uma das regiões, fazendo o levantamento segundo a referência da polícia e da organização do evento.

Os alunos levantaram questionamentos acerca do dado "não informado" (alguns estados não informaram o número de manifestantes), ou seja, queriam saber do que se tratava 
e sugeriram algumas conjecturas: "a polícia não tem interesse em divulgar o número de manifestantes"; "os estados mais desorganizados foram da região do Norte, porque a polícia nem falou o tanto de gente nas manifestações"; "só em dois estados não foi divulgado o tanto de manifestantes, o Acre e o Distrito Federal". Essas falas remetem-nos ao entendimento de que os alunos sabem fazer a leitura e interpretação de informações e também notam a falta da informação, como expressaram, comparando o comportamento dos estados entre as regiões. Um ponto notável foi que os alunos não tinham familiaridade com as siglas dos estados, mas o fato de trabalharem em grupos e com uma diversidade etária na composição de suas equipes contribuiu para que pudessem identificá-los.

As professoras mediavam nos grupos e depois favoreciam a socialização dos procedimentos para a resolução das situações. A análise que fazemos é que, "para aprender matemática, devemos estar mergulhados num ambiente que favoreça a vivência com a investigação matemática, de aceitação de situações desafiantes, de respeito e liberdade à ação cognitiva, de registro e de confrontos de processos" (MUNIZ; IUNES, 2014, p. 134). Em outras palavras, o ambiente matematizador não deve ser refletido por um quadro branco (ou verde) cheio de riscos e números e operações feitos pelo professor. Ao contrário, nesse ambiente, o aluno e o professor são sujeitos da aprendizagem, porque se percebem mergulhados em contexto e situações significativas. São as possibilidades, os inéditos-viáveis que cada vez mais vão se tornando materializáveis no desenvolvimento do profissional docente, a partir da adoção de nova práxis.

Nesse contexto de mediação, os alunos sentiam-se encorajados e mais participativos e as professoras contribuíam para que houvesse cada vez mais engajamento. Além das operações de soma, subtração, das ações de comparar, os alunos também tiveram que interpretar as informações do quadro contendo o número de manifestantes. Por exemplo, tomando como base Alagoas - Maceió, o número de manifestantes segundo a polícia era de 500 e de acordo com os organizadores do evento era 1,2 mil. O que se pode entender por 500 ? E como podemos ler 1,2 mil?

Duas ponderações foram possíveis, a primeira foi que os alunos apresentaram certa tendência para ler "500 mil pessoas", ao invés de 500 pessoas. A fala deles já apontava a justificativa para tal interpretação: "se do lado de lá tem pra lá de mil manifestantes, então do lado de cá tem 500 mil". Quando se reportaram ao "lado de lá" se referiam à ultima coluna (informações divulgadas pelos organizadores do evento), e o "lado de cá" (coluna em que tinham os dados informados pela polícia). 
A segunda foi que os alunos tinham a noção de que havia mil manifestantes porque estava grafada ao lado do número a palavra "mil", contudo como o texto "1,2 mil" não fazia parte de um contexto cotidiano, então não conseguiram fazer a leitura "1.200 manifestantes". Depois dessa explicitação, os demais grupos realizaram a leitura "3,5 mil" como "3.500 mil manifestantes". Outro dado que chamou a atenção dos alunos foi o tamanho da variação dos números informados, como o exemplo: Ceará-Fortaleza tinha 2,5 mil manifestantes que contrastava com 20 mil (segundo os organizadores), ou seja, de um lado havia a informação de que estavam presentes na manifestação da capital cearense 2.500 pessoas (informado pela polícia) e de outro o número era oito vezes maior. Como explicar essa diferença, perguntavam para as professoras. Estas, ao invés de sugerir respostas, voltavam para eles a indagação, instigando-os a levantar hipóteses, mas eles não chegavam a respostas numéricas. As conclusões a que chegaram foi que envolvia interesses políticos e partidários entre as instituições divulgadoras das informações.

Algumas descobertas também foram importantes, na perspectiva do letramento, que consistiu no modo como se reportavam aos estados do Nordeste que comumente os alunos mais idosos tendiam a se referir como Norte. Falas como: "quando eu vou visitar meus parentes no Norte"; "vim do Norte por causa da seca". Ou seja, falavam das histórias de suas vidas e de seus familiares no Nordeste do Brasil, mas diziam a palavra "Norte", de tal modo como se ambas as palavras se referissem ao mesmo lugar. A observação do mapa com a distribuição dos estados em cada uma das regiões brasileiras também foi significante porque, de certa forma, permitiu a identificação de suas raízes histórico-culturais.

Além disso, perceber no mapa o "quadradinho desenhado" que representa o DF também foi uma descoberta porque eles estabeleciam relação de comparação entre os demais estados. A turma ficou dividida quando perguntamos que dado seria mais confiável, o que havia sido informado pela polícia ou pelos organizadores do evento. Contudo, pelo fato de terem preenchimento numérico para quase todos os estados, as informações sobre o número de manifestantes divulgado pelos organizadores dos protestos foi mais discutida entre os grupos que realizaram operações no quadro branco. Faremos abaixo uma simulação do que foi feito no quadro. Registramos no caderno de campo e tiramos fotos dos momentos subsequentes em que as professoras mostraram outros procedimentos possíveis para resolução de situações-problemas.

As professoras solicitaram que os grupos analisassem os dados que tinham em mãos, atentando para a quantidade de manifestantes em cada região e contabilizassem quanto tinha ao todo. Enquanto discutiam e calculavam nos grupos, uma das professoras registrou um 
quadro para dispor a síntese da quantidade de pessoas que protestaram em cada uma das regiões brasileiras. Em seguida, um aluno, representante de cada um dos grupos, teria que registrar as respectivas quantidades de cada um dos estados de sua região, conforme reproduzimos a seguir.

Tabela 8: Síntese realizada pelos grupos de alunos com as informações acerca do número de manifestantes divulgado pela organização do evento (conforme Apêndice F)

\begin{tabular}{|c|c|c|c|c|c|c|c|c|c|}
\hline \multicolumn{2}{|c|}{$\begin{array}{l}\text { Grupo } 1 \\
\text { Norte }\end{array}$} & \multicolumn{2}{|c|}{$\begin{array}{c}\text { Grupo } 2 \\
\text { Nordeste }\end{array}$} & \multicolumn{2}{|c|}{$\begin{array}{c}\text { Grupo } 3 \\
\text { Sul }\end{array}$} & \multicolumn{2}{|c|}{$\begin{array}{l}\text { Grupo } 4 \\
\text { Sudeste }\end{array}$} & \multicolumn{2}{|c|}{$\begin{array}{c}\text { Grupo } 5 \\
\text { Centro-Oeste }\end{array}$} \\
\hline $\mathrm{AC}$ & 0 & $\mathrm{AL}$ & 1.200 & PR & 5.000 & RJ & 25.000 & GO & 1.000 \\
\hline $\mathrm{AP}$ & 200 & BA & 10.000 & RS & 2.000 & SP & 75.000 & MT & 1.000 \\
\hline $\mathrm{AM}$ & 5.000 & $\mathrm{CE}$ & 20.000 & SC & 2.000 & ES & 1.000 & MS & 600 \\
\hline PA & 400 & MA & 1.500 & & & MG & 12.000 & DF & 0 \\
\hline RO & 100 & PB & 400 & & & & & & \\
\hline $\mathrm{RR}$ & 1.200 & PE & 5.000 & & & & & & \\
\hline TO & 300 & PI & 3.000 & & & & & & \\
\hline & & $\mathrm{RN}$ & 1.000 & & & & & & \\
\hline & & SE & 3.500 & & & & & & \\
\hline Total & 7.200 & Total & 45.600 & Total & 9.000 & Total & 113.000 & Total & 2.600 \\
\hline
\end{tabular}

Fonte: elaborado pela pesquisadora com base no registro que os alunos fizeram no quadro.

Olhar para esse registro fez com que as professoras analisassem o comportamento dos alunos frente a uma temática atual e, em termos de conceitos matemáticos, permitiu algumas inferências: na vida real, os alunos fazem cálculos organizando essas quantidades em ordem decrescente para contar/calcular, mas, no caso dessa situação, didaticamente organizaram as informações na ordem que apareceu no quadro; o registro do zero não representou a falta de pessoas protestando, mas a ausência da informação sobre a quantidade de manifestantes e, de qualquer modo, ocupou uma posição porque estava fazendo a referência a um dos estados daquela região (sete registros na região Norte porque eram 7 estados; 9 no Nordeste; 3 no Sul; 4 no Sudeste; 3 estados no Centro-Oeste e mais o Distrito Federal que totalizavam quatro registros); os dados expostos permitia uma visualização mais detalhada e compreensível porque os números foram grafados conforme a posição decimal, isto é, 1.200 no lugar de 1,2 mil, o que requer leitura, interpretação, transformação de diferentes representações.

Quando tratou de detalhar, as professoras foram apontando aquelas quantidades aleatoriamente e fazendo perguntas para que os alunos fizessem uma leitura inversa, com a identificação e correspondência do número escrito com o respectivo estado. Esse trecho do diálogo também valeu a pena descrevermos. 
Professora Rita: Pessoal, vamos fazer algumas análises aqui. Olhem para essas informações e digam qual ou quais os estados que não divulgaram o número de manifestantes?

Os alunos olhavam para o quadro-síntese e cruzavam com as informações no quadro impresso para dar a resposta.

Alunos: Acre e Distrito Federal.

Professora Rita: Se deixarmos de fora esses dois, quais os estados que tiveram o menor número de manifestantes?

Os alunos circulavam em seu material impresso. Essa questão demorou um pouco mais porque envolvia a leitura das informações de cada região brasileira.

Aluno V: Foi aquela Rondônia velha. (Falou como se reprovasse o comportamento dos habitantes de Rondônia, por não aderirem mais pessoas aos protestos).

Aluno R: Mas o Amapazinho também teve pouca gente. (Parece que o aluno se apoiou na fala do colega que o antecedeu e usou o diminutivo como sinal de desprezo ao lugar porque tivera também poucos adeptos nos protestos).

Professora Rita: Alguém mais observou se em outro estado teve menos de mil manifestantes?

Aluno V: Ah, menos de mil, teve ainda o Tocantins e a minha Paraíba. (Ao mencionar a Paraíba, fala em tom mais baixo como reconhecimento das raízes e se identifica com o lugar usando o pronome possessivo "minha").

Aluna MJ: O Norte foi o lugar que teve menos pessoas protestando. Olha aí só 7.200.

A aluna parece olhar precipitadamente para dar essa resposta.

Aluna J: Foi o último ali que tem só 2.600. (Se referindo à região Centro-Oeste).

Aluno P: É mais tem que ver que o do Centro-Oeste só tem quatro valores pra somar e no Norte tem é sete. Então no Norte deveria ter muito mais gente protestando.

Professora Rosa: E qual a região que teve o maior número de manifestantes?

Alunos: $O$ Sudeste. (Falam em coro).

Professora Leitinho: Vocês tocaram em um assunto muito importante que é a diferença populacional. Veja, por exemplo, se olharmos no mapa (mostrando o mapa), a maior região em extensão territorial é o Norte. O que quero dizer é que as terras do Norte são as maiores, mas isso não quer dizer que lá é onde têm mais habitantes não. Por exemplo, vocês sabem qual a região e qual o estado mais populoso do Brasil?

Aluno V: Tenho certeza que é São Paulo, porque ali tem gente, ali tem gente viu.

Professora Leitinho: Exatamente. É a Região Sudeste a que tem maior população. E o estado de São Paulo é o mais populoso do país, ou seja, tem mais pessoas ocupando um metro quadrado. Estão entendendo?

Alunos: Sim. (Falam em coro).

Professora Rute: Vamos fazer uma coisa aqui. Vamos fazer uma comparação com gráfico. (Desenhou no quadro).

Ressaltamos que, em determinada aula, a professora da $3^{\text {a }}$ etapa já havia desenvolvido uma aula sobre leitura, interpretação e construção de gráficos. Não trouxemos o recorte para análise porque não envolveu todas as turmas e todas as professoras. 
Depois de desenhar o gráfico, comparando dois estados da região Sudeste, Rio de Janeiro e São Paulo, a professora Rute provoca um diálogo.

Figura 13: Gráfico desenhado pela professora Rute

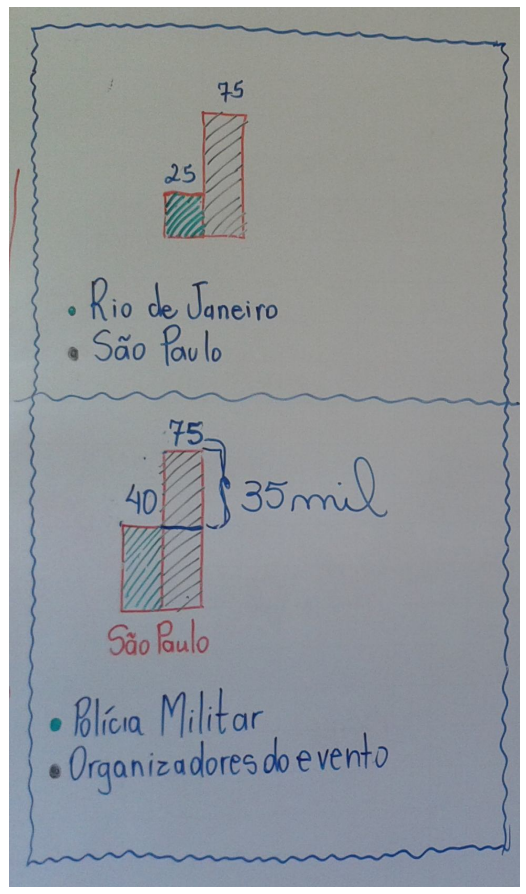

Professora Rute: $O$ que podemos perceber aqui nesse gráfico?

Alunos: Que o Rio de Janeiro é menor que São Paulo.

Professora Rute: Esses números representam o tamanho dos estados?

Alunos: Ah não! Esse aí é o número de manifestantes.

Aluno V: Mas tá faltando zeros aí professora. (Fala isso porque pensa no valor absoluto 25.000 e não 25 , ou seja envolve inclusive noções de escala, proporção, representação e construção gradativa de gráfico de coluna com a noção dos eixos e suas escalas numéricas).

Professora Rute: Você está certo, porque é 25 mil e 75 mil (mostrando), então faltam três zeros. Utilizei os números que estão no quadro que vocês têm na mão. Então olhem aqui e digam o que vocês estão vendo?

Fonte: Arquivo da pesquisadora.

Alunos: Em São Paulo têm mais manifestantes.

Professora Rute: Perfeito. E quanto tinha a mais?

Alunos: $50 \mathrm{mil}$. (Os alunos fazem cálculo mental).

Professora Rute: Muito bem. Está certo. Agora vou fazer esse outro gráfico aqui. (Desenha logo abaixo). Observem que agora eu escrevi só os dados de São Paulo e marquei colorida a legenda. Então, as listas em verde são os manifestantes que a polícia informou que tinha em São Paulo e de vermelho foi o que os organizadores do evento informaram. Qual é essa diferença entre essas duas quantidades?

Alunos: 35 mil.

A professora escreve ao lado do gráfico, confirmando a diferença de 35 mil.

Professora Rosa: Quanta coisa vocês sabem gente. Estamos impressionadas com a rapidez de vocês, com a inteligência. E ainda tem gente aqui que diz que não consegue aprender né! (Fala sorrindo). Estão vendo como vocês são espertos!

Os alunos aplaudiram como se validassem aquilo que a professora havia falado. Eles se sentiram orgulhosos, valorizados, importantes, inteligentes, capazes. Eram sentimentos que 
percebíamos no brilho do olhar e no sorriso aberto. E de outro lado, conseguimos enxergar a realização das professoras de estarem tratando de um assunto tão importante e que tomou uma proporção maior do que aquilo que havíamos planejado, estudado e preparado, porque envolveu a conexão com outros saberes. Eclodiu também a predominância da participação ativa do aluno como sujeito da aprendizagem que não reproduzia os saberes das professoras, mas mobilizavam os seus conhecimentos de modo a ampliá-los.

Nessa dinâmica, o professor entra como animador, instigador, provocador e, em dado momento, como o agente da institucionalização do saber mobilizado pelos alunos e socialmente validado. É o momento em que o professor volta-se para o aluno ou o grupo e diz: "você pode fazer assim, sim!", "Que legal! Nunca tinha visto isto antes, mas dá certo, podemos fazer assim também!" [...] É quando o pensamento e esquemas mentais do professor não é o conhecimento mais importante, nem o único válido e nem sempre o ponto de partida ou chegada. (MUNIZ; IUNES, 2014, p. 135).

Concordamos com o posicionamento dos autores que contemplam totalmente a perspectiva freireana de que é possível aprendermos com nossos alunos e que eles têm um conhecimento vasto que precisa ser valorizado. Esse reconhecimento é importante porque faz com que os alunos se percebam cada vez mais capazes de agir sobre o mundo e modificá-lo. E possibilita ao professor perceber que ele é um dos responsáveis diretos por esse crescimento humano, social, político do sujeito. Em outras palavras, o professor permite que o aluno não seja mero reprodutor de fórmulas, mas oportuniza que construa caminhos próprios para construir respostas e resolver problemas e conflitos. Assim, quando os autores supracitados disseram que o conhecimento do professor nem sempre é o mais importante, nos quer chamar a atenção para rompermos com o que ele denominou de "narcisismo pedagógico", ou seja, não alimentar a prática de repetição dos passos do professor pelo aluno.

Diante de todo o exposto até agora, podemos assegurar que as ações desenvolvidas pelas professoras como agentes da práxis garantem a não submissão do aluno no processo de aprender e ensinar. A aprendizagem vai sendo "guiada" pelas professoras, pois quanto mais assumiram o desafio de romper as situações-limite, mais foram capazes de constituir os inéditos-viáveis que se materializaram nos diálogos e na relação entre os campos do saber (permitam dizer que foram assumidos com tamanha naturalidade). Esses inéditos também foram possíveis a partir da escolha e seleção de contextos polêmicos e atuais, relacionados ao conteúdo matemático, proporcionado pela perspectiva do letramento.

Vale ressaltar que os inéditos-viáveis, muitas vezes, não aprecem nos planejamentos pedagógicos previamente concebidos, não são anteriores às experiências e trocas em si. Mas quando planejados de forma antecipadas, estes vão sendo tecidos em processo, no contexto de 
trocas, questionamentos, desconstruções, a partir de uma postura educacional-política e de acolhimentos dos diversos e diferentes saberes que vão sendo mobilizados no processo. Os inéditos, assim, são de autoria do coletivo a partir de um educador que respeita cada um como autor de processos constitutivos, ressignificando os sentidos e significados da importância da participação de todos.

Ademais, não se pode dizer que houve ou que existe um equilíbrio entre situaçõeslimite e inéditos-viáveis, pois romper os obstáculos, anunciando os inéditos, é um modo de descortinar um contexto de novos obstáculos que precisam ser paulatinamente superados. $\mathrm{Ou}$ seja, se uma situação-limite requer e motiva a constituição de inéditos-viáveis, tais construções favorecem o desenvolvimento de uma visão crítica, criativa e ética, que motiva o alargamento e o aprofundamento da visão dos participantes do processo. Desse modo, tornam-se mais criteriosos, mais críticos, mais exigentes, gerando o levantamento de novas situações-limite, num processo infindável, em busca de uma completude no coletivo. Cada constituição pessoal é fundamental, percebidas como integrante de um grupo em profundo e complexo movimento formativo, seja aluno, seja professor, seja pesquisador. As análises desta pesquisa buscam captar, explicitar, interpretar, teorizar estes movimentos entre situaçãolimite e inéditos-viáveis e de novo situações-limite, num devir sem fim de sonhar-concretizarsonhar, que na perspectiva freireana é por isso que caminharemos sempre.

Esse é o eixo da vida cotidiana, seja na escola, no trabalho, na família e nós vamos criando força, habilidade, construindo conhecimentos para resolver nossos problemas e conflitos. Isso acontece porque o conhecimento é uma construção gradual. Nesse contexto, concordamos com Fávero (2012, p. 104) quando disse que "pensamento é uma forma de ação, de modo que a ciência e a tecnologia constituem as etapas históricas da práxis humana". O pensamento não é uma teoria desassistida de ação, é a própria ação teorizada, fundamentada.

Sumariamente, o pensamento enquanto projeção da ação vem contribuindo para a práxis das professoras que lançam a mão de situações-problema contextualizadas, valorizando também as várias linguagens que contribuem para a aprendizagem. Desse modo concordamos Muniz (2009, p. 114), quando expressou que "a resolução de situações-problema favorece um trabalho multimediatizado envolvendo as mais diferentes representações: corporal, gestual, manipulativa, gráfica, pictórica, simbólica escrita ou não". Mas sabemos que essa não é uma prática comum nas salas de aula. Contudo, nosso compromisso com a modalidade de Educação de Jovens e Adultos foi e ainda é oportunizar o diálogo, as diversas formas de representação como processos próprios de construção de caminhos, seja "corporal, gestual, 
manipulativa, gráfica, pictórica, simbólica escrita ou não" para resolução de situaçõesproblema e mais que isso, há espaço para validação.

Segundo as professoras, as aulas práticas, a oportunidade de manipular materiais, o estudo de teóricos ajudaram na construção de uma aprendizagem que é para a vida, que não é só para se sair bem na escola. Esse é o cerne da aprendizagem significativa porque tem um valor, uma compreensão ampla, uma intencionalidade política e pedagógica para o sujeito que aprende. Desse modo, as professoras passam a se perceber como possíveis autoras de proposição de superações, autoras de inéditos-viáveis. Neste contexto, é importante destacar que ao constituírem os inéditos-viáveis, as pessoas envolvidas se aperceberem como autoras, e assim, se lançaram num profundo processo de desilenciamento. Por isso, chegamos ao entendimento, a partir do diálogo com as professoras, que a aprendizagem tem uma dimensão importante de formação política e as falas foram agrupadas porque tinham essa característica comum, dando vida a nossa terceira categoria.

Quadro 8: Aprendizagem enquanto formação política

\section{Trechos das falas das professoras participantes}

Rosa: Um dos pontos positivos que vejo é que estamos QUEBRANDO A RESISTÊNCIA à utilização desses contextos na Matemática, porque isso AMPLIA A VISÃO DE MUNDO.

Rute: Não só eles, mas nós também temos aprendido muito com eles. Eles SABEM SE POSICIONAR. Eles têm noção dos acontecimentos.

Rita: Você vê o brilho no olhar, aquela VONTADE DE PARTICIPAR, de DIZER O QUE ELES $S A B E M$. E os mais idosos têm tanta experiência e vontade de aprender ainda mais e, na verdade, nós é que aprendemos com eles.

Leitinho: Mas também ABRE A MENTE sobre as coisas do cotidiano. Acho bacana porque no fundo você ABRE UMA VISÃO CRÍTICA para viver no mundo, para tomar uma decisão, falar, dar uma opinião.

Fabí: A GENTE JÁ SAI DAQUI COM OUTRA VISÃO. E trabalhar a Matemática desse jeito os alunos já terão outra visão, por exemplo, quando entrarem em um ônibus ou metrô. Também vão ter o cuidado de ver as informações de uma revista quando forem fazer pedidos. Mas a gente sabe que ainda precisa mais sistematização.

Fonte: arquivo da pesquisadora extraído dos diálogos gravados nas formações.

Os diálogos expressavam um novo modo de pensar a Educação Matemática, assim como o mundo a sua volta, ou seja, como a Matemática formata o mundo possibilitando ler este mundo de forma mais crítica e ética, por meio dos conceitos e procedimentos matemáticos, envolvendo contextos que exigiram muito mais que o domínio ou habilidade com escrita, números e cálculos. Foi muito além porque tratou de situações-problemas que 
perpassam o cotidiano e a atualidade, o que exigiu uma postura política e crítica tênue. Assim, quando defendemos a transformação, na e pela práxis, podemos enxergar essa mudança a partir de todo o contexto explicitado. De um lado, alunos envolvidos e interessados por resolver a situação, mostrando domínio e habilidade de conhecimentos que a escola não tem como mensurar; de outro, as professoras que tanto mais se lançaram no desafio de romper com as situações-limite (substituir situações descontextualizadas), construíram inéditosviáveis (adoção de situações-problemas atuais, contextualizadas na perspectiva do letramento) e abriram espaço para novas situações-limite (sistematizar e aprofundar conceitos matemáticos).

Quando olhamos para as informações que emergiram do diálogo das professoras, foi ficando cada vez mais clara que a aprendizagem não ocupava apenas o campo do saber escolar, mas alcançava outra dimensão que, além de humana, é também de formação política. Pois as professoras mencionaram "amplia a visão de mundo", "abre uma visão crítica", "a gente sai daqui com outra visão". Em nossa análise, o modo e o entusiasmo da discussão não se reportava apenas à capacidade dos alunos, mas o reconhecimento e a validação do esforço e do trabalho das próprias professoras. A professora Rosa assume a contextualização matemática como ponto positivo, mas o sentido que atribuiu não se limitou a isso, referendou uma ampliação de "ser e estar no mundo" (FREIRE, 2011), porque compreende e interfere nos acontecimentos.

No mesmo sentido, a professora Leitinho reforçou essa ideia de que "abre uma visão crítica", ou seja, destaca a função da escola e do professor para combater a alienação e o imobilismo, o que podemos confirmar com a continuação de seu discurso quando abertamente diz que é "para viver no mundo, para tomar uma decisão, falar, dar uma opinião". Essa é uma postura ética diante da Educação, porque se depreende da visão de reprodução, memorização e atuação propedêutica, e adere a uma educação que forma para a vida em todas as instâncias, isso inclui sua formação política.

De acordo com Ausubel (1968 apud MOREIRA; MASINI, 2001, p. 24) "uma longa experiência em fazer exames faz com que os alunos se habituem a memorizar não só proposições e fórmulas, mas também causas, exemplos, explicações e maneiras de resolver "problemas típicos"”. Em contrapartida, o autor alertou que proceder de tal forma pode resultar uma falsa impressão de aprendizagem, isto é, o professor poderá associar que houve aprendizagem porque o aluno soube "dar uma resposta certa", porque foi capaz de memorizar. Mas diferentemente disso, que denominou de "simulação da aprendizagem significativa", também pontuou que o modo de evitar esse engano é "utilizar questões e problemas que sejam 
novos e não familiares e requeiram máxima transformação do conhecimento existente" (AUSUBEL, 1968 apud MOREIRA; MASINI, 2001, p. 24).

O que o autor nos sugeriu foi não só viável como possível, pois as questões novas que inserimos no contexto das aulas e das discussões traziam um aspecto não familiar porque não era uma ação frequente na sala de aula de trabalhar com temas polêmicos e substancialmente carregados de intencionalidade política. Assim, o termo "não familiar" não se referiu a algo que fosse distante da compreensão e do cotidiano, mas alheio ao contexto da sala de aula. Reconhecemos que são temas capazes não só de fazer com que todos mobilizassem conhecimentos já existentes tanto para resolver as questões matemáticas como também para externalizarem suas opiniões e ponto de vista sobre determinadas situações, demonstrando posição crítica e potencial para aprendizagem significativa.

Ainda com o mesmo entendimento a professora Fabí fala: "a gente sai daqui com outra visão". O contexto de onde a professora fala não se reduz à ação da sala de aula, mas ela exprime que se sente implicada com os resultados da formação, especialmente porque percebe uma Educação Matemática que afeta o cotidiano das pessoas. Reconhece que o modo de tratar os conteúdos tem surtido um efeito mais amplo que extrapola os muros da escola e supera os objetivos didáticos e pedagógicos construídos para a finalidade da aula.

Ao analisarmos o enunciado que expressa sair daqui não se refere ao lugar físico, mas à condição epistêmica em que se sente munida de saberes que lhe permite olhar o mundo de outro modo, compreendo e percebendo o significado das coisas e dos acontecimentos. Esse posicionamento também se estende ao aluno que sai de uma condição de expectador, para a condição de protagonista da história, que não só conhece o mundo e as coisas que estão à sua volta, mas que também se sente capaz de interferir e modificá-lo de acordo com suas necessidades.

Isso é oportuno ainda em sua fala quando se refere aos alunos dizendo que eles já não terão a mesma visão quando entrarem em um ônibus ou metrô, porque sua relação com as pessoas e com o mundo se altera, porque o homem, sendo um ser histórico transforma o mundo e por ele é transformado. Além disso, contribuem para essa nova visão de mundo, não apenas a abordagem dada, mas a oportunidade de os próprios alunos intervirem e mediarem, suas falas denotavam autonomia do pensamento livre e articulado. A justificativa que encontramos para isso foi a valorização dos ambientes letrados.

Ambientes letrados ou ambientes alfabetizadores são aqueles contextos nos quais as pessoas usam a leitura e a escrita cotidianamente (lar, escola, igreja, círculos de reunião). Estes ambientes podem animar e promover o uso e a apropriação da leitura e da escrita se: 1) contam com materiais escritos ou visuais, tecnológicos, formais ou 
informais (pré-programados ou programados pelas pessoas em seus contextos); e 2) os formadores ou implementadores compreendem as práticas letradas cotidianas das pessoas (o que, para quê e com quê intenções lêem e escrevem) e às articulam com os programas existentes, ou seja, levam os textos e situações de uso do ambiente dos adultos ao espaço educativo. A combinação dos dois fatores poderia contribuir para criar oportunidades de aprendizagem em educação de pessoas jovens e adultas. (GUERRERO, 2014, p. 113)

A contribuição que o autor trouxe fez alusão aos ambientes letrados como os contextos sociais que concernem à validade das práticas extraescolares e escolares para a efetiva aprendizagem. Nessa lógica, alerta que ambientes letrados não se faz apenas com a disponibilização de recursos (como os textos escritos), mas especialmente ocorre por meio do uso e das práticas letradas no cotidiano das pessoas. Quando estabelecemos a relação entre as práticas letradas, podemos, por exemplo, trazer o episódio da simulação de pedido de revista em que professoras e alunos tiveram que realizar as mesmas ações, manipulando os mesmos objetos para chegar ao mesmo resultado: a construção da bolsa.

Para construção da bolsa, os procedimentos e caminhos utilizados foram tomados a partir de acordos entre os participantes dos grupos, alguns com leitura da escrita outros nem tanto, contudo realizaram a ação de medir, comparar, contar. Em contextos cotidianos, há pessoas que não sabem ler e escrever, mas tem habilidades de corte e costura que envolve noção, medida, comparação e, portanto, estão imersas em ambientes letrados e fazem uso dos elementos do letramento.

Quando frisamos a "mudança de visão", estamos assim conferindo a validade e a importância dos ambientes letrados e do uso das práticas de letramento. Isso, na concepção de Soares $(2014$, p. 37) significa para o sujeito "mudar seu lugar social, seu modo de viver na sociedade, sua inserção na cultura - sua relação com os outros, com o contexto, com os bens culturais torna-se diferente”. A autora antecipadamente alertou que não se trata de mudar de classe social, mas na faceta freireana, trata-se de mudar a condição de menos saber para a de mais saber. Mas não é um saber ingênuo, ao contrário, está imerso no conhecimento mais elaborado e mais significativo para estabelecer a relação consigo mesmo enquanto agente de saber, com o outro e com o mundo.

Para Fonseca e Simões (2015, p. 872-873), "no campo da EJA, o conceito de práticas de letramento tem permitido refletir sobre os conhecimentos, os valores e as habilidades envolvidas na configuração das práticas de leitura e de escrita vivenciadas por jovens e adultos pouco escolarizados". Isso quer dizer que mesmo não tendo construído uma proficiência de leitura e escrita efetiva, os(as) adolescentes, jovens, adultos(as) e idosos(as) já 
estabeleceram modos próprios de se relacionar com as demandas sociais e culturais da leitura e da escrita.

Se estamos pontuando que existia, mesmo antes do ambiente de escola, uma relação social envolvida, isso implica diretamente conhecimentos ou saberes já existentes, por isso, não fazemos referência à criação ou construção de uma outra visão. Estamos sempre nos referindo à ampliação e, portanto, só se amplia aquilo que já existe. Esse é o ponto principal da aprendizagem significativa porque não partimos de "um não saber", pelo contrário, o potencial do trabalho formativo reside no saber acumulado que precisa ser ampliado. É intrigante esse modo de conceber a aprendizagem porque não se faz no contexto em que se adota a concepção de ensino como transferência de conhecimentos. Partindo desse pressuposto Freire (1996, p. 47) já tinha alertado:

É preciso insistir: este saber necessário ao professor - que ensinar não é transferir conhecimento - não apenas precisa de ser apreendido por ele e pelos educandos nas suas razões de ser - ontológica, política, ética, epistemológica, pedagógica, mas também precisa de ser constantemente testemunhado, vivido.

A essência dos dizeres de Freire traduzem nossas intenções de articularmos um trabalho que envolve os saberes do sujeito e ressalta nossa crença no processo de aprender e ensinar superando o método da transmissão. Coerente à proposta do autor, é necessário que o educando possa vivenciar os conhecimentos que tem a ver com as dimensões ontológica (própria do ser humano), política (de participação ativa e transformadora), ética (de respeito), epistemológica (que se refere ao conhecimento sistematizado), pedagógica (envolve o aprender e o ensinar). Ligado a esse pensamento foi que tomamos a decisão de pesquisar com professores e não sobre estes porque reconhecemos e valorizamos que o conhecimento que tem sobre a modalidade EJA contribui significativamente para a ampliação e fortalecimento desse campo de saber.

De partida, esse reconhecimento também faz parte do discurso e da ação das professoras que disseram em relação aos alunos, como reflexo de suas práxis, que "eles sabem se posicionar" e tem oportunidade de "dizer o que eles sabem", "abre a mente". O sentido que demos a essas unidades de análise foi que as professoras reconhecem e valorizam os saberes dos alunos e que tais saberes estão além do plano didático, são conhecimentos críticos que em outras circunstâncias não teriam sido oportunizados. Conquanto, essa descoberta representou a possibilidade das professoras conceberem novos inéditos-viáveis que, talvez, de outro modo, não proporiam.

Saber se posicionar é decorrente da formação política, mas também porque foram dadas as condições necessárias para esse fim, para "pensar certo" que Freire (1996) definiu 
como direito do sujeito em relação ao mundo e aos acontecimentos. Para este "o clima do pensar certo não tem nada a ver com o das fórmulas preestabelecidas, mas seria a negação do pensar certo se pretendêssemos forjá-lo na atmosfera da licenciosidade ou do espontaneísmo" (FREIRE, 1996, p. 49). No sentido adotado pelo autor, pensar certo diz respeito ao pensar sem adestramentos, refere-se tão somente ao pensar livre, autônomo e crítico, portanto, com o cuidado de não ser confundido com qualquer modo de pensar.

Freire sempre alertou para a impossibilidade de existirmos sem os sonhos, porque eles é que nos movem enquanto pessoas, enquanto educadores e alertava que uma das maiores tarefas que temos como profissionais da educação era de "gerar nas pessoas sonhos políticos, anseios políticos, desejos políticos” (apud NITA FREIRE, 2014, p.51). Mas fazia uma advertência importante: "A mim, como educador, é impossível construir os anseios do outro e da outra. Essa tarefa cabe a ele ou a ela, não a mim" (FREIRE, apud NITA FREIRE, 2014, p.51). Dito de outro modo, a formação política não pode ser transmitida a alguém. Ela é construída na singularidade e na coletividade, emerge das relações sociais, mas podem ser provocadas por situações e acontecimentos que viram temáticas de discussões dentro da sala de aula.

Se analisássemos as falas das professoras como a verbalização de uma sequência de ações, poderíamos dizer que os alunos se sentem instigados com os contextos utilizados em sala de aula, porque tem ligação direta e indireta com suas necessidades pessoais e profissionais. Por isso, "abrem suas mentes" para a discussão, aceitam-na como instigadora de sentimentos de repulsão e cedem à provocação querendo "dizer sua palavra". Mas não é uma palavra dita de qualquer jeito, eles amadurecem suas opiniões em coletividade e então "dizem o que sabem" e ao conquistar o direito de dizer a palavra de repúdio, de indignação, de não aceitação à situação, mostra que "sabe se posicionar".

Se retroalimentamos esses diálogos, temos uma análise mais afinco que se trata da aproximação e aprovação dessa postura pelas professoras. Pois como poderíamos pensar em formação política em um cenário outorgado pela prática do exercício, "do dever de casa", dos testes e simulados? Então, se culminamos na aprendizagem enquanto formação política estamos homologando a formação no sentido mais amplo que envolve a práxis mediada em um contexto em que há prioridade para falar/escutar, aprender/ensinar, teorizar/agir, compreender/transformar, porque são elementos imprescindíveis para um processo formativo dessa natureza. Arriscamo-nos a confirmar que a formação política ocorre em vias de mãodupla, do aluno para o professor (vice-versa). 
Essa formação política também se revestiu de inédito-viável porque superou o drama da "aprendizagem mecânica" (AUSUBEL, 1968) e apostou na aprendizagem significativa, porque, desse modo, observamos a presença da criatividade, da autonomia, da criticidade e da ética, na perspectiva de consideração do diferente e do outro, nos processos epistemológicos para a mobilização de saberes e fazeres. Nesse sentido, parafraseamos a professora Rosa quando disse que estamos "quebrando a resistência", ou seja, é a verbalização direta da superação de situações-limite, pois, se fazemos essa ruptura, estamos oportunizando os alunos e despertando neles a "vontade de participar" que é também um inédito-viável. A diferença residiu na adoção de uma postura pedagógica ancorada na práxis-emancipadora, isto é, na ação teorizada e consciente de que somos seres históricos que, no movimento formativo, se percebe munido de habilidades e conhecimentos capazes de transformar o mundo, mesmo que essa mudança pressuponha dificuldades. Para Freire (apud NITA FREIRE, 2014, p.213):

\begin{abstract}
Evidentemente, a mudança está submetida a dificuldades. Quanto a isso, não há dúvida. Quer dizer, a mudança não é arbitrária, você não muda porque quer, nem você muda sempre na direção com que você sonha. O que é preciso é saber que a mudança não é individual, é social, com uma dimensão individual. Mas a mudança é possível!
\end{abstract}

Tangenciamos que esse pensamento é compatível com nosso modo de conceber a formação política enquanto potencialidade da aprendizagem significativa porque esta não deve ser vista à parte. A mudança de que tratou Freire também não é uma mudança apenas no mundo exterior, trata-se e muito da mudança causada dentro de nós devido à dialética de poder atuar no mundo e não poder fazê-lo, quando nos vemos sucumbidos por um movimento político que tenta enfraquecer nossos anseios e sonhos. Ante a isso, precisamos criar em nós antídotos para combater a alienação, a opressão, o conformismo, portanto, o trabalho coletivo e formativo consistiu nessa possibilidade.

A formação política foi uma das essências do pensamento freireano que ocupou um importante lugar no sentido adotado pelas participantes dessa pesquisa e, por isso mesmo, representou indícios de que era ela mesma consequente da aprendizagem significativa. Dito de outro modo, se tomarmos como ponto de partida os assuntos ligados à Educação Matemática, podemos inferir que lidamos com conteúdos com importante significado social, cultural e político, para a resolução de situações significativas. Tais conteúdos serviram apenas de apoio para avançarmos cada vez mais em "terrenos desconhecidos" aos quais se temia pisar, porque contornava o previsível, em busca do imprevisível, responsável portanto, pela formação política do sujeito enquanto ser de potencial criativo. 


\subsection{Aprender como condição ontológica e provocadora de inéditos-viáveis}

A dinâmica de aprendizagem a qual nos vinculamos, alinha-se à possibilidade do aprender continuamente na perspectiva ausubeliana e vergnaudiana que tem em comum a vertente em que o sujeito é protagonista de sua própria aprendizagem. Mais que isso, essas perspectivas defendem que esse sujeito, sócio-histórico, cultural e afetivamente situado possui saberes com clarividente necessidade de ampliação. Disso deve resultar um conjunto de conhecimentos e conceitos que contribuam significativamente para sua atuação e intervenção no mundo. Eis, portanto, a condição ontológica do ser humano enquanto sujeito de aprendizagens e que precisa aprender sempre.

Doravante, não podemos deixar de trazer uma importante contribuição acerca da aprendizagem pela qual se empenhou a Organização de Estados Ibero-Americano (OEI), em parceria com a Organização das Nações Unidas para a Educação, a Ciência e a Cultura (Unesco) que ressaltaram a aprendizagem ao longo da vida (AVL). Para esses órgãos seria importante construir um documento com contribuições conceituais no que concerne à Educação de Jovens e Adultos. Segundo Scasso (2014, p. 5) o objetivo do documento era

elencar um conjunto de termos relacionados às práticas de educação de pessoas jovens e adultas que precisam e delimitam as linhas de ação dos programas, estratégias e políticas educativas dos países, assim como dos organismos comprometidos com a educação e a aprendizagem ao longo da vida.

Então, como percebemos na manifestação do diretor-geral da OEI, o compromisso desse documento foi trazer contribuições conceituais e de certa forma consensos no que diz respeito à EJA, e um destes está no âmbito da perspectiva de aprendizagem que definem como aprendizagem ao longo da vida (ALV). Segundo essa concepção, Torres (2014, p.39) assevera que tal aprendizagem ocorre:

a) ao longo da vida (não em um período determinado, tipicamente a infância) e b) em todos âmbitos da vida (não unicamente no sistema escolar): aprendemos na família, na comunidade, na natureza, no grupo de amigos, no jogo, no trabalho, através dos meios de comunicação, da arte, na participação social e política, observando, lendo e escrevendo etc.

A forma como a aprendizagem é concebida nesse documento não anula nem invalida a perspectiva a qual nos apoiamos, pois representa uma contribuição teórica e conceitual importante no campo da EJA, porque mais uma vez reforça a compreensão de que somos seres ontológicos que aprendem, ensinam e fazem história. Nesse movimento a aprendizagem não espera o lugar para acontecer, vai acontecendo à medida que nos permitimos ser 
históricos e nos historicizar no mundo, ao nos envolvermos na rotina dialógica que permite cada vez mais concebermos inéditos-viáveis.

A abertura para esse modo de aprender continuou impulsionando nossas formações e as ações efetivas com os alunos, a tal ponto que foi conquistado um nível de liberdade e de autonomia das professoras para decidirem os caminhos que deveriam tomar, tendo em vista suas próprias aprendizagens e a de seus alunos. Algumas ponderações foram tomadas para pensarmos teoria e prática no trabalho de Educação Matemática: o período de paralisação das escolas que angustiava quanto ao cumprimento da "agenda curricular" (conteúdos didáticos que precisavam ser ministrados), a observância da sequência desenvolvida com o trabalho de sistema de medidas, a importância de assegurar uma diversidade de situações para mobilizar conjuntos de conceitos que contribuem para a aprendizagem significativa, além de articularmos ações que despertassem o gosto pela escola e pela continuação dos estudos. Por todos esses motivos, as professoras decidiram que poderíamos planejar nossas ações dentro do campo do conhecimento de medidas de massa, a partir do tema "alimentação saudável".

Então começamos a delimitar um recorte dentro desse tema e as professoras assumiram uma linha de ação que segundo elas envolveria a necessidade de ampliação de conhecimento dos alunos quanto às quantidades de alimentos de que o organismo necessita, trabalhar o tema da nutrição e da saúde do corpo. Em nossas discussões, fiz a seguinte provocação: "Vocês estão trabalhando Ciências ou Matemática?". Como se tivessem ensaiado, responderam em tom descontraído: "As duas coisas". Essa resposta tinha certa firmeza de que estavam escolhendo o caminho certo para trabalhar porque, no nosso entendimento, envolvia a conexão de saberes e a perspectiva do letramento.

Cada professora se mobilizou em termos de material de estudo, trocamos vários $e$ mails consultando as opiniões e distribuindo tarefas. Uma das propostas levantadas foi buscar uma nutricionista que era professora da escola, para que, reunindo todas as turmas, pudéssemos desenvolver uma aula do tipo "Pergunte à especialista". Nessa proposta teríamos uma nutricionista no meio da sala, os alunos com as professoras estariam ao redor fazendo perguntas acerca de alimentação saudável, dietas, quantidades de nutrientes para o corpo. Seria uma atividade de uma hora com perguntas livres. Contudo, a professora não tinha aderido ao período de paralisação de aulas, portanto, já havia encerrado suas atividades pedagógicas na escola e nos informou da impossibilidade de nos atender, o que exigiu nosso replanejamento. Mas as professoras não abriram mão de fazer tal abordagem e resolveram compartilhar seus planos de alimentação prescritos por profissionais nutricionistas. Depois de entrarmos em consenso escolhemos o plano alimentar (Apêndice G) da professora Rita. 
Consultamos a opinião dos alunos e eles mesmos sugeriram que não só realizássemos uma aula sobre alimentação como também nos confraternizássemos, haja vista que já se aproximava o encerramento do ano letivo. A mobilização foi tamanha que levaram sucos naturais, frutas, alguns pratos de comida (arroz, feijão, bife, salada). Como não poderia faltar os instrumentos para medição, providenciamos balanças (uma balança de pratos e outra digital). Para iniciarmos nossa atividade, como já havíamos acostumado, propusemos o seguinte contexto: "Você está em um restaurante que vende comida por quilo [...]".

Figura 14: Instrumentos de medidas de massa, alimentos e alunos (ao redor)

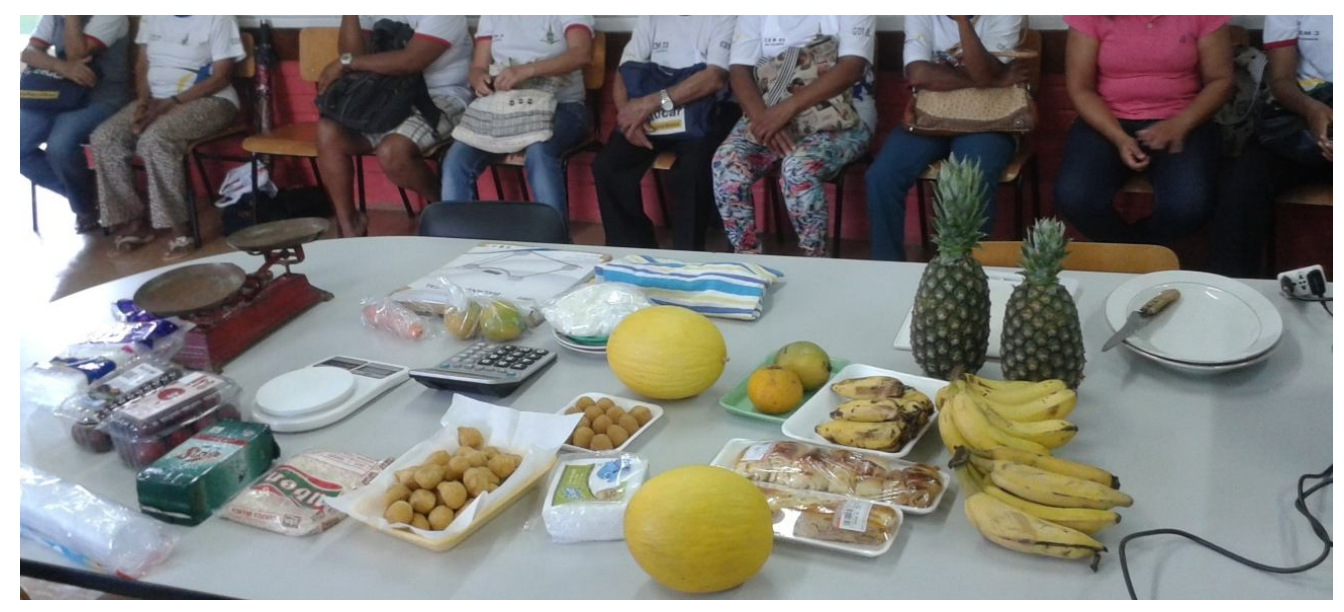

Fonte: arquivo da pesquisadora.

Nossa intenção pedagógica era que os alunos tivessem a noção da quantidade de comida para que medisse um quilograma, calculassem em reais a proporção (ou fração) de comida, conhecessem o que é a "tara" e como se calculava para chegar ao peso líquido daquilo que estava sendo pesado, manipulação dos dois tipos de balança para saber como aferir a medição de massas. Tudo isso, na concepção das professoras, geraria uma expectativa maior por ser um assunto importante e eles se mobilizariam para falar, exemplificar e participar com os conhecimentos que já tinham.

A título de planejamento, organizamos em sete slides informações sobre o que seria alimentação saudável (de acordo com a nutricionista da professora Rita), a pirâmide alimentar, cuidados com a alimentação e a saúde, passos para garantir a alimentação saudável. Optamos por um material bem ilustrado que permitisse compreensão e fomentasse a participação dos alunos. Reservamos o projetor de imagens e também a sala de coordenação para desenvolvermos a atividade. 
A natureza da atividade fez com que as professoras escolhessem a sala de coordenação como melhor ambiente físico da escola para trabalharmos a temática. Nessa sala havia uma mesa grande ao centro e, ao redor, colocamos apenas as cadeiras, para que os alunos se sentassem em um grande círculo. Na mesa ao centro, cada aluno deixava o alimento que trazia, que seria tanto para usarmos no trabalho com medidas como também para confraternizarmos ao final. Foi tamanha a organização e o empenho de todos por essa aula, mas que tomou uma proporção de aprendizado tão grande que superou a titulação de "aula", foi uma formação integradora de conhecimentos importantes para a vida.

As professoras começaram com uma provocação interessante que inquietou os alunos: “Nós vivemos para comer ou comemos para viver?” (e escreveram no quadro). A turma ficou dividida, mas a maioria respondeu que "vivemos para comer". Então, a professora Rita exemplificou: "Fulano vive para trabalhar". E perguntou: O que significa dizer isso? Os alunos disseram que é uma pessoa que trabalha muito. Nas palavras deles: "É quando a pessoa só trabalha e trabalha"; "é quando a pessoa não viaja e não passeia, só trabalha".

Depois de escutá-los a professora Rosa interviu dizendo que as frases tinham sentidos diferentes e explicitou: "viver para comer" significa dizer que a pessoa só quer comer; "comer para viver" quer dizer que a pessoa precisa se alimentar porque o organismo tem essa necessidade. Então a professora Rita retomou a pergunta: "E agora, nós vivemos para comer ou comemos para viver?”. Os alunos responderam em coro: “comemos para viver”. A opção por iniciarmos a discussão com essa frase foi interessante porque envolveu a linguagem, precisou de interpretação e análise. Nesse contexto, a mediação das professoras com exemplificações foi fundamental para que os alunos construíssem a resposta.

A professora Rosa mais uma vez interviu perguntando se havia diferença entre comer e alimentar-se. Uma das alunas mais idosas da sala foi logo se antecipando e dizendo: "se alimentar quer dizer comer os alimentos certos". A turma aplaudiu a resposta, validando a contribuição da aluna. A professora ratificou a importância de se alimentar para não gerar deficiência de qualquer tipo de nutriente no organismo. Dito isso, iniciou com os slides acerca do tema alimentação saudável, dizendo que se trata de alimentação equilibrada e fez uma explanação mais geral, enquanto os alunos observavam a fala e as ilustrações.

A participação com muitas falas começou quando a professora Rita pediu para fazer um parêntese para falar de comida e alimento, fazendo a seguinte distinção: comida é qualquer coisa que você come, alimento é aquele com nutrientes e que o consumo é saudável. Então perguntou: "Quem aqui já trabalhou na roça?” (Quase toda a turma levantou a mão), e a professora continuou, “quem trabalhou na roça, já ingeriu bastante alimento forte 
e saudável, não é?" e pediu para que eles falassem os nomes desses alimentos, e eles listaram: arroz, feijão, abóbora, mandioca, cuscuz, rapadura, qualhada (nesse momento havia muitas falas juntas).

Então a professora Rosa retomou dizendo que esses alimentos são saudáveis e dão muita energia ao corpo, por isso as pessoas falam que é comida forte (eles responderam: dá sustância). Daí continuou falando sobre a importância de alimentos que não sejam industrializados, que não estejam em conservas para que nosso organismo permaneça saudável, mas alertou que não basta apenas ingerir alimentos naturais e saudáveis, é necessário saber a quantidade, as porções para consumir esses alimentos. Ao chegar nesse ponto da explanação, as professoras começaram um amplo diálogo com os alunos, fazendo perguntas, interlocuções, conforme transcrevemos abaixo.

Professora Rute: Vocês sabem o que significa quando dizemos que é preciso ingerir duas porções diárias de tal alimento?

Aluna MA: É comer esse alimento duas vezes ao dia.

Professora Rute: E o que é porção, é encher o prato?

Os alunos falaram todos ao mesmo tempo e o áudio ficou comprometido. Mas foi possível compreender que eles tinham conhecimento de que não poderia encher o prato de comida.

Professora Leitinho: A porção é dada em fatia, em gramas, em xícara, colheres, copos. E quem diz essa quantidade, essa porção é a nutricionista que prescreve.

Aluna IV: Eu sei porque foi passado pra minha mãe, pra ela comer uma porção de arroz, que a médica falou que era só duas colherzinhas de arroz.

Professora Rute: E alguém mais aqui come em porção?

Aluna MI: Minha mãe come. Ela come duas colheres de arroz, uma de feijão e mais salada.

Professora Raquel: Que tipo de colher?

Aluna MI: Colher de sopa.

Professora Rita: Ela sacia a fome?

Aluna MI: Minha mãe diz que sacia, mas eu acho que não. Eu acho tão pouquinho!

Professora Rosa: E porque a nutricionista passou essa alimentação para ela? Ela faz dieta?

(A professora escreve a palavra “dieta” no quadro e diz que vai falar sobre o assunto).

Aluna MI: Por causa de colesterol e diabetes.

Professora Raquel: Tem uma coisa importante aí que é a saúde e a importância de comer na quantidade certa, na porção certa é também para que não fiquemos doentes.

Aluno P: Professoras, eu faço dieta.

Professora Rosa: Fale Senhor P, como é essa sua dieta.

Aluno P: De manhã eu como uma pera. E mais tarde como um pedacinho de queijo. 
Professora Rute: E no almoço?

Aluno P: Eu não almoço não.

(Professoras, alunos e a pesquisadora perguntam admirados: "não almoça?" - os alunos conversavam e discordavam da atitude de $P$ porque ele disse não se alimentar no almoço). O Senhor $P$ tem 72 anos, já sofreu um AVC e anda com certa dificuldade.

Professora Raquel: Foi o nutricionista que passou essa dieta para o Senhor?

Aluno P: Fui eu mesmo.

Professora Raquel: Mas não pode fazer isso Senhor P. Porque o nosso organismo precisa de proteínas - como as carnes, carboidratos - como feijão e arroz - e não podemos ficar sem ingerir isso. Só o nutricionista é que pode dizer as porções que devemos comer. Ele até fala que devemos diminuir a ingestão desses alimentos, ou seja, ele manda comer uma porção menor, mas nunca diz para deixar de comer isso. Entendeu?

\section{$O$ aluno $P$, mas também os demais alunos ficam atentos à informação.}

Professora Rute: Gente, isso é muito sério. O alimento da refeição é o mais importante para o organismo. Por isso não se pode ficar sem comer e também não pode comer em excesso. Tem que ser nas porções corretas.

Aluna V: Professora, eu sei que quanto mais colorido o nosso prato, mais nutrientes tem, não é?

Professora Rute: Tem que comer um pouquinho de cada nutriente e os nutricionistas recomendam que devemos comer mais verduras, legumes e frutas porque é mais saudável. E também tem os horários de comer. O ideal é que possamos comer a cada três horas, mas tem que ser nas porções certas.

Aluna J: Tem que comer pouquinho.

Professora Rosa: Vocês viram na pirâmide alimentar que o que tem na base da pirâmide são aqueles alimentos que nós dizemos que são os mais fortes, são os que dão mais energia e que vocês disseram que é o que dá mais sustança, que são os cereais, o arroz, as batatas.

Professora Rute: É isso mesmo, e se vocês não utilizarem isso em suas refeições, viu Senhor $P$, então, vão ficar com o organismo fraco e deficiente desses nutrientes.

Os alunos dialogam entre si, falando coisas sobre comida leve, comida sem sal, comida sem óleo, até que uma aluna disse:

Aluna AM: Só sei que tem que aproveitar pra comer bem enquanto a gente é novo, porque quando vai ficando velho a comida é insossa e sem graça, porque é tanta doença que a gente vai adquirindo...

Professora Rita: Gente, estamos falando de um assunto muito sério, porque se deixar de comer esses alimentos da pirâmide alimentar, o organismo não só fica fraco, como também fica doente. Mas tem que ter cuidado para não colocar no mesmo prato arroz, macarrão e batata porque tudo isso é carboidrato, e o organismo precisa de uma refeição balanceada e em porções. Então tem que variar a alimentação, mastigar bem e não comer bebendo.

Aluno R: Aí fica difícil né. E quem já é acostumado a só comer bebendo?

Professora Raquel: Essa é outra coisa importante. Todos os médicos falam que não podemos comer bebendo, nem água, nem suco, nem refrigerante. O recomendável é beber meia hora antes do almoço ou meia hora depois do almoço. Mas o problema é que as novelas só 
mostram as pessoas comendo e bebendo e isso influencia na cultura das pessoas. E observem também que latinhas de refrigerante, às vezes, podem estar enferrujadas.

Professora Leitinho: Pessoal a professora tocou em um assunto importante, por isso deixa eu perguntar uma coisa: quem aqui confere a data de validade dos alimentos?

\section{Poucos alunos levantaram a mão.}

Professora Leitinho: Essa é uma questão muito importante. Tem que conferir a data de validade. Eu sei que é difícil, às vezes, porque os números são bem pequenos, mas se tiverem dificuldade, peçam para alguém ajudar vocês. E desconfiem, por exemplo, se um produto no supermercado estiver muito barato, muito abaixo do preço normal. Olhem a validade do produto antes de comprar. Muitas vezes a data de validade fica no fundo ou no verso.

Aluna V: Professora, às vezes, o produto vai pra promoção porque tá perto de vencer. Aí é só não comprar muito e usar logo. Eu já comprei leite e não consegui usar tudo e depois vi que tava vencido, aí joguei fora, mas joguei com pena porque perdi dinheiro.

Professora Rosa: E por falar em perder dinheiro, quero chamar a atenção de vocês para um assunto também muito importante, que é o fato de ter muitas propagandas falando sobre perder peso e aí fala de comprimidos milagrosos, fala em substituir alimentação por sheiks. Não caiam nessa armadilha porque vocês estarão perdendo dinheiro. Isso não existe. Nada substitui a alimentação. Mas algumas pessoas querem fazer dieta.

Professora Rute: Às vezes ouvimos falar que fulano está de dieta, mas o que é dieta?

Alunos: É quando quer emagrecer. (Falou a maioria da turma).

Professora Rute: Dieta é fazer uma alimentação saudável nas quantidades e porções adequadas. É também chamado de hábito alimentar. E para seguir uma dieta é preciso consultar um médico ou nutricionista. Então, dieta não é sinônimo de emagrecimento não.

Professora Rosa: Como já dissemos, as porções são medidas em quantidades que podem ser fatias, ou colheres ou gramas. Por exemplo, se o médico prescrever que você tem que ingerir duas colheres de sopa de algum cereal, olhem aqui o que é essa colher de sopa (pegou uma colher sobre a mesa e mostrou), e se for uma colher de chá (mostrou uma colher pequena), ou se disser que é uma concha de feijão (levantou a concha). E ainda vamos ver as gramas dos alimentos também.

As discussões foram muito mais amplas, mas fizemos esse recorte para analisar a contribuição das professoras em um contexto que ultrapassou os objetivos matemáticos. Envolveu a conexão de saberes em um contexto de alimentação e saúde, trouxe importantes elementos informativos que ajudam os alunos a interagirem melhor no contexto sociocultural, a partir do momento que é instigado a observar os fatores presentes nas situações diárias. Além disso, proporcionou uma descoberta interessante acerca da alimentação do aluno P que já é um idoso e por sua conta própria deixou de almoçar porque, segundo ele, precisa manter uma dieta. As professoras fizeram a mediação com esclarecimentos sobre a importância não apenas dos alimentos, mas enfatizaram que devem ser ingeridos nas porções certas, para garantir uma alimentação balanceada. 
Além disso, muitos elementos matemáticos estiveram envolvidos na perspectiva do letramento, como ler a validade dos alimentos, fazer refeições a cada três horas, o cuidado para não perder dinheiro comprando alimentos para emagrecer, além de familiarizar os instrumentos básicos de medida em que são dadas as porções (colheres e gramas). Temos que destacar que cada um desses itens já poderia constituir uma temática para cada aula diferente, pois implicaria muito mais discussões e ainda daria para explorar situações-problema que resultaria em grandes e importantes aprendizados. Contudo, não devemos deixar de observar o avanço que tivemos em trazer essas discussões para a sala de aula e destacar o engajamento das professoras que cada vez mais queriam dialogar, informar e esclarecer sobre uma temática que é indispensável para a saúde do corpo, a fim de estabelecer a relação com os conhecimentos matemáticos.

As situações de diálogos se estendiam para além daquilo que estava planejado, como as falas dos alunos sobre colesterol, diabetes e o equilíbrio da alimentação quando deve-se seguir recomendações médicas - eles deram exemplos de suas vidas e de seus parentes. E, ao invés de interromper, as professoras aproveitaram a oportunidade para problematizar e simular um contexto em que os alunos deveriam usar os conhecimentos de medidas de massa. A professora Rosa interviu dizendo: "Alimentar-se em casa contribui para que possamos ingerir alimentos mais saudáveis. Mas temos dificuldade quando precisamos fazer as refeições fora de casa, não é pessoal?".

Então, nesse momento começaram um diálogo mais voltado para medida de massa.

Professora Rita: Vamos imaginar que você está em um restaurante que vende comida por quilo. Você pega o prato e vai colocando comida, depois vai para a balança pesar e saber quanto você vai pagar. Você costuma olhar quanto custa o quilo de comida? Você confere o peso da sua comida? Você acha que o pessoal do restaurante cobra o peso do prato também?

(Foram muitas falas ao mesmo tempo para responder a todas as perguntas. $O$ ponto positivo foi que estimulou a turma e despertou para um assunto que eles não costumavam observar. $O$ negativo foi que o áudio ficou comprometido, mesmo assim conseguimos captar algumas falas em que os alunos afirmaram não conferir o peso de sua comida e todos disseram que o peso do prato é cobrado).

Professora Raquel: Pessoal, nós comumente chamamos de peso, mas, na verdade, o que medimos é a massa dos alimentos. Mas quase ninguém usa esse termo, por isso, vamos denominar de peso mesmo.

Professora Rita: Então vejam que o prato tem um peso, mas ele é descontado na hora de pesar a comida. O nome do peso do prato é "tara". E na balança digital tem um botão que a gente aperta e ele já calcula o peso do alimento com o desconto do prato, ou seja, o restaurante não cobra pelo preço do prato. 
Professora Rosa: Vamos fazer o teste com o prato para conferir se é verdade sobre a tara? Venham e fiquem aqui, ao redor da balança. (Entregou o prato para os alunos sentirem o peso. O prato passou em algumas mãos). E aí, quanto vocês acham que pesa esse prato ?

Alunos: Pesa 100 gramas. 200 gramas. (Alguns estimaram).

A professora colocou o prato na balança e pediu para que conferissem.

Professora Rosa: Olhem aí quanto pesa.

Alunos: 294 gramas. (Falaram quando conferiram na balança).

Aluno V: Nossa, que prato pesado hein! Se fosse cobrar pelo preço do prato, hein! Ia sair mais caro que a comida. (Fala sorrindo).

Professora Rosa: Agora vou apertar esse botão com o nome tara e vejam o acontece. (Apertou). O que aconteceu?

Alunos: Zerou tudo. (Falaram ao ver que o registro em gramas na balança ficou zero).

Professora Rosa: Pois é isso que acontece no restaurante. Eles zeram para pesar só a comida. Agora tiro o prato e vocês vão me dizer quanto vocês acham que pesa essa banana.

Alunos: Pesa menos de 100 gramas. 50 gramas (Estimaram um peso menor que do prato).

Professora Rita: Confiram na balança quanto pesa a banana.

Alunos: 129 gramas. (Falaram admirados quando conferiram na balança).

Professora Rosa: Eu quero chamar a atenção de vocês para uma coisa super importante, antes de continuarmos, que é o modo como escrevemos e falamos a palavra grama. Tem duas formas de tratarmos esse substantivo, uma no feminino e outra no masculino. No feminino tem significado de capim (escreve no quadro a grama = capim). No masculino significa medida de massa (escreve no quadro o grama = medida de massa). Entenderam?

Professora Rute: Então, voltando a falar sobre a tara, vamos ver se o restaurante desconta o peso do prato. (Coloca o prato na balança, aperta do botão com o nome "tara" e coloca a banana sobre o prato na balança). Quanto pesou?

Alunos: 129 gramas. (Falaram com um tom de alegria quando conferiram que a balança registrou apenas o peso da banana desconsiderando o peso do prato).

Professora Rute: Vou agora apertar de novo a tecla que tem o nome tara e olhem o que vai acontecer. Quanto ficou?

Alunos: Nossa! Ficou 423 gramas. (Falaram com um tom de surpresa quando conferiram que a balança aumentou a quantidade em gramas).

Professora Rute: Por que apareceu 423 gramas?

Aluno V: Porque é o peso da banana com o do prato.

Professora Rute: Exatamente. Agora quero um voluntário para pesar outro alimento. Vamos pesar o arroz. Se o médico disser que você deve comer só uma concha de arroz, vamos ver quantas gramas tem? Vamos fazer o seguinte, colocar um guardanapo e pesar o arroz e depois colocamos o prato, apertamos a tecla tara e verificamos se tem a mesma quantidade em gramas. (A aluna $\mathbf{J}$ fez conforme a orientação da professora e verificou que em ambos os casos, a balança mediu a mesma quantidade em gramas).

Aluna J: Olha aí gente, 53 gramas de arroz. (Enquanto fala aplaude, como se estivesse validando uma descoberta, um conhecimento). 
Professora Rosa: Agora vamos fazer de conta que estamos em um restaurante e a primeira coisa é saber o preço que cobram pelo quilo da comida. Nós estamos falando em quilo porque é referente a quilograma. E vocês sabem quantos gramas tem um quilograma?

Alunos: Mil gramas. (Responderam com segurança).

Professora Rute: Muito bem. (Escreve no quadro $1 \mathrm{~kg}=\mathbf{1 . 0 0 0} \mathrm{g}$ ).

Professora Rosa: E quanto vai custar o quilo da comida em um restaurante?

Aluno R: Tem um restaurante self service aqui na Ceilândia que custa dez reais.

Professora Rita: Então vamos usar essa referência. J você pode vir aqui fazer um prato como se fosse para você comer? Sirva-se como se fosse para você. Não precisa ter vergonha. Tem arroz, feijão, bife e salada. Você coloca a quantidade que quiser. (A aluna J se serve).

Professora Rute: Pessoal, nós estamos falando de alimentação saudável. Vocês viram quantas colheres de arroz e de feijão a J colocou?

Alunos: Foram três colheres de arroz e duas de feijão.

Professora Rita: Pessoal, vou pedir para a J fazer um giro na sala para vocês olharem de pertinho o tanto de comida tem no prato. Vocês acham que vai pesar mais ou menos quanto? Vai passar de dez reais? (A aluna J deu uma volta na sala, mostrando a comida no prato).

Alunos: Menos de um quilo. Não dá dez reais não.

Professora Rute: Mas esse menos de um quilo corresponde a quanto?

Aluna J: Dá uns 250 gramas.

Aluna IV: Dá nada. Acho que vai dar mais ou menos 500 gramas.

Professora Rita: Vocês lembram quanto pesava a banana?

Aluna J: 129 gramas.

Professora Rita: E esse prato de comida pesa mais ou menos que essa banana? Já é uma forma de comparar.

Alunos: Pesa mais.

Aluno R: Essa comida aí vai dar uns 300 gramas.

Aluno V: Vai ser uns 350.

Professora Rita: Então vamos conferir na balança. (Colocou o prato na balança)

Alunos: Deu 419 gramas.

Professora Rute: Isso é meio quilo?

Alunos: Não. Meio quilo é 500 gramas. Deu menos.

Professora Rute: Então vamos fazer um cálculo aqui. Quanto era o preço do quilo da comida?

Alunos: Dez reais.

Professora Rute: E quanto de comida a J colocou?

Alunos: Menos de dez reais.

Professora Rute: Em gramas foi quanto?

Alunos: Menos de 500 gramas. 
Aluna J: Não vai dar nem cinco reais o preço do meu prato.

Professora Rute: Como você sabe que não vai dar nem cinco reais?

Aluna J: Porque se um quilo é dez reais, então meio quilo é a metade, e meu prato ainda foi menos de meio quilo. Então, vai ser um pouco menos de cinco reais.

Professora Rita: Maravilha! Acho que agora todos sabem medir a massa dos alimentos e conferir na balança quanto aproximadamente vai pagar. Não é? Nós podemos pesar outros alimentos também.

Observamos, nesse diálogo, que o raciocínio proporcional está muito presente no cálculo mental, o que fazemos no dia a dia quando não recorremos ao uso de lápis e papel. Entretanto, às vezes, a escola nega a importância do cálculo mental, supervalorizando os cálculos no papel, indo na contramão da cultura do mundo adulto, que no cotidiano realiza cálculos mentais apoiados tanto na proporcionalidade quanto na estimativa e aproximações. Por outro lado, trazer tais tipos de situações para a sala de aula na EJA é transpor a cultura matemática do trabalhador para o espaço pedagógico, portanto, valorizando suas estratégias para resolução das situações-problemas.

Quando começamos a descrever esse cenário de aprendizagens tivemos dificuldade para delimitar o recorte por considerarmos tudo importante, inclusive a preocupação das professoras para explicar a utilização da palavra "grama" no masculino e no feminino. Quanto a isso, ouvi o áudio e voltei algumas vezes para compreender se os alunos se referiam a "quinhentas gramas ou quinhentos gramas". Eles usaram o artigo correto, no masculino. Além disso, mobilizaram muitos conhecimentos envolvendo estimativa, comparação, cálculos, dinheiro em uma situação semelhante ao contexto cotidiano.

Essas análises não conseguem dar conta de todas as dimensões que o trabalho alcançou. Um registro que fiz no caderno de campo, que me tocou bastante, foi que o prato de comida preparado pela aluna $\mathbf{J}$ foi parar nas mãos do aluno P. Aquele aluno idoso que confessou não almoçar porque fazia dieta. Ele saboreou todo o prato de comida e ao final, chamou $\mathrm{J}$ e pediu para que colocasse mais um pouco de comida. Eu não interferi, só anotei, mas me dou conta da dimensão social e política desse acontecimento que é muito maior que a proposta matemática que nos propusemos em desenvolver. Esse episódio geraria outra discussão importante, sobre condições básicas de vida, saúde e alimentação, a qual ponderamos, para não incorrermos em digressões. 
Figura 15: Aluno P (de camisa azul)

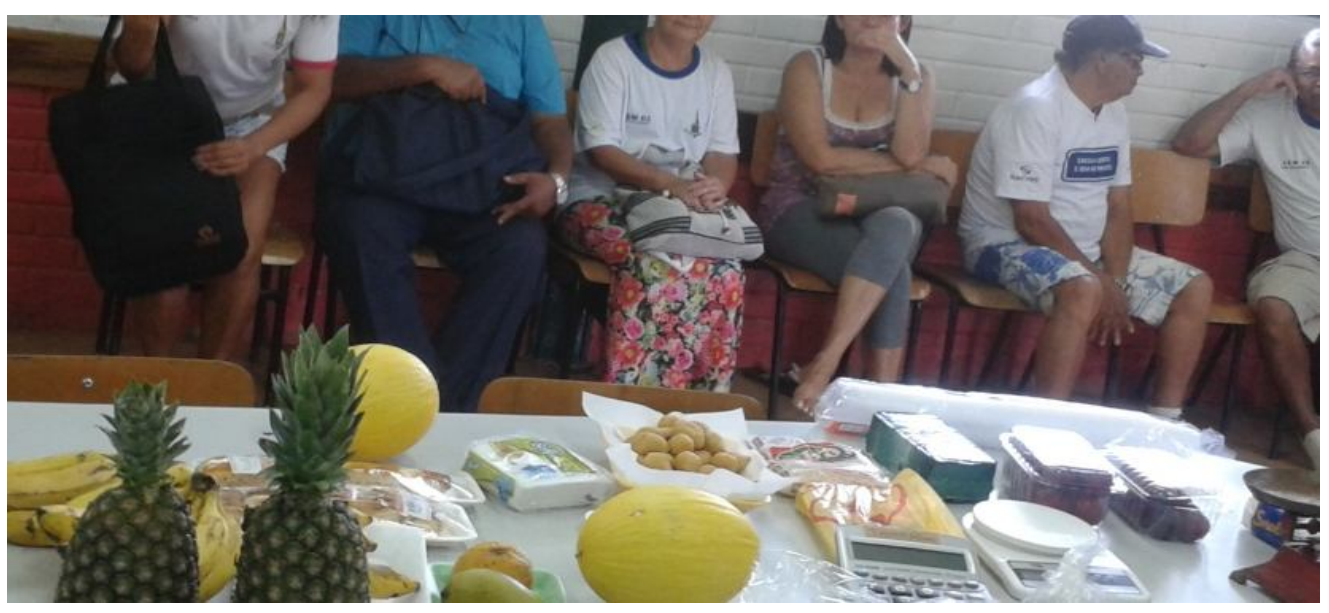

Fonte: arquivo da pesquisadora.

Enquanto isso, de outro lado, as professoras pareciam ter ensaiado, as suas falas se alternavam e seus diálogos se complementavam, provocando os alunos para que pensassem e verbalizassem os processos mentais para resolver a situação-problema. Permitiram que os alunos fizessem a experiência e comprovassem aqueles conhecimentos, a fim de que fosse significativo para eles.

Quando o professor não é mais apenas o elaborador do problema para gerar conhecimento matemático, esse profissional assume outras competências profissionais que requerem, entre outras, ver como a matemática está impregnada nos mais variados contextos culturais, buscando fazer com que os alunos desenvolvam os conceitos e procedimentos matemáticos para, de um lado, favorecer suas estruturas mentais e, de outro, munir-se de ferramentas lógicas para agir e transformar o mundo. (MUNIZ, 2009, p. 111)

Todas essas ações estiveram articuladas com o contexto social, afetivo e cultural dos alunos, para que aproximando dessa realidade, eles pudessem mobilizar conhecimentos semelhantes ao que faria na vida real. Tais conhecimentos constituem ferramentas para compreender os fenômenos, interferir neles, transformando-os e, no caso do episódio matemático descrito, construir o conhecimento representou também entender as relações sociais, incluindo o valor que pagamos pela prestação de serviços.

Outras simulações foram realizadas, mas dessa vez, as professoras entregaram um recorte do plano alimentar (Apêndice G) prescrito pela nutricionista da professora Rita, a fim de que os alunos pudessem comparar uma medida caseira com a respectiva medida em gramas, utilizando as balanças disponíveis na sala. Até a balança de pratos foi utilizada, pois dispomos dos pesos de 50 gramas, 100 gramas, 500 gramas e $1 \mathrm{~kg}$ e quando os alunos se 
deram conta da limitação de pesos (sem outras variações), abandonaram a balança manual e optaram pela balança digital.

$\mathrm{Na}$ sequência, as professoras trouxeram duas situações-problemas impressas para os alunos analisarem e resolverem em equipes. Para proceder com a resolução, os alunos teriam que consultar os dados contidos no plano alimentar (Apêndice G) e depois precisavam escrever a dieta, conforme orientava a questão.

QUESTÃO 1) Suponhamos que a nutricionista informou que você terá que escolher para seu almoço apenas: um tipo de arroz, um tipo de feijão, um tipo de carne ou ovos; três tipos de folhagens; dois tipos de frutas. Pesquise no quadro de alimentos e monte a sua dieta. Depois calcule quantos gramas você comerá nesse almoço.

Como podemos notar a resolução da situação não envolveu fórmulas matemáticas, mas decisões (tipos de arroz, feijão, carne) e cálculo (quantos gramas) para compor uma refeição balanceada. Os alunos tinham que negociar e entrar em acordo para escolher os tipos de alimentos e, em seguida, precisavam registrar por escrito. E uma forma de validar esses procedimentos foi proposta pela professora Rute que solicitou a um grupo para expor no quadro a dieta que eles construíram. Um dos alunos foi registrar, com a ajuda dos outros que ditavam as informações para que escrevesse no quadro.

arroz integral cozido $=140,0 \mathrm{~g}$

feijão preto cozido $=80,0 \mathrm{~g}$

bife grelhado $=90,0 \mathrm{~g}$

agrião + alface + brócolis $=(130,0 \mathrm{~g}+120,0 \mathrm{~g}+60,0 \mathrm{~g})$

banana-prata + laranja-pêra $=(86,0 \mathrm{~g}+137,0 \mathrm{~g})$

Alguns pontos que analisamos foram que os alunos tiveram o cuidado de escrever a unidade grama em cada medida e a conservação da vírgula seguida do zero, como se tivessem que registrar os submúltiplos daquela medida. Depois desse registro, as professoras interferiram perguntando se eles achavam que um prato contendo todos esses alimentos pesaria mais ou menos de um quilo. Eles fixaram o olhar no quadro, como se estivessem calculando de cabeça aquelas quantidades. Até que começaram a opinar que daria mais de meio quilo e menos de um quilo. Então, a professora Rute pediu para que prosseguissem e realizassem o cálculo no quadro, a fim de sabermos quantos gramas seriam ingeridos naquele almoço. A opção do aluno que foi registrar no quadro foi de somar os gramas das folhagens e depois das frutas e em seguida somou todas as quantidades $(140,0+80,0+90,0+310,0+$ 
$223=843,0$ gramas). Os alunos aplaudiram o resultado mais uma vez, como se estivessem aplaudindo a validação dos processos construídos e do resultado ao qual chegaram.

Apesar de usarmos comumente a medida caseira, os alunos fizeram a leitura e interpretação das informações usando a referência em gramas. O interessante é que os alunos escolheram o arroz integral para compor a dieta, provavelmente porque sabem que é mais saudável. Contudo, no supermercado, eles compram arroz branco e quando perguntamos o motivo de preferir o arroz branco, eles responderam: "é porque o integral é mais caro". Então, o que podemos notar é que a realidade sociocultural fala mais alto que as indicações de especialistas da saúde, pois o que é mais saudável, muitas vezes é também mais caro e inviável para a aquisição pelo trabalhador. Disso podemos concluir que os alunos realizavam atividades dentro de seu contexto e também além dele, mostrando em todo o caso as suas habilidades matemáticas em relacionar o tipo de alimento e seu respectivo preço.

A segunda situação-problema, mesmo tendo sido contemplada nessa atividade foi proposta como tarefa adicional e poderia ser resolvida em casa.

QUESTÃO 2) Escolha, em um dos quadros, uma alimentação em que você só poderá ingerir entre 700 a 1.000 gramas de alimentos. Escreva que alimentos serão esses e calcule a quantidade total em gramas.

A essa altura os alunos já perguntavam que horas iríamos comer. Além disso, também levamos uma balança digital para pesar pessoas e informamos que eles poderiam se pesar ao final das atividades. Para esse momento, eles fizeram fila e enquanto o colega pesava, os demais ficavam de olho na balança para conferir. Eles sabiam dizer os quilos e os gramas, mesmo quando a balança registrou, por exemplo: 65,3 eles leram sessenta e cinco quilos e trezentos gramas. A observação que fazemos é que no cotidiano eles têm essa vivência acerca de alimentos que pesam em gramas. No próprio supermercado, há disponível uma balança para que eles pesem carnes, legumes e frutas, a fim de que possam estimar um valor aproximado da mercadoria, quando esta é vendida por quilograma. Por isso não faz sentido trabalharmos questões que envolvam o raciocínio e o uso mecânico de fórmulas e nos fixarmos nisso para acompanhar se os alunos aprenderam ou não.

Avaliação da aprendizagem significativa não deve ser apenas somativa, deve incluir também aspectos formativos e recursivos. A avaliação do tipo "resposta correta", "sim ou não", "certo ou errado", "branco ou negro", é comportamentalista e estimula a aprendizagem mecânica, a "decoreba”. (MOREIRA, 2015, p. 5)

A intenção pedagógica não consistiu tão somente em ensinar conteúdo de medida de massa, tampouco apresentou questões de análise de certo ou errado, mas buscamos ampliar o 
conceito e fazer com que o aluno cultivasse o hábito de conferir pesos e medidas quando se perceber em situação de compra, inclusive oportunizando de resolver situações-problemas. Uma característica marcante em todas as atividades realizadas foi a presença das práticas de letramento, ou como disseram Fonseca e Simões (2014; 2015) práticas de numeramento, que permitem ao aluno, mas também ao professor ampliar os conhecimentos. Tal contribuição foi também possível porque tivemos como parceiras, professoras que atuam na EJA com o ensino de Língua Portuguesa, que aproveitaram todas as oportunidades possíveis para trabalhar a leitura e a grafia das palavras, bem como seus significados e o uso correto da linguagem.

Na concepção de Moreira e Masini (2001, p. 14):

Novas ideias e informações podem ser aprendidas e retidas na medida em que conceitos relevantes e inclusivos estejam adequadamente claros e disponíveis na estrutura cognitiva do indivíduo e funcionem, dessa forma, como ponto de ancoragem para as novas ideias e conceitos.

O modo como os autores fizeram a afirmação nos convoca para reflexão de que o caminho pelo qual decidimos percorrer foi o mais acertado, de acordo com a proposta de aprendizagem ausubeliana e vergnaudiana, na qual nos apoiamos. Por isso não apenas os alunos, mas também as professoras se pautaram nos conhecimentos já construídos ao longo da vida e da carreira, para ampliarmos os conceitos e seus significados, o que caracteriza a aprendizagem significativa, provocando um ensino cada vez mais articulado.

Esse modo de conceber o ensino e de provocar aprendizagens também diz respeito à constituição de inéditos-viáveis pelas professoras que se lançaram sem medo e com ousadia no processo formativo, com o compromisso de favorecer a formação integral dos alunos da EJA. Essa foi a reflexão que as professoras fizeram em relação ao envolvimento nas ações, pois as falas denotaram segurança e propriedade no conhecimento das informações que ora se dava no campo da matemática, de língua portuguesa, de ciências naturais, mas não em separado. Um processo rico de aprendizagens no âmbito do letramento sob a ótica da conexão de saberes, que forma o sujeito na perspectiva emancipatória, isto é, o sujeito exerce sua autonomia, consciência crítica e (re)constrói conhecimentos significativamente porque é oportunizado pelo diálogo, em colaboração com os pares.

Os indícios e sinais da aprendizagem entendidos como elemento que fortalece o profissional professor na sua função de ensinar fizeram com que analisemos e consideremos outra dimensão dos processos formativos que é a da emancipação como possibilidade. As professoras reconheceram como imprescindível o trabalho engajado e coletivo, o que compreendemos por Aprendizagem enquanto processo formativo emancipatório. 
Quadro 9: Aprendizagem enquanto processo formativo emancipatório

\section{Trechos das falas das professoras participantes}

Rosa: É fantástico que os alunos conseguem perceber que o que eles aprendem aqui já faz parte da vivência deles. Mas o que é mais bacana é a socialização. A nossa nem se fala porque TEMOS UMA SINTONIA DE TRABALHO MUITO BOA. E a socialização dos alunos é muito interessante, há uma preocupação dos adolescentes com os mais idosos, a ajuda que eles dão para os outros. E eu só tenho mesmo a agradecer porque tenho aprendido muito e tenho percebido que é possível atuar de forma diferente, inclusive com a união das turmas que nos permitiu desenvolver trabalhos interessantes. Eu ME SENTI PROVOCADA e acho que o grupo foi também, por isso que REALIZAMOS TANTA COISA.

Rute: É impressionante tudo o que foi feito. Nós não trabalhamos só com a Matemática. E olha que tinha conteúdos para trabalhar em várias aulas. E com isso A GENTE TEM MAIS CONSCIENCIA DE QUE NÓS PRECISÁVAMOS TER UMA COORDENAÇÃO CONJUNTA, porque foi muito boa toda essa experiência. Olha quanta coisa boa que realizamos juntas e com as turmas juntas também. Então se nós tivéssemos mais oportunidade de coordenar juntas, mais e mais nós realizaríamos. É claro que podemos realizar essas atividades cada uma em sua sala, mas não teria essa RIQUEZA DE APRENDIZADO do jeito que foi com as quatro turmas juntas. Os alunos ficam mais motivados e a gente também. Porque às vezes parece que a gente está trabalhando sozinho, sabe?Porque fica cada um na sua sala. E eu sinto isso, desde que eu entrei na EJA, que tem um trabalho solitário. Eu já trabalhei com jornada ampliada e aí sim tem muitas trocas. Mas aqui na EJA só está acontecendo por causa de NOSSAS FORMAÇÕES QUE TEM SIDO A NOSSA COORDENAÇÃO. Por isso, a gente só tem a agradecer pelo projeto de formação. A gente tem aprendido muito e tem sido uma experiência muito boa.

Rita: Normalmente a gente trabalha sozinha mesmo e fica um trabalho solitário. E com essas formações foi que TIVEMOS A OPORTUNIDADE DE TRABALHAR JUNTAS, CONSEGUIMOS UM TEMPO EM COMUM PARA FAZER ISSO. E até mesmo para o aproveitamento melhor do aluno seria interessante que a gente continuasse trabalhando juntas, porque esse movimento de estudar $e$ planejar as atividades, desenvolver com os alunos e voltar para fazer a avaliação do que deu certo $e$ o que não deu, e aprimorar e trocar ideias, dando sugestões de como melhorar, isso foi muito significativo. E O PROJETO FOI UM INCENTIVO PARA NÓS NOS ORGANIZARMOS E TRABALHARMOS EM CONJUNTO. Se nós pararmos para pensar, vamos perceber muitas coisas que realizamos e nos preparamos para isso. Porque se não tem esse incentivo, com o tempo a gente vai ficando cansado e acomodado, mas quando reunimos e trocamos ideias e aparece sugestão para fazermos diferente, aí a gente vai ficando animado e entra no ritmo. Eu mesma SOU MOVIDA A ESTÍMULOS e gosto quando tem alguém para me incentivar.

Leitinho: Sabe o que achei de mais interessante é que eles tinham uma sede de participação. Eles se sentiam importante porque eles queriam falar. Essa coisa de juntarmos as turmas foi UM GRANDE APRENDIZADO não só para os alunos, mas pra nós mesmas.

Fabí: Acho que tudo que vem pra somar é importante. Mas continuo insistindo que nós podemos fazer muito mais, PRECISAMOS TRABALHAR MAIS CONCEITUALMENTE, PRECISAMOS DE MAIS TEMPO PARA ISSO.

Raquel: Uma coisa muito positiva em misturar, reunir as turmas foi que a gente tem uma dimensão do que são cada um dos alunos de todas as etapas. E nenhum aluno questionou o fato de estarem juntos. Eles TROCARAM CONHECIMENTOS E APRENDERAM MUITO.

Fonte: arquivo da pesquisadora extraído dos diálogos gravados nas formações.

Ao pesquisador fica a difícil tarefa de fazer o recorte mais apropriado para analisar, mas essa não é uma ação simples, especialmente quando o objetivo é reunir informações 
convergentes a uma categoria que não é estática, com a intenção de endossar a tese que pesquisamos. Uma fala recorrente das professoras é a relação que fazem da formação com a aprendizagem, que ocorre a partir de um movimento dinâmico, dialógico e coletivo e, segundo elas, é nisso que reside toda a força criativa da ação que realizaram e que precisam continuar realizando. Por isso também é que adotaram uma fala plural, como se marcasse uma nova identidade, uma identidade coletiva e solidária de um grupo coeso que aprovou o trabalho em equipe, conforme podemos observar nas suas falas a presença de palavras que denotam esse sentido: "socialização", "juntas", "em comum", "em conjunto".

Essas unidades de análise não são meros dizeres, elas contêm um sentido político de coletividade, de força conjunta pela emancipação, porque no âmago da fala as próprias professoras denunciaram um trabalho solidário e anunciaram as conquistas, os inéditosviáveis constituídos na solidariedade do grupo. Esses diálogos denotaram que essa coletividade se fez na ação e na reflexão, "como unidade que não deve ser dicotomizada" (FREIRE, 2011, p.73), portanto, que ocorre na e pela práxis. Essa dicotomia parece existir, analisando as entrelinhas das falas, quando o trabalho é individual e solitário, pois não há a validação pelo outro, ou seja, as professoras sentiam a necessidade de um trabalho articulado e coletivo porque conseguiam trocar conhecimentos e validar suas produções com os pares.

A formação assumida como princípio da aprendizagem esteve revestida de parceria e cumplicidade, tanto no que concerne aos encontros contínuos na escola com uma professora de cada etapa como também o reflexo disso nas ações com as turmas reunidas no mesmo espaço. Isto implica que a mesma necessidade que as professoras tiveram de trabalhar em conjunto porque rendeu mais aprendizado, estenderam para os alunos o mesmo anseio, apostando que também viveriam uma experiência rica em aprendizado, como de fato ocorreu. Um contexto ímpar para a geração de inéditos-viáveis que não ocorreu no vazio, mas na tessitura social, emocional e política, pois o inédito tomou sentido e valor na relação com o outro, sendo este outro, o professor colega, os alunos com suas realidades e motivações. Mas não apenas isso, sobretudo, o mundo passa a ser relido e ressignificado por todos os envolvidos com o inédito concebido, inclusive os próprios pesquisadores envolvidos profundamente no processo.

A tempo, é mister destacar que uma vez superadas as situações-limite, oportuniza-se a constituição de inéditos-viáveis, mas o próprio movimento cíclico da formação vai descobrindo novas situações-limite que demandam outros inéditos. Em outras palavras, queremos dizer que os inéditos-viáveis não constituem o ponto final e a resolução definitiva 
dos problemas, mas são instigadores de novos desafios que demandam novos esforços, impulsionando para mais inéditos-viáveis, que convergem para a aprendizagem.

No caso da formação com as professoras essa aprendizagem não aconteceu apenas porque estavam reunidas, mas especialmente porque estando juntas tiveram oportunidade de trocas de ideias, opiniões, experiências que ampliaram os conhecimentos. Tais conhecimentos foram mobilizados dentro de um campo conceitual do sujeito "que o permite captar, significar, posicionar-se diante de uma dada realidade" (MUNIZ, 2009, p. 37). Essa foi, sem dúvida, a maior contribuição das ações formativas que realizamos, porque não nos centramos no encadeamento algorítmico, mas na habilidade de resolver situações-problema envolvendo contextos matemáticos que representavam as práticas de letramento, e dessa forma possibilitavam a compreensão e o posicionamento diante de dada realidade.

A sintonia do trabalho das participantes da pesquisa denota não apenas a concentração da força mobilizadora da aprendizagem, mas também o espírito cooperativo movido pela ação dialógica. A respeito disso, na concepção de Freire (2011, p. 227) os "sujeitos que se encontram para a pronúncia do mundo, para a sua transformação”. Isto é, as professoras inscrevem-se continuamente no movimento de denúncia das situações-limite e anúncio de inéditos-viáveis à medida que se unem pela organização do trabalho pedagógico, problematizando-o, distanciando-se da teoria da ação antidialógica - conforme trata o quarto capítulo de Pedagogia do Oprimido (FREIRE, 2011, p. 167-253).

A teoria da ação antidialógica, no entendimento freireano, diz respeito à prescrição de normas por alguns e a obediência e cumprimento por outros, em que se abandona a práxis e em seu lugar se assenta o ativismo, que é o puro fazer. Domesticado, o sujeito se assujeita, ocupando um lugar de tarefeiro, de executor das linhas de produção que, no caso da Matemática, corresponderia ao professor que reduz seu trabalho ao ensino de fórmulas para que os alunos reproduzam. Na contramão dessa teoria e blindados pela ação dialógica ou porque não dizer dialogia da ação, na e pela práxis, foi que o movimento formativo ocorreu na escola, tendo em vista que a opção por esse caminho representou que:

os sujeitos dialógicos se voltam sobre a realidade mediatizadora que, problematizada, os desafia. A resposta aos desafios da realidade problematizada é já a ação dos sujeitos dialógicos sobre ela, para transformá-la. Problematizar, porém, não é sloganizar, é exercer uma análise crítica sobre a realidade problema. (FREIRE, 2011, p. 229)

A repercussão da afirmação do autor ocorreu no âmbito de nossa pesquisa em cada um dos momentos pedagógicos concebidos e vividos nos e a partir dos círculos de investigação formativos. As professoras se entregaram ao diálogo, uma experiência que transcendeu a 
verbalização, materializando-se em ações concretas de intervenção no campo da Educação Matemática, na perspectiva do letramento. Os desafios da realidade representaram as situações-limite que uma vez problematizados foram superados pela análise e ação crítica, transformando e alterando os processos de ensino e aprendizagem da EJA, constituídos no próprio movimento dos inéditos-viáveis.

Claramente notamos a declaração de que uma situação-limite superada foi o trabalho individual, sectário alimentado por anos na escola. Em seu lugar, o privilégio de um trabalho em conjunto que a professora Rosa se referiu a "uma sintonia de trabalho muito boa". Do qual se podia presumir respeito ao outro (quanto à fala, ao posicionamento e às ideias), reciprocidade, convergência de interesses para a aprendizagem significativa.

O sentido empregado na expressão sintonia aparece carregado de intencionalidade, expressando concordância, harmonia, equilíbrio entre as participantes. Nossa análise permitiu inferir que o cerne de tal sintonia se deu pela construção de um cenário de formação dentro da escola, em que as professoras enfrentaram o desafio de tempo e de espaço para a formação. O ponto de tensionamento foi rompido pela união de esforços, em que ao exercer a autonomia pelos processos formativos, as professoras enveredaram por uma práxis que transforma, que emancipa o sujeito ativo. Doravante, não implantamos um curso de formação na escola, tão somente dialogamos sobre questões que provocaram incômodo e reação, e ocupou o lugar da acomodação, na substituição do pessimismo pelo otimismo de que mudar é possível.

O encorajamento também foi uma força motriz que ganhou sentido na fala da professora Rute quando expressou: "a gente tem mais consciência de que precisávamos ter uma coordenação conjunta". Muitos elementos são importantes nessa análise, desde a cultura do "nós" - a gente - como assunção de uma identidade coletiva (caracterizando-se como um importante inédito-viável), até o entendimento afinco de como se concebe essa consciência. Afinal, nesse contexto, o que então seria ter consciência? A luz de nossa interpretação e parafraseando Freire, é o anúncio de que "mudar é difícil, mas é possível” (apud NITA FREIRE, 2014, p. 201), quando nos lançamos, sem medo e sem esquivos, na ação dialógica de quem sabe que tem muito a enfrentar, mas não renuncia, não nega a luta e por isso mesmo faz história.

Na concepção de Freire, mudar não é impossível, mas também não é fácil, não é simples nem se dá fora da complexidade, não é linear, mas faz parte da ontologia do ser humano que sendo gente, sente a necessidade de mudar. Neste contexto dialético em que acontece o processo de mudança o autor explicitou: 
Eu gosto de ser gente porque eu vivo entre a possibilidade de mudar e a dificuldade de mudar. É viver a dialética de poder e não poder que satisfaz a minha presença no mundo, de um ser que é, ao mesmo tempo - e porque é - objeto da história e, no momento em que se reconhece objeto da história, pode vir a ser sujeito da história. (apud NITA FREIRE, 2014, p. 212).

A certa altura já sabemos o que isso significa que a consciência a que se referiu a professora não foi um fenômeno ocorrido ao raiar do dia, não se torna consciente porque alguém disse que teria que ser assim. A consciência é uma construção história e social do sujeito que se permite sentir, viver, experienciar, comparar, contrastar fenômenos, ou seja, não é tomada de empréstimo, não é transferível, não é específica de certo momento. Ainda nas palavras do autor, envolve a dialética, por isso não se deve descuidar de questões importantes para a formação do sujeito, porque ele constrói a história e se reconstrói nela.

Concomitante a isso, os inéditos-viáveis suprem a necessidade individual e coletiva, porque as professoras reforçaram "nós precisávamos ter uma coordenação conjunta". Disto podemos inferir que ao usar o tempo verbal no pretérito imperfeito "precisávamos", justifica que no passado ou há bastante tempo já havia essa necessidade, ou seja, passou por certa maturação para acontecer. O verbo precisar também é utilizado pela professora Fabí, porém com a ênfase no presente e na primeira pessoa do plural: "precisamos". Uma denotação evidente de que já estão fazendo isso, mas que ainda é pouco, diante de tantos conhecimentos e porque não dizer, mediante a um currículo escolar extenso, como o Currículo em Movimento do DF (DISTRITO FEDERAL, 2014).

Assim, no mesmo ritmo foi essa tomada de "consciência" para com o trabalho de Educação Matemática que muitas vezes é sucumbido pelo ensino da Língua Portuguesa ou, quando encontra espaço, ocorre pelo método cartesiano, no qual se valoriza o registro escrito, como possibilidade única do fazer matemático. Por isso, o verbo precisar conjugado na primeira pessoa do plural trouxe essa carga pedagógica e política de que é necessário continuar trabalhando com os campos conceituais e, consciente disso é necessário mais tempo. Nesse ponto alertou Vergnaud (2009) que os conceitos não são construídos de imediato, para construí-los, o sujeito precisa de tempo e de um conjunto de situações.

De partida, ao aderir às práticas de letramento como possibilidade de ampliar a aprendizagem de conceitos matemáticos, as professoras provocaram mudanças nos modos de conceber a Matemática no cotidiano escolar e extraescolar, valorizando os registros orais e escritos e, o mais importante, validando-os. Maximize-se que as decisões não foram tomadas simplesmente para delinear um campo de possibilidades pelo ativismo, nada teria sido possível sem a análise crítica do contexto. O embasamento teórico dos campos conceituais e 
da aprendizagem significativa foi profícuo e determinante para isso. Tangencie-se que disso resultou a decisão de juntar as turmas, por reconhecer que todos tinham potencial para aprender, ou como diziam as professoras, "de expandir os horizontes do conhecimento". Assumir esse compromisso representou não estar imunes ao risco de não acertar, todavia o movimento de busca pelo ser-mais foi latente e reminiscente.

A sensação de que os círculos de investigação formativos configuraram uma coordenação coletiva favoreceu a tomada de decisões e a similitudes das ações. Um dos consensos a que chegamos foi que, se reuniríamos todas as turmas, então os procedimentos e modos de resolução das situações-problemas deveriam ser considerados, sem distinção, especialmente porque deveria respeitar os saberes dos educandos e seus tempos de aprendizagem. Cada professora tinha conhecimento das singularidades de suas turmas e, ao invés de supor que os alunos não acompanhariam o ritmo do ensino e da aprendizagem, as profissionais ousaram e apostaram na possibilidade da socialização e da participação de todos. Então, ficou acertado que a verbalização, o cálculo mental, as estratégias de cálculo, o modo de pensar e de expressar-se seria também oportunizado.

Em contextos não escolares, mulheres e homens, especialmente aquelas e aqueles cuja socialização não foi forjada pela escolarização, apresentam estratégias localizadas de cálculo oral, muitas vezes bastante sofisticadas, que desdenham dos valores das certezas cartesianas, discursivamente produzidas pela matemática escolar escrita, em sua pretensão de marcar como corretos apenas determinados modos de pensar que se configuram em certas estratégias de cálculo. (FONSECA; SOUZA, 2010, p. 96).

A oportunidade dessa citação não é para desprezar a matemática escrita, sua utilização nesse contexto se deu pela necessidade de frisarmos que as práticas de letramento concebidas dentro da modalidade EJA permitiram a ousadia de valorizar a oralidade, sem, contudo, abrir mão da escrita. Uma ação dialógica de corresponsabilidades que, nas palavras das professoras, provocou muitas aprendizagens, e sob nossa análise podemos dizer, que a aprendizagem ocorreu em um caminho inverso, no qual as professoras também aprenderam com os alunos, bem como aprenderam em colaboração com os pares.

No conjunto do nosso trabalho temos destacado a dialogicidade na dimensão cognitiva, social, afetiva cultural e política, pois nosso compromisso com a modalidade EJA não se limitou nem se limita a ensino de elementos específicos da Educação Matemática, mas além desses, buscamos trabalhar a conexão de saberes e as práticas de letramento. Nos contextos elaborados, não nos distanciamos da realidade de alunos adolescentes, jovens, adultos e idosos, inclusive ao lançar mão de situações-problema envolvendo contextos mais politizados da atualidade, que demandou um posicionamento crítico. A contento, esses 
assuntos, informações e conteúdos foram provocativos para as professoras e, uma vez provocadas, também o fizeram com os alunos, porque sabiam do potencial formativo e de aprendizagem.

\begin{abstract}
Mergulhar em diferentes contextos e tratar do conhecimento matemático fora do livro didático requer do professor uma nova relação com o conhecimento. [...] Estar trabalhando com situações-problema implica assim estar mobilizando diferentes conteúdos matemáticos num mesmo espaço e de forma articulada, o que deve gerar na escola e no currículo uma nova visão da matemática. (MUNIZ, 2009, p. 116)
\end{abstract}

É bem verdade que os conteúdos eram uma preocupação das professoras inicialmente, mas, à medida que estudamos na dimensão da conexão de saberes, mais encorajadas, as professoras se sentiram para mudar a ênfase no conteúdo pelo conteúdo. Ao invés disso, buscamos o desenvolvimento de um trabalho articulado, com sentido e significado, capaz de provocar e promover a aprendizagem significativa.

Esse sentido é captado nas falas das professoras, que disseram: "me senti provocada" (ROSA); "foi um incentivo [...] sou movida a estímulos" (RUTE). Além disso, a professora Rute usou o termo motivação, para dizer que elas (as professoras), assim como os alunos, ficavam "mais motivados". Se observarmos bem o contexto em que esses discursos foram produzidos, podemos relacioná-los à aprendizagem, pois, no mesmo enunciado, a professora Rosa expressou "realizamos tanta coisa", bem como a professora Rute que desabafou que foi uma "riqueza de aprendizado". Na mesma linha a professora Leitinho reiterou "foi um grande aprendizado". Mesmo quando as professoras pareciam terceirizar as ações e os sentimentos decorrentes, ainda assim, o faziam como extensão da sua experiência.

A motivação, o incentivo a que se referiram estava relacionado ao movimento formativo que desenvolvemos dentro da escola que pela natureza e organização provocaram "mudanças no seu modo de conceber a matemática, seu ensino e aprendizagem, por meio da própria mediação do campo conceitual do conhecimento matemático" (FÁVERO; NEVES, 2013, p. 321). A primeira aprendizagem que devemos considerar foi o modo de conceber a Matemática como uma onda dinâmica de conhecimentos que não está alheia ao cotidiano e que não é específica da sala de aula. A segunda e, portanto, decorrente da anterior, é que a "oferta" dos conteúdos matemáticos não se deu de forma estanque, mas articulada com outros campos do saber. A terceira foi talvez a mais significativa, porque se vinculou às duas anteriores, mas há uma ênfase para a construção de um campo conceitual, assegurando uma aprendizagem significativa.

Analisando as entrelinhas das falas das professoras, com naturalidade, afirmam que elas mesmas construíram "um tempo em comum" (RITA), e que se durante esse tempo 
realizaram muitas coisas (se referindo ao processo de ensino e de aprendizagem), muito mais teriam para realizar. Quanto ao espaço que os círculos de investigação formativos ocuparam na escola, a professora Rute explicitou "nossas formações têm sido a nossa coordenação". Destarte, fizeram a ressalva que diferentemente da proposta da escola, as formações priorizaram um trabalho coletivo e de colaboração, "ocupando um lugar que seria para coordenação", o que foi fundamental para suas aprendizagens.

As ações dialógicas estiveram presentes em todas as categorias em que tivemos a aprendizagem como centralidade, constituindo-se em um grande disseminador de inéditosviáveis, e uma vez validadas pelo coletivo, configurou-se como aprendizagem enquanto processo formativo emancipatório. Porque a emancipação prescinde a autonomia, a criatividade, a criticidade, a postura ética que contribui para o desenvolvimento profissional do(a) professor(a). Ser um profissional crítico-emancipado significa, na ação dialógica, trabalhar com base na e pela práxis efetiva.

Reiteramos que nosso movimento de idas e vindas para provocar e fazer emergir os inéditos-viáveis aconteceu nas reuniões ou sessões formativas os quais denominamos círculos de investigação formativos, que aconteceram em todas as quartas-feiras letivas do ano de 2015. Nesses encontros, discutimos quais as situações-limite percebidas pelas professoras e listamos algumas ações possíveis de serem desenvolvidas (os atos-limite). Os consensos foram muito maiores que os dissensos porque, embora as professoras ministrassem em etapas de ensino diferentes, elas mesmas diziam que o conteúdo curricular era basicamente o mesmo para todas as etapas, o que mudava era o nível de complexidade para abordagem das questões.

Com base nisso, selecionamos o acervo teórico para estudarmos, providenciamos sempre com antecedência os materiais necessários para utilizar nas atividades - que desenvolvíamos das 14 às 16 h20 nas quartas-feiras. Nesse dia da semana, depois de trabalhar com os alunos das quatro etapas reunidos em um mesmo espaço, eles eram liberados para o intervalo e em seguida poderiam ir para a casa. As professoras faziam também seu intervalo, na sala dos professores e a pesquisadora aguardava na sala de coordenação. Às $16 \mathrm{~h} 40$ as professoras se dirigiam para a sala de coordenação a fim de que avaliássemos as ações e planejássemos as próximas intervenções e, às vezes, chegávamos a ficar até às $18 \mathrm{~h} 20$ na escola, porque sendo horário de verão, anoitecia e como ficávamos envolvidas, não nos dávamos conta de que o tempo havia passado.

Desde o título desse trabalho, buscamos enfatizar que os inéditos-viáveis são constituídos na e a partir da formação continuada. Quando trouxemos os episódios que marcaram o diálogo entre professoras e alunos estivemos procurando explicitar os inéditos 
que emergiam "a partir da" formação, ou seja, foram consequentes de nossas discussões, estudos e planejamentos nos círculos de investigação formativos. Do mesmo modo, ao recortarmos trechos dos diálogos que tivemos com as professoras, tivemos a intenção de mostrar os inéditos surgidos "na formação", durante o processo formativo que também envolveu a reflexão e se materializou na práxis.

Em todas as situações de aprendizagem e de ensino, precisamos enfrentar desafios e conflitos, verdadeiras situações-limite que serviram de impulsionamento para a constituição de inéditos-viáveis enquanto reflexo de aprendizagem das professoras, tanto na formação quanto a partir desta. As trocas de experiências, a valorização de saberes diferentes, o compartilhamento de metas, o compromisso em comum com a modalidade EJA, o desejo de ampliar os conhecimentos dentro do campo da Educação Matemática, a decisão de trilhar pelo caminho da conexão de saberes, na perspectiva das práticas de letramento, representaram elementos centrais para a constituição de inéditos-viáveis.

Refletindo acerca da potencialidade do processo formativo e da coerência com os princípios formativos os quais já descrevemos no item "3.2.1 Do ocular aos vestígios que a pesquisa precisou captar", sentimos a necessidade de propor uma síntese do que o trabalho participativo provocou no grupo, com especial destaque para a aprendizagem permanente do professor. Prada e Longarezi (2008, p. 109) traduziram do seguinte modo:

Os professores como seres humanos que aprendem permanentemente têm o aprender como elemento que faz parte e contribui ao seu desenvolvimento, como profissionais da educação e, portanto, como mediadores da aprendizagem dos estudantes e do coletivo institucional da escola onde trabalham.

Corroboramos com os autores por compreendermos que o elemento central do nosso compromisso formativo foi a aprendizagem significativa do coletivo e, para nós esse aprender se dá na constituição de inéditos-viáveis, conforme tentamos reproduzir esquematicamente. 
Figura 16: Contexto da constituição de inéditos-viáveis

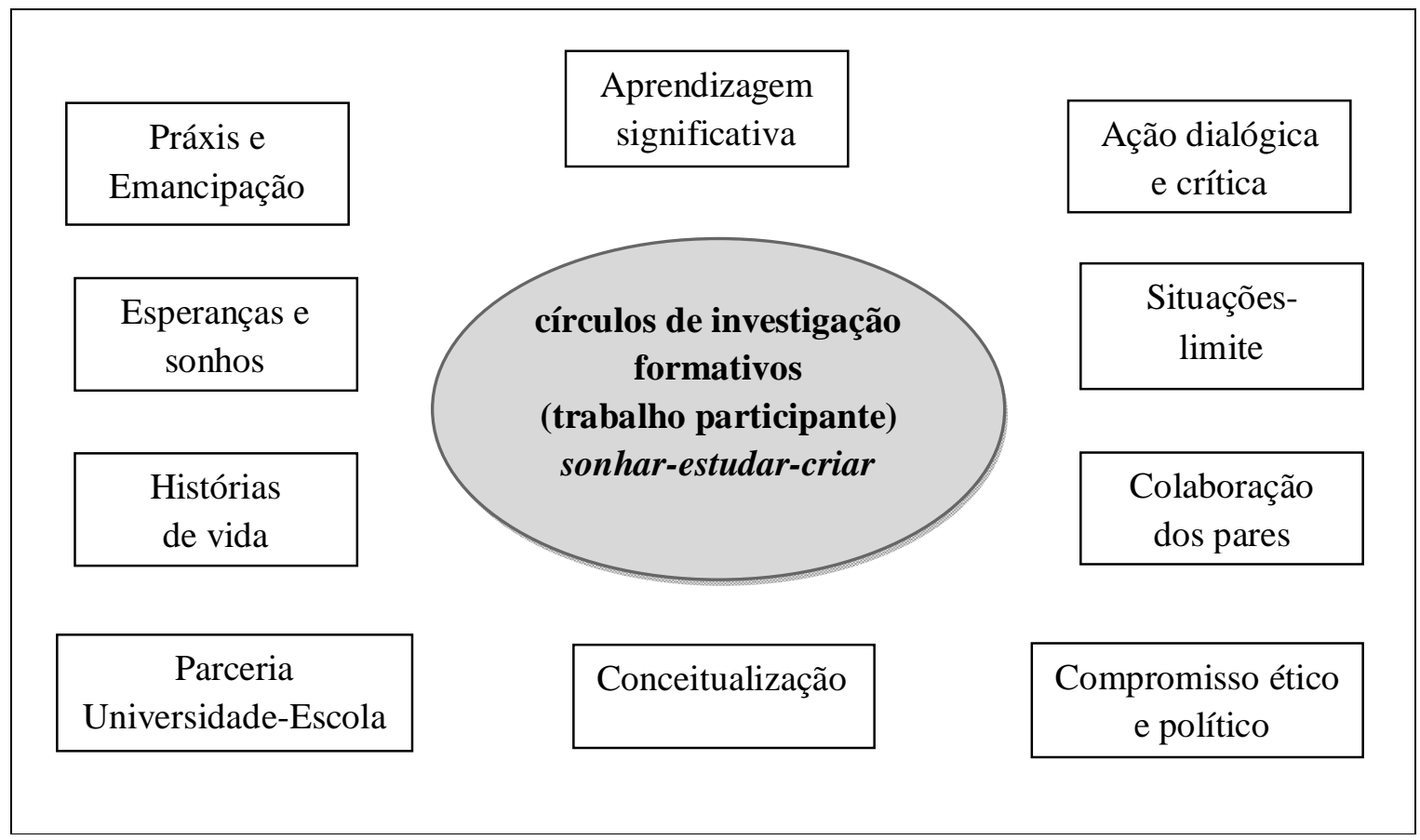

Fonte: elaboração da pesquisadora.

Pensar em uma síntese que pudesse reunir todos os elementos e suas complexas relações dialógicas do contexto em que foram constituídos os inéditos-viáveis não foi uma tarefa fácil, porque incorremos no risco de não destacar as singularidades que permearam esse processo de ampliação da aprendizagem. Cada participante da pesquisa possui experiências historicamente acumuladas, sentimentos e emoções, sonhos e expectativas, conhecimentos prévios, conhecimentos sócio-histórico e social que se configuraram como importantes e significativos no âmbito coletivo, articulando-se na ação dialógica ou, como dizemos na intenção freireana, na dialogia da ação. Nas trocas e nos planejamentos, foi marcante o posicionamento crítico frente às situações de aprendizagem que, por conseguinte, se dava nas práticas de letramento e na conexão de saberes. Com destaque para a colaboração dos pares não apenas em termos de conteúdo didático, mas especialmente porque refletiu o compromisso ético e político com a modalidade EJA, permitindo um trabalho coeso e coerente com a proposta de ensino e aprendizagem que tem por base a teoria dos campos conceituais.

Reiteramos que a parceria Universidade-Escola não ocorreu por vias de contrato didático-pedagógico em que um formador adentrou a escola para ensinar técnicas e metodologias para a atuação na EJA. Ao contrário disso, buscamos respeitar a subjetividade 
de professoras e alunos, com suas histórias de vida, esperança e sonhos e, reunindo essas qualidades a um amplo e complexo corpus de conhecimentos epistemológicos, políticos, filosóficos, sociais, resultando na práxis efetiva e na emancipação desses sujeitos. São, portanto, sujeitos sócio-históricos, cultural e afetivamente situados (REIS, 2011) que aprendem a partir das múltiplas relações, que constroem uma aprendizagem significativa e, por tamanha dimensão, intitulamos de inéditos-viáveis.

A partir dessa reflexão, e considerando que a Matemática no letramento é uma perspectiva do inédito-viável no percurso formativo com educadoras e educandos(as) da EJA, podemos listar esses inéditos-viáveis constituídos pelas professoras na ação dialógica. Desse modo não poderíamos deixar de ressaltar:

produção de significados nos processos de aprender e ensinar;

ampliação dos conceitos matemáticos que envolveram as operações aritméticas;

utilização de situações variadas, socioculturalmente significativas para os sujeitos, que permitiu mobilizar conjuntos de conceitos;

* superação da ênfase exclusiva nas operações enquanto "contas armadas";

* construção de situações matemáticas envolvendo a conexão de saberes;

* ampliação das condições de letramento no contexto das aulas e para além destas; inserção de contextos dialógicos e suprimento das aulas em forma de monólogo;

criação de redes de conexões entre os conteúdos matemáticos, portanto, superando a dicotomia entre tempo versus conteúdo;

estruturação de enunciados familiares aos alunos, favorecendo maior participação e a construção da autonomia intelectual, social e política;

A dimensão afetiva como potencializadora dos processos de produção de conhecimentos matemáticos;

valorização das estratégias de cálculo oral e mental dos alunos, como princípio articulador de aprendizagens;

* utilização de diferentes gêneros textuais no processo de aprender matemática;

exploração de diferentes ambientes dentro da escola para promover a aprendizagem;

estimulação do potencial do educando enquanto produtor de conhecimentos;

realização de atividades que permitiram a socialização entre grupos de diferentes faixas etárias e níveis de conhecimento, favorecendo desde a argumentação até a validação de procedimentos matemáticos; 
descentralização do processo de ensino como função exclusiva do professor, permitindo que os alunos realizassem atividades mediados pela coletividade;

maturação da capacidade intelectual em que a própria professora se reconhece como sujeito de aprendizagem contínua;

valorização do papel formativo da matemática em relação à educação política, ética e moral do sujeito;

\& adoção de práxis emancipadora em que cada professora se percebeu enquanto agente criativo, intelectual e crítico; e

integração de teoria e prática como par dialeticamente inseparável no processo de conhecimento.

Nesse processo rico em aprendizagens, talvez não tenhamos dado conta de abarcar em uma listagem, as peculiaridades presentes no movimento formativo, e por isso mesmo pôr em relevo tudo o que foi possível realizar, não foi e não se faz em uma ação simples. Porque a aprendizagem foi se desenvolvendo à medida que fomos nos inscrevendo na história, correndo os riscos (pela imprevisibilidade) de um trabalho que foi ao mesmo tempo provocante e provocador de situações de aprendizagem. Nesse aspecto, concordamos com Prada e Longarezi (2008, p. 108-109), quando afirmaram:

A aprendizagem requer compreender múltiplas relações dos conhecimentos, sejam estas nas dimensões ideológicas, políticas, sociais ou nas dimensões epistemológicas, filosóficas e/ou da área específica do conhecimento que se quer aprender. Porém o processo de aprendizagem estará completo quando conscientemente (isto é, passado pela crítica) se incorporem ou não esses conhecimentos e suas relações ao desenvolvimento individual e coletivo.

Nessas relações de construção de aprendizagens significativas, portanto, da instituição de inéditos-viáveis, não apenas as professoras e os alunos foram sujeitos de aprendizagem, mas também a pesquisadora que mergulhada em um cenário potencialmente formativo se envolveu em múltiplas situações de aprendizagem contínua. A ampliação cognitiva não se deu em separado do desenvolvimento emocional, social, cultural, político, profissional, mas esteve diretamente relacionado a estes, tanto na dimensão individual quanto coletiva. Impreterivelmente, o encorajamento pelo diálogo foi a mola propulsora de tal cenário, porque, antes de tudo, estivemos lucidamente comprometidos ético, social e politicamente com as profissionais da educação, e esse compromisso foi duplamente validado, por estes e pelos alunos, provocando em nós sentimentos de gratidão pela confiança recíproca. 


\subsection{O diálogo com as participantes e os sonhos como possibilidade}

A ação dialógica que permeou o processo formativo na escola CEM 03 teve uma configuração importante no modo como nos organizamos enquanto coletivo, pois ao mesmo tempo, que permitia a comunicação entre os pares, também era possível expressar as expectativas, as inquietações e denunciar as situações-limite. O diálogo permitiu o equilíbrio das tensões e interferiu nas condições dialéticas do contexto de formação, e também foi importante para os alinhavos dos momentos pedagógicos de sonhar, estudar e criar (FREITAS, 2001), potencializando a aprendizagem de todos os envolvidos.

Depois de um ano letivo de vivências com trocas de conhecimentos em coletividade, decidimos que seria importante também dialogar individualmente com cada professora, para que tivessem a oportunidade de falar sobre a contribuição da formação continuada para sua profissão docente. Para isso, elaboramos um roteiro com enunciados que permitiam que as professoras falassem o que pensavam, as expectativas, os pontos fortes e os pontos fracos do processo de formação continuada dentro da escola, conforme trazemos.

\section{Rejane: Fale de suas impressões acerca dessa formação em Educação Matemática.}

Rosa: Representou uma grande provocação. Fui provocada a fazer diferente, a ousar e descobrir novos caminhos. Porque às vezes, diante da realidade, o professor acaba ficando inerte e não busca inovações para trabalhar e não busca formas diferentes de promover a construção de conhecimentos. Esse projeto fez despertar o nosso lado criativo. Eu tive que reativar a minha criatividade. Antes nós ponderávamos quando tinha um assunto pra trabalhar e que exigia fazer um link com outros assuntos, mas agora agente pensa diferente, porque a gente viu na prática que é possível fazer a conexão de saberes.

Rute: Representou uma aprendizagem significativa, principalmente porque trabalhamos no coletivo. E antes nós trabalhávamos de forma estanque os conteúdos. Eu mesma fui uma das que falou que não dava tempo de trabalhar todos os conteúdos do currículo escolar, mas aí a gente viu que é possivel trabalhar os conhecimentos todos, quando faz em conexão de saberes.

Leitinho: Participar desse projeto formativo foi interessante porque nós ficamos bitoladas a um tipo de formação e até de orientação dos alunos. Às vezes a gente achava que na EJA não podíamos fazer atividades mais dinâmicas porque achava que isso era só para criança e aí ficávamos naquela rotina. E aqui a gente viu como as aulas eram mais interessantes $e$ dinâmicas e os alunos se tornaram mais participativos, além disso, nós vimos vários conteúdos ligados uns aos outros, com a conexão de saberes. E esse projeto foi um ânimo para o nosso trabalho na EJA.

Rita: O projeto de formação foi importante porque deu um novo sentido para nossa prática, movimentou as turmas e também nosso trabalho, nos deu ânimo e força porque estivemos trabalhando juntas. Outra coisa interessante foi que nos fez ver o quanto os alunos sabem sobre aquilo que a gente pensa que vai ensinar, porque tem muitos conhecimentos que eles sabem até mais do que a gente. E no caso da Educação Matemática, os alunos sabem muito porque faz parte da vivência deles. 
Fabí: O projeto foi muito válido, principalmente porque agregou vários conhecimentos, a conexão de saberes. Sempre que há comunicação, há trocas que são importantes para que possamos fazer um trabalho mais articulado em nossas turmas e isso foi muito bacana.

Rejane: O fator (ou os fatores) limitador(es) da formação foi ...

Rosa: O fator tempo é o limitador, porque todas as atividades que realizamos e depois discutimos pra ver o que deu certo e o que não deu [...], acho que nas nossas discussões $e$ depois delas nós teríamos ainda muitas coisas pra trabalhar, mas precisaríamos ainda de mais tempo. E nós queremos que o projeto de formação continue porque toda essa construção do conhecimento é importante para nosso trabalho.

Rute: Nós rompemos a questão do tempo, porque nós conseguimos nos reunir com periodicidade, mas acho que ainda podemos fazer muita coisa, porque eu olho e vejo tudo o que realizamos e tudo o que aprendemos.

Leitinho: Acho que nós deveríamos ter muito mais tempo porque nós poderíamos crescer muito ainda, aprenderíamos muito mais.

Rita: Nós fizemos muita coisa, mas se nós tivéssemos mais tempo, mais aprendizado nós construiríamos e os alunos também.

Fabí: Eu acho que não teve ponto fraco porque tudo o que aconteceu de discussão e de trabalho com os conteúdos matemáticos vieram para somar. E acho que esse trabalho pode ser anual mesmo porque aí contribui muito com a gente e com as turmas.

\section{Rejane: Você entende essa formação continuada como...}

Rosa: Esses momentos de formação precisam ser rotina em nossa carreira porque eles são enriquecedores. E o mais importante é que foi concebido aqui na escola, e dentro da nossa sala de aula, nosso ambiente de trabalho. Isso fez toda a diferença e isso eu nunca vivi antes, porque sempre nós temos que migrar para outro local, aí a teoria nos é passada, mas não estamos ali em nosso momento de atuação com nossos alunos, então fica só na teoria. Mas no caso dessa formação aqui foi muito produtivo, nós ganhamos muito.

Rute: Houve muita aprendizagem da gente e dos alunos. Nós de fato aliamos a prática à teoria. Não foi um curso teórico como os que têm por aí. Vou confessar que no início a gente não se deu conta da proporção desse trabalho de formação, mas ao longo do processo, da pesquisa, a gente foi percebendo o quanto nós estudamos, realizamos e aprendemos.

Leitinho: Nós estivemos motivados para construir novos conhecimentos, inovamos, fomos estimuladas. Ajudou em nosso desenvolvimento profissional.

Rita: Nós trabalhamos de forma contextualizada e trabalhamos o conteúdo matemático, mas não como ensino do que não sabiam. Nossa ação foi mesmo de acrescentar àquilo que os alunos já sabiam.

Fabí: A gente acaba ficando em nosso mundinho e acaba realizando um trabalho muito mecânico, e aí quando tem uma coisa assim diferente, como foi essa formação, aí abre os horizontes, abre a mente e a cabeça para que a gente possa buscar novos caminhos [...], porque quando tem uma coisa que nos provoca e que a gente gosta, a gente vai atrás e pesquisa e se envolve, e isso ajuda na formação do professor.

\section{Rejane: Fale o que significa aprendizagem matemática.}

Rosa: A matemática é importante contextualizada, porque aprendemos que não devemos trabalhar, por exemplo, com conteúdos de forma estanque, aí tudo passa a ter um maior significado, para nós e para o aluno. E é justamente essa produção de sentido que instiga-nos 
a aprender e a buscar cada vez mais e, claro, a gostar da matemática. Eu não só aprendi muito, mas também passei a me sentir muito mais motivada. Sabe por quê? Porque esse projeto não é como um curso teórico que nós nos apoiamos em frases de efeito, mas em momentos de formação no coletivo que foi o mais importante e por isso deu tão certo.

Rute: $O$ mais importante é a construção da aprendizagem significativa pra que a gente possa trabalhar com os alunos. Nós ganhamos muito com essa formação porque a gente aprendeu muito, muito mesmo e os alunos também ganharam muito.

Leitinho: Sabe uma das aprendizagens interessantes é que há muitas formas de aprender è̀s vezes a gente fica apenas no quadro e na voz de tal forma que a gente esquece podemos estimular a aprendizagem se usarmos contextos a partir do cotidiano. Vou dar um exemplo, a atividade de medida de comprimento foi uma aprendizagem pro resto da vida dos alunos porque até quando eles forem até fazer um pedido em uma revista, eles vão lembrar do quanto foi significativo o que eles aprenderam, sobre a importância de prestar a atenção nas medidas. Mas a maior aprendizagem foi nossa que ampliamos os conhecimentos.

Rita: Vou dizer uma coisa, a gente estudou numa época que a gente se apegou àquilo que nós estudamos e aí acaba que a gente não se atualiza. E o que tivemos aqui foi uma formação contínua em que buscamos trabalhar com contextos atuais, e claro, nós trabalhamos juntas e por isso aprendemos muito. E nós conseguimos, a partir da conexão de saberes, romper com aquela coisa de trabalho segmentado, conteúdos por partes e separados. Nós conseguimos perceber a relação dos conteúdos e isso foi muito legal, tanto é que até a Rosa que é de Lingua Portuguesa trabalhou com a gente e as trocas de saberes no nosso grupo ajudaram para que nosso trabalho fosse tão rico.

Fabí: $O$ que nós procuramos trabalhar dentro da pesquisa foram contextos que os alunos vão levar pra vida, como por exemplo, as atividades que realizamos com medidas, a confecção da bolsa e as medidas de área foram conhecimentos importantes e que eles vão lembrar sempre. Ou seja, não foi apenas o conteúdo que aprenderam em sala de aula, são conhecimentos que eles vão usar no dia a dia. Nessa relação todos aprendem, os alunos, as professoras, a escola, todos que estão nesse movimento formativo aprendem.

\section{Rejane: $O$ que representaram os círculos de investigação formativos...}

Rosa: Foi desafio. Os desafios que precisaram ser vencidos e nós fomos construindo modos de superá-los. O ser humano é movido a desafios e se nós olhamos de forma positiva para esses desafios, eles funcionam como motivadores e foi isso que aconteceu com nosso grupo. E houve muita empolgação e muita interação, especialmente entre os alunos porque era uma mistura de gerações que foi bastante enriquecedor no processo de aprendizagem. Os próprios alunos têm muito a nos ensinar e eles se sentiram valorizados porque tivemos muitas trocas de conhecimentos e de experiências.

Rute: Foi o entusiasmo de todos. Inclusive o que nós fizemos com os alunos, juntando todas as turmas foi muito interessante, pois eles participaram mais porque nós trabalhamos com contextos matemáticos que valorizaram a realidade deles e por isso eles foram mais participantes. E quando se aproximava as quartas-feiras os alunos já ficavam empolgados porque sabiam que iríamos propor algo diferente, nós juntávamos as turmas.

Leitinho: Além de trabalharmos todas juntas, também o fato de trabalharmos a matemática na conexão de saberes foi ótimo, porque nós temos a mania de trabalhar os conteúdos separados e agora nós ampliamos a possibilidade de fazer um trabalho articulado $e$ significativo. Na minha concepção, uma aprendizagem que ficou marcada na vida dos alunos foi medida de comprimento. Acho que as aprendizagens tiveram um alcance muito maior que do conteúdo em si. 
Rita: O mais importante mesmo de tudo foi trabalhar em equipe, sem dúvida. Porque a gente rende mais, aprende mais. E isso foi tão marcante que até as turmas nós juntamos, independente da série que o aluno estava cursando. E nós rompemos uma barreira porque percebemos que podemos trabalhar todos os conteúdos matemáticos usando a conexão de saberes. E os alunos trocam ideias e entram em acordo e dão respostas. Tudo fluiu tão bem, foi uma formação sem cobranças que rendeu muita aprendizagem.

Fabí: $O$ mais interessante mesmo foi a integração. $E$ a integração de todas as turmas também, porque favoreceu um trabalho conjunto, a troca de conhecimentos. Isso rendeu muita aprendizagem para eles e para nós que aprendemos com eles.

\section{Rejane: Fale das implicações de trabalhar com a Educação Matemática.}

Rosa: $O$ que é fascinante na matemática é que podemos explicar o porque das coisas e fazer abstrações. E a contextualização faz com que tenhamos mais motivação para compreender melhor as coisas. E, ao meu ver, uma das grandes dificuldades para a aprendizagem da matemática é a utilização de questões descontextualizadas, e eu posso afirmar com toda certeza, que essa foi uma situação que nós rompemos durante o projeto de formação.

Rute: Quando trabalhamos com situações contextualizadas a gente vê a diferença $e$ envolvimento de todos e eles até melhoram a autoestima. A autoestima dos alunos é baixa porque muitas vezes eles dizem que não sabem, mas da forma como trabalhamos com o contexto deles, eles não só sabiam resolver como também tinham vontade de participar e olha que nós trabalhamos os conteúdos matemáticos com todas as turmas juntas e eles deram conta porque foi de acordo com a vivência deles.

Leitinho: Foi muito positivo o modo como foi trabalhado na conexão de saberes, porque aí a matemática já não era mais só as operações, e o contexto valorizava a realidade dos alunos, fazendo com que eles se interessassem mais e ficassem mais participativos. E também trabalhamos os campos de saberes que deram todo o significado daquilo que estávamos abordando na matemática e isso fez muita diferença. E com certeza nós plantamos a semente, tanto foi que os alunos já perguntavam se quarta-feira teria aquela aula que juntava todo mundo. Então a gente via o quanto eles gostavam de estarem todos juntos e de aprenderem juntos. Isso era diferente para eles. Agora, muito mais positivo do que isso foi que as professoras que aceitaram participar do projeto aprenderam muito, muito mesmo. E com certeza o modo de ver a Educação Matemática dentro da EJA já não é mais o mesmo porque agora nós já fazemos a conexão de saberes e de conhecimentos que serve para a aprendizagem dos alunos e muito mais pra gente, porque quanto mais a gente ensina mais a gente aprende.

Rita: As aulas e as formações passavam voando e era tanto conhecimento que nós não dávamos conta de explorar tudo porque o tempo já tinha acabado. Não estou falando que o trabalho ficava pela metade, mas é que foi um trabalho dinâmico, com tantas ideias e participação que outras ideias já surgiam em nossas discussões e nós já queríamos avançar, mas aí o tempo não dava.

Fabí: Acho que não é exatamente ponto negativo, porque nós fomos desenvolvendo atividades e mobilizando conhecimentos e isso foi gerando novas necessidades, e precisamos sistematizar mais coisas e não tínhamos mais tempo. E com os alunos nós rompemos muita coisa e eles aprenderam muito. Depois que realizamos a atividade da confecção das bolsas, eles não olham mais os objetos do mesmo jeito, eles já sabem dizer se o tamanho é ideal, se é muito comprida ou funda, então eles já sabem, eles têm uma noção e sabem se vai atender as suas necessidades ou não. E aí a gente vê que é um conhecimento que o aluno leva pra vida.

Rejane: Você enfrenta as dificuldades para aprender e para ensinar matemática assim ... 
Rosa: Eu sou movida pela curiosidade, porque eu acho importante a gente saber o significado das coisas. Então para eu aprender, eu acho importante saber para que serve determinado conhecimento, quando e como eu empregarei na minha vida, aí sim, é como se meu cérebro se abrisse para aquele conhecimento. E tem mais, se for só uma informação estanque, sem significado, o próprio cérebro faz questão de descartar. E à medida que o conhecimento apresenta significado, a aprendizagem é potencializada. Deixa eu dar um exemplo: Você lembra que trabalhamos sobre medidas de comprimento, aí quando fomos trabalhar o metro quadrado os alunos mesmos já compararam aquela situação com o fato de eles usarem o metrô e o ônibus, ou seja, foi significativo aquele conhecimento, aquela aprendizagem de ocupação de espaço. Ou seja, ao invés de se lembrarem de letras ou símbolos, os alunos se lembraram da cena, do momento da vivência deles e relacionam com o conteúdo da aula.

Rute: Nós buscamos construir mais conhecimentos e essa formação aqui tem mostrado novas possibilidades porque geralmente a gente investe na nossa formação sozinha e corre atrás para ensinar para os alunos. As formações que a gente costuma participar têm uma dimensão genérica e não trata das especificidades da sala de aula. O projeto de formação que estivemos agora na escola foi no coletivo, houve muitas trocas e isso ajuda na aprendizagem.

Leitinho: A primeira coisa é ser humilde. Temos que ter humildade para reconhecer que não sabemos tudo e temos que correr atrás. E o que esse projeto despertou em mim foi que eu podia ir além e aprender muito. E nós somos amigos dos nossos alunos, temos idades aproximadas e temos conhecimentos diferentes e temos que ter humildade também para reconhecer que aprendemos com nossos alunos.

Rita: A gente viu que matemática está em nossa vida. A Educação Matemática tem o lado útil e nós contextualizamos os conteúdos, os conhecimentos, e isso contribuiu para a aprendizagem da gente. E para ensinar, a gente precisa aprender e na nossa formação inicial não foi dada a ênfase para esse trabalho com a Matemática e agora eu consigo perceber mais claramente isso, por isso eu tenho necessidade de aprender ainda mais. Também é importante considerar o que o outro já sabe, respeitar a sua vivência e aproveitar os conhecimentos que ele tem. Além disso, agora eu sei bem que só ensinar que "dois mais três é igual a cinco" não vai resultar numa aprendizagem com sentido. É necessário trazer isso dentro de um contexto porque se aprende mais.

Fabí: Eu não tenho dificuldade para aprender matemática porque é uma área do conhecimento que eu gosto muito e me identifico. E também não costumo ter dificuldades para ensinar, mas confesso que teve um caso em que eu não conseguia ensinar divisão pra uma turma. E eu falei que achava que o problema estava comigo, então eu pedi ajuda a um colega professor que é da área de exatas, para ver se ele dava conta de ensinar os alunos. Mas tenho que reconhecer que ensinar de forma contextualizada os alunos aprendem mais $e$ é muito significativo.

\section{Rejane: Fale da experiência de trabalhar a matemática na perspectiva do letramento.}

Rosa: Nós percebemos que a matemática não se resume a número e cálculos, ela envolve contextos mais amplos. Olha! Quantos textos nós trabalhamos e em tudo tinha matemática. E eu vou ser sincera, os alunos ficam mais interessados, porque chama a atenção deles, é significativo e esclarecedor.

Rute: Foi tão interessante porque quando a gente ouve falar em letramento, vem logo na cabeça o Português, mas nós utilizamos o contexto de letramento na Matemática. E o fato de nós juntarmos as turmas, alguns alunos sabiam ler e escrever e outros nem tanto, mas nas trocas eles conseguiam compreender o contexto e participavam e davam respostas. 
Leitinho: Vou confessar uma coisa, foi uma coisa bem diferente e muito interessante, porque veja só, depois que nós começamos a trazer esses contextos para dentro da sala de aula, os alunos ficaram muito mais atentos. Um dia na minha sala eu levei uma receita de pão de mel e a primeira coisa que eles fizeram foi ler e identificar as medidas. E eu consigo enxergar a diferença, o entendimento, a aprendizagem mesmo, o olhar matemático é diferente.

Rita: Nós aprendemos que matemática vai além de números e cálculos, ela envolve contextos e nós exploramos isso bastante. Você vê, por exemplo, que os alunos sabem fazer a leitura dos panfletos de supermercados, mesmo não sabendo a decodificação gráfica das palavras, mas os alunos da EJA sabem de que supermercado é aquele panfleto, fazem comparação de preços, sabem se está mais caro que em outro supermercado e fazem cálculos de cabeça e dizem a diferença de preços. E eles são tão inteligentes que alguns até dizem assim "será que compensa eu ir lá, porque fica longe de casa, aí vou ter que pagar passagem e vai acabar ficando mais caro". É interessante isso.

Fabí: Eu acho que foi muito bacana e nós temos que ter mais oportunidade de trabalhar a matemática nessa perspectiva, até porque o letramento já faz parte da vida cotidiana do aluno. Por exemplo, eles fazem a leitura e a interpretação daqueles panfletos de supermercado, sabem diferenciar que produto é, sabem dizer se a marca é boa ou não e se vale a pena pagar aquele valor por aquele produto.

Rejane: De toda a experiência de trabalho na EJA (você pode especificar quanto tempo), fale como tem sido a sua relação com a formação.

Rosa: Eu tenho praticamente 20 anos de EJA e vou te falar que essas formações são novidades que desestressam a gente, sabe por quê? Porque foram formações que não fizeram cobranças pra gente. Nós não fomos observados e nossos erros não foram apontados. Foram momentos formativos de verdade e enriquecedores, foram formações dialógicas com muitas provocações que serviram de motivação e deu mais ânimo pra nós porque foi dentro da escola e envolveu todas nós. Porque por aí a fora, essas formações são para receber certificados, mas não foi o que aconteceu aqui com a gente. Nós tivemos uma formação humana e profissional, por isso eu só tenho a agradecer, porque a semente foi plantada $e$ árvore já começa a crescer e muitos frutos ainda serão colhidos. E eu quero e necessito dessas formações porque foi a primeira vez que a formação veio ao meu encontro e não precisou que eu fosse atrás. Outras pesquisas já aconteceram aqui, mas não foi nada parecido com o que vivemos aqui. Eu tenho esperança de que é possível fazer uma educação diferente em que os alunos da EJA possam cada vez mais compartilhar os conhecimentos que eles têm com os colegas e com os professores. Os conhecimentos que nós construímos são incomensuráveis e fica a certeza de que muito mais nós temos a descobrir e a construir, e a formação foi um terreno fértil e fantástico para nós aprendermos.

Rute: Há quase 14 anos eu trabalho na EJA e nós nunca tivemos esse espaço para trabalharmos juntas, estudando, discutindo, tomando decisões juntas e trocar ideias. Nossas coordenações sempre foram individuais, mas agora foi possível trabalharmos juntas e eu sentia falta disso. Então, o projeto foi excelente. Nós aprendemos muito e os alunos também. Foi uma experiência única, nós queremos continuar com esse projeto de formação.

Leitinho: Eu já trabalhei no ensino especial e no ensino regular, mas na EJA tem pouco mais de três anos, mas de todas as experiências que eu já tive, foi a primeira vez que eu participei de uma formação que não foi teórica e que foi voltada para a EJA. E também o que foi oportunizado aqui pra gente foi a coordenação em conjunto que favoreceu o nosso crescimento, a nossa aprendizagem e o fortalecimento de nossas ações porque cada uma podia ajudar a outra. Se esse trabalho acontecesse em todas as EJAs, com certeza hoje a 
modalidade seria outra. O mais importante foi a coordenação coletiva, porque nós tivemos várias cabeças pensando e decidindo juntas com a mesma finalidade que era a aprendizagem. As provocações no grupo serviram para estimular a gente, tanto é que a nossa ideia de juntarmos as turmas foi sensacional porque ninguém nem dizia que tinha ali turmas de etapas diferentes porque eles trocavam ideias, entravam em acordo, participavam e aprendiam muito. E por tudo isso é que eu acho esse projeto formativo de grande valor e que a EJA ganharia muito se fosse ampliada para todas as escolas e foi um presente pra nós porque foi muito positivo em termos de organização, de trabalho em equipe, de planejamento de estudo e de ação mesmo na sala de aula.

Rita: Olha eu já estou caminhando para 15 anos de atuação na EJA. E nesse projeto formativo nós tivemos tantas ideias, foi tanta criatividade que nós contribuímos para grandes aprendizagens. Um aprendizado que os alunos irão levar para a vida é o de medida de comprimento, especialmente por causa da confecção das bolsas, porque a aprendizagem maior foi para que eles não fossem mais enganados, e observem as medidas, especialmente se for para comprar algum objeto que ele não está vendo, como pedidos em revistas. E o fato de nos juntarmos para estudar e planejar as ações foi tão bom que nós conseguimos criar muitas coisas interessantes. A gente conseguiu trabalhar os conteúdos do currículo, pois fizemos a relação com outros campos do saber. O trabalho coletivo faz com que haja mais aprendizagem, porque olha o que aconteceu com o nosso último trabalho do ano que foi sobre alimentação saudável, cada uma de nós tinha um pouco de conhecimento e os alunos também e a atividade fluiu tão bem, foi tão rica. A gente precisa continuar, porque foi a nossa primeira formação voltada para a Educação Matemática e o projeto despertou em nós o desejo de ampliar os conhecimentos e de aprender mais.

Fabí: Eu completei 20 anos de EJA e eu busco muita informação. Por exemplo, muitas coisas que eu aprendi para trabalhar a matemática, eu aprendi com o grupo GEEMPA ${ }^{20}$, da Estrer Grossi e fiz também curso envolvendo letramento e eu procuro fazer muitas coisas diferentes porque os meus alunos mais idosos têm problema de esquecimento. Então, se as atividades não forem interessantes e não tiver relação com a vida deles, eles não vão aprender. E isso foi uma coisa muito bacana nesse projeto de formação, mas eu confesso que no início eu pensei que ia ser como muitos outros que já passaram por aqui, mas aí eu fiquei analisando e vi o compromisso e o empenho e a adesão do grupo, aí percebi que era diferente e nós temos aprendido muito. O nosso grupo é muito bom, a gente se dá super bem, a gente consegue conversar e trocar ideias, porque nós somos muito coesas.

$\mathrm{Na}$ fala das professoras, fica evidenciado o maior inédito-viável constituído que foi a coletividade, o trabalho coletivo e articulado permitiu mobilizar elementos conceituais que contribuíram para a construção de uma aprendizagem significativa. Nas entrelinhas do discurso das professoras, o processo formativo foi motivador e fomentador de nova práxis que auxiliou no modo como concebe, aprende e ensina a Matemática, estabelecendo relação com outras áreas de saberes e considerando os conhecimentos prévios que os alunos têm, na intenção de ampliá-los.

Ao voltamos nosso olhar para as questões que nos inquietaram no desenvolvimento dessa pesquisa, percebemos que as professoras não apontaram como limitação as condições

\footnotetext{
${ }^{20}$ Grupo de Estudos Sobre Educação, Metodologia de Pesquisa e Ação.
} 
materiais, pois se engajaram nas ações dialógicas e buscaram, em parceria, contornar essas condições, tendo em vista que apostaram na contribuição da formação, para o processo de aprendizagem. Em relação ao tempo dedicado para a formação, nós admitimos que não foram só as quartas-feiras que dedicamos aos processos formativos, porque mesmo quando não estávamos reunidas na escola, buscávamos materiais de estudo e socializávamos por e-mail. As professoras disseram que os nossos momentos de estudo e discussão contribuíram para ampliar os conhecimentos porque consistiram em provocação, debate, troca de ideias e, por isso, percebemos no diálogo a preponderância de uma identidade plural, em que as professoras se afirmam como grupo de estudo, de coordenação conjunta, de parceria.

Ainda a respeito do tempo dedicado à formação, cada professora manifesta a satisfação de que o tempo foi uma conquista conjunta em que todas as professoras do primeiro segmento conseguiram realizar uma coordenação conjunta e mais que isso, aderir à uma práxis coletiva. Se analisamos essa postura, podemos dizer, como defendeu Freire e Shor (1986, p. 69), que os professores se revelaram "substantivamente políticos e adjetivamente pedagógicos", porque assumiram com autonomia a decisão quanto à dedicação de tempo para a formação e reconheceram-se como sujeitos de aprendizagem.

Outra pista clarividente na fala das professoras é que as situações-limite instigadoras dos inéditos-viáveis foram a necessidade de ampliar o campo do conhecimento de Educação Matemática, porque uma vez aprendendo, tanto mais condições terão para ensinar. $\mathrm{Na}$ concepção das participantes, utilizar a prática de letramento como âncora do processo de aprendizagem, a utilização de contextos valorizando a conexão de saberes e a realidade do aluno favoreceram para a construção da aprendizagem significativa. Mas também elas dão ênfase à dialogicidade que permeou a formação e destacaram a liberdade que tiveram para tomarem decisões, sem cobranças, sem exigências.

Ao longo desse trabalho viemos destacando episódios em que temos a presença marcante dos inéditos-viáveis dentro das discussões dos círculos de investigação formativos e durante as aulas, porque estamos certos de que esses inéditos são constituídos e provocados por uma coletividade e se dá nas relações entre pesquisadora e professoras, entre as próprias professoras, e também entre professoras e alunos. Desse ponto, podemos inferir que os inéditos-viáveis surgiram de sonhos coletivos que puderam ser concretizados, mas como as próprias participantes da pesquisa afirmaram, ainda há muitas ações a serem empreendidas, o que requer a mobilização de mais conhecimentos para constituir novos inéditos, fazendo com que se mantenha o ritmo cíclico e contínuo da aprendizagem. 
A marca fundamental dos círculos de investigação formativos, segundo o posicionamento das professoras, foi o diálogo - na conjuntura da coletividade e, estimuladas por este movimento de formação, ampliaram também esse cenário, oportunizando experiência análoga para o trabalho com os alunos das quatro etapas de ensino. Nessa relação dialógica, é importante destacar que o processo de escuta foi favorecido pela prática da solidariedade, do afeto, do respeito ao outro, aos saberes desse outro. Na concepção de Freire (1996, p. 113) se "o sonho que nos anima é democrático e solidário, não é falando aos outros, de cima para baixo, sobretudo, como se fôssemos os portadores da verdade a ser transmitida aos demais, que aprendemos a escutar, mas é escutando que aprendemos a falar com eles".

No sentido dado pelo autor, temos que educar nossa escuta e no nosso entendimento, isso é tão importante quanto necessário para não reforçarmos o silêncio e, ao contrário disso, devemos contribuir para a manutenção de uma educação que favoreça o pensamento crítico, a autonomia, a formação do intelectual, a emancipação do sujeito. Foi esse o caminho pelo qual optamos ao nos engajarmos com esperança, alimentando sonhos freireanos de que mudar é difícil, mas é possível. Nesse caminho, aderimos voluntariamente aos processos formativos porque acreditamos na contribuição para a aprendizagem individual e coletiva, mobilizando conhecimentos científicos, culturais, sociais, políticos que foram indispensáveis para nosso desenvolvimento profissional. E para manter viva em nós a esperança de que é possível promover uma aprendizagem com significado tão necessária para nossa vida pessoal quanto profissional, no movimento ininterrupto da constituição de inéditos-viáveis.

Ainda a tempo, queremos trazer uma contribuição importante no que concerne a esse desejo de manter vivo e latente o compromisso pela formação do sujeito enquanto ser social, histórico, cultural, político, ético. E quando fazíamos essa reflexão, observei uma nova mensagem na caixa de e-mails, cujo remetente era a professora Nita Freire, com a intitulação do assunto "Viva Paulo!". Ao abrir aquele e-mail, li com atenção a matéria que descrevia o seguinte: "só um brasileiro aparece entre os 100 livros mais pedidos nas universidades dos EUA: Paulo Freire" de acordo com o Projeto Open Syllabus ${ }^{21}$.

Mas que relação poderia ter essa matéria com as discussões que temos empreendido neste trabalho de pesquisa? As categorias situação-limite, atos-limite e inéditos-viáveis são o que podemos chamar de pedra angular de nosso estudo investigativo, e nosso referente é a obra Pedagogia do Oprimido, que escrito na década de 60, se faz atual. E a isso se reporta a matéria, quando traz informações que o Projeto norte-americano (Open Syllabus) reúne

\footnotetext{
${ }^{21}$ Para conferir a lista completa, acesse: 〈http://explorer.opensyllabusproject.org/〉.
} 
ementas das disciplinas de instituições de ensino superior nos Estados Unidos (EUA), a fim de mapear quais são os livros mais solicitados pelos professores. De acordo com este Projeto, o livro Pedagogia do Oprimido (Pedagogy of the Oppressed), ocupa a 99ª posição na lista geral de temas de todas as áreas, tendo sido solicitado em 1.021 ementas de universidades e faculdades dos EUA. Sendo que na área da Educação é o segundo livro mais pedido, o primeiro é "Teaching for Quality Learning at University: What the Student Does", de John Biggs e Catherine Tang.

Figura 17: Livros mais solicitados no ensino superior dos EUA, na área da Educação segundo o Projeto Open Syllabus

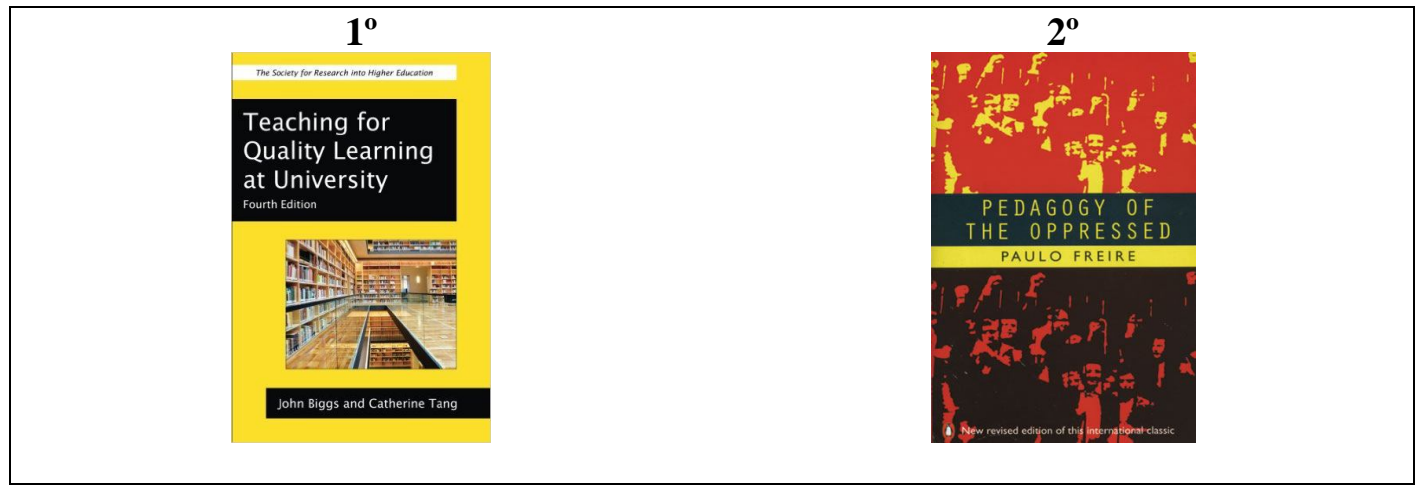

Fonte: consulta livre na internet.

Até essa notícia não me escapou a análise, desde o assunto "Viva Paulo!", que não sugeriu apenas a vibração pela posição ocupada no ranking, mas, em nossa interpretação, representou o anúncio de que "Freire ainda vive", porque suas ideias continuam atuais, dialogam com os acontecimentos cotidianos, mesmo tendo sido escrito e publicado há décadas. Isso porque "Freire permanece vivo em nossas práticas, em função do amplo movimento de educadores e educadoras que assumem o compromisso não apenas com sua memória, mas também com a recriação de seu pensamento" (FREITAS, 2014, p.81-82).

O verbo viver também nos permite compor de outras formas, conforme nossas experiências nos círculos de investigação formativos, em que tivemos a oportunidade de VIVER, conVIVER, reVIVER. Vivemos emoções, sonhos e ansiedades, convivemos com pessoas que se emocionaram e sonharam conosco, revivemos situações de aprendizagem. Voltando à obra, analisamos também que se é a segunda mais indicada na área da Educação, isso implica que mais pessoas terão acesso aos inéditos-viáveis que podem se tornar articuladores de outros processos formativos. Isso pode até parecer utopia, mas é no movimento utópico que nos inscrevemos na história pela busca de mais realizações e garantindo a perpetuação da história. 


\section{CONSIDERAÇÕES NEM SEMPRE FINAIS}

[...] nos daremos por satisfeitos se, dos possíveis leitores deste ensaio, surgirem críticas capazes de retificar erros e equívocos, de aprofundar afirmações $e$ de apontar para o que não vimos.

(FREIRE, Pedagogia do Oprimido, 2011, p. 252)

Começo dizendo considerações nem sempre finais devido à consciência de minha incompletude enquanto pessoa-estudante-professora-pesquisadora que sempre tem algo a dizer e a acrescentar, porque a minha relação com o mundo não é estática. Minha relação com o mundo é dialógica e histórica e por isso faço continuamente a leitura desse mundo e me sinto provocada a pronunciar a palavra como modo de ampliação do conhecimento no mundo. Os sentimentos que me tomam nessa parte da escrita são singulares e plurais, porque compartilhei experiências em vários cenários de aprendizagem e com pessoas das mais diversas formações, e isso vem refletido no modo como me posiciono frente ao mundo e às pessoas, com as quais dialogo.

No momento "derradeiro" dessa escrita, tomo fôlego para não ser tomada apenas pelas emoções decorrentes de tantos momentos ricos em aprendizagem que marcaram profunda e irreversivelmente minha história pessoal e profissional. O diálogo coletivo, a ação dialógica, a força eminente da palavra pronunciada como possibilidade de pronunciamento do mundo, a afetividade na relação com o orientador, com as professoras e também com os alunos no contexto da pesquisa. Os sonhos e as esperanças foram verdadeiros indicadores táteis, sonoros e luminosos da ação editanda nos participantes da pesquisa que se envolveram na luta pelo ser-mais. A coesão de um grupo que manteve e mantém um compromisso político e pedagógico com os sujeitos, porque acreditam que estes são construtores da aprendizagem significativa. Um universo fértil e fecundo de criatividade, autonomia, criticidade foi possível por meio do engajamento sério e encorajado, nos processos de formação, de pessoas que superam paulatinamente as situações-limite quando se inscrevem na história como seres históricos que mobilizam atos-limite para constituir inéditos-viáveis.

Os inéditos-viáveis revelam-se como constituidores da materialização dos sonhos. As pessoas que estão em busca de superar os obstáculos (as situações-limite) que se interpõe em suas vidas, o fazem porque acreditam na possibilidade da mudança, na realização dos sonhos. Vale salientar que estes não assinalaram o fim de um processo, pois somos marcados histórica e culturalmente por processos dialéticos em que superamos uma situação-limite, mobilizamos 
atos-limite e constituímos inéditos-viáveis e em seguida outros obstáculos aparecem e reunimos forças para mais uma vez superá-los. Assim ocorre o movimento de retroalimentação da vida pessoal e profissional, são os fatores provocativos, aos quais se reportam as professoras quando assumiram a participação coletiva com implicação formativa e promotora de aprendizagem.

A configuração do processo formativo dentro da escola se deu pela mobilização e organização de um grupo coeso e articulado que ousou sonhar, estudar e criar as condições de aprendizagem que pudessem ampliar os saberes da profissão, em diálogo com o conhecimento social, cultural e político. Nesse cenário reunimos elementos importantes para ampliarmos o entendimento, a utilização e a relação da Educação Matemática - dentro da modalidade EJA - com outros campos de saberes. A fim de fortalecer a ação dialógica nos processos formativos, favorecendo uma aprendizagem que não fosse mecânica, optamos por trabalhar na perspectiva do letramento que, a todo instante, esteve presente por meio dos contextos e situações-problemas que envolveram a Educação Matemática. Era o cenário propício para a denúncia das situações-limite e o anúncio dos inéditos-viáveis.

Impulsionados pelo sonho e acreditando na possibilidade de realizar um processo formativo pautado na práxis, pela transformação de dada realidade, foi que nos dedicamos em estudar e aprofundar os conceitos freireanos. Assim, quanto mais mergulhamos nesse universo, mais tivemos convicção do potencial de tais categorias conceituais para a formação continuada de professores. A primeira delas, as situações-limite, atravessou nosso caminho durante a pesquisa, nos provocando e inquietando em busca de elementos que dialogassem com o contexto, com vista ao desenvolvimento da aprendizagem e dos conhecimentos evocando, portanto, a segunda categoria freireana, os atos-limite, na interlocução com a terceira categoria, os inéditos-viáveis. Estas não são categorias separadas, mas constituem elementos dialéticos representados por um processo dinâmico e complexo na vida pessoa, social e profissional de todos os envolvidos na pesquisa.

As situações-limite que apareceram não apagaram em nós a esperança e o sonho de que é possível ser-mais, de que uma Educação mais digna, democrática e ética está logo à nossa frente, possível de ser alcançada se dissermos não à acomodação e se trabalharmos em coletividade. Reside aqui a potencialidade deste trabalho investigativo. Por isso minha relação com a pós-graduação sempre foi regada de experiências que contribuíram para o desenvolvimento do espírito crítico, do ser curioso, sujeito cultural e histórico da ação editanda, que está definitivamente engajado e comprometido com a educação-formação. 
Ao longo do semestre letivo de 2015, estivemos envolvidas em processos formativos dentro da escola. Estudamos, discutimos e aprofundamos conceitos matemáticos, estabelecendo relação com outros saberes. Cada aula havia uma temática, por exemplo: o que sabemos sobre medidas; questões sobre aposentadoria (salário-mínimo, despesas fixas mensais, inflação); estatística do Distrito Federal; contexto de compra em que se faz pedidos em revistas; as manifestações no Brasil; alimentação saudável. Dentro das temáticas, trabalhamos os conteúdos como operações, sistema monetário; tratamento da informação, estatística, frações e outros conhecimentos matemáticos, além de andarmos por outros campos do saber, como Língua Portuguesa, História, Geografia, Política.

Em linhas gerais, nosso compromisso com a EJA atende aos objetivos de um estudo investigativo e mais que isso, trata-se de um projeto de vida em que apostamos na afirmação do sujeito enquanto ser-mais. Aquele sujeito que sonha, que tem esperança, que ousa, que enfrenta, que supera, que critica, que denuncia e que anuncia um mundo de possibilidades, que constitui continuamente inéditos-viáveis. Na relação com a Educação Matemática, não estivemos interessados em fazer com que professoras e alunos dessem respostas corretas, realizassem algoritmo formal, porque nosso objetivo foi e continuará sendo de que possamos utilizar a Matemática para tomar decisões e para não incutirmos na passividade e na alienação. Os conhecimentos matemáticos nos ajudam a compreender os acontecimentos, a nossa saúde, a situação econômico-financeira e política do nosso contexto.

A Matemática explica as relações comerciais, as tarifas e os impostos, o preço dos alimentos, o preço de aluguel, as medidas, auxilia na leitura de folhetos de supermercados, ajuda na localização, mobiliza habilidades de leitura e escrita em situações cotidianas. Dessa forma, a Educação Matemática contribui para a compreensão do mundo e do homem em suas relações histórico-social com este mundo, como possibilidade de intervenção, porque acredita na possibilidade de transformação. Enquanto agente histórico e esperançoso, pode-se apoiar nos conhecimentos matemáticos para propor uma realidade diferente, mais humana, mais dialógica, inclusiva, democrática, atenta aos preceitos da moral e da ética, em que os direitos e os saberes sejam respeitados.

A respeito disso, as professoras tomaram a direção das nossas formações, entraram em consensos acerca de como e por quais caminhos e teorias seriam conduzidos os círculos de investigação formativos. Assim, nossas formações não seguiam programas rígidos e não fechamos a priori uma carga horária nem blocos de conteúdos a ser cumpridos. Fomos realizando as ações de acordo com a demanda apresentada pelas professoras. E nas poucas vezes em que alguma professora não pode estar na escola, no dia da formação, avisou no 
grupo do whatssapp, e não deixou de enviar as sugestões do que pensou. Assim, destacamos o valor do trabalho coletivo que era mediado pelos processos formativos dialógicos de construção do conhecimento, porque a formação constituiu em espaço privilegiado para compartilhar ideias, experiências e construir aprendizagens.

O conjunto de aprendizagens que descrevemos até aqui reflete o fio condutor da tese que defendemos neste trabalho, qual seja: a constituição dos inéditos-viáveis propicia ao professor a construção de conhecimentos, a superação das situações-limite e a reorganização do trabalho pedagógico com a Matemática, o que ocorre na e a partir da formação continuada. Contudo viemos alertando que os inéditos não são a resolução de todos os problemas, pois, uma vez constituídos, tanto mais prosperam e se ampliam, como também se alternam entre outras situações-limite e outros inéditos-viáveis, em processos que geram outras aprendizagens.

Tomamos a aprendizagem significativa como referência para sustentar a análise que realizamos acerca da possibilidade dos inéditos-viáveis no contexto formativo. Com base nessa aprendizagem, consideramos que cada ser tem um conhecimento acumulado que serve de ancoradouro para novos conhecimentos, o que o torna significativo - são os conhecimentos de experiência feitos. E foi com esse entendimento que assemelhamos os inéditos com a aprendizagem. Ao participarmos e decidirmos os rumos da formação, tivemos intenção política e pedagógica de formar não apenas na perspectiva do conhecimento matemático sistematizado. Antes, em coletividade, assumimos uma identidade coletiva e coesa, potencialmente capaz de transformar a Educação Matemática em uma lupa por onde podemos ver o mundo, ler o mundo, compreendê-lo e transformá-lo. Por isso, trabalhamos com a conexão de saberes, na perspectiva do letramento, para favorecer as condições de letramento, interpretação e intervenção dos sujeitos.

Ao assumir o inédito-viável como elemento articulador de aprendizagens, prevíamos que este não se constituísse no vazio, mas que resultasse de uma rede de situações complexas e dialéticas que, por isso mesmo, permitiria uma formação de base sólida, ancorada na práxis. Desse modo, não poderíamos conceber uma formação teórica e frágil, mas tecida na ação dialógica em que reflexão e ação andam juntas e convergem para formar um profissional cada vez mais engajado e comprometido com a Educação e a formação epistêmica, científica, filosófica, política, social, moral, ética do sujeito.

Nessa perspectiva, esta pesquisa também revelou que a formação contribuiu para que as professoras se reconhecessem como um coletivo emancipado, autônomo, criativo e crítico que lançou mão de contextos matemáticos ligados à realidade dos(as) educandos(as), como as 
situações de compra. As professoras também decidiram explorar a discussão de temas atuais, como as manifestações no Brasil, além disso, trataram de assunto que quase nunca é discutido em sala de aula como o preço do metro quadrado em terrenos de cemitérios. Nesse cenário, houve destaque para a valorização da oralidade, inclusive do cálculo oral e mental enquanto possibilidade de descrição e validação de procedimentos, o que é representativo em termos de aprendizagem significativa.

Para fazer os alinhavos deste estudo, retomamos a importância dos campos conceituais de Vergnaud para a garantia da aprendizagem significativa, pois o conjunto de situaçõesproblema que construímos permitiu a ampliação dos conhecimentos. As professoras e os(as) alunos(as) passaram a compreender que os conceitos não são dados nem estáticos, eles são dinâmicos, dependem da diversidade de situações e necessitam de tempo para se constituírem. Por isso mesmo que os conceitos remontam à aprendizagem e esta depende de outros fatores e condições para ser construída, entre eles destacamos: a continuidade, a coletividade, a formação política e a emancipação. Essas palavras estão carregadas de sentido político e epistemológico porque aparecem em cada uma das categorias de análise desta pesquisa e representaram a síntese dos diálogos das professoras em situação de aprendizagem.

A primeira categoria de análise previu a continuidade como marca fundamental. Assim descrevemos a aprendizagem como processo contínuo e inconcluso, pois as falas das professoras estiveram carregadas de gerúndio, que denota o acontecimento presente, mas expressa, de certa forma, a perpetuação do acontecimento. Em nossa análise, as professoras se perceberam constituindo inéditos-viáveis e, ao mesmo tempo, contribuíram para que os alunos fossem agentes de sua aprendizagem.

A segunda categoria teve seu ponto de apoio na coletividade. O inédito-viável mais expressivo no diálogo e nas ações das professoras que não cansavam de ressaltar a força do trabalho coletivo (inédito) que ocupou o lugar da coordenação individual (situação-limite). Daí que nomeamos a categoria de análise: aprendizagem como processo de construção coletiva e formativa. As tratativas, decisões e ponderações eram negociadas no grupo que foi sempre harmonioso, coeso e comedido, pois não propuseram ações esvaziadas de intenção política e pedagógica. As professoras construíram um caminho formativo em que o centro de suas preocupações era a aprendizagem significativa, a fim de que pudesse refletir na aprendizagem dos alunos.

A terceira categoria se pautou na formação política. Os sinais de que uma formação integral estava sendo vivenciada apareceram desde o início, quando as participantes valorizaram o contexto do aluno e propuseram situações-problema que permitisse a discussão, 
os consensos e os dissensos em grupo, a fim de produzirem aprendizagem. Contudo essa aprendizagem estava muito além da proposta pedagógica de ensino, aprender era uma condição para a formação do sujeito político, o que motivou a denominação da terceira categoria de análise: aprendizagem enquanto formação política. Os problemas matemáticos e as operações algébricas deram espaço para situações-problema que exigiam leitura, interpretação, julgamento, análise crítica e posicionamento com tomada de decisão. Nesse contexto, as práticas de letramento foram fundamentais para contribuir com a aprendizagem.

A quarta categoria de análise está firmada na emancipação, portanto, na práxis que acontece, segundo as professoras por causa do trabalho coordenado que facilita e orienta suas ações, permitindo a superação das situações-limite e favorecendo a constituição de inéditosviáveis. Até o fato de juntar as turmas de etapas diferentes, de explorar outros espaços da escola, de promover discussões de temas políticos e polêmicos, de abrir mão de aulas mais expositivas, para realizarem um trabalho teórico e prático, foram inéditos-viáveis que se revelavam potencialmente emancipadores. Razão pela qual essa categoria recebeu a denominação de aprendizagem enquanto processo formativo emancipatório. É nessa perspectiva que temos a emancipação como a responsabilidade pela tomada de decisões, sem a interferência de outras pessoas e como disseram as professoras, sem que alguém exigisse qualquer coisa.

Sumariamente, os inéditos-viáveis protagonizaram as ações dialógicas, ou podemos dizer de outro modo que, imbricaram-se na dialogia da ação, mantiveram coerência com os princípios de formação sob os quais nos situamos, no qual defendemos: o trabalho coletivo, as decisões em conjunto, a prática do diálogo, o desenvolvimento da práxis e a busca pela emancipação. Quanto mais nos envolvemos nessa conjuntura formativa, mais apresentamos desejo de fazer muito mais, de forma a fomentar mais aprendizagens. Tal realidade foi tão provocativa que as professoras queriam que realizássemos atividades utilizando o computador porque oportunizaria seus alunos de vivenciarem essa experiência, e para alguns seria o primeiro contato com um computador. Entretanto, no laboratório de informática da escola, só havia cinco computadores funcionando, por isso fomos atuar em outros espaços.

Discutindo sobre os conhecimentos atuais, chegamos à conclusão que o celular tem sido o objeto de "vício" das pessoas de toda e qualquer faixa etária. Algumas professoras até falaram exemplo de alunos que não dominam com propriedade a leitura e a escrita, mas que se comunicam pelas redes sociais sem nenhuma dificuldade. Por isso também pensamos que um modo de aproveitar didaticamente o uso do celular seria propor atividades com o uso da calculadora, tendo em vista que todo aparelho telefônico já dispõe desse aplicativo. Mas não 
chegamos a realizar essa ação por causa do período em que as aulas foram interrompidas pela paralisação. Isso explicita o que as professoras já tinham falado, que quanto mais estivemos discutindo, estudando, analisando em coletividade, mais ideias tínhamos para aprofundar os conhecimentos e ampliar a aprendizagem.

Essa foi e continua sendo a minha maior motivação, pois, desde que iniciei o doutorado, fui tomada por um desejo de fazer algo importante para o cenário educacional e não seria algo que fizesse para as pessoas, mas com as pessoas e isso fez toda a diferença ao longo dessa caminhada. Então, eu tive que buscar parcerias que deram muito certo, a começar pela orientação de um educador que se importa e se empenha pela aprendizagem de todos, sem distinção, o professor Cristiano Alberto Muniz. Esse orientador que tem uma história de vida humilde que se confunde com a minha e a de muitas outras pessoas que precisaram trabalhar desde cedo para mudar o curso da própria vida e a dos outros que dele depende. Sua entrega pela e na Educação, especialmente no Distrito Federal, tem refletido um trabalho importante, coerente e válido no campo da Educação Matemática, o que me tocou e que me provoca continuamente.

Eu sempre estive engajada com as questões da Educação de Jovens e Adultos e construí uma ponte com a Educação Matemática porque meu interesse era fazer com que as pessoas percebessem que não se pode reduzir a EJA a um processo de alfabetização em que se tem por princípio apenas a leitura da palavra. Nesse sentido, meu orientador compreendendo essa dinâmica me estendeu a mão e nós fomos construindo caminhos de modo que cada um compartilhou conhecimentos específicos (ele da Educação Matemática e eu da EJA) e o resultado dessa relação pode ser observado ao longo desse texto: uma contribuição ímpar no campo da Educação de Jovens e Adultos aliada à Educação Matemática.

Nessa caminhada, tivemos a participação direta e indireta de professoras e professores da Educação Básica e do Ensino Superior que contribuíram com indicação de leituras, nas discussões e estudos dentro grupo de Educação Matemática (Edem). Além disso, estar vinculada à Sociedade Brasileira de Educação Matemática (SBEM) na Regional do Distrito Federal foi decisivo para minha constituição enquanto ser matemático que continuamente aprende e (re)significa conhecimentos e conceitos nesse campo do saber. Isso porque as pessoas que formam a SBEM têm formações diversas (matemáticos, pedagogos, historiadores, licenciados em outras áreas) e atuam em modalidades e níveis de ensino diversas também, e assim formamos uma comunidade de educadores com um compromisso em comum: aprender-ensinar-estudar-ampliar a Educação Matemática. 
A relação com o professor Cristiano Muniz tem sido não só de orientador-orientanda, mas também de respeito ao trabalho que ele tem desenvolvido com crianças, jovens e adultos sempre na perspectiva de que TODA PESSOA TEM POTENCIAL PARA APRENDER. Trata-se de um jeito ímpar de olhar o outro na horizontalidade, de fazer com que cada pessoa acredite em si mesma enquanto gente que tem conhecimento e que pode aprender continuamente. É uma qualidade de educador comprometido com a educação e com a formação para a vida, porque faz com que as pessoas conquistem uma condição de ser-mais e cria em professores e alunos o encorajamento para serem os educadores matemáticos do futuro, fazendo-os superar o pavor e a rejeição da tradicional Matemática escolar. Eu fui contagiada por essa onda benigna da Matemática possível. Estudei e aprendi muito com esse educador.

Nossa relação também é de afetuosidade, ou como diz o professor Renato Hilário, é de amorosidade porque envolve o cuidado e a preocupação com o bem-estar um do outro, pois como meu orientador-companheiro sempre diz, "para que tudo ande bem é necessário que a cabeça, o corpo e o espírito estejam em harmonia". E como se tivesse pressentimento, enviava $e$-mails, dava telefonemas e trocava mensagem no whatssapp para cuidar, mesmo não estando perto fisicamente, e para dizer "estou aqui para o que precisar"; "parabéns pela evolução"; "seu texto está lindo"; "você sabe muito mais do que imagina". Então, essas foram algumas das muitas palavras de encorajamento desse orientador-companheiro (e deveria ser grafado assim mesmo) ao longo da minha caminhada na Universidade de Brasília.

Outra experiência edificante foi atuar no PNAIC/Matemática em 2014 enquanto formadora e tendo os planejamentos coordenados pela professora Nilza Bertoni que contribuiu para que eu ampliasse minha compreensão acerca de conceitos e conhecimentos da área da Matemática. Além disso, a troca de experiências com as demais formadoras que eram licenciadas em Matemática foi decisiva para que essa pedagoga aqui se constituísse cada vez mais uma educadora matemática que aprende continuamente.

O ano de 2015 foi o mais marcante na minha trajetória de estudos doutorais, não só pela imersão no campo de pesquisa, mas principalmente porque participei de oito eventos de Educação a fim de divulgar este trabalho e de dialogar com outros pesquisadores acerca da relação entre Educação de Jovens e Adultos e Educação Matemática. O motivo de tantos eventos foi porque nesse mesmo ano, no mês de maio, fui para o "III Simpósio Nacional de Grupos Colaborativos e de Aprendizagem do Professor que Ensina Matemática" que aconteceu em São Paulo, e uma professora/pesquisadora da área de Matemática me disse: "saia dessa área de Educação de Jovens e Adultos porque é uma modalidade falida". 
Essa colocação está esvaziada de sentido, refletindo aquilo que a professora Rosa já havia denunciado, que as pessoas "vão ler aqueles dados de uma forma totalmente fora da realidade", seja porque pegam dados e fazem uma leitura superficial, seja porque não atua ou não se importa com a modalidade. Então, ao escutar de uma pesquisadora, que a EJA é uma modalidade falida fiquei consternada porque pensei nos adolescentes, nos jovens, nos adultos e nos idosos com os quais convivi na escola e que, por todo lado, encontramos, que têm vontade de ter mais conhecimento, desejosos de aprender. Por causa dessa provocação, resolvi ir a outros eventos científicos, para saber se outros pesquisadores tinham essa opinião, ou se como eu, acreditavam e acreditam na educação de qualidade para todos, sem distinção, sem prestigiar uma modalidade em detrimento de outrem. Participei de eventos de alcance nacional e internacional, na área de Educação, de Educação de Jovens e Adultos e de Educação Matemática e nesses últimos tive a oportunidade de dialogar com professores e alunos das licenciaturas em Matemática, Física e Química. Em todos esses eventos, pesquisadores de diferentes áreas, muito respeitosamente escutaram acerca deste trabalho que aqui descrevemos e falaram da contribuição deste para a construção de um conhecimento válido para a modalidade EJA e por sua natureza extrapolaria os muros da escola.

As despesas de congressos/encontros/simpósios/seminários dos quais participei foram arcadas pela bolsa de estudos da Capes, as passagens foram compradas com milhas aéreas e a estadia nas cidades dos eventos era a suficiente para apresentar o trabalho de comunicação oral e trocar experiências com outros pesquisadores. Também foi possível todas as viagens porque a maioria dos eventos aconteceram nos meses de outubro e novembro de 2015, quando as escolas públicas do Distrito Federal enfrentavam uma paralisação. Assim não houve prejuízos ou atrasos na pesquisa, porque os encontros com as professoras estavam temporariamente suspensos haja vista que as escolas estavam fechadas. Mas nosso grupo participante-colaborador continuou trocando materiais por e-mail a fim de estudarmos e planejarmos as ações quando retornassem as aulas.

O ano letivo de 2016 na Secretaria de Educação do Distrito Federal iniciou dia 29 de fevereiro (segunda-feira). Meu contato novamente com as professoras se deu na segunda semana de aula, quando elas me convidaram para participar de um trabalho que estavam organizando com as quatro turmas do primeiro segmento para comemorar o dia da mulher. Quando cheguei à escola, dia 9 de março, a professora Rosa veio ao meu encontro e falou: "juntamos todas as turmas no refeitório, vamos realizar as atividades lá". Isso já me encheu de alegria porque, além da atitude de juntar as turmas, o espaço do refeitório mais uma vez estava sendo utilizado. As professoras, os alunos e as alunas me acolheram com um caloroso 
abraço. Eu ofereci ajuda, mas, na verdade, já estava tudo pronto, os materiais organizados sobre a mesa e os lanches em outra mesa para a confraternização ao final.

Sentei no banco com os alunos e eles perguntavam se nós voltaríamos a desenvolver as atividades juntos e cada um queria contar alguma coisa que vivera, relacionando à experiência que vivemos na sala de aula. Mas pedi que conversássemos ao final da atividade que estava sendo proposta a fim de não atrapalhar. Após a conclusão daquela atividade, ficamos em círculo conversando sobre experiências que viveram e expectativas para 2016, enquanto observava o brilho no olhar daquelas pessoas mais idosas que falavam de sonhos, como a aluna MJ (82 anos); o aluno P (73 anos); o aluno R (76 anos); o aluno V (58 anos). Em diálogo com a aluna MJ, ela disse "eu tenho que cuidar na minha vida, porque ninguém cuida, ninguém me acompanha em lugar algum, eu faço ginástica de manhã, venho pra aula de tarde e, de vez em quando, eu viajo para conhecer outros lugares, porque tudo isso é conhecimento".

Os fios que tecemos nas notas nem sempre finais traz a clara compreensão de que o exercício da formação continuada dentro do próprio local de trabalho das professoras rompe com os modelos tradicionais de cursos de formação, ao passo que sublinha as características de uma Escola pública de qualidade. Essa escola tem profissionais comprometidos com o desenvolvimento humano e epistemológico do sujeito que aprende e se mostra na possibilidade da produção de conhecimentos e validação de conceitos que uma vez contextualizados influenciam diretamente na realidade de todos os envolvidos. Rompe também com a segmentação das etapas/séries e promove o desenvolvimento humano e coletivo nos processos de aprender e ensinar, contribuindo, portanto, para que professores e professoras possam se sentir preparados para atuar na modalidade EJA.

Quando reflito sobre todos os acontecimentos, descobertas, trocas de experiências que vivi desde que comecei os estudos doutorais, em 2013, percebo o quanto essa vivência contribuiu para meu crescimento pessoal e profissional, pois, nesse primeiro ano, cursei disciplinas e estabeleci contatos. Em 2014, continuei as disciplinas no doutorado e atuei como formadora do PNAIC/Matemática. Em 2015, qualifiquei e me inseri no campo de pesquisa durante todo o ano letivo e participei de muitos eventos científicos, a maioria com apresentação de trabalho, além disso, fiz as duas entrevistas e agendei a terceira para compor uma parte importante do trabalho de pesquisa. Agora, em 2016, ao me pegar registrando os acontecimentos que marcaram a minha trajetória acadêmica, chego à conclusão que essa estudante está realizando não só o próprio sonho, mas se vê constituindo o inédito-viável de uma família que nunca deixou de ter esperança e de sonhar (meus pais, irmãos e esposo). 
Quanto às mudanças que me ocorreram, uma das mais significativas é que sou uma pessoa humanamente melhor, porque me inseri sem medo e com ousadia na relação dialógica com pessoas de crenças, ideologias, saberes, formações pedagógicas e políticas diferentes, mas soube respeitar quando optei pela dialogia permanente. Também me considero uma professora melhor porque tive oportunidade de sonhar, estudar e criar com um coletivo de professoras que acreditam na EJA e por essa motivação nos envolvemos em processos de formação continuada. Outra incontestável contribuição da minha experiência de doutoranda foi a clareza de que me tornei uma pedagoga que compreende, sente, aprende-ensina matemática, sendo deste modo, um inédito-viável (um sonho-possível) na minha vida.

Postulamos que os olhares críticos sobre este estudo vão trazer questões provocativas, e isso também faz parte do processo, porque somos seres inconclusos e incompletos e as provocações nos impulsionam pela busca do ser-mais, para realizarmos mais. Assim, contamos com a contribuição de leitores do campo da Educação Matemática, da Educação de Jovens e Adultos, da formação de professores, do mundo da pesquisa para inaugurarmos um tempo de possibilidades, não é um tempo novo, mas um novo modo de conceber o tempo que se inscreve como INÉDITO-E-VIÁVEL, um SONHO-POSSÍVEL.

Optamos por utilizar uma linguagem clara na escrita deste texto, buscamos explicitar e exemplificar as terminologias tanto do campo da Pedagogia quanto da Educação Matemática, a fim de que possamos disponibilizar um material de consulta de fácil compreensão para professores(as) que atuam nos anos iniciais. Como se trata de uma escrita que aconteceu em um contexto com histórias, crenças, valores, ideologias próprios, poderá não se adequar a outros contextos, por isso desejamos que possa ser reinventada, acrescentada e melhorada.

Assim como prefaciamos neste capítulo, nos daremos por satisfeitos se os(as) possíveis leitores(as) deste trabalho lançarem seus olhares críticos a fim de contribuir para retificar nossos prováveis resvalamentos (erros, deslizes), alertar para os equívocos conceituais e sinalizar elementos que não vimos ou não aprofundamos. De outro lado, este trabalho põe em relevo e tangencia indícios de uma Educação e Formação possível na perspectiva da práxis emancipadora. Nesses termos, provocamos pelo diálogo desafiante para que cada um que aqui depositar seu olhar possa fazê-lo sempre no sentido da horizontalidade, para contribuir com sua eminente ampliação. 


\section{REFERÊNCIAS}

ADAMS, Telmo. As 'situações-limite' como mediações pedagógicas para chegar a 'inéditosviáveis': o trabalho associado na Associação dos Recicladores de Dois Irmãos. Revista Eletrônica Fórum Paulo Freire, Ano 2, n. 2, p.1-11, ago.2006.

ALBUQUERQUE, Leila Cunha de; GONTIJO, Cleyton Hércules. A complexidade da formação do professor de matemática e suas implicações para a prática docente. Espaço Pedagógico, Passo Fundo v. 20, n. 1, p. 76-87, jan./jun. 2013.

AUSUBEL, David. Educational psychology: a cognitive view. Nova York: Holt, Rinehart na Winston, 1968. (tradução livre: psicologia educacional : uma visão cognitiva)

ALONSO, Luísa. Desenvolvimento profissional dos professores e mudança educativa: uma perspectiva de formação ao longo da vida. In: FLORES, Maria Assunção; VIANA, Isabel Carvalho (Orgs.). Profissionalismo docente em transição: as identidades dos professores em tempos de mudança. Braga: Centro de Investigação em Educação da Universidade do Minho, 2007.

BACHELARD, Gaston. A formação do espírito científico. São Paulo: Contraponto, 1996.

BARCELOS, Valdo. Formação de professores para educação de jovens e adultos. 3.ed. Petrópolis, RJ: Vozes, 2009.

BARDIN, Laurence. Análise de conteúdo. São Paulo: Edições 70, 2011.

BERTONI, Nilza Eigenheer. Pedagogia, Educação e linguagem matemática II: Numerização. Brasília: Universidade de Brasília, 2007.

BRANDÃO, Carlos Rodrigues (Org.). Pesquisa participante. São Paulo: Brasiliense, 1981.

O que é o método Paulo Freire. 6. ed. São Paulo: Brasiliense, 1984.

(Org.). Repensando a pesquisa participante. 3.ed. São Paulo: Brasiliense, 1999.

A pesquisa participante e a participação da pesquisa. In: BRANDÃO, Carlos Rodrigues; STRECK, Danilo Romeu (Org.). Pesquisa participante: a partilha do saber. Aparecida, SP: Ideias \& Letras, 2006.

BRASIL. Secretaria de Educação Básica. Diretoria de Apoio à Gestão Educacional. Pacto Nacional pela Alfabetização na Idade Certa - Matemática. Caderno 4: Operações na resolução de problemas e caderno 6: Grandezas e medidas. Brasília: MEC, SEB, 2014.

BRASIL. LEI No 12.612, de 13 de abril de 2012. Declara o educador Paulo Freire Patrono da Educação Brasileira. Brasília, 2012.

BRUNELLI, Osinéia Albina; DARSIE, Marta Maria Pontin. Algumas reflexões sobre a formação continuada desenvolvida pelos Cefapros para os educadores de matemática que atuam na EJA. In: ENCONTRO NACIONAL DE EDUCAÇÃO MATEMÁTICA, 11. 2013, Curitiba/PR. Anais... Curitiba, 18-21 de julho de 2013.

CARR, Wilfrd; KEMMIS, Stephen. Teoría crítica de la enseñanza: la investigación-acción en la formación del profesorado (tradução livre: Teoria crítica da educação: pesquisa-ação na formação de professores). Barcelona: Martinez Roca, 1988.

Becoming Critical: Education, Knowledge and Action Research (tradução livre: Tornar-se crítico: Educação, Conhecimento e Pesquisa-Ação). Nova York: Taylor \& Francis e-Library, 2004. 
CÔRTES, Simone Alves. A organização e o desenvolvimento curricular pelo professor e sua relação com o processo de ensino e aprendizagem de matemática nos anos iniciais. 2015. 300f. Dissertação de Mestrado (Programa de Pós- Graduação em Educação) Faculdade de Educação, Universidade de Brasília, Distrito Federal, 2015.

COSTA, Janaína Santana. A emancipação como inédito-viável no projeto da educação do campo: uma viagem etnográfica a Escola Paulo Freire. 2008. 150p. Dissertação de mestrado (Programa de Pós- Graduação em Educação) - Universidade Federal de Mato Grosso, Cuiabá/MT, 2008.

CURI, Edda. A matemática e os professores polivalentes. São Paulo: Musa, 2005.

; PIRES, Célia Maria Carolino. Pesquisas sobre a formação do professor que ensina matemática por grupos de pesquisa de instituições paulistanas. Educação Matemática e Pesquisa, São Paulo, v. 10, n. 1, p. 151-189, jun. 2008.

CRUZ, Shirleide Pereira da Silva. A construção da profissionalidade polivalente na docência nos anos iniciais do ensino fundamental: sentidos atribuídos às práticas por professoras da Rede Municipal de Ensino do Recife. 2012. 280f. Tese de doutorado (Programa de Pós- Graduação em Educação) - Universidade Federal de Pernambuco, Recife, 2012.

CYRINO, Márcia Cristina de Costa Trindade. Preparação e emancipação profissional na formação inicial do professor de Matemática. In: NACARATO, Adair Mendes; PAIVA, Maria Auxiliadora Vilela Paiva (Orgs.). A formação do professor que ensina Matemática: perspectivas e pesquisas. 3.ed. Belo Horizonte: Autêntica, 2013.

D’AMBRÓSIO, Ubiratan. Etnomatemática: arte ou técnica de explicar e conhecer. 2.ed. São Paulo: Ática, 1993.

Filosofia, Matemática e a Formação de Professores. In: COLÓQUIO INTERNACIONAL DE PSICOLOGIA DO CONHECIMENTO, 1, 2008, Brasília. Anais... Brasília: UnB, 2008.

DEMO, Pedro. Pesquisa participante: mito e realidade. Rio de Janeiro: Senac, 1984.

Elementos metodológicos da pesquisa participante. In: BRANDÃO, Carlos Rodrigues (Org.). Repensando a pesquisa participante. São Paulo: Brasiliense, 1999.

DI PIERRO, Maria Clara. Balanço e perspectivas da pesquisa sobre formação de educadores(as) de jovens e adultos. In: SEMINÁRIO NACIONAL DE FORMAÇÃ̃O DE EDUCADORES DE JOVENS E ADULTOS, 3, Porto Alegre. Anais... Porto Alegre: Deriva, 2011. p. 167-177.

DISTRITO FEDERAL. Currículo em movimento da educação básica: Educação de Jovens e Adultos. Secretaria de Estado da Educação do Distrito Federal, 2014.

DiStrito Federal. Projeto Político Pedagógico do Centro de Ensino Médio 03. Ceilândia/DF, 2014.

FALS BORDA, Orlando. Pela práxis: o problema de como investigar a realidade para transformá-la. Bogotá, Colombia: Federação para a análise da realidade colombiana (Fundabco), 1978.

FÁVERO, Maria Helena. A pesquisa de intervenção na construção de competências conceituais. Psicologia em Estudo, Maringá, v. 17, n. 1, p. 103-110, jan./mar. 2012. 
; NEVES, Regina da Silva Pina. A pesquisa de intervenção psicopedagógica: evidências sobre o ensinar e aprender matemática. Revista Linhas Críticas, Brasília, v.18, n.35, p.47-68, jan./abr.2012.

; __. A docência universitária como lócus de pesquisa da psicologia do desenvolvimento adulto. Revista Semestral da Associação Brasileira de Psicologia Escolar e Educacional, São Paulo, v. 17, n. 2, p. 319-328, jul/dez. 2013.

; CASTRO, Franciana Carneiro de. Tornando-se professor de matemática: o caso de Allan em práticas de estágio supervisionado. In: FIORENTINI, Dario (Org.). Formação de professores de matemática: explorando novos caminhos com outros olhares. Campinas, SP: Mercado de Letras, 2003. p.121-156.

; NACARATO Adair Mendes (Org). Cultura, formação e desenvolvimento profissional de professores que ensinam matemática: investigando e teorizando a partir da prática. São Paulo: Musa Editora; Campinas, SP: GEPFPM-PRAPEM-FE/UNICAMP, 2005.

FONSECA, Maria da Conceição Ferreira Reis (et.al.). Letramento no Brasil: habilidades matemáticas. São Paulo: Global Editora, 2004.

Educação matemática de jovens e adultos: especificidades, desafios, contribuições. 2.ed. Belo Horizonte: Autêntica, 2005.

; SOUZA, Maria Celeste Reis Fernandes de. Relações de gênero, Educação Matemática e discurso: enunciados sobre mulheres, homens e Matemática. Belo Horizonte: Autêntica, 2010.

;

. Práticas de numeramento e relações de gênero: tensões e desigualdades nas atividades laborais de alunas e alunos da EJA. Revista Brasileira de Educação (Impresso), v. 18, p. 921-938, 2013.

; SIMÕES, Fernanda Maurício. Apropriação de práticas de numeramento na EJA: valores e discursos em disputa. Educação e Pesquisa, USP, Impresso, São Paulo, v. 40, n. 2, p. 517-532, abr./jun. 2014.

; ___ . Apropriação de práticas de letramento escolares por estudantes da Educação de Jovens e Adultos. Revista Brasileira de Educação, v.20, n.63, p.869-884, out./dez. 2015. FREIRE, Paulo. Educação e mudança. São Paulo: Paz e Terra, 1979.

Criando métodos de pesquisa alternativa: aprendendo a fazê-lo melhor através da ação. In: BRANDÃO, Carlos Rodrigues. Pesquisa participante. São Paulo: Brasiliense, 1981.

Educação como prática da liberdade. 13. ed. Rio de Janeiro: Paz e Terra, 1982.

Educação: o sonho possível. In: BRANDÃO, Carlos Rodrigues. O educador: vida e morte. 4. ed. Rio de Janeiro: Edições Graal, 1983.

; SHOR, Ira. Medo e ousadia. Rio de Janeiro: Paz e Terra, 1986.

Pedagogia da esperança: um reencontro com a pedagogia do oprimido. 13 ed. Notas: Ana Maria Araújo Freire. Rio de Janeiro: Paz e Terra, 1992. Terra, 1996.

Pedagogia da autonomia: saberes necessários à prática educativa. São Paulo: Paz e 2000 .

Pedagogia da Indignação: cartas pedagógicas e outros escritos. São Paulo: UNESP: 
Política e Educação. 5. Ed. São Paulo: Cortez, 2001.

Pedagogia do Oprimido. 50. ed. Rio de Janeiro: Paz e terra, 2011.

FREITAS, Ana Lúcia Souza de. Pedagogia da Conscientização: um legado de Paulo Freire à formação de professores. Porto Alegre: EDIPUCRS, 2001.

. Pedagogia do inédito-viável: contribuições da participação pesquisante em defesa de uma política pública e inclusiva de formação com educadores e educadoras. 2004. Tese de doutorado (Programa de Pós-Graduação em Educação) - Pontifícia Universidade Católica do Rio Grande do Sul, PUCRS, Porto Alegre/RS, 2004.

Pedagogia do inédito-viável: contribuições de Paulo Freire para fortalecer o potencial emancipatório das relações ensinar-aprender-pesquisar. In: COLÓQUIO INTERNACIONAL PAULO FREIRE, 5., 2005, Recife. Anais... Recife, 19-22 de setembro de 2005.

; MACHADO, Maria Elisabete. Formação com educadores/as e os desafios da práxis da Educação Popular na Universidade. Educação, Porto Alegre, v. 33, n. 2, p. 137-144, maio/ago, 2010.

- Parentesco intelectual entre Paulo Reglus Neves Freire e BoaVentura de Sousa Santos. In: FREITAS, Ana Lúcia Souza de; GHIGGI, Gomercindo; PEREIRA, Thiago Ingrassia (Orgs.). Paulo Freire em diálogo com outros autores. Passo Fundo: Méritos, 2014. p.17-40.

Leituras de Paulo Freire: uma trilogia de referência. Passo Fundo: Méritos, 2014.

FULLAN, Michael; HARGREAVES, Andy. Teacher development and educational change (Tradução livre: O desenvolvimento dos professores e mudança educacional). Londes: The Falmer Press, 1992.

GAMBOA, Silvio Sánchez. Epistemologia da Pesquisa em Educação. Campinas: Praxis. 1998.

GARCÍA, Carlos Marcelo. Desenvolvimento Profissional Docente: passado e futuro. Sísifo. Revista de Ciências da Educação, Portugal, n. 08, p. 7-22, Universidade de Lisboa, 2009.

GARCIA, Renilda Martins. Ser mais: um princípio educativo. Revista Caminhando, Universidade Metodista de São Paulo, v. 16, n. 2, p.89-95, jul./dez. 2011.

GATTI, Bernadete Angelina; BARRETO, Elba Siqueira de Sá (Coords.). Professores do Brasil: impasses e desafios. Brasília: UNESCO, 2009.

Formação de professores no Brasil: características e problemas. Educação e Sociedade [on-line], Campinas, v. 31, n. 113, p. 1355-1379, out./dez. 2010.

Formação de professores e profissionalização: contribuições dos estudos publicados na Rbep entre 1998 e 2011. Revista Brasileira de Estudos Pedagógicos, Brasília, v. 93, n. 234, [número especial], p. 423-442, maio/ago. 2012.

GIROUX, Henri. Os professores como intelectuais: rumo a uma pedagogia crítica. Porto Alegre: Artes Médicas, 1997.

GUERRERO, Irán. Ambientes letrados. In: RIVERO, José; MACHADO, Maria Margarida (et al coords.). Contribuições conceituais da educação de pessoas jovens e adultas: rumo à construção de sentidos comuns na diversidade. Organização dos Estados Ibero-americano [e] UNESCO. Goiânia: Editora UFG, 2014. 
LOPES, Anemari Roesler Luersen Vieira; SILVA, Diaine Susara Garcez da; VAZ, Halana Garcez Borowsky; FRAGA, Laura Pippi. Professoras que ensinam matemática nos anos iniciais e a sua formação. Linhas Críticas, Brasília, v. 18, n. 35, p. 87-106, jan./abr. 2012.

LOPES, Juliana Bello. Mulheres adultas e idosas em busca do inédito-viável: as táticas empregadas no cotidiano de uma turma de EJA. In: CONGRESSO DE LEITURA DO BRASIL, 17, Campinas. Caderno de resumos... Campinas: Unicamp/FE, 2009.

LOPES, Lailson dos Reis Pereira; RESENDE, Marilene Ribeiro. Formação de professores de matemática 'para' e 'na' EJA: saberes docentes necessários e saberes construídos na prática. In: ENCONTRO NACIONAL DE EDUCAÇÃO MATEMÁTICA, 10. 2010, Salvador/BA. Anais... Salvador, 7-9 de julho de 2010.

MONTEIRO, Maria Isabel Nascimento Ledes. Inovação Pedagógica no Curso de Pedagogia da Universidade de Brasília (UnB): um estudo de abordagem etnográfica. 2010. 373f. Tese de doutorado (Programa de Pós- Graduação em Educação) - Universidade de Madeira, Portugal, 2010.

MOREIRA, Marco Antonio; MASINI, Elcie F.Salzano. Aprendizagem significativa: a teoria de David Ausubel. São Paulo: Centauro, 2001.

A teoria dos campos conceituais de Vergnaud, o ensino de ciências e a pesquisa nessa área. Revista Investigações em Ensino de Ciências (UFRGS). Porto Alegre/RS, v.7. n1, p.7-29, 2002.

- Aprendizagem significativa, campos conceituais e pedagogia da autonomia: implicações para o ensino. In: COLÓQUIO INTERNACIONAL EDUCAÇÃO E CONTEMPORANEIDADE, 9, São Cristóvão, Sergipe. Anais... UFSE, set. 2015. p.1-26.

MOURA, Danieli Veleda; LOUREIRO, Carlos Frederico Bernardo; ANELLO, Lúcia de Fátima Socoowski de; PEREIRA, Maria Odete da Rosa. Situação-limite, ato-limite e inédito viável: as categorias freireanas presentes nas representações e práticas de educação ambiental no fórum da Lagoa dos Patos. In: ENCONTRO PESQUISA EM EDUCAÇÃO AMBIENTAL, VII EPEA, Rio Claro. Anais... Rio Claro, São Paulo, 2013.

MOURA, Tânia Maria de Melo. Formação de educadores de jovens e adultos: realidade, desafios e perspectivas atuais. Práxis Educacional, Vitória da Conquista, v. 5, n. 7, p. 45-72, jul./dez. 2009.

; RIBEIRO, Nadja Naira Aguiar. O ponto cego da formação de professores dalpara Educação de Jovens e Adultos. Debates em Educação, Maceió, v. 3, n. 6, ago./dez. 2011.

MUNIZ, Cristiano Alberto. Educação e linguagem matemática, UnB. In: Curso de Pedagogia para professores em exercício no início da escolarização (PIE) - Módulo I, v.2. Brasília: UnB-FE/SEDF, 2001.

Um jeito novo de ensinar matemática. In: Conferência Nacional de Educação, Cultura e Desporto. Uma escola para a inclusão social. Brasília: Câmara dos Deputados Coordenação de Publicações, 2003.

Pedagogia, Educação e linguagem matemática. Aprender e ensinar matemática: seus significados. Brasília: UnB-FE/SEDF, 2007.

; BATISTA, Carmyra Oliveira; SILVA, Erondina Barbosa da. Módulo IV: Matemática e Cultura: decimais, medidas e sistema Monetário. Brasília: Universidade de Brasília, Brasília, 2008. 
Diversidade dos conceitos das operações e suas implicações nas resoluções de classe de situações. In: GUIMARÃES, Gilda; BORBA, Rute (Orgs.). Reflexões sobre o ensino de matemática nos anos iniciais de escolarização. Recife: SBEM, 2009. p. 101-118.

O conceito de "esquema" para um novo olhar para a produção matemática na escola: as contribuições da Teoria dos Campos Conceituais. In: MUNIZ, Cristiano Alberto; BITTAR, Marilena (Orgs.). A aprendizagem matemática na teoria dos campos conceituais. Curitiba: CRV, 2009. p. 37-52.

; IUNES, Silvana M.Silva. Educação Matemática na Educação à distância. In: FERNANDES, Maria Lidia Bueno; DECONTO, Neuza Maria; LOPES, Ruth Gonçalves de Faria (Orgs.). Tessituras e tramas: refletindo sobre a experiência da Licenciatura em Pedagogia a distância na FE/UNB. Brasília: Editora UnB: 2014. p.125-154.

NACARATO, Adair Mendes; FERREIRA, Ana Cristina; LOPES, Celi Espasandin; FIORENTINI, Dario; GRANDO, Regina Célia. Modalidades de pesquisas em Educação Matemática: um mapeamento de estudos qualitativos do GT-19 da ANPED. In: REUNIÃO ANUAL DA ANPEd, 28., 2005, Caxambu, MG. Anais..., Caxambu/MG: Associação Nacional de Pós-graduação e Pesquisa em Educação, 2005. (Trabalho apresentado na Mesa redonda: Conquistas e problemáticas em metodologia da pesquisa na área de formação de professores).

; MENGALI, Brenda Lemes da Silva; PASSOS, Cármem Lúcia Brancaglion. A matemática nos anos iniciais do ensino fundamental: tecendo fios do ensino e do aprender. Belo Horizonte: Autêntica, 2009.

; GRANDO, Regina Célia; TORICELLI, Luana; TOMAZETTO, Miriam. Professores e futuros professores compartilhando aprendizagens: dimensões colaborativas em processo de formação. In: NACARATO, Adair Mendes, PAIVA, Maria Auxiliadora Vilela (Orgs.). A formação do professor que ensina matemática: perspectivas e pesquisas. 3.ed. Belo Horizonte: Autêntica, 2013. p.197-212.

; PAIVA, Maria Auxiliadora Vilela. A formação do professor que ensina matemática: estudos e perspectivas a partir das investigações realizadas pelos pesquisadores do GT 7 da SBEM. In: NACARATO, Adair Mendes; PAIVA, Maria Auxiliadora Vilela (Orgs.). A formação do professor que ensina matemática: perspectivas e pesquisas. 3.ed. Belo Horizonte: Autêntica, 2013. p.7-26.

NEVES, Regina da Silva Pina; FÁVERO, Maria Helena. A pesquisa de intervenção psicopedagógica: evidências sobre o ensinar e aprender matemática. Revista Linhas Críticas, Brasília, v. 18, n. 35, p. 47-68, jan/abr. 2012.

NITA FREIRE (Ana Maria Araújo Freire). Notas explicativas. In: FREIRE, Paulo. Pedagogia da esperança: um reencontro com a pedagogia do oprimido. 21 ed. Rio de Janeiro: Paz e Terra, 2014.

NITA FREIRE (Ana Maria Araújo). Pedagogia dos sonhos possíveis. São Paulo: Paz e Terra, 2014.

NÓVOA, Antonio. Os professores e a sua formação. 3.ed. Lisboa, Portugal: Publicação Dom Quixote, 1997.

(Org.). Profissão professor. 2 ed. Porto: Porto Editora, 1999.

Formação de professores e Profissão docente. Ensaio. Portugal: Universidade de Lisboa, 2009. 
NUNES, Terezinha; CARRAHER, David; SCHLIEMANN, Analúcia. Na vida dez, na escola zero. 16.ed. São Paulo: Cortez, 2011.

PAIS, Luís Carlos. Didática da matemática: uma análise da influência francesa. Coleção: Tendências em Educação Matemática. Belo Horizonte: Autêntica, 2001.

Ensinar e aprender Matemática. 2.ed. Belo Horizonte: Autêntica, 2013.

PINTO, Álvaro Vieira. Consciência e realidade nacional. Rio de Janeiro: ISEB, 1960.

Sete lições sobre educação de adultos. 16.ed. São Paulo: Cortez, 2010.

PONTE, João Pedro. Perspectivas de desenvolvimento profissional de professores de Matemática. In PONTE, João Pedro et al (Eds.). Desenvolvimento profissional de professores de Matemática: Que formação? Lisboa: SEM-SPCE. 1995. (p. 193-211).

PRADA, Luis Eduardo Alvarado; LONGAREZI, Andrea Maturano. Aprendizagem docente na formação continuada de professores em serviço. In: GALVÃO, Afonso Ceso Tanus; SANTOS, Gilberto Lacerda dos (Orgs.). Educação: tendências e desafios de um campo em movimento. Brasília: Líber Livro Editora, 2008. p.105-121

PROPOSTA CURRICULAR - $\mathbf{1}^{\mathbf{0}}$ segmento da Educação para jovens e adultos. Coordenado por Vera Maria Masagão Ribeiro. São Paulo: Ação Educativa; Brasília: MEC, 2001.

REIS, Renato Hilário dos. A Constituição do Sujeito Político, Epistemológico e Amoroso na Alfabetização de Jovens e Adultos. Tese de Doutorado. Campinas: Universidade de Campinas, 2000.

A constituição do ser humano: amor-poder-saber na educação/alfabetização de jovens e adultos. Campinas, SP: Autores Associados, 2011.

; RÊSES, Erlando da Silva; VIEIRA, Maria Clarisse. Presença e pegadas de Paulo Freire no Distrito Federal: uma primeira aproximação. Linhas Críticas, Brasília, v. 18, n. 37, p. 529-550, set./dez. 2012.

; CASTIONI, Remi; TELES, Lúcio. Proeja-transiarte: construindo novos sentidos para a educação de jovens e adultos trabalhadores. Brasíli: Verbena, 2012.

RIOS, Terezinha Azerêdo. Ética e competência. 20. ed., São Paulo: Cortez, 2011.

ROLDÃO, Maria do Céu. Função docente: natureza e construção do conhecimento profissional. Revista Brasileira de Educação, v. 12, n. 34, p. 94-103, jan./abr. 2007.

SANTOS, Boaventura de Sousa. A crítica da razão indolente: contra o desperdício da experiência. São Paulo: Cortez, 2000.

SANTOS, Edlamar Oliveira dos. A formação continuada na rede municipal de ensino do Recife: concepções e práticas de uma política em construção. 2010. 365f. Tese de doutorado (Programa de Pó-Graduação em educação) - Centro de Educação, Universidade Federal de Pernambuco, Recife, 2010.

SAVIANE, Dermeval. História das Ideias Pedagógicas no Brasil. 3. ed. rev. 1 reimp. Campinas: Autores Associados, 2011.

SILVA, Adriano Cavalcante da. O processo de ensino-aprendizagem em matemática na perspectiva freiriana. In: ENCONTRO NACIONAL DE EDUCAÇÃO MATEMÁTICA, 11. 2013, Curitiba/PR. Anais... Curitiba, 18-21 de julho de 2013.

SILVA, Kátia Augusta Curado Pinheiro Cordeiro da. Professores com formação stricto sensu e o desenvolvimento da pesquisa na educação básica da rede pública de Goiânia: 
realidade, entraves e possibilidades. 2008. 292f. Tese de doutorado (Programa de PósGraduação em Educação) - Faculdade de Educação, Universidade Federal de Goiás, Goiânia, 2008.

A formação de professores na perspectiva crítico-emancipadora. Revista Linhas Críticas, Brasília, Universidade de Brasília/FE, v. 17, n 32, p.13-31, jan./abr. 2011.

SOARES, Leôncio. As especificidades na formação do educador de jovens e adultos: um estudo sobre propostas de EJA. Educação em Revista (UFMG. Impresso). Belo Horizonte, v. 27, n. 02, p.303-322, ago. 2011.

; PEDROSO, Ana Paula Ferreira. Dialogicidade e a formação de educadores na EJA: as contribuições de Paulo Freire. Educação Temática Digital (ETD), Campinas/SP, v. 15, n. 2, p.250-263, maio/ago. 2013.

SOARES, Magda. Alfabetização e Letramento: caminhos e descaminhos. Revista Pátio. p.96-100., fev. 2004.

2014.

Letramento: um tema em três gêneros. 3.ed., 2.reimp. Belo Horizonte: Autêntica,

SOUSA, Carlos Alberto Lopes de. Professor, quero ser oprimida!: situação-limite e atoslimites no habitus professoral. Revista Linhas Críticas, Universidade de Brasília - DF, v. 18, n. 37, p.551-568, set./dez. 2012.

SCASSO, Luis. Prefácio OEI. In: RIVERO, José; MACHADO, Maria Margarida (et al coords.). Contribuições conceituais da educação de pessoas jovens e adultas: rumo à construção de sentidos comuns na diversidade. Organização dos Estados Ibero-americano [e] UNESCO. Goiânia: Editora UFG, 2014.

SCHEIDER, Sônia Maria. Dilemas práticos para a formação de professores em Educação Matemática de Jovens e Adultos. In: SIMPÓSIO INTERNACIONAL DE PESQUISA EM EDUCAÇÃO MATEMÁTICA, 3., Águas de Lindóia/SP. Anais... Águas de Lindóia, 10-14 de outubro de 2006.

SHULMAN, Lee. Those who understand: knowledge growth in teaching. Educational Research, n. 15 (2), p. 4-14, 1986. (Tradução livre: Aqueles que entendem: o crescimento do conhecimento no ensino).

SKOVSMOSE, Ole; ALRO, Helle. Diálogo e Aprendizagem em educação Matemática. 2.ed. Belo Horizonte: Autêntica, 2010.

STRECK, Danilo Romeu. Pesquisar é pronunciar o mundo: notas sobre método e metodologia. In: BRANDÃO, Carlos Rodrigues; STRECK, Danilo Romeu (Orgs.). Pesquisa participante: a partilha do saber. Aparecida, SP: Ideias \& Letras, 2006. p. 259-277.

Algumas lições do mestre. Revista do Instituto Humanistas Unisinos, São Leopoldo/RS, Ano VII, n. 223, p.6-8, jun. 2007.

; REDIN, Euclides; ZITKOSKI, Jaime José (Orgs.). Dicionário Paulo Freire. Belo Horizonte: Autêntica, 2008.

; ADAMS, Telmo. Uma Prática de Pesquisa Participante: análise da dimensão social, política e pedagógica. Revista de Educação Publica (UFMT), v. 20, n.44, p. 481-497, set./dez.2011.

A pesquisa em educação popular e a Educação Básica. Práxis Educativa, Ponta Grossa, v. 8, n. 1, p. 111-132, jan./jun. 2013. 
Prefácio. In: FREITAS, Ana Lúcia Souza de; GHIGGI, Gomercindo; PEREIRA, Thiago Ingrassia (Orgs.). Paulo Freire em diálogo com outros autores. Passo Fundo, Rio Grande do Sul: Méritos, 2014.

TORRES, Rosa María. Aprendizagem ao longo da vida. In: RIVERO, José; MACHADO, Maria Margarida (et al coords.). Contribuições conceituais da educação de pessoas jovens e adultas: rumo à construção de sentidos comuns na diversidade. Organização dos Estados Ibero-americano [e] UNESCO. Goiânia: Editora UFG, 2014.

VAILLANT, Denise. Formação de Formadores: Estado da Prática. Programa de Promoção da Reforma Educativa na América Latina e Caribe - PREAL. n. 25. Outubro de 2003.

Percalços da formação na América Latina. In: Gestão Escolar. Edição Especial n. 6. p.28-29, jun. 2011.

VERGNAUD, Gérard. O que é aprender? In: MUNIZ, Cristiano Alberto; BITTAR, Marilena (Orgs.). A aprendizagem matemática na teoria dos campos conceituais. Curitiba: CRV, 2009. p.13-35. 
APÊNDICES 
Apêndice A

\section{UNIVERSIDADE DE BRASÍLIA (UnB) \\ PROGRAMA DE PÓS-GRADUAÇÃO EM EDUCAÇÃO (PPGEd) CURSO: DOUTORADO EM EDUCAÇÃO}

\section{TERMO DE CONSENTIMENTO LIVRE E ESCLARECIDO}

Título do projeto: Os inéditos-viáveis na e da formação continuada de professores que ensinam matemática nos anos iniciais da Educação de Jovens e Adultos

Orientador responsável: Prof. Dr. Cristiano Alberto Muniz

Pesquisador responsável: Rejane de Oliveira Alves*

Universidade de Brasília (UnB)/ Faculdade de Educação / Programa de Pós-Graduação /

Curso: Doutorado em Educação

Professor(a), muito respeitosamente viemos convidá-lo(a) para participar da pesquisa sobre inéditos-viáveis constituídos na práxis de professores(as) que ensinam matemática nos anos iniciais da EJA. Para isso nos comprometemos com a parceria no projeto de educação matemática e com a preservação de sua identidade.

O objetivo geral da pesquisa é analisar a constituição dos inéditos-viáveis que auxiliam na construção de conhecimentos e na superação das situações-limite as quais interferem na organização do trabalho pedagógico do professor e da professora que ensina matemática nos anos iniciais da EJA.

A pesquisa se efetiva por meio de encontros denominados círculos de investigação formativos em torno das situações-limite a fim de produzir conhecimentos que são os inéditos-viáveis. As sessões formativas podem ser gravadas em áudio para transcrição.

Então, se concordar em participar do estudo, após ter recebido as informações necessárias e os esclarecimentos devidos das contribuições do projeto, pedimos gentilmente que assine o presente termo de consentimento para que possamos apresentar ao Departamento ao qual essa pesquisa está vinculada.

Local e data

\begin{tabular}{c}
$\begin{array}{c}\text { Participante do estudo } \\
\text { (informar o RG) }\end{array}$ \\
\hline Pesquisadora responsável direta pelos estudos \\
(informar o RG)
\end{tabular}
WhatsApp/ Oi (61) $8420-9833 /$ Vivo (61) $9608-2859 /$ Claro (61) $9105-2558$

* Contatos com Rejane Alves

E-mail: rejanne1@ @otmail.com

Tim (61) 8330-1607 WhatsApp/ Oi (61) 8420-9833/ Vivo (61) 9608-2859/ Claro (61) 9105-2558 


\section{Apêndice B}

\section{UNIVERSIDADE DE BRASÍLIA (UnB) \\ PROGRAMA DE PÓS-GRADUAÇÃO EM EDUCAÇÃO (PPGEd) \\ CURSO: DOUTORADO EM EDUCAÇÃO}

\section{QUESTIONÁRIO DESTINADO AO PROFESSOR}

\section{PREZADO (A) PROFESSOR (A)}

Este questionário tem como objetivo traçar o perfil dos participantes da pesquisa intitulada "Os inéditos-viáveis na e da formação continuada de professores que ensinam matemática nos anos iniciais da Educação de Jovens e Adultos" do Curso de Doutorado em Educação da Universidade de Brasília (UnB).

Neste sentido, contamos com sua contribuição e desde já agradecemos a colaboração e disponibilidade para fortalecer as bases epistemológicas desse estudo.

\section{Dados pessoais}

Nome completo:

Pseudônimo que gostaria de utilizar no estudo

Naturalidade (Cidade e Estado): Idade:

\section{Formação acadêmica}

2.1 Cursou a Escola Normal no Ensino Médio?

2.2 Curso(s) de graduação (indicar a graduação, o ano de início e conclusão do curso e a modalidade se presencial ou à distância):

2.3 Pós-graduação (especificar se foi especialização, mestrado e/ou doutorado, a área a que se vincula e a modalidade de ensino - se presencial ou à distância)

\section{Dados Profissionais:}

\subsection{Locais de trabalho atualmente:}

Nome da Escola1:

Em que ano/etapa atua:

Jornada de trabalho semanal (20horas; 40 horas ou mais):

Horário de trabalho (matutino/vespertino ou noturno):

Forma de admissão: (concurso efetivo ou temporário):

Nome da Escola2:

Em que ano/etapa atua:

Jornada de trabalho semanal (20horas; 40 horas ou mais):

Horário de trabalho (matutino/vespertino ou noturno):

Forma de admissão: (concurso efetivo ou temporário):

\subsection{Tempo de docência:}

Há quanto tempo você atua na carreira de magistério?

Há quanto tempo você atua como professor (a) na Educação de Jovens e Adultos?

$* 1^{\mathrm{o}}$ Segmento - Anos iniciais $\left(1^{\mathrm{a}}, 2^{\mathrm{a}}, 3^{\mathrm{a}}\right.$ ou $4^{\mathrm{a}}$ etapa):

$* 2^{\mathrm{o}}$ Segmento - Anos finais ( $5^{\mathrm{a}}, 6^{\mathrm{a}}, 7^{\mathrm{a}}$ ou $8^{\mathrm{a}}$ etapa):

$* 3^{\circ}$ Segmento - Ensino Médio $\left(1^{\circ}\right.$ ano, $2^{\circ}$ ano ou $3^{\circ}$ ano $)$ 
Apêndice C

\section{UNIVERSIDADE DE BRASÍLIA (UnB) \\ PROGRAMA DE PÓS-GRADUAÇÃO EM EDUCAÇÃO (PPGEd) \\ CURSO: DOUTORADO EM EDUCAÇÃO}

Título do projeto: Os inéditos-viáveis na e da formação continuada de professores que ensinam matemática nos anos iniciais da Educação de Jovens e Adultos

Orientador responsável: Prof. Dr. Cristiano Alberto Muniz

Pesquisador responsável: Rejane de Oliveira Alves

Universidade de Brasília (UnB)/ Faculdade de Educação / Programa de Pós-Graduação /

Curso: Doutorado em Educação

\section{ROTEIRO DE ENTREVISTA COLETIVA COM OS ALUNOS DO PRIMEIRO SEGMENTO DA EDUCAÇÃO DE JOVENS E ADULTOS DO CENTRO DE ENSINO MÉDIO 03 DE CEILÂNDIA/DF}

\section{(Roda de Conversa)}

1) Fale sobre o motivo de vocês estudarem na Educação de Jovens e Adultos.

2) Descrevam como é a relação de vocês com os professores e os outros alunos.

3) No dia a dia, vocês convivem com a Matemática?

4) Descrevam o que vocês acham da disciplina de Matemática. E se vocês pudessem mudar a aula de Matemática, o que vocês mudariam e por quê?

5) Há algum assunto/ conteúdo que vocês gostariam de aprender em Matemática?

Modo de proceder: Diálogo gravado com aparelho de áudio para posterior transcrição. 


\section{Apêndice D}

\section{UNIVERSIDADE DE BRASÍLIA (UnB) \\ PROGRAMA DE PÓS-GRADUAÇÃO EM EDUCAÇÃO (PPGEd) \\ CURSO: DOUTORADO EM EDUCAÇÃO}

Título do projeto: Os inéditos-viáveis na e da formação continuada de professores que ensinam matemática nos anos iniciais da Educação de Jovens e Adultos

Orientador responsável: Prof. Dr. Cristiano Alberto Muniz

Pesquisador responsável: Rejane de Oliveira Alves

Universidade de Brasília (UnB)/ Faculdade de Educação / Programa de Pós-Graduação /

Curso: Doutorado em Educação

\section{ROTEIRO DE ENTREVISTA INDIVIDUAL COM AS PROFESSORAS DO PRIMEIRO SEGMENTO DA EDUCAÇÃO DE JOVENS E ADULTOS DO CENTRO DE ENSINO MÉDIO 03 DE CEILÂNDIA/DF}

1 Fale de suas impressões acerca dessa formação em Educação Matemática.

$2 \mathrm{O}$ fator (ou os fatores) limitador(es) da formação foi ...

3 Você entende essa formação continuada como...

4 Fale o que significa aprendizagem matemática.

5 O que representaram os círculos de investigação formativos...

6 Fale das implicações de trabalhar com a Educação Matemática.

7 Você enfrenta as dificuldades para aprender e para ensinar matemática assim ...

8 Fale da experiência de trabalhar a matemática na perspectiva do letramento.

9 De toda a experiência de trabalho na EJA (você pode especificar quanto tempo), fale como tem sido a sua relação com a formação.

Modo de proceder: Diálogo gravado com aparelho de áudio para posterior transcrição e análise. 


\section{Apêndice E}

\section{Situacões-problemas}

Questionar: Podemos dividir 1 para 2? (esperar que os alunos respondam)

Exemplificar: 1 laranja $\div 2$ pessoas 1 real $\div 2$ pessoas

RESPOSTA: $1 \div 2=$ metade ou 0,5 ou $1 / 2$ ou $50 \% \quad(1$ laranja $=100 \%)$

Questionar: Como posso dividir 2 para 8? (esperar que os alunos respondam)

Exemplificar: 2 doces $\div 8$ pessoas 2 reais $\div 8$ pessoas

RESPOSTA: $2 \div 8=$ um quarto ou 0,25 ou $1 / 4$ ou $25 \%$

A) Imagine que você é a encarregada dos pagamentos de uma empresa de calçados. O dono da empresa lhe entregou um envelope em que tinham 22 notas de $\mathrm{R} \$ 100,00 ; 20$ notas de $\mathrm{R} \$ 50,00$. Você precisa conferir quanto tem de dinheiro no envelope e pagar o salário igual para 4 funcionários. Quanto cada funcionário receberá de salário?

Resposta: $(22 \times 100)=\mathbf{2 . 2 0 0 , 0 0}+(20$ X 50,00 $)=1.000,00$ SOMADO É $3.200,00 \div 4=\mathbf{R} \$ 800,00$

B) Uma empresa de panfletagem contratou você e lhe entregou 24 vales transportes. Se você usar 2 por dia, em quantos dias você usará todos os vales?

Resposta: $24 \div 2=12$ dias

C) Uma cartela de ovos comporta 30 ovos. Sobre a mesa estão 5 cartelas de ovos vazias que precisam ser preenchidas. Quantos ovos serão necessários para preencher todas as cartelas?

Resposta: 30 X 5 = 150 ovos

F) Se você sacou no banco $\mathrm{R} \$ 300,00$ e quer colocar a metade em cada bolso, quantos reais ficarão em cada bolso? Resposta: $\mathbf{3 0 0 , 0 0} \div \mathbf{2}=\mathbf{R} \$ \mathbf{1 5 0 , 0 0}$

H) Se você recebesse $R \$ 900,00$ e tivesse que guardar em envelopes em quantidades iguais de $R \$$ 150,00 . Quantos envelopes seriam necessários para guardar todo o dinheiro?

Resposta: $900,00 \div 150,00=6$ envelopes

I) Maria está lendo um livro que tem 100 páginas. Todos os dias ela lê 5 páginas. De quantos dias ela precisa para ler o livro completo? Resposta: $100 \div 5=20$ dias

J) Se você trocar uma nota de $\mathrm{R} \$ 100,00$ por notas de $\mathrm{R} \$ 5,00$, com quantas notas você ficará?

Resposta: $100,00 \div 5=20$ notas

K) Em uma vasilha há 48 ovos que precisam ser colocados em cartelas de 12 ovos. Quantas cartelas serão preenchidas?

Resposta: $48 \div 12=4$ cartelas

O) Imagine que você só tem notas de $\mathrm{R} \$ 2,00$ e essas notas estão separadas em montes de $\mathrm{R} \$ 6,00$. Se você tiver 8 montes desse valor, quanto de dinheiro você tem disponível?

Resposta: 6 X $8=\mathbf{R} \$ 48,00$

R) Você vai sair para caminhar, o dia está frio e você precisa decidir que roupa vai usar. Se você tem uma camisa amarela, uma camisa azul e uma camisa branca e tem uma calça azul e uma preta, quais as combinações possíveis de usar a calça e a camisa?

Resposta: 3 X 2 = 6 combinações diferentes

S) Se você tem os algarismos 6, 9,3, quantos números diferentes você poderá formar com eles?

Resposta: SEIS números diferentes $(369 ; 396 ; 639 ; 693 ; 936 ; 963)$ 


\section{Apêndice F}

Quadro: Balanço das manifestações do dia 16 de agosto de 2015 nas capitais brasileiras, divulgado no site da Rede Globo.

\begin{tabular}{|c|c|c|}
\hline $\begin{array}{c}\text { Regiões com estados } \\
\text { e capitais }\end{array}$ & $\begin{array}{l}\mathbf{N}^{0} \text { de manifestantes } \\
\text { (segundo a Polícia) }\end{array}$ & $\begin{array}{c}\mathrm{N}^{0} \text { de manifestantes } \\
\text { (organização do evento) }\end{array}$ \\
\hline \multicolumn{3}{|c|}{ NORTE } \\
\hline Acre - Rio Branco & não informado & não informado \\
\hline Amapá - Macapá & não informado & 200 \\
\hline Amazonas - Manaus & $4 \mathrm{mil}$ & $5 \mathrm{mil}$ \\
\hline Pará - Belém & não informado & 400 \\
\hline Rondônia - Porto Velho & não informado & 100 \\
\hline Roraima - Boa Vista & não informado & $1,2 \mathrm{mil}$ \\
\hline Tocantins - Palmas & 200 & 300 \\
\hline \multicolumn{3}{|c|}{ NORDESTE } \\
\hline Alagoas - Maceió & 500 & $1,2 \mathrm{mil}$ \\
\hline Bahia - Salvador & $8 \mathrm{mil}$ & 10 mil \\
\hline Ceará - Fortaleza & $2,5 \mathrm{mil}$ & 20 mil \\
\hline Maranhão - São Luis & 400 & $1,5 \mathrm{mil}$ \\
\hline Paraíba - João Pessoa & não informado & 400 \\
\hline Pernambuco - Recife & não informado & 5 mil \\
\hline Piauí - Teresina & $1 \mathrm{mil}$ & $3 \mathrm{mil}$ \\
\hline Rio Grande do Norte - Natal & 500 & $1 \mathrm{mil}$ \\
\hline Sergipe - Aracaju & 500 & $3,5 \mathrm{mil}$ \\
\hline \multicolumn{3}{|c|}{ SUL } \\
\hline Paraná - Curitiba & 600 & $5 \mathrm{mil}$ \\
\hline Rio Grande do Sul - Porto Alegre & $1,2 \mathrm{mil}$ & $2 \mathrm{mil}$ \\
\hline Santa Catarina - Florianópolis & $1 \mathrm{mil}$ & 2 mil \\
\hline \multicolumn{3}{|c|}{ SUDESTE } \\
\hline Rio de Janeiro - Rio de Janeiro & não informado & 25 mil \\
\hline São Paulo - São Paulo & 40 mil & 75 mil \\
\hline Espírito Santo - Vitória & 150 & $1 \mathrm{mil}$ \\
\hline Minas Gerais - Belo Horizonte & $6 \mathrm{mil}$ & 12 mil \\
\hline \multicolumn{3}{|c|}{ CENTRO-OESTE } \\
\hline Goiás - Goiânia & 300 & $1 \mathrm{mil}$ \\
\hline Mato Grosso - Cuiabá & 350 & $1 \mathrm{mil}$ \\
\hline Mato Grosso do Sul - Campo Grande & não informado & 600 \\
\hline Distrito Federal - Brasília & 500 & não informado \\
\hline
\end{tabular}

Fonte: http://especiais.g1.globo.com/politica/mapa-manifestacoes-no-brasil/20-08-2015/ 


\section{Apêndice G1}

Quadro: Quantidade para consumo de arroz, pães, massas, batata e mandioca

\begin{tabular}{|c|c|c|}
\hline ALIMENTOS & PESO (g) & MEDIDA CASEIRA \\
\hline angu1 & 105,0 & 3 colheres de sopa \\
\hline arroz branco cozido & 125,0 & 4 colheres de sopa \\
\hline arroz integral cozido & 140,0 & 4 colheres de sopa \\
\hline feijão branco cozido & 48,0 & $11 / 2$ colher de sopa \\
\hline feijão cozido (50 \% de caldo) & 86,0 & 1 concha \\
\hline feijão cozido (somente grãos) & 50,0 & 2 colheres de sopa \\
\hline feijão preto cozido1 & 80,0 & 1 concha média rasa \\
\hline batata doce cozida & 150,0 & $11 / 2$ colheres de servir \\
\hline batata cozida & 175,0 & $11 / 2$ unidade \\
\hline biscoito tipo "cream cracker" & 32,5 & 5 unidades \\
\hline biscoito tipo "cream cracker" & 32,5 & 5 unidades \\
\hline biscoito tipo "maizena" & 35,0 & 7 unidades \\
\hline biscoito tipo "maria" & 35,0 & 7 unidades \\
\hline $\begin{array}{l}\text { biscoito recheado chocolate/doce de leite/ } \\
\text { morango }\end{array}$ & 34,0 & 2 unidades \\
\hline bolo de banana1 & 50,0 & 1 fatia pequena \\
\hline bolo de cenoura1 & 30,0 & 1 fatia pequena \\
\hline bolo de chocolate & 50,0 & 1 fatia \\
\hline bolo de milho1 & 50,0 & 1 fatia \\
\hline cará cozido/ amassado & 126,0 & $31 / 2$ colher de sopa \\
\hline farinha de mandioca & 30,0 & 2 colheres de sopa \\
\hline inhame cozido/ amassado & 126,0 & $31 / 2$ colher de sopa \\
\hline macarrão cozido & 105,0 & $31 / 2$ colheres de sopa \\
\hline mandioca cozida & 96,0 & 3 colheres de sopa \\
\hline milho verde em espiga1 & 100,0 & 1 espiga grande \\
\hline milho verde em conserva (enlatado) & 142,0 & 7 colheres de sopa \\
\hline pamonha1 & 100,0 & 1 unidade \\
\hline pão de forma tradicional & 43,0 & 2 fatias \\
\hline pão de queijo & 40,0 & 1 unidade \\
\hline pão francês & 50,0 & 1 unidade \\
\hline polenta frita & 80,0 & 2 fatias \\
\hline polenta sem molho & 200,0 & 2 fatias \\
\hline purê de batata & 135,0 & 2 colheres de servir \\
\hline
\end{tabular}

Fonte: Prescrição da Nutricionista da professora Rita. 


\section{Apêndice G2}

\section{Quadro: Quantidades para consumo de carnes e ovos}

\begin{tabular}{|c|c|c|}
\hline ALIMENTOS & PESO $(g)$ & MEDIDA CASEIRA \\
\hline bife de fígado frito & 100,0 & 1 unidade médial \\
\hline bife grelhado & 90,0 & 1 unidade1 \\
\hline carne assada (patinho) & 75,0 & 1 fatia pequena \\
\hline carne cozida1 & 80,0 & 4 pedaços pequenos \\
\hline carne moída refogada & 90,0 & 5 colheres de sopa \\
\hline carne seca & 40,0 & 2 pedaços pequenos1 \\
\hline costela bovina assada 1 & 40,0 & 1 pedaço pequeno \\
\hline espetinho de carne & 92,0 & 2 unidades \\
\hline \multirow[t]{3}{*}{ frango assado inteiro } & \multirow[t]{3}{*}{100,0} & 1 pedaço de peito ou \\
\hline & & 1 coxa grande ou \\
\hline & & 1 sobrecoxa \\
\hline frango filé grelhado & 100,0 & 1 \\
\hline frango sobrecoxa cozida s/ pele c/ molho & 100,0 & 1 sobrecoxa grande \\
\hline linguiça de porco cozida & 50,0 & 1 gomo \\
\hline merluza cozida (filé) & 200,0 & 2 filés \\
\hline mortadela & 45,0 & 3 fatias médias \\
\hline omelete simples & 74,0 & 1 unidade \\
\hline ovo cozido1 & 90,0 & 2 unidades \\
\hline ovo frito & 50,0 & 1 unidade \\
\hline peru assado sem pele & 96,0 & 2 fatias grandes 1 \\
\hline porco lombo assado & 80,0 & 1 fatia \\
\hline salsicha & 60,0 & $11 / 2$ unidade \\
\hline sardinha em conserval & 41,5 & 1 unidade média \\
\hline
\end{tabular}

Fonte: Prescrição da Nutricionista da professora Rita. 


\section{Apêndice G3}

Quadro: Quantidades para consumo de folhagens

\begin{tabular}{|l|c|l|}
\hline ALIMENTOS & PESO $(\mathrm{g})$ & MEDIDA CASEIRA \\
\hline Abóbora cozida (menina, japonesa, moranga) & 53,0 & $11 / 2$ colher de sopa \\
\hline Abobrinha cozida & 81,0 & 3 colheres de sopa \\
\hline \hline Acelga crua (picada) & 90,0 & 9 colheres de sopa \\
\hline Agrião & 130,0 & 22 ramos \\
\hline Alface & 120,0 & 15 folhas \\
\hline Beterraba cozida & 30,0 & 3 fatias \\
\hline Beterraba crua ralada & 42,0 & 2 colheres de sopa \\
\hline Brócolis cozido & 60,0 & $41 / 2$ colheres de sopa \\
\hline Cenoura cozida (fatias) & 35,0 & 7 fatias \\
\hline Cenoura cozida (picada) & 36,0 & 1 colher de servir \\
\hline Cenoura crua (picada) & 36,0 & 1 colher de servir \\
\hline Chuchu cozido & 57,0 & $21 / 2$ colheres de sopa \\
\hline Couve-flor cozida & 69,0 & 3 ramos \\
\hline Couve manteiga cozida & 42,0 & 1 colher de servir \\
\hline Ervilha em conserva & 13,0 & 1 colher de sopa \\
\hline Jiló cozido & 40,0 & $11 / 2$ colher de sopa \\
\hline Maxixe cozido1 & 120,0 & 3 colheres de sopa \\
\hline Pepino japonês & 130,0 & 1 unidade \\
\hline Pepino picado & 116,0 & 4 colheres de sopa \\
\hline Pimentão cru fatiado (vermelho/ verde) & 70,0 & 10 fatias \\
\hline Pimentão cru picado (vermelho/ verde) & 72,0 & 3 colheres de sopa \\
\hline Quiabo cozido & 80,0 & 2 colheres de sopa \\
\hline Repolho branco cru (picado) & 72,0 & 6 colheres de sopa \\
\hline Repolho cozido & 75,0 & 5 colheres de sopa \\
\hline Tomate caqui & 75,0 & $21 / 2$ fatias \\
\hline Tomate cereja & 70,0 & 7 unidades \\
\hline Tomate comum & 80,0 & 4 fatias \\
\hline
\end{tabular}

Fonte: Prescrição da Nutricionista da professora Rita. 


\section{Apêndice G4}

Quadro: Quantidade para consumo de frutas

\begin{tabular}{|c|c|c|}
\hline ALIMENTOS & PESO (g) & MEDIDA CASEIRA \\
\hline abacate & 32,0 & 1 colher de sopa \\
\hline abacaxi & 130,0 & 1 fatia \\
\hline acerola & 224,0 & 32 unidades \\
\hline banana-prata & 86,0 & 1 unidade \\
\hline banana nanica & 86,0 & 1 unidade \\
\hline caju & 147,0 & $21 / 2$ unidades \\
\hline caqui & 113,0 & 1 unidade \\
\hline goiaba & 95,0 & $1 / 2$ unidade \\
\hline jaca & 132,0 & 4 bagos \\
\hline kiwi & 154,0 & 2 unidades \\
\hline laranja-pêra & 137,0 & 1 unidade \\
\hline limão & 252,0 & 4 unidades \\
\hline maçã & 130,0 & 1 unidade \\
\hline mamão formosa & 160,0 & 1 fatia \\
\hline mamão papaia & 141,5 & $1 / 2$ unidade \\
\hline manga & 110,0 & 1 unidade \\
\hline maracujá (suco puro) & 94,0 & 1/2 xícara de chá \\
\hline melancia & 296,0 & 2 fatias \\
\hline melão & 230,0 & 2 fatias \\
\hline morango & 240,0 & 10 unidades \\
\hline $\begin{array}{l}\text { salada de frutas (banana, maçã, laranja, } \\
\text { mamão) }\end{array}$ & 125,0 & 1/2 xícara de chá \\
\hline suco de abacaxi & 125,0 & $1 / 2$ copo de requeijão \\
\hline suco de laranja (puro) & 187,0 & 3/4 copo requeijão \\
\hline suco de melão & 170,0 & $3 / 4$ copo de requeijão \\
\hline suco de tangerina & 164,0 & $3 / 4$ copo requeijão \\
\hline suco de uva (industrializado) & 100,0 & $1 / 2$ copo requeijão \\
\hline tangerina/mexerica & 148,0 & 1 unidade \\
\hline uva comum & 99,2 & 22 uvas \\
\hline uva itália & 99,2 & 8 uvas \\
\hline uva rubi & 103,0 & 8 uvas \\
\hline
\end{tabular}

Fonte: Prescrição da Nutricionista da professora Rita. 


\section{Apêndice H}

\section{UNIVERSIDADE DE BRASÍLIA (UnB) \\ PROGRAMA DE PÓS-GRADUAÇÃO EM EDUCAÇÃO (PPGEd) \\ CURSO: DOUTORADO EM EDUCAÇÃO}

\section{TERMO DE AUTORIZAÇÃO DE PUBLICAÇÃO DE CONTEÚDOS DA PESQUISA}

$\mathrm{Eu}$ $\mathrm{RG}$

que recebi o pseudônimo de na pesquisa de Doutorado de

Rejane de Oliveira Alves, RG 2266125, intitulada "Os inéditos-viáveis na e da formação continuada do professor que ensina matemática nos anos iniciais da Educação de Jovens e Adultos" autorizo a divulgação e publicação das gravações e dos registros realizados pela pesquisadora durante o ano de 2015 envolvendo minha participação no trabalho de formação realizado na escola Centro de Ensino Médio 03 de Ceilândia/DF, onde atuo como professora dos anos iniciais. Acrescento que fui informada dos procedimentos da pesquisa, desde seu início, quando assinei o termo de consentimento livre e esclarecido. Após a transcrição das falas e entrevistas, antes da publicação das informações, tive conhecimento de seu conteúdo, bem como fui oportunizada de corrigir, retirar ou acrescentar qualquer trecho que julgasse necessário. Assim, tendo em vista o cumprimento das condições de preservação da minha privacidade e a descrição fiel da minha participação na pesquisa, autorizo a divulgação e publicação de seu conteúdo.

E por ser verdade os termos aqui presentes, assino o presente documento.

Local e data

\section{Colaboradora do estudo}

\section{Pesquisadora responsável pelo conteúdo da pesquisa}

Declaramos para os devidos fins que esse Termo de Autorização de publicação de conteúdos e registros tem validade junto aos documentos da pesquisa. 